\title{
'Vergeet niet dat je arts bent' : Joodse artsen in Nederland 1940-1945
}

Citation for published version (APA):

van den Ende, H. L. (2015). 'Vergeet niet dat je arts bent' : Joodse artsen in Nederland 1940-1945.

[Doctoral Thesis, Maastricht University]. Uitgeverij Boom. https://doi.org/10.26481/dis.20150402he

Document status and date:

Published: 01/01/2015

DOI:

10.26481/dis.20150402he

Document Version:

Publisher's PDF, also known as Version of record

\section{Please check the document version of this publication:}

- A submitted manuscript is the version of the article upon submission and before peer-review. There can be important differences between the submitted version and the official published version of record.

People interested in the research are advised to contact the author for the final version of the publication, or visit the DOI to the publisher's website.

- The final author version and the galley proof are versions of the publication after peer review.

- The final published version features the final layout of the paper including the volume, issue and page numbers.

Link to publication

\footnotetext{
General rights rights.

- You may freely distribute the URL identifying the publication in the public portal. please follow below link for the End User Agreement:

www.umlib.nl/taverne-license

Take down policy

If you believe that this document breaches copyright please contact us at:

repository@maastrichtuniversity.nl

providing details and we will investigate your claim.
}

Copyright and moral rights for the publications made accessible in the public portal are retained by the authors and/or other copyright owners and it is a condition of accessing publications that users recognise and abide by the legal requirements associated with these

- Users may download and print one copy of any publication from the public portal for the purpose of private study or research.

- You may not further distribute the material or use it for any profit-making activity or commercial gain

If the publication is distributed under the terms of Article $25 \mathrm{fa}$ of the Dutch Copyright Act, indicated by the "Taverne" license above, 
'VERGEET NIET DAT JE ARTS BENT' 



\section{'VERGEET NIET DAT JE ARTS BENT'}

Joodse artsen in Nederland 1940-1945

\section{PROEFSCHRIFT}

ter verkrijging van de graad van doctor aan de Universiteit Maastricht, op gezag van de Rector Magnificus, Prof. dr. L.L.G. Soete

volgens het besluit van het College van Decanen,

in het openbaar te verdedigen

op donderdag 2 april 2015 om I6.00 uur

door

Hannah Laetitia van den Ende 


\section{Promotores}

Prof.dr. E.S. Houwaart

Prof.dr. J.Th.M. Houwink ten Cate (Universiteit van Amsterdam)

\section{Beoordelingscommissie}

Prof.dr. G. de Wert (voorzitter)

Prof.dr. F.G. Huisman

Prof.dr. B. Moore (University of Sheffield, United Kingdom)

Prof.dr. A. Nieuwenhuijzen Kruseman

Prof.dr. M. Schwegman (directeur NIOD, Universiteit van Utrecht)

Mede tot stand gekomen dankzij

Stichting Maatschappij tot Nut der Israëlieten in Nederland 


\section{INHOUD}

INLEIDING 9

Waarom dit boek? I2

Internationale literatuur 17

Geschiedenis als morele les 22

Medische ethiek is vervormbaar 24

Opbouw en methode 28

1. GEWONE HOLLANDSE ARTSEN 35

Joodse artsen in Nederland in de jaren dertig, tussen assimilering en profilering

In de eerste plaats arts 35

Emancipatie en integratie 36

Prominente Joodse artsen in de jaren voor de bezetting 38

'De Joodsche zedeleer gaat wonderwel samen met de geneeskundige zedeleer' 42

Een deontologische gids 47

Gewone Hollandse artsen met een Joodse identiteit 52

Manifestatie van Joodse identiteit 6I

Aan de vooravond van de Duitse inval 64

2. AFSTAND VAN DE ARTSENSTAND 69

De uitsluiting van de Joodse artsen uit de Nederlandse artsenstand, I940-194I

Strijdbaarheid en vrees 69

De ultieme vlucht: zelfmoord onder Joodse artsen $\quad 72$

Antisemitisme in $1940 \quad 80$

Ambtenaar-artsen ontheven uit hun functie 82

Ontslag 87 
Het behandelverbod 89

Joodse reacties en het leedwezen van secretaris-generaal Verwey 92

Praktische, financiële en morele gevolgen van de isolatie 97

Gebrek aan daadkracht bij het medisch establishment IO5

'Een poging tot knechting en onteering van den Nederlandschen artsenstand' IO7

3. GOEDGEKEURD? 113

In isolement op zoek naar een nieuw moreel kompas, I94I-juli 1942

Isolement en de Joodsche Raad II3

Positie en gevaar in I94I en begin 1942 II6

Alles achterlaten II9

De medische afdeling van de Joodsche Raad $\quad$ I22

Keuren voor de 'werkverruiming' I26

Vervalsing en sabotage $\quad$ I3O

De Groningse kwestie: NSB-artsen nemen de keuringen over $\quad$ I34

Groningse artsen tewerkgesteld $\quad$ I37

4. GENEESKUNDE ALS REDDINGSSLOEP 141

De eerste maanden van de deportaties, juli 1942 tot januari 1943

Juli I942: een dramatische cesuur I4I

Het 'sauve qui peut' I44

Schweitzer-werk in Westerbork I5O

Vluchten I53

Suïcide $\quad 156$

Hulp bij zelfmoord? $\quad 158$

Artsen als attestenfabrieken I6I

Simuleren om deportatie te voorkomen $\quad 165$

Psychiatrie in tijden van angst $\quad$ I68

5. 'ONDER HET VURIG BEGEERDE DAK VAN HET

\section{ZIEKENHUIS' 173}

Ziekenhuizen als veilige havens, juli 1942 tot januari 1943

De opnameaantallen stijgen $\quad$ I73

Schijndiagnoses en 'sham'-operaties 176

Ruimhartig opname- en personeelsbeleid $\quad$ I78

De Joodsche Invalide en de dilemma's van een geneesheer-directeur I8I

Het Apeldoornsche Bosch: blijven of vluchten? I86

De ontruiming van Het Apeldoornsche Bosch I9I

'Ik vermoed dat ze ze wel van kant maken' I95

Reacties in niet-Joodse kring $\quad$ I97 
6. ALS KAPITEINS OP EEN ZINKEND SCHIP 201

Geneesheren-directeur van de bedreigde Joodse ziekenhuizen, jananuari-september 1943

De ontruimingen gaan onverminderd voort $20 \mathrm{I}$

'Bijeen waren de allertrouwste krachten met het meeste plichtsbesef' 203

Afbrokkelende autonomie 2IO

Een laatste bastion van veiligheid $2 \mathrm{I} 3$

Samenwerking tussen het NIZ, de lege JI,

de GGD en de Hollandsche Schouwburg 216

Het NIz 'loopt op z’n laatste benen' 22I

Sterilisatie 223

Valse Sterielverklaringen 228

'Het gehele NIZ ontruimd' 23I

'Zij allen weten het zwaard van Damocles boven hun hoofd' 232

7. BEVOORRECHT? 237

Toch nog profijt van de artsenstatus, januari tot september 1943

Het net sluit zich 237

Kennis over Westerbork 243

'De kippen' lijken veiligheid te bieden 245

De aantrekkingskracht van Barneveld 247

'Zuster, breng mij de champagne' 253

8. DE LEGALE EN DE ILLEGALE REST 259

Joodse artsen in beschermde uitzonderingsposities of de onderduik

'Geariseerd' 259

De Portugezenlijst 263

Gemengd gehuwd 264

In een desolaat Mokum 266

De illegale optie: onderduiken 269

Collegialiteit versus afhankelijkheid $\quad 272$

De dokter incognito 277

Verzet 280

9. ARTS IN GEVANGENSCHAP 285

Joodse artsen in kampen in Nederland

Kampen op Nederlandse bodem 285

Kamp Amersfoort 286

Kamp Vught 289

Kamp Westerbork 294 
Uitdijende ziekenzorg 296

'Oogenschijnlijk normale' gezondheidszorg... $30 \mathrm{O}$

... maar toch ook weer geen paradijs 305

'Medicina Westerborkiana' 307

Vitamine R $3 \mathrm{I} 3$

Machteloos? 316

Transportstop en wetenschappelijk werk 3I9

Het 'Schicksal im Osten' 32I

SAMENVATTING EN CONCLUSIE 327

Samenvatting 327

Conclusies 335

Geschiedenis als morele les 340

NOTEN 343

LITERATUUR EN BRONNEN 399

SUMMARY 421

VALORISATIE-ADDENDUM 429

PERSONENREGISTER 434

CURRICULUM VITAE 445 


\section{INLEIDING}

Als Joodsch arts mag ik met een speciale vergunning na acht uur op straat.

Op dat oogenblik voel ik mij zeer ellendig. Daar sta ik nu, machteloos, tegenover dat gespuis, dat de macht heeft. ${ }^{\mathrm{T}}$

Nazomer 1942. Berthold Stokvis, 36 jaar, psychiater in zijn geboortestad Amsterdam, vertrouwde zijn dagboek toe de wanhoop nabij te zijn. Opkijkend van zijn bureau zag hij de bomen van het Sarphatipark, die hem zo vertrouwd waren. Bedrieglijk vertrouwd, want in feite was Stokvis' wereld onherkenbaar geworden sinds de Duitse nationaalsocialisten aan de macht waren gekomen. Nederland was Nederland niet meer en Amsterdam was Amsterdam niet meer, nu de bezetter de Amsterdamse Joden in hoog tempo deporteerde. Zelfs het Sarphatipark was het Sarphatipark niet meer: het heette plotseling Bollandpark. ${ }^{2}$ Dat Samuel Sarphati gold als stadsvernieuwer van allure en als arts verantwoordelijk was geweest voor belangrijke verbeteringen van de leefomstandigheden in Amsterdam, was niet langer ter zake doende. ${ }^{3}$ Dat hij Jood was, dát telde. Om diezelfde reden was ook Berthold Stokvis zelf van gerespecteerd burger, hooggewaardeerd medicus, gedegradeerd tot vervolgde, die machteloos stond tegenover de nationaalsocialistische heersers en hun rassenwaan.

Deze vijandige overheersing kende gelukkig een einde. De platanen van het Bollandpark staan officieel sinds I8 mei 1945 weer gewoon in het Sarphatipark. ${ }^{4}$ Onder hun bladerdak is het borstbeeld van dr. Sarphati teruggezet op zijn sokkel. Berthold Stokvis maakte het mee dat hij weer in vrijheid van 
het uitzicht kon genieten. Hij wel. De familie Stokvis was in december 1942 (via een zogenoemde Calmeyer-procedure) 'geariseerd', ofwel niet-Joods verklaard. Dat was levensreddend gebleken. De herinnering aan vijf jaren nationaalsocialistische overheersing en aan hen die die jaren niet overleefden, vervaagde echter niet. Ook Stokvis' dagboek bleef ervan getuigen. Intact was het de oorlog doorgekomen, zijn vrouw typte het over en schonk een kopie aan het Rijksinstituut voor Oorlogsdocumentatie, waar het de lezer nog steeds een rechtstreekse inzage biedt in Stokvis' gevoelsleven tijdens de bezetting.

Stokvis was Jood. Hij was ook arts. Niet alleen dat hij, ondanks de avondklok, een vergunning had om 's avonds na achten op straat te komen is daarvan een teken, ook in het verdere relaas speelt zijn beroep een belangrijke rol. Telkens bleek het hem in uitzonderlijke situaties te brengen, die soms in zijn voordeel of in het voordeel van anderen werkten. In dergelijke gevallen betekende het medische beroep - tot op zekere hoogte - een voorrecht. De vergunning om 's avonds op straat te mogen is een simpel voorbeeld. Anderzijds bracht zijn vak hem juist ook in situaties waarin de specifiek voor artsen geldende plichten ingewikkelde dilemma's opleverden. Zo beschreef Stokvis dat hij moest bepalen of hij zijn met deportatie bedreigde patiënten een dodelijk middel zou voorschrijven:

In de wachtkamer zitten veel mensen. Zij allen komen met hetzelfde smekende verzoek: Help ons toch, geef ons toch een vergif, wij willen deze ellende niet meemaken! Dokter, zult u het ooit voor uw verantwoording kunnen nemen, wanneer ik in een concentratiekamp word doodgemarteld? Zij zoeken mij, help mij toch! ${ }^{5}$

Onder vredesomstandigheden zou Stokvis, als rechtgeaard medicus, van oudsher juist beschermer van het leven, hier niet over hebben gepeinsd. Nu echter, onder de geldende omstandigheden, beraadde hij zich zeer serieus op de vraag of hij aan dit verzoek om hulp zou moeten voldoen. Niet veel later beschreef hij iets wat hem voor de oorlog net zo bizar zou zijn voorgekomen: het feit dat artsen hun patiënten nu, in plaats van hen beter te maken, zieker probeerden te laten lijken. Dat diende namelijk om hen te beschermen tegen deportatie: 'Het is in de geschiedenis der geneeskunde wellicht nog nimmer voorgekomen, dat de artsen zoo vindingrijk zijn geweest de menschen te helpen bij het simuleeren van ziekten.' ${ }^{6}$

Dit zijn voorbeelden van situaties die een arts in het vrije hedendaagse Nederland volstrekt vreemd zijn, maar voor Stokvis en de andere Joodse medici, die leefden en praktiseerden onder nationaalsocialistische heersers, was dit bit- 
tere realiteit. De beroepsuitoefening van deze artsen ging iets totaal anders inhouden dan zij ooit voor mogelijk hadden gehouden. Beroepsnormen die voorheen als vanzelfsprekend hadden gegolden, gingen wankelen en bleken op de nieuwe situaties nauwelijks toepasbaar. Maar als niets meer is wat het altijd was, hoe weet je dan hoe te handelen? Of zoals internist Jacques Reisel op 7 februari 1943 in zijn dagboek noteerde: 'En waar zouden wij onze gedachten en handelingen (al valt er vaak zo bitter weinig te handelen, maar ook niets doen kan in deze omstandigheden handelen betekenen!!) aan moeten toetsen als alle maatstaven veranderen of op zijn minst devalueren of vervlakken?'7

Hoe zat het bijvoorbeeld met de aloude medische zorgplicht ten opzichte van je patiënten? Moest je als arts nog op je post blijven als er van die post niets overbleef omdat je patiënten werden weggevoerd? Terwijl je eigen leven bovendien in gevaar was? Immers, de Joodse artsen zelf waren net zozeer vervolgden, die met een toenemende vrees voor het eigen bestaan moesten leven. Maurits Frenkel, die nog niet eens afgestudeerd arts was, herinnerde zich tijdens een interview in 2009 dan ook zijn innerlijke tweestrijd op het moment dat hij voor zijn eigen veiligheid koos en naar Zwitserland vluchtte. Hierbij liet hij zijn werk in het Nederlandsch Israëlietisch Ziekenhuis in Amsterdam achter: 'Het ethisch dilemma was het verlaten van de zaak, dat was het voor mij. Ik had geen eed met twee vingertjes opgestoken [...] maar ik voelde mij wel verplicht aan alle verplichtingen die het arts zijn, hoewel ik pas semi-arts was, aan mij oplegde. ${ }^{8}$

Salomon Koster, psychiater in Amsterdam, koos er eveneens voor een poging te wagen om zijn eigen leven in veiligheid te brengen. Hij dook onder, maar raakte in een diepe depressie en vroeg zich af of hij niet beter met zijn patiënten mee gedeporteerd had kunnen worden. Ook uit zíjn dagboek spreekt de vertwijfeling over wat van hem als arts verwacht werd: 'Dan nog liever naar Westerbork, of, desnoods, naar Polen, waar ik, als dokter, nog nuttig werk had kunnen doen, voor al die arme stakkerds.'

Direct daarna vroeg hij zich echter af wat voor zin dat daadwerkelijk gehad zou hebben. Dergelijke dilemma's waren om radeloos en wanhopig van te worden. Geen enkel 'moreel kompas' leek toegerust om in dergelijke situaties de juiste richting te wijzen. Berthold Stokvis werd daar dan ook bijna nihilistisch van en vroeg zich af of zijn beroep er nog wel iets toe deed:

Mijn werk was vroeger het belangrijkste van mijn bestaan. Tegenwoordig: onbetekenend. Of neen, toch is het eigenlijk weer het werk, dat mij in dezen tijd staande houdt. Als het mij te machtig wordt, verdiep ik mij in het werk 'le travail pour le travail'. Het werk, waartoe dient het nu? Wat doet alles ertoe? ${ }^{\text {Io }}$ 
Wat betekende het artsenberoep onder de omstandigheden waaronder Stokvis en zijn collegae moesten leven en werken? Deed het er nog iets toe? Stokvis betwijfelde het.

\section{WAAROM DIT BOEK?}

Dit boek probeert de positie van de door de nazi's vervolgde Joodse medici in Nederland invoelbaar te maken voor eenieder die bereid is zich in hen in te leven. Op basis van allereerst egodocumenten en persoonlijke mondelinge getuigenissen - dé aangewezen bronnen voor het benaderen van gedachten en gevoelens - maar ook met behulp van archiefonderzoek, ontstaat een beeld van de manier waarop 534 Joodse artsen in Nederland - 488 mannen en 46 vrouwen -, van wie de lotgevallen zijn na te gaan, de bezetting hebben ondergaan. Zo wordt zichtbaar of, en hoe hun beroep voor hen een rol bleef spelen en in hoeverre hun oorspronkelijk aan het medisch beroep verbonden plichten en voorrechten evolueerden. Duidelijk zal worden of het imperatief 'Vergeet niet dat je arts bent', zoals de vader van de jonge Duits-Joodse arts Hans Keilson zijn zoon op het hart drukte toen de omstandigheden hen dwongen afscheid van elkaar te nemen, te allen tijde nageleefd kon worden. ${ }^{\text {II }}$

Waarom dan een studie over enkel de Joodse artsen in Nederland tijdens de bezettingsjaren? Voor hun niet-Joodse collegae gold toch evenzeer dat zij onder vijandelijke heerschappij moesten werken? Ook zij moesten hun houding ten opzichte van door de bezetting veroorzaakte problemen bepalen. Ook over hen zijn interessante observaties te doen ten opzichte van hun beroepsuitoefening en hun zoektocht naar een moreel kompas om hun werk te blijven doen. ${ }^{\text {I2 }}$ Toch is er reden de Joodse artsen als een aparte groep te bestuderen.

Het grootste deel van de Nederlandse artsen verfoeide de nationaal socialistische visie op de maatschappij en op de taak van de artsenstand en gaf daarvan ook blijk. Zo organiseerden zij zich al snel na het begin van de Duitse bezetting in de artsenverzetsgroep Medisch Contact. Met dit collectief trachtten zij verzet te bieden tegen de nazificering van de medische stand. Zij schreven in I94I in een brief aan de Rijkscommissaris voor de bezette Nederlandse gebieden, Arthur Seyß-Inquart: 'Gebonden als wij ons weten aan de eed of de plechtige belofte waarmee wij ons ambt hebben aanvaard, gevoelen wij ons verplicht, $\mathrm{u}$ te verklaren dat wij trouw zullen blijven aan de hoge normen waarop sinds mensenheugenis ons beroep heeft gerust en dat wij in de uitoefening van ons beroep nimmer andere overwegingen zullen kunnen laten gelden dan zulke welke gerechtvaardigd zijn door ons geweten, ons plichtsbesef en onze wetenschap.' ${ }^{\text {I3 }}$ 
De artsen wilden vasthouden aan de ethiek die zij van voor de bezetting kenden, zo meldden zij de bezetter. ${ }^{14}$ De formulering klinkt bijzonder mooi en de onomfloerste stellingname tegen het vijandelijke regime is beslist moedig te noemen, maar was deze principiële opstelling echt altijd houdbaar? Kón de ethiek van voor de bezetting, gesymboliseerd door de eed van Hippocrates, nog wel in alle gevallen standhouden? Een deelnemer aan de Artsen-Veteranendag, in 2009 gehouden voor artsen werkzaam tijdens de Tweede Wereldoorlog, getuigde van een ijzeren beroepsplichts-besef door te zeggen: 'We zouden zelfs Adolf Hitler nog reanimeren. ${ }^{\text {Is }}$ Men kan zich afvragen of dit de juiste keuze is. Onder de specifieke omstandigheden van oorlog en vervolging had een dergelijk dilemma ook een politieke dimensie. Daarbij: wat te doen als meerdere andere levens gevaar lopen? Of het eigen leven? De Joodse artsen, zelf slachtoffer van de vervolging, maakten die situaties in sterk verhoogde mate mee. Bovendien werd hun door het Medisch Contact afgeraden mee te doen aan protestacties, omdat zij daarmee een te groot persoonlijk risico zouden nemen. ${ }^{16}$ Ook daarom is de geschiedenis van de Joodse artsen een andere dan de geschiedenis van de niet-Joodse.

In de historiografie over de Tweede Wereldoorlog in Nederland is eerder erkend dat de geschiedenis van het Joodse bevolkingsdeel wezenlijk afwijkt van de ervaringen van de niet-Joodse Nederlanders. Abel Herzberg schreef reeds in zijn Kroniek der Jodenvervolging uit 1950:

Het is Joodse geschiedenis, geen Nederlandse. Er is geen theorie en geen wet, die dit achteraf ongedaan kan maken. Er is rechtsherstel. De scherven van een stukgeslagen pot kan men lijmen, de barsten blijven en de eenheid is weg. Vanaf de veertiende mei 1940 zouden de Joden in Nederland hun eigen weg moeten gaan, ondanks alle hulp en alle medeleven. Zij kregen, tegen wil en dank, een eigen levenslot te dragen. ${ }^{17}$

In internationaal perspectief valt in dit verband het pleidooi van de historicus Philip Friedman op, die in 1957 een 'judeocentrische' geschiedschrijving van de Shoah voorstond, om de specifieke lotsverbondenheid te benadrukken. ${ }^{18}$ In de eerste naoorlogse jaren was dit echter nog geen gangbare mening. Althans niet in Nederland. De historiografie over de Tweede Wereldoorlog kenmerkte zich hier aanvankelijk door een sterke nadruk op de verzetsgeschiedenis en de nationale verbondenheid tegen de bezetter. De ervaringen van de (Joodse) slachtoffers stonden minder in de belangstelling. Het boek over de artsenverzetsgroep Medisch Contact van de Joodse historicus Philip de Vries uit 1949 paste nog in deze vroege traditie. ${ }^{19}$ De Joodse artsen en hun ervaringen kregen 
in dit werk nauwelijks aandacht. Volgens Madelon de Keizer en Marije Plomp, in hun studie van de herinneringscultuur rond de Tweede Wereldoorlog, hadden de Joden na de oorlog niet de kracht en de getalssterkte om tegen deze tendens in de historiografie op te staan en offerden zij 'hun gruwelijke herinneringen op [...] aan de nationale smeltkroesherinneringen van de naoorlogse Nederlandse natie. ${ }^{20}$

$\mathrm{Na}$ het proces tegen Adolf Eichmann in 1961, dat de wereld maandenlang in zijn greep hield, en nadat in Nederland de publicaties van Herzbergs Kroniek en vooral Jacques Pressers Ondergang in 1965 een groot publiek hadden bereikt, kwam er in bredere kring inzicht in het Joodse lijden tijdens de bezetting. Dit inzicht in en daarmee de belangstelling voor de Holocaust namen verder toe in de jaren zeventig met de publieke discussie rondom de vrijlating van de Drie van Breda (in Nederland actieve Duitse oorlogsmisdadigers) en in de jaren tachtig, toen het einde van de Koude Oorlog de definitieve afsluiting van de Tweede Wereldoorlog markeerde. Over het bestaan van deze ontwikkeling in het collectieve nationale geheugen en de historiografie heerst een breed gedeelde consensus onder Nederlandse historici. ${ }^{21}$ Historicus Ido de Haan wees er echter tegelijkertijd op dat in de professionele geschiedschrijving vanaf diezelfde jaren tachtig ook weer aandacht kwam voor de samenhang tussen de Joodse lotgevallen en de context van de Nederlandse samenleving onder Duitse overheersing. ${ }^{22}$ Monografieën over andere beroepsgroepen tijdens de bezetting onder de loep nemend, treft men daar dan ook geen enkele aan die alleen over de Joodse beroepsbeoefenaars gaat. In de werken van bijvoorbeeld Hans Mulder over kunstenaars, Pauline Micheels over musici, Derk Venema over rechters, Joggli Meihuizen over advocaten en Klaas van Berkel over de Koninklijke Nederlandse Akademie van Wetenschappen werd aan de Joodse beroepsbeoefenaars aandacht besteed in de context van de totale beroepsgroep. ${ }^{23}$ Er zijn aanvullende redenen die desondanks een aparte monografie over juist de Joodse artsen rechtvaardigen. Op verschillende punten weken zij af van Joden in andere beroepsgroepen.

Allereerst: de specifieke mogelijkheden die juist het artsenberoep leek te bieden. In de genoemde werken over andere beroepsgroepen gingen de hoofdstukken over de Joodse vakgenoten met name over hun verwijdering uit de algemene beroepsgroep. Het beeld ontstaat dat zodra die verwijdering geëffectueerd was, het lot van de besproken Joodse beroepsbeoefenaars opging in het overkoepelende Joodse fatum van rechte- en brodeloosheid, deportatie en moord. Dat deze mensen ooit een bepaald beroep hadden uitgeoefend, was daarbij dan niet meer terzake doende en onderscheidde hen niet van hun lotgenoten. Een Joodse advocaat ging geen ander noodlot tegemoet dan een Joodse kunstenaar. 
Met het artsenberoep lag dat anders. Hoewel de Joodse artsen evenzeer als andere beroepsbeoefenaars geïsoleerd en uit collegiale verbanden met nietJoden uitgesloten werden en slechts nog praktijk voor Joodse patiënten mochten uitoefenen, hield hun werkzame leven daarna nog niet op. Zelfs tot in de vernietigingskampen aan toe kon het arts-zijn betekenen dat de betrokkene in zijn beroep kon werken, zo blijkt uit diverse getuigenissen. Bij aankomst in Auschwitz-Birkenau werd omgeroepen: '̈̈rzte und Pfleger austreten. ${ }^{.24}$ De bekendste Nederlandse oorlogshistoricus Loe de Jong meldde over de toestand in de kampen een bijzondere positie voor gevangenen-artsen: 'Er was in die grote massa misschien maar één kategorie gevangenen waarvoor vele ss'ers enig schuw ontzag koesterden: de medici. ${ }^{25}$ Zowel Elie Aron Cohen als zijn collega-arts Ellis Hertzberger hebben na de oorlog getuigd dat zij hun gevangenschap in Auschwitz overleefden dankzij hun beroep. ${ }^{26}$ 'Werkelijk, arts was het beroep voor de kampen,' aldus Elie Cohen. ${ }^{27}$ Het arts-zijn betekende kennelijk meer dan alleen een beroep of bestaansmiddel; het was voor deze beroepsbeoefenaren de sleutel tot overleven en had het bestaan in de allerbasaalste zin mogelijk gemaakt.

Ten tweede was het artsenberoep niet zomaar een manier om je brood te verdienen. Ook in vredestijd was arts-zijn al meer geweest dan alleen een beroep. Het was een roeping. Zo werd dat althans gevoeld door vele medici, zowel Joods als niet-Joods. Van oudsher was dit gevoel van roeping bij Joodse artsen wellicht zelfs nog iets duidelijker aanwezig, ingegeven door de volgens velen speciale historische banden tussen het Jodendom en de geneeskunst. Joden kozen traditiegetrouw vaak voor de medische studie en het artsenvak, aldus diverse auteurs. 'Few occupations are as immediately linked to a group as medicine is to the Jews', stelde bijvoorbeeld de Amerikaanse hedendaagse historicus John Efron..$^{28}$ Medisch-historicus Sherwin Nuland noemde het een legendarische en zelfs met mythen vervlochten relatie tussen Joden en geneeskunde. ${ }^{29}$ Voorbeelden van wetenschappelijk onderzoek over deze relatie stammen al van vorige eeuwen. Onder anderen Moritz Steinschneider, Samuel Krauss en Harry Friedenwald toonden in hun studies vooral de verdiensten van individuele beroemde Joodse artsen in vervlogen tijden. ${ }^{30}$ De modernere schrijvers over dit onderwerp, die veelal onder invloed stonden van de brede belangstelling voor de sociale geschiedenis van de geneeskunde, ${ }^{3 \mathrm{I}}$ benadrukten naast de verschillende verdienstelijke Joodse artsen ook de band tussen het Jodendom als religie en cultuur enerzijds en de geneeskunde anderzijds. ${ }^{32}$ In de Joodse religieuze geschriften is namelijk al een sterke belangstelling voor gezondheid en ziekenzorg te ontwaren. Zo zijn van de 613 'mitswot' (geboden) die de Thora voorschrijft, er liefst 2I3 van min of meer medische aard. ${ }^{33}$ 
De Allerhoogste zelf wordt gekenschetst als geneesheer (Exodus 15:26). ${ }^{34}$ Ook de Talmoed onderstreept het belang van gezondheidszorg, met het verbod in een stad of dorp te gaan wonen waar geen arts is (Sanhedrin I7b). ${ }^{35}$ Nog belangrijker dan dat al is het Joodse principe 'Pikoeach Nefesj': de oneindige, allesoverstijgende waarde van behoud van menselijk leven. Een leven redden is in het Jodendom belangrijker dan wat ook, maakt alle ge- en verboden ondergeschikt, met uitzondering van de verboden op moord, incest en afgoderij. Wie levens redt als arts, kan vanuit die religieuze gedachte dus rekenen op instemming en respect. Ook in cultureel opzicht bood het artsenvak onder Joden van oudsher al aanzien, omdat in de Joodse traditie leren en studeren hoog gewaardeerd wordt. Omdat daarbij in vele diasporalanden de medische studie vaak een van de weinige studies was die toegankelijk waren voor Joden, kwam er bij die religieuze en culturele ook een maatschappelijke motivatie om voor het medische vak te kiezen. Met het beoefenen van de geneeskunde konden Joden al vroeg een mate van maatschappelijk succes bereiken die op andere manieren eeuwenlang vrijwel onhaalbaar zou blijven. ${ }^{36}$

Een derde reden voor een apart boek over de Nederlandse Joodse artsen is hun grote getal, zeker ook in verhouding tot het totaal aantal artsen in Nederland in de tijd waarover dit boek gaat. In het gedenkboek voor de in de Tweede Wereldoorlog omgekomen Joodse artsen, Anafiem Gedoeiem (Gebroken takken), werd gesproken van 600 Joodse artsen op een totaal van ruim $6500 \mathrm{Ne}-$ derlandse medici. ${ }^{37}$ Loe de Jong hanteerde in de verschillende delen van zijn Koninkrijk verschillende aantallen Joodse artsen: nu eens 370, dan weer 677 en 'bijna zevenhonderd'..$^{38}$

In dit onderzoek heb ik van 534 personen vastgesteld dat zij Nederlands arts waren en dat zij door de bezetter als Jood waren aangemerkt en om die reden vervolgd werden. Dit betekent dat dit boek gaat over een groep die ongeveer 8 procent van de Nederlandse artsenstand uitmaakte. Afgezet tegen het percentage Joden op de totale Nederlandse bevolking van vlak voor de oorlog, een percentage van I, 4 , is dat opvallend hoog. Alleen dit al maakte hen tot een zichtbare groep binnen de artsenstand, zeker op het moment dat de bezetter een scheiding tussen Joods en niet-Joods aanbracht.

Hierbij moet men wel in ogenschouw nemen dat de hier beschreven groep artsen door de bezetter als Joods was aangemerkt, ongeacht hun eigen persoonlijke binding met de Joodse achtergrond. Die binding zal voor ieder van hen verschillend zijn geweest, en bijvoorbeeld voor een seculiere zionist anders hebben aangevoeld dan voor een vrome, traditioneel levende arts en ook weer totaal anders dan voor een gedoopte, gemengd gehuwde dokter. De laatste zal zichzelf mogelijk helemaal niet als een Joodse arts gezien hebben en ook door 
collegae niet als zodanig bekend zijn geweest. De nationaalsocialisten hadden daar echter geen boodschap aan. De door hen in gang gezette Jodenvervolging zorgde ervoor dat totaal uiteenlopende individuen een lotsverbondenheid gingen delen. Zo kan van de verhalen van de 534 individuen een gezamenlijke geschiedenis geschreven worden.

\section{INTERNATIONALE LITERATUUR}

Een lotsverbondenheid deelden de Nederlandse Joodse artsen uiteraard ook met Joodse artsen in andere bezette Europese landen. Buiten Nederland zijn reeds enkele studies naar de lotgevallen van Joodse artsen tijdens de naziperiode verricht. Daarmee is een basis voor vergelijking geboden en kunnen deelvragen voor het onderzoek in Nederland geformuleerd worden.

Ook in andere landen waren vaak relatief veel Joodse artsen werkzaam. In Duitsland bijvoorbeeld was in de jaren twintig nog I6 procent van de artsen Joods, in Berlijn zo'n 30 procent, terwijl Joden o,9 procent van de totale bevolking uitmaakten. ${ }^{39}$ Voor hen, door historicus John Efron algemeen gekarakteriseerd als 'seculiere Joodse intellectuelen' die volledig geïntegreerd waren in de Duitse maatschappij, waren uitsluiting en vervolging al ver voor de bezetting van Nederland bittere realiteit. ${ }^{\circ}$ In 1933 moesten de Duitse ziekenfondsen de Joodse artsen ontslaan, in 1935 werd er een numerus clausus voor hen ingevoerd. ${ }^{4 \mathrm{I}}$ In 1938 mochten slechts enkele Joodse artsen, in de grote steden waar veel Joden woonden, blijven praktiseren, uitsluitend voor Joodse patiënten. In de jaren 1933 tot 1945 vluchtten dan ook 4500 tot 6000 Joodse artsen uit Duitsland. Hitler leek de uitschakeling van deze medici met extra voortvarendheid door te willen voeren. In zijn ogen waren zij niet alleen zelf Joods, zij hielden ook Joods leven in stand. Bovendien wilde Hitler de Duitse niet-Joodse bevolking bang maken voor de behandeling door een Joodse arts door haatzaaiende propaganda over de zogenaamd barbaarse praktijken van Joodse artsen te laten verspreiden. ${ }^{42}$ Duits-Joodse artsen konden hierdoor niet of nauwelijks nog functioneren als arts en dat maakt bij voorbaat een vergelijking met juist de beroepsuitoefening van de Nederlandse Joodse artsen problematisch.

Wel is over de vervolging van de Duitse Joodse artsen enige literatuur beschikbaar. Michael Kater schreef over hen in breder verband in het werk $\mathrm{Me}$ dicine and the Third Reich van John Michalczyk en ook in zijn eigen studie Doctors under Hitler wijdde hij een hoofdstuk aan de 'Persecution of Jewish Physicians', waarin hij bijvoorbeeld meldde dat 5 procent van de Joodse artsen in Duitsland onder Hitler zelfmoord pleegde. ${ }^{43}$ John Cornwell lichtte in 
zijn Hitler's Scientists toe waarom zoveel artsen tot die daad gedreven werden: 'Casual torture, terror and murder of Jewish doctors' was aan de orde van de dag. ${ }^{44}$ Saul Friedländer beschreef de gebeurtenissen rondom de vervolging en grootschalige vluchtacties van de Joodse artsen in zijn standaardwerk NaziDuitsland en de Joden. ${ }^{45}$ Daarnaast zijn plaatselijke of regionale gedenkboeken voor de vermoorde artsen redelijk vertegenwoordigd. Udo Benzenhöfer bijvoorbeeld schreef over de Joodse artsen in Hannover, Barbara Becker-Jakli bracht de geschiedenis van het Joodse ziekenhuis in Keulen onder de aandacht en de Amerikaan Daniel Silver deed hetzelfde voor het Joodse ziekenhuis in Berlijn. ${ }^{46}$ Eduard Seidler schreef een herdenkingsboek voor de Duitse Joodse kinderartsen, die liefst 54,4 procent uitmaakten van het totale aantal kinderartsen in vooroorlogs Duitsland. ${ }^{47}$ Tot op heden blijven er initiatieven in de Duitse geneeskundige wereld ontstaan om de destijds verjaagde en vermoorde collegae te herdenken. ${ }^{4}$ Silver vormde met zijn boek over het unieke verhaal van het Joodse ziekenhuis in Berlijn een uitzondering op de regel dat deze werken met name biografische gegevens van de vervolgde artsen bevatten. Silvers werk vertelt ook over de bijzondere taken die de Joodse artsen in het ziekenhuis uitvoerden, zoals het opgenomen houden van gezonde mensen. Temidden van de vernietigende kracht van de naziheerschappij en later de geallieerde bombardementen op Berlijn bleef dit ziekenhuis overeind. Het personeel en de patiënten zochten hun toevlucht in dit relatief veilige gebouw. Na de Duitse capitulatie trof een Amerikaanse Joodse soldaat het ziekenhuis in functie aan, met artsen en verpleegsters in keurige witte jassen, en met nog een handjevol Joodse patiënten. Silver portretteerde daarbij de Joodse geneesheer-directeur als een militaristische Pruis, die zelf aanvankelijk weinig ophad met het Jodendom en als directeur als een potentaat kon optreden, maar daarmee kennelijk toch de juiste snaar bij de nationaalsocialistische autoriteiten wist te raken en het ziekenhuis zo in stand kon houden. Hij werd daarbij echter wel geconfronteerd met het moeten kiezen tussen mensen: wie zou wel binnen de ziekenhuismuren mogen blijven en wie niet? Een duivels dilemma. Hoe geneesheerdirecteur Lustig daarmee omging staat nog altijd ter discussie. ${ }^{49}$ Wellicht is er iets vergelijkbaars gebeurd in de Joodse ziekenhuizen in Nederland.

Over de lotgevallen van de Joodse artsen in Frankrijk bestaan twee monografieën, die een gedetailleerd beeld schetsen van de systematische uitsluiting van Joodse artsen uit de Franse artsenstand. Het gaat hier om de werken van Henri Nahum, La médécine française et les Juifs I930-I945 (Parijs 2006) en van Bruno Halioua, Blouses blanches, étoiles jaunes (Parijs 2000). ${ }^{50}$ Beide auteurs gingen in op de protectionistische maatregelen die al vanaf de jaren dertig in Frankrijk de instroom vanuit Midden- en Oost-Europa van Joodse medisch 
studenten en later ook Joodse artsen in de Franse universiteiten en artsenpraktijken aan banden probeerden te leggen. In Frankrijk had het merendeel van alle Joden een Oost-Europese achtergrond en daarom dus een andere nationaliteit of in ieder geval een ander geboorteland, waardoor zij als vreemdelingen werden gezien..$^{\mathrm{SI}}$ Zowel Nahum als Halioua toonde aan dat de Franse artsenstand al voor de oorlog protectionistisch handelde en daarmee met name Joodse artsen benadeelde: vele Franse artsen waren ervan overtuigd dat het aantal Joodse artsen beperkt moest worden om genoeg werkgelegenheid voor Franse artsen te behouden en zij steunden maatregelen die dit bewerkstelligden..$^{52} \mathrm{Het}$ onrecht de Joodse collegae angedaan door de Franse artsenstand, werd door Halioua scherp aan de kaak gesteld. Nahum nuanceerde iets door ook individuele steunacties van niet-Joodse aan Joodse artsen te noemen, maar ook hij toonde aan dat op hoger niveau het protectionisme de toon zette. ${ }^{33}$ De vraag dient zich aan of iets dergelijks ook in Nederland speelde.

Op de beroepsuitoefening van de Franse Joodse artsen onder de nieuwe omstandigheden ging Bruno Halioua alleen in het hoofdstuk over de periode van de razzia's dieper in. De toestand in het Joodse Rothschild-ziekenhuis te Parijs komt hier aan bod. De artsen kregen er veel patiënten uit het doorgangskamp Drancy, die ter plekke niet behandeld konden worden. Artsen ondernamen pogingen om deze gevangen patiënten via het ziekenhuis te helpen ontsnappen. Omdat zij hiermee een groot risico namen, en hun eigen leven en dat van hun familieleden op het spel zetten, ontstond het dilemma of zij hier wel of niet mee door moesten gaan. ${ }^{54}$ Nahum meldde voorts dat de meeste Franse Joodse artsen al in de herfst van 1942 geen praktijk meer voerden, omdat dat hun onmogelijk was gemaakt. ${ }^{55}$ Relatief veel Joodse artsen ontvluchtten daarop Frankrijk of sloten zich aan bij het (communistische) verzet. ${ }^{56}$ Een logische vraag zou zijn in hoeverre dat ook in Nederland het geval was.

Over de artsen in het getto van Warschau is het meest bekend. Over hun activiteiten is onder ander door de Israëlische (medisch) historici Daniel Nadav en Shaul Shasha geschreven. ${ }^{57}$ Ook persoonlijke herinneringen van artsen die zelf in dat getto werkten, zijn vastgelegd, zoals door Adina Szwajger en Mordechai Lensky. ${ }^{58}$ De Canadees Charles Roland schreef zowel in John Michalczyks verzamelwerk als in een eigen monografie over de geneeskunde in het getto van Warschau. ${ }^{59}$ Hier woonden en werkten ongeveer 700 Joodse artsen, die hun werk trachtten te doen, terwijl buiten op straat de mensen letterlijk lagen te creperen. Teken van hun volhardendheid om het medische beroep uit te blijven oefenen op een manier die deze artsen zinnig vonden, was de oprichting van een medische school in het getto en een groots opgezette wetenschappelijke studie naar de gevolgen van honger, de 'ziekte' waaraan de 
bewoners van het getto massaal leden. ${ }^{60}$ Roland citeerde een van de studenten van de medische school die zijn motivatie voor de studie weergaf: 'We had the choice of total desperation, total demoralization, suicide (some did commit suicide), escapism (whiskey [more likely, vodka] or whatever they could find), but instead we started to study.' ${ }^{31}$ Volgens Roland was de hang naar wetenschappelijke studie en werk naast een manier om de wanhoop tegen te gaan en de schijn van normaliteit op te houden ook een vorm van verzet: 'It was not an escape from the dreadful reality but an expression of opposition to the iniquity and the desecration of cherished values. ${ }^{62}$ Dit valt inderdaad binnen de definitie van Joods verzet, ofwel 'Amidah', zoals Yehuda Bauer die hanteerde in zijn Rethinking the Holocaust. Amidah behelst immers alle vormen van gewapende en ongewapende actie - ofwel agency - tegen het anti-Joodse beleid van de nazi's en hun medewerkers. Zo zijn daar te noemen het smokkelen van voedsel de getto's in, zelfopoffering om dierbaren te laten overleven, en culturele, educatieve, religieuze en politieke activiteiten om het moreel hoog te houden. Bauer noemde daarbij ook expliciet 'the work of doctors, nurses, and educators to consciously maintain health and moral fiber to enable individual and group survival. ${ }^{{ }^{6} 3}$ Mogelijk waren er ook in Nederland dergelijke initiatieven.

Vergelijkbare situaties zouden er in Nederland bijvoorbeeld ook kunnen hebben bestaan wat betreft de chirurgische praktijken in het getto van Warschau. Roland verhaalde van een plastisch chirurg die besneden voorhuiden trachtte te reconstrueren teneinde de mannen in kwestie als niet-Joden door het leven te kunnen laten gaan. Zelfs neuzen werden in het getto geopereerd om een minder geprononceerd 'Joods' uiterlijk te bewerkstelligen. Medisch gezien waren dit natuurlijk onnodige en bizarre behandelingen. Dit alles stond echter in het teken van het vergroten van de uiteindelijke overlevingskansen van de patiënten. ${ }^{64}$ Hetzelfde gold voor abortus provocatus, een destijds medisch ethisch ongeoorloofde handeling, die desondanks onder de omstandigheden van het getto veelvuldig werd verricht. ${ }^{65}$ Of een dergelijke handeling zou vallen onder 'sanctification of life', dat staat voor de overweldigende impuls om het leven te bewaren te midden van de dood zonder gebruik te maken van geweld, en dat een belangrijk onderdeel van Amidah vormt, is uiteraard zeer discutabel. Immers, men probeerde weliswaar het leven van de moeder te redden, maar wel ten koste van het leven van het kind. Hier is sprake van een 'healing-killing-paradox' ${ }^{66}$ Bauer zou dit onder de gegeven omstandigheden van een wanhopige 'struggle for life' niet willen veroordelen, maar het ook niet onder Amidah willen scharen. ${ }^{67}$

De plichtsbetrachting van de Joodse artsen in het getto van Warschau was volgens Roland zelfs soms echt niet zoals die zou behoren te zijn: 'Life had be- 
come cheap in the ghetto, and the sympathy of some medical men dissipated in the face of so much misery and death.' Maar, zo stelde hij direct daarna: 'And yet, in the moments of greatest horror, there were doctors who went on believing that their duty was to strive and to save.' ${ }^{68}$ Dat deze laatsten er ook waren, was dus juist heel bijzonder. Roland concludeerde dan ook bewonderend: 'In addition to their general contribution to morale within the ghetto, and to our appreciation of the school and the research studies as victories of the human spirit, they achieved concrete goals. ${ }^{39}$ De artsen verdienden krediet omdat ze hogere doelen boven bepaalde voorheen geldende normen, regels en plichten hadden gesteld. Men zou hieruit kunnen deduceren dat Roland het geneeskundig optreden van de artsen categoriseerde als ingegeven door een teleologisch of zelfs utilitaristisch moreel kompas. Een teleologische ethiek is gericht op het uiteindelijke doel van het handelen en het utilitarisme streeft daarbij specifiek naar de beste uitkomst voor zo veel mogelijk mensen. Dit in tegenstelling tot een zogenaamde deontologische-, deugdenethiek, waarbij niet het doel van de medische handeling telt maar de intrinsieke waarde van de handeling zelf, de norm die als uitgangspunt voor het handelen dient. ${ }^{70}$ De Britse promovenda Dana Lewis prefereerde echter de term 'constructief' boven 'utilitaristisch' voor de handelwijze van de getto-artsen. ${ }^{7 \mathrm{I}}$ Volgens haar pasten de artsen hun medisch handelen effectief aan aan de omstandigheden die de Shoah veroorzaakte en vonden zij daarmee een manier om verzet te bieden tegen het onrecht dat hun werd aangedaan. Lewis schreef over artsen die stopten met het diagnosticeren van besmettelijke ziekten, omdat zij wisten dat patiënten met een dergelijke diagnose vermoord zouden worden. In plaats daarvan stuurden de artsen deze patiënten ziek naar huis. Een ander voorbeeld was dat van de arts die haar patiënten op de kinderafdeling een overdosis morfine toediende voordat dezen gedeporteerd zouden worden. Lewis oordeelde over al deze medische handelingen: 'I view this medicine as heroic.' 72

Dit stelde ook Michael Katz in Hunger disease, alleen dan nadrukkelijk vooral vanwege hun wetenschappelijk werk, dat onbediscussieerd tot Amidah gerekend kan worden. Hij vond dat de hongerstudie van de Joodse artsen een 'document of heroic human endeavor' was. ${ }^{73}$ Recentelijk, in het najaar van 20I4, werd Jewish Medical Resistance in the Holocaust gepubliceerd, onder redactie van Michael Grodin, arts en hoogleraar medische ethiek in Boston. Met name de zeer extreme situaties die artsen in de getto's in Midden- en OostEuropa en in de nazikampen meemaakten staan hierin centraal. Auteurs zijn onder anderen Charles Roland en Paul Weindling. Ook hier worden de Joodse artsen geprezen vanwege de 'greatness of their ethical and humanistic stance during the Holocaust.' 74 De vraag dringt zich op hoe de handelingen van de 
Joodse artsen in Nederland te classificeren zijn: handelden zij vergelijkbaar? Was er dan in hun geval sprake van een teleologische of zelfs utilitaristische motivatie van hun handelen of van een deontologische? En kan hieraan, naar internationaal voorbeeld, een waarde-oordeel verbonden worden: handelden de artsen in bepaalde situaties constructief of heroïsch? Pasten bepaalde handelingen binnen de definitie van Amidah? Hoe zat het met de 'sanctification of life' en de 'healing-killing-paradox' in het medisch handelen van de Nederlandse Joodse artsen?

\section{GESCHIEDENIS ALS MORELE LES}

Roland, Lewis en Katz zagen de beroepsuitoefening van de artsen in het getto van Warschau als een voorbeeld voor artsen van nu. Voor hen was de educatieve, moraliserende waarde van de geschiedenis daarmee een reden om de beroepsuitoefening van Joodse artsen onder nazi-heerschappij onder de loep te nemen. Dit is echter een reden die in historische kringen met enige reserve bekeken wordt. Een moraliserende motivatie voor historiografie is in Nederland immers sinds de jaren tachtig uit de mode geraakt. Hier was tot voor kort met name een historiserende tendens waarneembaar, waarbij de morele dimensie uit de geschiedschrijving werd geweerd. De oraties van Hans Blom en - in mindere mate - Jan Bank in 1983 hebben hiertoe de aanzet gegeven. ${ }^{75}$ Niet iedereen kon zich hierin vinden. Bijvoorbeeld historicus Saul Friedländer toonde zich een fel tegenstander van het weglaten van de moraal. ${ }^{76}$ Ook de Nederlandse socioloog Abram de Swaan, die ook recentelijk weer in dit debat van zich liet horen, reageerde eind jaren tachtig al met waardering op het werk van De Jong en diens heldere tweedeling in goed en fout:

Wat toen kwaad was, dat is duidelijk, en al wat daartegenin ging dat is goed. Ik ben het daarmee eens. De hel heeft echt bestaan, in onze tijd van leven. Wie die hel heeft aangericht is uit den boze. Als de woorden hels en duivels iets betekenen, dan staan ze voor het nationaal socialisme en zijn misdaden. ${ }^{77}$

Toch was de historiserende ontwikkeling niet tegen te houden, waarbij ook een steeds verdere nivellering van slachtofferschap en daderschap in de historiografie gewoon werd. Evelien Gans noemde dit treffend: 'Iedereen een beetje slachtoffer, iedereen een beetje dader. ${ }^{3}{ }^{7}$ Deze tendens leidde onder meer tot Grijs verleden van Chris van der Heijden. Het centrale hoofdstuk in dit werk 
draagt de veelzeggende titel: 'Ik dobber en blijf drijven', in duidelijke tegenstelling tot het meer heldhaftige credo 'Luctor et emergo' (Ik worstel en kom boven). ${ }^{79}$ Hoofdbron voor dit hoofdstuk was overigens het manuscript van de Joodse arts Ruben Bollegraaf uit Oss. En hoewel Van der Heijden zijn latere proefschrift Dat nooit weer heeft genoemd, een moreel imperatief implicerend, blijft die titel toch een negatief credo. Zoals Ido de Haan opmerkte: dat lijkt 'de spreker [...] te ontslaan van de plicht om in positieve zin aan te geven hoe de maatschappij ingericht moet worden'. ${ }^{80}$

Het zal niet verbazen dat hierop de laatste jaren weer een tegengeluid hoorbaar is. De huidige NIOD-directeur Marjan Schwegman en onderzoeker Jolande Withuis hebben een statement gemaakt door te pleiten voor herwaardering van heldendom in de context van de Tweede Wereldoorlog. ${ }^{8 \mathrm{~S}}$ Schwegman was daarbij geenszins van plan terug te keren naar een romantische verheerlijking van het verzet, maar vond bewondering voor mensen die verzet pleegden vaak omdat zij vasthielden aan wat zij zelf juist 'gewoon' vonden - wel op zijn plaats. ${ }^{82}$ Uit die bewondering kan ook een educatief potentieel ontstaan. In protagonist Pim Boellaard, ronduit verzetsheld genoemd, zag Withuis een voorbeeld dat 'ons veel kan leren over het samen-moeten-leven onder de ergste omstandigheden, over het overleven van geweld, vervolging en onmenselijkheid'. ${ }^{83}$

In Israël onderkent men ook het educatieve potentieel van voorbeelden stellen vanuit de geschiedenis. Yehuda Bauer schreef in 200r: 'A historian must also be a teacher. ${ }^{84}$ In Haifa bevindt zich het Technion-instituut, waar het Program for the Study of Medicine and the Holocaust is opgezet met als doel aankomend artsen het denken over ethiek onder extreme omstandigheden mee te geven: 'The courage required to be a healer, especially in extreme circumstances, is a theme with potential for further development as a curriculum enhancer.' ${ }^{85}$ Onder anderen arts en medisch historica Tessa Chelouche houdt zich in Haifa bezig met onderzoek naar de Joodse artsen ten tijde van de Tweede Wereldoorlog. ${ }^{86}$ Dit ook in het kader van het internationaal gecoordineerde project vanuit Boston, waarover Michael Grodin de leiding voert. Chelouche publiceerde reeds in 2005 in Medicine and Law het artikel 'Ethical Dilemmas Faced by Jewish Doctors during the Holocaust' waarin zij de memoires van artsen die gevangenen waren in verschillende concentratiekampen en ook getto's bestudeerde. De healing-killing-paradox werd in het artikel in meerdere vormen getoond. ${ }^{87}$ Het dilemma van enerzijds meewerken aan selecties voor de gaskamers om anderzijds mensen daarvoor te kunnen behoeden beschreef Chelouche bijvoorbeeld indringend. Ook abortus provocatus of het doden van een pasgeborene, bedoeld om de moeder te redden, noemde zij. 
Zeer extreme keuzes, onder zeer extreme omstandigheden.

In dit boek zullen de concentratiekampen buiten de Nederlandse landsgrenzen buiten beschouwing gelaten worden, waarmee de beschreven situaties iets minder extreem zullen zijn, maar toch zijn er vergelijkingen te maken en is er mogelijk een les te leren. Chelouche onderschrijft het belang van kennisneming van de ethische dilemma's van de Joodse artsen voor artsen en medisch studenten van nu. Collega-arts Alan Jotkowitz uit Beer-Sheva deed dat evenzeer. Hij bestudeerde de rabbinale responsa (Joods-juridische antwoorden) op medisch ethische dilemma's tijdens de Shoah, zoals de casus van rabbijnen die onder de gegeven omstandigheden toestemming gaven tot het plegen van abortus provocatus. Zijn conclusie over de gevonden dilemma's en responsa luidde: 'They can contribute to the discourse on modern dilemmas in medical ethics. ${ }^{88}$ Wellicht zou men in de ervaringen van de Joodse collegae toen ook in Nederland een 'curriculum enhancer' kunnen zien. ${ }^{89}$

\section{MEDISCHE ETHIEK IS VERVORMBAAR}

In Israël onderwijst men de medisch studenten niet alleen over de Joodse artsen, maar ook over de nazi-artsen in het Duitsland van Adolf Hitler. Hun misdragingen dienen in het lesprogramma als waarschuwing voor de toekomstige generatie medici. Wereldwijd zijn deze misdragingen ook onderwerp geweest van talrijke historische studies, vele malen talrijker dan de studies over de Joodse artsen..$^{\circ}$ Voor een studie over de Joodse artsen in Nederland en hun zoektocht naar hoe zij hun beroep vormgaven, is deze context van artsen die in het wetenschappelijk hoog aangeschreven buurland opereerden, zeker van belang. ${ }^{9 \mathrm{I}}$ De misdragingen van de nazi-artsen vormen namelijk hét bewijs dat medische ethiek kan veranderen en zelfs volledig kan perverteren. Met de eed van Hippocrates als universele of in elk geval breed gedeelde morele leidraad zou het paradigma van het artsenberoep als een te allen tijde moreel zelfregulerende discipline gewaarborgd moeten zijn, aldus medisch historicus Robert Baker. ${ }^{92}$ Maar dat bleek niet zo te zijn. De nazi-artsen behandelden patiënten onmenselijk en legden daarbij normen en waarden uit de eed van Hippocrates en de gangbare medische ethiek volledig naast zich neer om die te vervangen door een hele eigen 'ethiek'. Nadat de nazi-artsen in de jaren I930 en I940 het tegendeel van Bakers stelling hadden bewezen, bestond er dan ook grote behoefte aan een duidelijker vastgelegde professionele moraal die nationale verschillen oversteeg. ${ }^{93}$ In de geschiedschrijving van de medische ethiek wordt in brede kring de mening gedeeld dat met deze naoorlogse morele behoefte de 
geschiedenis van het vak medische ethiek pas echt een aanvang nam. ${ }^{94}$ In 1948 werd in de Verklaring van Genève een nieuwe formulering van de artseneed aan de wereld gepresenteerd en in het jaar daarvoor had de Code van Neurenberg al internationaal geldende concrete normen geformuleerd voor het doen van medische experimenten op mensen. Een paradigma-verschuiving van een paternalistische geneeskunde naar autonomie voor de patiënt vond mede naar aanleiding van deze naoorlogse herevaluatie plaats om te voorkomen dat artsen ooit nog misbruik van hun patiënten konden maken zoals de nazi-artsen dat gedaan hadden. 95

Toen zij proeven op gevangenen in concentratiekampen uitvoerden, hielden nazi-artsen zich bijvoorbeeld bepaald niet aan het 'niet-schaden-principe', in de eed van Hippocrates verwoord. En hun eugenetische 'euthanasie'-programma, waarbij gehandicapten op grote schaal gedood werden om te voorkomen dat zij zich voortplantten, kan onmogelijk worden uitgelegd als de Hippocratische waarde 'in het belang van de patiënt handelen', net zo min als hun latere medewerking aan selecties voor de gaskamers in vernietigingskampen. Onderzoek heeft laten zien dat de verantwoordelijke artsen deze handelingen aan hun eigen geweten konden uitleggen, omdat zij niet de individuele mens als hun patiënt zagen, maar het Duitse Rijk, dat was aangevreten door 'bacillen', oftewel Joden en andere 'minderwaardigen', en dat door middel van rigoureuze uitroeiing van het ziekteverwekkende element 'genezen' moest worden. ${ }^{96}$ Bovendien was vermenging van die 'minderwaardigen' met het 'arische ras' een gevaar voor de kracht van dit ras: degeneratie van het Duitse volk zou onherroepelijk plaatsvinden als hieraan geen paal en perk werd gesteld. Het Duitse volk, immers bestaande uit 'Übermenschen', moest en zou zegevieren. ${ }^{97}$ Voor de nazi-artsen heiligde dit doel alle middelen. Zij hanteerden in hun handelen dan ook een eigen, vanuit hun denktrant teleologisch of utilitaristisch te noemen 'ethiek'. ${ }^{98}$ Met een dergelijke morele leidraad konden ze hun handelen voor zichzelf verantwoorden. ${ }^{99}$ Maar eigenlijk was hier geen sprake meer van ethiek, teleologie of utilitarisme. Zoals Loe de Jong het verwoordde: 'Hun geweten was geperverteerd. Bij hen gold elke activiteit die ten voordele van Duitsland leek te strekken, als "goed" of althans als moreel toelaatbaar.' ${ }^{\text {'оo }}$

Artsen deden niet alleen mee aan de nazipraktijken, de geneeskunde stond ook aan de wieg van het nationaalsocialistische gedachtegoed. De nazi-ideologie paste biologische en medische theorieën toe op de maatschappij. Allereerst werd het darwinisme, met zijn uitleg van de natuur in termen van 'survival of the fittest', bereikt door 'struggle', door Hitler misbruikt. Hij vertaalde 'survival of the fittest' naar 'hegemonie van het Germaanse ras' en de 'struggle' die 
daarvoor geleverd moest worden naar het uitroeien van andere rassen. De internationale stroming in de geneeskunde die 'eugenetica' werd genoemd voegde daaraan toe dat erfelijkheid van ziekten, ongezonde eigenschappen en zelfs criminaliteit tot 'degeneratie', achteruitgang van de volksgezondheid, kon leiden als mensen die deze erfelijke eigenschappen bezaten zich voortplantten. De nationaalsocialisten telden er een rassentheorie bij op en hiermee was de voedingsbodem voor een dodelijke rassenpolitiek gecreëerd. ${ }^{\text {Ior }}$ Van sterilisatie van gehandicapten en misdadigers als maatschappijhygiënische maatregel in de jaren twintig, via 'euthanasie' van dezelfde categorieën mensen in de jaren dertig, naar machinale massamoord van 'minderwaardige rassen' in de jaren veertig: het bleek mogelijk. En ook artsen schrokken er niet voor terug. ${ }^{\text {IO2 }}$

Robert Lifton toonde in zijn boek Nazi Doctors aan hoe de nazi-artsen hun moorden niet alleen ideologisch konden verantwoorden, maar ook konden uitvoeren door het psychologische mechanisme te reconstrueren dat zich bij hen manifesteerde; het 'doubling'. De artsen creëerden een nieuwe 'ik', die naast de oorspronkelijke 'ik' kon bestaan en het vuile werk kon opknappen waar de oorspronkelijke 'ik' voor teruggeschrokken zou zijn. Volgens Lifton waren artsen beroepshalve al eerder dan anderen tot een dergelijke dubbele persoonlijkheid in staat. $\mathrm{Zij}$ hadden vanaf het begin van hun medische opleiding moeten leren kalm om te gaan met omstandigheden waar normaal gesproken heftige emoties mee gepaard gaan. Het voorbeeld van het eerste snijzaalpracticum is daarbij treffend. Vrij snel na die kennismaking met het op zichzelf ongewone fenomeen van snijden in lijken lukt het de meeste medisch studenten al een soort professionele distantie en koelte op te brengen. Een afstompingsproces heeft dan al plaatsgevonden. Buiten de snijzaal betekent dat echter niet dat ze koude en gevoelloze mensen geworden zijn. Artsen moeten gedurende hun carrière de juiste balans blijven vinden tussen enerzijds behoud van menselijke betrokkenheid en anderzijds een professionele afstand ten opzichte van hetgeen hun patiënten overkomt. Nazi-artsen waren daar volgens Lifton uitgesproken goed in. Zij konden enerzijds liefhebbende echtgenoten en vaders zijn en ondertussen koelbloedige moordenaars. ${ }^{\text {I03 }}$

Diverse andere auteurs hebben zich over de nazi-artsen en hun onvoorstelbare gedragingen gebogen. ${ }^{\mathrm{IO}}$ Met name Fridolf Kudlien benadrukte dat er ook veel artsen in Duitsland waren die zich niet verwant voelden met de nationaalsocialistische denkbeelden en op de hun vertrouwde manier medisch ethisch bleven handelen. Lid zijn van de nationaalsocialistische partij betekende bovendien nog niet dat een arts automatisch overging tot wandaden in het kader van de nazi-ideologie. ${ }^{\text {IO5 }}$ Van de ongeveer zestigduizend artsen in Duitsland aan het eind van de jaren dertig waren er 'slechts' 350 die dusdanig 
optraden dat zij hiervoor na 1945 veroordeeld werden. Toch had het nationaalsocialisme onder de Duitse artsen veel steun gekend. Ongeveer 40 procent van hen was in 1938 lid van de Nationaal Socialistische Artsenbond. ${ }^{106}$ Ook in de ss (Schutzstaffel, de paramilitaire organisatie binnen de nazipartij) waren opvallend veel artsen. ${ }^{107}$ En er waren niet alleen véél artsen lid van de NSDAP, procentueel meer dan advocaten of zakenmensen, zij waren ook vaak al heel vroeg lid geworden. ${ }^{\text {I08 }}$ De specifieke aantrekkingskracht van de nazi-ideologie op medici is volgens Omar Haque en collegae van de afdeling Psychiatry and Law van Harvard te verklaren door meerdere factoren, waaronder de wetenschappelijke pretenties, biomedische terminologie en propaganda van de nazi-ideologie, maar ook specifieke artseneigenschappen als conformisme en gezagsgetrouwheid. Artsen waren in hun opleiding immers al gewend geraakt aan hiërarchie en hadden het verleerd zich kritisch op te stellen, in tegenstelling tot bijvoorbeeld advocaten. Specifiek aantrekkelijk voor artsen, hoeders van het leven, zou ook zijn geweest de suggestie van onsterfelijkheid van het Duizendjarige Rijk. Bovendien waren de Duitse artsen in een economisch lastige positie geraakt na de Eerste Wereldoorlog. Er was een overschot aan artsen en men zag een kans op economische voorspoed in het elimineren van Joodse vakgenoten. En inderdaad, in 1936, nadat het Joodse artsen grotendeels onmogelijk was gemaakt verder te praktiseren, was het inkomen van de gemiddelde Duitse niet-Joodse arts verdubbeld ten opzichte van tien jaar eerder. ${ }^{\text {Io9 }}$ Ten slotte was ook de demoralisering die het gevolg was van de ervaringen van de Eerste Wereldoorlog een oorzaak van de populariteit van de nazi-ideeën onder Duitse artsen. Immers, zij hadden als artsen aan het front vaak allerlei gruwelijkheden meegemaakt en waren daardoor afgestompt. ${ }^{\text {IIO }}$ Michael Kater introduceerde deze visie. Hij geloofde dat velen van de oud-front artsen in Duitsland hun menselijke compassie waren kwijtgeraakt. ${ }^{\text {III }}$

Tessa Chelouche zag als duidelijk punt van lering uit het voorgaande hoe kwetsbaar medische ethiek is, hoezeer deze door externe factoren beïnvloed kan worden:

It is essential to enlighten the fact that biomedical ethics are not immutable but malleable, and can be shaped by many external forces. Today each physician is obliged to make a commitment to the ethics of medicine in light of the lessons of the past, the problems and pressures of our time and the judgment of those who follow us. Examination of the events of the Holocaust, and the complicity of Nazi medicine in demonstrating the vulnerability of medical ethics, can provide a lens that can help in this difficult but compelling task. ${ }^{\mathrm{II}}$ 
Medische ethiek is 'malleable': vervormbaar, kneedbaar of -zo men wil- kwetsbaar. Op welke manier voor Nederlandse Joodse artsen, onder de omstandigheden van de Duitse bezetting, medisch ethische beginselen door externe krachten vervormden en hoe zij zelf de medische ethiek onder de gegeven omstandigheden kneedden, zal beschreven worden in dit boek. Dit boek probeert voorts niet alleen antwoord te geven op de vraag hoe dit gebeurde, maar ook - zo goed als mogelijk - op de vraag waarom: wat bewoog de betrokken artsen? Hielden zij zo veel mogelijk vast aan de 'oude' ethiek of werd deze verdrongen door politieke of andere 'hogere' belangen? Was er onderlinge verdeeldheid of juist consensus over hoe te handelen, of was er sturing vanuit de officiële beroepsgroep en niet-Joodse collegae? Al deze vragen zullen aan bod komen.

\section{OPBOUW EN METHODE}

Hoe vergaat het een arts die zijn beroep probeert uit te oefenen onder de gegeven omstandigheden van ontrechting en vervolging? Welke weg leidt zijn beroep hem? Welke moeilijkheden komt hij op zijn pad tegen? De tocht op dat pad is onderwerp van dit boek.

Het eerste hoofdstuk zal een beeld schetsen van de uitgangssituatie van de Joodse artsen in Nederland voorafgaande aan de Tweede Wereldoorlog. De positie van de Joodse artsen in de Nederlandse samenleving en in de beroepsgroep vóór de Duitse bezetting komt daarin aan bod, evenals de gangbare beroepsethiek in het interbellum. Wat waren de uitgangspunten in de Nederlandse medische ethiek terwijl de Duitse onder Hitler perverteerden? Werden de Joodse artsen in de Nederlandse artsenstand gediscrimineerd of golden zij als volwaardige collegae? Wat waren de plichten en voorrechten inherent aan het artsenberoep? Zonder kennis van deze uitgangssituatie is het onmogelijk de veranderingen gedurende die bezetting te analyseren. In de verdere hoofdstukken zullen de lotgevallen, ervaringen en morele dilemma's van de Joodse medici tijdens de bezetting grotendeels in chronologische volgorde aan bod komen. De thematiek van hoofdstukken 2 en 3 is allereerst hun verwijdering uit de algemene artsenstand middels discriminerende maatregelen van de Duitse bezetter en de soms moreel ingewikkelde artsentaken die zij in de geïsoleerde Joodse kring moesten uitvoeren.

In hoofdstuk 4 tot en met 8 zal blijken hoe het de artsen verging tijdens de deportatiefase, die duurde van juli 1942 tot september I943. Hoofdstuk 4 verhaalt van de reacties van de Joodse artsen op de deportaties in de eerste maanden van de wegvoeringen. Konden zij met hun beroep iets voor zichzelf 
of voor anderen betekenen? Hoe zetten zij hun beroep in? En welke artsenplichten of -voorrechten kwamen in het gedrang? Hoofdstuk 5 toont hoe de Joodse ziekenhuizen tijdens de deportaties de functie van vluchthaven kregen, totdat met de ontruiming van het Joodse psychiatrische ziekenhuis Het Apeldoornsche Bosch een nieuwe fase begon: de fase waarin de artsen met hun medische middelen steeds minder konden betekenen. Hoofdstuk 6 beschrijft deze nieuwe fase en geeft antwoord op de vraag of er toch nog iets met het artsenberoep gedaan kon worden in het belang van patiënten. Hoofdstuk 7 toont vervolgens aan in hoeverre de artsen erin slaagden met hun beroep hun eigen lot te beïnvloeden. In hoofdstuk 8 worden de ervaringen van artsen in onderduik en illegaliteit getoond. Hierna vertelt hoofdstuk 9 het verhaal van de Joodse artsen in gevangenschap in de nazikampen in Nederland: Westerbork, Vught en Amersfoort. Wat betekende hier het artsenberoep? Vergaten zij ook onder die omstandigheden niet dat ze arts waren?

Dit boek gaat, zoals gezegd, over 534 Nederlandse Joodse artsen. Van hen heb ik een database met zoveel mogelijk biografische en beroepsgegevens opgebouwd, welke het mogelijk maakt enkele statistische uitspraken te doen over deze groep. Deze database is ontstaan door het combineren van registraties van zowel Nederlandse artsen als Nederlandse Joden, afkomstig van onder andere de Geneeskundige Hoofdinspectie en de Duitse autoriteiten. Daarnaast is gebruikgemaakt van de 'sneeuwbalmethode', waarbij persoonlijke mededelingen, de artsendatabank van Medisch Contact, de Geneeskundige Jaarboekjes en het digitaal Joods monument aanvullende namen en levensverhalen opleverden. ${ }^{\mathrm{II3}}$ Uiteraard is gestreefd naar volledigheid en dat zou in dit verband betekenen een database van alle medici praktiserend (of niet meer praktiserend) in het bezette Nederland, die op basis van de rassenwetten van de bezetter als Jood vervolgd werden. Dit impliceert dat zogenaamde 'half-Joodse' artsen buiten beschouwing zijn gelaten, evenals Duits-Joodse artsen die als vluchteling in Nederland verbleven maar hier niet mochten praktiseren. Ondanks het streven naar volledigheid bestaat er een gerede kans dat sommige artsen ten onrechte niet in de database terecht zijn gekomen. Met name de groep van Joodse medici die nog in I94I en 1942 hun artsexamen haalde, zou deels gemist kunnen zijn, omdat zij op de momenten van registratie nog geen arts waren. Toch is op basis van deze database al meer inzicht in de gehele groep Nederlandse Joodse artsen te verkrijgen dan ooit eerder is gelukt.

Persoonlijke getuigenissen illustreren in dit boek de historische gebeurtenissen. Op deze manier wordt getracht de gemoedstoestand en het gedrag van de beschreven groep ten gevolge van de steeds verder opgevoerde vervolging zo dicht mogelijk te benaderen. Zowel hun gedeelde collectieve lotgevallen als 
de bestaande grote individuele verschillen zullen daarbij naar voren komen. Hiervoor is met name gebruikgemaakt van egodocumenten als dagboeken en persoonlijke verslagen. Dat past ook het beste bij de onderzoeksvraag en onderzoeksopzet en ook bij mij als onderzoeker. Deze studie is allereerst natuurlijk historisch van karakter, maar verricht vanuit het perspectief van een collega-arts. Zo is empathie, een bij uitstek belangrijke eigenschap voor artsen, en zeker ook voor dit onderzoek, hier ingezet. Inzicht krijgen in de ervaringen, gedachten, overtuigingen en interne worstelingen van de 534 mensen over wie dit onderzoek gaat, was het doel dat bereikt moest worden.

Het meest voor de hand liggende middel om dat doel te bereiken is rechtstreeks met de betrokkenen spreken en hun vragen naar wat hen dreef in hun handelen. Dat heb ik dan ook zo veel mogelijk gedaan. Ik vond echter nog slechts zeven collegae die uit eigen ervaring konden vertellen hoe het was om als Joods medicus in Nederland tijdens de Duitse bezetting het artsenberoep uit te oefenen. Ik was te laat om deze bron optimaal te kunnen gebruiken. Wel sprak ik nog twaalf mensen die tijdens de bezetting medisch student waren en vanuit die rol de oorlog beleefden. Tientallen anderen, echtgenotes en kinderen van artsen, verpleegsters en patiënten, interviewde ik eveneens. Een tweede bron van zogeheten 'oral history' vond ik in het project 'Tweeduizend getuigen vertellen', de gedigitaliseerde interviews met Shoah-ooggetuigen die op verzoek getoond kunnen worden in het Joods Historisch Museum te Amsterdam. Deze interviews zijn in de jaren negentig afgenomen in het kader van het door Steven Spielberg wereldwijd gefinancierde project om zo veel mogelijk overlevenden van de Holocaust te interviewen. Nadeel van deze in principe uiterst waardevolle databank is dat de destijds afgenomen interviews meestal niet erg diep op het specifieke interessegebied van mij als onderzoeker ingaan. Naast de beperkte beschikbaarheid van oral history over dit onderwerp, was ik me bewust van enkele andere nadelen van deze manier van dataverzameling.

Wie de oral history beoefent, moet zich realiseren dat de bruikbaarheid en geldigheid van mondelinge overlevering als bronmateriaal voor geschiedschrijving ter discussie staat. Hoe betrouwbaar zijn de herinneringen van mensen? Hoe gekleurd of subjectief zijn ze? Zijn herinneringen bruikbaar als bewijsmateriaal voor het beantwoorden van historische vraagstellingen? 'Memory is a treacherous thing' schreef historicus Peter Friedlander, die zelf geregeld oral history beoefent. ${ }^{\mathrm{II}}$ Een valkuil is het concept van herinnering als een niet veranderende, objectieve databank van het verleden, terwijl je het geheugen eerder zou moeten zien als een dynamisch geheel, waarbij hetgeen je vergeet even belangrijk kan zijn als hetgeen je onthoudt. ${ }^{\text {II }}$ De experts wijzen dan ook op het belang van hoor en wederhoor. Juist in het samenvoegen van verschil- 
lende herinneringen van verschillende mensen schuilt volgens hen de kracht van de oral history: 'Reality is complex and many-sided, and it is a primary merit of oral history that to a much greater extent than most sources it allows the original multiplicity of standpoints to be covered. ${ }^{1 \mathrm{II} 6}$ Met een veelheid aan standpunten, gezichtspunten van waaruit de historische gebeurtenissen zijn beleefd, kan de historicus tot een realistischer beeld van dat verleden komen. In dit onderzoek was dan ook het streven zo veel mogelijk mensen aan het woord te laten en uit al hun herinneringen een verhaal te destilleren dat de historische realiteit zo dicht mogelijk benadert.

Alle historici die interviews als bronmateriaal gebruiken, dienen bovendien met dit bronmateriaal en met de verstrekkers ervan zorgvuldig om te gaan. ${ }^{117}$ Intuïtief wordt dit uitgangspunt extra sterk gevoeld als de verstrekkers van de gegevens holocaustoverlevenden zijn die niet zelden na jaren van zwijgen, hun herinneringen aan de meest zware en bepalende tijd van hun leven proberen te verwoorden. Wat zijn de overwegingen die men in het achterhoofd dient te houden bij het interviewen van slachtoffers van de Shoah? Allereerst dat aan het proberen in woorden te vatten wat men zich kan herinneren, een mentaal proces voorafgaat waarbij de geïnterviewde weer terug is in de 'holocaustwereld': 'retelling is reliving. ${ }^{\text {II8 }}$ Herinnering is nu eenmaal niet een geschreven tekst in je hoofd. Daarnaast wordt gesteld dat de beelden die men tijdens het vertellen op het netvlies heeft, de geuren die men weer ruikt en de gevoelens die weer boven komen, nauwelijks in taal uit te drukken zijn. ${ }^{119}$ Taal is soms gewoonweg niet toereikend. De interviewer, die in dit geval zelf niet een dergelijk verhaal met zich meedraagt, zal daarmee nooit de volledige achterliggende realiteit kunnen bevatten. Ook al spreken soms ook non-verbale signalen boekdelen.

Naast gevoeligheid voor die non-verbale signalen is ook gevoeligheid en respect voor zwijgen noodzakelijk. Voor overlevenden zijn er verschillende redenen om te zwijgen over bepaalde belevenissen. Velen kiezen er - bewust of onbewust - voor om dát verhaal te vertellen waar zij mee kunnen leven. Allereerst om zichzelf te beschermen tegen de pijn die vertellen, herinneren, herbeleven oproept. Ook kunnen overlevenden het zwijgen zien als een eerbetoon aan hen die het niet overleefden. ${ }^{20}$ Dat deze gevoelens kunnen bestaan, dient de interviewer zich te realiseren. Forceren is om deze reden uit den boze. Ten derde kan het zwijgen bedoeld zijn om de luisteraar te beschermen tegen de schok van het aanhoren van gruwelijkheden óf om te voorkomen dat de luisteraar een oordeel velt. Naast het oordeel dat een ander kan hebben over iemands persoonlijke herinneringen, is er natuurlijk ook nog de eigen mening van de betrokkene. Ook Shoah-overlevenden hebben jaren van naoorlogs leven meegemaakt, waarin ze hebben kunnen terugkijken op wat ze 
hebben meegemaakt. Zij zijn daarbij beïnvloed door nieuwe ervaringen, meningen van anderen en politieke of maatschappelijke gebeurtenissen. Politiek en maatschappij vormen het zogenaamde collectieve geheugen van een groep mensen, dat vervolgens het individuele geheugen mede (ver)vormt. Er zijn deskundigen die menen dat er naast de herinnering als herbeleving een tweede herinnering bestaat, die gekleurd wordt door de naoorlogse positie, kennis en ervaring van de overlevende. Dit impliceert dat bij het vertellen van een relaas naast het rechtstreekse verslag van wat men op zijn netvlies opnieuw ziet gebeuren, ook de interpretatie van die gebeurtenissen zoals men die in de latere jaren heeft gevormd, een rol speelt. ${ }^{\text {I2I }}$

Naast de invloed van emoties, het herbelevingsproces, de ontoereikendheid van taal daarbij, het mogelijke zwijgen over bepaalde herinneringen en de kleuring van herinnering door reflectie achteraf is er natuurlijk nog een heel aardse complicerende factor voor het gebruik van herinneringen, namelijk de achteruitgang van het geheugen bij oudere mensen. In dit onderzoek heb ik gebruikgemaakt van herinneringen van over het algemeen zeer oude mensen. Het oudere brein en bijbehorende geheugen zijn helaas net als de rest van het menselijk lichaam aan slijtage onderhevig. Sommige meer of minder belangrijke dingen zal men op den duur vergeten. Sieg Gitter schreef mij naar aanleiding van de vragen die ik hem over zijn tijd als Joodse arts in bezet Nederland had gesteld wijselijk: 'N.B. Neemt u aan, dat dit allemaal herinneringen zijn, waar ook vergissingen in zitten.' ${ }^{122}$

Oral history heeft al met al naast een grote zeggingskracht de nodige beperkingen. Daarom zijn schriftelijke getuigenissen van tijdens of vlak na de oorlog zo mogelijk nog interessanter en bruikbaarder bronnen. Van dagboeken van Joodse artsen, op schrift gestelde memoires van eerdere naoorlogse jaren en getuigenissen opgetekend door Yad Vashem in de jaren zestig heb ik voor dit onderzoek dan ook dankbaar gebruikgemaakt. Het gebruik van dergelijke 'egodocumenten', een term door Jacques Presser geöntroduceerd, is echter net als de oral history onder historici onderwerp van discussie.

In navolging van Presser waren Nederlandse historici relatief vroeg geneigd egodocumenten als interessante en bruikbare bronnen te beschouwen. In 1970 haalde Hermann von der Dunk als verantwoording voor deze neiging het aloude adagium aan dat geschiedenis nu eenmaal altijd geschiedenis van mensen betekent. ${ }^{123} \mathrm{Hij}$ citeerde de gerenommeerde historicus Henri Pirenne, die eens had uitgeroepen: 'Je suis historien, parce que j'aime la vie.' 'La vie' vervolgens echt leren kennen is mogelijk door ontmoetingen met de geleefde levens van anderen, aldus Von der Dunk. Zelfs als men individuen beschouwt als producten van externe factoren, dus als het gevolg van cultuur en geschiedenis, 
in plaats van de aanstichters ofwel producenten daarvan, dan nog blijft het geleefde leven dat men onder de loep neemt een uniek snijvlak, 'die eenmalige herkenbare persoonlijkheid, wiens ego dwars door alles heen aan de kern van ons eigen ego vermag te appelleren en het vinden van onze eigen identiteit mogelijk maakt, zoals niets anders. ${ }^{\text {I24 }}$ Ook recentelijker onderstreepten $\mathrm{Ne}-$ derlandse historici als Peter Romijn, Eva Moraal en Marieke Meeuwenoord de kracht van het egodocument als historische bron. Ook zij wezen op het vermogen met het individuele relaas een al dan niet adequater, maar dan toch zeker rijker beeld van de geschiedenis te creëren. ${ }^{125}$ Eva Moraal merkte in haar proefschrift over Kamp Westerbork op: 'Tegenwoordig kán een geschiedschrijving over de oorlog en jodenvervolging haast niet meer geschreven worden zonder gebruik te maken van egodocumenten. ${ }^{126}$ Dit ook omdat het perspectief van de slachtoffers zo belangrijk is geworden in het historisch onderzoek naar dit onderwerp. ${ }^{127}$ Selma Leijdesdorff verdedigde in deze lijn treffend het gebruik van egodocumenten, zelfs als deze schaars zijn: 'Eén leven of één bron kan exemplarisch zijn omdat zij een verdieping in onze kennis kunnen geven die meer generaliserende onderzoeken, als zij al mogelijk zouden zijn, niet aan het licht brengen. ${ }^{\mathrm{I} 28}$

Tijdens de oorlog zelf hadden niet weinigen ook reeds het besef dat wat zij meemaakten, bijzonder was en vastgelegd diende te worden. De Pools-Joodse historicus Emanuel Ringelblum beijverde zich voor het zo uitgebreid mogelijk documenteren van wat de inwoners van het getto van Warschau overkwam. Documentatie vanuit de gebeurtenissen zelf was in zijn ogen van groot belang om de valkuil van de vervormingen en selectiviteit van herinneringen achteraf te ontlopen. ${ }^{129}$ Ringelblums inspanningen resulteerden in een aanzienlijke hoeveelheid persoonlijke geschriften en getuigenissen van gebeurtenissen in het getto, die na de Duitse nederlaag als belangrijke historische bron gingen dienen. Voor Nederland was het de in Londense ballingschap verkerende journalist Loe de Jong die het belang van het opschrijven van persoonlijke ervaringen onderkende. In een toespraak voor Radio Oranje door minister Gerrit Bolkestein op 28 maart 1944 liet hij zijn verzoek aan de Nederlanders om van hun ervaringen onder Duitse onderdrukking een dagboek bij te houden voorlezen. Te meten aan het relatief grote aantal - I500 - oorlogsdagboeken dat bij het Nederlands Instituut voor Oorlogsdocumentatie bewaard wordt, gaven veel Nederlanders aan deze oproep gehoor. Van deze dagboeken, een specifiek soort egodocumenten, hebben Nederlandse historici dan ook dankbaar gebruikgemaakt. Het recentelijk verschenen werk van Bart van der Boom, Wij weten niets van hun lot, is zelfs volledig gebaseerd op dagboeken. Hijzelf en zijn critici zagen echter ook de nadelen van het gebruik van deze historische bron: 
dagboeken werden vaak met een bepaald doel en voor een bepaald publiek geschreven. Bovendien werden ze na de oorlog soms herschreven, alvorens men ze bij Oorlogsdocumentatie inleverde. ${ }^{130}$ De schrijver van een egodocument modelleert een beeld van zichzelf dat hij zelf acceptabel vindt, ondanks de claim van volledige eerlijkheid. Volledige objectiviteit van bronmateriaal is echter voor veel moderne historici niet meer het ultieme streven, ook een subjectieve beleving van gebeurtenissen is de moeite waard om als bron gebruikt te worden. ${ }^{131}$ Zeker in een onderzoek dat gaat over morele dilemma's en gewetensvraagstukken, zijn dergelijke bronnen bruikbaar en onontbeerlijk.

Onontbeerlijk voor een waarheidsgetrouw kader waren echter zeker ook de meer conventionele historische bronnen: het archiefmateriaal. Niet zelden waren in privébezit nog documenten aanwezig die een waardevolle bijdrage aan de verzameling van gegevens konden leveren. Puttend uit voorts een grote hoeveelheid beschikbaar archiefmateriaal uit onder andere het Nederlands Instituut voor Oorlogsdocumentatie, Nationaal Archief, Joods Historisch Museum, Stadsarchief Amsterdam en Yad Vashem, was ik in staat vele gegevens over de lotgevallen van de 534 Joodse artsen te vergaren. Veel van de persoonlijke verhalen van die artsen zouden een aparte biografie waard zijn. Als ik David Rothman in zijn Strangers at the Bedside moet geloven is de neiging tot het schrijven van biografieën, van 'case history' in plaats van 'history' voor een arts makkelijker dan het grotere geheel te overzien. Zo zijn artsen immers getraind. ${ }^{132} \mathrm{Ik}$ heb er hier dan ook inderdaad voor gekozen veel casuïstiek te beschrijven, maar tegelijkertijd getracht alle individuele ervaringen te bundelen tot één overkoepelend verhaal van de lotgevallen van de Nederlandse Joodse artsen. In de context van chronologie en feiten uit archiefmateriaal, die als het ware het 'skelet' van het verhaal vormen, komen de individuele ervaringen en onderlinge verschillen zoals verkregen uit egodocumenten en oral history indringend naar voren. De Joodse artsen van weleer worden daardoor voor mij als schrijver inderdaad weer mensen van vlees en bloed. Naar ik hoop voor u ook. 


\section{GEWONE HOLLANDSE ARTSEN \\ JOODSE ARTSEN IN NEDERLAND IN DE JAREN \\ DERTIG, TUSSEN ASSIMILERING \\ EN PROFILERING}

De Nederlandse artsen vormden door hun beroep een onverbrekelijke en vanzelfsprekende eenheid. Collegialiteit was stevig verankerd in de beroepsethiek. Het afleggen van de eed van Hippocrates markeerde het toetreden tot het hechte, selectieve en elitaire gezelschap der medici. Of zoals de befaamde medisch historicus G.A. Lindeboom het uitdrukte: 'De geneesheren sluiten zich nauw aaneen in een gilde, dat zijn leden overal allen bijstand verzekert.'

\section{IN DE EERSTE PLAATS ARTS}

De gedeelde 'roeping' smeedde een onderlinge band, die religieuze, politieke en sociale verschillen oversteeg, ook in de verzuilde maatschappij van het $\mathrm{Ne}$ derland van de jaren dertig. Of geneesheren Joods, protestant, katholiek of communist waren, telde ook, maar zij waren in de eerste plaats collega. Voor al het andere was men arts, zo leek te gelden. Niet voor niets bestond ook het gezegde: "t Is geen baan, 't is een bestaan. ${ }^{2}$ Een stelling van de Joodse gynaecoloog Maurits Muller (I884-I943), op de dag dat hij zijn praktijk vaarwel moest zeggen wegens gezondheidsproblemen, luidde: 'Ik vier heden mijn geestelijke begrafenis. ${ }^{3}$ Zozeer was hij verknocht aan en vergroeid met zijn beroep.

Deze geest ademen ook Mullers memoires en die van de eveneens Joodse Stephan Sturkop (1882-1953), die schreef onder het pseudoniem J. van Arkel Zegwaard. Beide memoires stammen van net voor en tijdens de oorlog en zijn 
na de bevrijding uitgegeven. ${ }^{4}$ De twee auteurs repten met geen woord over Jodendom of Joods-zijn. Het arts-zijn stond voorop. Hun boeken waren bedoeld voor het grote publiek en beoogden een tipje van de sluier op te lichten van hoe het artsenbestaan eruitzag. De leek zou dat weliswaar nooit helemaal begrijpen, maar kon nu toch een klein inkijkje krijgen. Alleen artsen onderling begrijpen elkaar écht. Alleen elkaar kunnen zij te allen tijde volledig inlichten. Ten opzichte van hun patiënten moeten zij altijd een paternalistische - vaderlijk bevoogdende en zorgende - houding aannemen. Zo was de boodschap.

Dat in de onderlinge contacten onder artsen het gedeelde arts-zijn vooropstond, valt ook op te maken uit het dagboek van Berthold Stokvis. Met een schok besefte hij in I94I, na invoering van anti-Joodse maatregelen door de bezetter: 'Wacht even! Nu zullen zij ineens allemaal weten, dat ik een Jood ben. Alle artsen, die er tot dusver misschien nooit op gelet hebben. Van nu af aan zullen zij mij met andere oogen bekijken. Kijk, daar gaat een Jood.'s

Ben Sajet (I887-I986), huisarts in Amsterdam-Oost, liet een Amerikaanse journalist na zijn spectaculaire vlucht uit bezet Nederland in het verlengde hiervan optekenen: 'Up to the war I lived quietly in Holland, the ordinary, orderly life of a Dutch physician. ${ }^{6}$ Ondanks zijn Joodse opvoeding en zijn verbondenheid met die achtergrond had hij het gevoel een gewone Nederlandse dokter te zijn en geen uitzonderingspositie in te nemen. ${ }^{7}$ Joodse artsen in $\mathrm{Ne}$ derland waren voor de Tweede Wereldoorlog gewone Hollandse artsen. Daar was wel een geschiedenis aan voorafgegaan.

\section{EMANCIPATIE EN INTEGRATIE}

Portugees-Joodse artsen die vanaf de zestiende en zeventiende eeuw in Nederland gevestigd waren geweest, hadden weliswaar al vanaf het begin veel aanzien genoten, maar hadden nog geen burgerrechten gehad. ${ }^{8}$ Toen die er vanaf de 'Gelykstaat der Joden' in I796, mede bereikt dankzij de inzet van Joodse artsen als Hartog de Lémon, ook voor Joden waren, hadden medici onder hen de mogelijkheid gekregen te integreren en zich te emanciperen, zowel in de artsenstand als in de Nederlandse maatschappij. ${ }^{9}$ Een naam die in dit verband niet ongenoemd kan blijven is Samuel Sarphati (I8I3-I866). ${ }^{\text {IO }}$ Onder de wapenfeiten van deze uitzonderlijke Amsterdamse figuur zijn te noemen de oprichting van de Maatschappij tot Bevordering van de Pharmacie (I842), van de Maatschappij tot Bevordering van Landbouw en Landontginning (I847) en van de Vereeniging voor Volksvlijt (I852), waarvoor het Paleis voor Volksvlijt 
werd gebouwd. Ook de Maatschappij voor Meel- en Broodfabrieken (I855) was zijn geesteskind. Hij stichtte de Nederlandse Crediet- en Depositobank in 1863 en de Nationale Hypotheekbank in I864. Het was zijn droom van Amsterdam een mooie en moderne stad met veel werkgelegenheid en een goede levensstandaard te maken. Ook de bouw van het statige Amstelhotel was zijn initiatief. II Sarphati leefde met zijn hoge maatschappelijke positie tegelijkertijd zeer bewust Joods en zette zich in voor de Joodse gemeenschap in Amsterdam. ${ }^{\text {I2 }}$

In de academische wereld konden Joodse artsen vanaf omstreeks dezelfde tijd, de tweede helft van de negentiende eeuw, een hoogwaardigheidspositie gaan bekleden. In I85I werd er voor het eerst een Jood als (buitengewoon) hoogleraar benoemd, aan de Universiteit van Groningen. Het was de arts Isaac van Deen (I804-I869), die een persoonlijke vriendschap onderhield met de liberale staatsman Thorbecke. ${ }^{33}$ Van Deen was de wegbereider voor andere Joodse hoogleraren in de medicijnen. Een zeer befaamd Joods hoogleraar in de geneeskunde na hem was Barend Joseph Stokvis (I834-I902). Vanaf I877 bekleedde deze de leerstoel inwendige geneeskunde, algemene ziektekunde en geneesmiddelenleer in Amsterdam. ${ }^{\mathrm{I}}$ In hetzelfde jaar werd in Groningen Aletta Jacobs (I854-I929) als studente tot de medische faculteit toegelaten om later de eerste vrouwelijke arts in Nederland te worden. Haar toelating was omstreden omdat zij een vrouw was, niet vanwege haar Joodse afkomst. ${ }^{\text {I5 }}$ Eveneens in het jaar I877 werd Abraham Hartog Israëls (I822-I883) benoemd tot hoogleraar geneeskunde in Amsterdam. Hij was naast medicus en medisch historicus een vooraanstaand representant van de 'hygiënisten', net als bijvoorbeeld zijn goede vriend, de Groningse medicus Levy Ali Cohen (I8I7-I889). De hygiënisten spanden zich in om de leefomstandigheden in de steden te verbeteren zodat besmettelijke ziekten minder makkelijk om zich heen zouden kunnen grijpen. ${ }^{16}$ De hygiënistische stroming, met Joodse kopstukken als Israëls en Ali Cohen maar ook Samuel Senior Coronel (I827-I892) en Isaac Teixeira de Mattos (I822-I904), zou het fundament vormen voor de gemeentelijke openbare gezondheidszorg, zoals die vanaf 1893 vorm kreeg en uitmondde in de oprichting van de Gemeentelijke Geneeskundige en Gezondheidsdienst (GG\&GD, later GGD), eerst in Amsterdam, later ook in de andere steden in Nederland. ${ }^{17}$

In de traditie van Joodse artsen die zich inspanden voor de openbare gezondheidszorg past ook Louis Heijermans (I873-1938). Hij was van I9I9 tot een jaar voor zijn dood de veelgeroemde directeur van de GG\&GD in Amsterdam. ${ }^{\text {I8 }}$ Deze dienst was, na de impulsen van de hygiënisten in de negentiende eeuw, onder zijn leiding de voorloper in de openbare gezondheidszorg in Nederland. 
In de sfeer van sociaaldemocratie die in het Amsterdamse gemeentebestuur heerste, paste Heijermans uitstekend, evenals veel van zijn Amsterdams-Joodse sociaaldemocratische vakgenoten. De GG\&GD floreerde onder hun bezielende leiding: 'Regelmatig kwamen er buitenlandse deskundigen en delegaties om de organisatie van de Amsterdamse GGD van nabij te bestuderen. Hoger in aanzien dan rond het midden van de jaren twintig zou de dienst nooit reiken.' ${ }^{\text {I9 }}$

De emancipatie van de Joden in medische kringen was in de tweede helft van de negentiende eeuw ook op landelijk niveau dermate ver gevorderd dat het mogelijk was dat Barend Stokvis in 1870 werd benoemd tot voorzitter van de 21 jaar eerder opgerichte Nederlandsche Maatschappij tot bevordering der Geneeskunst. Dit was hét vertegenwoordigend orgaan van de Nederlandse artsen; zo'n 90 procent van hen was er lid van. ${ }^{20}$ Stokvis werd vervolgens vier keer in die functie herbenoemd. Hiermee was de Joodse arts Stokvis jarenlang dé vertegenwoordiger van de Nederlandse artsenstand. Een teken van verregaande emancipatie en integratie.

\section{PROMINENTE JOODSE ARTSEN IN DE JAREN VOOR DE BEZETTING}

De Nederlandse artsenstand in het interbellum was al tientallen jaren gewend aan Joodse artsen in prominente, vertegenwoordigende posities. Het grote merendeel van de artsen die in de jaren dertig en veertig praktiseerden, moet ook wel college hebben gevolgd bij een van de Joodse hoogleraren aan de medische faculteiten in den lande, vooral als zij hun studiejaren in Amsterdam hadden doorgebracht. Van de twaalf Joodse hoogleraren in de medische wetenschap die Nederland in de jaren 1918-1940 telde, waren er zes werkzaam in de hoofdstad, te weten: Jacob de Bruin (I86I-1927), pionier in de kindergeneeskunde, Simon van Creveld (1894-1971), eveneens kinderarts, de kno-arts Charles Emile Benjamins (1873-1940), Ernst Laqueur (I880-1947), farmacoloog en internationaal bekend om zijn onderzoek naar geslachtshormonen, ${ }^{21}$ de internist Isidore Snapper (I889-1973) en de dermatoloog Samuel Mendes da Costa (I872-1943), die in 1920 rector magnificus was geworden. In Groningen waren vier Joodse professoren in de geneeskunde actief. Hartog Jacob Hamburger (I859-I924) doceerde tot zijn dood de fysiologie, Alexander Klein (I865-1946) zou naast hoogleraar bacteriologie ook rector magnificus worden, en zowel Abraham Albert Hijmans van den Bergh (I869-1943) als Leonard Polak Daniëls (1872-1940) bekleedde de leerstoel interne (toen nog 
inwendige) geneeskunde. Polak Daniëls nam het stokje van Hijmans van den Bergh over toen deze in I9I8 naar Utrecht vertrok. In Utrecht werkte toen al Ludwig Karel Wolff (1879-1938), hoogleraar fysiologische hygiëne en fysiologische chemie, pionier op het gebied van voedingsonderzoek in Nederland. ${ }^{22}$ Als laatste moet genoemd worden de Leidse professor Pieter Thomas Leonard Kan (I872-1940), die in 1920 zijn oratie had gehouden over de keel- neus- en oorheelkunde. In 1940 waren er nog vier Joodse hoogleraren geneeskunde in functie, te weten Hijmans van den Bergh, Polak Daniëls, Benjamins en Laqueur. Met één lector en zes privaatdocenten van Joodse komaf kwam het totaal aan Joodse universitair docenten in de geneeskunde op dat moment op elf, op een totaal aan docenten in Nederland van I24, ofwel een percentage van $9,{ }^{23}$ vergelijkbaar met het percentage Joodse artsen op de totale artsenstand en daarmee een evenredige vertegenwoordiging. Amsterdam was niet alleen in de openbare gezondheidszorg en in het aantal Joodse hoogleraren een geval apart. De stad had ook veruit de grootste Joodse gemeenschap en dus ook de meeste Joodse artsen. In 1930 woonden er volgens de volkstelling van de II2 ooo Joden in Nederland 65000 in de hoofdstad. ${ }^{24}$ Van de 534 artsen over wie dit boek gaat, woonden en praktiseerden er in elk geval 26I in Amsterdam. Van de Amsterdamse artsen, in 1939665 in totaal, was daarmee bijna 40 procent Joods. ${ }^{25}$ In de Amsterdamse straatarme Joodse buurt gold de medische studie als de emancipatoire studie bij uitstek. Zo herinnerde David Moffie, die opgroeide in de Jodenbuurt, zich dat zijn moeder hem had gepusht om medicijnen te gaan studeren, om zo 'uit het moeras van het proletariaat' te komen. ${ }^{26}$

De Amsterdamse Joodse medici waren veelal actief binnen de Amsterdamse Geneeskundige Kring van de Nederlandsche Maatschappij tot bevordering der Geneeskunst, kortweg NMG. ${ }^{27}$ Hierin bekleedden zij diverse representatieve functies. Gynaecologe Rosalie Wijnberg (I887-I973) klom bijvoorbeeld als eerste vrouwelijke arts op tot de top van de NMG door aangesteld te worden als tweede secretaresse van de Geneeskundige Kring Amsterdam. In het Amsterdams Geneeskundig Genootschap waren voorts de Joodse artsen Jacob de Hartogh sr. en Meyer Leon van der Stempel geziene figuren. ${ }^{28}$ Ook buiten de medische kringen stonden diverse Amsterdams-Joodse artsen in aanzien. Nicolaas Marinus Josephus Jitta (I858-I940), oogarts, bijvoorbeeld, was niet alleen voorzitter van de Gezondheidsraad, maar ook enige tijd waarnemend burgemeester van Amsterdam. Arts en wethouder Isidoor Henry Joseph Vos (I887-I943) werd in I928 lid van de Tweede Kamer voor de liberale Vrijheidsbond. ${ }^{29}$

Maar ook buiten Amsterdam waren Joodse artsen in het interbellum zowel in medische als in niet-medische representatieve functies goed verte- 
genwoordigd. De Middelburgse arts Louis Weijl (I879-I972) zwaaide bijna 30 jaar (van 1906 tot 1935) de scepter over de NMG-afdeling Walcheren. In Gorinchem was Salomon Biegel (I866-I94I) voorzitter van de NMG en enige tijd loco-burgemeester. ${ }^{30}$ In het interbellum bekleedden volgens het Joods Biografisch Woordenboek in totaal zestien Joodse artsen politieke functies: dertien als gemeenteraadslid, drie als wethouder en vier ook als lid van de Provinciale Staten. Deze cijfers, die mogelijk niet volledig zijn, zijn opmerkelijk hoog als men in ogenschouw neemt dat in de politiek over het algemeen nog een ondervertegenwoordiging van het Joodse volksdeel gold. Van de 4000 wethouders in Nederland in 1935 waren er slechts tien à vijftien Joods. ${ }^{3 \mathrm{I}}$ Twee Joodse juristen hadden het tot minister gebracht, maar dat was al voor 1920 geweest. Het tijdvak I920-I940 kende geen Joodse minister. ${ }^{32}$ Verder was er in 1938 nog geen enkele Joodse officier van justitie geweest. ${ }^{33}$ In het onderwijs waren Joden eveneens relatief weinig werkzaam. ${ }^{34}$ In de representatieve overheidssfeer was het Joodse volksdeel ondervertegenwoordigd. ${ }^{35}$ Een uitzondering vormden de rechterlijke macht, waar Lodewijk E. Visser (I87I-I942) president van de Hoge Raad was, en de advocatuur. ${ }^{36}$ En dus ook de artsen konden hoog op de maatschappelijke ladder stijgen. De enige Joodse burgemeester die Nederland voor de oorlog kende, Eduard Jacobs, was weliswaar zelf geen arts, maar kwam wel uit een artsengezin. Zijn vader en broer waren huisarts, Aletta Jacobs was zijn zuster. ${ }^{37}$

Bij verenigingen en belangenbehartigers van medici, naast de NMG, waren eveneens verschillende Joodse artsen actief. In het bestuur van de Nederlandse Vereniging voor Huisartsen $(\mathrm{NVH})$ zat de Meppelse huisarts Julius Leydesdorff (I874-1952). ${ }^{38}$ Actief in de Vereniging ten behoeve van het ziekenhuiswezen waren de Joodse geneesheren-directeur Salomon Kroonenberg (I89I-I96I), Samuel Poliakoff (I895-I945) en Charles Mendes de Leon (I893-I962). ${ }^{39}$ De twee vrouwelijke artsen Rosalie Wijnberg en Jo Aronsohn (I894-I943) waren voortrekkers in de oprichting van de Vrouwelijke Artsen Reünie in Amsterdam (I928) en de Vereniging van Nederlandse Vrouwelijke Artsen (I933). ${ }^{40} \mathrm{De}$ verdiensten van diverse Joodse artsen hadden ook hun neerslag in het gebruik van leerboeken van Joodse auteurs. Voor huisartsen waren bijvoorbeeld van de 42 titels op een lijst van benodigde literatuur uit 1939 er zeven geschreven door Joodse medici. ${ }^{4}$ Om vakinhoudelijk bij te blijven was ook het referatenblad Keesings Medisch Archief, met Joodse oprichter en naamgever, alom in gebruik. ${ }^{42}$ Het standaardwerk Handleiding der gezondheidsleer. In verband met de Nederlandse wetgeving van Salomon Biegel werd tussen I900 en I927 vijf keer herdrukt. ${ }^{43}$ Waarschijnlijk stond het bij verreweg de meeste Nederlandse artsen in de kast. In de serie Morks' beroepsbibliotheek, waarin diverse beroepen 
in een beknopte brochure de revue passeerden, was de bekende Joodse arts en publicist Herman Pinkhof (I863-1943) als auteur voor het deeltje over het artsenberoep aangetrokken. ${ }^{44}$ Ook voor een dergelijke, de beroepsgroep representerende, functie was het kennelijk de normaalste zaak van de wereld een Joodse arts te benaderen. Zo werd ook de eveneens Joodse huisarts Joël van der Kous (I887-I943) uit Amsterdam bereid gevonden een radiorede te geven in de serie Wat zal ik worden?, in het deel gericht aan schooljeugd die overwoog om het artsenberoep te kiezen. 45

Joodse artsen participeerden ook in discussies rondom controversiële thema’s binnen de medische wetenschap, zoals Bernard Premsela (I889-1944), een van de grote pleitbezorgers van geboortebeperking volgens het neo-malthusianisme. Premsela, bijgenaamd 'de rode dokter van Amsterdam', schreef een serie boeken en hield educatieve radiopraatjes over het huwelijksleven en richtte in 1932 de Nederlandse afdeling van de 'World League for Sexual Reform' op. Hij was zeker niet onomstreden. ${ }^{46}$ Collega Coen van Emde Boas (1904-I98I) had evenzeer progressieve ideeën over geboortebeperking en seksualiteit en publiceerde hierover. ${ }^{47}$

In de redacties van vele medische tijdschriften, vaak afkomstig uit Amsterdam, waren Joodse artsen eveneens goed vertegenwoordigd en gewaardeerde leden..$^{8}$ De Amsterdamse Joodse huisarts Izaak van Esso (I889-1966) richtte in 1938 het huisartsentijdschrift Aesculaap op. ${ }^{49}$ De bekendste onder de Joodse artsen-publicisten, Herman Pinkhof, ontving voor zijn jarenlange bijdragen aan het Nederlandsch Tijdschrift voor Geneeskunde hoge waardering, zoals bijvoorbeeld bleek uit het feit dat hoofdredacteur G. van Rijnberk hem in 1929 de hoogste onderscheiding van het $N T v G$, de gouden medaille, toekende. ${ }^{\circ}$ Zes jaar later verscheen een volgende loftuiting ter gelegenheid van zijn gouden artsjubileum, een artikel waarin P.A. de Wilde schreef: 'Ieder die Pinkhof kent, weet niet wat meer in hem te bewonderen; zijn diep zetelend Joodsche geloof, zijn groote belezenheid, zijn eerlijkheid, zijn heldere geest, zijn groote werkkracht. '’I Voor Pinkhof gold dan ook eigenlijk dat hij meer was dan alleen een gewone Hollandse arts: hij was een buitengewone, zeer gerespecteerde Hollandse arts, waarbij het feit dat hij belijdend Jood was geen enkele reden vormde hem te diskwalificeren. 


\section{'DE JOODSCHE ZEDELEER GAAT WONDERWEL SAMEN MET DE GENEESKUNDIGE ZEDELEER'}

Dat ook Pinkhof, Talmoedkenner met de eretitel 'Chover', ${ }^{52}$ ondanks zijn 'diep zetelend Joodsche geloof' in de eerste plaats collega onder de collegae was, bleek bijvoorbeeld uit de positie die hij innam in de discussie over de pathologische anatomie. Zowel Pinkhof als Salomon Kroonenberg, de eveneens Joodse geneesheer-directeur van het Nederlandsch Isrälietisch Ziekenhuis (NIZ) in Amsterdam, stelde zich op als actief pleitbezorger van het uitvoeren van secties op overleden patiënten, ook al ging dat tegen de Joodse leer in.

$\mathrm{Al}$ in 1924 en 193I had Herman Pinkhof over dit onderwerp redevoeringen gehouden, waarin hij betoogde dat rabbinale toestemming met sectie al meerdere malen gegeven was. Het ging daarbij om gevallen waarbij het uitvoeren van de sectie direct een ander leven kon redden. ${ }^{53}$ Kroonenberg, zelf niet vroom, hield vijftien jaar later eveneens een reeks lezingen met de strekking dat sectie bij Joodse overledenen makkelijker zou moeten worden gemaakt en dat de rabbinale regels overeen zouden moeten stemmen met de medisch ethische regels. Hij vermeldde daarbij dat het feitelijk in zijn NIZ al tien jaar praktijk was dat er met enige regelmaat secties werden verricht. ${ }^{44}$ Pinkhof en Kroonenberg toonden met hun openlijke pleidooi voor het verruimen van de mogelijkheden tot sectie dat zij de gangbare Nederlandse medische ethiek op dit punt leidend wilden laten zijn ten opzichte van de Joodse traditie.

Op het specifieke punt van de secties conflicteerden de algemeen geldende medische ethiek en de Joodse regels dan weliswaar, maar dat was uitzonderlijk. Herman Pinkhof, die in het $N T v G$ wekelijks bijdragen over allerlei onderwerpen, vaak medisch-ethisch van aard, verzorgde, wist dit als geen ander.55 Hij schreef dan ook: 'De Joodsche zedeleer gaat wonderwel samen met de geneeskundige zedeleer. ${ }^{56} \mathrm{Hij}$ liet deze stelling volgen door het voorbeeld van de sjabbat die mag worden geschonden als er medische behandeling nodig is, het Joodse verbod op abortus tenzij het leven van de moeder in gevaar is en het verbod op onvruchtbaar maken, tenzij uit medische noodzaak. ${ }^{57} \mathrm{Zo}$ was bijvoorbeeld ook van de orthodoxe Groningse arts Samuel Nathans (I88II94I) bekend dat hij de sjabbat in ere hield, tenzij hij voor een spoedgeval werd weggeroepen. In zo'n geval ging de medische noodzaak voor, ook volgens de Joodse ethiek. Een auto besturen op de rustdag was voor Nathans wel religieus bezwaarlijk, maar de Groningse politie bood daarvoor de oplossing door hem 's zaterdags per politiewagen naar zijn patiënten te vervoeren. ${ }^{58}$ Uitgaande van het allesoverstijgende belang van het redden van een leven, 'Pikoeach Nefesj', 
en met enige flexibiliteit van de niet-Joodse omgeving konden dus ook orthodox levende Joodse dokters gewone Hollandse artsen zijn.

Joodse medische ethiek had als zelfstandige entiteit een historie die ver terugging. De Joodse geneesheer Asaph stelde, vermoedelijk in de zesde eeuw, in Mesopotamië een artseneed op. ${ }^{59}$ Nog bekender was het 'Ochtendgebed voor de Arts', dat werd toegeschreven aan rabbi Moses ben Maimon, ofwel Maimonides (II35-I204), de beroemdste Joodse arts (en filosoof) aller tijden. Waarschijnlijk was dat gebed niet door hemzelf maar wel naar diens geest geschreven door de Duits-Joodse medicus Marcus Herz (I747-I803). ${ }^{60}$ Asaphs eed en het Ochtendgebed van Maimonides schreven voor dat de arts zich, als dienaar van God, op een verantwoordelijke, altruïstische en compassievolle manier diende te gedragen, met een diep respect voor het leven, nog uitgesprokener dan dat in de hippocratische eed tot uitdrukking kwam. De Joodse arts zou volgens Asaph en Maimonides (ofwel Herz) indien nodig zelfs gratis zorg aan een behoeftige zieke moeten leveren, daarmee zijn eigen belang ondergeschikt makend aan dat van de zieke. ${ }^{6}$ Als men de tekst van het ochtendgebed van de arts leest, valt inderdaad de menslievendheid op. Daarvoor is de volgende passage tekenend:

Laat liefde tot de kunst en Uw schepselen mij bezielen. Verhoed dat begeerte naar gewin, roem of aanzien zich menge in mijn arbeid. Want dat zijn vijanden van de waarheid en de mensenliefde, en ze zouden me kunnen doen dwalen in het grote ondernemen Uw schepselen wel te doen! Houd de krachten van mijn lichaam en ziel in stand, zodat ze onafgelaten steeds gereed zijn voor de rijke en de arme, de goede en de boze, de vriend en de vijand! ${ }^{62}$

Naast de eed van Hippocrates is dit gebed na de eerste publicatie ervan in 1783 in brede, maar vooral Joodse, kring bekend geraakt. Zo herinnerde Jacques Baruch zich in het $N T v G$ in 1952 dat er een tijd was geweest dat een Nederlandse vertaling van het 'Gebed voor de arts' tot de gebruikelijke cadeaus voor het behalen van het artsexamen behoorde. In 1952 vond men volgens hem het gebed van Maimonides in menig spreekkamer in Nederland terug. ${ }^{63}$ Twaalf jaar eerder zal dat ongetwijfeld ook het geval zijn geweest. Een bekende kernachtige uitdrukking in deze Joodse traditie om de ware betekenis van het artsenberoep aan te duiden, was dat de arts een 'Mensch' - uitgesproken als mensj - moest zijn. $^{64}$

In de algemene Nederlandse medische ethiek in het interbellum gold in feite ook dat een arts een 'mensj' moest zijn, al werd dat niet met die titel 
geëxpliciteerd. Maar 'een goed mens' zijn, dat was een voorwaarde voor het artsenberoep.

De Dokter is een goede man, die heel veel weet en heel veel kan.

En alles wat hij zegt en doet, en wat hij wil, is juist en goed.

Wie hem gelooft in ieder woord, die leeft gezond en veilig voort.

En ben je ziek, misschien gewond, hij maakt je in een wip gezond!

Wat hij al weet en wat hij kan, lees daar nu dit boekje van.

Hoor nu wat Dokter u gebiedt, houd veel van hem en vrees hem niet! ${ }^{65}$

Ziehier de inleiding van het prentenboekje De goede dokter van Max Nassauer, gynaecoloog uit München, dat in 1909 uit het Duits vertaald werd. De medicus werd in dit kinderboek als een bijna bovenmenselijke figuur voorgesteld. Een beter mens dan de dokter bestond niet. In een kinderboek wordt de waarheid over het algemeen natuurlijk vrij simplistisch voorgesteld, maar ook voor volwassenen gold in de eerste decennia van de twintigste eeuw dat in de titel 'arts' automatisch deugdzaamheid, beschaving en een hoge moraal lag besloten. Zo hield de Nederlandse arts Th. Hammes (I874-I95I) in I935 een voordracht ter gelegenheid van de algemene ledenvergadering van de NMG. De titel van zijn rede was: 'De pijlers van onze ethiek'. Voor het feit dat hij het gehoor, bestaande uit enkel collega-artsen, een verhandeling over gedragsleer zou voorschotelen, verontschuldigde hij zich al in de eerste zinnen. Hij zou zich beperken tot 'bespiegelingen' over ethiek. Hij besefte namelijk ten volle 'dat voor een gedetailleerde uiteenzetting hoe iemand zich hoort te gedragen, dit illustere gezelschap niet het aangewezen auditorium zou zijn. ${ }^{66}$

Deze overtuiging van vanzelfsprekende rechtschapenheid kwam voort uit neoromantische opvattingen waarvan de medisch-ethische verhandelingen uit het fin de siècle en het begin van de twintigste eeuw doordrenkt waren. Rond de eeuwwisseling heerste in Europa een heroïsch beeld van de arts, die als 'gentleman-physician' doordrongen zou zijn van mensenliefde, verantwoordelijkheidsgevoel en wijsheid, onder andere opgedaan door studie van de letteren en de kunst. ${ }^{67}$ De Italiaanse arts G.B. Ughetti (I852-I930) zag zelfs een duidelijke dichotomie tussen artsen en leken, alsof het om twee verschillende menssoor- 
ten ging: 'er is juist een scherpe grens: aan de ene zijde de geneesheer, daartegenover de leek!' ${ }^{68}$ Van die twee menssoorten dichtte hij de geneesheer de beste eigenschappen toe. Zijn Nederlandse collega Hector'Treub (I856-I920) voegde daar op zijn beurt aan toe dat menig arts in zelfopofferende liefde voor geen priester, in moed voor geen krijgsman en in scherpzinnig verstand voor geen man der zuivere wetenschap onder' zou doen. ${ }^{69}$ In 1903 haalde de overigens zelf niet-Joodse Treub in zijn bundel Medische Fatsoensleer in dit verband ook Maimonides aan, wiens Ochtendgebed naadloos aansloot bij zijn idee van de ideale, moreel verheven, zelfopofferende, altruïstische arts. ${ }^{70}$

De neoromantische, bij de Joodse medische ethiek aansluitende opvattingen van de medische ethiek vonden onder Nederlandse medici tot in het interbellum weerklank, zeker doordat er door nieuwe ontdekkingen en technische vooruitgang ook oude verworvenheden verloren dreigden te gaan. J.L.C. Wortman (I868-I95I) bijvoorbeeld gruwde in 1929 van de moderne tendens om in de geneeskunde de nadruk te leggen op technisch vernuft in plaats van op de helende persoonlijkheid van de arts. Volgens hem was de geneeskunst vooral een voortbrengsel van intuïtieve gaven van de arts en niet zozeer van diens technische mogelijkheden. 'De medicus, uit welken tijd ook, met een verfijnde kennis van het menschelijk gevoel en een groote waarnemingsgave van de levensverschijnselen, is een even goede arts geweest als doctoren van tegenwoordig, voorzien van een hele technische uitrusting.' ${ }^{11}$ Wortman verlangde terug naar de hippocratische traditie, die volgens hem in de eerste plaats 'ethica' predikte: 'menschelijke waardigheid, liefde voor de zieken en het leven in het algemeen, kuischheid, schaamte, altruïsme en onthouding van eigen gewin.' 72

Een ouderwetse, ideale arts had eigenlijk geen ethische richtlijnen nodig, maar kon van nature juist handelen. Die overtuiging spreekt ook uit het volgende citaat uit Dokter en publiek van W.B. Huddleston Slater (I882-I954) uit hetzelfde jaar:

Een groot aantal doktoren behoort tot de oude degelijke soort, die (mag ik zeggen) instinctiefmatig de traditie en nobele roeping van den geneeskundigen stand hoog houden. Liet men hen begaan en ieder handelen naar beste weten, er zou geen wolkje aan de lucht zijn, ook al bestond er geen enkele wet, bepaling of bindend besluit der Ned. Mij. t.b.d. Geneeskunst. ${ }^{73}$

Dat het toch wel praktisch zou zijn enkele ethische regels op te schrijven en onder de Nederlandse artsen te verspreiden was een idee dat desalniettemin 
leefde onder Nederlandse artsen in het interbellum. Dat bleek uit de publicatie van de gids Medische ethiek, die vanaf 1936 aan de leden van de Nederlandsche Maatschappij ter bevordering der Geneeskunst werd gegeven en tot I94I herdrukken beleefde. In de inleiding verantwoordden de auteurs zich naar aanleiding van een opsomming van goede eigenschappen die de arts moest bezitten:

Wij hebben hier voor ons liggen een lijstje van eigenschappen die een goed medicus moet bezitten om terecht dien naam te dragen, zooals dit voorkomt in verschillende deontologische handleidingen. Evenwel, wanneer men die na lezing bij elkaar voegt, komt men tot de constructie van een zoodanig volmakte collega, dat men met alle eerbied voor een dusdanigen Übermensch, men toch een lichtelijk wee gevoel niet kan onderdrukken. ${ }^{74}$

Hoewel in 1936 de samenstellers van Medische ethiek niet meer spraken van intuïtieve gaven, wel degelijk een lijstje met gedragsregels opgaven en vonden dat de arts niet tot een soort 'Übermensch' moest worden uitgeroepen, was van een moreel superioriteitsgevoel zeker nog wel sprake: 'Alleen een goed mensch kan een goed arts zijn, ziedaar een stelling die niet gemakkelijk bestreden zal worden.' ${ }^{75}$ Arts worden deed je immers nog altijd uit roeping; je moest bereid zijn je eigen belang ondergeschikt te maken aan dat van de patiënt. Je moest 'dienaar van de zieke mens' willen worden. ${ }^{76}$ Met andere woorden: iemand die niet zijn eigen persoon kon achterstellen bij het heil van zijn patiënten kon beter winkelier, assuradeur of bankier worden. ${ }^{77}$ Joël van der Kous drukte zijn jonge toehoorders in zijn radiorede op het hart dat zij over de keus voor het beroep van arts niet lichtzinnig moesten denken:

Voor het beroep, waarover ik vanmiddag met jullie heb gesproken, voor het doktersberoep, geldt véél meer dan voor elk ander, dat zoodra de geroepen persoonlijkheid met zijn werk begint, dat wil zeggen, zich tegenover de zieke bevindt, die van hem hulp verwacht, hij niet moet vergeten, dat het niet voldoende is, zijn kennis, zijn verworven geleerdheid ten toon te spreiden, maar vooral ook als mensch tegenover mensch zijn overwicht als helpende persoonlijkheid. ${ }^{78}$

Dat het ochtendgebed voor de arts van Maimonides uitstekend aansloot bij dat heersende ideaal, bewees professor A. A. Hijmans van den Bergh toen hij zijn afscheidscollege in 1938 afsloot met het voorlezen van het hele gebed om daarmee zijn gehoor de ultieme laatste, wijze, humane les mee te geven. ${ }^{79} \mathrm{Jood}-$ 
se artsen als Hijmans van den Bergh, die overigens verregaand geassimileerd leefde, konden zelf dan ook een bijdrage leveren aan het medisch ethisch discours. Zo is ook duidelijk dat Herman Pinkhof invloed had op de Nederlandse medisch ethische ethiek: de in de gids Medische ethiek gebruikte casuïstiek was grotendeels ontleend aan zijn rubriek 'Beroepsbelangen' in het NTvG. ${ }^{8 \circ}$ Pinkhof hielp actief mee om de ethische richting uit te zetten voor de Nederlandse artsenstand. 'Decennia lang heeft hij met ijver en vuur beleden wat hem in de beoefening der geneeskunst, oirbaar, eerbaar, en eerbiedwaardig scheen,' schreef het $N T v G$ bij zijn veertigjarig jubileum als redacteur. ${ }^{81}$ Pinkhof kon tot op zekere hoogte meehelpen om de Joodse en de geneeskundige 'zedeleer' compatibel te houden. Zowel via het tijdschrift als via Medische ethiek had de mede door hem gevormde ethische denkwijze een enorm bereik onder de $\mathrm{Ne}$ derlandse artsen. Medische Ethiek bereikte net als het NTvG alle leden van de $\mathrm{NMG}^{82}$ Dat maakt het boekje Medische Ethiek dan ook bij uitstek geschikt om een indruk te krijgen van de belangrijkste gedragsregels, normen en waarden, van de Nederlandse artsenstand in het interbellum en daarmee ook van de Joodse artsen onder hen.

\section{EEN DEONTOLOGISCHE GIDS}

'De arts behoort niet te handelen, vóór hij twee vragen beantwoord heeft: I. Wat wil (kan) ik bereiken, en 2. Welke middelen zal (kan) ik hiertoe gebruiken?'83

Aldus de Joodse psychiater Arie Querido in zijn memoires. Als zowel doel als middelen wenselijk te noemen zijn, mag je als arts een medische handeling verrichten. Zowel deontologische als teleologische overwegingen tellen. Medische ethiek was vooral een deontologische gids, een explicitering van de deugden die de Nederlandse medische ethiek in 1936 voorstond. Het boekje was bedoeld als hulpmiddel voor de artsen, maar bewust niet op dwingende toon geschreven. Immers, de arts van de jaren dertig kon dan misschien niet altíjd intuïtief de juiste keuze maken, maar hij mocht heus wel in staat worden geacht zijn eigen besluit te nemen. Maar, zo waarschuwde de recensie in het $N T v G$ : 'klopt dat niet met wat neergelegd is in het boekje dan weet hij althans dat hij handelt in strijd met wat de meeste bezadigde vakgenooten, op wier oordeel hij prijs moet stellen, oirbaar achten.' ${ }^{84}$ Waarschijnlijk voor velen genoeg reden om toch maar het boekje te volgen.

In hun inleiding wezen A. ten Bokkel Huinink, C. Fehmers en Th. Hammes echter ook op de oorsprong van de genoemde normen en daarmee op de 
hoge doelstellingen van de geneeskunde, traditioneel teruggaand op de eed van Hippocrates. De eed die in Nederland sinds de hervorming van de volksgezondheid en instelling van het Geneeskundig Staatstoezicht door Thorbecke in 1865 in gebruik was genomen, was echter ten opzichte van de oorspronkelijke eed van Hippocrates drastisch ingekort en eigenlijk alleen nog maar gericht op geheimhouding. ${ }^{85}$ Deze luidde als volgt:

Ik zweer (beloof), dat ik de genees-, heel- en verloskunst volgens de daarop wettelijk vastgestelde bepalingen naar mijn beste weten en vermogen zal uitoefenen, en dat ik aan niemand zal openbaren wat in die uitoefening als geheim mij is toevertrouwd of ter mijner kennis is gekomen, tenzij mijne verklaring als getuige of deskundige in rechten gevorderd of ik anderszins tot het geven van informatie door de wet verplicht worde. Zoo waarlijk helpe mij God almachtig. ${ }^{86}$

Voor Thorbecke was deze eed met name instrumenteel in zijn streven om de beroepsgroep van artsen onder staatstoezicht te plaatsen. ${ }^{87}$ Tegelijkertijd vonden de Nederlandse medici zelf de eed van Hippocrates echter nog wel degelijk letterlijk, in de oorspronkelijke tekst bruikbaar. Hiervan getuigden ook de woorden van Hammes in zijn rede van 1935: 'De groote gebeurtenissen in het leven der menschheid tastten het wezen van Hippocrates' inzichten niet aan. Drie en twintig honderd jaren van ontwikkelingsgeschiedenis vermochten de wijsheid van Hippocrates niet te schokken. ${ }^{98}$ De normen en waarden die Hammes uit de oorspronkelijke eed haalde, gebruikte hij dan ook om de handleiding Medische ethiek aan op te hangen.

Dezelfde 'geheimhouding' leeft onverzwakt voort; 'het leven behouden en niet door vergiften verkorten, ook als mij daarom gevraagd wordt', belijden ook wij; 'de beheersching der begeerte' is ook ons een eerste plicht; het belang van den zieke, 'dien ik niet mag schaden of leed doen', is ook voor ons een beginsel; het 'niet afbreken eener zwangerschap' leeft in onze wetgeving voort. ${ }^{89}$

Ten Bokkel Huinink, Fehmers en Hammes werkten Hippocrates' voorschriften in Medische ethiek verder in detail uit en spitsten deze toe op de Nederlandse situatie. De verschillende onderwerpen konden worden onderverdeeld in drie categorieën, op basis van de drie overkoepelende waarden die de auteurs uit de eed van Hippocrates destilleerden: algemene deugdzaamheidsvoorschriften, vraagstukken van collegialiteit en de reikwijdte van de verantwoordelijkheid voor de patiënt. 
De 'verantwoordelijkheid voor de patiënt' verdient het allereerst nader bekeken te worden. Het 'heil van de enkeling' was namelijk niet letterlijk terug te vinden in de tekst van de oorspronkelijke eed van Hippocrates, maar leek met name ingegeven te zijn door de tijdgeest. "In het belang van den vrede", "tot heil van den staat", of "tot heil van de kerk", zijn leuzen, die de geneesheer niet kent,' '90 zei Hammes, terwijl tegelijkertijd in Duitsland een geneeskunde opkwam waarin juist het heil van de staat het hoogste doel was. Onomwonden meldde Hammes, in zijn rede voor de leden van de NMG:

Wanneer iets anders dan het belang van den zieke bij den arts zou gaan meespreken, dan zou dit tot vreemde gevolgen kunnen leiden. Dan zou het voor een niet zuiver Arischen zieke, in een gemeenschap die het zuivere Ariërdom als ideaal stelt, geraden zijn zich voor alle zekerheid maar door een niet Arischen arts te doen behandelen. ${ }^{91}$

Uiteraard was van dit al bij Hippocrates nog geen sprake geweest, maar ook bij Hippocrates werd geen enkel ander doel dan het heil van de zieke genoemd, en kennelijk vond Hammes hierin al genoeg ondersteuning van zijn stelling. 'De beroepseed is met het belang van den enkeling niet in strijd, integendeel - uiteindelijk is deze vaak de eenige steun voor den geneesheer wiens gemeenschapsgevoel in opstand komt.' ${ }^{2}$

Dat de arts een deugdzaam mens was, kon hij volgens Medische Ethiek op een aantal manieren aan de buitenwereld tonen. Zo mocht hij, zoals het een notabele betaamde, geen te opzichtige kleding dragen, niet te vaak het café bezoeken en dan vooral niet te veel alcohol nuttigen. Als stelregel gold dat het gedrag in het openbare leven dusdanig diende te zijn dat er niet over gesproken zou worden. ${ }^{93}$ Ook fel en onverdraagzaam optreden moest te allen tijde vermeden worden, en dus was het verstandig zich als arts niet op politiek terrein te begeven. Eventueel alleen oudere, door de jaren gelouterde dokters zouden hiervoor in aanmerking kunnen komen. ${ }^{94}$ Volgens de gids konden artsen wel lid zijn van een kerkgenootschap. Immers, ethiek zelf was geworteld in de godsdienst. Welke godsdienst dat moest zijn, werd niet voorgeschreven. De arts diende alleen niet zijn religieuze opvattingen aan patiënten op te dringen; een combinatie arts-theoloog was dan ook niet wenselijk. De arts diende de religieuze uitingen van patiënten te eerbiedigen, ongeacht eventuele eigen religieuze overtuigingen. Die eigen religieuze overtuigingen mochten niet te zwaar het handelen bepalen: 'Wat men van hem mag vergen, is dat hij vóór alle dingen een goed medicus is, d.i. een goed verzorger van het lichamelijk welzijn van zijn patiënten.' ${ }^{95}$ 
Aan de vraagstukken van collegialiteit wijdde Medische Ethiek meerdere paragrafen. Allereerst werd gemaand collegae en hun gezinnen geen rekening te sturen. Soms ook niet aan directe naasten van collegae. Deze stelregel viel onder de noemer 'Latijn betaalt niet aan Latijn' en gold dus ook voor andere 'notabelen', maar naar deze laatsten kon de arts naar eigen inzicht wel of geen rekening sturen. Ook het overdoen van een praktijk aan een collega ging liever niet met een financiële transactie gepaard, immers: patiënten waren niet het eigendom van de arts. Omdat er voor zogenaamde 'goodwill' wel een bedrag gebruikelijk was, werd dat dan ook door de schrijvers niet direct ethisch ongepast genoemd. ${ }^{96}$ Als de praktijk eenmaal was overgenomen, was het daarna met nadruk niet de bedoeling dat de voorganger zich weer in zijn vroegere woonplaats zou vestigen. Dit in verband met de kans dat oude patiënten dan liever weer bij hem in de praktijk zouden willen in plaats van bij hun nieuwe arts. Pas als de opvolger geen bezwaar zou maken tegen vestiging van zijn voorganger in dezelfde plaats, zou deze dit mogen doen. In hetzelfde verband - het voorkomen van oneerlijke concurrentie - waren er strikte regels over de mogelijkheid van adverteren. Driemaal een advertentie plaatsen bij vestiging, eenmaal bij verhuizing en bij het begin en einde van een vakantie was het maximaal toelaatbare. Indirecte reclame door dankbetuigingen van patiënten in kranten, een vrij gebruikelijk verschijnsel, werd ook als onwenselijk gezien en diende dus niet aangemoedigd te worden. Desnoods kon men dagbladadministraties verzoeken om plaatsing van dergelijke advertenties te voorkomen.

Openlijke kritiek op collegae was ook uit den boze. Men viel hen niet af bij patiënten; een diagnose van een collega in twijfel trekken was absoluut niet acceptabel. Dit gold voor een waarnemend arts in de praktijk van een ander, maar ook voor een specialist in zijn houding ten opzichte van de huisarts of voor een behandelend arts ten opzichte van een controlerend arts. Ook ten opzichte van verpleegsters werd van artsen een respectvolle houding verwacht. De schrijvers benadrukten het belang van een goed observerende verpleegster aan het ziekbed en van het nut dat deze ook voor het werk van de arts had. Vanzelfsprekend was het ook aan de arts om een goede werkrelatie op te bouwen met vroedvrouw en apotheker. Wat betreft recepten voorschrijven werd nog vermeld dat het niet eerlijk zou zijn middelen voor te schrijven waarvan de samenstelling alleen bekend was bij de arts die ze voorschreef. Hiermee kon men collegae namelijk ook in een positie van achterstand plaatsen. Mocht er toch een conflict tussen collegae ontstaan, dan diende bemiddeling onderling geregeld en intercollegiaal opgelost te worden. Via de NMG werd een dergelijke situatie intern afgehandeld. Evenzo gold voor de rechtspraak: geschillen met patiënten werden sinds 1928 in medische tuchtcolleges afgehandeld. De Me- 
dische Tuchtwet van dat jaar was weliswaar een poging van de staat meer greep te krijgen op het handelen van artsen, en in de medische tuchtcolleges namen rechtsgeleerden zitting, maar het merendeel van de leden van de colleges was zelf medicus. Misdragingen werden dus beoordeeld door collegae. Verbazingwekkend is dit niet als de traditionele opvatting hierover in overweging wordt gegeven: 'Er zijn weinig menschen die meer door het publiek beoordeeld worden dan de dokter, en echter is het publiek volstrekt niet in staat den dokter te kunnen beoordelen: dat kunnen slechts zijn collegae doen. ${ }^{97}$ Patiënten achtte men per definitie niet in staat een goed oordeel te kunnen geven over de hun geboden medische zorg.

Deze paternalistische opstelling was eveneens zichtbaar in de regels betreffende de reikwijdte van de verantwoordelijkheid voor patiënten die in $\mathrm{Me}$ dische Ethiek aan bod kwamen. Een goede arts nam de zorgen van de patiënt vaderlijk over. 'Hij is het die de zorgen van zijn patiënt heeft te dragen, hij mag ze niet op diens schouder leggen.' Hij mocht daarbij ook zijn eigen mogelijke twijfel aan de gunstige afloop aan de patiënt niet laten blijken. Hij moest in zijn uitspraken praktisch en opgeruimd zijn en slechts in het geval dat de patient stellig wenste te weten wat zijn prognose was, uitspraken in deze richting doen. De patiënt had weliswaar tot op zekere hoogte het recht te weten wat hem mankeerde, maar het was aan de arts met behulp van zijn mensenkennis in te schatten wanneer het beter was te zwijgen over ongunstige verwachtingen. 'Bij het stellen der prognose moet de doos van Pandora als symbool gelden: de hoop moet steeds op den bodem achterblijven. De arts heeft tot taak het leven te verdedigen, de pleitbezorger van dat leven te zijn. ${ }^{9} 8$ Zodra de patiënt op de hoogte was van een sombere prognose, zou hij de moed laten zakken. In de taakopvatting van de arts als hoeder van het leven paste natuurlijk ook de opvatting dat abortus en een dodelijk middel toedienen op verzoek van de patiënt niet geoorloofd waren. In de paragraaf over het uitproberen van nieuwe geneesmiddelen werd het principe van 'primum-non-nocere' (allereerst niet schaden) aangehaald. In het kader van dit gebod maanden de auteurs de medicus zijn eigen grenzen te kennen en te bewaken. Er diende een specialist geconsulteerd te worden op het moment dat men zich aan de grenzen van zijn bekwaamheid dacht te bevinden. In noodsituaties mocht en moest de arts echter wel altijd behandelen.

Een andere grens voor een arts was die van keuring voor ziekte en arbeidsverzuim. Dit kon men beter niet bij eigen patiënten doen, bij wie men niet geheel objectief kon oordelen, omdat men - zeker als huisarts - ook een soort huisvriend was. Dit laatste moest ook weer niet te ver doorgevoerd worden. De arts moest zich niet verlagen tot het lukraak uitschrijven van medische 
verklaringen op verzoek van de patiënt met het doel om bij deze patiënt in het gevlij te komen. Zulke medische verklaringen, attesten, konden de betreffende arts in discrediet brengen bij collegae. Als er van één bepaalde arts opvallend veel attesten in omloop waren, wisten de collegae namelijk snel genoeg dat de waarde ervan niet groot kon zijn. ${ }^{99}$ Mocht de arts in een dergelijk geval zelfs geld aannemen voor een attest, dan stelde hij zich bloot aan een tuchtmaatregel.

Ten zeerste af te keuren was ook het uitvoeren van schijnoperaties, bij wijze van placebo-behandeling. Hoewel er op het eerste gezicht groot succes mee behaald kon worden, werd het toch laakbaar geacht. Als de patiënt er namelijk alsnog achter zou komen dat er niet daadwerkelijk een operatie was uitgevoerd, zou hij voorgoed zijn vertrouwen in de medische stand verliezen. Bovendien was het ook voor collegae moeilijk een bij een dergelijke nepbehandeling opgelopen litteken te duiden. Het vertrouwen in de medische stand mocht ook geen geweld aangedaan worden door het beroepsgeheim te schenden. Slechts in geval van gerechtelijke noodzaak mocht de arts gegevens van de patiënt openbaren. En ten slotte, geheel en al in de paternalistische traditie en ook al door Treub aanbevolen: als de arts zijn patiënten aan het eind van zijn carrière over moest dragen aan een jongere collega, kon hij dit alleen doen aan iemand van wie hij het idee had dat ook hijzelf, in het geval het nodig zou zijn, door deze collega geholpen zou willen worden.

Hiermee is een korte samenvatting gegeven van de plichtenleer van de Nederlandse arts in het interbellum, zoals gepresenteerd in een boekje 'zonder eenige pretentie (...) laten wij hopen tot heil van den geneeskundigen stand in Nederland. ${ }^{\text {Ioo }}$ Inmiddels nodeloos te zeggen: inclusief de Joodse collegae.

\section{GEWONE HOLLANDSE ARTSEN MET EEN JOODSE IDENTITEIT}

De Joodse artsen waren gewone Hollandse artsen in hun beroepsuitoefening, maar dat wilde zeker niet zeggen dat zij geen Joodse identiteit hadden. Het voorbeeld van Herman Pinkhof is daarbij al veelzeggend. Hij was (meer dan) volwaardig lid van de artsenstand en leefde orthodox Joods. Assimilatie was dus geen voorwaarde voor emancipatie, integratie en succes in de artsenstand. Assimilatie was er uiteraard wel onder Joodse artsen. De Joodse identiteit van de Nederlandse Joden in het algemeen kenmerkte zich immers in de jaren twintig en dertig door het tegelijkertijd bestaan van assimilatoire en antiassimilatoire bewegingen. Een eenduidig beeld van 'de' Joodse identiteit van 
de Nederlandse Joden is daarom moeilijk te verkrijgen. Er was te veel variatie om een algemene uitspraak te doen. 'Als uitersten konden Joden enerzijds volledig opgaan in de samenleving met verlies van joodse identiteit, en anderzijds kiezen voor bewuste handhaving en diepgaande beleving van de orthodoxie in eigen kring. Daartussen vertoonden zich vele variaties en combinaties van bindingen zowel met (groepen uit) de samenleving als met de Joodse traditie en herkomst,' schreven historici Blom en Cahen. ${ }^{\text {IoI }}$ In I923 introduceerde Sigmund Seeligmann in zijn Die Juden in Holland. Eine Characteristik het begrip 'Species Judaica Hollandia', een begrip dat legendarisch werd, maar uiteraard het gevaar van generalisatie in zich droeg. ${ }^{\text {IO2 } ~ ' D e ' ~ N e d e r l a n d s e ~ J o o d ~ b e s t o n d ~}$ niet. 'De' Nederlandse Joodse arts dus ook niet. Vele mogelijke factoren konden bepalen of de Joodse artsen zich in meer of mindere mate verbonden voelden met hun Joodse achtergrond. Religie, traditie, zionisme, het 'rasbewustzijn' of antisemitisme: dat alles kon een rol spelen.

Bij de volkstelling van 1930 was gebleken dat II2 000 Nederlandse burgers behoorden tot ofwel het Nederlandsch Israëlietisch Kerkgenootschap, ofwel het Portugeesch Israëlietisch Kerkgenootschap. Dit betekende dat I,4 procent van de Nederlandse bevolking zich Joods noemde. De telling van I930 was de eerste die een daling ten opzichte van de vorige telling liet zien. Vanaf I870 was er telkens groei geconstateerd van het Joodse deel van de bevolking, vermoedelijke dankzij een verbeterde registratie en hygiënischer leefomstandigheden in de arme Joodse buurten, waardoor de sterfte hier was gedaald. ${ }^{103}$ Uit onderzoek van Herman Pinkhof in 1907 bleek dat Joodse zuigelingen gemiddeld een grotere overlevingskans hadden door de in de krotten van de Amsterdamse Jodenbuurt veelvuldig - meer dan bijvoorbeeld in de even arme Jordaan - gegeven borstvoeding. ${ }^{104}$ De krimp die in 1930 echter onmiskenbaar had ingezet, was allereerst het gevolg van de relatief hoge gemiddelde huwelijksleeftijd in Joodse kring. De vrouwen trouwden later dan bij andere gezindten en kregen daarom ook gemiddeld minder kinderen. Het Nederlandse Jodendom vergrijsde hierdoor. ${ }^{\text {Ios }}$ Een tweede oorzaak voor de daling was het toenemend aantal gemengde huwelijken. Deze tweede oorzaak is een teken van voortschrijdende assimilatie. Joden die geen sterke binding meer met het Jodendom hadden, vonden steeds vaker een niet-Joodse partner. Een gemengd huwelijk betekende in het geval van een Joodse man en een niet-Joodse vrouw dat eventuele kinderen voor het Jodendom verloren gingen. Met een niet-Joodse moeder golden de kinderen halachisch - volgens de Joodse wet - immers als niet-Joods, een gevolg dat zeer verstrekkend genoemd kan worden en daarmee een extra drempel kon vormen voor een huwelijk buiten de eigen gezindte. Steeds meer mensen waren echter bereid over die drempel te stappen. Was 
het percentage huwelijken met een niet-Joodse partner in de periode I9OI1906 nog 6,o geweest, in 193I-I934 was het al 16,9 procent. ${ }^{106}$ In heel Europa deed zich een dergelijke assimilatoire trend voor. ${ }^{107}$ Elders overigens meer dan in Amsterdam, waar het percentage gemengde huwelijken ten opzichte van steden als Budapest, Berlijn en Frankfurt nog relatief laag was. ${ }^{108}$ Men merkte echter ook in Nederland met enige zorg op dat als deze demografische trend van assimilatie zich zou voortzetten, de Joodse bevolkingsgroep langzaam als herkenbare eigen groep uit de samenleving zou verdwijnen. ${ }^{\text {109 }}$

Een zichtbare trend binnen de Joodse gemeenschap was de ontkerkelijking, zoals ook bij andere religies in het interbellum het geval was. Deze secularisatie ging echter niet automatisch gepaard met een volledig verlies van hechting aan de Joodse identiteit. De Joodse identiteit hing voor velen meer samen met traditie dan met godsdienst. Hoewel in de jaren dertig zelfs op de Hoge Feestdagen, wanneer de synagoges tot de nok gevuld waren en extra zaaltjes gehuurd moesten worden, de sjoelgangers niet meer dan is procent van de Joodse bevolking uitmaakten, waren de belangrijke momenten in het leven vaak nog wel traditioneel. Zo werd in 1934 nog 90 procent van de pasgeboren Joodse jongetjes besneden en trouwde 92 procent van de Joodse stellen onder de choepa. Ter vergelijking: bij de katholieken trouwde tezelfdertijd 76 procent in de kerk en bij de protestanten slechts 31 procent. ${ }^{\text {IIO }}$ Bij Joden was dus relatief veel neiging naar het vasthouden aan traditie, wat bij de onmiskenbare secularisatie-trend toch volledige assimilatie voorkwam. Zoals internist Juda Groen zich herinnerde: 'Ze hebben [het Jodendom] toch gecontinueerd, ofschoon ze zich losmaakten van de synagoge. Iets van die warme huiselijkheid, dat zorgen voor kinderen, de familieband, dat de Joden, burgerlijk of arbeiders, kenmerkte.'

En dat ondanks het feit dat, aldus Groen: 'velen van ons [en hij bedoelde hier de Amsterdamse Joodse artsen], zoals dat heet, gemengd gehuwd zijn.' ${ }^{\text {'II }}$

De groep Joodse artsen was relatief verregaand geassimileerd als men de mate van assimilatie afmeet aan het aantal gemengde huwelijken. Van de 534 Joodse artsen van wie de gegevens bekend zijn, waren er waarschijnlijk 92 getrouwd met een niet-Joodse partner. Voorts waren III artsen niet gehuwd, of is van hen geen huwelijk bekend. Dit betekent dat de gemengd-gehuwden zo'n $2 \mathrm{I}, 5$ procent van het totaal aantal gehuwde artsen uitmaakten. Meer dus dan de I6,9 procent onder de algemene Joodse populatie. ${ }^{\mathrm{II} 2}$ De mate van gehechtheid aan traditie onder de Joodse artsen is moeilijker meetbaar, omdat het hier gaat om een subjectieve beleving, zich afspelend in de huiselijke sfeer. Hierover zijn daarom nauwelijks uitspraken te doen, hoewel men een indruk zou kunnen verkrijgen uit ex librissen - vaak uitdrukkingen van persoonlijke hartstochten 
en kenmerken - die van diverse Joodse artsen bewaard zijn gebleven. In een verzameling van 672 ex librissen, onder Nederlandse medici verzameld in 1940 en net na de oorlog, valt op dat er op de 36 ex librissen van de Joodse artsen slechts bij vijf voorstellingen een verwijzing kan worden gevonden naar de Joodse achtergrond. ${ }^{\text {I3 }}$ Hieruit zou men kunnen afleiden dat voor de andere 3I Joodse artsen het Joods-zijn geen enorm grote rol speelde. ${ }^{\text {II } 4}$

Zeker is dat er onder de 534 artsen verschillende waren die volstrekt geassimileerd leefden en pas toen de Duitse bezetter hen als Jood aanmerkte, in deze categorie gingen vallen. Het toppunt van assimilatie zou de anekdote van de latere psychiater Max Hamburger genoemd kunnen worden, die als schooljongen tegen zijn moeder verzuchtte: 'Ik wou dat ik een Joods jongetje was', jaloers als hij was op de vrije zaterdag die zijn Joodse klasgenootjes vergund was. Dat hijzelf ook Joods was, maar dat noch zijn ouders noch zijn omgeving hem enig bewustzijn daaromtrent hadden meegegeven, realiseerde hij zich pas na uitleg van zijn moeder. ${ }^{\mathrm{II}}$ Eveneens getuigend van een grote mate van assimilatie is de herinnering van Joseph Kater: 'Mijn meeste school- en studievrienden waren niet-Joods. Toen ik me als huisarts vestigde kreeg ik al gauw een heel gemengde praktijk wat godsdienst betrof.' Kater was zich, in tegenstelling tot de jonge Hamburger, wel bewust van zijn Joods-zijn, maar voor hem gold dat puur als een religieus gegeven, dat bij hem niet erg op de voorgrond stond: 'Je was en voelde je ook volkomen Nederlander in alle opzichten, en je godsdienst was daarnaast een intieme persoonlijke kwestie, waarmee anderen niets te maken hadden.' ${ }^{\text {II6 }}$ Kater was toevallig Joods, net zo goed als een andere Nederlander katholiek of protestant kon zijn; dat is de strekking van zijn woorden.

Slechts enkele Joodse artsen hadden voor zover bekend een sterke religieuze binding met het Jodendom. Hierbij denken we dan weer even aan Herman Pinkhof terug. Net als Pinkhof leefde ook Maurits Elzas, geneesheer-directeur van het Rotterdamse Joodse ziekenhuis en bekend arts, orthodox Joods. ${ }^{\text {II7 }}$ In Pinkhofs geval werd zijn Joodse identiteit overigens niet alleen door religie gevormd, maar ook door zijn zionisme, een combinatie die hem ertoe had gebracht in 1902 de Nederlandse afdeling van de orthodox zionistische organisatie Mizrachie mede op te richten. ${ }^{\text {II8 }}$ Orthodoxie op zichzelf was overigens allerminst automatisch gekoppeld aan een zionistisch ideaal. De Rotterdamse huisarts David Hausdorff, die net als Pinkhof orthodox leefde, keerde zich juist duidelijk tegen het zionisme door zich aan te sluiten bij Agoedas Jisroël, de organisatie die het streven naar de stichting van een Joodse staat, anders dan door de Messias zelf, bestreed. Voor Hausdorff was zijn Joodse identiteit daarmee veel meer religieus van aard. Hausdorff was overigens, net als Pinkhof, bepaald niet alleen in Joodse kring een bekend figuur. Jarenlang riepen Rotter- 
damse tramconducteurs de onofficiële 'Halte Hausdorff' om, op het moment dat de tram zijn huis naderde. ${ }^{\text {II }}$ Geïsoleerd was hij, met zijn gemengde praktijk, allerminst. Heel anders was dat voor de Amsterdamse huisarts Isaac Dasberg, die vroom leefde en bovendien een bijna geheel Joodse praktijk had. ${ }^{120}$ Dasberg was dan ook vooral in de eigen Joodse kring een bekende verschijning. Generaties Joodse mannen hebben rondgelopen met een 'Coupe Dasberg', een gevolg van het feit dat Dasberg een geliefd moheel (besnijder) was. De arts Betty Prins leefde ook orthodox en had als assistent in het Wilhelmina Gasthuis haar eigen bestek en botervloot. Toen een nieuwe collega nietsvermoedend zijn mes plantte in Betty's boter, spraken de andere assistenten hem er meteen op aan. Voor Betty Prins vormde haar orthodoxe levenswijze geen enkele belemmering in haar beroepsuitoefening. Pas toen zij in het huwelijk trad, had dat directe gevolgen voor haar beroepsuitoefening. Haar man vond het beter als zij zou stoppen met werken en dus deed ze dat. ${ }^{12 \mathrm{I}}$

Streng religieuze Joodse artsen waren er verder volgens de gevonden gegevens nauwelijks. De anti-assimilatoire, Joodse identiteit versterkende kracht die van de religie uitging, was daarom waarschijnlijk onder de artsen niet erg sterk. De anti-assimilatoire kracht die van het zionisme uitging, was evenmin zeer sterk, maar zeker niet onbeduidend. Van de 534 artsen is van in elk geval 4I bekend dat zij zich in de jaren dertig actief met het zionisme bezighielden. De zionistische bewustwording versterkte bijvoorbeeld bij gynaecoloog Maurits Muller zijn Joodse identiteit. In I9I3 schreef hij na zijn kennismaking met het zionisme: 'Ik was wel ras-Jood, maar had geen enkele houvast om dit te uiten. En als men mij dan vroeg, wat ik was, dan antwoordde ik: niets. $\mathrm{Nu}$ is dat anders, nu zeg ik: "Een Jood."'

Muller had het in dit dagboekfragment niet alleen over de betekenis van zijn zionistische ideaal, maar hij bezigde ook als vanzelfsprekend de term 'rasJood'. De term 'ras' was in die tijd zeer gebruikelijk. Voor hen die zich niet gebonden voelden aan religie of zionisme, kon dit 'rasbewustzijn' dan ook een factor van betekenis vormen in het gevoel Joods te zijn. Ook dít kon de Joodse identiteit bepalen. De Dordrechtse arts Oscar Cahen refereerde eraan in zijn vlammende betoog tegen het antisemitisme, in november 194I opgedragen aan zijn collegae van het Medisch Dispuut Dordrecht. Hij zag een verregaande assimilatie: 'Want de assimilatie van de Joden gaat en ging zo ver, dat zij zich uitwendig volkomen aanpasten aan het volk, waarbij zij een groot deel van hun leven individueel sleten. ${ }^{123}$ Maar ondanks de sterke assimilatoire beweging nam Cahen wel degelijk tegelijkertijd een 'rasbewustzijn' waar, dat bij niet-religieuze Joden 'inwendig leefde'. ${ }^{124}$ Een dergelijk bewustzijn sprak ook uit correspondentie van medisch student Jaap Spanjaard met een dier- 
bare niet-Joodse vriendin. Jaap uitte in een brief zijn teleurstelling: 'Het is de kwestie, dat ik gemeend heb, dat in een vriendschapsomgang er geen sprake

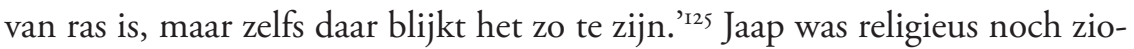
nistisch, maar toch bewust Joods, zoals hij aan zijn vriendin schreef: 'Phiet, ik ben een Jood en zal me ook mijn Godganselijke leven niet anders voordoen, al hoop ik 't op een goede manier te doen, zoals een goede Jood dat zonder twijfel ook doet!' ${ }^{226}$ Jaap Spanjaard luchtte zijn hart naar aanleiding van een gesprek tussen de beide vrienden over het Joods-zijn van Jaap en zijn angst daarop te worden beoordeeld. Daarop had Phiet gezegd dat als Jaap zich niet als een Jood zou gedragen, hij ook niet als een Jood zou worden beoordeeld. In plaats van een geruststellend effect ging er van deze opmerking juist een krenkende werking uit: kennelijk vond Phiet dat er zoiets als 'typisch Joods gedrag' bestond en dat dat afkeurenswaardig was, zo vatte Jaap althans haar opmerking op.

Tussen Jaap en Phiet bestond groot wederzijds respect en met hun vriendschap zou het helemaal goedkomen, maar de opmerking van Phiet, of in elk geval Jaaps interpretatie daarvan, was wel exemplarisch voor het sentiment dat onder niet-Joden ten opzichte van Joden kon leven: het sentiment dat met de term 'risjes' wordt aangeduid en waarmee een vorm van antisemitisme bedoeld wordt. Deze vorm van antisemitisme, bestaande uit stereotypering en het negatief generaliseren van 'de' Joden als een onaangenaam volk, zou als relatief mild bestempeld kunnen worden en als vergelijkbaar met het discrimineren van andere groepen binnen de verzuilde maatschappij. ${ }^{127}$ Virulenter vormen van Jodenhaat waren er echter ook, zoals het anti-judaïstische antisemitisme, waarbij de Joden vanuit christelijke hoek verketterd werden vanwege de moord op Christus, en het sociaal-darwinistische antisemitisme, waarbij men ervan uitging dat het 'Joodse ras' de kracht van het volk ondermijnde. ${ }^{128}$ Een confrontatie ermee kon, hoe zijdelings ook, voor de artsen een negatieve versterking van hun Joodse identiteit betekenen. Paradoxaal genoeg kon door antisemitisme juist ook een assimilatoire neiging ontstaan. Angst voor antisemitisme kon immers betekenen dat men liever niet meer Joods wilde zijn. Van enkele Joodse artsen is bekend dat zij inderdaad negatieve sentimenten koesterden ten opzichte van hun Joodse wortels. Zo was Paul Lopes Cardozo als medisch student in Leiden in de jaren dertig door zijn Portugees-Joodse moeder meermaals gewaarschuwd zich niet in (asjkenazische) Joodse kringen te begeven. Zelfs Joodse academische kringen, zoals het Genootschap voor de Joodsche Wetenschap, waren wat moeder Celine Lopes Cardozo betrof beneden haar zoons waardigheid: 
Prof Snapper is geen heer en wordt het ook niet met het gevolg, dat hij nu zogenaamd blij is met zijn kring, maar inderdaad een worm voelt knagen, omdat hij ondanks zijn geleerdheid vulgair is, evenals prof. Palache, Polak, Cohen enz, die zich noemen de Ver.v. Joodsche academici en geleerden: brr, een akelig iets, intellectueel proletariaat, zoodra je maar even gewoon beleefd of vriendelijk bent, probeeren ze je in hun onbeschaafde, geleerde en vaak parvenu-achtige kring te trekken, waar je nooit meer uit komt. ${ }^{\mathrm{I} 9}$

In meerdere brieven drukte moeder Lopes Cardozo zich laatdunkend uit over het 'ras' waar zij zich van wenste te distantiëren. Hoe haar zoon Paul er zelf precies over dacht, is niet duidelijk, maar hij profileerde zich in elk geval de rest van zijn leven niet als Jood. ${ }^{130}$ Ook Loe de Jong beschreef in zijn Koninkrijk een Joodse arts die zich volgens verschillende bronnen 'sterk geneerde' voor zijn Joodse komaf. ${ }^{\text {.3r }}$ Over de Amsterdamse huisarts Sieg Emmering en zijn vriend de psychiater Frits Grewel is in diezelfde lijn opgetekend: 'Voor de oorlog leefde oom Sieg in kringen van gegoede Amsterdam-Zuid-Joden, die geen Joden wilden zijn. ${ }^{{ }^{1} 32}$ Toch lukte het ook hun niet het Joods-zijn van zich af te schudden: 'Sieg, Zus, mijn ouders en de Grewels waren verneinende joden, maar het gekke is dat de hele groep alleen maar joodse vrienden had, die integreerden helemaal niet met de rest! Want zij konden wel willen dat ze niet jood wilden wezen, maar de hele rest om ze heen wees hen wel aan als Joden.' ${ }^{133}$ Kortom, ook de omgeving was een factor van betekenis in de mate van assimilatie of anti-assimilatie.

Elitaire kringen, waar ook de artsenstand toe gerekend moet worden, waren zeker niet geheel gespeend van antisemitische sentimenten. ${ }^{34}$ Zo kozen Sieg Emmering en zijn jaargenoten en latere collega-medici Arie Querido en Max Roeper bewust voor de studentenvereniging Unitas en niet voor het Amsterdams Studenten Corps, omdat de ontgroening bij het corps bekendstond als extra zwaar voor Joodse aankomend studenten. ${ }^{135}$ Antisemitische uitlatingen waren tot op zekere hoogte bon ton bij de conservatieve elite: raadsheer in de Hoge Raad B.M. Taverne zei bijvoorbeeld dat hij 'geen jodenvriend' was. ${ }^{136}$ Tegelijkertijd hoopte hij tijdens de bezetting wel dat de Duitsers de Joden met rust zouden laten. Ook het voorbeeld van de vrouwelijke arts Jeltje Stroink is in dit opzicht treffend, die in haar dagboek noteerde: 'Dol op de Joden zijn we nu bepaald niet', ${ }^{137}$ maar ze toonde zich gedurende de bezetting fel antinazi en verborg Joodse onderduikers in haar huis. ${ }^{138}$ Belangrijk in dit verband is het onderscheid tussen anti-Joodse sentimenten in de vorm van 'risjes' en virulentere vormen van antisemitisme in gedachte te houden. Met name de sociaal-darwinistische vorm bleek, met de nationaalsocialistische invulling, 
levensgevaarlijk. In Nederland was deze variant niet erg populair en onder artsen al helemaal niet. Er waren uiteraard wel artsen die het nationaalsocialistische gedachtegoed aanhingen. De medische afdeling van de NSB, het 'Medisch Front', telde op haar hoogtepunt, in december 1942, 2IO leden. ${ }^{139}$

Waarschijnlijk was het aantal sympathisanten voor sociaal-darwinistische en nationaalsocialistische ideeën onder de Nederlandse artsen tijdens het interbellum echter niet groot. Er was immers weliswaar aandacht voor eugenetica, en over rassen werd in dat kader ook gesproken, maar niet met de lading die het onderwerp in Duitsland had. ${ }^{140}$ De Duitse rashygiëne was naar de Nederlandse zin veel te radicaal en werd bovendien gekaapt voor politieke doeleinden, iets wat de Nederlandse artsen en zelfs de eugenetici onder hen principieel afwezen. ${ }^{\mathrm{I} 4 \mathrm{I}}$ De Duitse eugenetische sterilisatiepraktijken vanaf 1933 wezen zij sterk af. Ook over het 'Jodenvraagstuk' publiceerden Nederlandse eugenetici nauwelijks.

In 1933 opperde nazi-ideoloog Julius Streicher het idee om Joden - in navolging van zwakzinnigen - te steriliseren om daarmee het Joodse ras te laten uitsterven. Dit leidde tot ontsteltenis in de Nederlandse (Joodse) pers. ${ }^{142}$ In het $N T v G$ werd voorts verslag gedaan van buitenlandse sterilisatiepraktijken op eugenetische basis, niet alleen in Duitsland maar ook in Amerika, Zweden en Denemarken. De toon was over het algemeen niet erg enthousiast, hoewel sommige artsen sterilisatie van zwakzinnigen en misdadigers wel als opportuun zagen. ${ }^{143}$ Echter, de meeste auteurs uitten twijfels of een geneesheer wel 'voorzienigheid' mocht spelen en of een sterilisatie-operatie niet even ongeoorloofd zou zijn als het amputeren van een been om iemand ongeschikt te maken voor militaire dienst. ${ }^{\mathrm{I} 4}$ Zeker toen sprake was van sterilisatie van blinden en epileptici in Duitsland verschenen er ronduit afwijzende reacties in het $N T v G .{ }^{\mathrm{I} 45}$ L.J.J. Muskens schreef: 'zijn wij er in onze dagen getuigen van, dat het volk dat zich tooide met den naam "Volk der Denker", het goede spoor bijster is geworden?' ${ }^{146}$ Collega U.G. Bijlsma schreef op zijn beurt dat sterilisatie misdaad en verloedering niet tegen zou gaan, omdat niet erfelijke degeneratie de oorzaak van de criminaliteit was, maar 'de vermindering van de achting voor de rechten van den persoon; een verschijnsel, waaruit misschien ook de roep naar sterilisatie voortkomt. ${ }^{\text {'T7 }}$ Dat de Nederlandse artsen over het algemeen, anders dan in andere westerse landen, niet in groten getale eugenetica en de daarbij behorende sterilisatie-ideeën steunden, wordt wel toegeschreven aan de verzuiling, die staatsinterventie in de reproductie van hun achterban tegenhield, en aan de invloed van de katholieke kerk, die fel gekant was tegen welke vorm van sterilisatie dan ook. ${ }^{148}$

De meeste publicaties over dit onderwerp in het $N T v G$ waren van de hand 
van Herman Pinkhof, een principieel tegenstander van de sterilisatie op eugenetische gronden en van sterilisatie zonder medische noodzaak in het algemeen:

Nog steeds moet, naar mijn gevoelen, worden volgehouden dat een geneeskundige handeling, welke ingrijpt in de verrichtingen of de anatomische ongeschondenheid van het lichaam, door den arts slechts mag worden ondernomen tot herstel, ter verzachting, of ter voorkoming van stoornissen in den physiologischen gang van zaken of van afwijkingen van den normalen bouw van het lichaam bij den persoon, die de handeling heeft te ondergaan. ${ }^{149}$

Aldus Herman Pinkhof in 1933. ${ }^{\text {I50 }}$

Opvallend genoeg was de voorvechtster bij uitstek van de eugenetica in Nederland zelf een Joodse arts. Marianne van Herwerden (1874-1934), kleindochter van Isaac van Deen, had een protestants-christelijke opvoeding genoten, maar had een Joodse moeder. ${ }^{\text {III }} \mathrm{Zij}$ leek ofwel geen binding te hebben met het Jodendom ofwel om strategische redenen geen blijk te geven van een dergelijke binding. In haar boek over de vriendschap tussen haar grootvader en de fysiologen J.A.W. Moleschott en F.C. Donders repte zij in elk geval met geen woord over de Joodse achtergrond van haar opa Van Deen. ${ }^{152}$ Maar ook Van Herwerden schrok terug voor de rassenhygiëne van haar Duitse vakgenoten. Nederlandse deskundigen meenden dat de Joden geen apart ras vormden, maar een mengelmoes waren van verschillende rassen. ${ }^{153}$ Hun werden wel bepaalde lichamelijke en geestelijke eigenschappen toegedicht, die onderwerp van studie waren. Die studies werden vaak door Joodse artsen uitgevoerd. ${ }^{54} \mathrm{Zo}$ was de Joodse huisarts Jacob Sanders directeur van de afdeling voor medisch statistisch erfelijkheidsonderzoek van het Nederlandsch Instituut voor Erfelijkheidsonderzoek bij den mensch en voor rassenbiologie. Tegelijkertijd was hij een actief zionist. Zijn proefschrift uit I9I8 was getiteld Ziekte en sterfte bij Joden en niet-Joden in Amsterdam en bevatte de stelling 'De verwezenlijking van de Zionistische idee is een eerste voorwaarde voor de hygiëne van het Joodsche ras. ${ }^{\text {sss }}$ Net als zijn collega Samuel Poliakoff, eveneens een Joodse arts, sprak hij weliswaar van 'het' Joodse ras, maar bedoelde hiermee een conglomeraat van verschillende rassen. Zo schreef Poliakoff in de jaren 1924 en 1925 een serie over de raskenmerken der Joden in het Joodse tijdschrift De Vrijdagavond. Zijn conclusie luidde: 
Uit dit, uit den aard der zaak zeer oppervlakkig overzicht van de ontwikkeling van de Joden als ras, blijkt direct dat van raszuiverheid allerminst gesproken kan worden. Voortdurend zijn kleinere of grootere groepen van een, tot een ander ras behoorende, bevolking in de Joodsche groep opgenomen. ${ }^{156}$

De Joodse artsen Frits Grewel en Coen van Emde Boas publiceerden later eveneens over dit onderwerp, met dezelfde boodschap: 'het' Joodse ras bestond niet. ${ }^{157}$ Het simpele feit dat er over deze kwestie onder artsen gesproken werd en dat het onderwerp van serieuze wetenschap was, kan natuurlijk wel een Joods bewustzijn bij de Joodse artsen versterkt hebben.

\section{MANIFESTATIE VAN JOODSE IDENTITEIT}

Een zeker Joods bewustzijn kon zich bij de artsen op vele manieren manifesteren. Zo waren er Joodse medische voorzieningen en onderlinge verbanden waar Joodse artsen elkaar konden ontmoeten en zich als Joodse arts konden profileren. Voor de situatie van de Joodse artsen in het interbellum is wel opgemerkt dat zij niet over een eigen Joodse beroepsvereniging beschikten, zoals die voor katholieke en protestantse artsen in het kader van de verzuiling wel bestonden, en dat zij daarom in een zeker isolement verkeerden. ${ }^{158}$ Het tegenovergestelde kan echter ook van deze situatie gezegd worden: juist omdat de Joodse artsen integraal onderdeel van de algemene artsenstand uitmaakten en niet alleen in Joodse kring opereerden, verkeerden zij over het algemeen genomen niet in een isolement. En zelfs als men een gebrek aan een beroepsvereniging voor enkel Joodse artsen als teken van isolement opvat, zijn er argumenten aan te dragen waarom er toch genoeg mogelijkheid was voor Joods intercollegiaal contact. In Amsterdam bestonden bijvoorbeeld drie Joodse ziekenhuizen, aan welke Joodse artsen verbonden waren. Er was het Nederlandsch Israëlietisch Ziekenhuis voor de arme Joodse buurt, het Portugeesch Israëlietisch Ziekenhuis met veelal Portugees-Joods personeel en patiënten, en de Centraal Israëlietische Ziekenverpleging in het chique Amsterdam-Zuid. In Haarlem en Rotterdam waren eveneens Joodse ziekenhuizen en in Apeldoorn bevond zich het Joodse psychiatrisch gesticht Het Apeldoornsche Bosch, dat ressorteerde onder het Centraal Israëlietisch Krankzinnigengesticht. ${ }^{59}$ Overigens werkten in al deze Joodse instellingen ook grote aantallen niet-Joodse artsen en verplegers. Tot 1936 had Het Apeldoornsche Bosch zelfs jarenlang een niet-Joodse geneesheer-directeur: Jan Kat. ${ }^{160}$ In Den Haag was het aparte 
Joodse ziekenhuis in 1904 gesloten, maar daarna had het gemeenteziekenhuis aan de Zuidwal een voorziening voor rituele spijsbereiding. ${ }^{16 \mathrm{I}} \mathrm{Net}$ als artsen van andere gezindten konden ook Joodse artsen die zich als huisarts wensten te vestigen, bij het Bureau van Vestiging van de NMG aangeven waar hun voorkeur naar uitging wat betreft de religieuze achtergrond van hun toekomstige patiëntenpopulatie. Mocht men graag een praktijk willen in een gebied waar veel potentiële Joodse patiënten woonden, dan kon het vestigingsbureau daar rekening mee houden. ${ }^{162}$

Bij eventuele behoefte aan internationale contacten in specifiek Joods-medisch verband, bestond er de OSE of OzE, een van oorsprong Russische organisatie van Joodse artsen die opkwamen voor de gezondheid van Joden, met name in Midden- en Oost-Europa, maar ook wereldwijd. ${ }^{163}$ In elk geval Herman Pinkhof en Izaak van Esso onderhielden contacten met deze organisatie. ${ }^{164}$ Veel Joodse artsen zetten zich voorts in voor allerlei Joodse welzijnsinstellingen. Zo waren er Joodse artsen betrokken bij de Israëlitische kerkgenootschappen, het Nederlandsch Israëlietisch Armbestuur, de Rudelsheimstichting, de Bergstichting, sportvereniging Maccabi, de Joodsche Boekerij, de Joodse Blindenzorg, het Centraal Israelietisch Krankzinnigengesticht, de stichting 'Liefdadigheid zij ons doel' en het verpleeghuis De Joodsche Invalide, om er maar een aantal te noemen. ${ }^{165}$

De Amsterdamse dermatoloog David Ezechiël Cohen en huisarts Izaak van Esso troffen elkaar in het Genootschap voor de Joodsche Wetenschap, waar wekelijks voordrachten werden gehouden over facetten van het Jodendom en de Joodse geschiedenis. ${ }^{166}$ Voor beiden leverde hun Joodse identiteit, in combinatie met hun artsenidentiteit, een liefde op voor de traditie waar zij deel van uitmaakten: de Joodse medische traditie in Nederland. In november 1926 opende het Amsterdamsch Historisch Museum een tentoonstelling over de geschiedenis van de Joodse artsen in de hoofdstad. ${ }^{167}$ David Cohen was hiervan de initiatiefnemer. Hij schreef in de jaren twintig en dertig bovendien een kleine reeks artikelen in het $N T v G$ over de geschiedenis van de Joodse artsen in Nederland. Van Esso, huisarts aan de hoofdstedelijke Constantijn Huygensstraat, getuigde eveneens van een grote belangstelling voor de geschiedenis van de Nederlands-Joodse medici. Hij schreef het hoofdstuk over de artsen in het in 1940 uitgegeven historische overzichtswerk Geschiedenis der Joden in Nederland. ${ }^{168}$ Niet alleen in Joodse kring, maar ook daarbuiten probeerde Van Esso historische belangstelling bij anderen te bevorderen. In het door hem in 1938 opgerichte huisartsentijdschrift Aesculaap nam de rubriek 'De geschiedenis der geneeskunde' een prominente plaats in. In het eerste nummer gaf Van Esso te kennen om zich heen te zien dat veel medici een aversie koesterden tegen 
medische geschiedenis, en liever een artikel over pathologie of fysiologie lazen. Van Esso zelf echter had een grote liefde voor de geschiedenis meegekregen van zijn geschiedenisleraar Johan Huizinga en hij vond dat een arts die meer wilde zijn dan 'receptschrijver en longkijker' iets van de historie van het vak diende te weten. Hij haalde daarbij een opmerking aan van de beroemde patholoog Rudolph Virchow, aan hoogleraar medische geschiedenis A.H. Israëls geschreven: 'Ich halte jeden Unterricht ohne historische Grundlage für eine Barbarei.' Voor Van Esso genoeg reden zijn collegae een 'wekelijkse injectie historische vitamine' toe te dienen. ${ }^{169}$ En hoewel hij in Aesculaap met geen woord over het Jodendom repte, lag ook Van Esso's hart, als zionist en belijdend Jood, het meest bij de Joodse medische geschiedenis en had hij warme gevoelens voor het feit dat hij een Joodse arts was. Zo schreef hij in het Joodse blad De Vrijdagavond over het specifieke karakter van de Joodse patiënt en diens bijzondere band met zijn Joodse dokter:

Eigenaardig is ook weer de verhouding van den Jood-uit-het-volk tot zijn 'gebenschte [gezegende] dokter'; uitbundigen lof en dankbaarheid voor den dokter, die zich 'veel aan den patiënt heeft laten gelegen liggen', als de genezing van een ernstige ziekte tot stand is gekomen. Dan moet er openlijk getuigd worden van de dankbaarheid; behalve het traditionele geschenk aan den dokter, meest in den vorm van een lekkernij, de geijkte advertentie in het Joodsche weekblad! Is deze uiting van dank in het openbaar eigenlijk niet te beschouwen als het substituut van de 'mie-sjebeirach' [zegenwens], die ook ten aanhoore van de gansche gemeente uitgesproken wordt, nu een van beide partijen of beide partijen niet (meer) ter synagoge verschijnen?'170

Van Esso zag direct dat deze gang van zaken volgens de gids Medische ethiek eigenlijk niet door de beugel kon: 'De vereeniging van artsen, uiteraard niet goed op de hoogte van het eigenaardige instituut van de mie-sjebeirach, heeft haar afkeuring uitgesproken over dergelijke dankadvertenties; onze Joodsche patiënten echter leggen deze motie van afkeuring rustig naast zich neer.' ${ }^{\text {'7r }}$

Met een zekere vertedering merkte Van Esso deze 'typisch Joodse' gang van zaken op, zonder dat hij er daadwerkelijk een probleem in zag. De Joodse identiteit was voor hem zeer positief en dat droeg hij ook uit, ook toen de buitenwereld in de jaren dertig vijandiger werd. In Geschiedenis der Joden in Nederland schreef Van Esso in I940 dan ook niet zonder trots: 'Geen volk heeft zoveel bekwame en wetenschappelijk gevormde artsen voortgebracht als het Joodse', om dit vervolgens met de wapenfeiten van een rij roemrijke voorgan- 
gers te illustreren. ${ }^{172}$ Niet toevallig verscheen juist in dit jaar deze overzichtsgeschiedenis van de Joodse bijdragen aan de Nederlandse samenleving. Vraagstukken van assimilatie en acceptatie van Joden waren zeer actueel geworden door de invloed die de Machtübernahme van Adolf Hitler in Duitsland in 1933 ook op de Nederlandse maatschappij had.

\section{AAN DE VOORAVOND VAN DE DUITSE INVAL}

Het lijvige werk Geschiedenis der Joden in Nederland beoogde niet in de laatste plaats aanzwellende anti-Joodse sentimenten in de samenleving tegen te gaan. 'Zeker, geschiedschrijving is geen politieke zaak, en dit boek is zeker geen politiek boek, maar toch is het niet toevallig, wanneer men juist in een bepaalde periode bepaalde vraagstukken in historisch verband aan de orde gaat stellen' schreven de auteurs dan ook in de verantwoording. ${ }^{173}$ De socioloog J.P. Kruyt schreef met hetzelfde politieke doel een hoofdstuk over de positie van de Joden in Nederland in een bundel uit 1939, waarin de auteurs fel tegen het opkomende fascisme en antisemitisme ageerden. Voor het behoud van eigen tradities en identiteit binnen het kader van het Nederlands burgerschap had volgens Kruyt altijd een zekere ruimte bestaan, die behouden diende te worden.

Pluriformiteit werd in Nederland, in het licht van de traditie van tolerantie en in de toestand van verzuiling als iets positiefs of in elk geval vanzelfsprekends beschouwd. ${ }^{174}$ Assimilatie van Joden in de zin van volledig opgaan in de massa was niet nodig:

Naast assimilatie, het volledig opgaan in het geheel, bestaat nog de mogelijkheid van accommodatie, van aanpassing: het voortleven van de groep met eigen karakter naast andere groepen, zonder conflicten en met overwelving van alle groepen door een groter geheel. Wie meent, dat een niet volledig geassimileerde Jood geen Nederlander kan zijn, heeft zijn begrip van natie opgeschroefd tot dat der totalitaire levensbeschouwing. Niemand heeft behoefte aan nog groter eenvormigheid, aan één kerk, één partij, één volkstype. Fries en Limburger, Katholiek en Protestant, socialist en liberaal, rechtzinnige, plattelander en stedeling, Jood en niet-Jood, zij verrijken door hun verscheidenheid ons sociaal en cultureel leven. Mits zij over de grenzen van hun groep heenzien, mits zij elkaar begrijpen, waarderen en verdragen. Zo was het drie eeuwen lang in ons land tussen Jood en niet-Jood, zo moge het ook in de toekomst blijven!'175 
Zo ideaal als Kruyt de situatie graag wilde zien, was die echter niet altijd. Antisemitisme was weliswaar in Nederland niet zo algemeen en virulent als in andere Europese landen, maar afwezig was het zeker niet en het nam toe door de antisemitische retoriek uit Duitsland. ${ }^{176}$

Deze retoriek en de angstaanjagende en antisemitisme bevorderende werking die ervan uitging had een merkbaar effect op de Nederlandse Joden. De hang naar traditie onder Nederlandse Joden nam in de late jaren dertig toe, zo blijkt uit demografische gegevens. Bijvoorbeeld het aantal gemengde huwelijken nam weer af in de tweede helft van de jaren dertig. ${ }^{177}$ Het zionisme won in Nederland eveneens aan aanhang toen de situatie voor Joden in Duitsland steeds dreigender werd. ${ }^{178}$ Ook in Nederland vatte het idee in toenemende mate post dat de veiligste optie voor de Joden waarschijnlijk uiteindelijk een eigen staat zou zijn. De Nederlandse Zionisten Bond (NZB) groeide van een ledental van 2094 in 1932 naar een ledental van 4246 in $1939 .{ }^{179}$ Dit was ondanks de verdubbeling nog altijd maar 3 procent van de Joodse bevolking. Consensus over of en in welke vorm men het zionistische ideaal moest nastreven was er immers niet. Er waren binnen het zionisme dan ook verschillende stromingen te onderscheiden: de NZB werd gedomineerd door de bourgeoisie, het bij de Bond aangesloten Mizrachie was de organisatie van religieus-bewuste zionisten, en het eveneens in de NZB opgegane Poale Zion die van meer socialistisch georiënteerde, veelal seculiere zionisten. ${ }^{\mathrm{I} 0}$ Maar niet alleen bij de zionisten intern, ook van buitenaf werd er discussie gevoerd. Moest men zich gedragen naar wat de Igde eeuwse bankier en filantroop A.C. Wertheim had gezegd: 'In den Kerk Israëlieten, moeten wij daarbuiten in den vollen, onverdeelden, onsplitsbaren zin van het woord medeburgers zijn?' ${ }^{81}$ En vloeide hieruit voort dat men niet van twee volksgemeenschappen tegelijkertijd lid zou kunnen zijn? ${ }^{\text {?82 }}$ Of was een Joodse staat uiteindelijk de enige oplossing voor het identiteitsprobleem en de altijd maar weer terugkerende vervolgingen waar het Joodse volk aan ten prooi viel?

De discussie kreeg een extra dimensie door de vluchtelingentoestroom uit Duitsland. Vooral na de Kristallnacht in november 1938, zetten Nederlandse Joodse organisaties acties op touw om de vele Duits-Joodse vluchtelingen op te vangen. ${ }^{183}$ Voor de leden van die vluchtelingencomités gaf het contact met de vluchtelingen een rechtstreekse confrontatie met de vervolging en met (de onontkoombaarheid van) hun eigen Joodse achtergrond. ${ }^{184}$ Daar kwam nog bij dat er vaak grote culturele verschillen bestonden tussen de Nederlandse en de Duitse Joden, waardoor de onderlinge relaties niet altijd even soepel verliepen. Medisch student Boes Lankhout herinnerde zich hoe zijn ouders weliswaar vluchtelingen in huis namen, maar tegelijkertijd deze mensen als vreemdelin- 
gen beschouwden. Hun oordeel over de normen van hun buitenlandse gasten was niet zeer positief. Lankhout noemde het zelfs 'licht antisemitisme' waarmee zijn Nederlands-Joodse ouders hun Duits-Joodse gasten beoordeelden. ${ }^{185}$ Nederlandse Joden vreesden en zagen ook daadwerkelijk om zich heen dat de aanwezigheid van de Duitse Joden antisemitisme in Nederland aanwakkerde. ${ }^{186}$

Joods bewustzijn kon in de loop van de jaren dertig dan ook voor de Joodse artsen samengaan met een verhoogd besef van potentieel gevaar. Dat leidde tot verschillende reacties. Internist Jacob Goudsmit bijvoorbeeld volgde de politieke ontwikkelingen in Duitsland op de voet en was daardoor goed op de hoogte van de anti-Joodse politiek aldaar. Hij legde een plakboek aan met artikelen uit diverse kranten en debatteerde avonden lang met politieke vrienden over de beste manier om met de ontwikkelingen om te gaan. ${ }^{187}$ Janos Freud, die in zijn geboorteland Hongarije geen medicijnen had mogen studeren vanwege zijn Joodse afkomst en dus al verregaande ervaringen met antisemitisme had gehad, wilde met een niet-Joodse vrouw trouwen om eventuele kinderen de gevaren van het Joods-zijn te besparen. ${ }^{188}$ Huisarts David de Miranda nam in 1938 met anderen het initiatief tot oprichting van de Stichting tot Verdediging van de Culturele en Maatschappelijke Rechten der Joden, kortweg Stichting Joodse Rechten (sJR), en werd hiervan ook voorzitter. ${ }^{189}$

Voor Joodse artsen gold in verhoogde mate dat zij contact hadden met Duits-Joodse vluchtelingen, omdat velen van hen medische hulp aan deze vluchtelingen boden. Daarmee vernamen zij hun verhalen uit de eerste hand. De hoogste Nederlandse ambtenaar ten behoeve van de medische verzorging van de vluchtelingen was zelf ook een Joodse arts: generaal Salomon Wolfeus Praag. ${ }^{190}$ In Rotterdam was voorts huisarts Maurits Hertzberger actief in de Commissie van Bijstand voor de Vluchtelingen. ${ }^{\text {I9I }}$ Max Louis van der Heijden zette zich daar ter stede in als kamparts van het vluchtelingenkamp Koninginnehoofd. Hij vaccineerde aldaar alle kinderen tegen difterie. ${ }^{192}$ Geen overbodige luxe, want tezelfdertijd heerste er onder de Joodse vluchtelingenkinderen in Amsterdam een difterie-epidemie. ${ }^{193}$ Deze kinderen werden opgenomen in het Burgerweeshuis en door kinderarts Maurits de Bruin behandeld. Zijn Arnhemse collega Jacques Hartogs droeg zorg voor een extra goede voeding voor de vluchtelingkinderen in koloniehuis Sonsbeek. ${ }^{194}$ In Amsterdam was Gerard Levy verantwoordelijk voor de medische zorg in Quarantaine-inrichting Zeeburg en zijn collega Jonas Jacobs voor de vluchtelingen in het Lloyd-hotel aan de Oostelijke Handelskade. ${ }^{195}$ In Den Haag ondervond het Haagsch Vluchtelingencomité van vele artsen medewerking om de vluchtelingen in de vluchtelingenopvanghuizen gratis medische zorg te bieden. Dit initiatief was geno- 
men door Anselm Polak Daniëls, Haags huisarts en zoon van de Groningse hoogleraar interne geneeskunde Leonard Polak Daniëls. Ook vader Polak Daniëls zelf was actief in het vluchtelingenwerk. Haagse Joodse artsen die hieraan eveneens belangeloos hun medewerking verleenden waren Eliazer Polak, Jos Kalker, Julius Lankhout, kinderarts Salomon Simons, chirurg Samuel Klein en dermatoloog Machiel K. Polano. Van de Haagse huisarts Willem van Furth is bekend dat hij thuis vluchtelingen opving. ${ }^{196}$ Overigens waren het lang niet alleen Joodse artsen die bereid bleken tot het belangeloos verlenen van hulp aan de vluchtelingen: ook tien niet-Joodse Haagse artsen deden van harte mee. ${ }^{197}$

De gebeurtenissen in Duitsland en de aanwezigheid van de vluchtelingen versterkten weliswaar de Joodse identiteit bij de Nederlandse Joodse artsen, maar voorlopig leek de collegialiteit nog een verwijdering tussen de Joodse en de niet-Joodse artsen in Nederland te voorkomen. Zowel Joodse als nietJoodse artsen participeerden ook in steunacties ten behoeve van hun vervolgde Duits-Joodse collegae. In de jaren na 1933 verschenen er enkele artikelen over de behandeling van de Duits-Joodse artsen in het $N T v G{ }^{198}$ De toon was verontwaardigd, al was er ook één collega die pleitte voor een tijdschrift zonder politiek en die de ophef over de Joodse artsen nogal overdreven vond. Katholieke artsen hadden volgens hem immers door de jaren heen ook vaak aan vervolging blootgestaan. Daarover was, aldus deze arts, nooit iets in het Tijdschrift verschenen. ${ }^{199}$ Dit individuele protest ten spijt, leidde de breder gedeelde verontwaardiging van de Nederlandse artsen tot een concrete hulpactie. $\mathrm{Na}$ het Duitse beroepsverbod voor Joodse artsen in september 1938 zamelden Joodse en niet-Joodse medici in Nederland geld in voor het Joods vluchtelingencomité. Bovendien gaven zij een brochure uit over de wetenschappelijke verdiensten van beroemde Joodse geneesheren uit de negentiende en twintigste eeuw, om te tonen hoe onrechtvaardig zij dit beroepsverbod achtten. ${ }^{200}$

Minder collegiaal werden de Duits-Joodse artsen behandeld als ze eenmaal naar Nederland gevlucht waren. ${ }^{201}$ Uit statistische gegevens van I oktober I94I bleek dat er op dat moment IIs mannelijke en II vrouwelijke Duits-Joodse artsen in Nederland waren. ${ }^{202}$ Duitse artsdiploma's waren echter niet geldig in Nederland. Als een Duitse arts in zijn vak wilde werken in zijn nieuwe thuisland, was dat dus niet eenvoudig. ${ }^{203}$ Slechts van een handjevol Duitse artsen is bekend dat het hen lukte een Nederlandse bevoegdheid te krijgen. Voor anderen, zoals de vermaarde farmacoloog Emil Starkenstein (I884-I942), werd een functie gezocht waarvoor het Nederlandse artsdiploma geen vereiste was, zoals laboratoriumonderzoek. ${ }^{204}$ Erg welkom zullen de Duits-Joodse artsen zich waarschijnlijk niet gevoeld hebben, temeer daar er eind jaren dertig sprake was 
van een discussie over 'overvulling' van het medische beroep in Nederland. ${ }^{205}$ Er dreigde een overschot aan artsen en daarmee hadden met name jonge artsen moeite om an hun broodwinning te komen. Veel vluchtelingen verbleven echter maar tijdelijk in Nederland, omdat zij op doortocht waren naar veiliger geachte landen. ${ }^{206}$ Maar toch werd door het binnenstromen van Duits-Joodse artsen het probleem van die 'overvulling' als nog nijpender ervaren. De NMG reageerde door een commissie in te stellen die mogelijke oplossingen moest onderzoeken. In elk geval moest bevorderd worden dat pasafgestudeerde artsen naar de koloniën zouden vertrekken, en in het verlengde hiervan konden de Duits-Joodse artsen dat ook doen. Voor Suriname bestond in 1939 al een redelijk vastomlijnd plan. ${ }^{207}$ De uitvoering daarvan werd echter onmogelijk door de Duitse inval op Io mei 1940. De Duits-Joodse artsen die op dat moment nog in Nederland waren, hadden voor het overgrote deel geen Nederlands artsdiploma en praktiseerden dientengevolgde niet. Deze niet-praktiserende Duits-Joodse collegae blijven dan ook in het verdere relaas voor het grootste deel buiten beschouwing. Maar net als hun Nederlands-Joodse collegae en de I40 ooo Joden die Nederland nu in totaal telde, gingen zij de Iode mei 1940 een nieuwe, ongeëvenaard moeilijke fase in. De Utrechtse Ina Boudier-Bakker schreef in haar dagboek: 'Dan komt bij ons, onze buurman, de Joodse dokter Perel, en zegt zacht: "Nu begint het voor ons." 208 


\section{AFSTAND VAN DE ARTSENSTAND \\ DE UITSLUITING VAN DE JOODSE ARTSEN UIT DE \\ NEDERLANDSE ARTSENSTAND, 1940-1941}

De Tweede Wereldoorlog begon in Nederland op Io mei 1940, toen Duitse troepen de grens overschreden. Hoewel de Joodse artsen in Nederland voor die tijd allerlei redenen konden hebben voor Joods besef, vormde dat geen belemmering om zich tegelijkertijd en zelfs in de eerste plaats volwaardig lid van de Nederlandse artsenstand te voelen. Zij waren gewone Hollandse artsen, collegae onder de collegae. Binnen een jaar na de Duitse inval zou daar nog allerminst sprake van zijn.

\section{STRIJDBAARHEID EN VREES}

In de meidagen van 1940 zelf konden de Joodse artsen nog niet bevroeden wat hun te wachten stond. Getuige zijn dagboeknotities had Berthold Stokvis al wel angstige vermoedens toen hij na de capitulatie van het Nederlandse leger op I4 mei door Amsterdam reed:

In de tram heerste een gedrukte stemming. In het pension, waar ik moest zijn, sprak een student, dien ik wel kende, mij aan. Ik memoreer dit feit, omdat ik toen voor het eerst over de in ons land dreigende Jodenvervolging dieper doordacht: Ja vriendje, nu worden wij nog gelijkwaardig geacht; morgen mag ik wellicht niet meer op straat en is de discriminatie een feit geworden, wie weet in hoeveel vormen, ook op wetenschappelijk gebied. ${ }^{\mathrm{I}}$ 
In de pers hadden de Nederlanders sinds 1933 kunnen volgen wat er met de Duitse Joden gebeurde onder de naziheerschappij. Een gedetailleerde berichtgeving over hetgeen in Duitsland geschiedde had via de diverse dagbladen de Nederlandse huishoudens bereikt. ${ }^{2}$ Desalniettemin hadden de meeste mensen niet verwacht dat het niet bij berichten over buitenlandse problematiek zou blijven, maar dat de terreur de grens over zou komen. ${ }^{3}$ Onder de Nederlandse Joodse artsen waren er slechts enkelen die uit de berichtgeving de conclusie trokken dat zij uit Nederland moesten vertrekken: in de periode april I939 tot en met april 1940 emigreerden in elk geval vier artsen naar de Verenigde Staten, terwijl ten minste een viertal anderen de oversteek naar Palestina maakte. ${ }^{4} \mathrm{Het}$ zal hun niet licht gevallen zijn in het nieuwe vaderland een bestaan op te bouwen. Emigreren betekende veelal dat diploma's niet meer geldig waren zodat men opnieuw moest studeren om als arts te kunnen praktiseren. Dit creëerde behalve een mentale ook een financiële drempel, die wellicht voor vele achterblijvers te hoog was. Daar kwam nog bij dat specifiek de artsen een sterke binding en een sterk verantwoordelijkheidsbesef kenden jegens hun vaste kring in Nederland: zij wilden hun patiënten niet in de steek laten. Gezien de paternalistische, zorgende traditie van de artsen was dat een logische opstelling. Dit werd dan ook later door hun nazaten als reden genoemd waarom zij niet tijdig het land verlieten. 5 Internist Ju Groen herinnerde zich daarnaast ook naïef te zijn geweest:

Ik had de oorlog wel voelen aankomen, maar ik was naïef. Ik had geen enkel idee wat ons te wachten stond. Ik vond dat het me niet sierde om veilig in een lab in Amerika te zitten terwijl landgenoten, en vrienden van me hier onder bedreiging leefden. Ook dacht ik nog: wanneer ik in een kamp terecht kom, kan ik me voor anderen nuttig maken... ${ }^{6}$

Voor de Duits-Joodse vluchtelingen, die het nationaalsocialistisch antisemitisme al aan den lijve hadden ondervonden en daarmee doorgaans minder naïef waren, was de strijd die in de dagen na de Duitse inval gevoerd werd, zo mogelijk nog belangrijker dan voor de Nederlandse Joden. Op geheel eigen wijze streed bijvoorbeeld de uit Duitsland gevluchte oogarts Fritz Fischer mee tegen het Duitse leger. Oogletsel kwam veel voor onder de soldaten en ook Duitse militairen meldden zich hiermee bij het Ooglijders Gasthuis te Utrecht, alwaar zij door Fischer behandeld konden worden. Fischers ervaring was dat de Duitse troepenartsen niet erg goed op de hoogte waren van oogaandoeningen. Hier makte hij handig gebruik van door met veel Latijnse termen indrukwekkende diagnoses te stellen, zodat de betreffende soldaten wegens ernstig 
letsel naar huis gestuurd werden. Ook speelde hij in op hun psyche, door hen tot in den treure te onderzoeken, met een zorgelijk gezicht en alle mogelijke instrumenten, om vervolgens tot de conclusie te komen dat hij weliswaar niets gevonden had, maar dat deze ogen toch van een veel ouder iemand leken te zijn dan van een ongeveer 25 -jarige. Het gevolg was vaak dat de soldaat brak en een klaagzang op zijn zware leven ten gehore gaf. Ook dit leidde soms tot ongeschiktheid voor verdere dienstplicht. Aldus doende, stelde Fischer zelf met enige ironie in zijn memoires, 'habe ich täglich die Wehrmacht um 2 Kämpfer kleiner gemacht'.7 Dit was weliswaar uiteraard strijdig met de heersende medische ethiek, maar wel een teken van de politieke strijdbaarheid van deze arts. Kennelijk was voor Fischer de situatie dusdanig dat hij het aan zijn geweten kon verantwoorden dat die politieke strijdbaarheid prevaleerde boven de normen die hij als arts gewend was te hanteren.

Strijdbaar in de meidagen van 1940 was ook Eddy Behr, Groninger arts, die als soldaat sneuvelde 'toen hij met deernis en dapperheid een poging deed om eenige gewonde soldaten uit de Grebbelinie naar veiliger plaats te evacueren'. ${ }^{8}$ Collega Eliazer Sekir kwam eveneens om in de eerste oorlogsdagen; hij werd slachtoffer van het bombardement op Rotterdam. Het Coolsingelziekenhuis, waar hij aan het werk was, stortte in en Sekir werd onder puin bedolven. ${ }^{9}$

Toen de capitulatie op I4 mei 1940 een feit was, verdrong angst voor wat komen zou bij velen de strijdbaarheid. Nu de gevreesde bezetting van Nederland realiteit was geworden, poogden velen alsnog om per boot naar Engeland te ontkomen. IJmuiden liep die dag vol met mensen die maar één doel voor ogen hadden: de territoriale wateren uit varen. Slechts enkele artsen lukte het. ${ }^{\text {I0 }}$ I.H.J. Vos, naast arts ook bekend liberaal politicus, zette op I4 mei om tien voor acht zijn vrouw en twee zoons op de boot naar Engeland. Zelf bleef hij in Nederland, 'omdat hij dat als zijn plicht beschouwde'. ${ }^{\text {II }}$ De artsen David van der Poorten, Aron Vedder, Bernard Premsela, Izaak van Esso, Sally de Jong, Jacob Goudsmit en Marinus Mortier Hijmans waren onder degenen die tevergeefs probeerden hun gezin (en zichzelf) op een boot te krijgen. ${ }^{12}$ De familie Hartogs uit Arnhem was ook op weg naar IJmuiden, maar kwam niet verder dan Rotterdam. ${ }^{13}$ Allen keerden onverrichter zake en gedesillusioneerd terug naar huis. Ook het Middelburgse artsenpaar Louis en Rachel Weijl-Snuijf, dat in de vroege morgen van I5 mei met een veerboot de Schelde overstak, moest na mislukking van hun vluchtpoging huiswaarts keren. ${ }^{14}$ Simon Weijl, psychiater te Den Haag, slaagde er wel in geallieerd grondgebied te bereiken: hij volgde zijn assistente en haar niet-Joodse man. In een klein bootje staken zij in de nacht van I4 op I5 mei naar Engeland over. ${ }^{15}$ Oogarts Eugen Marx en zijn vrouw was het gelukt voor hun kind een plek op een boot naar Engeland te 
bemachtigen, zelf keerden zij echter terug naar Rotterdam, waar ze vervolgens een einde aan hun leven maakten.

\section{DE ULTIEME VLUCHT: ZELFMOORD ONDER JOODSE ARTSEN}

Niet alleen voor het echtpaar Marx was de drang tot vluchten voor het dreigende onheil zo groot dat deze hen in de armen van de dood dreef. Een ware zelfmoordepidemie spreidde zich over Joods Nederland uit. Het gemiddelde aantal suïciden in Nederland in de maand mei van de vijf aan 1940 voorafgaande jaren was 71,2 geweest. In mei 1940 pleegden in totaal 317 mensen in Nederland zelfmoord, van wie 2I0 Joodse Nederlanders. ${ }^{16}$ De Joodse artsen kregen op verschillende manieren met deze zelfmoordgolf te maken.

Gemeentearts Elazar Aäron Rodrigues Pereira was voor de Amsterdamse GGD belast met het schouwen van de overledenen. Een loodzware taak. Zijn zoon Arnold zag hem in die dagen steeds stiller worden. ${ }^{17}$ De wachtkamers van de psychiaters zaten, als we de getuigenis van Berthold Stokvis mogen geloven, vol met mensen met hevige spanningen door de 'oorlogstoestand' en een doodswens. Over de toestand op I5 mei 1940 schreef hij in zijn dagboek:

In de wachtkamer zitten veel menschen. Zij allen komen met hetzelfde smeekende verzoek: 'Help ons toch, geef ons toch een vergif, wij willen deze ellende niet meemaken!' [...] Ik zal niet gauw den Joodsch Duitschen emigrant vergeten, die in doodsangst een voetval voor mij deed en mijn beenen omklemde, met de smeekbede zijn reis naar het hiernamaals te bespoedigen. ${ }^{18}$

Stokvis liet in het midden of hij op deze klemmende verzoeken inging. Van de Amsterdamse chirurg Willy Levy is bekend dat hij familieleden cyanidetabletten aanbood om zich daarmee van het leven te kunnen beroven, iets wat ook Levy zelf, samen met zijn echtgenote, besloot te doen. ${ }^{19}$

Eugen Marx en Willy Levy waren niet de enige Joodse artsen die zichzelf het leven benamen. Nog negen Joodse medici gingen daar in mei 1940 toe over. ${ }^{20} \mathrm{Op}$ het totaal aantal Joodse artsen vormden deze elf een percentage van 2 procent. Veruit de meerderheid, 98 procent, van de Joodse artsen ging dus niet over tot deze uiterste noodgreep. Elf van de in totaal 2IO zelfmoorden is echter wel 5,24 procent, terwijl, uitgaande van een aantal van 534 artsen, van de Joodse bevolking nog geen half procent arts was. Relatief veel van de Joden 
die zelfmoord pleegden, waren dus arts. ${ }^{2 \mathrm{I}}$ Een opvallend gegeven, angezien suïcide lijnrecht indruiste tegen de hen bekende ethiek: "het leven behouden en niet door vergiften verkorten, ook als mij daarom gevraagd wordt", belijden ook wij, ${ }^{22}$ had Hammes nog in 1935 uit de eed van Hippocrates geciteerd. Een leven opzettelijk verkorten kon per definitie niet goedgekeurd worden volgens de medische ethiek. Volgens de Joodse ethiek net zo min. Suïcide was daarmee voor de Joodse artsen een verre van voor de hand liggende keus. Herman Pinkhof schreef nog in het $N T v G$ van 1932: 'het [zelfmoord] is een juridische diagnose, evenals diefstal of oplichterij'. ${ }^{23}$ Bovendien kon een arts het simpelweg niet máken om de patiënten op deze manier in de steek te laten. De Amsterdamse psychiater Salomon Koster was daarvan doordrongen, maar speelde niettemin met de gedachte een eind aan zijn leven te maken. Hij moest door zijn vrouw tot de orde geroepen worden, zo vertrouwde hij zijn dagboek toe. Het gesprek was als volgt verlopen:

Maar man, wat een egoïsme, je denkt helemaal niet aan moeder, aan Elly en aan onze kinderen. Wat moeten die beginnen zonder jou. En dan al je patiënten.' 'Zeker heb ik aan hen allen gedacht, maar ik geloof niet, dat ik nog veel voor hen zal kunnen doen. Je weet, hoe in Duitschland alle Joden gekweld en tot iedere daad onmachtig zijn gemaakt. En wat mijn patiënten betreft, de Duitschers zullen mij wel direct uit mijn praktijk zetten.

De discussie tussen de echtelieden zette zich voort en mevrouw Koster nam het voortouw:

Zolang er leven is is er hoop. En bovendien, in de allereerste plaats een zelfmoord is ook een moord. Mag een mensch zich een Goddelijk recht, het recht om te doden, aanmatigen? Je kunt dat recht nemen natuurlijk, Hitler neemt zich ook zoveel rechten, maar dan doe je ook iets immoreels, net als hij.

Koster zou zelf niet tot suïcide overgaan, maar wat hij om zich heen zag gebeuren, ging hem zeer aan het hart:

Wel was het een nacht der verschrikkingen! Het spook der zelfmoordgedachte waarde over ons land en als een geheimzinnige infectieziekte, had het vele hersenen in ons land geïnfecteerd: welhaast alle Joden waren ermee besmet en vele honderden Joden stierven dien nacht, of in de eerstvolgende dagen, door zelfmoord. ${ }^{24}$ 
Salomon Koster beschreef aldus in zijn dagboek het morele conflict dat suïcide onder deze ongeëvenaarde omstandigheden veroorzaakte: zelfmoord plegen kón eigenlijk niet, maar nu, in deze tijden, kon men er wel begrip voor opbrengen. Niet alleen Koster dacht zo; mededogen voor deze normaal gesproken ongehoorde stap lijkt in de artsenstand breed gedeeld te zijn geweest.

De bekendste van de elf Joodse medici die zelfmoord pleegden was de Groningse hoogleraar interne geneeskunde Leonard Polak Daniëls. Hij ging ertoe over in Den Haag, samen met zijn (niet-Joodse) echtgenote. Het echtpaar logeerde in de hofstad bij zoon Anselm, huisarts, om Polak Daniëls sr. de gelegenheid te geven het Rode Kruis, waarvan hij voorzitter was, ter plekke te kunnen leiden. Nadat het nieuws van de capitulatie hun ter ore was gekomen diende Leonard Polak Daniëls eerst zijn vrouw een slaapmiddel toe om haar daarop een dodelijke injectie cyaankali te geven, waarna hijzelf hetzelfde slaapmiddel innam en zich door zijn zoon eenzelfde injectie liet inspuiten. ${ }^{25}$ Het $N T v G$ ruimde drie pagina's in voor zijn in memoriam, waarin een in verdekte termen opgestelde verwijzing naar de suïcide te ontwaren was:

Op den I4den Mei 1940 overleed te 's-Gravenhage Leonard Polak Daniëls. Te midden der geweldige gebeurtenissen dezer dagen, die in hun snelle opeenvolging ons geen tijd tot bezinning omtrent de beteekenis van hetgeen wij beleven, laten, bereiken ons enkele berichten, die ons plotseling het diep dramatische van hetgeen geschiedt, overweldigend doen gevoelen. $^{26}$

Het in memoriam sprak, ondanks de eigenlijk ongeoorloofde handeling van de suïcide, enkel met eerbied over de ontvallene. De doodsoorzaak werd, onder de gegeven omstandigheden, met de mantel der liefde bedekt. Dit gold ook voor de artikelen die verschenen om de Rotterdamse Joodse artsen die zichzelf van het leven hadden beroofd te herdenken. In Rotterdam pleegden naast oogarts Eugen Marx ook oogarts Jacques van den Borg en huisarts Maurits Hertzberger zelfmoord. In het $N T v G$ werd voor alledrie een eerbiedig in memoriam opgesteld. ${ }^{27}$ Ook hierin werd de doodsoorzaak niet genoemd, tenzij men de vermelding van het 'zwaarmoedige karakter' van Van den Borg als een hint in die richting wil beschouwen. ${ }^{28}$ W.P.C. Zeeman schreef in zijn in memoriam voor Marx: 'Met diepen weemoed vernemen wij van het heengaan van onzen collega Marx, en ondergaan met hem de pijn, die het scheiden van een intens en wijd en warm leven in vrede moet hebben betekend. ${ }^{29}$ De goede verstaander begreep waarschijnlijk wel waar het over ging, maar letterlijk werd niet van suïcide gesproken. Van de Joodse achtergrond van de ontvallenen 
werd evenmin melding gemaakt. Gemene deler was dat de schrijvers vol respect over de ontvallenen als arts en als persoon schreven en hun medische, wetenschappelijke en maatschappelijke verdiensten met waarderende woorden memoreerden. Zo noteerde collega H. Burgerhout over Van den Borg:

Hij verwierf zich een goede naam onder zijn collegae en een groote practijk onder zijn stadsgenooten. Bij de groote schare zijner patiënten was hij zeer geliefd, omdat hij niet alleen een goed medicus, maar ook een hartelijk meevoelend mensch was. ${ }^{30}$

Een dergelijke kwalificatie gebruikte ook Maurits Muller voor het in memoriam van de Utrechtse maag- en stofwisselingsspecialist Eduard van Lier. Muller roemde Van Lier om zijn grote inzet voor de NMG Utrecht en gaf uiting aan het grote gemis voor de Utrechtse geneeskunde dat ontstaan was door zijn heengaan: 'De Utrechtse medische stand zonder Van Lier, het is haast ondenkbaar!'31 Ook Muller maakte van de exacte doodsoorzaak van de overledene geen melding.

Voor vier van de vijf Amsterdamse artsen die door suïcide de dood vonden, verscheen eveneens een gedenkartikel. Het ging allereerst om kinderarts Maurits de Bruin, die een overdosis van het slaapmiddel Veronal had ingenomen. Hij was nog in comateuze toestand binnengebracht bij het Nederlandsch Israëlietisch Ziekenhuis, maar de behandeling mocht niet meer baten. ${ }^{32}$ Zijn collega Cornelia de Lange herdacht hem in het $N T v G$ : 'In de huispractijk een voortreffelijk paedagoog, een arts vol toewijding. Amsterdams kinderen zijn hem dank verschuldigd. Eere zij zijn nagedachtenis.' ${ }^{33}$ Mondarts Elkan Sanders maakte met zijn vrouw en driejarig dochtertje een eind aan zijn leven. Zijn vriend chirurg Willy Levy, die samen met zijn vrouw eerst een slaapdrank innam en vervolgens vermoedelijk cyanidetabletten, stierf een dag na Sanders. ${ }^{34}$ Eduard Wiener, huidarts, overleed aan een overdosis morfine, die hij ook had toegediend aan zijn echtgenote en hun 23-jarige zoon. De oudste zoon, die 26 was, weigerde mee te doen. ${ }^{35}$ Collega N. Knapper schreef een in memoriam in het $N T v G$, waaruit zijn compassie ten opzichte van Wiener en diens benarde situatie doorklonk:

Wij stonden aan de groeve van Wiener. Drie kisten daalden gelijktijdig. Wiener, zijn vrouw, zijn zoon! Onze vriend was reeds lang lichamelijk ziek; dat zag men hem aan. Maar daarnaast ook geestelijk op, ten doode vermoeid. Dat wisten wij, die vrijdagsavonds een enkel uur met hem samen waren. Om de zorgen terzijde te zetten, die hèm in het bijzonder 
zwaar drukten! Hem, die altijd geweest was de vlotte, de opgewekte, de onderhoudende collega! ${ }^{36}$

Voor de jonge huisarts Bernard Aa, praktiserend in de Amsterdamse Pijp, verscheen geen in memoriam. Volgens registratiekaartjes die het Amsterdamsch Joodsch Psychiatrisch Gezelschap over de doodsoorzaken bij suïcidanten bijhield was de gang van zaken bij Bernard Aa als volgt geweest: 'De man heeft zijn ouders en zijn vrouw de polsen doorgesneden, intusschen vergif ingenomen. ${ }^{37}$ Aangenomen wordt dat Ludwig Pincus, 30-jarig waarnemend huisarts en volontair-assistent op de afdeling oogheelkunde van het Academisch Ziekenhuis Groningen, die op I5 mei 1940 stierf, ook de hand aan zichzelf had geslagen. Hij was oorspronkelijk Duits, maar had in 1938 zijn Nederlands artsexamen gehaald, waarna hij als arts in Nederland kon praktiseren. ${ }^{8}$ Met Pincus erbij komt men op elf Joodse artsen die in de meidagen van 1940 tot suïcide, de ultieme vlucht, overgingen. ${ }^{39}$ Hoe kwamen zij ertoe deze drastische stap te zetten en waarom kon men daar ogenschijnlijk zoveel begrip voor opbrengen?

Een praktische verklaring voor het feit dat juist artsen relatief vaak zelfmoord pleegden, zou kunnen zijn dat zij makkelijk aan middelen voor zelfdoding konden komen. Koster schreef: 'Vooral onder de artsen was het aantal zelfmoorden natuurlijk groot, omdat zij de middelen daarvoor zoo bij de hand hadden.' ${ }^{40}$

Van Willy Levy en zijn vrouw is bijvoorbeeld nog een kwitantie van de apotheek in de Surinamestraat bewaard gebleven voor een slaapdrank, een van de middelen voor het plegen van suïcide. ${ }^{4 \mathrm{r}}$ Het recept zal Levy zelf hebben uitgeschreven. Ook van de tien andere artsen is in bijna alle gevallen vast te stellen dat zij inderdaad medicamenten gebruikten voor hun daad. Dit terwijl in de registratiekaartjes van het Amsterdamsch Joodsch Psychiatrisch Gezelschap, dat een statistiek van de zelfmoordgevallen bijhield, in ruim de helft van alle gevallen (86 van de I63) gesproken werd van gas als doodsoorzaak. ${ }^{42}$ Voor niet-medici was de gaskraan opendraaien kennelijk de meest voor de hand liggende manier. Medici daarentegen benutten hun medische mogelijkheden. Voor aanvullende verklaringen voor het hoge percentage artsen kan men te rade gaan bij diverse auteurs.

Emile Durkheim (I858-1917), die als grondlegger van de sociologie een eerste gezaghebbende studie naar het fenomeen suïcide publiceerde, observeerde dat zelfmoord samenhing met scholing en ontkerkelijking. Moreel individualisme zou door beide gestimuleerd worden en daarmee het gebruik van het zelfbeschikkingsrecht bevorderen. ${ }^{43}$ De Joodse artsen waren inderdaad hoog- 
opgeleid en in meerderheid niet bijzonder gebonden aan religieuze wetten. Durkheims theorie zou dus een deel van de verklaring kunnen bieden. Sociologen Ultee en Luijkx, die de suïcidegolf in de meidagen van 1940 onderzochten, zagen een relatie tussen het plegen van suïcide en het hebben van contacten met Duits-Joodse vluchtelingen. ${ }^{44} \mathrm{Zij}$ ontdekten voorts met collega $\mathrm{Van} \mathrm{Tu}$ bergen dat degenen die in mei 1940 tot suïcide overgingen, over het algemeen inderdaad hoogopgeleid waren en in een relatief gunstige economische situatie verkeerden. ${ }^{45}$ Die bevindingen stonden ook met elkaar in verband: juist in deze hogere sociale laag bestonden veel contacten met Duits-Joodse vluchtelingen. Ook dat zou voor de artsen een reden van betekenis kunnen zijn. Ook andere 'notabelen' hielpen in de vluchtelingencomités. Artsen kregen echter op een specifieke manier met de vluchtelingen te maken, omdat ze hen ook als patiënt behandelden. Daardoor was hun contact met hen diepgaander dan tussen de vluchtelingen en andere helpenden. Van de elf artsen die door suïcide omkwamen, waren er in elk geval vijf die ofwel zelf in Duitsland hadden gewoond ofwel bewijsbaar actief waren geweest in de vluchtelingenopvang. ${ }^{46}$

Voorts zouden, volgens de Amerikaanse sociologe Nechama Tec, hoogopgeleiden, als zijnde vooraanstaande leden van de maatschappij, minder opgewassen zijn tegen plotselinge discriminatie en minderwaardigheid. Lagere klassen zouden al meer tegen vernedering en een gevoel van minderwaardigheid gewapend zijn door eerdere ervaringen van achterstelling. ${ }^{47}$ Dit zou voor de artsen, die zich altijd een gelijkwaardig deel van de medische stand en dus van de Nederlandse elite hadden gevoeld, zeker kunnen opgaan. Het gevoel er niet meer helemaal bij te horen werd door Berthold Stokvis in de meidagen van 1940 treffend weergegeven in zijn dagboek: 'nu worden wij nog gelijkwaardig geacht, maar morgen...' $4^{8}$ Volgens Durkheims belangrijke 'politieke integratie-theorie' en de verbetering daarvan door Van Tubergen en Ultee, de 'sociale integratie theorie', zou men inderdaad een verklaring voor het hoge zelfmoordpercentage onder Joodse artsen kunnen vinden in het opkomend gevoel van isolement. De politieke integratietheorie stelt immers dat zelfmoord voorkomen kan worden door sterke sociale verbindingen tussen mensen. Oorlog op zichzelf kon, volgens Durkheim, een bindende factor zijn, omdat een gezamenlijke vijand van buitenaf een interne verbondenheid bevorderde. ${ }^{49}$ Echter, in het geval van déze oorlog gaf de situatie in mei I940 de Joodse artsen een aanleiding om juist een breuk met de bekende sociale groep, de artsenstand, te ervaren. Dit komt overeen met de observatie van Van Tubergen en Ultee dat mensen die de overtuiging hebben dat zij worden buitengesloten, vaker suïcide plegen..$^{\circ 0}$ In Duitsland was het volgens historicus Michael Kater zo dat de Joodse artsen in deze omstandigheden proportioneel vaak zelfmoord 
pleegden omdat zij zich meer Duits dan Joods voelden. Dat zij niet meer als volwaardig Duits burger werden beschouwd deed hen besluiten niet verder te willen leven..$^{\text {SI }}$ Een parallel met de Nederlands-Joodse artsen, voorheen altijd gewone Hollandse artsen en nu opeens niet meer vanzelfsprekend als zodanig geldend, is hier te ontwaren.

Het gevoel los te staan van de rest van de artsenstand zou ook verklaren waarom voor de artsen die tot zelfmoord overgingen de medische wetten niet meer doorslaggevend waren. Psychiater Eugène Carp noemde in een artikel over suïcide in I94I ook het gevoel 'losgeslagen' te zijn als oorzaak: 'In tijden, waarin bepaalde groepen van personen en ook meer individueele persoonlijkheden de voor hen geldende levenswaarden verloren zien gaan en zich losgeslagen gevoelen uit de continuïteit van het levensgebeuren, missen helaas niet weinigen den moed en het vermogen een "nieuw" leven aan te vangen.' 52

Door het woordje 'helaas' schemert in dit citaat wel door dat zelfmoord ondanks het begrip dat men ervoor kon opbrengen nog steeds als falen werd beschouwd. Het bleef dan ook de eerste taak van de geneesheer om suïcide te voorkomen, zoals ook de vooroorlogse overtuiging was geweest. ${ }^{53}$ En helemaal de geneesheer zelf zou de moed moeten vinden door te gaan. In zijn artikel 'Zelfmoord en arts' in de Geneeskundige Gids van I940 sprak Abraham Meerloo, 'half-Joods' psychiater, dan ook onomwonden 'vol weemoed en vol schaamte' over degenen 'die vrijwillig van ons gingen'. 54 Meerloo schreef: 'Onze diepste medische plicht zegt: dat nooit, dat nooit. Het leven blijft ons heilig!' Juist een arts mocht hiertoe niet overgaan: 'Hij, die het leven vrijwillig verlaat, vergeet zijn verantwoording. Hij laat in ellende alle anderen achter, die zijn voorlichting noodig hadden, zijn inzicht, zijn hulp.'55

In dit licht extra dramatisch is het relaas van Maurits Hertzberger, die zich volgens zijn zoon suïcideerde vanwege schuldgevoel over het feit dat hij zijn gezin niet in veiligheid had gebracht. Hij had voor de Duitse invasie de mogelijkheid gehad naar Amerika te ontkomen, maar had hier geen gebruik van gemaakt omdat hij zijn patiënten niet in de steek had willen laten. ${ }^{56}$ Dat hij in mei I940 hen, en ook zijn gezin, wél losliet, moet ingegeven zijn door een verstrekkend gevoel dat niets meer zou zijn zoals het was, dat hij losgeslagen was van alles wat hem voorheen houvast had geboden: een allesoverheersende panische angst dus. Dat is dan waarschijnlijk ook de allerbelangrijkste reden geweest waarom ook de artsen hiertoe overgingen. Of zoals Presser het uitdrukte: 'Het ene woord paniek vormt in de meidagen van 1940 wel een sleutel.' 57 Sally de Jong, Amsterdams Joods arts en tweelingbroer van historicus Loe de Jong, schreef over de situatie rond de Nederlandse capitulatie dat er een stemming onder de Nederlandse Joden heerste van grote vrees dat het 'binnenkort "afge- 
loopen" zou zijn met de Nederlandse Joden. Hoe was nog niet bekend, maar men had voldoende ervaren van de Duitsche Joden om door een panische angst gegrepen te worden. ${ }^{58}$ Loe de Jong heeft in zijn Koninkrijk getracht de paniek en de gemoedstoestand die de mensen tot deze uiterste daad dreef weer te geven: 'Aan hen die de hand aan zichzelf sloegen, leek de zon van het leven ondergegaan - dan kon men beter zelf de nacht bestendigen.' $59 \mathrm{Zij}$ verkeerden in een staat van opperste vertwijfeling, die zich ook kon voordoen als een staat van 'opperste luciditeit'. ${ }^{60}$ Voor hen was in elk geval duidelijk: de dood was te verkiezen boven een leven onder Duits bewind.

De angst voor wat komen zou, werd voor enkele artsen door concrete aanleidingen gevoed. Een van de in Amsterdam-Zuid praktiserende artsen werd door Stokvis anoniem in diens dagboek genoemd. Deze door Stokvis hooggeachte collega had hem in vertrouwen genomen over zijn specifieke angst: hij had even tevoren geweigerd NSB'ers te behandelen en vreesde daar nu de gevolgen van. ${ }^{61}$ Even later bereikte Stokvis het bericht van zijn overlijden door suïcide. Of het om Wiener, Sanders of Levy ging, blijkt niet uit het citaat, maar een van deze drie moet het geweest zijn. Leonard Polak Daniëls op zijn beurt had al voor mei 1940 last gehad van een toenemend antisemitische stemming in de Groningse interne kliniek. Het door hem gewenste privaatdocentschap van zijn Joodse assistent Leopold Meijler was door invloedrijke sympathisanten van het nationaalsocialisme in de kliniek gedwarsboomd. ${ }^{62}$ Ook de Groningse huisarts Elie Cohen, die in goed contact stond met Polak Daniëls, had dit antisemitisme gevoeld. Samen hadden zij besproken wat te doen als de Duitsers Nederland zouden aanvallen. Polak Daniëls had Cohen onomwonden gezegd: 'dan plegen mijn vrouw en ik zelfmoord en we nemen onze hond mee in het graf.' ${ }^{\prime} \mathrm{Hij}$ had zich aan zijn woord gehouden.

Wat er exact in het hoofd van elk van de beschreven elf artsen omging is niet meer te achterhalen, maar dat dat niet meer de eed van Hippocrates was is duidelijk. Voor hen had het artsenberoep en de daarbij behorende plichten en voorrechten geen doorslaggevende betekenis meer. Zelfs Meerloo, die zich zo sterk tegen het fenomeen zelfmoord uitsprak, gaf te kennen voor zichzelf toch door twijfel overmand te zijn:

Ik ga peinzen over vluchten. Engeland of Amerika, maar hoe of wat? Voor en achter mij zit de vijand en hier houdt medische plicht mij vast. De gedachten gaan werktuiglijk naar mijn revolver. Dit niet overleven! Alles worstelt om die ene centrale idee: zelfmoord of vrijheid? Ik lach om mezelf: ik schreef eens een boekje over zelfmoord. ${ }^{64}$ 
Uit plichtsgevoel, uit religieuze overtuiging, of gewoon omdat ze aan het leven hingen en hoopten dat het mee zou vallen: de meerderheid van de Joodse artsen pakte na de meidagen van 1940 zo goed en zo kwaad als het ging de draad weer op. In de eerste bezettingsmaanden leek de bezetter zich ook nog redelijk ingetogen te gedragen. Achter de schermen werd echter al gewerkt aan de systematische losweking van het Joodse bevolkingsdeel uit de Nederlandse samenleving. In de artsenstand zelf waren er ook al enkele onaangename voorvallen waaruit Joodse artsen konden opmaken dat sommigen hen niet meer als gewone collegae zagen.

$\mathrm{Na}$ Polak Daniëls' overlijden werd de sfeer in de interne kliniek in Groningen onmiddellijk grimmiger. Het portret van Polak Daniëls werd uit de collegekamer gestolen en vernietigd door twee arts-assistenten die lid waren van de NSB. ${ }^{65}$ De Nationaal-Socialistische Beweging had vanaf I2 oktober 1940 een eigen medische afdeling, het Medisch Front, waarin aanvankelijk ongeveer I65 artsen waren verenigd. ${ }^{66}$ Een beeld van de manier waarop zij over hun Joodse collegae dachten is te verkrijgen uit een toespraak van hun leider Koenraad Keijer. Hierin verkondigde deze dat er teveel artsen waren, door een door de Joden en marxisten 'listig' in gang gezette 'massa-produktie van geneesheren'. Dat de Joodse artsen volgens hem naast te veel, ook de best betaalde artsenbanen bezet hielden, verbaasde hem niet, net zo min als het door hem vermeende feit dat een zogenaamd verderfelijk vakgebied als geslachtsziekten een 'typisch joods specialisme' was geworden. ${ }^{67}$

Een Joodse arts die reeds in 1940 met ernstige antisemitische uitingen in aanraking kwam, was Salomon Citroen uit Hilversum. Hij was voorzitter van het bestuur van het plaatselijke Algemeen Ziekenfonds Hilversum, AZH. Dit fonds was een Maatschappijfonds, wat inhield dat het door de NMG erkend was omdat het aan een aantal eisen voldeed, zoals een bestuur waarin artsen zaten en een lage welstandsgrens. Dit was in het belang van de artsen, want zo hadden zij invloed op de honoraria en sloten zich niet te veel mensen bij de ziekenfondsen aan, zodat er voldoende particuliere - meer betalende - patiënten overbleven. Daarom had de NMG een dergelijk keurmerk ingevoerd. $\mathrm{Nu}$ was er in Hilversum door NSB'ers nog een ziekenfonds opgericht, het zogenaamde 'Nederlandsch Ziekenfonds'. Tot hun grote frustratie werd dit ziekenfonds niet erkend als Maatschappijfonds. Dit betekende dat het fonds zeer waarschijnlijk minder leden zou kunnen interesseren. De hierover ontstane frustratie werd niet alleen op de Maatschappij gebotvierd, maar ook op collega-concurrent Citroen, van wie zij vermoedden dat hij de grootste dwarsligger 
was. Dit omdat hij Joods was en in de regionale afdeling van de NMG actief was. Deze afdeling had echter geen inspraak in de beslissing over erkenning; dit werd centraal door de Maatschappij geregeld. Hieraan had de agent van het Nederlandsch Ziekenfonds, Johan Verzendaal, geen boodschap. Op I2 juni I940 ontving Citroen een eerste dreigbrief van deze Verzendaal. Een maand later volgde de tweede brief, waarvan namens het bestuur van het AZH een kopie naar het hoofdbestuur van de NMG werd gezonden. ${ }^{68}$ Tezelfdertijd schakelde Verzendaal zijn machtige vriend H.J. Woudenberg in, de man die net tevoren namens de NSB het Nederlandsch Verbond van Vakverenigingen had 'gelijkgeschakeld', wat inhield dat de voorzitter en secretaris op staande voet ontslagen waren en de overige bestuurders werden bedreigd met ernstige straffen als zij het werk zouden neerleggen. Woudenberg pleegde een telefoontje met de NMG, waarin hij aankondigde dat als het Hilversumse nieuwe fonds niet erkend zou worden, met de NMG hetzelfde zou gebeuren als met het NVV Verzendaal stuurde daar op 3 augustus 1940 nog een briefje achteraan met de woorden: 'Ik heb heden bij Mr. Genechten te Utrecht verteld hoe U en de voorzitter van AZH (een Jood) ons tegenwerkt, en dit kan en mag niet langer. Wij zullen aansluiting eischen, niet goedschiks wilde u, dan maar op deze wijze. ${ }^{69}$

Inmiddels had de NMG bij monde van de secretarissen van de Huisarts Commissie en de Specialisten Commissie, respectievelijk Chr. Eggink en J.C. Diehl, aan het AZH laten weten dat 'het zeer dringend noodzakelijk was dat niet-Arische bestuursleden der fondsen dadelijk hun mandaat ter beschikking zouden stellen' ${ }^{70}$ Dit werd niet rechtstreeks aan Citroen medegedeeld, maar aan ziekenfonds-secretaris A. Le Comte. Het ziekenfondsbestuur was ontdaan, maar Citroen besloot inderdaad in het belang van het fonds zijn functie dan maar neer te leggen. Toen echter bleek dat Diehl en Eggink voor hun beurt gesproken hadden en het hoofdbestuur van de NMG helemaal niet bleek te vinden dat Citroen moest aftreden, werd een en ander teruggedraaid. Citroen werd weer voorzitter, ook al kon hij dat slechts een paar maanden blijven, maar het AZH besloot voorlopig nog slechts adviezen van het hoofdbestuur zelf en niet van de Huisarts en de Specialisten Commissie op te volgen. ${ }^{71}$ Niet geheel verbazingwekkend in deze context is ook dat met name Eggink maar ook Diehl een belangrijke rol gingen spelen in de enkele maanden later geïnitieerde gelijkschakeling van de Maatschappij. ${ }^{72} \mathrm{Zij}$ hadden in de zaak Citroen voor hun beurt gesproken, maar zouden niet veel later toch hun zin krijgen. 
Op II oktober 1940 ontving de afdeling Volksgezondheid van het Departement van Sociale Zaken een schrijven van Obermedizinalrat F. Reuter namens de General-Kommissar für Verwaltung und Justiz waarin deze haar opdroeg opgave te doen van alle artsen met een Joodse afstamming die werkzaam waren in overheidsfuncties, te weten gemeenteartsen, ziekenhuisdirecteuren, artsen werkzaam voor gemeentelijke universiteiten of medici van consultatiebureaus voor zuigelingenzorg of tuberculosebestrijding. Deze opgave diende uiterlijk op 19 oktober, acht dagen later, ingeleverd te zijn. ${ }^{73}$ Hiermee nam de uitsluiting van de Joodse medici uit de Nederlandse artsenstand nu ook formeel een aanvang.

De uitvoering van deze opdracht werd door het Departement opgelegd aan de Geneeskundige Hoofdinspectie. Cornelis (Cees) Banning (1894-1964), hoofdinspecteur van de Volksgezondheid, die zijn provinciale inspecteurs opdracht gaf tot opgave van namen van de betreffende artsen, begreep direct 'dat aan dit verzoek groote moeilijkheden zijn verbonden'. ${ }^{74} \mathrm{Hij}$ kan hiermee gedoeld hebben op zowel principiële moeilijkheden als praktische bezwaren. Immers, het doel van deze opdracht leek te zijn de uitschakeling van Joodse ambtenaren, en tot op dat moment was bij de Geneeskundige Hoofdinspectie niet geregistreerd wie Joods was en wie niet. Dit praktische probleem werd grotendeels ondervangen doordat alle Nederlandse ambtenaren in de eerste helft van de maand oktober een 'vraagformulier', in de wandeling ook wel 'ariërverklaring' genoemd, hadden moeten invullen. Deze ogenschijnlijk puur administratieve maatregel had in ambtenaren- en bestuurlijke kringen wel discussie losgemaakt, maar toch hadden vrijwel alle ambtenaren, Joods en nietJoods, de verklaring ingevuld en teruggestuurd. Op ongehoorzaamheid stond de sanctie van onmiddellijk ontslag. ${ }^{75}$ De informatie van deze ariërverklaringen was half oktober echter nog niet bekend bij de provinciale inspecteurs voor de volksgezondheid. $\mathrm{Zij}$ moesten dus zelf een lijst met namen aanleggen. Dit leverde nogal wat onzekerheid op. L.A. Veeger, geneeskundig inspecteur voor Limburg en Gelderland, antwoordde Banning dat hij in zijn ambtsgebied Limburg alleen van de Maastrichtse ziekenhuisdirecteur en gemeentearts Charles Mendes de Leon zeker wist dat deze van Joodse komaf was.

In Heerlen zijn geen Joden in leidende functies, in Sittard, Kerkrade, Roermond, Weert, Venlo evenmin. Zoover ik het kan beoordelen is geen der artsen in den dienst van tuberculosebestrijding, geslachtsziektenbestrijding, zorg voor moeder en kind van Joodsche afkomst, zoodat 
Limburg praktisch niets oplevert. Is het gewenscht om zekerheidshalve alle ziekenhuisdirecteuren en consultatiebureau-artsen in Limburg nog een formulier te laten tekenen, ik weet immers niet met roo procent zekerheid of er nog tusschen ouders en grootouders een lid is van Joodsche afkomst. ${ }^{76}$

Veeger toonde zich hiermee meer dan gezagsgetrouw: hij stelde voor om nog een extra formulier rond te zenden. Banning antwoordde echter dat het, zowel gezien de beperkte tijd die er was voor de opgave als met het oog op het '(naar ik wil: nodeloos) verontrusten van betrokkenen', niet raadzaam was nóg een formulier toe te sturen. ${ }^{77}$ Deze formulering suggereert dat Banning zelf niet geheel en al overtuigd was van de nodeloosheid van de verontrusting. Niettemin verstrekte hij de gevraagde gegevens aan het Departement.

De provinciale inspecteurs verzochten de gemeentebesturen in hun regio om opgave van de namen van betrokkenen, die zij vervolgens in lijstjes aan Banning zonden. Banning op zijn beurt informeerde de directeur-generaal van Volksgezondheid op het Departement van Sociale Zaken. Hij gaf in opeenvolgende berichten in totaal 86 namen door van artsen die volgens zijn provinciale inspecteurs Joods waren. $3 \mathrm{I}$ van hen werkten in Amsterdam. Het ging hierbij om artsen die een dienstverband hadden bij de GGD, de Gemeentelijke Universiteit of een van de gemeentelijke ziekenhuizen: het Wilhemina Gasthuis en het Binnengasthuis. Een van hen, Maurits van der Stempel, werkte als instructeur 'ЕНво en gasmaskerdiscipline' bij de Amsterdamse brandweer. ${ }^{78}$ Buiten Amsterdam werden bijvoorbeeld Maurits Taytelbaum, gemeentearts van Veere en Vrouwenpolder, Leo Lezer, gemeentearts van Wijhe, en Jacob Bramson, tweede geneesheer aan de Psychiatrische Inrichting van de gemeente Franeker, opgegeven. ${ }^{79}$ Deze lijstjes waren overigens niet compleet; ten minste vier andere artsen werden getroffen door de maatregel. Daarnaast werd er over negen twijfelgevallen aanvullende correspondentie gevoerd. Zo had de kno-arts René Fernandes laten weten niet met zekerheid te kunnen zeggen of hij als Jood aangemerkt zou moeten worden: 'Naar mijn beste weten hebben geen mijner ouders en grootouders behoord tot de Joodsche Gemeente. Door het ontbreken van postverbinding met Suriname, waar deze grootouders gewoond hebben, kan ik geen nader onderzoek instellen.' ${ }^{80}$

Collega A.H.J. Nord uit Zwollerkerspel kon wel een nader onderzoek instellen naar zijn afstamming. Hieruit bleek dat zijn grootouders van vaders zijde hun huwelijk hadden laten voltrekken in de 'Joodse kerk' en daarom werden zij door de Joodse gemeente beschouwd als behoord hebbende tot het Joodsche Kerkgenootschap. De namen van Nords ouders kwamen niet meer 
in de kerkregisters voor. Nord ging te rade bij de burgemeester van Zwollerkerspel, die twijfelde omdat volgens hem inzegening van een huwelijk nog geen lidmaatschap hoefde te betekenen. Zijn advies aan Nord was dan ook om zich voor alle zekerheid toch te melden bij provinciaal inspecteur G.D. Hemmes en van hem verder advies af te wachten. Nord reageerde: 'Natuurlijk zou een ander bericht mij liever geweest zijn, maar ik wensch mij aan den anderen kant ook niet bloot te stellen aan eventueele latere moeilijkheden. Buitendien meen ik, dat wat mijn ambtelijke functies betreft, deze hierdoor nog niet in gevaar komen.' ${ }^{\text {II }}$

Klaarblijkelijk was hij van mening dat onttrekking gevaarlijk zou kunnen worden. In Nederland waren persoonsgegevens voor de oorlog al zo ordentelijk geregistreerd, ofwel bij bevolkingsregisters ofwel bij kerkelijke registers, dat de meeste burgers veronderstelden dat de gevraagde gegevens eenvoudig door de Duitsers achterhaald zouden kunnen worden. ${ }^{82}$

Over de definitie 'Jood' zoals die door de bezetter gehanteerd werd, bestond onduidelijkheid. Bij de 'ariërverklaring' van begin oktober was het dan ook voor velen, zoals Nord, onduidelijk welke criteria gehanteerd dienden te worden. Op 22 oktober 1940 echter liet Rijkscommissaris voor het bezette gebied Arthur Seyß-Inquart per Verordening, artikel 4, vaststellen:

I. Jood is een ieder, die uit tenminste drie naar ras voljoodsche grootouders stamt. 2. Als jood wordt ook aangemerkt hij die uit twee voljoodsche grootouders stamt en hetzij zelf op den negenden mei I940 tot de joodsch-kerkelijke gemeente heeft behoord of na die datum daarin wordt, opgenomen, hetzij op den negenden mei I940 met een jood was gehuwd of na dat oogenblik met een jood in het huwelijk treedt. 3. Een grootouder wordt als voljoodsch aangemerkt, wanneer deze tot de joodsch-kerkelijke gemeenschap heeft behoord. ${ }^{83}$

Toen de betrokkenen op 22 november 1940 een brief ontvingen waarin hun werd medegedeeld dat zij vanaf die datum ontheven waren van hun functie, was Nord als 'half-Jood' daar niet bij. 2535 'vol' - of 'driekwart'-Joodse ambtenaren daarentegen ontvingen wel deze boodschap. ${ }^{84}$ Onder hen waren ongeveer honderd artsen.

De GGD Amsterdam leed een zwaar verlies: 32 van zijn werknemers, artsen en ander personeel, dienden hun functie neer te leggen, onder wie arts en adjunct-directeur Salomon Spijer. Met deze werknemers verdween ook een belangrijk deel van de grondvesten van de dienst. De GGD had goed beschouwd Joodse wortels: zijn bestaan was geïnitieerd door de grotendeels Joodse hygi- 
enisten en werd gedragen door de sfeer van emancipatie die door met name sociaaldemocratische Joodse bestuurders van de stad in het interbellum gecreeerd was. Heijermans' succesvolle leiderschap van de dienst lag nog vers in het geheugen. ${ }^{85}$ De bezetter had aan dit alles uiteraard geen boodschap.

De ontheffingsbrief was, althans voor het honderdtal artsen-ambtenaren, afkomstig van de waarnemend secretaris-generaal van het Departement van Sociale Zaken R.A. Verwey. Verwey en zijn collegae secretarissen-generaal hadden gediscussieerd over het wel of niet uitvoeren van deze opdracht. ${ }^{86}$ Over het algemeen kon men echter over de houding van de hoge ambtenaren ten opzichte van de anti-Joodse maatregelen stellen: 'Sommigen accepteerden de maatregelen met pijn in het hart, anderen legden een opmerkelijke ijver aan de dag en zelfs een bereidheid "mee te denken". ${ }^{87}$ Men ging dan ook tot uitvoering over, in de overtuiging niet bij machte te zijn de maatregel te verhinderen en in de hoop door medewerking een gunstiger regeling voor de betrokkenen te kunnen bewerkstelligen. Zo werd er inderdaad voor gezorgd dat in de brief niet werd gesproken van 'ontslag' maar van 'ontheffing' uit de functie. Hieruit volgde dat er ook een wachtgeldregeling werd getroffen. ${ }^{88}$ Of aan deze 'geste' van de bezetter enkel de houding van de secretarissen-generaal ten grondslag lag, is twijfelachtig. De niet-Joodse arts Jeltje Stroink gaf op 26 november 1940 in haar dagboek uiting aan haar vermoeden van een bijkomende drijfveer voor de Duitse gezagsdragers: 'De ontslagen Joden zullen voorloopig hun salarissen door ontvangen. Zijn de Duitsche autoriteiten toch wat geschrokken van de reactie van het publiek hier en wilden ze ons coûte que coûte rustig houden?'89

Er was inderdaad een reactie van het publiek gekomen. Zij kwam uit kerkelijke en met name uit universitaire hoek. Stroink werkte bij een Utrechtse universiteitskliniek, waar de Joodse directeur L. Leydesdorff moest verdwijnen. ${ }^{90}$ Vol verontwaardiging schreef Stroink hierover in haar dagboek. Door anderen werd de verontwaardiging ook hardop uitgesproken. Onder hoogleraren en studenten was beroering ontstaan, waaraan de Leidse hoogleraar van de rechtenfaculteit R.P. Cleveringa een - beroemd geworden - stem gaf. Minder bekend is dat Cleveringa's collega van de medische faculteit, professor J.A.J. Barge, op dinsdag 26 november 1940 tijdens zijn college in het Anatomisch Laboratorium aan de Wassenaarseweg, op hetzelfde moment als Cleveringa op het Rapenburg, eveneens zijn afkeuring kenbaar maakte. Dit sloot aan op de collegecyclus rassenleer die Barge vanaf september gaf, volgens een van de studenten: 'om ons een solide basis te geven van een soort geestelijk verweer tegen de verderfelijke rassenleer van de Duitsers. ${ }^{91}$ Op 25 oktober had hij al aangetoond dat het Joodse ras als zodanig niet bestond; de Joden dienden als een volk te worden beschouwd en niet als een ras. Op 26 november eindigde 
hij zijn betoog met de zin: 'Dames en Heren, het Duitse ras bestaat niet.' Het begrip 'ariër' had volgens hem geen betekenis. In een zuiver wetenschappelijk betoog legde hij dit uit. De medische studenten waren diep onder de indruk, geïnformeerd door de rechtenstudenten die waren gaan staken naar aanleiding van het moedig optreden van Cleveringa besloten ze hierop dat voorbeeld te volgen..$^{22}$ Deze twee Leidse hoogleraren protesteerden in hun colleges, evenals hun Utrechtse collega V.J. Koningsberger een dag eerder, tegen het ontslag van hun Joodse collegae. ${ }^{93}$

In Leiden en Delft gingen de studenten over tot staking, wat tot gevolg had dat deze universiteit en Technische Hogeschool door de Duitse autoriteiten gesloten werden. ${ }^{94}$ In Amsterdam en Utrecht verhinderden de rectores magnifici dit. In Amsterdam geschiedde dit door vakantie uit te schrijven, in Utrecht door de oproep van rector H.R. Kruyt: 'Ook al voelt men zich gewond, daarom slaat men nog niet de hand aan zichzelf.'95 Daarbij bleef het daarna wat betreft protest op bestuurlijk niveau. Berthold Stokvis, die verbonden was aan de medische faculteit van de Amsterdamse universiteit, verhaalde in zijn dagboek wel van een 'alleszins adequate reactie' van zijn naaste collegae en medewerkers in het laboratorium waar hij gedwongen afscheid nam. Zij waren tot tranen geroerd, wisten niet wat ze moesten zeggen en drukten hem zwijgend de hand toen hij hen verslagen achterliet. ${ }^{96}$ Voor Ju Groen, die afscheid nam van zijn studenten aan de Amsterdamse Universiteit, klonk na zijn laatste college een daverend applaus, 'als voor een beroemd dirigent'. ${ }^{97}$

Zulke taferelen zullen zich vaker hebben afgespeeld. Ongetwijfeld hebben velen op individueel niveau hun afschuw uitgesproken. Verder protest op collectieve schaal was er echter niet. Aan de andere kant waren er wel ook onaangename ervaringen. In het Groningse academisch ziekenhuis werd de internist Frits Klein uit zijn functie ontheven. Zijn collegae en studenten zamelden geld in om een afscheidscadeau voor hem te kopen en nodigden hem nog uit voor een refereeravond. Dit werd echter verraden door de twee Duitsgezinde assistenten. Als hoogleraar interne geneeskunde werd hier ook de 'deutschfreundliche' G.A. Kreuzwendedich von dem Borne aangesteld..$^{8}$

In niet-universitaire medische kringen waren er uiteraard ook reacties, maar ook deze bleven meestal van persoonlijke aard. Zo zou in het Heerenveens gemeentelijk ziekenhuis een sfeer van verslagenheid hebben geheerst toen bekend werd dat de chirurg Max Roeper uit zijn functie ontheven zou worden. ${ }^{99}$ De geneesheer-directeur van het ziekenhuis schreef een brief over de situatie aan provinciaal inspecteur van de Volksgezondheid P. Muntendam, waarschijnlijk in de hoop dat deze iets voor Roeper zou kunnen betekenen. De precieze inhoud van de brief is helaas niet bewaard gebleven. ${ }^{\text {Ioo }}$ Van de Am- 
sterdamse directeur van de GGD, J.H. Tuntler, werd gezegd dat hij huilde op de dag dat hij zijn Joodse werknemers, onder wie adjunct-directeur Salomon Spijer, de deur moest wijzen. ${ }^{\text {Ior }}$ Tot een formeel protest kwam het hier echter evenmin. Ondertussen bleven Joodse ambtenaar-artsen, zoals Berthold Stokvis, vertwijfeld achter:

Ik zou in de vertrouwde stationswachtkamer een kopje koffie bestellen. Morgenochtend komt die patiënt voor het rapport, dat klaar moet; niet vergeten! En overmorgen na de ochtendvisite... Wat, de ochtendvisite! Ik zou geen visite op zaal meer maken en dat rapport duvelt niet meer. Dat moet zonder mij. En mijn onderzoek? En mijn nieuwe proef? En mijn cursus? En mijn apparaten? En? En? Hemel! Dat is dus allemaal afgelopen? Maar dat is toch niet mogelijk? Dat kan toch niet? En waarom, waarom? Omdat ik een Jood ben. Een Jood. Ja, 'es ist schwer ein Jid zu sein.' [...] In dit, ons, ook mijn land was men mensch en geen Jood of Katholiek enz. en nu is het bedorven. Zal het ooit moeizaam te heroveren zijn? Evenmin als vroeger vind ik het erg Jood te zijn. Ik wensch het niet te verbergen, maar hier worden fundamentele menschen rechten aangetast. ${ }^{102}$

\section{ONTSLAG}

Al spoedig bleek dat de ontheffing van de ambtenaren nog maar het begin was. Nog geen maand later spraken de Duitse gezagsdragers al met de secretarissen-generaal over ontslag. De maatregel was in november volgens de Duitsers verkeerd geïnterpreteerd: ontslag was wel degelijk de bedoeling geweest. $\mathrm{Nu}$ werden de secretarissen-generaal onder druk gezet door te stellen dat als zij zouden meewerken aan ontslag, de Joodse ambtenaren toch nog een geldelijke vergoeding zouden krijgen. $\mathrm{Zij}$ zouden dan een wachtgeldregeling blijven behouden. Het kwam daarom inderdaad tot formeel ontslag, per I maart I94I. ${ }^{103}$ Dit hield in feite in dat de Joodse ambtenaren met vervroegd pensioen gingen. Alleen degenen die pensioenrecht hadden, en dat gold lang niet voor allen, konden dan ook daadwerkelijk aanspraak maken op een wachtgeldregeling. ${ }^{104}$ Het wachtgeld bedroeg gedurende de eerste drie maanden 85 procent van het oorspronkelijke salaris en werd vervolgens voor de eerstkomende vijf jaren vastgesteld op 70 procent van dit bedrag. ${ }^{\text {I05 }}$ In de daaropvolgende jaren zou het percentage elke vijf jaar dalen met Io procent, en voor niet-kostwinners was de uitkering vanaf het begin al to procent lager. ${ }^{106}$ 
Bij de Joodse artsen die in dienst waren geweest van de Amsterdamse GGD is uit archiefstukken op te maken wat de inkomstenderving inhield. Arie Querido bijvoorbeeld, het hoofd van de afdeling Geestesziekten, kreeg in de maanden november I940 tot en met februari I94I $f$ 2558,96 bruto uitbetaald. Dit was zijn volledige salaris. Hij genoot dus normaal gesproken een jaarsalaris van $f 7676,88$ bruto. Dit gold als een goed inkomen, vergelijkbaar met dat van een hoogleraar. ${ }^{107}$ In de periode I maart tot en met 3I december 194I werd hem nog maar $f$ 3637,64 betaald. Ook arts Cosman Gomperts werd door de GGD doorbetaald, maar zijn salaris kromp eveneens aanzienlijk. Na I maart I94I nam hij dan ook een eigen praktijk ter hand, waaruit hij in het hele jaar I94I slechts $f$ 59,7I verdiende. ${ }^{108}$ Naast Gomperts meldden ook Willem H.D. de Haas en Elazar A. Rodrigues Pereira zich na hun ontslag bij de GGD bij het Algemeen Ziekenfonds Amsterdam (AZA) teneinde een ziekenfondspraktijk te kunnen starten. In de notulen van de algemene vergadering van dit ziekenfonds wordt melding gemaakt van een levendige discussie over de vraag of deze artsen nu inkomsten uit de ziekenfondspraktijk mochten trekken terwijl hun salaris nog (deels) werd doorbetaald. Hieraan kwam pas een einde toen Rodrigues Pereira opmerkte dat tegen deelname aan het ziekenfonds van overheidswege geen bezwaar werd gemaakt en dat de inkomsten daaruit op het salaris in minderheid werden gebracht, wat de standaardprocedure bij een

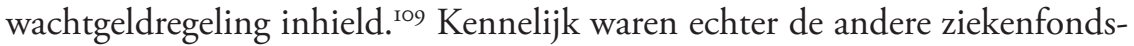
artsen wat zenuwachtig bij de nieuwe concurrentie: hoeveel patiënten zouden zij kwijtraken aan de nieuwe praktijkhouders? Frits Klein in Groningen koos voor een oplossing die minder concurrentiegevoelens bij collegae kon oproepen. Hij ging kamers verhuren aan studenten om wat meer inkomsten te genereren. ${ }^{\text {IIO }}$

Van oogarts Fritz Fischer, in deeltijd werkzaam in het Ooglijders Gasthuis te Utrecht, is bekend dat zijn toelage hier direct na het ontslag tot nul werd gereduceerd. Uit naoorlogse notulen kan worden opgetekend: 'De rentmeester brengt in herinnering, dat Dr Fischer voor den oorlog in het gasthuis een toelage van $\mathrm{f}_{750}$,- per jaar genoot. Deze toelage is na het ontslag van Dr Fischer stopgezet omdat regenten van oordeel waren dat zij het Gasthuis niet mochten blootstellen aan de gevaren, welke er waren verbonden aan het doorbetalen van een ontslagen Joodsch-ambtenaar.' ${ }^{\prime I I}$ Fischer had het geluk dat geneesheerdirecteur H.J.M. Weve van het Ooglijders Gasthuis hem gedurende de hele oorlog uit eigen zak deze toelage doorbetaalde. ${ }^{\mathrm{II} 2}$

Janos Freud, samen met Ernst Laqueur ontdekker van het testosteron en daarmee een belangrijk wetenschapper, kreeg hulp van een groepje van vier niet-Joodse collegae die een fonds oprichtten om hem financieel te ondersteu- 
nen. ${ }^{113}$ Een ander voorbeeld van steun van een collega-medicus was de houding van gynaecoloog M.A. van Bouwdijk Bastiaanse na het ontslag van zijn assistent Elsa Jessurun d'Oliveira. Bij haar ontslag was vanwege een administratieve fout een vertraging opgetreden: zij was op 22 november als enige van de Joodse werknemers van het Wilhelmina Gasthuis in Amsterdam niet ontheven uit haar functie. Toen de registratie kennelijk geperfectioneerd was, kwam deze vergissing uit en werd zij alsnog uit haar ambt gezet. Van Bouwdijk Bastiaanse zorgde er echter voor dat zij gewoon naar het Wilhelmina Gasthuis kon blijven komen om er in een apart kamertje aan haar proefschrift te werken. Hij had een bordje op de deur gehangen: Verboden toegang. ${ }^{\text {II }}$

Zulk een behulpzame houding werd niet door alle collegae aangenomen. Schrijnend is het voorbeeld van kinderarts S.B. de Vries Robles, die door het bestuur van het Amsterdamse Emma Kinderziekenhuis in december 1940 ontslagen werd, hoewel dit ziekenhuis geen overheidsinstelling was. Toen in februari 194I bekend werd dat dit ontslag voor de particuliere instelling die het Emma Kinderziekenhuis was helemaal niet nodig was geweest, vroeg het bestuur De Vries Robles terug te keren. Deze weigerde echter op dit verzoek in te gaan. ${ }^{\text {II }}$ Min of meer hetzelfde geschiedde in het Antoni van Leeuwenhoekziekenhuis, eveneens geen gemeentelijk ziekenhuis. Ook hier werden de Joodse artsen, Betty Levie en Nathaniël Waterman, in februari 194I uit hun functie ontheven. ${ }^{116}$ Toen directeur W.F. Wassink er echter achter kwam dat in een ziekenhuis zonder overheidssteun Joodse artsen nog wel werkzaam mochten zijn, haalde hij zijn twee werknemers terug. In haar opgetekende herinneringen weet Betty Levie haar ontslag door Wassink aan onwetendheid, en niet aan pro-Duitse sentimenten. ${ }^{117}$ Maar ook nu zou het niet lang meer duren voor de situatie wederom veranderde, ten nadele van de Joodse artsen. Niet alleen de ambtenaar-artsen, maar alle Joodse artsen zouden formeel afgezonderd worden van de rest van de Nederlandse artsenstand.

\section{HET BEHANDELVERBOD}

Verdere segregatie van de Joodse ten opzichte van de niet-Joodse medici bereikte de bezetter met de maatregel die met ingang van I mei I94I van kracht was. Vanaf deze datum mochten Joodse artsen geen niet-Joodse patiënten meer behandelen. Hun praktijken dienden enkel en alleen te bestaan uit Joodse patiënten.

In de maanden januari, februari, maart en april 194I was er intussen nog veel meer gebeurd. Allereerst vond de registratie van alle Joden in Nederland 
doorgang. Zij werd voorgeschreven door Verordening nr. 6 van Io januari I94I en hield in dat eenieder met een, twee of drie Joodse grootouders aanmeldingsplichtig was, op straffe van vijf jaar gevangenisstraf. In het bevolkingsregister werd vervolgens onderscheid gemaakt tussen Jood ( $\mathrm{J}$ ), 'Bastaardjood' met één Joodse grootouder (BI) en 'Bastaardjood' met twee Joodse grootouders (BII), later ook wel GI en GII, wat stond voor 'Gemischt'. De aanmelding verliep zonder voor de bezetter noemenswaardige problemen. Nederlandse ambtenaren werkten mee en eventuele twijfelgevallen werden beoordeeld door de Duitse jurist Hans Calmeyer. ${ }^{\mathrm{II} 8}$ De Nederlanders met Joodse grootouders meldden zich zelf aan, slechts zeer weinige uitzonderingen daargelaten. ${ }^{119}$ In februari 194I braken echter rellen uit in de Jodenbuurt in Amsterdam door provocatie van de WA, de Weerafdeling van de NSB. Als reactie daarop werd als vertegenwoordigend orgaan voor de Nederlandse Joden de Joodsche Raad in het leven geroepen en werden groepen jonge Joodse mannen bij straatrazzia's op 22 en 23 februari mishandeld, vernederd en opgepakt. Eerst werden zij naar Schoorl en later naar Buchenwald en Mauthausen gezonden. Als protest daartegen vond de Februaristaking plaats. Ook die bleef niet onbeantwoord: de Duitsers arresteerden drie stakingsleiders en executeerden hen op I4 maart 194I gelijk met vijftien verzetsmensen. ${ }^{120}$ Hiermee maakte Nederland voor het eerst in brede kring kennis met de terreur die de bezetter zo bleek te kenmerken. Angst zwol aan onder de bevolking, en onder de Joodse bevolking in verhoogde mate. Tegelijkertijd leidde de Februaristaking bij de bezetter tot het besef dat publiek geweld tegen Joden kon leiden tot onrust en economische schade. ${ }^{\mathrm{I21}}$ Voorzichtigheid was dus geboden vanuit het Duitse perspectief.

Naast aanzwellende angst was er in dit voorjaar van 194I ook sprake van een steeds verder opgevoerde algehele segregatie: Joden mochten niet meer in bioscopen, bij restaurants en cafés hingen bordjes 'Joden niet gewenscht' aan de deur en per I maart I94I mochten Joden geen bloed meer geven voor de bloedtransfusiedienst, tenzij dit bloed bestemd was voor andere Joden. ${ }^{122}$ Schriftelijk protest hiertegen van het Rode Kruis mocht niet baten. In een brief, ingediend bij het Departement van Sociale Zaken, legde het Rode Kruis uit dat er reeds een vooroorlogs beleid bestond dat inhield dat ontvangers van bloed zelf restricties mochten aangeven ten aanzien van hun bloeddonor. Zo hoefden Amerikanen bijvoorbeeld geen bloed te accepteren afkomstig van zwarten. Duitsers die geen bloed van Joden wilden, zouden dus al bij de bestaande regelgeving daarin geen problemen ondervinden. Dat nu ook Nederlanders die geen bezwaar tegen 'Joodsch bloed' hadden, dat bloed niet meer mochten ontvangen, ging het Rode Kruis te ver en zou de dienst impopulair 
kunnen maken, met alle gevolgen voor de volksgezondheid van dien. ${ }^{123}$ De bezetter voerde niettemin deze maatregel onverbiddelijk door, net als de maatregelen die erop volgden. Complete isolatie, in combinatie met een klimaat van angst, bleek de juiste tactiek voor de uitvoering van de Duitse plannen. In dit licht was het behandelverbod ingaand op I mei I94I een te verwachten stap.

Op 5 februari 194I werd aan de artsen bekend gemaakt dat deze nieuwe maatregel ingevoerd zou worden. Het behandelverbod gold in één richting: Joodse artsen mochten geen niet-Joodse patiënten meer behandelen, maar Joodse patiënten hoefden niet per se een Joodse arts te consulteren. NietJoodse artsen mochten immers blijven behandelen wie zij wilden, ook Joodse patiënten. Het ging er dus om te achterhalen welke artsen Joods waren. Alle artsen ontvingen daartoe een circulaire van waarnemend secretaris-generaal R.A. Verwey van het Departement van Sociale Zaken, waarbij een formulier gevoegd was waarop men al of niet Joodse afstamming kon invullen. Bij deze tweede 'ariërverklaring' was uitgegaan van de definitie zoals die was vastgelegd in artikel 4 van de Verordening 189/1940. Eenieder moest daarom het aantal Joodse grootouders invullen. Eenzelfde circulaire met formulier werd gestuurd aan apothekers, tandartsen en advocaten. Deze laatsten ontvingen hun circulaire van het Departement van Justitie. Allen restte hierna een luttele twee maanden om zich op de gevolgen van deze nieuwe regel voor te bereiden.

In ambtelijke kringen was officieel al langer bekend dat deze maatregel getroffen zou worden. De secretarissen-generaal hadden reeds in november 1940 uit een 'Anordnung' van de Rijkscommissaris kunnen opmaken dat personen 'van Joodsen bloede' die voor hun beroep een eed of belofte hadden afgelegd 'uit de openbare dienst' verwijderd dienden te worden. Deze formulering in de bewuste Anordnung gaf de secretarissen-generaal aanvankelijk aanleiding om de ijdele hoop te vestigen op een verschillende behandeling van beëdigden in overheidsdienst en beëdigden die dat niet waren. ${ }^{124}$ Op II januari had Generalkommissar für Verwaltung und Justiz Friedrich Wimmer alle hoop de grond ingeboord. Het argument dat uitsluiting van de Joden uit deze ambten grote maatschappelijke problemen zou kunnen veroorzaken, vond geen gewillig oor. ${ }^{125}$ De verwijdering van de Joden uit alle beëdigde beroepen zou onherroepelijk een feit worden. 


\section{JOODSE REACTIES EN HET LEEDWEZEN VAN SECRETARIS-GENERAAL VERWEY}

Hoewel misschien verwacht was het behandelverbod daarom niet minder verwarrend, schokkend en grievend. De reacties van Joodse artsen getuigen daarvan. Briefwisselingen tussen hen en waarnemend secretaris-generaal van het Departement van Sociale Zaken Verwey zijn bewaard gebleven. De brief van de Haagse huisarts Julius Lankhout als reactie op de circulaire van Verwey luidt als volgt:

Uwerzijds bereikte mij een circulaire inzake artsen, tandartsen enz. Is het strafbaar het antwoord op die circulaire niet in te zenden? Ik zie daaromtrent geen bepaling in het stuk uitgedrukt. Immers het is zoo eigenaardig dat men den onschuldig getroffene nog verzoekt zijn eigen strop aan te halen. Op de circulaire oefen ik geen critiek. Uw handtekening daaronder te vinden, van $\mathrm{U}$, die zijt een ernstig, christelijk man, voor wien godsdienstzin, naastenliefde geen lippenbelijdenis zijn, doch de heiligste dingen des bestaans, hoog boven het gewoon aardse uitgaande, wekte wel mijn bevreemding.

De felle Lankhout ventileerde zijn teleurstelling over de lijdzame houding van Verwey. En hij had scherp opgemerkt dat er inderdaad geen sanctie in de circulaire vermeld was, anders dan bij de voorgaande ambtenaren-aanmelding. Toch volgde iedereen de procedure, Verwey voorop. Deze was aanvankelijk voornemens op de beschuldiging van Lankhout te antwoorden: 'Ik wijs er, nav Uw opmerking, dat "den onschuldig getroffene nog verzocht wordt zijn eigen strop aan te halen" op, dat de inzending van de verklaring geen uitvoering van een vonnis betekent, doch een administratieve maatregel.' Deze passage is in de kladversie van de antwoordbrief in Verweys archief echter doorgestreept en zal de getergde Lankhout dus niet bereikt hebben. Verwey wist als geen ander dat het hier bepaald niet alleen om een onschuldige administratieve maatregel ging. Lankhout schreef enkele dagen later nog een tweede brief aan Verwey waarin hij zich min of meer verontschuldigde voor zijn felheid: 'Mijn eerste brief werd ingegeven door een affect, dat zich te spontaan uitte. [...] Hiermede wil ik niet goed praten hetgeen spontaniteit in geschoktheid voortbracht, maar $\mathrm{U}$ slechts het menschelijke doen begrijpen. ${ }^{\mathrm{T} 26}$

Een minder felle, maar zeker zozeer door affect ingegeven brief schreef de Amsterdamse Joodse huisarts Jacob de Hartogh. Deze zou tot zijn grote verdriet, na 54 jaar het volste vertrouwen te hebben genoten van zijn bijna vol- 
ledig niet-Joodse patiëntenpopulatie, zijn praktijk nu vaarwel moeten zeggen. Niet alleen een emotioneel verlies zou De Hartogh door dit opgelegde afscheid lijden, ook een materieel verlies: 'Niettegenstaande mijn 8I jarigen leeftijd ben ik nog dagelijks in de praktijk, daar ik de inkomsten nog niet kan missen. Ik zou dolgraag nog eenigen tijd werkzaam willen blijven, daarom richt ik mij thans tot u. ${ }^{\text {'27 }}$ De Hartoghs verzoek kon niet ingewilligd worden.

De meeste artsen die bij Verwey ontheffing aanvroegen (van tien artsen is een dergelijk verzoek bewaard gebleven), beriepen zich op hun vermeende nietvolledig Joodse afstamming. Slechts bij één van hen, David Meijer Levy uit Eefde, leidde dit snel tot het gewenste resultaat: hij werd van de lijst van Joodse artsen 'afgevoerd'. ${ }^{128} \mathrm{Zijn}$ advocaat kon geloofwaardig aantonen dat Levy slechts twee Joodse grootouders had. Immers, zijn grootvader van vaders zijde was, volgens deze verklaring, een onecht kind van ene Van Lamick, een nietJood. Door goedkeuring van de Duitse verantwoordelijke Hans Calmeyer kon Levy zich 'gecalmeyerd' en dus officieel niet-Joods noemen. Ook collega Israël Batavier uit Amsterdam-West huurde een advocaat in, maar was minder fortuinlijk, ondanks zijn wanhopig appèl op Verwey. Batavier was al jaren eerder, in 1925 , gereformeerd gedoopt en getrouwd met een niet-Joodse vrouw. Zijn praktijk bestond bijna uitsluitend uit niet-Joodse patiënten. Vertegenwoordigers van de gereformeerde kerk, een wethouder en zijn advocaten betoogden dat een Joodse praktijk voeren voor hem als gedoopte niet mogelijk zou zijn en dat de maatregel aldus 'ten enenmale funest' voor Batavier zou uitpakken. $\mathrm{Na}$ Verwey werd Rijkscommissaris Seyß-Inquart zelf aangeschreven. En ook al antwoordde deze het te betreuren, ook hij kon voor Batavier geen uitzondering maken. ${ }^{129}$ Voor Theodoor Heimans, arts uit Ede, kon evenmin een uitzondering worden gemaakt. Zijn verzoek daartoe werd ondersteund door generaalmajoor N.T. Carsten van het Nederlandse leger. Heimans had zich volgens Carsten als reserveofficier van gezondheid tijdens de slag op de Grebbeberg bijzonder moedig gedragen en aldus bewezen een goede vaderlander te zijn. ${ }^{130}$ Ook Samuel van Dam uit Naarden waagde een poging om op basis van zijn verrichte diensten voor de zeemacht, in combinatie met zijn katholieke doop en huwelijk met een katholieke vrouw, van de maatregel verschoond te blijven. Verwey hoopte aanvankelijk zelf ook dat voor de groep artsen die zich militair hadden onderscheiden, dispensatie verkregen zou kunnen worden. Geneeskundig hoofdinspecteur Banning echter wees deze mogelijkheid van de hand. Hij verklaarde hiermee namelijk onherroepelijk onbillijkheden uit te lokken: het was hem niet bekend wie van de Joodse artsen officier van gezondheid met bijzondere onderscheiding was en was daarom bang mensen onterecht over te slaan. ${ }^{13 \mathrm{I}}$ Overigens bleek dat Verwey en Banning hierover zelf bitter weinig te 
zeggen hadden: de Rijkscommissaris beschikte in alle gevallen negatief. ${ }^{\mathrm{I} 2} \mathrm{De}$ enkele dokter die op grond van vermeende onmisbaarheid een poging waagde, maakte al helemaal geen schijn van kans. De aanvraag van Jacob Kijzer, de enige seksuoloog in Rotterdam, werd direct afgewezen. Ook Jules Samuels, die een eigen, zeer omstreden, maar unieke kankertherapie in zijn Amsterdamse praktijk had ontwikkeld, moest zijn niet-Joodse patiënten overdragen. Hun 5o handtekeningen maakten geen verschil. Zelfs de 2000 handtekeningen van de bijna voltallige Boskoopse bevolking waren niet voldoende om hun geliefde huisarts Jacob Hamburger, al 28 jaar in de stad werkzaam, te mogen behouden. De notabelen van het dorp, drie artsen, een pastoor en vier predikanten, schreven in de begeleidende brief over Hamburger:

dat hij zich in dien tijd heeft doen kennen als een medicus, die geheel meeleeft met zijn patiënten, wier vreugde zijn vreugde is, hun leed tot het zijne makende; dat elk werk op maatschappelijk gebied zijn volle steun en sympathie geniet, waarom hij een waardevol en een leiding gevend lid is van de Boskoopsche gemeenschap; dat echter de heer Hamburger ingevolge uw schrijven van 5 februari jl op I mei a.s. als zijnde Jood, zijn practijk alleen ten gunste van Joden zal mogen uitoefenen; dat in Boskoop, voor zoover bekend is, slechts 2 Joodsche gezinnen worden gevonden, hetgeen voor den heer Hamburger en de gemeente Boskoop betekent, dat hij per I mei 194I zijn hooglijk gewaardeerden arbeid zal moeten neerleggen. Redenen, waarom zij zich wenden tot $\mathrm{U}$, hoogedelgestrenge, met het eerbiedig doch dringend verzoek, het wel daarheen te willen leiden, dat den heer J. Hamburger, voornoemd, wordt toegestaan ook na I mei a.s. zijn volle practijk te blijven uitoefenen, waarvoor zij $\mathrm{U}$ in hooge mate erkentelijk zouden zijn. ${ }^{133}$

Uit de notities van Verwey blijkt dat hij onder de indruk was van deze actie, maar wederom machteloos bleef. Dat bleef hij ook in de gevallen van twee zwangere vrouwen, een in Amsterdam en een in Leeuwarden, die hem smeekten hun eigen dokter voor hun bevalling - na I mei 194I verwacht - te mogen houden. Patiënte D. de Leijer uit Amsterdam gaf in de volgende niet mis te verstane bewoordingen uitdrukking aan haar woede:

Het is al verschrikkelijk genoeg als men een zeer bekwaam en een zeer goede docter heeft dat men zich aan rassentheorie moet storen. Dat men gedwongen wordt om er aan mede te werken dat deze kundige en bekwame menschen op straat komen te staan. Immers hun Joodsche 
patiënten zijn zoo miniem, dat ze hiervan geen bestaan kunnen hebben. Het verdwaasde idee het is een jood dus hij is minderwaardig. Terwijl zij toch op een zelfde manier geboren zijn als wij. Als ik een Jodin was zou ik dan tegen deze bevalling niet moeten tegenopzien omdat ik een joodsch kind ter wereld moest brengen. Besmet. Dit is toch de beschaving die men ons brengt nietwaar. Maar met al die opgedrongen beschaving die men als behoorlijk mensch veracht en verafschuwt maar niettemin gedwongen is tijdelijk te aanvaarden, verzoek ik u beleefd doch dringend in mijn toestand mij ter hulp te willen zijn dat docter Drukker mij de tweede helft van mei mij bij de bevalling zal mogen blijven helpen. ${ }^{\mathrm{I34}}$

Verweys antwoord als spreekbuis van de Rijkscommissaris was, eentonig genoeg, ook hier negatief, zij het 'met leedwezen'. Zelfs van uitstel van het ingaan van de maatregel kon geen sprake zijn, zoals Salomon Zwaap uit Hilversum ondervond toen hij na thuiskomst op 12 maart, anderhalve maand als represaillearrestant in gijzeling achter de rug hebbende, hiertoe een verzoek indiende. Hij zag namelijk geen mogelijkheid in een dermate korte tijd zijn niet-Joodse praktijk op een goede manier over te dragen aan een niet-Joodse collega. Maar ook voor dit argument bleef de bezetter, bij monde van Verwey, ongevoelig. ${ }^{135}$

De enige echte mogelijkheid om onder de maatregel uit te komen, was door ofwel geen Jood ofwel geen arts meer te zijn. Die eerste optie werd benut door degenen die middels een afstammingsonderzoek 'bewezen' slechts gedeeltelijk, dus half- of kwart-, Joods te zijn. In de loop van I94I lukte dit nog bij Leon H. Levie uit Rijswijk en Charles Mendes de Leon uit Maastricht, voor wie Zuid-Limburgse collega-artsen en enkele goede advocaten een grootscheepse campagne hadden opgezet om hem te 'ariseren'. Zoals al duidelijk werd bij Israël Batavier maakte voor het als Joods te boek staan een lidmaatschap van een christelijk kerkgenootschap niets uit; het ging puur om het 'naar ras Joods zijn'. Voorouders, soms tot meerdere generaties terug, moesten daartoe - creatief - uitgeplozen worden. Hans Calmeyer moest vervolgens zijn handtekening zetten. ${ }^{36}$ De tweede mogelijkheid, geen arts meer zijn, betekende 'vrijwillig' de gehele praktijk neerleggen. Daartoe gingen enkele medici over die toch al de pensioengerechtigde leeftijd hadden bereikt. Dat waren de Haagse arts H.M. Hijmans, ${ }^{137}$ die nog een redelijk inkomen genoot vanwege zijn deels doorbetaalde gemeentesalaris, de Amsterdammer Abraham Grünwald, August W. Cramer uit Wassenaar en de dermatoloog Machiel Polano uit Den Haag. ${ }^{138}$ Deze laatste weigerde vanwege zijn terugtreden ook de bijgevoegde ariërverklaring bij de circulaire terug te zenden naar Verwey. Deze was 
bereid dat dit keer door de vingers te zien, maar wees er wel op dat er eigenlijk administratief diende te worden vastgelegd aan wie het wel en aan wie het niet was toegestaan algemene praktijk te voeren. ${ }^{139}$

Dat Verwey er ook verder op toezag dat de maatregel nauwkeurig werd doorgevoerd, blijkt uit de correspondentie die hij voerde met diverse partijen over de praktische uitvoering ervan. Zo verstuurde hij op 26 maart een brief aan de Bond van Ziekenfondsen, dat deze ervoor moest zorgen dat alle nietJoodse ziekenfondsleden die stonden ingeschreven bij Joodse artsen, tandartsen en apothekers, nog voor I mei 194I naar niet-Joodse artsen, tandartsen en apothekers werden overgeschreven. Een van deze ziekenfondsen, coöperatie De Volharding te Den Haag, dat een eigen ziekenhuis had en dat artsen in loondienst had, vroeg hem vervolgens of de bij zijn in dienst zijnde Joodse artsen ontslagen moesten worden, en zo niet, of zij dan in dezelfde gebouwen mochten blijven werken en van dezelfde instrumenten gebruik mochten maken. Verwey antwoordde hierop dat indien de Joodse artsen enkel Joodse patiënten zouden behandelen, zij niet ontslagen behoefden te worden, maar dat het wellicht wel gewenst was afzonderlijke spreekuren of lokalen voor hen in te richten. ${ }^{\mathrm{I}+} \mathrm{Bij}$ de GGD in Den Haag speelde een soortgelijke kwestie. Hier vroeg de directeur zich af of het geoorloofd was in dezelfde wijkgebouwen GGD-spreekuren te houden als waar Joodse artsen poliklinische werkzaamheden verrichtten. Verwey meende dat dat geoorloofd was, mits Joodse en nietJoodse patiënten niet in één wachtkamer hoefden te wachten. ${ }^{\text {I4I }}$

In het geval van de Amsterdamse arts-seksuoloog Coen van Emde Boas had Verwey ook een duidelijke boodschap. Van Emde Boas bedacht halverwege mei dat hij weliswaar zijn praktijk voor niet-Joodse patiënten had neergelegd, maar dat dat wellicht voor zijn seksuologische werkzaamheden niet nodig was geweest. In een brief aan Verwey betoogde hij dat dit werk namelijk meer pedagogisch van aard was dan medisch; hij was een soort huwelijksconsulent. Dit zou hij toch in principe ook voor niet-Joodse echtparen kunnen blijven doen, zo meende Van Emde Boas. Precies hetzelfde verzoek kwam van artsseksuoloog Bernard Premsela. ${ }^{142}$ Verwey liet hun echter in reactie hierop weten dat zij dit dan in geen geval naast hun medische werk (alleen voor Joden) konden doen. 'Zodat u zult moeten kiezen tusschen den werkkring van arts of dien van consulent voor huwelijks- en gezinsmoeilijkheden.' ${ }^{\text {I433 }}$ Zowel Van Emde Boas als Premsela koos ervoor dan toch maar arts te blijven. Alhoewel zij niet meer in alle opzichten volwaardig arts konden zijn zoals zij dat vóór I mei I94I gewend waren geweest. 


\section{PRAKTISCHE, FINANCIËLEEN MORELE GEVOLGEN VAN DE ISOLATIE}

$\mathrm{Nu}$ de scheiding tussen Joodse en niet-Joodse artsen een feit was geworden, was dat niet alleen voor de voorheen zo sterke collegiale banden een ernstige aantasting, maar ook voor het inhoudelijke werk en de taakopvatting van de arts. Hadden de artsen immers niet beloofd iedere hulpbehoevende te helpen, iedere zieke gelijk te behandelen? Dit principe te moeten verlaten was, naast het hun persoonlijk aangedane onrecht, een pregnant gevolg van de uitsluiting. Het ontslag van de ambtenaar-artsen had, vanwege hun relatief geringe aantal en de geldelijke regeling na het ontslag, nog naar verhouding weinig gevolgen gehad. 'Slechts' honderd artsen waren door die maatregel gedupeerd en voor hen bestond een wachtgeldregeling die desastreuze financiële gevolgen nog voorkwam. Nu echter alle Joodse artsen in Nederland door het behandelverbod getroffen waren, werd de situatie totaal anders. De gevolgen waren groot, zowel praktisch, financieel als moreel.

In praktisch opzicht moest veel geregeld worden. Allereerst dienden de patiënten geïnformeerd te worden. Slechts enkele Joodse artsen hadden een dermate grote Joodse praktijk dat hun patiëntenbestand niet noemenswaardig zou veranderen. Dit was eigenlijk alleen het geval voor enkele huisartsen in de Amsterdamse Jodenbuurt, zoals Isaac Dasberg, die een praktijk op de Nieuwe Herengracht bestierde met ongeveer 98 procent Joodse patiënten. ${ }^{\text {I4 }}$ Het tegenovergestelde kwam vaker voor, met name onder Joodse artsen op het platteland. Het voorbeeld van Jacob Hamburger uit Boskoop is treffend in dit opzicht. Maar ook in grotere plaatsen zoals Tilburg bleek het na de maatregel onmogelijk om een normpraktijk - voor een huisarts ongeveer 2500 patiënten - bij elkaar te sprokkelen. De Tilburgse Joodse gemeenschap telde immers twee artsen en slechts 300 zielen. ${ }^{145}$ De Tilburgse huisarts Alfred de Wit kreeg toestemming om op die grond ook in Oisterwijk en Breda patiënten te zoeken. ${ }^{146}$ Niet alleen dorpsartsen zagen hun praktijk in rook opgaan, ook bijvoorbeeld Izaak van Esso, die een bloeiende praktijk had aan de Constantijn Huygensstraat in Amsterdam-West, zag zich genoodzaakt te verhuizen en een nieuwe praktijk te starten in Zuid. Dit was een wijk waar hij meer patiënten zou kunnen krijgen, omdat er meer Joden woonden. ${ }^{147}$ Ondanks het feit dat er daar ongetwijfeld concurrentie was, omdat alle Joodse artsen opeens aangewezen waren op deze doelgroep, lukte het hem om een redelijk patiëntenbestand aan zich te binden. ${ }^{148}$ Voor specialisten was het weer anders dan voor huisartsen. Zij praktiseerden vaak niet alleen in een praktijk aan huis, maar ook in een ziekenhuis. Er waren Joodse ziekenhuizen, waar weliswaar altijd ook veel 
niet-Joodse patiënten opgenomen waren geweest, maar waar in elk geval na I mei I94I geen gebrek was aan Joodse patiënten. Hier konden de specialisten - aanvankelijk - min of meer ongestoord verder werken. Anders was het in de niet-Joodse ziekenhuizen. Henri A.Ph. Hartog, de cardioloog van het St. Elisabeth Gasthuis te Haarlem had in 1940 nog 49 nieuwe patiënten en in I94I slechts twaalf. Hij verdween dan ook in I94I uit het Gasthuis om alleen nog maar aan huis praktijk te houden, enkel voor Joodse patiënten. ${ }^{49}$ Ook voor Betty Levie van het Antoni van Leeuwenhoekziekenhuis brak het moment aan dat zij niet meer kon blijven. Ze vertrok naar de Centraal Israëlietische Ziekenverpleging aan de Jacob Obrechtstraat in Amsterdam-Zuid. ${ }^{\text {I5o }}$

Onder de patiënten waren van oudsher twee groepen te onderscheiden: de particuliere patiënten en de ziekenfondsleden. Veel artsen combineerden een particuliere met een ziekenfondspraktijk. De restrictie dat zij slechts voor Joodse patiënten mochten werken, gold voor beide categorieën. De particuliere patiënten moesten daarbij door de artsen zelf aangeschreven worden, de ziekenfondspatiënten moesten er door hun ziekenfonds op worden gewezen dat zij een andere arts, deelnemer van hetzelfde fonds, moesten kiezen. De

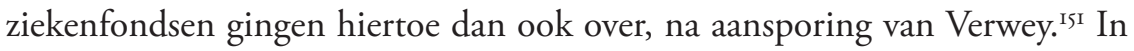
de notulen van diverse bestuursvergaderingen van ziekenfondsen gedurende maart en april I94I is terug te vinden dat men voor dit doel brieven opstelde en rondstuurde. ${ }^{152}$ Van Mozes Franzie, huisarts in Den Haag, is de aankondiging die hijzelf naar zijn patiënten stuurde, bewaard gebleven. ${ }^{153}$ Oscar Cahen uit Dordrecht verspreidde de aankondiging, die tegelijkertijd ook een aanklacht was, 'In Neerland rouwt Israël'. ${ }^{154}$

Net zoals niet altijd duidelijk was geweest wie zou moeten worden aangemerkt als Joods arts, was het ook niet altijd zonneklaar wie als Joods patiënt gold. Verwey ontving diverse vragen hieromtrent. Hij deelde de Joodse artsen mede dat alle patiënten die als vol-Jood geregistreerd stonden, behandeld mochten worden, iedereen die dat niet was, niet. Personen aangemerkt als 'van gemengden bloede' mochten dus niet meer door Joodse artsen behandeld worden. Wanneer een gemengd gehuwd stel patiënt was, mocht alleen de Joodse helft nog behandeld worden en de niet-Joodse helft niet meer. Huisartsen die jarenlang als behandelaars van hele gezinnen hadden opgetreden mochten plotseling nog maar de helft van de familie behandelen. ${ }^{55}$ Als de Joodse artsen zelf een niet-Joodse huwelijkspartner hadden, mochten zij ook voor deze niet meer als behandelaar optreden, en ook niet voor eventuele eigen kinderen. ${ }^{156}$

Ook voor de patiënten moet dit regelmatig een hard gelag zijn geweest. 'De groote Men was verontwaardigd,' noteerde Berthold Stokvis in zijn dagboek. ${ }^{157}$ En men liet ook aan de artsen zelf blijken het niet eens te zijn met 
de maatregel. Zo staan bij verschillende artsenkinderen de grote hoeveelheden bloemen en cadeaus die hun vaders bij deze gelegenheid ten afscheid kregen in hun geheugen gegrift. ${ }^{158}$ Bernard Premsela vond een heel ingenieuze, maar onder normale omstandigheden volstrekt ontoelaatbare manier om een zwangere niet-Joodse patiënte toch nog bij haar bevalling te kunnen bijstaan. De vrouw was begin mei uitgerekend, maar kreeg van Premsela kinine toegediend, dat de bevalling opwekte. $\mathrm{Zij}$ beviel iets eerder dan gepland, eind april, van een gezonde zoon. Nog net onder legale begeleiding van haar vertrouwde eigen Joodse huisdokter. ${ }^{59}$

Niet alle artsen en patiënten legden zich, na I mei 194I, neer bij de maatregel. Zo is overgeleverd dat bijvoorbeeld de Amsterdamse huisarts Herman Hertzberger 's avonds nog wel niet-Joodse patiënten ontving, 'die liever bij hun eigen dokter bleven. ${ }^{160}$ Ook bij Salomon Koster hadden 'tientallen patienten [...], bij het afscheid gesmeekt, hen verder te blijven behandelen'. ${ }^{16}$ Dit klinkt echter makkelijker dan het was. Zodra de Joodse arts immers een recept zou uitschrijven voor de niet-Joodse patiënt, zou ontdekking van de illegale praktijk zeer wel mogelijk zijn. Alleen voor zenuwartsen, die in geval van psychoanalyses en dergelijke toch al geen recepten uitschreven, waren er minder risico's aan verbonden. ${ }^{162}$ Over het algemeen konden de artsen niet anders dan gehoorzamen.

En hoe handelden de Joodse artsen na deze ingrijpende verandering? De een verhuisde naar een andere wijk of stad, de volgende nam onbetaald werk aan. ${ }^{163}$ En weer een ander ging dan maar een cursus voor masseur of opticien volgen. ${ }^{164}$ Ook medische banen zonder patiëntencontact behoorden tot de mogelijkheden. Zo ging Frits Klein, internist in Groningen, zuiver laboratoriumwerk verrichten, en Herman Vos, directeur van het Volkssanatorium te Hellendoorn, werd administrateur van deze instelling, terwijl zijn niet-Joodse vrouw, ook arts, zijn taken als directeur overnam. ${ }^{165}$ Deze laatste keuzes waren niet alleen ingegeven door de behoefte de vrijgekomen tijd op een nuttige manier in te vullen, maar ook en waarschijnlijk voornamelijk om in het levensonderhoud te kunnen blijven voorzien. Zo schreef de burgemeester van Hellendoorn over de gevonden oplossing ten behoeve van Vos en zijn vrouw dat deze gekozen was om hen in de directeurswoning te kunnen laten wonen en om hen 'niet brodeloos te maken'. ${ }^{166}$ Naast de praktische gevolgen waren namelijk ook de financiële gevolgen van de segregatie voelbaar voor alle Joodse artsen wier praktijk voor een substantieel deel uit niet-Joodse patiënten bestond.

De Utrechtse huisarts Jacob Weyel diende in juni 194I een verzoek in bij de NMG tot uitstel van betaling van de contributie, in verband met zijn 'sedert 
I mei jl zeer gewijzigde levensomstandigheden'. ${ }^{167} \mathrm{Had}$ hij in april I94I nog I698 ziekenfondspatiënten, in mei waren het er vijf. Dit patiëntental liep in de daaropvolgende maanden weer iets op, totdat het rond de vijftig bleef hangen. Dit vermoedelijk door een herschikking van patiënten, waardoor een aantal Joodse patiënten van een niet-Joodse arts naar Weyels praktijk verhuisde. Of de ziekenfondsen zelf actief hebben geprobeerd Joodse patiënten te interesseren om over te stappen naar een Joodse arts of dat het een collegiale geste van de niet-Joodse arts was, is niet meer na te gaan. ${ }^{168}$ Omdat het honorarium dat een ziekenfonds uitbetaalde aan een deelnemer-arts gekoppeld was aan het aantal ziekenfondsleden (patiënten) dat op zijn naam ingeschreven stond, daalde Weyels inkomen even drastisch als zijn patiëntental. Was zijn ziekenfondshonorarium over het jaar I940 nog $f$ 6869,95, in I94I verdiende hij in totaal $f$ 3990,66. Dezelfde financiële ontwikkeling is zichtbaar bij collega Aron Ossendrijver, eveneens deelnemer aan Ziekenzorg, die net als Weyel een enorme inkrimping van zijn ziekenfondspraktijk moest aanzien. ${ }^{169}$

Wat betreft een geldelijke vergoeding van de overnemende niet-Joodse arts aan de getroffen Joodse collega, is bekend dat deze uit collegiaal oogpunt inderdaad gegeven zou moeten worden. Geneeskundig hoofdinspecteur Banning liet de NMG in april I94I weten dat de niet-Joodse praktijken van Joodse artsen 'op de gebruikelijke condities' mochten worden overgedragen aan nietJoodse collegae. ${ }^{170}$ Die gebruikelijke condities waren volgens de gids Medische ethiek en het vestigingsbureau van de NMG in de late jaren dertig: het gemiddelde jaarinkomen berekend over de laatste drie jaren plus de waarde van het huis. Dit bij elkaar opgeteld was de som geld die de overnemende arts diende te betalen. ${ }^{171} \mathrm{Nu}$ ging het in de onvoorziene situatie van I94I natuurlijk over het algemeen slechts om een deel van de praktijk dat diende te worden overgedragen. Bovendien bleven Joodse artsen veelal in hun huis wonen om daar in hun eigen praktijkruimte en met hun eigen instrumentarium te blijven praktiseren voor het overgebleven Joodse deel van de praktijk. Voor een dergelijke gedeeltelijke overname was geen precedent en dus kon erover onderhandeld worden. Aan deze onderhandelingen hield niet iedereen even prettige herinneringen over. Sommige - net beginnende - niet-Joodse artsen zullen het als een buitenkansje gezien hebben dat hun, in een tijd van artsenoverschot, op deze manier een praktijk in de schoot geworpen werd. ${ }^{172}$ Het bleek dat van de 580 artsen die tussen I januari 1939 en I oktober 1940 waren afgestudeerd er op 30 oktober 1940 nog II4 waren die geen werk hadden gevonden. ${ }^{173}$ Deze werkloze artsen zullen het vrijkomen van de praktijken van de Joodse artsen niet louter onaangenaam gevonden hebben. Elie Cohen herinnerde zich dan ook: 'Als gieren op het aas kwamen ze op die praktijk af. De Ariërs. Ze wilden alle- 
maal die praktijk wel overnemen.' ${ }^{174}$ Uiteindelijk vond Cohen een fatsoenlijke collega die de praktijk voor hem waarnam, met de intentie die na de oorlog weer terug te geven. ${ }^{175}$ Van een dergelijke, behulpzame houding van de nietJoodse overnemende arts, zijn meerdere getuigenissen. ${ }^{176}$ De Heerenveense chirurg Max Roeper en zijn vrouw raakten zelfs goed bevriend met de collega, Van der Veen uit Den Helder, die de niet-Joodse praktijk overnam. ${ }^{177}$ En Berthold Stokvis schreef: 'men was vast besloten Joodsche collegae te helpen en dit geschiedde dan ook in dien zin, dat practijken formeel aan zg arische collegae werden verkocht (practisch: tijdelijk overgedaan), waardoor de Joodsche artsen een deel van hun inkomen behielden.' ${ }^{178}$ Collega Ruben Bollegraaf uit Oss zag naast een sympathieke houding van de niet-Joodse collegae echter ook al een mogelijk probleem voor de toekomst:

Er werden pogingen gedaan, de inkomsten voor de Joodse artsen te behouden door de gelden, binnenkomende van hun vroegere patiënten, aan hen af te dragen. Ook gaven sommige niet-Joodse artsen ondertekende blanco receptenpapiertjes aan hun Joodse collegae. Wanneer na jaren de Joodse artsen, advocaten, enz, weer op hun oude plaats terugkomen, hoe zullen ze dan worden ontvangen? ${ }^{\text {I79 }}$

Zover was het nog niet, eerst moest er bepaald worden hoe nú gehandeld diende te worden. De NMG gaf aan dat er een bedrag moest worden vastgesteld, dat vervolgens in termijnen zou worden uitbetaald. Op die manier zou een verdenking op door de Duitsers verboden 'Gewinnbeteiligung' van de overname ontlopen worden. ${ }^{\mathrm{I} 80}$ De bezetter had namelijk middels een annonce in het $N T v G$ laten weten dat overnamecontracten waarin winstuitkering aan de Joodse arts opgenomen was, bestraft zouden worden. Zowel tegen de Joodse als tegen de niet-Joodse partij zou daarbij opgetreden worden. ${ }^{\text {I8I }}$ In juni werd in het $N T v G$ zelfs melding gemaakt van de Duitse afkeuring van enige geldelijke tegemoetkoming voor een praktijk, zoals dat voor de Nederlandse artsen gebruikelijk was. Er mocht van de Duitsers enkel voor instrumenten en dergelijke betaald worden, niet voor 'het vertrouwen van de patiënten'. ${ }^{182}$ Men diende dus voorzichtig te handelen.

In het geval van de Middelburgse huisarts Louis Weijl werd de praktijk verdeeld over zeven niet-Joodse artsen, die samen $f$ I5 000 aan Weijl betaalden. ${ }^{183}$ Op het bewaard gebleven overnamecontract van de Amsterdamse huisarts Willem de Torres blijkt dat zijn niet-Joodse opvolger eveneens $f$ I 5 ooo voor de praktijk betaalde, in vijf jaarlijkse termijnen van $f 3000$ uit te keren. Overigens werd al de eerste termijn, op I mei I942, niet aan De Torres, maar aan de (roof-) 
bank Lippmann, Rosenthal \& Co in Amsterdam uitgekeerd. ${ }^{184}$ De in I94I net opgerichte medische afdeling van de Joodsche Raad gaf een voorbeeld van hoe een overnameconstructie eruit kon zien en welke bedragen ermee gemoeid zouden kunnen zijn. Vast stond dat het bedrag van tevoren afgesproken moest worden, onafhankelijk van de latere opbrengst van de praktijk. Als voorbeeld voor het bruto inkomen van een arts in het jaar I940 werd uitgegaan van $f$ IO 500 samengesteld uit $f$ Iooo uit vermogen, $f$ 9000 uit praktijk en $f$ 500 uit verschillende werkzaamheden, zoals tijdschriftartikelen en dergelijke. (Overigens werd hier vermoedelijk uitgegaan van een redelijk lucratieve stadspraktijk; voor een plattelandspraktijk werd het jaarinkomen op ongeveer $f 7000$ bruto geschat. ${ }^{185}$ Als nu in 194I het jaarinkomen als volgt was samengesteld: $f 600$ uit vermogen, $f 4600$ uit de praktijk, $f 200$ uit tijdschriftartikelen en dergelijke plus de overnamesom van de niet-Joodse praktijk ter hoogte van bijvoorbeeld $f$ Io ooo, dan oversteeg het totale inkomen over I94I dat van I940. Immers, het totaal over I940 was $f$ IO 500 en dat over I94I $f$ I5 400. ${ }^{\text {I86 }}$ Als deze 'winst', kennelijk door de medische afdeling van de Joodsche Raad als representatief voorgesteld, in termijnen werd uitbetaald en via een constructie niet geheel voor de inkomstenbelasting werd opgegeven, maar afzonderlijk belast werd, dan kon de arts er dus even mee vooruit. De betaling in termijnen was echter minder dan wat men met de eigenlijke praktijk had verdiend. Voor een weer volledig inkomen zou men of op zoek moeten naar meer Joodse patiënten of niet-medische werkzaamheden moeten uitvoeren. Elie Cohen bijvoorbeeld vestigde zich in de stad Groningen, waar nu verhoudingsgewijs te veel Joodse artsen waren op de niet zo heel grote Joodse gemeenschap, en ging voor extra inkomsten medische instrumenten en steunzolen maken. ${ }^{187}$ De Emmense huisarts en voormalig gemeentearts Marcus Samson was praktisch brodeloos geraakt en vestigde zich om een grotere Joodse praktijk te kunnen opbouwen in Assen. Hij moest hier echter vaststellen dat de uitgaven voor die vestiging de inkomsten verre overtroffen. Een poging om zijn wachtgeld van de gemeente Emmen verhoogd te krijgen liep eveneens op een mislukking uit. ${ }^{\text {I8 }}$ Financieel waren de Joodse artsen veelal aangetast en ook dit benadrukte, naast de praktische segregatie, hun afstand tot de rest van de artsenstand.

Deze afstand had ook gevolgen voor het moreel van de Joodse artsen en voor hun beroepsmoraal. 'Van arts tot ziekenverzorger', zo noemde Berthold Stokvis de transformatie die de Joodse artsen na I mei I94I hadden ondergaan. ${ }^{189}$ En de situatie was ook letterlijk zo. Voor Joodse patiënten waren de artsen dan nog wel echt arts, voor niet-Joodse patiënten officieel niet, zelfs niet als dezen in spoedeisende gevallen een Joods arts troffen. Meerdere artsen stuurden Verwey vragen hoe zij dienden te handelen in dergelijke situaties, bij 
ongelukken of bewusteloze patiënten. Als voorbeeld een briefje van huisarts Meijer Hertzberger uit Amsterdam-Zuid: 'Naar aanleiding hiervan verzoek ik u beleefd mij voor I mei a.s. te willen mededelen, hoe ik moet handelen bij een eventueel ongeval op straat, indien ik niet weet of het slachtoffer een Jood is, ja of neen. Tevens zou ik gaarne willen weten, hoe ik moet handelen als ik met spoed word ontboden bij een niet-Jood, waarbij hulp dringend gewenscht is. ' ${ }^{\prime} 90$

Het antwoord was even simpel als ontstellend: de Joodse arts mocht in een dergelijk geval weliswaar eerste hulp verlenen, maar alleen op een manier die ook een niet-arts, bijvoorbeeld een ervaren verpleegster of Енво'er, kon hanteren. Zuiver medische handelingen mocht men niet verrichten, daarvoor moest men een 'bevoegd' (lees: niet-Joods) arts ter plekke bestellen. Sterker indruisend tegen de medische beroepsethiek kon bijna niet, waardoor deze maatregel de Joodse artsen voor extreem moeilijke situaties stelde. Stokvis verhaalde ervan:

Zonderlinge complicaties doen zich voor, wanneer er op straat een ongeval plaatsvindt en men als geneesheer niet mag helpen. Een mij goed bekend collega, die op straat een ernstige patiënt een injectie had gegeven, kreeg eenige dagen later de SiPo [Sicherheitspolizei, de Duitse politieke politie] bij zich. Ik zag een ongeval, waarbij door iemand op verkeerde wijze eerste hulp werd verleend. Zich ermede bemoeien betekent de grootste moeilijkheden krijgen. Ik kon het echter niet aanzien, hoe met dezen patiënt op straat werd omgegaan; het was een epilepticus, wiens schokken door twee sterke mannen werd belemmerd. Dus wendde ik mij tot een agent, die erbij stond en zeide hem, dat ik hem raadde de beide mannen van den patiënt te verwijderen. Naar den zieke zelf mocht ik natuurlijk niet omkijken. Ik zal niet vergeten, hoe ik op bezoek bij een oude collega, door dezen verzocht werd even in de buurt te gaan kijken, daar er net was opgebeld, dat er een ernstige patiënt was. Het betrof een vrouw die hevige koliekpijnen had. Zij was echter geen Jodin. Ik belde den geneeskundigen dienst op, om te vragen of ik een injectie zou geven, daar er - het was midden op de dag - geen collega uit de buurt was te krijgen. Men raadde mij dit met klem af. Ik laat het lezer dezes te raden, wat ik in dit geval gedaan heb. ${ }^{\text {I9I }}$

Ongetwijfeld hebben vele artsen zich in soortgelijke omstandigheden ook niet in kunnen houden. Betty Levie bijvoorbeeld was bekend handig in het aanleggen van intraveneuze anesthesie-infusen. $\mathrm{Zij}$ mocht weliswaar in het Antoni 
van Leeuwenhoekziekenhuis geen niet-Joodse patiënten meer behandelen, maar werd er nog meer dan eens bij geroepen, op het moment dat de patiënt toch al onder zeil was, om haar expertise in te zetten. ${ }^{192}$ De Zandvoortse huisarts Max B. Bloch schreef in een brief aan Banning dat hij zich niet kon voorstellen in een geval van verdrinking, in een kustplaats een veelvoorkomend geval, niet te mogen handelen. ${ }^{193} \mathrm{Al}$ dit handelen zou immers, zijnde in het belang van de patiënt, geheel en al beantwoorden aan de taakopvatting van de arts. Zo had men het geleerd en geïnternaliseerd. De reflex om deze taakopvatting, de medische plicht ten opzichte van een zieke of hulpbehoevende, na te leven, moet soms niet te onderdrukken geweest zijn. Een anekdote waarbij juist het omgekeerde het geval was, komt van oogarts Fritz Fischer. Een 'foute' politieman kwam regelmatig bij hem en zijn gezin over de vloer, bij wijze van intimidatie, en werd dan zoet gehouden met goede sigaren. Bij een dergelijke gelegenheid verwondde de agent zich aan zijn vinger. Hij verwachtte van Fischer dat deze hem zou helpen. Fischer echter kon - met een triomfantelijk gevoel - zeggen dat het hem, gezien de opgelegde verordeningen waarvoor de politieman zoveel sympathie koesterde, verboden was om hem te helpen. ${ }^{194}$

Dat de maatregel een dergelijke triomf mogelijk makte was een kleine pleister op de wonde, die voor de artsen in het algemeen behoorlijk schrijnde. Opkomende opstandigheid ertegen moest echter uit veiligheidsoverwegingen onderdrukt worden, zo voelde althans Salomon Koster het. Hij verwachtte bij ontdekking van het behandelen van niet-Joodse patiënten het volgende:

Dan word ik gevangen genomen en zal wel, of den kogel krijgen, of naar een concentratiekamp gaan, in elk geval zal ik dan nooit meer terugkomen, om mijn praktijk te doen, terwijl, als ik mij nu strict aan de voorschriften van de Duitschers houd, ik waarschijnlijk, als de Duitschers weer weg zijn, de gelegenheid krijg, mij weer voor de menschen nuttig te maken. Ik heb mijn eigen moraal en laat mij in de hoogste zedelijke kwesties, niets door de Duitschers voorschrijven, maar ik heb mijn vrouw moeten beloven, het niet te doen. En zij heeft vaak een praktischer kijk op de dingen, dan ik. Zij zegt, dat zoiets onmogelijk geheim kan blijven. ${ }^{195}$

De razzia's in februari I94I hadden een diepe indruk gemaakt. Gehoorzamen uit veiligheidsbelang was dus geboden. De Amstelveense huisarts Jacob Ailjon schreef in het verlengde daarvan letterlijk dat hij de I mei-maatregel zou gehoorzamen, omdat hij zichzelf zag als 'goed Nederlander, die het belang van zijn volk ziet om niet in strijd te handelen met de verordeningen van den bezetter'. ${ }^{196}$ En dus had ook Ailjon, net als zijn Joodse collegae, geen andere 
keus dan genoegen te nemen met deze segregatie en degradatie. Vanuit de artsenstand waren zij verbannen naar een tweederangs niveau. Zowel praktisch, financieel als moreel. De Joodse artsen zelf zullen zich geamputeerd hebben gevoeld. Het mes sneed echter aan twee kanten: ook het niet-Joodse deel van de Nederlandse artsen was aangedaan. Hoe was hun reactie?

\section{GEBREK AAN DAADKRACHT BIJ HET MEDISCH ESTABLISHMENT}

Van de artsen die Joodse praktijken overnamen, zijn verschillende indrukken achtergebleven: van 'aasgieren' tot collegiale opstellingen, de bandbreedte van individuele reacties was aanzienlijk. Iets vergelijkbaars was zichtbaar in de kring van advocaten, waar zich grotendeels hetzelfde proces voltrok. ${ }^{197}$ Maar hoe was de reactie bij de vertegenwoordigers van de artsenstand? Bij het medisch establishment?

Zeker 90 procent van de Nederlandse artsen was verenigd in de beroepsvereniging Nederlandsche Maatschappij ter bevordering der Geneeskunst. Het bestuur van de NMG was, net als de Nederlandsche Advocaten Vereniging, geschokt, maar had tegelijkertijd moeite om een juiste houding te bepalen. Zij stonden tussen de praktiserend artsen, die de maatregelen hadden te slikken, en de ambtenarij, die de verordeningen uitvoerde, in.

Van secretaris-generaal Verwey bleek reeds uit eerder geciteerde correspondentie dat hij de afdeling Volksgezondheid van het Departement van Sociale Zaken op secure wijze bestuurde. Zoals voor de andere secretarissen-generaal ook gold: hij voerde de opdrachten van de bezetter uit. Verwey was geen arts en er zijn geen aanwijzingen dat hij specifieke belangstelling voor het lot van de artsen had. Die koesterde hij wel voor de bestrijding van de werkloosheid. ${ }^{198}$ Onder artsen was de werkloosheid in het begin van de oorlog aanzienlijk. Met de uitschakeling van de Joodse artsen kwamen er voor pas afgestudeerde artsen in elk geval praktijken en overheidsfuncties vrij. Cees Banning, geneeskundig hoofdinspecteur, maakte wel degelijk zelf ook deel uit van de artsenstand. Hij was collega en gedroeg zich ook zo. Zijn brieven begonnen vaak met 'Amice' als hij een medicus in den lande aanschreef. Uit zijn correspondentie blijkt dat hij met enkele Joodse artsen vriendschappelijke banden onderhield. ${ }^{199} \mathrm{Hij}$ stelde zich echter niet erg daadkrachtig op in het geval van de uitsluiting van de Joodse collegae. Toen de NMG hem om advies vroeg ten behoeve van een beoogde protestbrief aan de Rijkscommissaris naar aanleiding van de uitsluiting van de Joodse artsen, reageerde hij als volgt: 'Het is logisch, dat men zijn 
gemoed wel eens lucht wil geven, maar ik zou de Maatschappij dringend willen raden, zich van eenige actie, hoe dan ook, te onthouden. Ik meen dat ik dit advies moet geven, ter wille van alle niet-Joodsche artsen en zeker ook ter wille van onze Maatschappij, die natuurlijk in dit stadium wel uitermate voorzichtig moet zijn.' ${ }^{200}$

De vrees voor het voortbestaan van de NMG bleek enkele maanden later inderdaad zeer gegrond te zijn, maar toch had een vorm van principieel verzet gepast bij de moreel hoogstaande houding die de artsen zichzelf van oudsher toedichtten. Kennelijk had bij enkele leden van het bestuur direct na de bekendmaking van het ophanden zijnde beroepsverbod inderdaad de behoefte bestaan in elk geval iets van protest te laten horen, ook al zou het niets aan de situatie kunnen veranderen. 'Succes zal het absoluut niet hebben, maar het is meer om het gemoed lucht te geven.' Ze hadden zich weliswaar voorgenomen een 'zeer gematigd gesteld stuk' te sturen, maar daarin toch te vermelden 'dat bij de Nederlandsche artsen nooit eenige neiging heeft bestaan tot een dergelijke discriminatie, dat ook volgens de rechtspraak zij niet meer dan andere artsen fouten begaan en dat ook onder hen hoogst bekwame geneesheren voorkomen'. ${ }^{201}$ Het on recht werd gevoeld en intern besproken, maar men trad er uiteindelijk niet mee naar buiten. Zelfs een aansporing om te protesteren, gegeven door de Geneeskundige Kring in Amsterdam, bracht het hoofdbestuur niet tot daden in die richting. ${ }^{202}$ De angst voor verstrekkende gevolgen weerhield het hier waarschijnlijk van. Aanleiding om bevreesd te zijn was er namelijk.

Een paar weken eerder had F.A. Schalij, de voorzitter van de NMG, een bespreking gehad met Obermedizinalrat F. Reuter. Deze had plaatsgevonden op 2 februari, toen dus nog net niet in bredere kring bekend was gemaakt wat de Joodse artsen te wachten stond. Schalij werd op de hoogte gebracht van het voornemen de circulaires met bijgevoegde invulformulieren over Joodse afstamming binnen enkele dagen op te sturen. Hij vroeg wat er zou gebeuren als bijvoorbeeld 3000 artsen het formulier niet zouden invullen. Reuter antwoordde dat zij dan op alle mogelijke manieren geprest zouden worden dit alsnog te doen. Indien ze zouden persisteren in hun weigering, zouden allen als Joden worden behandeld. ${ }^{203}$ Wat een dergelijke behandeling precies in zou houden, wist men natuurlijk niet, maar dit dreigement maakte principieel protest voor de NMG bij voorbaat een hachelijke onderneming. Dat principiële protest vanuit de NMG kwam er dan ook niet. 'Deze Maatschappij voor Geneeskunst heeft mij - ik weet niets over anderen - volledig in de steek gelaten.' ${ }^{204}$ Zo herinnerde Elie Cohen zich dan ook de opstelling van de NMG. 
Wel zorgde de Maatschappij voor steun in individuele gevallen, zoals kwijtschelding van contributiegelden bij te weinig inkomsten, zoals al eerder vermeld. Ook bijvoorbeeld Herman Pinkhof, tot op hoge leeftijd zeer actief voor de Maatschappij, bleef door de NMG financieel gesteund worden, zij het met 85 procent van zijn kleine pensioentje. ${ }^{205}$ Ook E.M. Meyers, die jarenlang als juridisch adviseur aan de NMG verbonden was geweest en nu vanwege het verwijderen van Joden uit ereambten ontslagen was, kreeg een kleine tegemoetkoming. ${ }^{206}$ Hoe men over het ontslag van deze beide voor de NMG belangrijke figuren dacht, werd niet in de notulen vastgelegd. Als laatste zin in dit verband werd genotuleerd: 'Vervolgens doet spreker eenige mededelingen, welke niet in de notulen worden vermeld.' ${ }^{207}$ Wellicht werden de gesproken woorden ingeschat als te gevaarlijk voor het papier. Overigens werden op dat moment nog 'slechts' de Joden in ereambten verwijderd, de gewone leden mochten voorlopig lid blijven. Al bleek dat lidmaatschap toch nog maar van korte duur te zijn. In de maanden die volgden op de uitsluiting van de Joodse artsen voerden de Duitsers de nazificering van de artsenstand door. Hierop zou wél grootschalig verzet volgen.

\section{'EEN POGING TOT KNECHTING EN ONTEERING VAN DEN NEDERLANDSCHEN ARTSENSTAND'}

Dat de NMG door de bezettingstoestand van Nederland in zijn bestaan bedreigd werd, was al in de laatste maanden van 1940 bij het bestuur bekend geworden. Zoals op alle maatschappelijke terreinen, streefde de bezetter ook op medisch gebied naar gelijkschakeling. Dit hield in dat alle artsen lid zouden moeten worden van een op nationaalsocialistische leest geschoeide Artsenkamer zoals die in Duitsland al bestond, en dat de NMG daarin zou worden opgeslokt als onderafdeling. De ziekenfondsen zouden eveneens in deze overkoepelende organisatie worden opgenomen, onder de afdeling Nederlandsche Vereniging voor Ziekenfondsartsen, kortweg NVvZA. Al in geheime notulen van november 1940 werd uitdrukking gegeven aan de vrees dat als dit inderdaad doorgang zou vinden, de NMG geen vrij lichaam meer zou zijn, maar een staatsorgaan. ${ }^{208}$ Als de nationaalsocialisten inderdaad de ziekenfondsen in beheer zouden hebben, zouden de artsen om financiële redenen wel gedwongen zijn zich bij dit staatsorgaan aan te sluiten. $\mathrm{Al}$ in december 1940 een afschrikwekkende, maar realistische voorspelling. Nog eerder, reeds in september 1940, was dit idee van Duitse zijde al eens aan het hoofdbestuur van de NMG voorgelegd, waarbij door de Maatschappij nog expliciet gevraagd werd of de Joodse artsen zich er 
ook bij konden aansluiten. En jawel: 'geen onderscheid wordt gemaakt naar ras en geloof, zoodat ook Joodsche artsen gewoon kunnen meedoen'. ${ }^{209}$ En hoewel in de loop van de bezetting bleek dat aan een Duitse belofte niet al te veel waarde diende te worden toegekend, in dit geval bleek het niet helemaal onwaar: Joodse artsen zouden inderdaad lid mogen worden van de Artsenkamer.

Dat deze Artsenkamer er zou komen, bleek vanaf halverwege i94I onafwendbaar. Het NMG-hoofdbestuur moest vanaf I8 mei slikken dat een vertegenwoordiger van het Medisch Front, G.A. Schalij, niet te verwarren met de oorspronkelijke voorzitter F.A. Schalij, bij alle vergaderingen aanwezig zou zijn. Bij weigering hiervan zou een 'Verwalter' aangesteld worden en werd het bestuur alle zeggenschap uit handen genomen. De aanwezigheid van G.A. Schalij werd dan ook als minste van twee kwaden aanvaard. In het Maatschappijweekblad $N T v G$ van I4 juni werden de leden van deze gang van zaken op de hoogte gesteld. Hierbij publiceerde men een lijst van twaalf door G.A. Schalij en zijn achterban nagestreefde doelen ter hervorming van de Nederlandse artsenstand. De punten 9, Io en II van deze lijst waren achtereenvolgens: 9. Ausschaltung jüdischer Ärzte. Io. Entfernung jüdischer Mitglieder aus allen ärztlichen Standesvereinigungen und Standesorganisationen. II. Uberleitung von Praxis und Praxiswerten von jüdischen an nicht-jüdischen Ärzte.

In de bestuursvergadering van de NMG werd tegen deze punten geprotesteerd, en gezegd dat punten 9 en Io reglementair niet te realiseren waren. Punt II was volgens het bestuur al een afgedane zaak, maar G.A. Schalij vertrouwde er niet op dat de doelstelling van de bezetter, namelijk volledige overdracht verwezenlijkt was. Hij meende dat ermee gesjoemeld was en dat er vaak vanuitgegaan werd dat de overdracht van tijdelijke aard zou zijn. Het bestuur probeerde hem op andere gedachten te brengen, maar G.A. Schalij hield de tekst zoals hij was. Dr. I. Wessel bedong nog op het laatste moment dat gepubliceerd zou worden dat punten $9 \mathrm{t} / \mathrm{m}$ II de NMG 'opgelegd' waren. ${ }^{210}$ Opgelegd of niet, de NMG had zijn geloofwaardigheid verloren. Ook de andere punten uit de lijst van G.A. Schalij waren de Nederlandse artsen zeer onwelgevoeglijk. Daar werd de oprichting van de beoogde Artsenkamer genoemd en de plicht om bijscholingen in Duitsland te volgen. Men koesterde vrijwel collectief grote weerzin tegen de invoering van de Duitse geneeskunde in Nederland. Bovendien was men gekrenkt door de laatste zin die in de mededeling was opgenomen: 'Kritiek op de getroffen maatregelen is niet toegestaan.' ${ }^{21 I}$ Een storm van kritiek was juist daarom het gevolg. Een ongedateerde oproep aan de NMG-leden die hiervan treffend blijk geeft, is hierna geciteerd: 
Aan de leden der NMG. Door de Duitsche overheid wordt in het hoofdbestuur der NMG een Nederlander geplaatst, die tot taak heeft aan het hoofdbestuur opdrachten der Duitschers ter uitvoering voor te leggen. Welke opdrachten dit zullen zijn behoeft men niet te vragen! Het eenige waardige antwoord op deze poging tot knechting en onteering van den Nederlandschen artsenstand is: MASSAAL UITTREDEN DER ARTSEN UIT DE ALDUS VERBASTERDE MAATSCHAPPIJ. Maar direct! Het is 'BIJNA TE LAAT”! Het bezwaar dat men aan ziekenfondsen niet zou kunnen blijven werken, zal niet bestaan als allen meedoen, aangezien geen vervangers beschikbaar zullen zijn. Zij, die meenen, dat het beter is te schipperen om de Maatschappij in stand te houden, mogen het volgende bedenken: INDIEN HET DUITSCHE BEWIND BLIJFT VALT MET SCHIPPEREN NIETS TE BEREIKEN. INDIEN HET NIET BLIJFT, IS HET GEEN BEZWAAR, DAT DE MAATSCHAPPIJ TIJDELIJK BUITEN WERKING IS! ${ }^{\text {I2 }}$

De NMG liep leeg en het artsenverzet was geboren. In plaats van de NMG, die nog maar tot 27 september I94I bleef bestaan - op deze dag traden ook de bestuursleden terug -, werd nu het artsenverzet, Medisch Contact gedoopt, hét verbindend orgaan van de Nederlandse artsen. Die verbinding was uitstekend georganiseerd. Een landelijk 'centrum' van enkele voortrekkers coördineerde de acties en via estafetteberichten gaf men plannen en oproepen door. Eerst aan de 'districten', de provincie-afdelingen, waaronder vervolgens de afzonderlijke 'groepen' ressorteerden. Deze groepen bestonden uit de afgetreden leden van de voormalige plaatselijke Maatschappij-afdelingen. Zowel de groepen als de districten kenden voormannen die de berichten doorspeelden. Op deze wijze was het mogelijk elkaar snel en massaal op de hoogte te stellen en vrijwel collectief actie te voeren. Met als gevolg dat de oproep die F.A. Schalij in oktober 1940 voor de NMG had bedoeld, nu van toepassing werd op het Medisch Contact: 'Laten we toch vooral zien dat wat ons vereenigt, want juist door die vereeniging kunnen we wat bereiken, wat ons bij schisma niet zal gelukken.'213

Inderdaad, de collectiviteit was de grote kracht van het artsenverzet: doordat bijna iedereen meedeed, was het voor de Duitsers onmogelijk 'de schuldigen' van een actie te arresteren. Zo ondertekenden 426I artsen de eerste protestbrief, op 5 december I94I aangeboden aan Seyß-Inquart. ${ }^{214}$ Arrestatie van 426I artsen was allereerst praktisch niet haalbaar, maar zou daarnaast ook een ramp voor de volksgezondheid betekenen en de Duitsers onder de Nederlandse bevolking bepaald niet geliefder maken. Daartoe zou de bezetter dus niet zo snel overgaan. Niettemin was een dergelijke actie natuurlijk niet zonder risico, maar de breed gevoelde eensgezindheid zorgde ook voor een gezamen- 
lijk gedragen moed. Deze moed was niet in de laatste plaats ingegeven door de bijzondere positie die de artsen zichzelf al sinds jaar en dag toedichtten. De artsen hadden een stand hoog te houden. In het eerste 'estafettebericht' werd dan ook gesteld: 'Dat wij trouw zullen blijven aan de hooge normen waarop sinds menschenheugenis ons beroep heeft gerust, en dat wij in de uitoefening van ons beroep nimmer andere overwegingen zullen laten gelden, dan zulke, welke gerechtvaardigd zijn door ons geweten, ons plichtsbesef, onze wetenschap. ${ }^{215}$

De onderwerping aan een leider, de dreigende beperking van het beroepsgeheim in het belang van de nationaalsocialistische heilstaat, het in praktijk moeten brengen van ras- en bloedleer: dit alles stond daar haaks op en diende dus bestreden te worden.

De onheuse bejegening van de Joodse collegae was duidelijk niet de directe aanleiding tot het verzet en niet de eerste reden waarom de artsen boos waren, maar droeg daar wel zeker toe bij. De artsen betoogden ook later, in een oproep van maart 1942 aan verschillende instanties naar aanleiding van anti-Joodse maatregelen, dat het verbod voor Joodse artsen om niet-Joodse patiënten te behandelen op volkenrechtelijke basis ongeoorloofd was. ${ }^{216} \mathrm{Bij}$ het Medisch Contact ontwierp men ook een mogelijkheid om Joodse collegae financieel bij te staan. Op de agenda voor de eerste landelijke conferentie, gehouden op I4 september 194I, stond op het programma:

Agendapunt II [...] voor de joodsche collegae wordt landelijk een steunregeling getroffen, waarvan de kosten naar billijkheid worden gedragen.

Agendapunt I2 [...] de groepsvertrouwensmannen geven aan de districtsvertrouwensmannen op, wat in hun groep gedaan is en gedaan moet worden voor de joodsche collegae. ${ }^{217}$

Uit enkele familieverhalen van Joodse artsenfamilies is inderdaad overgeleverd dat er een collega aan de deur kwam om wat geld te brengen. ${ }^{218} \mathrm{Bij}$ veel andere over dit onderwerp geïnterviewden is echter de herinnering aan het Medisch Contact zeer miniem of geheel afwezig. Ook in de gevonden dagboeken en egodocumenten wordt van hulp van het MC niet gerept. Dit zou heel goed het gevolg kunnen zijn van een ander streven van het MC: de Joodse artsen zo min mogelijk gevaar laten lopen. Bij de meeste acties werd Joodse artsen daarom geadviseerd niet mee te doen. Zij ontvingen dus weliswaar estafetteberichten, en een enkele Joodse arts was ook echt actief in de organisatie, ${ }^{219}$ maar in principe werden zij door het MC bewust uit de wind gehouden. Goed beschouwd zaten de Joodse artsen dus in een rare situatie. $\mathrm{Zij}$ werden collegiaal gesteund, 
maar hadden toch een relatieve buitenstaanderspositie. Elie Cohen getuigde hiervan in zijn memoires, waarin hij uiting gaf aan het gevoel ook aan steun van het MC niets ondervonden te hebben: 'Later is dat Medisch Contact gekomen, die schijnen dan wel wat gedaan te hebben, maar dat heb ik niet meer meegemaakt. ${ }^{220}$ Het artsenverzet was te laat georganiseerd om de segregatie tussen Joodse en niet-Joodse collegae tegen te kunnen gaan. De registratie van wie Joods was en wie niet, zowel in medische als in niet-medische kring, was reeds voltooid. $\mathrm{Na}$ de oorlog kon men constateren dat dit een gemiste kans was. In de woorden van J. van Woerden, chirurg en vrouwenarts te Gouda:

Juli 1940: Op deze conferentie kwamen voor sommige Amsterdammers de eerste 'Jodenbriefjes'. Een vriend van mij, Nico de Graaf, adviseerde, nee , bulderde tegen ons, “Teeken nooit iets!” Hij heeft zich er prompt aan gehouden, heeft dan ook jaren in Buchenwald gezeten. Ik teekende, als laatste in het ziekenhuis, toch, natuurlijk onder pressie, met 't ellendige gevoel laf te zijn. Waarom dit verhaal? Eeuwig jammer, dat het $\mathrm{MC}$ toen blijkbaar nog niet voldoende georganiseerd was om door te geven: weiger als één man elk jodenbriefje te tekenen. Eeuwig jammer. 't Is mijn eenige critiek op jullie beleid. ${ }^{221}$ 



\section{GOEDGEKEURD?}

IN ISOLEMENT OP ZOEK NAAR EEN NIEUW MOREEL

KOMPAS, 1941 - JULI 1942

De anti-Joodse maatregelen van de bezetter hadden er in 1940 en 194I voor gezorgd dat de Joodse artsen op afstand waren gezet van de rest van de Nederlandse artsenstand. In praktisch, financieel en moreel opzicht waren zij 'gedegradeerd tot ziekenverzorgers', om met de woorden van Berthold Stokvis te spreken. ${ }^{\mathrm{I}}$ Het artsenberoep was niet meer wat het geweest was. Ook de Joodse gemeenschap in het algemeen raakte in deze periode telkens meer afgezonderd van de algemene Nederlandse samenleving. Dit was het gevolg van bewuste isolatiepolitiek van de bezetter. In dit isolement, afgesneden van hun vroegere collegiale artsengemeenschap en de daarbij behorende mores en normen, én onder toenemend gevaar moesten de Joodse artsen verder werken en leven. Bij telkens nieuwe en precedentloze situaties moesten zij de plichten en voorrechten van het artsenberoep opnieuw uitvinden.

\section{ISOLEMENTEN DE JOODSCHE RAAD}

De periode I94I tot juli 1942 was de tijd van steeds verder opgevoerde discriminatie van het Joodse volksdeel. Niet alleen waren Joden uit overheidsfuncties en beëdigde beroepen verwijderd, ook van markten, beurzen en bioscopen werden zij geweerd. Radio's hadden zij moeten inleveren. Bedrijven en verenigingen met Joodse bestuurders waren 'geariseerd' of opgeheven. De letter 'J' van Jood verscheen in ieders persoonsbewijs. Plantsoenen, zwembaden, 
schouwburgen, cafés, restaurants en stranden werden verboden terrein voor Joden. Joods bezit moest geregistreerd worden bij de (roof)bank Lippmann, Rosenthal \& Co, Joodse kinderen moesten naar aparte scholen, Joden mochten geen lid meer zijn van niet-Joodse verenigingen of clubs. Vanaf voorjaar I942 moesten Joden uit plaatsen in de provincie successievelijk naar Amsterdam verhuizen. ${ }^{2}$ Kortom, een eindeloze reeks beknottingen en vernederingen viel de Joden en dus ook de Joodse artsen ten deel, een reeks die hun isolement telkens scherper maakte, hen steeds verder losweekte van de algemene Nederlandse maatschappij, zozeer zelfs, dat Presser sprak van een 'staat in een staat'. ${ }^{3}$ Aan het hoofd van deze 'staat' stond de Joodsche Raad, hoewel bediscussieerd kan worden in hoeverre dit Joodse bestuur daadwerkelijk enige macht had. Ook de artsen kregen met deze raad te maken.

Op I2 februari 194I had de Beauftragte für Amsterdam, Hans Böhmcker, opdracht gegeven tot oprichting van een Joods vertegenwoordigend orgaan in Nederland dat als 'Befehlsempfänger für die Judenschaft' zou dienen. ${ }^{4}$ In andere bezette landen had het nationaalsocialistisch bewind eveneens dergelijke Joodse organen opgericht en dat systeem was de nazi's goed bevallen. De dood van de WA-man Hendrik Koot, als gevolg van de rellen in de Jodenbuurt in Amsterdam begin februari, vormde voor Böhmcker een welkome aanleiding om in Nederland invoering van hetzelfde systeem te bespoedigen. Hij had dan ook enkele vooraanstaande leden van de Nederlandse Joodse gemeenschap op zijn kantoor ontboden. Om de ernst die het hem was te benadrukken had hij diezelfde dag de Joodse buurt in Amsterdam hermetisch laten afsluiten, zozeer dat zelfs artsen er niet in mochten. 5 Dit paste in het plan waarmee Böhmcker al langer rondliep, namelijk het plan om tot fysieke isolatie van de Joden door middel van daadwerkelijke gettovorming in Amsterdam te komen. Böhmcker wilde de Joden het liefst allemaal concentreren en opsluiten in de buurt rond het Waterlooplein waar van oudsher al veel Joden woonden. ${ }^{6}$ Het leek er echter op dat zijn plan moeilijk te realiseren was. Van bijvoorbeeld de zijde van de GGD was hiertegen in verband met gevaren voor de volksgezondheid geprotesteerd. ${ }^{7}$ Verwezenlijking van een fysiek, ommuurd getto in Amsterdam moest Böhmcker daarom uit zijn hoofd zetten. De onrust op straat had hem echter wel een argument gegeven om te bevelen dat er iets zou gebeuren om de Joden in hun bewegingsvrijheid te beperken. Vandaar zijn eis dat de Joodse gemeenschap zelf de rust in haar gelederen zou doen weerkeren middels een vertegenwoordigend orgaan, een 'Jodenraad'.

Abraham Asscher, diamantair en voorzitter van het Nederlandsch Israëlietisch Kerkgenootschap, had de opdracht gekregen om de te vormen raad voor te zitten. Hij op zijn beurt had de gewezen hoogleraar oude geschiedenis David 
Cohen, een vooraanstaand man in zionistische kringen en in de vluchtelingenopvang tijdens de jaren dertig, bereid gevonden om het voorzitterschap met hem te delen. Deze twee mannen hadden al vaker aan het hoofd gestaan van allerlei hulpacties, en zij beschouwden naar eigen zeggen ook dit voorzitterschap als zodanig. ${ }^{8}$ Een dag na de mededeling van Böhmcker, I3 februari, hadden zij een bijeenkomst belegd met achttien andere vertegenwoordigers van de Joodse gemeenschap in Nederland, onder wie de arts Jacob Arons, om hun te vragen met hen zitting te nemen in de op te richten Joodsche Raad voor Amsterdam, een Raad die, volgens Asscher en Cohen 'in hoofdzaak een uitvoerende en overbrengende taak zal hebben doch geen verantwoordelijkheid kan dragen voor de opdrachten die hij heeft over te brengen en anderzijds niet zo ver kan gaan voor de Joden oneervolle opdrachten te aanvaarden.' ${ }^{9}$ Hoe men ook over deze voorwaarde had gedacht, de Joodsche Raad was er gekomen. Aanvankelijk als 'Befehlsempfänger' voor de Amsterdamse 'Judenschaft', in de loop van het jaar 194I ook voor de Joodse gemeenschappen buiten Amsterdam, waarvoor plaatselijke afdelingen in het leven werden geroepen.

De Joodsche Raad had direct in februari 194I te maken gekregen met de terreur die de bezetter zou gaan kenmerken, ten tijde van de razzia's op straat op jonge Joodse mannen en de daaropvolgende Februaristaking. In juni vond wederom een grootschalige razzia in de Amsterdamse Jodenbuurt plaats. Tezelfdertijd waren al in vele Joodse families doodsberichten binnengekomen van zoons, broers en vaders die na arrestatie tijdens de razzia's in februari naar Buchenwald en vervolgens naar het nóg afschrikwekkender Mauthausen waren afgevoerd. In deze kampen hadden de grotendeels jonge en gezonde mannen het niet langer dan enkele weken tot maanden kunnen uithouden, dusdanig slecht waren de condities waar zij aan blootgesteld werden. In Mauthausen had men hen in een steengroeve tewerkgesteld waar zij urenlang met loodzware rotsblokken op hun nek een steile trap moesten beklimmen. Dit commando was speciaal ontworpen om hen zo snel mogelijk fysiek en mentaal te breken. Stierven zij niet aan de uitputting, dan stortten zij zich wel in wanhoop - soms hand in hand met hun kameraden - van bovenaf in het ravijn van de steengroeve. Op die manier 'werden zij gestorven', zoals Presser een van zijn informanten citeerde. ${ }^{10}$ Onder het mom van 'Auf der Flucht erschossen' en soortgelijke eufemismen rapporteerden de Duitse instanties vervolgens hun overlijden aan de Joodsche Raad. De raad schakelde daarop rabbijnen en in elk geval ook één arts in om de families in kwestie de onheilstijding te brengen. Dit was de jonge huisarts Herman Musaph, die samen met rabbijn Jacob Soetendorp op pad ging voor deze taak. Een onvergetelijk verdrietige ervaring voor Musaph. ${ }^{\text {II }}$ 
In deze sfeer van ontsteltenis die gevolgd werd door verdriet en angst, moest de Joodsche Raad in de loop van I94I verder vorm krijgen. Diverse afdelingen werden opgericht. Wekelijks kwam het nieuwsblad van de Joodsche Raad, Het Joodsche Weekblad, uit. De organisatie en taken van de Joodsche Raad groeiden gestaag. Tegen het bestaan van dit orgaan was echter groeiende, fundamentele kritiek hoorbaar. Men vroeg zich af of de Joden niet beter alle contact met de barbaarse onderdrukker konden vermijden. Iemand die zeer sterk die mening was toegedaan, was Mr. L.E. Visser, de uit zijn functie ontheven president van de Hoge Raad. ${ }^{\text {I2 }}$ Hij voerde binnenskamers een verhitte discussie met David Cohen over de juistheid dan wel onjuistheid van de beslissing de Duitse opdracht tot vorming van de Joodsche Raad te aanvaarden. Visser meende dat de raad enkel een instrument in de handen van de bezetter zou kunnen worden en dat het principieel onjuist was dit instituut in stand te houden. Cohen op zijn beurt echter meende dat hij iets positiefs kon betekenen voor de Joden door tussen hen en de Duitse bezetter in te staan en de werking van de bezetter mogelijk iets af te zwakken. Vissers eigen Joodsche Coördinatie Commissie zou uiteindelijk in oktober 194I opgeheven worden en Visser overleed in februari 1942, maar daarmee was de morele discussie niet voorbij. Tijdens en na de oorlog bleef de rol van de Joodsche Raad betwist. ${ }^{13}$ Bijvoorbeeld, de 'Twentse razzia' in september I94I had volgens sommigen aanleiding voor de twee voorzitters moeten zijn om hun taak neer te leggen en geen verdere medewerking te verlenen. ${ }^{\mathrm{I}} \mathrm{Bij}$ deze razzia waren, net als bij de eerdere razzia's in Amsterdam, ook artsen gearresteerd. Hoezeer de artsen ook geziene en geachte burgers waren geweest, onder de omstandigheid van de razzia's zoals die plaatsvonden in I94I bleken zij, net als de schoenmaker of de marktkoopman, weerloos.

\section{POSITIE EN GEVAAR IN 1941 EN BEGIN 1942}

Ten minste zeventien Joodse artsen werden in de eerste bezettingsjaren, tot juli I942, door de bezetter gearresteerd, gedeporteerd en soms ook al vermoord. In mei I94I kwamen Simon Blitz en Joseph van Straaten bijvoorbeeld in Buchenwald om het leven. ${ }^{15} \mathrm{Zij}$ zijn vermoedelijk bij de razzia's in de Jodenbuurt in februari opgepakt, net als Eddy de Wind, net afgestudeerd Amsterdams arts met aspiraties om psychiater te worden. De Wind ontkwam echter op het nippertje aan een wisse dood, omdat hij bij de medische keuring op de groep jonge mannen werd afgekeurd. ${ }^{16}$ Onder de doden van I94I bevonden zich wel de drie Enschedese artsen Menno Sallo Cohen, Otto Frank en Max van Leeu- 
wen, die tijdens de Twentse razzia in de nacht van I3 op I4 september I94I waren opgepakt. Met zo'n honderd andere Twentse Joodse mannen werden zij naar Mauthausen gedeporteerd, waaruit geen van hen terugkeerde. ${ }^{17}$ Ook voor de Joodse artsen bestond er dus reeds in 194I een reëel gevaar vermoord te worden enkel en alleen om het feit dat zij Jood waren of om reden van een of ander 'vergrijp'.

De Rijssense huisarts Rudolf de Haas bijvoorbeeld werd uit zijn huis gehaald, nadat de NSB-burgemeester van Olst hem had aangegeven vanwege het in huis hebben van een arisch dienstmeisje. ${ }^{18} \mathrm{Zijn}$ Bussumse collega Herman de la Parra werd gearresteerd na verraad van het in veiligheid brengen van huisraad bij niet-Joden. Ook hij zou daarvoor in Mauthausen met zijn leven moeten boeten. ${ }^{19}$ De redenen voor de arrestatie van Emil Starkenstein, befaamd, van oorsprong Duits, farmacoloog, zijn zelfs nooit duidelijk geweest noch opgehelderd. Hij werd in oktober 194I weggehaald uit zijn Amstelveense huis, waarna een gang langs verschillende gevangenissen en concentratiekampen volgde, voor hij in november 1942 eveneens in Mauthausen bezweek. ${ }^{20}$ Nog meer Joodse artsen werden in de eerste periode van de bezetting opgepakt. Bijvoorbeeld, Isidore Zeehandelaar, huisarts aan de Amsterdamse Koninginneweg, was al in september 1940 gearresteerd en naar achtereenvolgens de gevangenissen aan de Amstelveenscheweg en de Weteringschans overgebracht. Hij zou naar Kamp Amersfoort en Auschwitz gedeporteerd worden. ${ }^{21}$ David Slager, huisarts in Eindhoven, werd in gijzeling genomen. De Sipo-SD (Sicherheitspolizei-Sicherheitsdienst) arresteerde hem al op 7 oktober 1940 in Den Bosch. Hij zou de oorlog, na gevangenschap in achtereenvolgens Buchenwald, Haaren, Sint-Michielsgestel, Westerbork, Vught, Auschwitz, Lange Bielow en Reichenbach, weten te overleven. ${ }^{22}$ Ook Salomon Zwaap werd in gijzeling genomen. Samen met 34 andere Hilversumse notabelen werd hij op I februari I94I als represaillegijzelaar opgepakt. Op I2 maart I94I liet men de 35 Hilversummers, onder wie Zwaap, weer vrij. ${ }^{23}$ Later was ook Charles Mendes de Leon, de geariseerde geneesheer-directeur van het katholieke ziekenhuis Calvariënberg te Maastricht, het slachtoffer van gijzeling. Hij belandde in de gijzelaarskampen Haaren en Sint-Michielsgestel. ${ }^{24}$

Getuige diverse arrestatieverhalen waren de Joodse artsen nog niet allemaal doordrongen van hun weerloosheid tegen deze inhumane vijand. Het lijkt erop dat zij uitgingen van een respectvolle bejegening, zoals zij die als arts gewend waren te krijgen. Sommigen waren in elk geval geheel en al handelend in de hun vertrouwde rol van arts de Duitse fuik in gelopen. Volgens de vrouw van Rudolf de Haas was haar man vol goede moed vertrokken, met de opmerking: 'Wat zullen ze mij doen? Ik ben altijd goed geweest voor iedereen. 
Ik doe nooit iemand kwaad. Ik ben ook goed voor mijn patiënten, waarom zullen ze mij wat doen? Nee, dat zit best goed hoor.' ${ }^{25}$ Maar ook hij liet het leven in de steengroeve van Mauthausen. ${ }^{26}$ De weduwe van de Enschedese huisarts Max van Leeuwen herinnerde zich hoe de twee politiemannen die in de beruchte nacht van de Twentse razzia aanbelden, voorwendden voor een spoedeisende patiënt te komen. Van Leeuwen was daarop direct, en zonder verzet, meegegaan. Toen hij niet terugkwam, merkte zijn echtgenote, die evenzeer vol vertrouwen was geweest, pas dat zijn vertrek een andere reden had. Max van Leeuwen zou nog geen maand later, op 7 oktober I94I, omkomen in Mauthausen. ${ }^{27}$ Naar verluidt was zijn collega Otto Frank op de avond van I3 september gewaarschuwd dat er een razzia gaande was. Hij besloot daarop toch op pad te gaan naar een patiënt die hem nodig had. Agenten kwamen echter tegelijkertijd ook naar de patiënt om deze van huis te halen. Otto Frank zou geprotesteerd hebben: 'Deze patiënt kunt u niet meenemen.' Waarop het antwoord was: 'Nou, maar dan nemen we u mee. ${ }^{28}$ Frank werd inderdaad gearresteerd en naar Mauthausen gedeporteerd. Drie maanden later was hij al dood. ${ }^{29}$ Dat de vertrouwde reflex van een zieke te hulp schieten zo'n groot gevaar zou opleveren voor het eigen leven, hadden Van Leeuwen en Frank niet kunnen bevroeden. Zij handelden simpelweg zoals het hun als artsen betaamde: een patiënt had hun nodig en dus gingen zij op pad.

Dat er van het artsenberoep toch ook nog wel enige beschermende werking kon uitgaan, blijkt uit het verhaal van Louis Weijl, arts in Middelburg en plaatselijk contactpersoon van de Joodsche Raad. Begin maart 1942 ontving hij een telefonische mededeling dat de Zeeuwse Joden binnenkort naar Amsterdam zouden moeten verhuizen. Weijl interpreteerde de daarbij gedane waarschuwing dat een en ander vertrouwelijk was op eigen wijze en stelde alle betrokkenen zo snel mogelijk in kennis. Het nieuws van de ophanden zijnde evacuatie verspreidde zich als een lopend vuurtje en al snel was bij de Sicherheitspolizei doorgedrongen dat Weijl zijn mond voorbij had gepraat. Hij werd gearresteerd en gevangengezet in de Middelburgse gevangenis, waar hij jarenlang de behandelend geneesheer was geweest. Hij werd snel weer vrijgelaten om zich weer aan zijn vertegenwoordigend en medisch werk te kunnen zetten. ${ }^{30}$

Ook Jacques Reisel lukte het dankzij zijn beroep om spoedig weer vrij te komen na zijn arrestatie op 4 juni I94I. Hij was uit het Nederlandsch Israëlietisch Ziekenhuis in Amsterdam weggehaald en via het hoofdkantoor van de SiPo-SD aan de Euterpestraat, naar kamp Schoorl gebracht. Dankzij inspanningen van het ziekenhuis en de voorzitter van de Geneeskundige Kring, oogarts F. Wibaut, die pleitte voor zijn onmisbaarheid in het NIZ, kwam hij na tien 
dagen vrij. ${ }^{31}$ Een dag of twee later verdween de rest van de groep jonge Joodse mannen uit Schoorl naar Buchenwald en Mauthausen. Reisel ontkwam dus op het nippertje, en dankte zijn leven aan zijn beroep. Het artsenberoep kon dus nog wel een voorrecht betekenen. De keerzijde was dat juist dat beroep hem ook een schuldgevoel opleverde: had hij niet, omdat hij arts was, mee moeten gaan met zijn makkers?

En ik dus net op tijd ontsnapte aan een vreselijk lot. Dit ging gepaard met een identificatiegevoel met de anderen waar ik in tien dagen toch één gemeenschap mee gevormd had. Toch was het donquichotterie geweest indien ik gebleven was omdat zij mij als arts wellicht hadden kunnen gebruiken. Eventjes voel je je toch wel de verrader van deze gemeenschap die je zo aan z’n lot overlaat. ${ }^{32}$

Het verantwoordelijkheidsgevoel dat Reisel als arts had, had hij niet kunnen waarmaken in deze situatie. Ondanks zijn inschatting dat meegaan naar Mauthausen zinloos was geweest, omdat hij dan zelf binnen de kortste keren ook dood zou zijn en geen medische hulp meer zou kunnen bieden, leverde hem dat gewetensproblemen ten opzichte van zijn medische zorgplicht op.

\section{ALLES ACHTERLATEN}

Gewetensconflicten ten opzichte van de zorgplicht waren ook aan de orde voor artsen die overwogen Nederland te ontvluchten. Enkele artsen besloten dat het in dit stadium van isolement en toenemende terreur beter was de verdere ontwikkelingen niet af te wachten en alles op alles te zetten om het bezette Nederland te ontvluchten. Tot oktober 194I bestond er nog een mogelijkheid als legale emigrant het land te verlaten, daarna was het een illegale, risicovolle onderneming. Met daarbij het besef dat men patiënten en verantwoordelijkheden als arts achter moest laten, betekende dit geen eenvoudige stap. Niet veel artsen gingen er dan ook toe over. Een blik op de cijfers: al in de periode april I940 tot april I94I waren volgens het gedenkboek voor omgekomen Joodse artsen negen Joodse artsen Nederland ontvlucht of op legale wijze geemigreerd. ${ }^{33}$ Aanvullende bronnen laten daar in de gehele periode vanaf de bezetting tot juli 1942 nog eens vijftien namen bijkomen. ${ }^{34}$ Zeker niet meer dan enkele tientallen artsen ontvluchtten Nederland. Vaak ging het om relatief ongebonden medici, zo blijkt.

De Amsterdamse huisarts Salomon Prins zag de directe aanleiding voor 
zijn illegale vertrek in de maatregel van I mei 194I. Dat hij geen niet-Joodse praktijk meer mocht uitvoeren, zou voor hem betekenen dat hij zo goed als geen praktijk meer overhield. Direct na ontvangst van het bericht over deze beperkende maatregel in februari 194I was Prins begonnen met het maken van vluchtplannen, om die vervolgens in november van hetzelfde jaar ten uitvoer te brengen. ${ }^{35}$ Eveneens in november 194I passeerde de Amsterdamse arts Selma Joles de Nederlands-Belgische grens. Een Russische vriend, politiek vluchteling, had haar het voorstel gedaan met hem mee te gaan. Op i4 november legde hij haar het plan voor en op ig november reisden zij al samen per trein naar Bergen op Zoom, om vervolgens aan een passeur voorgesteld te worden. Ze brachten de nacht door bij een Joodse geestelijke om de volgende dag bij Putte de grens over te worden gesmokkeld. Maanden van omzwervingen volgden alvorens Joles bij de Nederlandse regering in ballingschap in Londen aankwam. ${ }^{36}$ Joles had een praktijk aan de Keizersgracht 484, en wat daarmee gebeurde na haar vertrek, is niet geheel duidelijk. Vermoedelijk was echter ook deze praktijk gedecimeerd na de maatregel van I mei I94I, want in juni I94I vroeg zij het ziekenfonds waar ze voor werkte of zij ook praktijk mocht gaan voeren aan de Roerstraat, in de Rivierenbuurt, een buurt waar veel Joden woonden. Dat werd haar niet toegestaan vanwege de te grote afstand tussen haar woning en haar beoogde patiënten. Ook zij zal dan ook niet veel patiënten hebben moeten achterlaten. ${ }^{37}$

Ben Sajet, een bekend huisarts en gemeenteraadslid uit Amsterdam-Oost, hoefde zich geen zorgen te maken over het achterlaten van zijn praktijk toen hij in juni I94I met zijn twee volwassen zoons Jaap, musicus, en Herman, eveneens arts, en vier anderen in een open bootje met buitenboordmotor naar Engeland voer. Zijn praktijk werd waargenomen door zijn niet-Joodse vrouw Thea en was dus in vertrouwde handen. Als door een wonder arriveerde Sajet met de andere opvarenden zelf ook in vertrouwde, Engelse handen, nadat zij een spectaculaire tocht hadden overleefd. Zij hadden genavigeerd doordat Sajet zijn arm had uitgestrekt naar de Poolster en de anderen loodrecht op de richting van Sajets arm hadden gestuurd. Bovendien had de buitenboordmotor het net voor de kust van Engeland begeven. Het bootje had 36 uur stuurloos rondgedobberd. ${ }^{38}$ Op 6 november I94I ontving Sajet wegens de grote moed die hij met deze ontsnapping uit het bezette Nederland had getoond uit naam van Koningin Wilhelmina in Londen het Bronzen Kruis. ${ }^{39}$ Sajet was nu officieel 'Engelandvaarder'. ${ }^{40}$

Zeer waarschijnlijk is dat voor Sajet zijn militaire achtergrond een grote rol speelde in de wens naar Engeland te ontkomen. Veel Engelandvaarders waren immers oud-militairen of aspirant-soldaten die zich bij het geallieerde leger 
wilden aansluiten om een bijdrage aan de bevrijding van het vaderland te kunnen leveren. Dat kon dus ook, naast het toenemende gevaar en de steeds verder opgevoerde beperkingen, de doorslag geven om een vluchtpoging te wagen. Zo getuigde in elk geval ook Sam Ritmeester, een jonge Joodse arts uit Amsterdam, die in maart 1939 was beëdigd als reserve eerste luitenant en daarom het gevoel had te moeten kiezen tussen zijn plichten als arts en zijn plichten als militair: ${ }^{4 \mathrm{I}}$

Mijn eigen inbreng, mijn - ik zou het dubbelleven kunnen noemen arts-zijn en toch moeten (willen) functioneren als officier van gezondheid in een oorlog. Ik probeerde duidelijk te maken hoe ik dat als arts kon opbrengen. Mijn taak van toen was deelnemen aan de bevrijding van ons vaderland. Daar heb ik voor gekozen..$^{22}$

Zijn plichtsgevoel als militair overheerste voor Ritmeester op dit moment zijn plichtsgevoel als arts. Mogelijk maakte het feit dat hij nog geen eigen praktijk had maar waarnam voor de in 1940 gevangengenomen huisarts Zeehandelaar van de Koninginneweg te Amsterdam, het voor Ritmeester minder bezwaarlijk zijn medische taken in Amsterdam te staken en de gevaarlijke reis naar zijn geallieerde strijdmakkers in Engeland te ondernemen. ${ }^{43}$ Hoe het ook zij, Ritmeester vertrok op Io januari 1942 uit Amsterdam en kwam na omzwervingen via België, Frankrijk, Zwitserland, Spanje en Portugal uiteindelijk op 4 januari I944 in Engeland aan.

Ook Alfred (Freddie) de Wit, arts te Tilburg, waagde een poging om naar Engeland te ontkomen. De Wit had vanwege het behandelverbod nauwelijks nog patiënten overgehouden en hoewel hij van Banning toestemming had gekregen zich ook buiten Tilburg te vestigen, had hij praktisch geen werk meer. 'In de praktijk is het uiteraard zeer rustig. Ik tennis veel,' had hij in juni I94I aan zijn zuster geschreven. ${ }^{44}$ De Wit had duidelijk geen vaste patiëntenschare meer die hem van vluchten weerhield. ${ }^{45}$ Bovendien had hij zijn vrouw en dochter in mei I940 al laten vluchten. In december poogde De Wit hen achterna te reizen. Zijn vluchtplan mislukte jammerlijk, en hij moest het als strafgeval met de dood in Auschwitz bekopen. Echter, niet nadat hij vanuit kamp Amersfoort had geïnformeerd wie er nu voor zijn patiënten zorgde. ${ }^{46}$

Frits Glaser was nog een voorbeeld van een relatief ongebonden arts die het aandurfde huis en haard te verlaten. Hij was geboren in I9I6 en afgestudeerd in 1940 en werkzaam als arts-assistent - en dus nog onder supervisie - in het NIZ. Ook Glaser koesterde de wens om zich in Engeland aan te sluiten bij de bevrijders. Samen met vriend en collega Jacob Cohen uit Den Haag had 
hij serieuze plannen gesmeed om met een bootje het Kanaal over te steken. De eerste poging liep echter op een mislukking uit. Hun dubbele kano en vluchtattributen waren in de duinen ontdekt. Vervolgens zag Glaser bij zijn neven Max en Bernard (Benjamin) Meijers dat hun opzet om Engeland rechtstreeks over het water te bereiken hopeloos mislukte. Bernard Meijers, eveneens arts-assistent in het NIZ, en zijn broer Max werden in maart 1942 door verraad tijdens hun vluchtpoging gearresteerd en op is augustus van hetzelfde jaar gefusilleerd. ${ }^{47}$ Medische verklaringen, zelfs van ontoerekeningsvatbaarheid van Bernard Meijers, opgesteld door de bevriende niet-Joodse artsen P. Th. Hugenholtz, H.T. Deelman en M.W. Marsman, Meijers' chef in het NIZ, hadden geen vrijlating kunnen bewerkstelligen..$^{4}$ Jacob Cohen en Frits Glaser gingen uiteindelijk apart van elkaar over land, via Zwitserland, op pad, maar alleen Cohen zou einddoel Engeland bereiken. Glaser beleefde in 1943 in Italië de landing van de geallieerden. ${ }^{49} \mathrm{Hij}$ wilde zich vervolgens met twee anderen bij de oprukkende legers aansluiten, maar tijdens hun pogingen daartoe werd het driemanschap gearresteerd. Omdat zij zich uitgaven voor ontsnapte krijgsgevangen Zuid-Afrikaanse onderofficieren, belandden zij niet in de vernietigingskampen. De twee metgezellen van Glaser ontsnapten vervolgens uit hun Duitse gevangenkamp, maar lieten Glaser op eigen verzoek achter. Juist nu bracht het artsenberoep hem namelijk in een bijzondere positie. Hij had als behandelend arts de verantwoordelijkheid gekregen voor de medische hulpverlening aan zijn medegevangenen en kon die voor zijn gevoel niet naast zich neer leggen..$^{\circ}$

De meeste Joodse artsen in het bezette Nederland van I94I konden ook hun verantwoordelijkheid ten opzichte van hun patiënten niet loslaten, of schatten vluchten in als gevaarlijker dan blijven. Zij zochten in ieder geval naar een manier om voorlopig hun beroep in eigen omgeving zo veel mogelijk op de normale wijze vast te houden. Al veranderde de inhoud van dat beroep onherroepelijk onder de omstandigheden die gingen gelden.

\section{DE MEDISCHE AFDELING VAN DE JOODSCHE RAAD}

In het kader van de opbouw van de organisatie van de Joodsche Raad, of beter gezegd: de afbraak van de mogelijkheden voor Joden om gebruik te maken van algemene voorzieningen, werd de medische afdeling van de Joodsche Raad in het leven geroepen. Ook tot gezondheidszorginstellingen was Joden namelijk de toegang ontzegd. Het lag voor de hand dat Joodse artsen voor deze medische afdeling zouden gaan werken, hetgeen dan ook gebeurde. Dat leek niet 
direct gepaard te gaan met grote problemen in de beroepsuitoefening. Inhoudelijk leek het werk aanvankelijk normaal medisch van aard.

De medische afdeling van de Joodsche Raad zag het levenslicht in december 194I, tien maanden na de oprichting van de Joodsche Raad zelf. Voor die tijd had de Joodsche Coördinatie Commissie van mr. Visser al een Medische Commissie gehad, waar mensen met allerlei vragen van medische aard terecht konden. ${ }^{51}$ In oktober 194I nam deze medische subcommissie van de Coördinatie Commissie het initiatief tot een 'Joodsche artsen cursus', een vakinhoudelijke nascholing, omdat de Joodse artsen aan dergelijke activiteiten buiten Joodse kring niet meer konden deelnemen. Per 22 oktober 194I mochten Joden immers geen lid meer zijn van verenigingen en mochten zij niet meer publiceren in vaktijdschriften. ${ }^{52}$ De Joodse artsencursus was een initiatief dat, zoals dat bij de medische school in het getto van Warschau het geval was, paste bij de poging de normaliteit zo veel mogelijk te bewaren en daarmee het moreel hoog te houden. En dat paste bij de opstelling van Visser in het algemeen. De deelnemers van de cursus moesten hun bijdrage (naar draagkracht) echter opvallend genoeg storten op de rekening van de Joodsche Raad..$^{53}$ De bezetter hief de Coördinatie Commissie namelijk al eind oktober I94I op. Na de opheffing van deze Coördinatie Commissie werd alle verantwoordelijkheid naar de Joodsche Raad overgeheveld. Op 3I oktober 194I maakte men hiervan melding in het Joodsche Weekblad. ${ }^{54}$ Anderhalve maand later maakte datzelfde blad bekend dat er een nieuw gebouw zou worden betrokken door verschillende afdelingen van de Joodsche Raad, waarbij nu ook voor het eerst melding werd gemaakt van een afdeling 'Medisch Sociale Zaken'.5s De Joodsche Raad nam daarmee het streven om op medisch gebied de normaliteit te bewaren op zich. Dat leek aanvankelijk redelijk te lukken.

In de interne nieuwsbrief van het Algemeen Secretariaat van de Joodsche Raad stond op I8 december vermeld wie deze nieuwe afdeling zou gaan voorzitten: Salomon Spijer, arts en voormalig adjunct-directeur van de GGD Amsterdam. Hij zou hoofd van de medische afdeling en medisch adviseur voor de Joodsche Raad worden. Naast de medische afdeling werd er ook een medische commissie in het leven geroepen, met dezelfde Spijer als secretaris en onder voorzitterschap van Alexander Roozendaal, kno-arts. ${ }^{66}$ Ook arts Jacob Arons nam zitting in deze commissie en bracht van het besprokene wekelijks verslag uit in de Joodsche Raad. ${ }^{57}$

De medische afdeling zette zich, naast de organisatie van de Joodse artsencursus, aanvankelijk met name aan taken die de GGD voorheen voor iedereen en dus ook voor de Joodse bevolking had verzorgd. Er was behoefte aan publieke gezondheidszorg. Zo voorzag de medische afdeling van de Joodsche 
Raad in zuigelingenzorg en schoolartsentoezicht voor Joodse kinderen en een armenarts met een wijkzuster voor Joodse zieke armen. Voor de Joodse artsen die voorheen voor de GGD Amsterdam hadden gewerkt, zoals Salomon Spijer, Jonas Jacobs, Icchok Kantorowicz en Elazar Rodrigues Pereira, was de overgang naar dit werk voor de Joodsche Raad inderdaad niet bijzonder groot. ${ }^{8}$ $\mathrm{Zij}$ konden min of meer hetzelfde werk blijven doen, maar dan enkel voor Joodse patiënten. De laatste twee genoemde artsen bleven zelfs nog enige tijd in dienst van de GGD, terwijl hun salaris door die dienst werd gedeclareerd bij de Joodsche Raad. Die relatief normale werksituatie zou voor de bewuste artsen echter niet lang blijven bestaan. In juli 1942 liet Beauftragte Böhmcker weten het niet eens te zijn met de gang van zaken: de Joodse artsen en de twee Joodse verpleegsters die nog voor de GGD werkten, moesten officieel in dienst van de Joodsche Raad komen. Iedere binding met de GGD moest worden doorbroken. ${ }^{59}$ Immers, de isolatie van de Nederlandse Joden moest op alle terreinen doorgang vinden. Dat maakte het bewaren van de normaliteit steeds problematischer. Ook in het ziekenhuiswezen probeerde de bezetter alle banden tussen Joods en niet-Joods te doorbreken. Hoewel het niet-Joodse artsen vrij stond Joodse patiënten te blijven behandelen, gold dit niet automatisch voor niet-Joodse ziekenhuizen. Waar Joodse ziekenhuizen waren, moesten Joodse patiënten daarvan gebruikmaken. Joodse patiënten die leden aan een ziekte waarvoor de Joodse ziekenhuizen geen behandeling konden bieden, mochten worden opgenomen in niet-Joodse ziekenhuizen. Zo overlegde de Amsterdamse burgemeester E.J. Voûte in november I94I een lijst van aandoeningen die niet in de Joodse ziekenhuizen behandeld konden worden aan Böhmcker. Joden met een hersen- of ruggenmergaandoening die operatie behoefden, mochten, net als lijders aan bepaalde infectieziekten of diegenen met netvliesloslatingen, nog in de algemene stadsziekenhuizen opgenomen worden. Dit gold ook voor onrustige geesteszieken en slachtoffers van verkeersongevallen die men met spoed naar een niet-Joods ziekenhuis had overgebracht en die nog niet transportabel waren. ${ }^{60}$ Vanaf maart 1942 zouden ook bordjes met de tekst 'Voor joden verboden' op niet-Joodse ziekenhuizen verschijnen. Echter, nog steeds zouden er Joden opgenomen worden, simpelweg omdat er niet overal Joodse ziekenhuizen waren. ${ }^{61}$ Een maand eerder, in februari 1942, was voorts bepaald dat niet-Joods personeel niet langer in Joodse instellingen mocht werken. Honderden verpleegsters en andere personeelsleden moesten, soms na jaren trouwe dienst, opeens de Joodse instellingen verlaten. In de vergadering van de Joodsche Raad sprak men van 'ontwrichtende gevolgen' voor de Joodse ziekenhuizen. ${ }^{62}$ De Joodsche Raad en zijn medische afdeling moesten deze abnormale toestanden in goede banen leiden. Voor de Joodse artsen die in 
Joodse ziekenhuizen werkten, leek de situatie echter nog, buiten het feit dat zij afscheid moesten nemen van niet-Joods personeel, relatief normaal. De Joodse ziekenhuizen werkten zelfstandig en in 194I en het begin van 1942 had de medische afdeling van de Joodsche Raad nog weinig bemoeienis met deze instellingen. ${ }^{63}$ En dus gold voor de Joodse artsen die in deze ziekenhuizen werkten dat zij relatief goed af waren: zij hadden zeker voldoende patiënten en hoefden niet voor de Joodsche Raad te gaan werken.

Voor de artsen die financieel gedupeerd waren door het behandelverbod van I mei 194I, was een dienstverband bij de medische afdeling van de Joodsche Raad wel een optie. Voorstelbaar is dat de artsen die in het beginstadium bij de medische afdeling van de Joodsche Raad in dienst traden, pragmatisch handelden en voor de broodwinning voor hun gezin voor de Joodsche Raad gingen werken en de inhoud van het werk nog niet als problematisch zagen. Toch gold ook voor hen dat het simpele feit dat zij onder auspiciën van de Joodsche Raad zouden werken, als een principiële barrière kon aanvoelen. Het wel of niet in dienst treden bij de raad had niet zozeer met beroepsethiek te maken, maar was veeleer een politiek dilemma. Van een huiver ten opzichte van de Joodsche Raad bij de Joodse artsen zijn echter enkel latere bronnen bewaard gebleven. Jacques Reisel bijvoorbeeld vermeldde in zijn dagboek zijn algemene aversie tegen de Joodsche Raad en de bewondering die hij daarentegen voelde voor de houding van mr. Visser. ${ }^{64}$ Het was echter 1943 toen hij dit opschreef en inmiddels was er veel meer gepasseerd waardoor de Joodsche Raad in een kwader daglicht was komen te staan. De in 1940 afgestudeerde Sieg Gitter herinnerde zich nog weer later, in 2009, dat hij 'ieder contact met de Joodse Raad (vermeed) in wier beleid ik géén geloof of vertrouwen had.' ${ }^{65}$ Dit gebrek aan vertrouwen deelden ook collegae Frits Glaser en Hans Keilson, getuige hun herinneringen decennia na de gebeurtenissen. ${ }^{66}$ Mani Leisen werkte weliswaar voor de Joodsche Raad, maar volgens de naoorlogse overlevering met grote tegenzin. Hij zou zich over de medewerkers van de Joodsche Raad hebben laten ontvallen: 'Allemaal lafaards. ${ }^{3}$

Echter, pas in januari 1942 was er naast het politieke bezwaar pas echt sprake van een medisch ethisch dilemma gekoppeld aan het werk voor de medische afdeling van de Joodsche Raad. Joodse artsen zouden Joodse werkloze mannen moeten keuren voor tewerkstelling in werkkampen in Noord- en Oost-Nederland. De vraag of, en zo ja, op welke manier, de Joodse artsen die opdracht zouden moeten aanvaarden, bracht levendige discussies en gewetensconflicten voor velen met zich mee. 
Reeds in juli 194I vernam de Joodsche Raad van Duitse officiële zijde dat er plannen bestonden om Nederlandse Joden tewerk te stellen in werkkampen net over de Nederlands-Duitse grens. Voor deze arbeidskampen zouden de betreffende Joodse mannen, onder wie ook een arts die de groep medisch zou moeten verzorgen, van tevoren een training krijgen in een werkkamp in Ommen. ${ }^{68}$ Dit 'Schulungslager'-plan kwam echter steeds maar niet ten uitvoer. ${ }^{69}$ Wel zouden er werkkampen op diverse plaatsen in Noord- en OostNederland voor werkloze Joden verrijzen, zo kregen Asscher en Cohen in oktober 194I te horen..$^{70}$ De organisatie van deze 'werkverruiming' zou liggen in de handen van de Rijksdienst voor de Werkverruiming, het Gewestelijk Arbeidsbureau en de Nederlandsche Heidemaatschappij, alle drie Nederlandse instanties, en de arbeidskrachten zouden voorafgaande aan het werk medisch worden gekeurd. Die keuring zou moeten geschieden door Nederlandse Joodse artsen. ${ }^{71}$ Dit plan vond wel doorgang. In januari 1942 vonden de eerste keuringen in Amsterdam plaats. Een Nederlandse organisatie, een keuring door de eigen artsen, het klonk allemaal vertrouwenwekkend. Toch bestond er argwaan onder de Joodse bevolking. De Mauthausen-ervaringen hadden wantrouwen gekweekt. De voorzitters van de Joodsche Raad weigerden dan ook zelf de oproepen naar de betreffende Amsterdamse Joden te sturen. Die taak nam het Gewestelijk Arbeidsbureau over. Wel kregen de opgeroepenen een circulaire van de Joodsche Raad waarin hun ernstig werd geadviseerd gehoor te geven aan de oproep..$^{72}$ In het Joodsche Weekblad stond eveneens een aansporing om vooral mee te werken. ${ }^{73}$ Dit onder druk van de Duitse verantwoordelijke, H. Rodegro.

Rodegro, Referent für Soziale Fragen van het bureau van Böhmcker, eiste van de Joodsche Raad dat er op Io januari 1942 een eerste groep van 1402 Joodse werklozen gereed zou staan op Amsterdam Centraal. ${ }^{74}$ Voor voldoende respons stuurde het Gewestelijk Arbeidsbureau in Amsterdam een ruim aantal van 2600 Joodse steuntrekkers een oproep om zich op Io januari naar het Centraal Station te begeven. Een dag tevoren dienden zij zich bij de Diamantbeurs op het Weesperplein te melden om gekeurd te worden. De medische afdeling van de Joodsche Raad had vier Amsterdamse Joodse artsen bereid gevonden voor de opdracht. Zij zouden hier een dagsalaris van $f$ I5 mee verdienen.75 Slechts een klein deel van de 2600 opgeroepenen liet zich echter op 9 januari ter keuring in de Diamantbeurs zien. Hoe vertrouwenwekkend de organisatie ook mocht lijken, het wantrouwen overheerste. Men zag deze tewerkstelling als iets waar men zich maar beter niet aan blootstelde. Vanwege het dreigende 
te geringe aantal arbeiders, kreeg de Amsterdamse politie de opdracht op straat Joodse venters op te pakken, hun ventvergunningen af te nemen, waarop zij zogenaamd werkloos waren, en hen naar de Diamantbeurs te brengen ter keuring. Deze gang van zaken stuitte de keurende artsen ernstig tegen de borst. Twee van hen, Salco Hertzberger en Isidor Spangenthal, staakten hierop hun werkzaamheden en stapten uit protest in de loop van de dag op. ${ }^{76}$ Ook David Nordheim legde zijn werk neer nadat enkele brodeloos gemaakte venters hem hadden gesmeekt hen toch vooral goed te keuren omdat ze anders hun gezinnen niet te eten konden geven. ${ }^{77}$ Tegelijkertijd probeerden de meeste andere opgeroepenen juist met alle macht afgekeurd te worden, omdat zij voor geen prijs naar de werkverruiming wilden. Een chaotische en verwarrende toestand. David Cohen was erbij aanwezig en herinnerde zich na de oorlog: 'De eerste keuring in de Diamantbeurs zal ik niet makkelijk vergeten. De wanhoop van hen die daar waren, de moeite die door verschillenden werd gedaan om hen van arbeid te ontslaan en dat niet altijd lukte. ${ }^{.78}$

Uiteindelijk vertrokken er op Io januari 1942905 Joodse mannen naar Drenthe. 170 anderen, die wel goedgekeurd waren, bleven weg. ${ }^{79}$ De vier artsen hadden dus in elk geval 1075 mannen goedgekeurd. Hoeveel zij er afkeurden, is niet te achterhalen vanwege het onbekende aantal van degenen die nooit ter keuring kwamen opdagen en vanwege het evenzeer onbekende aantal van de straat geplukte venters die nooit een oproep ontvangen hadden. David Cohen echter had de indruk dat de artsen veel mensen hadden kunnen afkeuren: 'De Joodse doktoren die keurden, werkten ook intensief mee om het getal zo klein mogelijk te houden. ${ }^{80}$ Zo tevreden als Cohen echter was geweest over het afkeuringspercentage, zo teleurgesteld was hij in de artsen toen die het werk neerlegden. Aan het eind van de keuringsdag was immers nog slechts één van de vier artsen die aan de keuring hadden deelgenomen overgebleven ${ }^{81} \mathrm{De}$ weigering van de drie anderen om door te gaan had Cohen danig geërgerd:

De Joodse doktoren hadden zich ook meer en meer teruggetrokken omdat zij geloofden door zich voor de keuring beschikbaar te stellen, zij meewerkten aan iets dat zij in de grond afkeurden. Ik heb hen eens bijeengeroepen en hen met klem voorgehouden dat zij het daardoor mogelijk maakten dat aan NSB-doktoren de keuring zou worden opgedragen. Zij konden zich echter niet in mijn argumentatie vinden en bleven, zonder tegenargumenten te uiten, in hun houding volharden. Slechts één stelde zich verder beschikbaar. Ik heb de houding van de overigen onjuist gevonden. Het was een principiële houding die tegenover die van de Joodsche Raad stond en ik kon deze niet veranderen. ${ }^{82}$ 
Het beleid van de Joodsche Raad, door Cohen verdedigd, schreef voor dat men beter 'zelf een vinger in de brij' kon houden dan principieel alle medewerking weigeren. Door zelf zo veel mogelijk in de hand te houden kon men erger voorkomen, zo was de overtuiging. Erger in dit geval zou betekenen dat NSB-artsen de keuringen zouden uitvoeren en dat er dan veel meer mensen goedgekeurd zouden worden. De artsen stelden zich echter na de eerste slechte indruk op het standpunt dat iedere verdere medewerking moreel verwerpelijk was. De toon van de morele discussie over de keuringen tussen de Joodsche Raad enerzijds en de artsen anderzijds was gezet. Naar verluidt heeft David Cohen arts David Nordheim in razernij opgebeld met de mededeling dat deze na zijn weigering te keuren niet meer rustig zou kunnen slapen. ${ }^{8}$ Nordheims zoon kon zich jaren later de angst van zijn ouders naar aanleiding van dit telefoontje levendig herinneren. Enigszins cynisch merkte hij op: 'That, then, is the price a man has to pay for his integrity. ${ }^{\prime} 4$ Voorlopig gebeurde er echter nog niets met de weigerende artsen.

De morele discussie van de keuringsartsen met de Joodsche Raad ten spijt, de realiteit was dat de groep van I075 werkloze Joodse mannen uit Amsterdam verdween naar de verschillende werkkampen bij dorpen als Diever, Gijselte en Geesbrug. In totaal zouden er 38 Joodse werkkampen in de provincies Groningen, Friesland, Drenthe, Overijssel en Gelderland operationeel worden. ${ }^{85}$ De tewerkgestelden moesten er ontginningswerkzaamheden verrichten. In de strenge winter van I94I-I942 was dat geen sinecure. Zoals Sally de Jong rapporteerde: 'In deze kampen is toen bij hevige vorst, zeer veel kou geleden. ${ }^{86}$ Wel was het eten er die winter nog vrij goed, omdat de rantsoenen door de Nederlandsche Heidemaatschappij vanwege het zeer zware werk verdubbeld waren. ${ }^{87}$ Tegelijkertijd was het loon dat de Joodse arbeiders uitbetaald kregen, wel 20 procent lager dan het loon van niet-Joodse arbeiders die hetzelfde werk verrichtten en bleken zij, tegen de beloftes in, niet of nauwelijks met verlof te mogen. ${ }^{88}$ In februari 1942 schafte men ook de dubbele voedselrantsoenen af. Bovendien was de bezetter nog allerminst tevreden over het aantal Joodse mannen dat in de werkkampen tewerkgesteld was. Meer mannen werden opgeroepen. In maart en april kwamen niet alleen werklozen, maar ook werkende Joodse mannen tussen 18 en 45 jaar, en later tot 50 en zelfs tot 55 jaar, in aanmerking voor de werkverruiming. ${ }^{89}$ En dus moesten er telkens opnieuw medische keuringen uitgevoerd worden. Opnieuw werden Joodse artsen met de vraag geconfronteerd of zij hieraan mee wilden werken.

Het voorbeeld van de artsen die op 9 januari op principiële gronden hadden gemeend hun medewerking te staken, vond echter ook navolging bij collegae, aldus Sally de Jong: 'Bijna alle Joodsche artsen weigerden echter hun 
medewerking. ${ }^{90}$ Zo ook bijvoorbeeld Govert de Haas, een jonge arts die net na zijn artsexamen in Amsterdam voor de keuringen gevraagd werd. Hij weigerde. ${ }^{91}$ De keuringen vonden echter wel doorgang. Joodse artsen die meer in de lijn van de Joodsche Raad dachten en oordeelden beter zelf de keuringen te kunnen verrichten in plaats van deze aan kwaadwillende NsB'ers uit handen te geven, voerden ze uit. Louis Schaap, internist en onderdirecteur van het NIZ, ontving een brief waarin Salomon Spijer hem verzocht aan de keuringen deel te nemen, en wel als specialist. Spijer presenteerde de keuringen aan Schaap als een continuüm met de werkverschaffingsprojecten voor werklozen zoals die voor de oorlog bestonden:

Zeer geachte collega, Den Joodschen raad is opgedragen alle Joden die door den overheid voor den werkverruiming opgeroepen worden, te keuren op hun geschiktheid voor tewerkstelling. Vroeger gebeurden deze keuringen door de afdeling Geneeskundig Onderzoek van de werkverschaffing (de zgn AGC) die echter thans haar bemoeiingen niet meer over Joden mag uitstrekken. Deze keuringen geschieden in opdracht van den Joodschen Raad, in een lokaal dat door het Ned. Isr. Armbestuur hiervoor ter beschikking is gesteld. Beleefd verzoek ik u, uw medewerking voor deze keuringen in zooverre te willen verlenen, dat candidaten voor wie specialistisch advies noodzakelijk is, naar uw polikliniek in het Ned. Isr. Ziekenhuis verwezen mogen worden. Indien u dit wenscht, is er geen bezwaar tegen, dat u den Joodschen Raad voor de verrichtingen het ziekenfondschtarief berekent. Daar het in het belang van de opgeroepenen geacht moet worden, dat de keuringen in handen van Joodsche artsen blijven, doe ik een dringend beroep op uw medewerking, en verneem gaarne zoo spoedig mogelijk, of $\mathrm{u}$ dit verzoek kunt inwilligen..$^{92}$

Schaap willigde het verzoek in en keurde 'de moeilijke gevallen, die de artsen niet konden oplossen'. ${ }^{93}$ En zo rapporteerde de Joodsche Raad-verantwoordelijke voor de werkverruimingskwestie, Meyer de Vries, in zijn zevende nota van 29 januari dat er enkele kleinschalige keuringen in het Nederlandsch Israëlietisch Ziekenhuis hadden plaatsgevonden. In totaal had men er 80 mannen onderzocht, van wie de meerderheid, 45 man, als ongeschikt voor zware arbeid was aangemerkt. ${ }^{94}$ In zijn zeventiende nota toonde Meyer de Vries de resultaten van de verdere keuringen in februari: I45 gekeurden, van wie 64 geschikt en 8 r ongeschikt. ${ }^{95}$ In maart vorderde de keuring van nieuwe tewerk te stellen personen eveneens, met ook ditmaal een afkeuringspercentage van zo'n 50 procent. ${ }^{6}{ }^{6} \mathrm{Om}$ precies te zijn: 52,82 procent van de gekeurden werd 
in die maand afgekeurd. ${ }^{97}$ De keuringen vonden dus doorgang en er waren dus artsen bereid ze uit te voeren, maar zij behaalden hoge afkeuringspercentages. Voor een mannelijke populatie met leeftijden tussen de I8 en 55 waren het zelfs opvallend hoge percentages. Zeker in vergelijking met bijvoorbeeld de niet-Joodse arbeiders die voor Arbeitseinsatz in Duitsland gekeurd werden door NSB-artsen van het Gewestelijk Arbeidsbureau..$^{98}$ Onder hen lagen de percentages 'tijdelijk ongeschikt' en 'ongeschikt' zo rond de 4 procent. ${ }^{99}$ Deze percentages waren zo laag omdat er veel gevallen bekend waren van onjuiste en onnauwkeurige keuring, waarbij mensen die eigenlijk niet konden werken, toch goedgekeurd werden. ${ }^{100}$ Bij de Joodse mannen die door de Joodse artsen gekeurd werden, was het tegenovergestelde aan de hand. Een manier van keuren die onder normale omstandigheden eveneens als duidelijk ongeoorloofd gezien zou zijn, raakte bij hen in zwang en breed geaccepteerd. Dit was een manier van vervalsing en medische sabotage in het belang van de gekeurden.

\section{VERVALSING EN SABOTAGE}

De vroegere norm voor de uitvoering van medische keuringen was eenvoudig en helder geweest, zoals ook in duidelijke bewoordingen in de gids Medische ethiekstond genoteerd: de arts diende medische keuringen altijd onbevooroordeeld en naar waarheid uit te voeren. Objectief keuren was geboden. ${ }^{\text {Ior }}$ Vanaf januari 1942 echter schoven Joodse keuringsartsen de norm van waarheidsgetrouw keuren terzijde. Vervalsing ofwel sabotage van de keuringen werd de nieuwe norm. 'De meesten hunner, die wel keurden, hebben gesaboteerd zoo goed en zoo kwaad als dat ging. ${ }^{\text {'02 }}$ Ook artsen die zelf niet keurden en nietJoodse artsen wier patiënten ter keuring waren opgeroepen, deden na aanvankelijke schroom volop aan de sabotage mee, aldus Berthold Stokvis. ${ }^{103} \mathrm{Zij}$ schreven daartoe attesten, verklaringen van ziekte, en lieten de patiënten de bijbehorende symptomen instuderen. In plaats van als een objectief gezondheidsonderzoek gold de keuring op deze wijze steeds meer als een zoektocht naar een klein kwaaltje dat kon worden opgeblazen tot een aandoening die fysieke arbeid ernstig zou belemmeren. Niet voor niets verspreidde de volgende - wrange - grap zich in Joodse kring: 'U hebt zeker last van hoofdpijn? Neen? Dan kunt u zeker moeilijk lopen? Ook niet? Natuurlijk heeft u hinder van uw hart? Niet? Dan moet ik u afkeuren: $\mathrm{u}$ is mesjogge!' ${ }^{\mathrm{IO}}$ Artsen, zelf keurend en niet-keurend, verzonnen van alles om hun voor keuring opgeroepen patiënten ziek te laten lijken. Huisartsen en specialisten verschaften hun patiënten valse verklaringen en de keuringsartsen deden net alsof ze de trucs niet doorzagen. 
Stokvis merkte op: 'Het is in de geschiedenis der geneeskunde wellicht nog nimmer voorgekomen, dat de artsen zoo vindingrijk zijn geweest de menschen te helpen bij het simuleeren van ziekten.' ${ }^{\text {ros }}$ Vindingrijkheid spreekt zeker uit het volgende voorbeeld: 'Dokter, ik heb mij enige weken geleden, voor ik naar de keuring moest voor een werkkamp in Nederland, een eczeem gemaakt op die hand, door een lap met petroleum er flink overheen te wrijven. Ik kreeg toen een attest van den huidarts en dat heeft mij erdoorheen geholpen.' ${ }^{\text {'o6 }}$

Expres eczeem opwekken met bijtende middelen was dus een mogelijkheid. ${ }^{107}$ Maar ook aan röntgenfoto's werd gesleuteld door bijvoorbeeld met wat kwikzalf een vlekje op de huid te maken, waar de röntgenstralen niet doorheen konden. Op de foto verscheen dan eveneens een vlekje. Vervolgens moest de betrokkene een kilo rauwe bloedworst eten om een positieve hemoglobinereactie in zijn faecestest te krijgen, oftewel een aantoonbare hoeveelheid bloed in de ontlasting. Samen zou dat onmiskenbaar duiden op een bloed sijpelende maagzweer, een ernstige aandoening. ${ }^{108}$ Simpeler kon ook. Patiënt J. Zwaaf meldde bij zijn keuring dat hij eerder gekeurd was, in verband met sportactiviteiten, en destijds afgekeurd, maar dat het bewijs daarvan bij het bombardement op Rotterdam verloren was gegaan. De arts keurde hem af. ${ }^{\text {109 }}$ Een ander voorbeeld was het voorafgaand aan de keuring voorschrijven van bloeddrukverhogende tabletten, wat naar verluidt in Den Bosch werd toegepast. ${ }^{\text {IIO }} \mathrm{Als}$ psychiater had Stokvis het relatief eenvoudig, aangezien psychische aandoeningen meestal niet met lichamelijk onderzoek geobjectiveerd kunnen worden. Hij schreef valse verklaringen van ernstige geestesziekte, waarbij het hem lukte 'een gelukkige formuleering te vinden voor het "lijden" van den patient. IJverig hebben wij de menschen ziekten ingestudeerd.' ${ }^{\text {'II }}$ Stokvis schreef het met een zekere trots. In elk geval schaamde hij zich onder de gegeven omstandigheden kennelijk niet voor deze bizarre medische praktijk. Collega Salomon Koster vond het zelfs volslagen logisch: 'Het spreekt vanzelf, dat de meeste mannen wel een of ander klein gebrek of kleine afwijking hadden, dat, in een attest, tot een wat grooter gebrek kon opgeblazen worden. Was er geen enkele afwijking, dan werd er meestal wel wat bijgefantaseerd. 'I2 En: 'Er waren veel simulanten, die ik, als het eenigszins kon, natuurlijk hielp, door ze af te keuren. Suikerziekte, hooge bloeddruk, maagzweer waren de gangbare diagnoses, schreef ook Louis Schaap alsof het doodgewoon was. ${ }^{\text {II3 }}$

Hoewel vanuit traditioneel medisch ethisch oogpunt bekeken eigenlijk bizar en onoirbaar, effectief was deze praktijk zeker wel. Volgens Sally de Jong waren de artsen dermate vindingrijk dat zij op een zeker moment zelfs een afkeuringspercentage van 85 procent bereikten. ${ }^{\text {II }}$ Ze hadden met deze praktijk een zeer concrete norm uit de vooroorlogse beroepsethiek overboord gezet, 
maar er een groot effect mee bereikt. Het oneigenlijke middel van sabotage was kennelijk acceptabel om het gewenste doel te bereiken: zo veel mogelijk afkeuringen. Sterker nog, sabotage werd de voorwaarde om het keuren voor de Joodsche Raad voor de artsen zelf en voor de publieke opinie aanvaardbaar te maken. ${ }^{\text {II }}$ Keuren mocht, mits men saboteerde. Men zou dit een meer teleologische benadering van de medische ethiek kunnen noemen, waarbij men in het individuele belang van de patiënt handelde, hoewel met in feite ondeugdzame middelen. Het handelen in het belang van de individuele patiënt was natuurlijk een van de overkoepelende waarden van de medische beroepsethiek die de artsen vertrouwd was. Daarmee kon men deze manier van handelen, hoe onorthodox ook, toch nog voor zichzelf verantwoorden, naast de (politieke) legitimering doordat zij hiermee iets deden wat tegen de wil van de bezetter inging.

Overigens werd dit handelen niet alleen maar ingegeven door overwegingen van altruïsme en verzetsgeest van de artsen. Met name sommige niet-Joodse specialisten zagen volgens Sally de Jong in het uitschrijven van attesten een interessante extra bron van inkomsten en 'hebben in deze maanden grof geld verdiend en de Jodenvervolging terdege geëxploiteerd'. ${ }^{\prime \prime}$ Ook twee Joodse artsen maakten zich hieraan volgens De Jong schuldig. Hij sprak hier zijn afkeer over uit. ${ }^{\text {II7 }}$ Louis Schaap op zijn beurt kreeg voor keuringsactiviteiten weliswaar niets vergoed van de Joodsche Raad, ook niet het ziekenfondstarief dat hem beloofd was, maar zijn praktijk werd opeens overspoeld door particuliere patiënten die hadden gehoord dat hij in de keuringscommissie zat en die hem uit eigen zak betaalden. Schaap kreeg het enorm druk en dat legde hem geen windeieren: 'Soms zaten er 40 betalende patiënten te wachten. Het geld vloeide binnen als water. Toch berekende ik normale tarieven. Ik heb nooit misbruik gemaakt van deze noodtoestand.' ${ }^{\prime \prime 8}$ In de ogen van Sally de Jong was het keuren op deze manier, voor normale tarieven en trachtend zo veel mogelijk mensen af te keuren middels medische sabotage, verdedigbaar. ${ }^{\text {II }}$ Deze overtuiging deelde de jonge Amsterdamse huisarts Max Koster, die aan de keuringen deelnam. Hij streefde bij zijn werkzaamheden naar een zo hoog mogelijk afkeuringspercentage. ${ }^{20}$ Net als de Osse huisarts Ruben Bollegraaf, getuige zijn verslag. In mei 1942 was Amsterdam 'als leverancier van Joodse werkkrachten uitgeput', waarop ook de Joodse mannen in de mediene aan de beurt kwamen voor tewerkstelling. ${ }^{\text {I2I }}$ Vanaf juni 1942 werden alle Joodse mannen tussen 18 en 55 jaar in de drie noordelijke provincies door de Gewestelijke Arbeidsbureaus opgeroepen en in Noord-Brabant en Limburg werden daartoe tezelfdertijd voorbereidingen getroffen. ${ }^{122}$

In Oss waren twee Joodse artsen werkzaam, maar aangezien dokter Marga- 
ret Danby een vrouw was, kwam alleen Bollegraaf in aanmerking om de keuringen bij de opgeroepen mannen uit te voeren. Samen met de hoofdvertegenwoordiger van de Joodsche Raad te Oss reisde Bollegraaf naar een vergadering in Amsterdam. Deze werd geleid door Meyer de Vries, algemeen adviseur van de Joodsche Raad, en mede bijgewoond door Salomon Spijer. Ook uit andere plaatsen waren artsen en hoofdvertegenwoordigers naar de bijeenkomst gekomen. Doel van De Vries en Spijer was de artsen bereid te vinden in hun woonplaats de keuringen uit te voeren. Een doel dat volgens Bollegraaf bereikt werd: 'De argumenten van de heer De Vries en Dr. Spijer, de medisch adviseur, waren dusdanig, dat de artsen hun medewerking toezegden. ${ }^{123}$ Direct daarna nam Spijer de artsen apart. Echter, bij die vergadering 'werd weinig positiefs vermeld. Scherpe richtlijnen voor de keuring werden niet gegeven. ${ }^{\text {'24 }}$ Enkele afspraken waren voor de aanwezige artsen vanzelfsprekend: 'Uit de aard der zaak besloot ieder voor zichzelf, het percentage goedgekeurden niet hoger te laten zijn dan in Amsterdam, met welk percentage de Duitsers tot dan toe genoegen hadden genomen. ${ }^{\text {'25 }}$ Bovendien opperde men dat men voor deze zware arbeid wellicht dezelfde strenge maatstaven moest laten gelden als voor militaire keuring, waar volgens een der aanwezigen een goedkeuringspercentage van slechts is procent gewoon was. Voorts spraken de drie Brabantse artsen - naast Bollegraaf Salomon Moerel uit Tilburg en Salomon Diamant uit Den Bosch - af dat zij de keuringen telkens met $z$ 'n tweeën zouden uitvoeren en daarbij zouden vermijden hun eigen patiënten te moeten keuren. ${ }^{126}$

Bollegraaf zelf nodigde, samen met de plaatselijke hoofdvertegenwoordiger van de Joodsche Raad, op een zondag in begin juni 1942 alvast de helft van de mannen die gekeurd zouden moeten worden uit voor een bespreking. Deze twintig mannen kregen van Bollegraaf bij die gelegenheid instructies hoe ze het best door de keuring zouden kunnen komen, met het gewenste bewijs van afkeuring in de hand. 'De bedoeling was, alle sociale en eventuele medische zaken, die tot vrijstelling of afkeuring konden leiden, te bespreken. Adviezen werden gegeven over attesten, in sommige gevallen werd met de huisarts

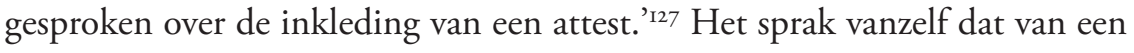
gezin de zwakste zoon ter keuring zou verschijnen, die had immers de meeste kans op afkeuring. De bezetter had beloofd dat slechts één man per gezin voor tewerkstelling in aanmerking zou komen. ${ }^{\text {I28 }}$ Bollegraaf zou echter nooit tot daadwerkelijk keuren komen. Nog voordat hij daartoe de kans had gekregen, kwam het bericht binnen dat een arts van het Gewestelijk Arbeidsbureau zou keuren, een NSB'er. Hiermee gebeurde waar de Joodsche Raad-vertegenwoordigers David Cohen, Meyer de Vries en Salomon Spijer, al die tijd bang voor waren geweest en wat hun belangrijkste argument was geweest om de Joodse 
artsen ervan te overtuigen mee te werken aan de keuringen. Het was er hun alles aan gelegen om de keuringen in eigen hand te houden. Op die manier hadden zij getracht te balanceren tussen enerzijds zo veel mogelijk afwijzingen en het aantal tewerkgestelden zo laag mogelijk te laten zijn en anderzijds wel de Duitse verantwoordelijke, Rodegro, tevreden zien te houden. Dat dit inderdaad een zeer wankel evenwicht was, was in april I942 al bij hen doorgedrongen: 'De resultaten voor de werkverruiming verloopen niet bevredigend. Het aantal goedgekeurden is gering. Dit vervult ons met zorg. 'I29

De zorg betrof Rodegro's ergernis over de hoge afkeuringspercentages en zijn wantrouwen jegens de Joodse keuringsartsen. Zo belde hij Cohen op om verhaal te halen toen hij vernomen had dat een man die hij kende en die twaalf jaar bij een bedrijf zware lichamelijke arbeid had verricht, nu opeens afgekeurd was. Rodegro ontstak in woede over het absurde aantal afgekeurden. Aan de telefoon probeerde Cohen hem te sussen:

Ik [Cohen] antwoordde, dat wij 7000 mensen hadden opgeroepen, om Iooo plaatsen te bezetten, dus meer dan tweemaal zoveel als gewoonlijk; dat de vermeerdering van afgekeurden ook kon worden opgemerkt bij niet-Joodse arbeiders, gelijk uit een bericht in de courant was gebleken; dat de vermeerdering geen wonder was (hoezeer wijzelf en de doktoren er eerst ons over hadden verbaasd en wijzelf daarom met de doktoren er een conferentie over hadden gehad) omdat de Joden tengevolge van de toestand zeer nerveus werden en wegens de slechtere omstandigheden niet voldoende te eten kregen. ${ }^{\mathrm{I30}}$

Mogelijk was Rodegro even gerustgesteld. De sabotagepraktijken van de keuringsartsen vielen echter op en irriteerden hem onmiskenbaar. In juni 1942 was voor de bezetter de maat vol. Juist in de principiële houding van de Joodse artsen in Groningen, die iedere medewerking aan de keuringen weigerden, werd nu een aanleiding gevonden de Joodse artsen de keuringen uit handen te nemen.

\section{DE GRONINGSE KWESTIE: NSB-ARTSEN NEMEN DE KEURINGEN OVER}

De Groningse Joodse artsen hadden vanwege de nabijheid van diverse werkkampen bij hun woonplaats al wat indrukken opgedaan van hoe het daar toeging. Zo was Elie Cohen naar werkkamp Geesbrug afgereisd om de mannen 
er op hun vrije zondag - sjabbat was door Rodegro niet als rustdag erkend - te onderhouden over het menselijk lichaam. ${ }^{13 \mathrm{I}}$ Collega Leopold Meijler deed kamp Sellingerbeetse een plaat van het menselijk lichaam toekomen, evenals enkele boeken, om het verblijf in het werkkamp enigszins 'te verluchtigen'. ${ }^{32}$ De Groningse artsen zullen in de loop van het voorjaar dan ook hebben gemerkt dat de toestanden in de werkkampen verhardden. De (niet-Joodse) kampartsen spraken meermaals hun zorg uit over de gezondheidstoestand van de tewerkgestelden. Er was begin juni zelfs sprake van het terugsturen van arbeiders naar huis vanwege ondervoeding. ${ }^{133}$ Wellicht heeft deze kennis de Groningse artsen meer dan gemiddeld doen twijfelen over hun bereidheid medeverantwoordelijkheid voor de tewerkstelling te dragen door keuringen te verrichten. Salomon Spijer reisde meermaals naar Groningen om de artsen daar te overtuigen van de noodzaak zelf te keuren. ${ }^{134}$ Telkens kwam hij onverrichterzake terug. De Groningse artsen bleven weigeren de keuringen te verrichten. Kennelijk kon zelfs de mogelijkheid de keuringen middels sabotage acceptabel te maken hen niet vermurwen. Niet alle artsen konden het aan hun geweten verkopen de deontologische 'oude' ethiek te vervangen door deze nieuwe aanpak, zo blijkt uit de Groningse kwestie. De Groningse weigering leidde ertoe dat de gebeurtenissen op 24 juni 1942 in een stroomversnelling raakten.

Rodegro had kennelijk genoeg gekregen van het wachten en hij liet de zogenaamde 'Aussenstellen' van de drie noordelijke provincies spoedoproepen sturen aan 88 o Joodse mannen in de leeftijd van 16 tot 55 jaar. Gebruikelijk was dat de Joodsche Raad eerst zelf aan het Gewestelijk Arbeidsbureau doorgaf wie niet voor tewerkstelling in aanmerking kon komen - artsen, geestelijken en leerkrachten -, waarop deze Gewestelijke Arbeidsbureaus vervolgens de oproepen rondstuurden. Op 24 juni 1942 vielen nu echter de spoedoproepen bij de willekeurig opgeroepenen op de mat en ontstond er paniekerig getelefoneer tussen David Cohen, de Groningse opperrabbijn Simon Dasberg en de Groningse arts Maurits van der Reis. Niet alleen was het oproepen nu volstrekt willekeurig geschied, ook had Rodegro twee NSB-artsen angesteld als keuringsartsen. ${ }^{135}$ Volgens een notitie van Meyer de Vries stelde Van der Reis nu nog voor alsnog te proberen de keuringen dan toch maar zelf te doen en in vliegende vaart een keuringslokaal te arrangeren. Het mocht echter niet meer baten; het besluit van Rodegro stond vast. ${ }^{136}$ Ook inmenging van secretarisgeneraal Verwey van Sociale Zaken en van de burgemeester van Groningen hielp niet. ${ }^{137}$ De tewerkstelling was nu een zaak van de Sicherheitspolizei geworden en niet meer van het Gewestelijk Arbeidsbureau. Het enige wat Beauftragte Böhmcker de Groningse burgemeester kon beloven, was dat als men 
bij de keuring zou melden dat men arts, geestelijke of leerkracht was, men ter plekke vrijgesteld zou worden. Rodegro zwakte dit af door te zeggen dat in de eerste plaats de Joodse artsen boven de 55 jaar zouden mogen blijven en als er dan nog een tekort zou zijn, zoveel artsen dat het Joodse volksdeel voldoende geneeskundige verzorging zou hebben. Zelfs protest van de inspectie voor de Volksgezondheid kon hieraan niets veranderen. ${ }^{138}$

Van de tien Joodse Groningse artsen, van wie er overigens niet één ouder dan 55 jaar oud was, doken er dan ook drie onder. Een vierde, Meyer Stern, vluchtte via Amsterdam naar Parijs, waar hij anderhalve maand later werd gearresteerd. ${ }^{139}$ Margaretha Dekker-Benjamins kwam als vrouw niet in aanmerking voor de tewerkstelling. Maurits van der Reis, Nathan (Nico) van Zuiden, Benjamin Pais en Ies van der Hal belandden echter zelf in de positie van gekeurde. Elie Cohen, die door een administratieve misser niet opgeroepen werd en even later vluchtte, beschreef de keuring als volgt:

Uiteindelijk geschiedde de keuring door NSB artsen, nl Dr. v.d. Horst hartspecialist en Dr. van Kuppen, die in Oldenhove mislukt was en nu ook in Groningen zijn kost niet kon verdienen. Het keuren ging als volgt. In 6 a 7 uur werden 1400 mensen gekeurd. Ook mensen met kunstledematen, hartafwijkingen enz werden goedgekeurd. Geen gewicht werd gecontroleerd, geen urine-onderzoek e.d. Van een zeer groot aantal werden er nog geen Io afgekeurd. De meeste Joden hadden attesten, maar deze werden niet eens ingezien. Dit alles gebeurde op 24 juni 1942, in de oude HBS aan de Violenstraat te Groningen. ${ }^{140}$

Huisarts les van der Hal onderging de keuring zelf. Hij had besloten niet onder te duiken, vooral omdat zijn vrouw na zeven jaar huwelijk tot hun grote vreugde eindelijk in verwachting was: 'De andere Joodse artsen waren allemaal ondergedoken. Wij dachten er niet over. Niet alleen met het oog op de aanstaande bevalling, maar ook omdat wij psychisch niet in staat waren onze ouders in de steek te laten, alleen, verloren in ons huis. ${ }^{141}$

Ies van der Hal werd goedgekeurd voor een werkkamp. De vier Groningse artsen bevonden zich allen onder de goedgekeurden, ondanks hun functie. Zij moesten mee naar de werkkampen. In de notulen van de vergadering van de Centrale Commissie van de Joodsche Raad van maandag 29 juni werd dan ook met ontzetting over deze Groningse keuring gesproken. Volgens deze notulen waren er slechts vijf afgekeurden onder de 880 gekeurden. ${ }^{142}$ Het overgrote deel van de gekeurden werd goedgekeurd. Hetzelfde was vervolgens het geval in Deventer en in Leeuwarden, waar in augustus eveneens door een NSB-arts 
werd gekeurd. ${ }^{143}$ Het vasthouden aan politieke overtuiging en de vertrouwde vooroorlogse artsennormen kon onder de gegeven omstandigheden dergelijke verstrekkende en rampzalige gevolgen hebben, zo bleek hieruit. Was het dan toch beter geweest de oude ethiek te vervangen door een nieuw moreel kompas, meer geënt op het voorbeeld van de Joodsche Raad? Met de wetenschap van achteraf beantwoordde Ies van der Hal deze vraag bevestigend. Hij had spijt van de standvastige houding waarin hij met zijn Groningse collegae had gepersisteerd. In een brief aan David Cohen getuigde hij eind 1947 van zijn gewetensnood. Medewerking aan de keuringen wees hij nog steeds in principe af, maar de keuringen overlaten aan NSB-artsen was eigenlijk nóg erger, achteraf bezien: 'De gevolgen waren verschrikkelijk.' 'I44 $\mathrm{Na}$ de oorlog kon Van der Hal zich beter inleven in het standpunt van de Joodsche Raad en voelde hij zich zelfs geroepen de op dat moment zwaar bekritiseerde en zelfs wegens vermeende collaboratie in hechtenis genomen David Cohen een hart onder de riem te steken. Tijdens de bezetting echter had het argument van de Joodsche Raad dat NSB-artsen meer schade zouden aanrichten dan als zij zelf mee zouden werken, geen gewillig oor gevonden bij Van der Hal en zijn collegae. En dus was de keuring geschied zoals beschreven.

\section{GRONINGSE ARTSEN TEWERKGESTELD}

De vier goedgekeurde artsen vertrokken op Io juli 1942 met de grote groep Groningers naar verschillende werkkampen. Zij hadden daarbij nog wel enig voordeel van hun beroep. Ies van der Hal kwam eerst in Balderhaar terecht, waar hij het als arts relatief goed had. Omdat er een niet-Joodse kamparts was, een huisarts uit een nabijgelegen dorp, werd Van der Hal ingezet als verpleger. Toen de kamparts er echter achter kwam dat Van der Hal een collega was, bezocht deze het kamp nog maar één keer per week. Ondanks de moeilijkheden was de sfeer in het kamp, met Groningers onder elkaar, volgens Van der Hal goed te noemen. Van der Hal verdiende er wat geld, dat hij naar zijn zwangere echtgenote en ouders kon sturen.

In Balderhaar kon men met het aardappelen rooien en verwijderen van boomstronken een klein bedrag verdienen. Dat was afhankelijk van de verrichte prestatie. Van het berekende loon werd een bedrag afgetrokken voor 'kost en inwoning'. De rest werd aan het gezin thuis overgemaakt. Gemiddeld kon men toen II gulden per week verdienen. Ik had als verpleger een vast loon van negentien gulden per week. Dat was zeer hoog, het hoogste loon dat mogelijk was. ${ }^{\text {I5 }}$ 
Na krap drie weken Balderhaar moest Van der Hal alweer verhuizen naar Sellingerbeetse, omdat men daar een arts nodig had. In Sellingerbeetse waren geen Groningers maar Amsterdammers tewerkgesteld. Aanvankelijk deprimeerde dat Van der Hal, omdat hij zich eenzaam voelde, maar de situatie bleek grote voordelen te hebben. Zo mocht hij, net als Maurits van der Reis, als arts meereizen met zieke arbeiders naar het Academisch Ziekenhuis in Groningen, wat hem de kans gaf zijn vrouw met enige regelmaat te bezoeken. ${ }^{146} \mathrm{Bij}$ de geboorte van zijn dochter zou Van der Hal weliswaar niet aanwezig zijn, maar hij kon haar wel vrij snel gaan bewonderen, een voorrecht dat hem als arts ten deel viel, en dat voor de andere tewerkgestelden ondenkbaar was. Het bezorgde hem echter ook een dilemma dat voor de andere tewerkgestelden nooit aan de orde zou zijn gekomen. Terwijl hij bij zijn eerstgeborene Henriëtte in de kraamkliniek aan de Ubbo Emmiussingel te Groningen was, stormde er een verloskundige de kraamkamer binnen: 'Dokter, dokter, kom gauw en help ons! Wij kunnen een stuitligging er niet uit krijgen.' ${ }^{477}$ Van der Hal mocht uiteraard geen niet-Joodse patiënte helpen en aarzelde over wat hem te doen stond. Op de belofte dat de andere stafleden hem nooit zouden verraden liep hij mee naar de vrouw in barensnood en beëindigde de partus succesvol. ${ }^{148}$ Zijn artsenplichtsgevoel ten opzichte van de patiënte die zijn medische hulp nodig had, had op dit moment de boventoon gevoerd boven het persoonlijke risico dat hij liep.

Van der Hals overplaatsing als arts naar Sellingerbeetse zou uiteindelijk zijn redding blijken te zijn toen het kamp, net als de andere werkkampen, op 2 oktober 1942 werd ontruimd. Alle Joodse mannen werden naar het doorgangskamp Westerbork overgebracht om vandaaruit vrijwel direct verder op transport te gaan naar bestemmingen in Oost-Europa. Voor sommigen, zoals de werkkrachten uit Zevenaar die vanaf I september in het kamp in Putten verbleven, en zoals de mannen uit Meppel, die nog op I oktober in hun werkkamp waren gearriveerd, volgden de gebeurtenissen elkaar in moordend tempo op en bleek het verblijf in de werkkampen van zeer korte duur. ${ }^{\text {I49 }}$ De bezetter haalde begin oktober 1942 ook de gezinnen van de tewerkgestelden aan de hand van de adressenlijsten uit hun huizen. Dit gebeurde zowel in Amsterdam als in de noordelijke provincies. Die provincies waren dan ook in één klap grotendeels van Joden ontdaan. Ies van der $\mathrm{Hal}$ stond echter met zijn Groningse adres op de lijst met Amsterdammers die in Sellingerbeetse tewerk waren gesteld. Zijn Groningse adres werd door deze administratieve fout met rust gelaten en zijn vrouw en kind merkten zelfs niets van de nachtelijke actie waarbij de andere gezinnen van de arbeiders opgepakt werden. Van der Hal zelf wist te ontsnappen en kon zich bij zijn gezin voegen. ${ }^{50} \mathrm{Zijn}$ collegae Maurits van der 
Reis, Benjamin Pais en Nico van Zuiden belandden wel in Westerbork. ${ }^{\text {Is }}$ Vanwege hun beroep mochten zij echter in dit kamp blijven en werden voorlopig nog niet mee op transport gestuurd met de arbeiders uit de werkkampen. Een groot voorrecht, althans, relatief gezien.

De drie Groningse medici waren nu wel in handen van de bezetter. In retrospectief waren de werkkampen namelijk een opstapje geweest naar de echte nazikampen. De illegale publicatie De Vonk had het in januari 1942 al bij het rechte eind gehad toen ze schreef dat de werkverschaffing eigenlijk maar schijn was, dat de werklozen eigenlijk al in een concentratiekamp zaten en dat het de Duitsers erom te doen was deze Joden samen met alle anderen naar Polen te deporteren en hen uit te roeien. ${ }^{152}$ Een bijzonder heldere vooruitziende blik, aangezien pas op II juni 1942 de definitieve beslissing werd genomen om de Nederlandse Joden inderdaad naar vernietigingskampen in Polen te deporteren. ${ }^{153}$ Presser noemde de tekst in De Vonk dan ook 'een profetisch woord, dat in een mate is vervuld, waar zelfs de profeten zelf nog wel geen voorstelling van gehad zullen hebben.' I54 In de zomer van 1942 werd met de start van grootschalige deportaties en moord door vergassing de voorspelling van De Vonk echter wel degelijk bewaarheid. Ook voor de Joodse artsen brak daarmee een volgende fase aan. 



\title{
4. GENEESKUNDE ALS REDDINGSSLOEP
}

\author{
DE EERSTE MAANDEN VAN DE DEPORTATIES, \\ JULI 1942 - JANUARI 1943
}

Het beroep van arts was voor de Joodse beoefenaars, na in I940 en I94I al te zijn ontdaan van het grootste deel van zijn status, in de eerste helft van 1942 ook ontdaan van voor de bezetting vanzelfsprekende ethische uitgangspunten. Het principe van objectief keuren hadden de artsen grotendeels verlaten. In plaats van beter wilden zij hun patiënten die ter keuring waren opgeroepen, zieker maken. Nieuwe mogelijkheden van het artsenberoep werden daarmee ontdekt, mogelijkheden waarvan het vóór de bezetting ondenkbaar was geweest ze in te zetten. Tegelijkertijd wankelde ook steeds meer hun eigen veiligheid. Terwijl in de eerste twee jaar van de Duitse bezetting de Joden in Nederland ten prooi waren gevallen aan stelselmatige uitsluiting, discriminatie en vernedering en sommigen ook al aan moord, was zich bij de Berlijnse machthebbers steeds vastomlijnder gaan aftekenen wat de uiteindelijke 'Endlösung' voor het 'Jodenvraagstuk' moest zijn: genocide, en wel op geïndustrialiseerde wijze.' Vanaf juli 1942 werden hiervan de consequenties voelbaar voor de Nederlandse Joden en daarmee ook voor de Nederlandse Joodse artsen. Wat te doen? Kon het artsenberoep nú nog iets betekenen?

\section{JULI 1942: EEN DRAMATISCHE CESUUR}

Op 26 juni 1942 ontbood Ferdinand Hugo Aus der Fünten, een van de leiders van de 'Zentralstelle für jüdische Auswanderung', het orgaan dat verantwoordelijk zou worden voor de 'Polizeilicher Arbeitseinsatz im Osten' van de Am- 
sterdamse Joden, een driekoppige delegatie van de Joodsche Raad. Deze delegatie kreeg het ontstellende nieuws te horen dat het in de bedoeling lag vanaf medio juli per dag enkele honderden Nederlandse en van oorsprong Duitse Joden, tussen 16 en 40 jaar, naar werkkampen in Duitsland te sturen. Tussen I4 en 17 juli zouden de eerste 4000 reeds vanuit Amsterdam moeten vertrekken. Via het 'doorgangskamp' Westerbork, waar zij medisch gekeurd zouden worden, zouden zij per trein naar hun bestemming over de grens worden gebracht. Aan dit plan kon niet getornd worden. De eerste oproepen om zich voor deze Polizeilicher Arbeitseinsatz te melden, vielen bij de ongelukkigen op de mat op zondag 5 juli 1942. ${ }^{2}$ Het bericht sloeg onder de Joodse bevolking in als een bom, en de vraag rees onmiddellijk: moest men hieraan gehoor geven? Was dit te vertrouwen? Kon men zich nog aan deze tewerkstelling onttrekken? Maar als men dat deed, zou men dan niet zwaar gestraft worden? De naam Mauthausen zong rond als afschrikwekkende strafmaatregel bij ongehoorzaamheid.

Wat men precies van deze tewerkstelling mocht verwachten, wist men niet, maar men had er grote weerstand tegen. ${ }^{3}$ Presser schreef over de stemming onder de Joodse bevolking: 'Het pessimisme, de twijfelmoedigheid moeten ver en ver overwogen hebben.' 4 Die angst zwol nog aan toen de Joden vanaf 3I augustus 1942 's avonds rechtstreeks thuis werden opgehaald, omdat het systeem van oproepen per post naar de smaak van de bezetter te weinig effect sorteerde. De opkomst was telkens te laag om de door de bezetter nagestreefde cijfers te halen. Vanaf de inwerkingtreding van deze rechtstreekse ophaalaanpak zat men iedere avond thuis - na achten 's avonds moesten Joden immers verplicht thuis zijn - in spanning en met gespitste oren te luisteren of er een overvalwagen de straat in reed. ${ }^{5}$ Joodse Amsterdammers die uit hun huizen werden gehaald, bracht men naar de Hollandsche Schouwburg aan de Plantage Middenlaan. Het theater had tot voor kort dienst gedaan als enkel voor Joden toegankelijke schouwburg en werd nu als verzameloord voor gearresteerden het toneel van een hartverscheurend reëel schouwspel. ${ }^{6}$ Ook buiten Amsterdam voltrok zich dit schouwspel, niet georganiseerd door de 'Zentralstelle' maar door het 'Judenreferat IV B4' vanuit Den Haag. Presser: 'Van juli 1942 af overschaduwden de wegvoeringen het hele Joodse leven; hun meedogenloos ritme bepaalde de gang van het Joodse bestaan dat onontkoombaar en onophoudelijk afbrokkelde, als een eiland, dat door steeds optredende vloedgolven geteisterd, elke keer kleiner wordt en tenslotte in de oceaan verdwijnt.' ${ }^{\text {}}$

De bezetter had inderdaad als doelstelling dat er geen enkele Jood in Nederland meer over zou blijven, maar liet dat nog niet al te duidelijk merken. Hij pakte de deportaties zo aan dat er ondanks de 'vloedgolven' elke keer een stukje droog land over leek te blijven. De deportaties geschiedden niet in één keer: 
telkens was er sprake van uitzonderingscategorieën en uitzonderinggevallen die voorlopig niet weg hoefden. Degenen die nog op een dergelijk 'eiland' verkeerden 'leefden immers in die tijd door, zoveel mogelijk zich aanpassend aan de nieuwe situatie, hopend of wanhopend. ${ }^{8}$ Presser vergeleek de toestand, in navolging van Abel Herzberg, ook treffend met een schipbreuk, waarbij de opvarenden in paniek de reddingsboten trachtten te bereiken, 'liefst de zeewaardigste'. ${ }^{9}$ Een zoektocht naar een zeewaardige reddingsboot was geboden. 'Men joeg op papieren, op Ausweise, men bedelde om één week uitstel, men verschafte "bewijzen", doktersvoorschriften, men was gedoopt, gewond, invalide. 'ro

Een reddingsboot heette in de realiteit van de nazomer van 1942 een 'Sperre', een stempel in het persoonsbewijs waarop 'Bis auf weiteres freigestellt vom Arbeitseinsatz' stond. Die werd aan circa 8500 Joden toegekend vanwege het behoren tot een bepaalde uitzonderingsgroep, zoals de protestants gedoopten, de Joden met een buitenlandse nationaliteit, degenen van wie de afstamming nog in onderzoek was bij Calmeyer, gemengd gehuwden en aan circa 16 ooo Joden die voor een industrie werkten die voor de bezetter noodzakelijk was. Bovendien waren zieken ook 'ausserhalb der Aktion' en hoefden niet mee. ${ }^{\text {II }}$ Eind september 1942 kon de Joodsche Raad bovendien 17500 eigen stempels verdelen. ${ }^{12}$ Of men tot deze 17500 uitverkorenen zou horen, beoordeelden de leiders en de vrijstellingscommissie van de Joodsche Raad. ${ }^{13} \mathrm{Zij}$ kozen de eigen medewerkers en andere 'onmisbaren', zoals artsen. Het aantal stempels was veel en veel te laag voor de circa 140 ooo Nederlandse Joden. Slechts ongeveer een derde van hen kon middels een stempel in de loop van de herfst van 1942 bescherming vinden. ${ }^{14}$ Tot overmaat van ramp verloren de Sperren een voor een hun geldigheid en waren telkens nóg minder mensen beschermd. Het ging hier dus om een schipbreuk waarbij telkens opnieuw aanvankelijk veilig geachte reddingssloepen vergingen. Het moeten kiezen tussen mensen die voorlopig - gespaard moesten worden, werd hét terugkerende dilemma van de Joodsche Raad. Velen hebben de Raad zijn handelwijze kwalijk genomen, maar Abel Herzberg schreef:

De mensen van de Joodse Raad deden wat alle mensen altijd doen. Als ze te kiezen hadden tussen iemand die hen lief was en een vriend, kozen ze de eerste. En als ze moesten kiezen tussen een vriend en een kennis, kozen ze de vriend. Moesten ze kiezen tussen een kennis en een vreemde, dan kwam de kennis aan de beurt. [...] Weg waren alle principes, behalve dat ene, dat toch ook werkt in ons hart als een wet van God: de verantwoordelijkheid voor wie ons lief zijn. [...] Ach mijn lief nageslacht, wees niet al 
te boos op ons, als je denkt aan die boze tijd onzer vervolging. Wij hebben voor problemen gestaan, die ons hebben aangegaapt uit een bodemloze afgrond. ${ }^{15}$

\section{HET'SAUVE QUI PEUT'}

Ook de Joodse artsen trachtten hun eigen deportatie te voorkomen en moesten daartoe balanceren op de 'droge stukjes land' of een 'zeewaardige reddingsboot' vinden. De paniekstemming die ontstond na aanvang van de deportaties in juli 1942 ging aan hen niet voorbij, maar niet zelden waren zij in staat wegen te vinden om inderdaad droge voeten te houden en zich voorlopig met hun beroep tegen wegvoering te beschermen. Dat hun beroep geen absolute bescherming bood, was al gebleken uit het feit dat er bij elkaar opgeteld al ten minste zeventien Joodse artsen in de periode voorafgaande aan juli 1942 gearresteerd en gedeporteerd waren. Maar net als Jacques Reisel, die in I94I door zijn beroep aan transport naar Mauthausen was ontkomen, hadden veel Joodse artsen een aanzienlijk netwerk van contacten die iets voor hen konden betekenen. Die relaties werden nu van vitaal belang. Een van de belangrijkste contacten was uiteraard dat met de Joodsche Raad.

Voor enkele artsen die in 1942 in een benarde positie verkeerden of op het punt stonden gedeporteerd te worden, deed de Joodsche Raad ook daadwerkelijk veel moeite. Dit was vlak voor de start van de deportaties al het geval geweest toen de geneesheren-directeur Salomon Kroonenberg van het NIZ en Jacques Buzaglo van De Joodsche Invalide in mei 1942 opnieuw krijgsgevangen waren gemaakt vanwege hun eerdere functie als officier van gezondheid van het Nederlandse leger. De Joodsche Raad had alles in het werk gesteld om deze twee weer vrij te krijgen. ${ }^{16}$ Ook de hulp van Cees Banning, geneeskundig hoofdinspecteur, was hiertoe ingeroepen. ${ }^{17}$ Dit had geresulteerd in de vrijlating van de twee eind juni. ${ }^{18}$ Tijdens Kroonenbergs afwezigheid had internist Louis Schaap het directeurschap van het NIZ waargenomen. Kort na het begin van de deportaties moest de Joodsche Raad echter ook voor hem in de bres springen. In de Rubensstraat in Amsterdam-Zuid, waar Schaap met vrouw en twee zoons woonde, werd op 9 augustus 1942 een grote razzia gehouden als vergelding voor de magere opkomst op oproepen voor tewerkstelling. Aus der Fünten en zijn mannen voerden 300 Joden uit Amsterdam-Zuid naar het Adama van Scheltemaplein, vanwaar zij gedeporteerd zouden worden, zelfs zonder dat zij tijd kregen een koffertje van huis te halen. Joodsche Raadvoorzitter David Cohen kreeg op deze onheilsplek de mogelijkheid twintig mensen 
uit te kiezen die naar huis zouden mogen terugkeren. Een taak die Cohen innerlijk verscheurde, maar die hij uitvoerde met als voor hem te verantwoorden criterium: onmisbaarheid voor de Joodse gemeenschap in Amsterdam. ${ }^{19}$ Vooraanstaand en naar Cohens oordeel onmisbaar arts Louis Schaap en zijn gezin waren onder de gelukkigen die naar huis mochten terugkeren. De 25-jarige Rita Simons, diëtiste van de ciz, die bij de familie Schaap inwoonde, behoorde niet tot de uitverkorenen. Zij moest wel mee. ${ }^{20}$ Ook de artsen Emanuel Roselaar, Jacob Roos, Simon de Vries, Moritz Gomperts, Jacques Gompertz en Hugo Salvendi werden in de augustusdagen van 1942 gedeporteerd. Zij waren - op Hugo Salvendi na - allen inwoner van Amsterdam-Zuid en vermoedelijk eveneens bij de razzia van 9 augustus gearresteerd. ${ }^{2 \mathrm{I}} \mathrm{Zij}$ werden vervolgens, met uitzondering van Simon de Vries, via Westerbork gedeporteerd naar vernietigingskamp Auschwitz. Hun beroep had daarin niets uitgemaakt.

Voor de op 9 oktober 1942 gearresteerde Izaak van Esso en zijn vrouw Louise van Esso- van Son deed de Joodsche Raad weer wel veel moeite. ${ }^{22}$ Dat juist deze zeer bekende Amsterdamse arts opgepakt was, moet als een grote schok in wijde kring gevoeld zijn. De eerste poging om Van Esso en zijn echtgenote vrij te krijgen, ondernam echter niet de Joodsche Raad, maar hun dochter Ima. Toen zij haar ouders in de gevangenis aan de Amstelveenscheweg probeerde vrij te praten, werd ze gearresteerd en naar de Zentralstelle overgebracht. Hier fingeerde zij met hulp van de Joodse verpleger aldaar, een maagzweer, waarop zij naar huis mocht. ${ }^{23}$ Izaak en Louise van Esso gingen ondertussen naar Westerbork. Op i9 november, toen verder transport voor Van Esso en zijn echtgenote dreigde, stuurden David Cohen en Abraham Asscher ss-Sturmbannführer Willy Lages van de Zentralstelle für jüdische Auswanderung een brief met het dringende verzoek kampcommandant Albert Konrad Gemmeker te bellen om de Van Esso's in Westerbork te houden. ${ }^{24}$ Klaarblijkelijk sorteerde dit effect, want Izaak en Louise van Esso werden voorlopig niet verder gedeporteerd, maar verbleven uiteindelijk nog tot januari 1944 in Westerbork. ${ }^{25}$

De arrestatie van de Van Esso's stond niet op zichzelf. Ten minste 54 andere Joodse artsen werden al vroeg in de deportatieperiode, tussen juli 1942 en januari 1943, gearresteerd. ${ }^{26}$ Vermoedelijk hadden in elk geval vier van hen zich actief ingelaten met verzet en waren in verband daarmee opgepakt, en van zeven van hen staat vast dat zij gearresteerd werden tijdens een vluchtpoging naar het buitenland. Een van hen, de Roermondse arts en jurist Richard Bromberg, was gearresteerd in het kader van de actie tegen katholiek gedoopte Joden. De katholieke kerk had op zondag 25 juli een officieel protest tegen de Jodenvervolging laten voorlezen en als vergelding waren ongeveer 250 katholieke Joden, onder wie Bromberg en zijn gezin, naar Kamp Amersfoort overgebracht. Een 
deel van hen was vervolgens naar Westerbork en Auschwitz gedeporteerd. Of het door zijn artsenberoep of eerder door zijn vooraanstaande positie als voormalig voorzitter van de Raad van Beroep en het Ambtenarengerecht kwam, Richard Bromberg werd op 23 augustus, met vrouw en kinderen, weer naar huis gestuurd. ${ }^{27}$

De andere 42 artsen werden vermoedelijk gearresteerd vanwege het feit dat ze Joods waren en de bezetter toevallig in hun buurt een razzia hield. Hoe het ook zij, dat zij arts waren had hun arrestatie niet kunnen voorkomen. Berthold Stokvis calculeerde dan ook in september 1942 dat in geval van arrestatie er 'dan nog wel een kans [bestaat], dat ik als arts vrijkom, maar een even grote kans, dat zulks niet gelukt'. ${ }^{28}$ Dat veel Joodse artsen, onder wie Stokvis, door de Joodsche Raad aangeboden bescherming aannamen, is niet verwonderlijk. Zij ontvingen een Joodsche Raad-Sperr. Een dilemma waar ook de artsen, net als alle anderen die voor een dergelijke Sperr in aanmerking kwamen, zich niet aan konden onttrekken was: konden zij zichzelf laten veiligstellen als anderen daarmee de kans op bescherming misliepen? Sally de Jong duidde het gewetensconflict in zijn manuscript als volgt: "Het "sauve qui peut" dat enkele maanden tevoren reeds begonnen was bij de oproepingen voor de werkkampen, werd nu, in begin Juli, oneindig veel sterker. Het was de eenige mogelijkheid, voorloopig het eigen lijf te redden ten koste van anderen: in dienst van de Joodsche Raad kon men vooralsnog in Nederland blijven.'29

Artsen traden nu in dienst van de Joodsche Raad of werden vanwege hun eigen al bestaande functie, bijvoorbeeld in Joodse ziekenhuizen, door de Joodsche Raad 'gesperrt'. In de - slechts deels bewaard gebleven - cartotheek die de Joodsche Raad bijhield van alle Joden in Nederland, zijn de persoonskaarten van 398 Joodse artsen terug te vinden. Op I55 van deze kaarten staat aangetekend dat de betrokkene gesperrt was wegens de functie die hij of zij vervulde. Meestal werd deze functie dan uitgebreid omschreven. Verder staat bij nog eens 46 artsen weliswaar niet letterlijk 'gesperrt wegens functie', maar wel een even uitgebreide functieomschrijving, wat de indruk wekt dat ook dat onmisbare functies waren.

De functies die op de kaarten worden aangegeven, variëren van een echt - soms al langere tijd bestaand - dienstverband bij de Joodsche Raad, zoals bij de Voorlichtingsdienst of als gedetacheerd arts bij de Zentralstelle, tot een vermelding van de eigen oorspronkelijke, onmisbaar geachte functie, zoals die van specialisten in de ziekenhuizen. ${ }^{30}$ Meerdere andere artsen werden nu als docent bij de artsencursus genoemd of bijvoorbeeld als medisch adviseur voor een plaatselijke afdeling van de Joodsche Raad. Anderen werden arts voor de medische sportkeuring van Joodse kinderen die met de 'Buitenschoolse 
Jeugdzorg', een andere Raadsafdeling, mee wilden sporten of arts voor de blindenzorg voor Joodse blinden. ${ }^{31}$ Ook controleerden artsen van de medische afdeling van de Joodsche Raad aan huis bij ziekte van de eigen Joodsche Raadmedewerkers. ${ }^{32}$ Controles voerde de medische afdeling eveneens uit bij Joodse rusthuizen. ${ }^{33} \mathrm{Zij}$ beoordeelde of een dergelijk rusthuis aan de gestelde criteria voldeed. ${ }^{34}$ Ook leidde de Joodsche Raad het al voor de oorlog bestaande Joodsch Psychiatrisch Consultatiebureau, dat nu extra drukte kende vanwege het grote aantal mensen dat door de omstandigheden in psychische nood was geraakt. ${ }^{35}$ Daarnaast bestaan er 32 Joodsche Raadkaarten van artsen waarop niet de precieze functie is aangegeven, noch vermeld staat dat de betreffende arts gesperrt was, maar waar wel met een blauw potlood JR of JRM (Joodsche Raad of Joodsche Raad Medische afdeling) staat aangetekend. Wat dit betekende, blijft ongewis. ${ }^{36}$

De cartotheek is onvolledig en van sommige artsen is alleen een naoorlogse registratiekaart bewaard, wat verklaart waarom de gevonden cijfers niet de gehele Joodse artsengroep beschrijven. Maar als pars pro toto geeft het gevonden resultaat wel de indruk dat veruit het grootste deel van de artsen door de Joodsche Raad beschermd werd. Die indruk had het publiek destijds ook, getuige het dagboek van Salomon Koster, die beschreef hoe een patiënte hoopte mee te kunnen delen in de bescherming die hij als arts genoot: 'Dokter, ik kom niet als patiënte, maar ik kom u vragen, of ik niet uw assistente kan worden, dan krijg ik een stempel van de Joodsche Raad, u hebt er zelf zeker ook al één?'37

Hoewel Koster op dat moment zelf nog geen Sperr had en het hele stempelgebeuren nog nieuw voor hem was, nam hij de patiënte inderdaad in dienst en schreef hij een briefje voor de Joodsche Raad dat zij onmisbaar voor hem was. Enkele pagina's later schreef hij in zijn dagboek over de verbazing die hij had over de arrestatie van een collega, want die collega 'heeft toch zeker een stempel gekregen, zoals de andere doktoren?'38 Op dat moment ging hij er kennelijk al van uit dat het arts-zijn automatisch tot een Sperr-stempel leidde. Joseph Kater schreef in zijn dagboek hoe hij en zijn Amsterdamse collegae naast een Sperr ook een band met het woord 'Arts' om hun arm kregen, bij wijze van een speciale vergunning om op straat te komen en niet gearresteerd te worden als er toevallig mensen van de straat opgepakt werden. 'Dat gebeurde menigmaal terwijl ik langsreed.' 39

In de privéarchieven van Jacob Goudsmit en Louis Schaap, collega-internisten in het NIZ, is nog de oproepbrief te vinden waarmee de beide specialisten in oktober 1942 naar de Zentralstelle werden geroepen, alwaar zij de felbegeerde stempel in hun persoonsbewijs konden laten zetten. ${ }^{40}$ Ook van Albert Denekamp, een jonge Haagse arts, is een dergelijke oproep bewaard geble- 
ven. ${ }^{\text {II }}$ David Hausdorff uit Rotterdam was medisch adviseur van de Joodsche Raad in Rotterdam. Daarnaast was hij ook lid van de financiële commissie van een van de afdelingen van de Joodsche Raad, namelijk de Joodsche Centrale voor Beroepsopleiding. Op 8 oktober 1942 kon hij bij de Zentralstelle in Amsterdam een vrijstellingsstempel komen halen. ${ }^{42}$ De dochter van psychiater Herman de Levie herinnerde zich dat niet alleen haar vader door de Joodsche Raad beschermd werd, maar dat ook zijzelf via hem een baantje bij de raad kon krijgen, dat levensreddend bleek te zijn. ${ }^{43}$ In principe gold de Joodsche RaadSperr van de arts ook voor inwonende echtgenoten, kinderen en ouders. Een Joodsche Raad-Sperr was dus voor de hele familie een kostbaar en nastrevenswaardig bezit. Weigeren van zo'n Sperr was daarmee niet voor de hand liggend. Huivering bestond er echter wel onder artsen.

Het artsenechtpaar Jonas en Lena Jacobs-Melkman kreeg in oktober 1942 eveneens een Sperrstempel, zoals Lena in een brief van is oktober aan haar oud-collega Westerhoff schreef, maar had er gemengde gevoelens over. Jonas Jacobs werkte weliswaar voor de medische afdeling van de Joodsche Raad, op kantoor aan de Lijnbaansgracht 366, wat de verwachting gaf dat hij goed gesperrt zou zijn. ${ }^{44} \mathrm{Zijn}$ vrouw Lena had er echter weinig vertrouwen in dat hun stempel echt duurzame bescherming zou bieden:

Ondertusschen hebben we onze 'stempel'. We hadden onze rugzakken al uitgepakt, maar ik ga ze weer inpakken, want de beroemde Bolle [Max Bolle, prominent vertegenwoordiger van de Joodsche Raad] en de opperrabbijn zijn gepakt en door hun stempel wordt een tweede 'ungültig' gedrukt. Dat is de waarde van de hele stempelarij, waar men zich zo dik om maakt. De Joden moeten nu eenmaal uitgeroeid worden en het is een dwaasheid te denken dat je net de eenige of een van de weinigen zult zijn, die niet uitgeroeid zullen worden. En toch moet je die dwaasheid wel denken, want dat is de eenige manier om de moed erin te houden. Want de andere mogelijkheid, namelijk de wedloop met 't einde van de oorlog winnen, lijkt wel hoe langer hoe kleiner te worden. ${ }^{45}$

Ondanks haar wantrouwen liet Lena Jacobs niet na deze kans op uitstel toch maar aan te grijpen. Een andere reële optie was er net als voor vele anderen niet.

Naast argwaan ten opzichte van de bestendigheid van de bescherming zijn er ook getuigenissen van afkeer ten opzichte van de Joodsche Raad in zijn algemeen. Stokvis vermeldde in zijn dagboek de bijnamen van de Joodsche Raad: 'het Joodsch Verraad, de Bloedraad, het Joodsche Onraad.' ${ }^{6}$ Twijfels 
over de morele juistheid van het aangaan van een connectie met de Joodsche Raad waren hem dan ook niet vreemd. Hij verweet zichzelf dat hij een baantje bij de Voorlichtingsdienst van de Raad had aangenomen: 'Zo heb ik - onnadenkend - gecapituleerd [...] Zoo profiteerde ik van het ongeluk van mijn broeders en zusters. Ik pleit mijzelf geenszins vrij, al ben ik ook maar een onbeduidend radertje in de duivelsche machinerie geweest.' 47 Toen Stokvis zelf toch een oproep voor tewerkstelling ontving en hem geadviseerd werd bij de Joodsche Raad voor hulp aan te kloppen, omdat hij immers - overigens belangeloos - voor de Raad werkte, had hij het gevoel voor de tweede maal te capituleren. ${ }^{48}$ Hij bleek niet immuun voor zijn eigen menselijke overlevingsdrang. Paradoxaal genoeg kon hij echter wel door zichzelf veilig te stellen ook arts blijven en daarmee nog iets voor anderen betekenen.

De taken die de artsen in dienst van de Joodsche Raad uitvoerden, waren, zoals Berthold Stokvis al voelde, onderdeel van de bekritiseerde instelling en daardoor van de 'duivelsche machinerie'. Maar de artsen konden wel nog iets in het geweer brengen tegen het onrecht dat zij om zich heen zagen gebeuren. Juist het blijven vervullen van een artsentaak, ook al was dat onder een bedenkelijke werkgever, bood hun mogelijkheden om ook anderen een 'reddingssloep' te bieden. Zo probeerde Stokvis zo veel mogelijk bruikbare ziekteattesten voor mensen te verzorgen. Als hij aannemelijk kon maken dat iemand te ziek was om gedeporteerd te worden, verzorgde hij daarmee dus een reddingsmogelijkheid voor zijn patiënt. Stokvis kon aldus zijn beroep nog voortzetten, iets wat onmogelijk zou worden op het moment dat hij niet meer voor de Joodsche Raad zou werken en zou moeten onderduiken: 'Een dokter's dilemma. Het is september 1942 . Ik leef nu half ondergedoken. Wanneer ik mijn patiënten niet had en mijn ouders niet alleen wilde laten, dan was ik stellig geheel en al "gedoken". ' ${ }^{9}$ De pas afgestudeerde arts Hetty Fortuin-Blitz trachtte ook het beste te maken van haar werk voor de Joodsche Raad in Den Haag. Na het begin van de deportaties had zij als arts de taak gekregen om bij de vertrekkende deportatietreinen medische hulp te verlenen. Zij kon in die rol 'Godzijdank een paar mensen uit de transporten weghouden'. Bijvoorbeeld toen zij tegen een dronken Duitse bewaker zei dat een hysterisch geworden vrouw niet mee kon met het transport: 'Die kann nicht mit. Muss operiert worden,' vertelde Hetty hem. De vrouw hoefde niet mee. Dat een dergelijke actie niet zonder gevaar was, bleek ook: de Duitser meldde dat er ook een arts met het transport mee moest. Doordat Hetty koel bleef en resoluut antwoordde dat zij daar niets van wist, hoefde ze niet in te stappen. ${ }^{50}$

Ook bij de Zentralstelle für jüdische Auswanderung, het centrum van de politionele Jodenvervolging in Amsterdam, waar ook enkele Joodsche Raad- 
personeelsleden werkten, zagen de artsen onder hen dankzij hun beroep kans iets voor de gevangen Joden te doen. Bernard de Vries Robles bijvoorbeeld was door Salomon Spijer van de medische afdeling van de Joodsche Raad aangesteld als arts bij de Zentralstelle, nadat ook hij eerst bij de afdeling Voorlichting attesten had verbeterd. In zijn nieuwe hoedanigheid kon De Vries Robles de stempels die op de Zentralstelle werden gebruikt voor vrijstellingen vervalsen, evenals 'blauwe formulieren' (velerlei vergunningen). De Vries Robles ontvreemdde, zo herinnerde hij zich later, de bruine potloden waarmee Aus der Fünten zijn papieren placht te ondertekenen, zodat hij diens gewilde handtekening kon vervalsen. Op die manier konden valse vrijstellingen worden verkregen. In een dubbele bodem van zijn draagbare medicijnkist verborg De Vries Robles deze kleinoden, aldus zijn eigen getuigenis. ${ }^{5 \mathrm{I}}$ De artsen die voor de Joodsche Raad werkten hadden dus behalve zichzelf droge voeten bezorgd, ook anderen nog een 'reddingssloep' te bieden.

\section{SCHWEITZER-WERK IN WESTERBORK}

Het vrijstellingsbeleid van de artsen leverde ook kritiek op, want waren niet 'hun diensten tijdens de reis en in Polen minstens net zo hard nodig [...] als hier te lande'?52 De behoefte aan artsen verplaatste zich tijdens de deportaties immers met de gedeporteerden mee. Het deel van de Joodse bevolking dat door de nazi's op de trein naar Westerbork was gezet, had net zozeer behoefte aan medische verzorging. Er waren in Westerbork dan wel een paar DuitsJoodse artsen, die er al sinds 1939 verbleven, maar met het groeien van de populatie in het kamp nam de vraag naar artsen toe. Logisch gevolg was dat men artsen probeerde bereid te vinden om de nood aldaar te lenigen. De Joodsche Raad deed een beroep op hun gevoel van zorgplicht toen hij enkele, meest jonge artsen het verzoek voorlegde om vrijwillig naar Westerbork te gaan.

De Contact Commissie van de Joodsche Raad nam de taak op zich om medici voor Westerbork te zoeken. ${ }^{53}$ De artsen die zij benaderde, praatten onderling natuurlijk over dit verzoek: zouden zij het wel of niet doen? De artsen zouden medische hulp kunnen verlenen aan de grote groepen gedeporteerden die in het najaar van 1942 het kamp gingen bevolken. Daarmee zouden zij hun beroep kunnen uitoefenen en noodlijdenden kunnen helpen. Bovendien beloofde men hun dat zij in dienst van de Joodsche Raad zelf een beschermde en bevoorrechte positie zouden hebben. $\mathrm{Zij}$ zouden niet verder op transport gesteld worden en goede huisvesting krijgen. Hun vertrouwde leven en woonomgeving moesten zij hiermee echter wel vaarwel zeggen, en zij moesten afrei- 
zen naar een oord waar velen met argwaan naar keken en probeerden juist zo ver mogelijk vandaan te blijven. Geen eenvoudige keuze. Wat woog voor ieder van hen het zwaarst: de wil om als arts te werken en de nood in Westerbork te lenigen plus de zoektocht naar bescherming? Of juist afkeer van de Joodsche Raad dan wel wantrouwen jegens de bestendigheid van de positie?

Arnold Rodrigues Pereira, zoon van de Amsterdamse gemeentearts Elazar Aäron Rodrigues Pereira, was in 1942 semi-arts en zou ook in dat jaar artsexamen doen, ware het niet dat hij een longontsteking kreeg en achteropraakte met de studie. Eenmaal fysiek hersteld was de universiteit voor hem als Joods student gesloten. Arts zou hij voorlopig nog niet kunnen worden. Het verzoek van de Joodsche Raad om vrijwillig in Westerbork te gaan werken kon dus niet aan hem gericht worden. Om zich heen zag en hoorde Arnold echter dat vrienden wel voor deze keuze werden gesteld. Bijna zeventig jaar na dato was hij nóg dankbaar dat hij zelf niet gevraagd werd. Immers, hij zou zeker ja gezegd hebben: 'Dat was je mensenplicht en je plicht als arts,' zo vond hij. Dat dit zijn eigen overlevingskansen danig en in negatieve zin beïnvloed zou hebben, besefte hij in 2011 terdege. ${ }^{54}$

Carel Wolff, net afgestudeerd arts en werkzaam als assistent interne geneeskunde in het NIZ, besefte dat destijds al. Hij werd op zekere dag ontboden bij David Cohen en Salomon Spijer. Cohen spiegelde hem een bevoorrechte positie als arts voor als hij eenmaal in Westerbork zou zijn gearriveerd, maar het idee stond Wolff niettemin direct tegen. Hij weigerde. Volgens eigen zeggen niet uit angst, maar meer vanuit het gevoel dat zijn aanwezigheid daar niets uit zou maken, hij daar toch niets kon betekenen en dat voor hemzelf het enige voordeel zou zijn dat hij 'in witte jas tenonder zou gaan'. Hij besprak zijn weigering met internist Ju Groen, die op dat moment in de Centraal Israëlietische Ziekenverpleging werkte. Groen gaf hem groot gelijk. ${ }^{55}$

Eddy de Wind begaf zich op Io oktober 1942 wel vrijwillig naar Westerbork. Althans, hem was gezegd dat zijn hier geïnterneerde moeder door zijn werkzaamheden beschermd zou zijn. Voor hem was dit onmiskenbaar op zijn minst een zwaarwegende bijkomende reden om naar het kamp af te reizen, maar, toen hij er arriveerde, was zijn moeder al doorgestuurd. Bijna een jaar lang woonde en werkte De Wind er, in een van de ziekenbarakken. Hij ontmoette er een verpleegster en huwde haar in het kamp. Met zijn echtgenote en een tweede arts woonde hij in de 'dokterskamer', een groot woord voor een kartonnen doos, afgeschut van de barak waar I30 vrouwen leefden. ${ }^{56} \mathrm{Het}$ voorrecht dat hij genoot, was wat betreft comfort zeer relatief. Het cruciale verschil tussen hem en zijn patiënten was dat hij niet met de deportatietrein mee hoefde. Ook kon hij, als employé van de Joodsche Raad voor Amsterdam, 
tussen Westerbork en Amsterdam op en neer reizen, zodat hij bijvoorbeeld bijeenkomsten van het Amsterdamsch Joodsch Psychiatrisch Gezelschap kon bijwonen.

Ook Sally de Jong bleek bereid naar Westerbork af te reizen. ${ }^{57} \mathrm{Hij}$ zou zijn ervaringen in het kamp in een verslag optekenen. De derde vrijwilliger was Paul Stibbe, een 32-jarige arts afkomstig uit Meppel, die zich in Utrecht gevestigd had. ${ }^{8}$ Vanuit die stad begeleidde hij vrijwillig een transport naar Westerbork:

Bij het eerste transport uit Utrecht naar Westerbork in augustus 1942 ging een aantal zieken mee en ik bood aan als vrijwilliger dit transport te begeleiden, waar ik kennis maakte met de Joodse chef arts in Westerbork, Spanier en de hoofdverpleger broeder Gottschalk. De volgende dag per trein terug naar Utrecht. Op 6 november werd door Aus der Fünten op mijn papieren aangetekend: als Lagerarts, en zo werd ik lid van de medische staf in Westerbork. We hadden daar een kamertje in barak 42, kregen post en af en toe een pakket via de groenteboer ter Brugge uit Meppel of de wasserij Tap, zodat het leven niet al te zwaar bleek. ${ }^{59}$

Albert Denekamp, Haags arts, toog eveneens vrijwillig naar Westerbork, en wel op I2 oktober 1942. De Haagse Joodsche Raad-vertegenwoordiger Henri Edersheim stuurde hem het bewijs van indiensttreding toe. ${ }^{60}$ De jeugdige arts Juda Buys kwam eveneens medio oktober 1942 in Westerbork aan en bleef er lange tijd werkzaam als kamparts. Het is mogelijk dat ook hij bij de groep vrijwilligers hoorde. ${ }^{61}$

Waarom deze artsen precies op het verzoek tot werken in Westerbork ingingen, is niet voor ieder van hen meer te achterhalen, maar hun besluit was waarschijnlijk - naast de eigen zoektocht naar een veilige positie - in elk geval deels te verklaren uit verantwoordelijkheidsgevoel, uit hun taakopvatting als arts. De deugdenethiek en paternalistische zorgplicht waarin de artsen waren opgeleid, sloten aan bij dit gedrag. Jacques Reisel oordeelde echter begin 1943 in zijn dagboek met een verwijzing naar Albert Schweitzer, de Frans-Duitse theoloog en arts die in I9I3 in Afrika eeen ziekenhuis had gesticht, dat deze idealisten inmiddels hadden gemerkt dat de reële situatie toch anders was geworden: 'Welke romantische idealen niet omtrent Westerbork gemaakt zijn, de medici die zich hebben laten verleiden tot werk van Schweitzer-allure, gecombineerd aan de verstandelijke overweging van goede dekking, zijn bedrogen uitgekomen. Ziekentransportlijsten maken, een werk dat geen mens, geen Jood en zeker geen arts mag doen. Hands off!'62 
Op het moment van schrijven, 7 februari 1943, waren er inderdaad net tevoren diverse transporten met zieken uit Westerbork richting onbekende bestemming vertrokken. Konden en moesten de artsen invloed uitoefenen op wie er nog van zulke transporten kon worden afgehouden? Werkten zij zo niet indirect aan mee? En konden zij met hun geweten in het reine komen keuzes te maken tussen de ene en de andere patiënt? Zij werden hiermee voor dilemma's geplaatst, waarover in het hoofdstuk over Westerbork meer zal volgen. Net als in het geval van de principiële opstelling van de Groningse artsen ten opzichte van de keuringen voor de werkkampen toont het voorbeeld van de vrijwilligers voor Westerbork hier al aan dat een traditioneel gezien nobele opstelling, in de praktijk van de nationaalsocialistische overheersing tot een conflictueuze medisch-ethische situatie kon leiden. Ook in dit geval kon men zich ernstig afvragen of de oude normen nog wel konden gelden.

\section{VLUCHTEN}

Gewetensconflicten over hoe te handelen ten opzichte van de medische zorgplicht hadden ook zij die na de aanvang van de deportaties een vluchtpoging ondernamen. Alles achterlaten of vaarwel zeggen, patiënten incluis, was immers ook nu, net als in eerdere fasen van de bezetting, niet iets wat men zomaar deed. In deze fase kwam het water menigeen echter zozeer aan de lippen dat er toch geen andere goede optie meer mogelijk leek. Maurits Frenkel verwoordde zijn innerlijke tweestrijd op het moment dat hij in najaar 1942 naar Zwitserland vluchtte, zoals eerder geciteerd, als volgt: 'Het ethisch dilemma was het verlaten van de zaak, dat was het voor mij. Ik had geen eed met twee vingertjes opgestoken [...] maar ik voelde mij wel verplicht aan alle verplichtingen die het arts zijn (hoewel ik pas semi-arts was) aan mij oplegde.' ${ }^{63}$

Maurits Frenkel was echter nog relatief ongebonden. Hij werkte in het laboratorium van het NIZ en had geen eigen groep patiënten voor wie hij verantwoordelijkheid droeg, noch had hij een eigen gezin. De artsen die in deze periode Nederland ontvluchtten waren, net als de eerder gevluchte artsen, vaak jong en hadden nog weinig eigen verantwoordelijkheden.

In totaal zeker 24 Joodse artsen hadden al voor juli 1942 een vluchtpoging ondernomen - soms als Engelandvaarder - of waren legaal geëmigreerd. Van nog eens negentien artsen is bekend dat zij in de periode daarna, in de zomer of het najaar van 1942, kort na aanvang van de deportaties, een vluchtpoging ondernamen. Van de in totaal 43 artsen die het land verlieten, zijn er twaalf onderweg gearresteerd. Slechts twee van deze twaalf zouden de oorlog overleven. 
De negentien Joodse artsen die na juli 1942 vluchtten, waren gemiddeld 35 jaar oud. Een flinke dosis jeugdige moed was een voorwaarde voor een hachelijke onderneming als een vluchtpoging. Hannah Koster-Souget, verpleegster in het NIz, herinnerde zich dat vluchten in de algemene opinie als levensgevaarlijk beschouwd werd. Toch besloten zij en haar verloofde Max Koster, die in 1940 zijn artsexamen had gehaald en amper de mogelijkheid had gehad enig eigen patiëntenbestand op te bouwen als waarnemend huisarts in de Amsterdamse Plantagebuurt, het er toch op te wagen. Hun poging slaagde en in september 1942 bereikten zij het neutrale Zwitserland. ${ }^{64}$

Het artsenstel Ben van Esso en Martha Polak is eveneens een voorbeeld van jonge, ongebonden artsen met voldoende moed om de grote sprong te wagen. Zij waren, idealistisch en vol verontwaardiging over het onrecht dat hun werd aangedaan, vastbesloten om over land Engeland te bereiken en vandaaruit een bijdrage te kunnen leveren aan de bevrijding van Europa van het nazi-juk. Ze vertrokken op II juli 1942, vlak nadat het nieuws van de aanstaande Polizeilicher Arbeitseinsatz bekend was geworden. Ben, de oudste zoon van Izaak van Esso, was nog semi-arts, Martha was net afgestudeerd. Drie dagen na haar artsexamen gingen zij op pad. ${ }^{65}$ Bijna een jaar later, op I juli 1943, kwamen zij in Engeland aan, na langdurige en riskante voettochten, treinreizen en interneringen in vluchtelingenkampen in Frankrijk en Spanje. Een fragment uit het lange reisverslag: 'Door controle van de Grüne polizei aan de Fransche grens werd ontdekt, dat eenige lieden met valsche kaarten reisden; deze werden uit de trein gesleept, wij gelukkig niet. Door de verwarring raakten wij de groep kwijt, passeerden zelf de demarcatielijn, 's nachts door een riviertje wadend. ${ }^{66}$

Hun poging om als Engelandvaarder bij te dragen aan de bevrijding van door Duitsland bezet gebied zou slagen, maar zij moesten er grote gevaren voor trotseren. Bens zuster Ima waagde eveneens een poging, met haar verloofde, de jonge arts Loet Micheels. In oktober 1942 vertrokken zij, om al spoedig daarna in België gepakt te worden. Er was verraad in het spel en de auto waarin Loet en Ima zaten, reed regelrecht de garage van een Duits hoofdkwartier in. In het ss-Sammellager Mechelen werden zij geïnterneerd en enkele maanden als arts en verpleegster tewerkgesteld in het kampziekenhuis. ${ }^{67}$ Het artsenberoep gaf Micheels nu enige bescherming, maar bracht hem ook in een lastig parket. Met het vluchten waren de artsen nog niet verlost van alle gewetensconflicten. In januari 1943 stonden Loet Micheels en Ima van Esso op de transportlijst voor Auschwitz. Op het laatste moment echter kwam er een Hollandse dokter het kamp binnen, vergezeld van vrouw en twee kinderen. Ook zij hadden een vluchtpoging achter de rug, en ook zij waren tegen de lamp gelopen. De 
Duitse kampleiding koos ervoor deze oudere arts en niet Micheels en Van Esso op transport te sturen, want dan konden er vier in plaats van twee namen op de lijst gezet worden. ${ }^{68}$ De oudere arts echter vroeg Micheels of ze van plaats konden ruilen, zodat Micheels als transportarts mee zou gaan op transport en de oudere arts zelf als kamparts in Mechelen zou blijven. Hij was immers een ervarener medicus, en daarmee geschikter voor het werk. Bovendien had hij met zijn gezin en zijn verder gevorderde leeftijd minder overlevingskansen dan de jonge Micheels, zo schatte hij in, Micheels daarmee opzadelend met een immens gewetensconflict. Micheels besloot de keuze voor de baan van kamparts aan de kampcommandant voor te leggen. Die koos voor Micheels. De oudere arts en zijn gezin gingen op transport. ${ }^{69}$ Vermoedelijk ging het om de Rotterdamse huisarts Jacob Neuberger, 43 jaar oud, met zijn vrouw Bertha en hun zoon en dochter van respectievelijk I4 en II jaar oud. ${ }^{70}$ Hun gegevens komen het meest overeen met de beschrijving van Micheels. Op is januari vertrok hun trein, op I8 januari 1943 werden zij vergast in Auschwitz-Birkenau. ${ }^{71}$ Wat bij Neuberger, als relatief oud en gebonden arts, de directe aanleiding was geweest om een vluchtpoging te wagen, wordt uit de bronnen niet duidelijk. Mogelijk had Neuberger verzetsactiviteiten ontplooid of zich aan een oproep voor Arbeitseinsatz onttrokken, want de Sicherheitspolizei had op 29 oktober 1942 een opsporingbevel naar hem uitgevaardigd. $7^{72}$

Sieg Gitter, afgestudeerd in 1940, was nog een bescheiden beginnend huisarts toen hij op 6 juli 1942 Amsterdam verliet. Zijn beginnende praktijk aan de Stadhouderskade droeg hij daarbij over aan collega Salco Hertzberger. Hij verkeerde echter in de bijzondere omstandigheid dat zijn vrouw Leah, die hem vergezelde, in verwachting was. In de nachttrein in Spanje begon de bevalling. In dit geval hielp Siegs beroep hem aan collegiale hulp: een Spaanse collega hielp het echtpaar niet alleen bij de geboorte van hun dochter, maar ook bij hun verdere tocht naar Argentinië. Gitter dacht jaren later nog vol dankbare gevoelens terug aan de stilzwijgende, de taalbarrière overstijgende collegiale eensgezindheid en verbondenheid die hij met deze Spaanse collega had gevoeld..$^{73}$

Vluchten was zeker niet eenvoudig en kon ook op pad nog veel gevaren en morele dilemma's opleveren, zo tonen deze voorbeelden. De enige weg om echt van alles af te zijn was ook nu, net als in mei 1940, het plegen van zelfmoord. 


\section{SUÏCIDE}

Voor een vluchtpoging moest men de nodige drempels over, voor een zelfmoordpoging natuurlijk al helemaal. Het was de ultieme manier om alles los te laten. Toch was na aanvang van de deportaties de angst onder de Joodse bevolking dusdanig groot dat velen daartoe overgingen en er sprake was van een tweede suïcidegolf. Pleegden in het eerste halfjaar van 1942 in Nederland gemiddeld vijf Joden per maand suïcide, in juli, augustus, september en oktober 1942 liepen de cijfers voor de tweede maal na de meidagen van 1940 drastisch op. In die respectieve maanden van 1942 ging het om 43, 3I, 44 en 5 I gevallen van zelfmoord door Joden. ${ }^{74}$ Elf Joodse medici hadden in de meidagen van 1940 suïcide gepleegd. Onder degenen die in de maanden na juli 1942 zelfdoding pleegden, waren minder artsen. Van drie Joodse artsen is bekend dat zij hiertoe overgingen. Hoeveel mislukte pogingen er daarnaast onder Joodse artsen voorkwamen, is niet na te gaan, maar er zijn verschillende getuigenissen van pogingen, dan wel zelfmoordplannen bij Joodse artsen. In 1943 volgden nog ten minste twee artsen bij wie de suïcidepoging, op hun onderduikadres, een dodelijke afloop had. ${ }^{75}$

In 1933 had Herman Pinkhof nog in het $N T v G$ een pleidooi gehouden voor de actieve behandeling van mensen die bewusteloos werden aangetroffen na een suïcidepoging. Hij vond dat een arts er in een dergelijk geval goed aan deed de bewusteloze patiënt het leven te redden, en dus tegen diens wil te handelen, want: 'De vernietiging van eigen leven doet te kort aan de belangen der gemeenschap. ${ }^{76}$ Dat deze opvatting onder de medici gangbaar was, is ook in de beschrijving van de suïciden in mei 1940 al getoond. De oorlogsomstandigheden zorgden ervoor dat velen milder over deze daad gingen oordelen, zo bleek ook al in mei 1940. Gezien de nog ernstiger bedreiging waar de Joodse bevolking nu aan was blootgesteld was het begrip in 1942 en 1943 mogelijk zelfs nog groter. Onder deze omstandigheid vond psychiater F.S. Meyers bijvoorbeeld dat de zelfmoorden onder de Joden niet als pathologische reacties te bestempelen waren: 'Zij lijken mij geheel adequaat aan de omstandigheden.' ${ }^{77}$ Sterker nog, psychopathologie als oorzaak voor suïcide kwam zelfs minder voor door de extreme omstandigheden. Meyers merkte niets van de toentertijd 'zoo algemeen aangenomen praedispositie van het Joodsche ras voor nerveuse en psychische stoornissen.' Juist 'een taai weerstands- en uithoudingsvermogen, dat meermalen bewondering afdwong' overheerste bij de getergde Joodse bevolking. ${ }^{78}$ De suïciden die, vaak en famille, plaatsvonden, moesten volgens Meyers ook in dat licht gezien worden: 'Veelal betrof het juist de gezinnen met een ideale gezinssfeer en van een cultureel en moreel niveau. Men moet wel 
onder de indruk komen van de vastheid van wil, van de zelfverzekerdheid van de gezinshoofden, die dat harmonische leven, vrijwillig voor eeuwig vaarwel zeiden. Het waren allen volkomen geestesgezonde menschen en van eenige voorbeschiktheid of ziekelijke aanleg of geestesonevenwichtigheid was bij hen geen sprake. 79

Deze beschrijving lijkt geheel toepasbaar op in elk geval een van de artsen die in najaar 1942 een einde aan zijn leven besloot te maken. Het ging om de zoon van Herman Pinkhof. Oogarts Jakob Pinkhof, zijn vrouw Branca Asscher en hun drie kinderen stierven in september 1942 aan suïcide nadat zij na twee dagen onderduik gedesillusioneerd terug in hun huis in AmsterdamZuid waren gekomen. ${ }^{80}$ Jakobs zuster Clara zou die gebeurtenis later in haar boek Danseres zonder benen beschrijven:

Mijn derde broer, op wie ik in leeftijd volgde, was oogarts. Hij woonde tegenover het Duitse hoofdkwartier, waar dag en nacht overvalwagens voorreden om hun geroofde mensenlading uit te braken. De kreten en de schreeuwen, van mishandelde en mishandelaar, drongen, vooral 's nachts, ononderbroken tot hen door. Als er Joden toch nog werden vrijgelaten, vonden ze toevlucht bij het gezin van mijn broer. Nacht aan nacht. Toen ik met hen sprak over een mogelijkheid van onderduiken voor hun kinderen, zei zijn vrouw, met onafwendbare beslistheid: 'Als we gaan, gaan we allemaal samen.' Ik wist dit toen nog niet te vertalen in haar werkelijke bedoeling. Toen nog niet. Ze probeerden nog eerlijk, het gezin verspreid onder te laten duiken, maar wat in hun oren bleef naklinken van de nachten in hun huis, dwong hen, terug te gaan als dieren in hun hol en daar te volbrengen wat ze allang wisten dat hun enige uitweg was. Zelf over het einde beslissen - niet de vijand te laten bepalen. ${ }^{81}$

Jakob Pinkhof werd als enige van zijn gezin nog levend aangetroffen, nadat de opengedraaide gaskraan zijn vrouw en drie kinderen van het leven had beroofd. Men bracht hem naar een niet nader gespecificeerd Joods ziekenhuis, waar de artsen en verpleegsters de behandeling startten, zoals Herman Pinkhof voor de oorlog ook had voorgestaan. Hermans dochter Clara echter bad dat haar broer niet meer wakker zou worden. Zij hoopte dat het hem bespaard zou blijven het verlies van zijn gezin bewust mee te maken. Deze gedachte is ongetwijfeld ook door de hoofden van de behandelend artsen en het verplegend personeel gegaan. Of zij de behandeling daarop aanpasten of beperkten, is natuurlijk niet meer te achterhalen, maar Jakob Pinkhof kwam niet bij uit zijn coma en stierf uiteindelijk twee dagen na zijn vrouw en kinderen, op 19 
september 1942. Clara Pinkhof bad het dodengebed en hoorde achter zich iemand mompelen: 'God geve dat we nooit hoeven zeggen, dat ze gelijk hebben gehad.' ${ }^{\prime 2}$ Wie zal weten wat vader Herman Pinkhof daarover gedacht heeft, voordat hijzelf niet veel later in een barak in Westerbork het leven liet? Het laat zich raden. ' $\mathrm{Zij}$ wenschten tot het einde toe hun levenslot en dat van hun naasten in eigen hand te houden. Hier was voor religieuze, ethische en zedelijke overwegingen geen plaats,' zo noteerde F.S.Meyers treffend. ${ }^{83}$

Een paar dagen na de dood van Jakob Pinkhof beroofde zijn Zaanse collega Bernard Eisendrath zich van het leven. Diens vrouw en vier kinderen leefden door om uiteindelijk gedeporteerd te worden, waarop dochter Iris in een afscheidsbrief vanuit Westerbork concludeerde: 'Vader had toch gelijk, geloof ik after all. ${ }^{\prime 84}$ Niemand van het gezin Eisendrath zou de oorlog overleven. Net als Pinkhof en Eisendrath sloeg ook Salomo Bendien, bekend en omstreden kankerspecialist uit Zeist, in het najaar van 1942 de hand aan zichzelf. ${ }^{85}$ Vermoedelijk deed hij het met medicamenten nadat hij door de politie gearresteerd en verhoord was. ${ }^{86}$ Ook hij voorkwam op het laatste moment dat de vijand zijn lot zou bepalen. Mogelijk was het middel dat hij gebruikte kaliumcyanide, een gif dat bij orale inname een razendsnel intreden van de dood tot gevolg heeft. Het was, net als in mei I940, voor artsen makkelijker dan gemiddeld te krijgen, zoals ook Maurits Frenkel, semi-arts, zich kon herinneren. Hij had eenvoudigweg een tubetje kaliumcyanide in zijn zak kunnen stoppen op het laboratorium van het NIZ, waar hij werkte. 'Vanaf dat moment had ik rust, want ik dacht: die lol zullen de moffen niet van mij hebben.' ${ }^{87}$ Frenkel had alleen al door het bezit van het tubetje een rustig gemoed, maar was van plan alleen in uiterste nood van dat bezit gebruik te maken. Voor Frenkel en voor de meeste artsen zelf was zelfmoord het alleruiterste middel. Toch kwamen zij er in hun beroep wel veelvuldig mee in aanraking.

\section{HULP BIJ ZELFMOORD?}

De Joodse artsen werden door deze nieuwe zelfmoordgolf opnieuw ook beroepsmatig geconfronteerd met de ellende en de dilemma's rondom het fenomeen suïcide, net als in mei 1940 was gebeurd. Hoe daarmee om te gaan was ook nu weer de vraag. Een vooroorlogs arts had nooit medewerking mogen verlenen aan een poging tot zelfdoding, maar de meningen waren onder de gegeven omstandigheden aan verandering onderhevig geweest. Psychiater F.S. Meyers zei ronduit dat hij meende de middelen voor zelfdoding niet te mogen weigeren: 'Meerderen van mijn vrienden bespraken openlijk hun voornemen, 
meestal met medeweten van hun echtgenote. $\mathrm{Zij}$ vroegen mij om middelen, welke ik dan ook niet heb gemeend te mogen weigeren. $\mathrm{Zij}$ beloofden er dan gebruik van te maken, als zij in omstandigheden kwamen, waarvan men algemeen overtuigd was, dat zij tot hun dood zouden voeren. ${ }^{88}$

De zoon van hoogleraar interne geneeskunde Leonard Polak Daniëls, Anselm, zelf huisarts te Den Haag, was gezien zijn actieve rol bij de suïcide van zijn eigen ouders ook duidelijk overtuigd van de juistheid van de hulp bij zelfmoord door artsen onder de gegeven omstandigheden. Een patiënt van hem, Frans van Raalte, werd bij een poging de grens over te steken ontdekt en beroofde zich in de cel van het leven met een capsule cyaankali die Polak Daniëls hem had verstrekt. ${ }^{89}$

Carel Wolff, die als assistent interne geneeskunde in het Nederlandsch Israëlietisch Ziekenhuis werkte, kreeg eveneens een patiënt bij wie hij moest beoordelen of hij haar doodswens als vervolgde zou respecteren of zijn aloude ethiek, die voorschreef dat het leven te allen tijde door de arts behouden diende te worden, moest aanhouden. Decennia later kon hij zich het medisch-ethisch dilemma nog haarscherp voor de geest halen. Wolff was op zekere dag in de nazomer van 1942 al bijna op weg naar huis, toen hij werd tegengehouden door een broeder: 'Goed dat u er nog bent.' Er bleek een vrouw, diabete, te zijn binnengebracht, die suïcide had willen plegen door middel van insuline. Wolff liet de broeder bij de ziekenhuisapotheek onmiddellijk een glucoseoplossing ophalen en ging zelf bij de patiënte een infuus aanleggen. Ze ontwaakte uit het hypoglycemisch coma, ${ }^{\circ}$ en Wolff bleef de hele nacht bij haar waken. De volgende ochtend was ze verward, maar ze leefde nog, waarop Wolff geneesheerdirecteur Salomon Kroonenberg erbij haalde. Deze zei hem dat hij het goed had aangepakt, net als opleider Emanuel Godfried, die later in de ochtend arriveerde. In de loop van de ochtend werd de inmiddels stabiele patiënte overgeplaatst naar een naastgelegen afdeling. Het 'heldenverhaal' was toen al in het hele ziekenhuis bekend. Zoals Carel Wolff nu zegt: 'Ten onrechte, want zowel de beslissing als de behandeling was uiterst eenvoudig.' Door zijn ervaringen met suïcidepogingen in de familie tijdens de meidagen van 1940 dacht hij te weten dat deze vaak werden ingegeven door de radeloosheid van het moment en niet door een duurzame doodswens. Die overtuiging maakte zijn handelen voor zijn gevoel volstrekt vanzelfsprekend. De oudere, ervaren hoofdzuster op de afdeling waar de patiënte naar werd overgebracht, dacht er echter anders over en zei: 'Nou voel je je zeker een hele piet, hè?' Zij was juist van mening dat de ongelukkige vrouw de kans had moeten krijgen te sterven, want wie weet wat voor ellende ze nu nog meer zou moeten doorstaan. Wolff was verrast, maar kon veel sympathie en begrip voor dit standpunt opbrengen. Toch had 
Wolff geen spijt van zijn handelen, omdat hij op dat moment niet kon weten hoe het verder zou gaan. Misschien zouden ze een paar maanden later wel bevrijd zijn, hij kon het niet zeggen. Hoe het met de bewuste patiënte verder is gegaan, is hem niet bekend geworden. Wel meende hij nadien dat in het algemeen velen die hun poging overleefden, later nog een lang en gelukkig leven hebben gehad. ${ }^{91}$

Carel Wolff handelde volstrekt in lijn met de 'oude' ethiek: namelijk de overtuiging dat artsen te allen tijde hoeders van het leven dienen te zijn. 'De artsen zijn er om al wat leeft in leven te houden', ${ }^{92}$ zo was het vooroorlogs vanzelfsprekend adagium, zoals ook genoteerd door de Utrechtse Joodse gynaecoloog Maurits Muller in het boekje dat hij in I939 en I940 over zijn werk schreef. Toch stond er behoorlijk wat druk op de artsen om die norm terzijde te schuiven, zeker nu de deportaties zo'n extra dreiging teweegbrachten. Bijvoorbeeld ook op Salomon Koster oefenden patiënten druk uit:

Dag dokter, ik moet u een verzoek doen en dat mag u mij niet weigeren. En dat is, meneer Rothkampf? Dat u mij een fleschje geeft, met een zeker werkend vergif, zodat ik, als ik het noodig heb, daarvan gebruik kan maken. Ik beloof u plechtig, dat ik het alleen in het alleruiterste geval, als er geen andere uitweg meer is, zal gebruiken. Meneer Rothkampf, u weet heel goed, dat een dokter zoo iets niet doen mag. Ja dokter, in normale tijden niet, maar nu zijn wij in heel abnormale omstandigheden. Ziet u liever, dat ik en mijn beide zusters, na alle ellende, die wij nu al jaren, eerst in Duitschland en daarna hier in Nederland, hebben meegemaakt, nu nog in slavermij, van honger en ellende omkomen? Meneer Rothkampf, ik doe dit niet. Ik kan, ik mag het niet doen. Waar wij geen uitweg meer zien, komt die soms heel onverwachts. Dokter, het is mogelijk, dat u gelijk hebt, maar ik reken toch op dat fleschje. ${ }^{93}$

Of Koster uiteindelijk overstag ging, vermeldt zijn dagboek niet. Mogelijk vond hij het te precair om dit aan het papier toe te vertrouwen. De beschrijving van deze casus geeft niettemin aan voor welk een moeilijke afweging hij geplaatst was en hoezeer hij zich ook in de overwegingen van de patiënt kon verplaatsen.

Een ander voorbeeld van het beëindigen van een leven door een arts is de praktijk van abortus provocatus. Van in ieder geval één Nederlandse Joodse arts is bekend dat hij deze medisch-ethisch als immoreel beoordeelde en illegale behandeling uitvoerde ten tijde van de deportaties. Deze Amsterdamse huisarts, Ben Swaab, wordt tot op de dag van vandaag door een van zijn toenmalige 
patiëntes bewonderd om wat hij voor haar betekend heeft. Immers, deportatie met een zwangere buik had voor haar een wisse dood betekend. ${ }^{94}$ Van twee artsenechtparen is zelfs overgeleverd dat zij zelf een abortus lieten uitvoeren, omdat zij onder deze omstandigheden geen kind op de wereld wilden zetten. ${ }^{95}$ Er waren dus zeker meer artsen bereid hun medewerking hieraan te verlenen. Wel herinnerde een van de artsenvrouwen zich dat dit in het grootste geheim moest plaatsvinden en dat het ook als 'heel erg' door de buitenwereld gezien werd. Maar ook dit was een praktijk die daadwerkelijk plaatsvond, omdat de vooroorlogse norm, het verbod op het helpen beëindigen van een leven, nu niet meer onvoorwaardelijk geldig leek.

Een suïcidepoging bleek echter in het najaar van 1942 ook om een andere reden ondernomen te kunnen worden. Met een ziekte kon men immers trachten tijdelijk van deportatie te worden vrijgesteld. Artsen konden patiënten 'transportunfähig' verklaren, wat tijdelijk respijt - droge aarde onder de voeten - kon bieden. Soms was niet geheel duidelijk welk doel de patiënten na hadden gestreefd, al was duidelijk dat wanhoop hen had gedreven. Joseph Kater bijvoorbeeld werd bij twee patiëntes geroepen, die nog leefden na een suïcidepoging. 'Deze oude dames, allebei leraressen aan een middelbare school, hadden zich de polsen doorgesneden, echter zonder dat zij haar slagaderen hadden geraakt. Het was ontzettend en ik kon niet anders doen dan de oppervlakkige wonden verbinden en zeggen dat zij niet transportfähig waren. ${ }^{.96}$

Met deze nieuwe mogelijkheid van het artsenberoep, het afgeven van 'transportunfähigkeits-verklaringen', werd nog een belangrijke inhoudelijke wijziging van het medische vak duidelijk.

\section{ARTSEN ALS ATTESTENFABRIEKEN}

Al vanaf de keuringen voor de werkkampen waren artsen zich gaan bezighouden met medische sabotage: het ziek(er) laten lijken van patiënten en hier verklaringen van afgeven. Een dergelijke werkwijze zou onder vredesomstandigheden als medisch-ethisch absurd en immoreel beoordeeld worden, maar in 1942 hanteerden vele medici deze methode ogenschijnlijk zonder blikken of blozen. Hogere belangen waren in het spel en sabotage was daarmee de nieuwe norm geworden. Ook in de deportatiefase. Immers, intransportabele zieken werden door de bezetter als 'ausserhalb der Aktion' beschouwd. ${ }^{97}$ Volgens de Amsterdamse huisarts Joseph Kater: 'Ziekte was in het kat-en muisspelletje eerst nog een mogelijkheid om een voorlopige vrijstelling te bemachtigen voor tewerkstelling of een andere dwangmaatregel. ${ }^{98}$ 
Kater gebruikte de metafoor van het kat-en-muisspelletje, maar in de metafoor van de schipbreuk gesteld: artsen boden zoveel mogelijk reddingssloepen in de vorm van attesten, waarin zij verklaarden dat hun patiënten te ziek waren om gedeporteerd te worden. Zij deden dat op grote schaal, getuige bijvoorbeeld de aantekeningen van Joseph Kater: 'zowel de huisartsen als de specialisten kregen ontelbare al-dan-niet gefundeerde verzoeken voor dergelijke attesten.' 99

Niet alle afgegeven verklaringen zullen bezijden de waarheid zijn geweest, er waren uiteraard ook mensen echt ziek, maar het was voor een creatieve dokter vrij eenvoudig een diagnose wat aan te dikken of geheel te verzinnen. Daardoor ontstond een bizarre situatie, zoals Berthold Stokvis het in zijn dagboek kernachtig uitdrukte: 'De arts is opgehouden geneesheer te zijn; de patiënten vragen hem slechts: "Hoe kan ik ziek zijn?"' Ziekte gold niet meer enkel als iets wat ongewenst was, ziekte kon nu een zeer gewenste, beschermende werking hebben. Zo ontstonden er in artsenpraktijken ware 'attestenfabrieken', een term door Berthold Stokvis gebezigd. Ook de kinderen van de Amsterdamse internist Calmer Roos spraken van een 'attestenfabriek' in de praktijk van hun vader. ${ }^{100}$ Huisarts Aron Vedder zou volgens zijn dochter eveneens 'attesten bij het leven' hebben geschreven. ${ }^{\text {or }}$ Stokvis noteerde over de toestand in de zomer van I942: 'Het is 22 augustus I942, des namiddags half drie. De deportatie van het Joodsche gedeelte van onze bevolking is bijna twee maanden aan den gang en er is een ware run op de artsen ontstaan. Zoo hoopt men door middel van attesten het veege lijf te redden.'

Attesten werden eveneens op grote schaal verstrekt door het Joodsch Psychiatrisch Consultatiebureau. In zijn naoorlogse verslag beschreef psychiater F.S. Meyers de toestand op dit bureau: 'In de meeste gevallen kwam men op het bureau om een attest, slechts 2 maal wenschte men te worden behandeld, van zijn kwalen te worden verlost.' ${ }^{\text {I03 }}$ Van de Amsterdamse huisarts Andries Blok is een agenda van 1942 bewaard gebleven, waarin hij achterin een lijstje bijhield van buiten de normale praktijk vallende bezigheden, met name afgegeven verklaringen. Hoewel niet allemaal leesbaar, lijken deze zeventien punten vooral gunsten verleend aan patiënten te zijn: grotendeels in de vorm van attesten. $^{\text {IO4 }}$

Uiteraard was valsheid in geschrifte artsen voor de bezetting een gruwel geweest. In de gids Medische ethiek stond zelfs dat het algehele fenomeen van attesten afgeven tot een minimum beperkt zou moeten worden. ${ }^{\text {Ios }}$ Nodeloos te zeggen dat de artsen in deze situatie hier geen boodschap meer aan hadden. Hoewel, van een Amsterdamse huisarts, J.B. Wolff is overgeleverd dat hij vasthield aan de hem vertrouwde ethiek en principieel weigerde om valse verkla- 
ringen te tekenen. ${ }^{106}$ Deze vanuit de oude ethiek bezien verdedigbare houding werd echter klaarblijkelijk niet door velen gedeeld. Direct na de bevrijding zou zelfs een commissie in het leven geroepen worden om nieuwe richtlijnen op te stellen voor het verstrekken van medische verklaringen, zozeer was deze praktijk tijdens de bezetting op grote schaal, ook onder niet-Joodse artsen, af gaan wijken van de vooroorlogse regels. Voor de oorlog had de arts al bijna dagelijks te maken met verzoeken om medische verklaringen, maar, zo stelde het 'Groene boekje', uitgegeven door het Medisch Contact en geschreven door de Joodse arts Albert Denekamp, in 1949: 'Het was echter de bezettingstijd, welke hieraan welhaast caricaturale afmetingen gaf. Enerzijds waren de gewetensconflicten voor de arts plotseling geheel anders komen te liggen en werd het een plicht (ja, vaak zelfs een sportief genoegen) om de almacht van het doktersattest uit te buiten in de strijd tegen de bezetter. ${ }^{\text {'07 }}$

Deze attestenstrijd viel ook in nationaalsocialistische kringen op. Op 7 augustus 1942 al verscheen in het blad Storm van de Nederlandse ss een artikel onder de titel 'Medische jodenliefde'. Onderwerp was de in de ogen van de auteur verfoeilijke praktijk van het uitschrijven van valse medische attesten, ook door niet-Joodse artsen voor Joodse patiënten: 'Het spreekt natuurlijk vanzelf dat de inhoud van deze attesten helemaal niet met de werkelijkheid overeenstemt, aangezien anders $3 / 4$ van de joden in Nederland aan den rand van het graf zou staan. ${ }^{108}$ Het uitschrijven, aandikken en vervalsen van de attesten nam kennelijk zulke groteske vormen aan dat het behoorlijk in de gaten liep.

De artsen namen met het uitschrijven van zo'n groot aantal attesten dan ook een zeker risico. Reactie van de bezetter kon niet uitblijven. 'Toen dit aantal te sterk toenam werd er controle op ingesteld, waardoor ook artsen in moeilijkheden kwamen, die "ongemotiveerde" attesten hadden afgegeven.' Op de oproepen voor tewerkstelling die mensen thuisgestuurd kregen, werd dan ook met nadruk vermeld dat ziekte geen verontschuldiging was voor het niet-nakomen van de oproep. Als iemand toch ziek werd verklaard en daarom niet kwam opdagen op het aangegeven tijdstip, was de arts volgens de tekst op de oproep 'ten volle verantwoordelijk. 'Io Een 'waarheidsgetrouwe en duidelijk geschreven doktersverklaring' diende per ommegaand aan de Zentralstelle fur jüdische Auswanderung toegezonden te worden. ${ }^{\text {III }}$ Twee Joodse artsen, voor de Joodsche Raad werkzaam in de Zentralstelle, konden dan na ontvangst van het attest bij de patiënt thuis komen om te beoordelen of deze echt ziek was. ${ }^{\text {II2 }}$ H. Wielek, oorlogshistoricus en ervaringsdeskundige, schreef in 1947 echter over de Joodse artsen bij de Zentralstelle: 'Het aantal, dat zij móchten afkeuren, was buitengewoon klein. En meer dan één keer werden de doktoren met 
"Mauthausen" bedreigd, omdat zij dringend hadden geadviseerd, een groter aantal zieken vrij te stellen. Zij konden alleen advies uitbrengen.' ${ }^{\text {II3 }}$

Gedreigd werd ook met controle door een Duitse politiedokter als er twij-

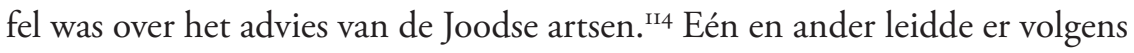
Wielek toe dat de Joodse artsen de meeste mensen niet konden afkeuren:

Ik heb voor me een lijstje liggen: ingediende ziekte-attesten in de ochtenduren van 30 juli I942: tbc I2 gevallen ingediend, 2 gevallen uitstel. Open tbc 8 gevallen ingediend, 2 vrijgesteld. Trachoom 6 gevallen ingediend, I vrijstelling (de man is bovendien blind). Scabies 2 gevallen, geen vrijstelling. Kinkhoest 2 gevallen, 2 weken uitstel. Impetigo I geval, 3 weken uitstel. Vele honderden attesten van 'minder zieken' mochten niet meer geaccepteerd worden, komen zodoende op geen lijst voor. ${ }^{\text {IIs }}$

Een ziekte moest dan ook aan vrij hoge eisen voldoen, wilde deze uitstel van deportatie kunnen afdwingen. Die ziekte diende vooral niet-vervoerbaarheid te veroorzaken. Of iemand wel of niet in staat zou zijn om te werken was nu, in tegenstelling tot de attesten voor de keuringen in de eerste helft van I942, niet meer relevant. De onmogelijkheid om vervoerd te worden, dat telde. ${ }^{\mathrm{II}}{ }$ Ruben Bollegraaf in Oss schreef dan ook terecht: 'Het was gebleken, dat de redactie van een attest van groot belang was, het woord "Transportunfähig" had meer effect dan een uitvoerige ziektegeschiedenis. ' ${ }^{117}$ Ook Stokvis schreef: 'Er worden hooge eischen gesteld aan de stylistische begaafdheid van den arts; die steeds weer nieuwe formuleringen moet vinden om dezelfde verschijnselen van verschillende patiënten niet in het daglicht te stellen.' ${ }^{\prime 18} \mathrm{Om}$ die redactie en formulering van de attesten in goede banen te leiden, bood de Joodsche Raad hulp. Voor de beste formulering van een attest konden patiënten en artsen aankloppen bij de Amsterdamse afdeling Voorlichting, waar onder anderen Berthold Stokvis, die bij deze afdeling in dienst was getreden, adviseerde over de meest kansrijke woordkeus. ${ }^{119}$ In Oss hield Bollegraaf, die benoemd was tot plaatselijk medisch adviseur van de Joodsche Raad, eveneens spreekuren om adviezen over attesten te geven. ${ }^{20}$ Medische sabotage was nu niet alleen breed geaccepteerd, maar zelfs geïnstitutionaliseerd.

Naast de vervalste of op zijn minst aangedikte of mooi geformuleerde attesten zijn er uiteraard ook verklaringen uitgeschreven voor mensen die echt ernstig ziek waren. Dit lijkt op het eerste gezicht minder te botsen met de voor de bezetting geldende medisch-ethische normen, maar dat gaat niet geheel op. Men diende een attest namelijk vast te hechten aan de oproep die men ontvangen had en deze twee papieren vervolgens samengevoegd naar de 
Zentralstelle te sturen. Bijkomend gevolg van deze gang van zaken, en tevens dilemma voor de arts, was dat de diagnose, ook als deze wel waarheidsgetrouw was, open en bloot voor iedereen, inclusief de patiënt zelf, zichtbaar was. Het beroepsgeheim werd dus geschonden, en tevens werd de patiënt zelf volledig geïnformeerd over wat hij had, terwijl de vigerende medisch-ethische opvatting was dat het veel beter was de patiënt niet volledig in te lichten in geval van een ernstige diagnose. Nu echter kwam men er niet meer onderuit om de patient toch op de hoogte te stellen van de eigen kwaal, hoe ernstig ook. Berthold Stokvis vreesde de psychologische gevolgen hiervan voor de betrokkenen. ${ }^{.21}$ In een dergelijk geval was dus weliswaar geen sprake van medische sabotage, maar alsnog van een praktijk die onder normale omstandigheden als zeer onwenselijk zou worden beschouwd. Echter, hier werd het in het belang van de patiënt geacht deportatie te trachten te voorkomen, en dat belang woog voor de artsen kennelijk ook zwaarder dan het beroepsgeheim.

\section{SIMULEREN OM DEPORTATIE TE VOORKOMEN}

Vanaf het moment dat de mensen rechtstreeks uit hun huizen werden opgehaald, eind augustus 1942, ging de medische sabotage weer een stapje verder. $\mathrm{Nu}$ werden de attesten vaak vergezeld van allerlei medische attributen teneinde een echt ziekbed na te bootsen. Zo zorgde de Amsterdamse huisarts-bacterioloog Aron Vedder er tijdens een nachtelijke Duitse inval in zijn huis voor dat hij gauw een warmtekap over het hoofd van zijn zoon Max kon leggen, volgens zijn verklaring ter behandeling van een kaakholteontsteking bij de roodvonk waar Max zogenaamd aan leed. ${ }^{122}$ Dit had succes. Garantie op succes bood een dergelijke truc niet. Berthold Stokvis liet bijvoorbeeld een bejaard echtpaar elke avond klaarzitten met gefingeerde dysenterie en een darmbloeding bij mevrouw, terwijl meneer een hartaanval had ingestudeerd voor het geval 'ze' aan zouden bellen. ${ }^{123}$ Toen 'ze' inderdaad voor de deur stonden, waren ze echter niet te vermurwen: de twee oude mensen moesten mee.

De inmenging van de artsen ging vaak verder dan enkel schriftelijk. Louis Schaap herinnerde zich bijvoorbeeld: 'In de omgeving razzia's en huiszoekingen. Tal van keeren werd ik bij zieken thuis ontboden als de zwarte politie thuis was om de familie te halen. Ik moest die dan overtuigen van de niet-vervoerbaarheid van de patiënt. Soms lukte het, soms ook niet.'124

Ook Stokvis ondervond dat. Zo fietste hij op zeker moment toevallig langs het huis van een oudere patiënte en haar zoon en zag dat er een ziekenwagen voor de deur stond, die op het punt stond de oude vrouw mee te nemen rich- 
ting Hollandsche Schouwburg, de belangrijkste verzamelplaats voor Joden die uit hun huizen waren gehaald en wachtten op transport naar Westerbork. $\mathrm{Na}$ een innerlijke tweestrijd, doorfietsen of afstappen, koos Stokvis voor het laatste. 'Doorrijden is laf, de menschen hebben je nodig, dus onmiddellijk naar

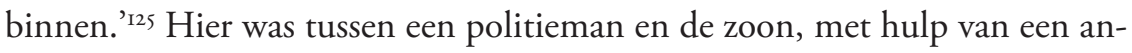
dere toegesnelde jonge huisarts uit de straat, de discussie gaande of de vrouw wel of niet in staat zou zijn om op transport te gaan. Stokvis verklaarde dat de vrouw een ver transport niet aan zou kunnen. Waarop de politieman zei dat dat niet de vraag was. Enkel de vraag of zij het transport naar de Hollandsche Schouwburg zou overleven, was volgens hem relevant. De daar aanwezige Joodse artsen zouden wel beoordelen of verder transport mogelijk zou zijn. In dit voormalig theater, met een zaal met 600 zitplaatsen en een koffiekamer, bescheiden uitgerust met slechts drie wc's en één wasbak, was een kleine ziekenvoorziening in de voormalige foyer en in de voormalige directeurswoning ingericht. ${ }^{\mathrm{I} 2}$ Er waren hier zo'n 25 bedden beschikbaar. ${ }^{\mathrm{I} 27} \mathrm{Nu}$ zat Stokvis klem. Hij kon niets anders dan toegeven dat vervoer naar de Hollandsche Schouwburg geen direct gevaar op zou leveren voor zijn patiënte. "“Heusch, het is het beste als u toch maar gaat." Ik kan wel van mijzelf spuwen, dat ik deze woorden moet uitspreken en zoodoende nog dit onmenschelijk bedrijf in de hand werk. Maar het is zonneklaar, dat langer verzet vruchteloos is.' En terwijl een tweetal broeders van de GGD, een van hen verdrietig en schuldbewust, aanstalten maakte de vrouw in de ambulance te leggen, kwam er een derde collega binnen: 'de huisarts, een boom van een man. Hoogopgericht komt hij met gekruiste armen het vertrek binnen, ziet de broeders, die de oude vrouw willen beetpakken: "wat is hier te doen? Wie zijn jullie? Zijn jullie broeders? Jullie kunnen je godverdomme schamen aan zooiets mede te werken. Wat zegt jullie baas daarvan?"' I28

Ook deze moedige collega bereikte niets. Wat volgde, was een roerende afscheidsscène tussen moeder en zoon, waarbij de drie collegae stonden te huilen. 'Wij hebben als dokters al heel wat menschelijk leed aanzien en sterfbed meegemaakt, doch nog nimmer iets dergelijks aan het bed van een gezonde.' ${ }^{2} 9$

De zo mogelijk nog risicovollere interventie van huisarts Herman Hertzberger bij een patiënt die in de Euterpestraat, in het hoofdgebouw van de Sipo-SD, gevangenzat, kende een beter einde. Met de woorden: 'U kunt mijn patiënt maar beter los laten, dat bespaart $\mathrm{u}$ veel moeite want hij heeft nog maar I a 2 dagen te leven,' wist hij de man naar verluidt vrij te krijgen. ${ }^{130}$ Bluf en bravoure hadden hier resultaat. Dat er ook creativiteit voor nodig was om een manier voor medische sabotage te ontwikkelen blijkt uit het volgende citaat, afkomstig van de niet-Joodse internist Henriette Lohr, praktiserend in Amsterdam-Zuid: 
Persoonlijk contact met de Duitschers had ik maar eens, toen ik bij een overvalwagen werd geroepen, waar een Joodsche patiënte van mij in werd meegenomen. De Duitsche officier die de leiding had, vloekte en zei dat hij met dokters niets te maken had. Voor het opwekken van schijnziekten bij menschen die met deportatie bedreigd werden, gebruikte ik schildklierpoeder en digitalis. Van beide waren enorme doses nodig om hartafwijkingen te veroorzaken. Het laatste beviel mij het beste, omdat men electrocardiografische veranderingen kon veroorzaken, die voor altijd op de curve als 'bewijs' waren vastgelegd. De verlaging van het ST-stuk in alle afleidingen werd door de Duitschers inderdaad als bewijs van een coronair-aandoening geaccepteerd. ${ }^{131}$

Voor zijn eigen moeder had Stokvis enkele collegae scherp geformuleerde attesten laten schrijven, met erin vermeld dat zelfs transport naar de Hollandsche Schouwburg levensgevaar zou opleveren. Elke avond vanaf halfacht ging zij omringd door deze attesten en enkele door haar zoon klaargelegde injectiespuiten in bed liggen, klaar om angina pectoris te simuleren. ${ }^{132}$ Ondanks deze uitgekiende strategie was zoon Berthold er allerminst gerust op dat hij zijn ouders 's ochtends weer in hun eigen huis zou aantreffen. Iedere morgen opnieuw was het een opluchting als ze er nog waren.

De attesten hadden niet altijd het gewenste resultaat. De Joodsche Raad rapporteerde weliswaar nog tot eind november 1942 dat men bij de ophaalacties 'over het algemeen' de richtlijn hanteerde dat niet-transportabele zieken vrijgesteld waren. ${ }^{\mathrm{I} 3}$ Maar het ging ook geregeld fout, zoals blijkt uit de genoemde voorbeelden. Men moest ook geluk hebben, zoals uit notities in het dagboek van psychiater Salomon Koster blijkt: 'In het begin mochten gewoonlijk zieken, die een goede geneeskundige verklaring van hun ziekte hadden, thuis blijven, als maar in de verklaring vermeld stond, dat zij niet getransporteerd mochten worden. Dit hing echter geheel van de menschelijkheid van de betrokken politiemannen en van de hardnekkigheid van de patiënt om in bed te blijven, af.' ${ }^{\prime 34}$

Hij hoorde van een patiënt het verhaal van de arrestatie van diens vader, die ziek in bed lag, maar in pyjama de deur opendeed: 'Het waren toen die vuile, jonge NSB-politiekerels. Enfin, toen ze vaders attesten gelezen hadden, verscheurden ze die en riepen: ja zeker hartgebrek, volkomen bedrust, jullie Joden zijn nu opeens allemaal ziek. Als je absolute bedrust nodig hebt, kan je zelf niet de deur open doen.' ${ }^{\mathrm{I} 35}$

Bij gebrek aan een betere mogelijkheid bleven velen toch hun toevlucht zoeken in deze medische middelen. Die middelen vormden immers hun laat- 
ste strohalm. In deze toestand is het dan ook niet verwonderlijk dat Stokvis én Sally de Jong in hun notities spraken van een 'ware run op de artsen'. ${ }^{136}$ Cijfers zijn hierbij niet te noemen, maar in de archieven van de Joodsche Raad die bij het NIOD bewaard worden en ook in de documentencollectie van het Joods Historisch Museum, zijn tientallen in najaar 1942 vervaardigde attesten bewaard gebleven. ${ }^{137}$ Een geschatte helft van deze attesten is afkomstig van niet-Joodse artsen. Volgens zowel Stokvis als De Jong waren deze attesten in de ogen van de Duitse functionarissen meer waard dan die van Joodse artsen. En dus hadden de 'patiënten' nog liever een attest van een niet-Joodse dokter dan van een Joodse. Stokvis vond de medewerking van alle artsen, Joods of niet-Joods, 'boven alle lof verheven'. ${ }^{138}$ Voor hem stond kennelijk vast dat de artsen dit deden met menslievende en eerbiedwaardige intenties. Onder deze omstandigheden gold dat als van een hogere orde dan de oude normen van waarachtigheid en geheimhoudingsplicht.

\section{PSYCHIATRIE IN TIJDEN VAN ANGST}

Ook op psychiaters ontstond een run. Joodse psychiaters kregen het na juli I942 veel drukker dan voorheen. De artsen van het Amsterdamsch Joodsch Psychiatrisch Gezelschap merkten dit tijdens hun werk voor het Joodsch Psychiatrisch Consultatiebureau in de hoofdstad. ${ }^{139}$ De vraag naar attesten veranderde het werk van de psychiaters inhoudelijk, maar tegelijkertijd namen zij de gelegenheid te baat, zoals het medisch wetenschappers altijd betaamd had, medisch wetenschappelijk onderzoek te doen. $\mathrm{Zij}$ trachtten een analyse te maken van de nieuwe psychiatrische toestand van de Joodse bevolking. Zij startten daartoe een gezamenlijke studie naar hetgeen op psychiatrisch gebied met de Nederlandse Joden gebeurde en stelden van de resultaten rapporten op.

Vanaf juli 1942 groeide het bezoekersaantal van het psychiatrisch consultatiebureau naar ongeveer het drievoudige van het vroegere, zo constateerden de psychiaters in september 1942. Naast de beschreven grote vraag naar attesten van gezonde mensen, waren hiervan ook 'reactieve toestanden' en 'hysterische reacties' op de spanning volgens de psychiaters deels de oorzaak. ${ }^{40}$ Toch spraken zij ook hun bewondering uit voor de vaak juist opvallend sterke houding van de Joden in de hemeltergende toestand waarin zij verkeerden. ${ }^{\mathrm{I} I \mathrm{I}}$ Herman de Levie sprak dan ook van 'de blijkbare taaiheid en elasticiteit der Joodse bevolkingsgroep, met zijn eigenlijk geringe aantal zware geestesstoornissen door dezen tijd'. ${ }^{142}$ Als verklaring hiervoor noemden de leden van het gezelschap met name de niet-aflatende hoop en verwachting onder de bevolking dat de 
oorlog spoedig ten einde zou lopen. ${ }^{\mathrm{I} 33}$ Met verbazing stelde F.S. Meyers na de oorlog vast: 'Vele z.g. zenuwlijders, o.a. de neurasthenici met hun overgevoeligheid en hun schijnbare orgaan-minderwaardigheid verloren hun klachten en werden zelfstandige personen, tot rustig overwegen en handelen in staat. $\mathrm{Zij}$ vergaten naar den medicus te lopen en hun herhaalde bezoeken bij den psychotherapeut bleven achterwege. 'I44

Met andere woorden, de omstandigheid dat er echt iets serieus aan de hand was, zorgde ervoor dat eerder bestaande psychische problemen door de betrokkenen als betrekkelijk en op dat moment niet meer relevant werden gevoeld. 'Wo es am Kragen geht, hört die Nervosität auf', zo stelde F.S. Meyers. ${ }^{\text {I45 }}$ De meerderheid van de mensen bleef verder, ondanks alle hectiek, angst en verdriet, gezond. Een opvallende uitkomst van het onderzoek.

Maar ook gezonden meldden zich juist, zoals gezegd, in deze maanden bij het Psychiatrisch Consultatiebureau. Zij waren het die op een beschermend attest of een ziekenhuisopname hoopten. Soms voerden zij daarbij toneelstukken op om de psychiater ook te overtuigen van de ernst van hun aandoening. ${ }^{146}$ Het leverde voor de psychiaters ook niet eerder vertoonde situaties op. Ze doorzagen deze simulatie natuurlijk vaak, maar uit hun verslaglegging blijkt dat dit hun begrip voor de patiënt niet in de weg stond:

Het betrof een joodsch meisje, dat bij den 'Expositur' werkzaam was, een Duitse instantie, welke de verbinding vormde tusschen, in het bijzonder de Amsterdamsche joden en de Duitsche overheid. Bedoeld meisje, moest vele gesprekken voeren, in verband met de Joden, die met de 'Expositur'beambten in aanraking kwamen en het is niet uitgesloten, dat zij bewust of onbewust bevorderde het wegvoeren van menig slachtoffer. Er ontwikkelde zich bij haar een eczeem om den mond, zoodat haar het spreken onmogelijk werd. In het algemeen meende men bewuste simulatie te moeten buitensluiten, ondanks, dat bij velen de wensch bestond ziek te zijn. En sprak men van een hysterische reactie die adequaat was aan de tijdsomstandigheden. Men had hier te maken met een orgaan-neurotischhysterisch verschijnsel, dat zinvol en adequaat kon worden genoemd. ${ }^{\text {I47 }}$

Een hoogst ongebruikelijk en onwaarschijnlijk ziektebeeld, maar naar het oordeel van de psychiaters een adequate reactie op de gegeven omstandigheden. $\mathrm{Zij}$ konden veel empathie opbrengen voor dergelijke specifiek in deze tijd ontstane 'reactieve toestanden'. Begripvol waren de psychiaters bijvoorbeeld ook ten aanzien van een patiënte die verkeerde in een variatie van een 'reactieve toestand': 
Ik bezocht een oude vrouw in een stuporeusen toestand, die te bed lag, alle voedsel weigerde en op geen enkele aanspraak reageerde. Mijn pogen om eenig antwoord van haar te verkrijgen, mislukte toen zij zich plotseling omdraaide en mij toesnauwde: 'kun je mij mijn kleinkind teruggeven?' en daarna weer in een absoluut stilzwijgen verviel. Hier stond men dus voor een reactieve toestand die adequaat was aan het leed, van de grootmoeder, ontstaan door het wegvoeren van haar kleindochter. ${ }^{\mathrm{I} 8}$

De psychiaters hadden hierbij hun diagnose weliswaar paraat, maar therapeutisch stonden zij met lege handen. De enige remedie die echt zou helpen hadden zij immers niet in hun arsenaal. Meyers beschreef dan ook zijn vertwijfeling: 'Ik ging heen met het ontmoedigende gevoel, dat onder de gegeven omstandigheden iedere hulp uitgesloten was. 'I49 Empathie hadden zij zeker, maar toch konden zij als arts niet echt helpen.

Niet in alle gevallen waren de psychiaters echter volkomen machteloos. Voor sommige patiënten kon wel degelijk aan de 'hulpvraag' tegemoetgekomen worden, zij het op medisch onorthodoxe wijze. Zo was voor een 4I-jarige 'ulcuslijdster', een patiënte met een maagzweer, die niet meer kon eten sinds haar vader plotseling naar Duitsland was weggevoerd, de benodigde therapie zonneklaar: 'Zij zeide dat, als zij maar wist, dat zij in een ziekenhuis veilig zou zijn, het eten vanzelf wel weer zou komen, nu ging het niet door de angst weggehaald te worden 's avonds. ' ${ }^{\text {I5o }}$ Opname in een ziekenhuis was haar ultieme streven. In een ziekenhuis zou zij veilig zijn, zo voelde zij dat. En met haar vele anderen. Hierin konden de artsen wel iets betekenen.

Mensen zoals de genoemde ulcuslijdster werden dan ook inderdaad veelal opgenomen, bijvoorbeeld onder de diagnose 'reactieve toestand' en bijvoorbeeld in de Joodse psychiatrische inrichting Het Apeldoornsche Bosch. Ver weg van de dreiging en de dagelijkse ellende op straat konden de patiënten dan bijkomen en de bevrijding afwachten, zo hoopten zij. Het Apeldoornsche Bosch gold, vanwege de fysieke afstand van de stadse ellende, als bij uitstek geschikt voor dit doel. ${ }^{151}$ Eenmaal opgenomen in Het Apeldoornsche Bosch werden mensen soms weliswaar 'ontmaskerd' als simulant, maar dan 'vanzelfsprekend' niet naar huis teruggestuurd. ${ }^{52}$ Hen werd de mogelijkheid tot veilig verblijf in de bossen van Apeldoorn geboden. ${ }^{53}$ De psychiaters aldaar faciliteerden deze mogelijkheid ook, eveneens als zij wisten dat de 'patiënt' niet echt ziek was. Wederom een staaltje medische sabotage, wederom in vredestijd ondenkbaar, maar wederom in deze situatie kennelijk als vanzelfsprekend aanvaardbaar geacht. In elk geval werd ze op grote schaal toegepast.

Het statistische gegeven dat er in 1942 vergeleken met mei 194025 pro- 
cent meer zelfmoordpogingen mislukten, ${ }^{154}$ zou heel goed door deze toestand kunnen worden verklaard. Zeer wel mogelijk is dat een in scène gezette suïcidepoging tot doel had opname in een ziekenhuis te bewerkstelligen. Uit het dagboek van Salomon Koster: 'Maar meneer Woster, wat is er met u aan de hand? Ik had u toch gezegd, dat u precies de hoeveelheid somnifeen, die ik u voorschreef, moest innemen en dat uw vrouw mij daarna zou opbellen, om mij mee te delen, dat u een ernstige zelfmoordpoging had gedaan. Ik had $\mathrm{u}$ dan prachtig in de Valeriuskliniek opgenomen gekregen.' Iss

Dat de scheidslijn tussen geënsceneerde suïcidepoging en een echte poging flinterdun was, bleek Koster echter ook in dit geval. Patiënt Woster poogde, toen hij gewis werd van nog bijkomende ellende, zich echt van het leven te beroven door de dubbele hoeveelheid slaapmiddel in te nemen. ${ }^{156}$

Uit dit citaat en andere beschikbare gegevens blijkt overigens eveneens dat niet alleen het Apeldoornsche Bosch, maar ook de niet-Joodse Valeriuskliniek Joodse psychiatrische patiënten kon opnemen. In de Valeriuskliniek in Amsterdam-Zuid werden tot eind 1942 in totaal 145 ernstige gevallen van 'reactieve toestanden' geherbergd en verzorgd, waarbij het in 63 procent van de gevallen om Joodse patiënten ging. Na het begin van de deportaties waren ook in het - eveneens niet-Joodse - Wilhelmina Gasthuis mensen met reactieve nerveuze toestanden opgenomen: in juli 1942 49, in augustus 38 en in september 37 patiënten. Dergelijke opnames geschiedden dus ook nog na het verbod voor niet-Joodse ziekenhuizen op het opnemen van Joodse patiënten. ${ }^{57}$ Er zijn meer voorbeelden van zowel Joodse als niet-Joodse artsen die meewerkten aan zo veel mogelijk opnames van Joodse patiënten, echte of simulerend. Zo werd een Joodse man met zogenaamd suïcidale neigingen opgenomen in een psychiatrische kliniek in Den Haag. Zijn vrouw werd tegelijkertijd door de plastisch chirurg Petersen van het Haagse Zuidwalziekenhuis geopereerd en met opzet twee weken op zaal gehouden. ${ }^{158}$ In het Utrechtse Diaconessenhuis zorgde onder anderen gynaecoloog Maurits Muller dat mensen voor hun veiligheid konden worden opgenomen. ${ }^{159}$ De niet-Joodse arts Kruimel had aan zijn Joodse patiënte beloofd: 'Als je een oproep krijgt, opereer ik je aan je voet.' Zo gezegd zo gedaan, en de vrouw en haar gezin kwamen onder de oproep uit. ${ }^{160}$ De Joodse medisch student Ernst Lankhout werd in de Haagse Ursulakliniek opgenomen voor een herniaoperatie en daarna overgeplaatst naar de Ramaerkliniek. Overigens niet om veiligheidsredenen, maar omdat hij het had aangelegd met een verpleegster, iets wat niet getolereerd werd. Naar eigen zeggen zaten er in de Ramaerkliniek zeker honderd Joden verborgen. ${ }^{161}$ In Maastricht bood de niet-Joods verklaarde geneesheer-directeur Charles Mendes de Leon onderdak aan enkele Joodse (pseudo-) patiënten. ${ }^{\text {I62 }}$ 
Dat deze voorbeelden te noemen zijn, is niet verwonderlijk. De psychiaters hadden het al van hun patiënten begrepen: mensen wilden maar al te graag opgenomen worden. Ziekenhuisopname leek nog veiliger dan met goede attesten en attributen thuis blijven wachten. Bij het begin van de deportaties was de voorzitters van de Joodsche Raad immers medegedeeld: 'Zieken zullen niet uit ziekenhuizen worden verwijderd.' ${ }^{\prime} 6_{3}$ In Oss maakte de bezetter vervolgens kenbaar bij een oproeping voor tewerkstelling 'dat ziekte alleen bij ziekenhuispatiënten als reden van wegblijven zou worden geaccepteerd. ${ }^{\prime 64}$ In de schipbreuktermen van Presser uitgedrukt: ziekenhuizen leken bij uitstek veilige reddingssloepen. 


\title{
5. 'ONDER HET VURIG BEGEERDE DAK VAN HET ZIEKENHUIS'
}

\author{
ZIEKENHUIZEN ALS VEILIGE HAVENS, \\ JULI 1942 - JANUARI 1943
}

Vanaf het begin van de deportaties in juli 1942 was de geneeskunde als een remedie tegen de gevreesde wegvoeringen gaan gelden. Het artsenberoep betekende voor de meeste Joodse artsen dat zij zichzelf voorlopig veilig konden stellen. Daarmee konden zij vervolgens ook trachten voor anderen veiligheid te creëren, al was het met onorthodoxe medische middelen. En zoals ziekte een andere klank kreeg, zo veranderde ook de waardering van het verblijf in een ziekenhuis. Voor de Nederlandse Joden was het vanaf de nazomer van 1942 vanwege de deportatiedreiging nastrevenswaardig geworden ziek te zijn en dan het liefst binnen vier ziekenhuismuren te verkeren. Veel mensen die een veilig heenkomen zochten, vonden dat in een van de Joodse ziekenhuizen, die dan ook significant groeiden in de loop van de tweede helft van 1942. Voor de artsen die daar werkten en in het bijzonder voor de verantwoordelijke geneesheren-directeur, bracht dat nieuwe situaties en nieuwe dilemma's met zich mee. Zeker toen het voortbestaan van de ziekenhuizen steeds meer bedreigd werd.

\section{DE OPNAMEAANTALLEN STIJGEN}

Psychiatrische inrichting Het Apeldoornsche Bosch bood onder normale omstandigheden plaats aan 750 psychiatrisch zieken. ${ }^{1}$ In het najaar van 1942 steeg het patiëntental echter van 750 patiënten naar $940 .{ }^{2}$ Om vervolgens de Iooo te overschrijden bij de jaarwisseling van 1942-1943. ${ }^{3}$ In Apeldoorn waande men 
zich ver genoeg verwijderd van het oorlogsgebeuren in Amsterdam en het gold daarmee als een relatief aantrekkelijk oord. De stijging in het patiëntental was deels ook het gevolg van het overbrengen van Joodse psychiatrische patiënten uit niet-Joodse instellingen naar het Apeldoornsche Bosch. ${ }^{4}$ In de Joodse ziekenhuizen in Amsterdam steeg het patiëntental eveneens aanzienlijk. Een lijst van de Joodsche Raad uit vermoedelijk september 1942 spreekt van een toename van patiënten in de Centraal Israëlietische Ziekenverpleging (CIZ), het Portugeesch Israëlietisch Ziekenhuis (PIZ) en het Nederlandsch Israëlietisch Ziekenhuis (NIZ) van IO-20 procent. ${ }^{5}$ Met name in het ruime gebouw van het NIZ werden steeds meer mensen dan normaal verpleegd. Presser noemde zelfs een patiëntental van boven de 500 in het NIZ in begin 1943. Normaal werden er 300 patiënten verpleegd. ${ }^{6}$

De Joodsche Raad had geen inspraak in het opnamebeleid, zo werd nog in november 1942 gesteld. ${ }^{7}$ Financieel verloren de ziekenhuizen echter hun onafhankelijkheid toen er een verbod kwam op alle Joodse stichtingen. Op 4 november 1942 werd een nieuw bestuursorgaan opgericht, waarin de afgeschafte Joodse welzijnsstichtingen werden samengevoegd: de Joodsche Vereeniging voor Verzorging en Verpleging, kortweg JVvVv ofwel JV4. ${ }^{8}$ Deze stond naast de Joodsche Raad, maar werd wel door Abraham Asscher voorgezeten en had als taak het beheer van alle bijeengevoegde Joodse instellingen voor verpleging en verzorging, zoals weeshuizen, oudeliedengestichten en ziekenhuizen. ${ }^{9} \mathrm{De}$ precieze grens tussen de verantwoordelijkheden van enerzijds de medische afdeling van de Joodsche Raad en anderzijds de JVvvv was nogal onduidelijk, mede doordat men de voorzitter van de medische afdeling, Salomon Spijer, tevens als 'groepsbestuurder' aanstelde voor de groep instellingen voor verpleging en verzorging van zieken, herstellenden en invaliden van de JVvvv. Men overwoog dan ook de gehele medische afdeling bij de JVvvv onder te brengen, zodat 'het medisch-sociale werk niet over twee instanties versnipperd wordt' . ${ }^{\circ}$ Uiteindelijk besloot men hier niet toe en bleven beide instanties naast elkaar bestaan, maar wel dicht bij elkaar, in hetzelfde gebouw aan de Lijnbaansgracht 366. "I De inkomsten van de JVvvv bestonden, zoals blijkt uit de notariële akte, uit 'vruchten van vermogen, verpleeggelden, contributies, schenkingen, erfstellingen en legaten'. ${ }^{\mathrm{I} 2}$ In december 1942 verzorgde de JVvVV met dat geld acht ziekenhuizen met 2280 verpleegden en 1480 personeelsleden, acht weeshuizen met 377 verpleegden en 152 man personeel, zes kindertehuizen van in totaal 390 kinderen en 130 medewerkers en 570 ouden van dagen met hun I70 verzorgers in een onbekend aantal bejaardenhuizen. ${ }^{\mathrm{I} 3}$ Maar wat betreft de opnames behielden de ziekenhuizen hun autonomie. Het was daarom aan de artsen zelf zo veel mogelijk mensen binnen de ziekenhuismuren te krijgen en te houden. 
Het Nederlandsch Israëlietisch Ziekenhuis, gevestigd aan de Nieuwe Keizersgracht te Amsterdam, was met 300 bedden het grootste Joodse ziekenhuis in de stad. Gelegen in de oude Joodse buurt werden hier vanouds met name armen verpleegd, vaak op kosten van de gemeente. Dit betekende dat de NIZartsen van oudsher geen volledige autonomie hadden over het opnamebeleid. De GGD moest toestemming geven alvorens een minvermogende patiënt op kosten van de gemeente in het NIZ kon worden opgenomen. ${ }^{14}$ Beter gesitueerde Joodse patiënten konden terecht in de Centraal Israëlietische Ziekenverpleging in de Jacob Obrechtstraat in Amsterdam-Zuid, die plaats bood aan 45 patiënten. Voor de Portugese gemeenschap had het Portugeesch Israëlietisch Ziekenhuis aan de Plantage Franschelaan een opnamecapaciteit van 55 bedden. Het NIZ herbergde naast het ziekenhuis ook een Oudeliedengesticht met 145 bewoners. Het PIz had eenzelfde voorziening, maar dan voor slechts twaalf ouden van dagen. 350 verzorgingsbehoeftigen konden terecht in het grote verpleeghuis aan het Weesperplein: De Joodsche Invalide. Buiten Amsterdam was er in het Haarlemse Jolesziekenhuis, een vleugel van het Elisabeth Gasthuis aan de Lange Wijngaardstraat, plaats voor twintig patiënten en in Rotterdam konden in het Joodse ziekenhuis aan de Schietbaanlaan 75 mensen opgenomen worden. ${ }^{\text {Is }}$

Deze ziekenhuizen gingen in het najaar van 1942 als vluchthaven fungeren, maar waren tegelijkertijd nog steeds gewoon behandelcentra voor daadwerkelijk zieke mensen. Carel Wolff herinnert zich van het medisch handelen op de afdeling Interne in het NIZ over het algemeen eigenlijk niets bijzonders. Hij deed zijn werk zo goed als hij kon, ongeacht de omstandigheden. ${ }^{16}$ Er werden in het NIZ als vanouds behandelingen gegeven en er werd lesgegeven. Het ziekenhuis had voor de oorlog een uitstekende reputatie als opleidingsziekenhuis genoten en de geneeskunde stond er op een hoog peil, zoals ook blijkt uit het feit dat juist in dit ziekenhuis in 194I, bij de elfjarige Annie Walg, de eerste geslaagde operatieve sluiting van een open ductus Botalli, een aangeboren hartdefect, was uitgevoerd. ${ }^{17}$ Het NIZ probeerde zo goed en zo kwaad als het ging zijn opleidingsfunctie vast te houden. $\mathrm{Zo}$ is aan het bewaard gebleven lesrooster van de voortgezette cursus voor Joodse artsen in het najaar van 1942 te zien dat er op drie dagen van de week in het NIZ onderwijs zou worden gegeven in de verschillende medische specialismen.$^{18}$ Ook werd er nog een cursus colloïdchemie aangekondigd. ${ }^{19}$ Aan de oppervlakte leek er, wat medisch inhoudelijk werk betreft, niet veel abnormaals aan de hand in het NIz. 


\section{SCHIJNDIAGNOSES EN 'SHAM'-OPERATIES}

Enkele jonge artsen in het NIz hadden besloten gezamenlijk sabotage te plegen. Het middel dat zij daartoe in handen hadden was hun eigen vak, dat zij op verre van normale manier gingen inzetten. Hun medische sabotage ging weer een stapje verder dan de eerder beschreven vormen, want zelfs het schade toebrengen aan of snijden in gezonde lichamen schuwden zij niet. Met een 'menu van de dag' vervalsten de NIZ-artsen, volgens orthopedisch chirurg Herman Herschel, elke dag nieuwe diagnosen.

Een neef van Herschel bijvoorbeeld had een oproep gekregen en wendde zich voor hulp tot Herman Herschel. Deze spoedde zich, zo herinnerde hij zich later, naar het huis van de neef in kwestie en diende hem scopolamine toe als slaapmiddel. Hij gaf hem vervolgens een snee in zijn hoofd en ving het bloed daarvan op om dat rond de ogen in de oogkassen te spuiten. Hierdoor ontstond alvast een 'brilhematoom', waarna de zogenaamde schedelbasisfractuur geloofwaardiger werd gemaakt door met schuurpapier enkele schaafwonden aan te brengen. Vervolgens belde Herschel de GGD om een ambulance te laten komen, die de 'patiënt' met spoed naar het NIZ afvoerde. De coassistent die de binnengekomen patiënt moest statussen, was ervan overtuigd dat hier inderdaad sprake was van een schedelbasisfractuur. Andere patiënten werden bijvoorbeeld met een gezond been in het gips gezet of zogenaamd geopereerd. ${ }^{20}$ Een dergelijke 'sham'-operatie betekende meestal dat er een ondiepe incisie werd gezet in de rechteronderbuik, met de verklaring dat de betrokkene zojuist aan een ontstoken blindedarm was geholpen. ${ }^{21}$

Co-assistent Max Hamburger had zijn eigen techniek ontwikkeld om mensen 'transportunfähig' te laten verklaren en in het ziekenhuis te kunnen houden. Uit zijn tijd als hulpje in de apotheek kende hij het middel Pyrifer, een koortsopwekkend middel (pyrogeen), dat gebruikt werd bij de behandeling van syfilis, vooral voor de cerebrale vorm. Hij had een voorraadje van dit middel uit de apotheek gesmokkeld en bewaarde dat op zijn kamer in het zusterhuis. In geval van dreiging voor een bepaalde patiënt, of zelfs voor een collega, spoot Hamburger wat van zijn voorraad Pyrifer intraveneus in en wachtte op de koortspiek die zou volgen. De hoge koorts kon dan een legitieme reden voor 'transportunfähigkeit' vormen. In Hamburgers herinnering heeft hij dit bij ongeveer vijf mensen voor elkaar gekregen. In één geval ging het bijna mis. Hij had de Pyrifer net iets te kort van tevoren toegediend, waardoor de patiënt maar 38,5 graden koorts had, niet indrukwekkend genoeg voor een afkeuring. Hij wist de keuringsarts, een arts van de GGD, die voor deze taak was ingeschakeld en volgens Hamburger allang blij was als hij iemand kon afkeuren, ertoe 
te bewegen even later nogmaals de temperatuur op te nemen, waarbij opeens bleek dat die was gestegen naar 4I graden. ${ }^{22}$ Verpleegster Ruth Bos-Watermann herinnerde zich dat Hamburger ook haar een dergelijke injectie aanbood toen zij een oproep ontvangen had. ${ }^{23}$

De artsen raakten met dergelijke praktijken weer een stap verder verwijderd van de oude medische ethiek. Immers, het 'primum-non-nocere'-principe moesten zij ervoor aan de kant schuiven. Zij schaadden gezonde lichamen, met alle risico's op complicaties van dien. Dat bleek ook bijvoorbeeld uit overgeleverde casuïstiek van een man die een hardnekkige blaasontsteking overhield aan een inspuiting met eiwit in de blaas en, nog veel ernstiger, van een meisje dat overleed na een sham-operatie. ${ }^{24}$ Journalist Philip Mechanicus schreef erover: 'Er is een tragisch geval bekend, waarin een moeder haar enig kind een blindedarmoperatie liet ondergaan en het dientengevolge verloor. ${ }^{25}$ Kennelijk konden de artsen deze uitzonderlijke maar vreselijke complicaties toch voor zichzelf verantwoorden, omdat zij hun patiënten over het algemeen, paradoxaal genoeg, ontegenzeggelijk hielpen. Zij konden mensen met hun medische trucs laten opnemen in het ziekenhuis ofwel langer binnen de ziekenhuismuren laten blijven en daarmee deportatie voorkomen. Voor deze artsen viel dit klaarblijkelijk nog binnen hun taakopvatting als arts, namelijk de plicht om te helpen en op te komen voor het belang van de patiënt. De NIZ-artsen vroegen ook geen vergoeding voor hun 'behandelingen' ${ }^{26}$ Middels uiteenlopende trucs redden zij, volgens Herman Herschel, honderden mensen van deportatie. ${ }^{27}$

In medisch-ethisch opzicht op geen enkele manier te billijken was echter de casus van een als verrader bekendstaande Joodse man, die op zeker moment zwaargewond werd binnengebracht. Hij was vanwege zijn slechte reputatie neergeschoten op de Weesperstraat, waarna men hem in allerijl naar het NIZ had vervoerd. De chirurgen verwijderden met een spoedoperatie de kogels uit zijn lijf, maar eenmaal op de verpleegafdeling aangekomen werd zijn bed bewust geheel horizontaal gehouden, waarop de verzwakte man een aspiratiepneumonie ${ }^{28}$ ontwikkelde, waaraan hij alsnog overleed. ${ }^{29}$ Dit was verre van handelen in het belang van de patiënt, dit was handelen in het belang van de maatschappij, een vanuit politiek en verzetsstandpunt invoelbare manier van handelen, maar niet vanuit medisch-ethisch standpunt.

Zowel het ruimhartige opnamebeleid als de pogingen het hoge medische peil te behouden, de medische sabotagepraktijken en een dergelijk geval van politieke moord: dit alles vond plaats binnen de muren van het NIZ, waar geneesheer-directeur Salomon Kroonenberg de scepter zwaaide en daarmee de verantwoordelijkheid droeg. Geen geringe opgave. 
Met hetgeen er in het NIZ zoal gebeurde, nam Kroonenberg aanzienlijke risico's. Als eindverantwoordelijke zou híj in geval van ontdekking gearresteerd worden. Dat Kroonenberg dit risico aanvaardde en zijn medewerkers hun gang liet gaan mag opmerkelijk worden genoemd. Bovendien zou, net als het aantal patiënten, het aantal werknemers aanmerkelijk stijgen. Ook zij zochten veiligheid in het ziekenhuis.

Kroonenberg beschouwde het ziekenhuis zelf ongetwijfeld net zo goed als een relatief veilige omgeving, die dermate van de buitenwereld was afgeschermd dat dit soort praktijken onopgemerkt konden blijven. Hij wist dat de Duitsers bang waren voor besmettelijke ziekten, wat hen er van weerhield om de drempel van het ziekenhuis al te vaak te overschrijden. Een anekdote uit het dagboek van Joseph Kater illustreert deze lichtelijk overdreven Duitse angst voor besmettelijke ziekten. Kater deed dienst op een van de hulpposten van de Joodsche Raad, een verzamelplek voor gearresteerde Joden:

Opeens werd een vrouw binnengebracht met een kind van een jaar of tien. Ze zei dat het kind zich ziek voelde, en ik onderzocht het in de voormalige keuken. Het had koorts en een rode keel. Toen de man van de Sicherheitsdienst mij vroeg wat er 'los' was antwoordde ik hem dat het een beginnend geval van 'Scharlach' [roodvonk] was en ging demonstratief mijn handen onder de kraan wassen. Hij schrok en vroeg of dit ook voor hem 'ansteckend' was, waarop ik bevestigend antwoordde, en hem adviseerde ook flink zijn handen te wassen. Hij raakte helemaal in paniek en stuurde de hele 'oogst' van die middag eruit... ${ }^{30}$

Medisch gezien een overtrokken reactie, maar buitengewoon wenselijk en bruikbaar in het streven van de artsen om hun patiënten in veiligheid te brengen. Men hoefde maar een bordje 'roodvonk' op te hangen of de Duitsers zorgden dat ze uit de buurt bleven. ${ }^{3 \mathrm{I}}$

Een naam die in verband met de medische sabotage in het NIZ zeker genoemd dient te worden is die van chirurg Johnny van Coevorden. Hij was een meester in het opereren van een 'appendix', een blindedarmontsteking, in slechts vijf minuten, zo vertelt de overlevering. ${ }^{32} \mathrm{Nu}$ bekwaamde hij zich tevens in het nep-opereren. Vanuit het NIz bezocht hij ook de Hollandsche Schouwburg aan de Plantage Middenlaan, waar de gearresteerde Amsterdamse Joden verzameld werden alvorens op transport te gaan, om te proberen nog mensen vrij te krijgen. Dit kon bijvoorbeeld slagen als hij een vrouw in de vruchtbare 
leeftijd - of zichzelf - een snee in de arm gaf en vervolgens het bloed tussen de benen van de vrouw smeerde. Hiermee fingeerde hij een miskraam en de vrouw kon met een ambulance worden afgevoerd naar het NIZ. ${ }^{33}$ Johnny van Coevorden zorgde er ook voor dat zijn broertje Sally als leerling-verpleger in het ziekenhuis aangenomen werd, nadat hij Sally, die reeds een oproep voor tewerkstelling had gekregen, van hun geboortedorp Strijen naar Amsterdam had gehaald. Dit was gelukt dankzij een valse verklaring dat hij zijn been gebroken had en behandeling in het NIz behoefde. Van gefingeerde patiënt werd Sally vervolgens als vanzelfsprekend leerling-verpleger. ${ }^{34}$ Deze gang van zaken was zeker niet uniek. De scheiding tussen patiënten en personeel vervaagde. In ruil voor de geboden bescherming hielpen gefingeerde patiënten vaak mee in het ziekenhuis. Zo herinnerde verpleegster Janny Bolle zich:

Velen zochten bij ons hun toevlucht. Ze kwamen met een koffertje en dan was het wel duidelijk dat ze wilden blijven. Het waren vooral mensen die in de buurt van het ziekenhuis woonden en niet meer naar huis konden vanwege de razzia's. Ze hoopten dat het NIZ ze zou beschermen tegen deportatie naar Duitsland. In ruil voor die bescherming hielpen ze mee. Ze werden overal ingedeeld: in de schilkeuken, in de waskeuken, in de strijkerij, bij de kolenafdeling voor de verwarming of waar dan ook. Het ziekenhuis puilde uit met zoveel inwoners. We leefden eigenlijk in een psychose - aan de ene kant moest alles gewoon blijven functioneren, aan de andere kant was het een gekkenhuis. ${ }^{35}$

Een gekkenhuis, een vluchthaven, of -zoals Herman Herschel zei - een asielzoekerscentrum; verschillende termen kunnen gebezigd worden om de toestand in het NIZ in die herfst van 1942 te beschrijven. Volgens Herman Herschel was het vooral 's nachts een drukte van jewelste in het NIz. Mensen die niet thuis durfden te blijven na acht uur's avonds verschansten zich in het ziekenhuispand. In Herschels herinnering herbergde het ziekenhuis nachtelijk zeker 600 mensen. Een deel van hen bleef vervolgens permanent als personeelslid, ook al was van enige medische kennis vaak in het geheel geen sprake. ${ }^{36}$

Geneesheer-directeur Kroonenberg faciliteerde het verblijf van zowel patiënten als pseudopatiënten maar ook van personeel en pseudopersoneel, dat enkel een functie kreeg om aan tewerkstelling te ontkomen. ${ }^{37}$ Immers, zoals werd besproken bij de vergadering van de Joodsche Raad waren de categorieën mensen die 'gesperrt' waren in september 1942: 'gedoopten, gemengdgehuwden, diamant-industrie, confectie-industrie, Portugeesche Joden met 
3 Port. Grootouders, leden en bepaald personeel van den Joodschen Raad, ambtenaren van Joodsche Gemeente, Ziekenhuizen enz. ${ }^{38}$ Niet alleen in het ziekenhuis liggen leek daarmee een veilige 'reddingssloep', maar vooral ook in het ziekenhuis werken leek veiligheid te garanderen. Met een baantje kreeg men daadwerkelijk een Sperrstempel in het persoonsbewijs. Daarmee trok het NIZ mensen van allerlei slag aan, die allen graag een functie in het ziekenhuis wilden vervullen. Dit blijkt bijvoorbeeld uit een brief van Ben Wessels aan zijn niet-Joodse vriend Johan Schipper, die hij in zijn geboorteplaats Oostvoorne had achter moeten laten: 'ook ik kan mogenlijk een baantje krijgen in het Joodsche ziekenhuis en neem ik dit natuurlijk onmiddellijk aan.' 39 Sigarenhandelaar Ies Cohen werd aangesteld als 'hoofd van de radiokamer', ook een verzonnen baantje, maar hij zou, met zijn onverschrokken houding, nog veel betekenen voor het ziekenhuis. Medisch student Sam Bos had weliswaar iets meer medische kennis, maar ging toch in de eerste plaats als leerling-verpleger in het NIZ werken, omdat hij het idee koesterde: 'hier kan me niks gebeuren.' 40 Hetzelfde gold voor broer en zus Guus en Elly Monnickendam, respectievelijk arts en verpleegster in het NIZ. Zij werden hierdoor gesperrt, en met hen ook hun ouders, omdat de Sperren per gezin werden verstrekt. ${ }^{41}$

Van het NIZ is de meeste informatie door overlevenden overgeleverd, en dit ziekenhuis spande naar het schijnt de kroon als vluchthaven, maar het was hierin niet uniek. Volgens chirurg Mau Henriques Pimentel was ook de CIZ gevuld met 'quasi-zieken'. ${ }^{42}$ Bij het PIz hoefde men ook niet vergeefs aan te kloppen, ook hier was een opname om veiligheidsredenen mogelijk. ${ }^{43}$ Hetzelfde gold voor het Rotterdamse en ook voor het Haarlemse Joodse ziekenhuis. ${ }^{44}$ Zij waren echter beduidend kleiner dan het NIZ en dus waren de mogelijkheden qua fysieke ruimte vele malen beperkter. Zo ervoer ook een patiënt van Salomon Koster:

U hebt het ook gedaan gekregen, dat ik in het NIZ werd opgenomen, hoewel ik niet de minste afwijking heb, maar daar moest ik toen na vier weken weer uit, omdat ik helaas zo volkomen gezond ben en het ziekenhuis zo overvol is: op de drie honderd bedden zijn er honderd en negentig bijgezet. Het is daar werkelijk stikvol, je kunt haast niet meer tusschen de bedden doorkomen. En in de twee andere kleinere ziekenhuizen is voorlopig in geen maanden kans, om opgenomen te worden..$^{45}$

In het Rotterdamse Israëlietisch Ziekenhuis aan de Schietbaanlaan werd Abraham van der Sluijs opgenomen onder de valse diagnose appendicitis. Echter, in zijn geval was er bij zijn opname geen bewuste medische sabotage aan de 
kant van de behandelend artsen in het spel geweest. Zijn huisdokter had hem uitgelegd hoe hij de typische 'loslaatpijn' bij blindedarmontsteking moest simuleren. Kennelijk speelde Van der Sluijs zijn rol zo overtuigend dat de artsen in het ziekenhuis meenden dat zij echt met een appendicitis te maken hadden. Zij opereerden hem dan ook echt. Nadat hij hiervan hersteld was, hoefde hij het ziekenhuis echter niet te verlaten. Hij kreeg een witte jas, een bewijs dat hij in het ziekenhuis werkte, en ging helpen in de verpleging. Niet veel later bemachtigde hij als personeelslid ook een Sperr, wat hem genoeg uitstel van deportatie en tijd bood om een goed onderduikadres te vinden. ${ }^{46}$ Een beleid vergelijkbaar met dat van Salomon Kroonenberg in het NIZ was hier gevoerd door zijn Rotterdamse collega, geneesheer-directeur Maurits Elzas.

\section{DE JOODSCHE INVALIDE EN DE DILEMMA'S VAN EEN GENEESHEER-DIRECTEUR}

In De Joodsche Invalide werd eveneens een ruimhartig opname- en personeelsbeleid gehanteerd. ${ }^{47}$ In dit verpleeghuis, dat normaal maximaal 350 mensen verzorgde, was eind november 1942 het aantal patiënten de 400 voorbijgestreefd. De Joodsche Invalide was gevestigd in een ultramodern gebouw met veel glas op de hoek van Weesperplein en Nieuwe Achtergracht te Amsterdam. Het was in 1937 geopend na grootscheepse landelijke inzamelingsacties door directeur Isaac Gans, die dankzij veel media-aandacht en een loterij met mooie prijzen genoeg geld hadden opgeleverd om de bouwplannen te realiseren. De Joodsche Invalide was een begrip tot ver buiten de Amsterdamse stadsgrenzen. Doel van de instelling was behoeftige ouden van dagen en invaliden uit de arme Jodenbuurt een verzorgde oude dag te bieden. Het medisch personeel bestond uit een geneesheer-directeur en een instellingshuisarts. Specialisten, zoals oogarts Regina Polak-van Gelder, konden in consult geroepen worden.

De Joodsche Invalide was weliswaar geen echt ziekenhuis, maar had ook niet dezelfde status als de 'rusthuizen', die na de aanvang van de deportaties als paddenstoelen uit de grond waren geschoten. In deze rusthuizen, meestal kleinschalige pensions, werden mensen opgenomen die niet meer voor zichzelf konden zorgen of die dachten hier veiliger te zijn dan in hun eigen huis. In de tweede helft van 1942 bleek dit echter een illusie: deze rusthuizen werden een voor een leeggehaald. ${ }^{48} \mathrm{De}$ Joodsche Invalide daarentegen gold juist wel als veilig gebied. Dit instituut groeide dan ook in de loop van de deportatiemaanden evenzeer als het NIz. Presser sprak van 'een soort geloof' in de onaantast- 
baarheid van de JI, zoals de Joodsche Invalide kortweg werd genoemd. Velen boden zich ook hier als personeel aan, vaak onbetaald. ${ }^{49}$ Geneesheer-directeur Jacques Buzaglo, die militair arts was geweest en pas sinds I94I de leiding over de Ji had, bevond zich hiermee in dezelfde situatie als collega Kroonenberg. ${ }^{50}$ Ook hij droeg, anders dan de meeste 'gewone' artsen, zowel verantwoordelijkheid voor zijn patiënten als voor zijn personeel.

De verantwoordelijkheid voor de personeelsleden ging gedurende de voortschrijdende deportatiemaanden steeds zwaarder drukken op de geneesherendirecteur. De belangen van alle personeelsleden om toch vooral aan de instellingen verbonden te blijven, waren letterlijk levensgroot. Nadat in september I942 enkele uitwonende personeelsleden van de Ji toch gedeporteerd waren, maakte Buzaglo zich dan ook sterk voor Sperren voor de rest van het personeel. Hij stelde lijsten samen van het personeel met - afhankelijk van een door een 'lijstencommissie' bepaalde graad van onmisbaarheid - een A, B of C achter hun naam. Vervolgens trachtte hij via de Joodsche Raad deze drie categorieën te laten sperren. $\mathrm{Zij}$ allen waren volgens hem voor het voortbestaan van de Ji niet te missen. Bovendien hadden de Duitsers zelf bevolen in de Ji een reservecapaciteit van $5 \mathrm{I}$ bedden permanent beschikbaar te houden. Welk doel hun hiermee voor ogen stond, was niet geheel duidelijk, maar het verschafte Buzaglo een extra argument om de Ji op volle sterkte in bedrijf te moeten houden. ${ }^{\text {I }}$ Over de afhandeling van zijn verzoek door de Joodsche Raad was Buzaglo echter niet erg tevreden, zoals blijkt uit de volgende brief aan de voorzitters:

Wij hebben de bindende toezegging van de JR ontvangen door bemiddeling van de door u aangewezen delegatie, Dr. S. Spijer en notaris A. van den Bergh, dat onze A- en B-lijst volledig zouden worden gehonoreerd en van de C-lijst nog een groot gedeelte in aanmerking zou komen voor een stempel, zoodat wij zouden mogen rekenen op ca. 85 à 90 procent van het bij de lijstencommissie op 30 sept $\mathrm{jl}$ bekende personeel. Het aantal ons door den JR ter rangschikking in groepen $\mathrm{A}, \mathrm{B}$ en $\mathrm{C}$ ter hand gestelde formulieren bedraagt in geheel 372 . Uitgaande van dit getal menen wij derhalve te mogen verlangen, dat tenminste 315 (85 procent van 372) oproepen aan ons personeel worden uitgereikt. Het aantal inderdaad uitgereikte oproepen bedraagt aanmerkelijk minder en heeft thans de 260 bereikt. Zelfs onze geheele B-lijst is nog niet gesperrt. ${ }^{52}$

Zeker in vergelijking met andere Joodse ziekenhuizen, waar zich kennelijk exact hetzelfde process afspeelde, vond Buzaglo dit niet juist: 
Wij meenen u erop attent te moeten maken, dat van het CIZ en PIZ personeel de B-lijsten wel volledig zijn gehonoreerd en dat daardoor in feite het geheele aanwezige personeel een stempel ontvangen heeft, doordat men in de gelukkige omstandigheid verkeerde op de C-lijst mensen te kunnen zetten, die in feite aan een stempel via den JR geen behoefte hadden. ${ }^{53}$

Waarschijnlijk slaagde Buzaglo uiteindelijk aardig in zijn pogingen, aangezien De Joodsche Invalide eind februari 1943 nog 355 personeelsleden telde. Dit betekent dat er zeventien mensen af hadden moeten vallen. Op welke zeventien ongelukkigen was de keus gevallen? Het opstellen van lijsten van personeelsleden die meer of minder belangrijk en meer of minder onmisbaar geacht werden, moet een onmogelijke opgave geweest zijn voor Buzaglo en andere geneesheren-directeur. Zij zagen zich voor de taak gesteld keuzes te maken die voor de betrokken personeelsleden verstrekkende gevolgen zouden hebben. Een loodzware verantwoordelijkheid en een vergelijkbare situatie als bij de Joodsche Raad, waar ook eindeloos geplust en gemind werd over wie wel en wie niet in aanmerking zou komen voor een Sperr. Voortrekken van dierbaren en vrienden leek hierbij onvermijdelijk. Buzaglo nam dan ook eigen familieleden in dienst om hun zo bescherming te kunnen bieden. ${ }^{54}$ Hoe schaarser reddingsboten bij een schipbreuk worden, hoe moeilijker het is te bepalen wie er gebruik van mag maken. Voor de hand liggend is dat de juiste contacten helpen. Ook voor opnamen in de hier beschreven ziekenhuizen gold dat. Dit blijkt bijvoorbeeld uit een bewaard gebleven verzoek tot opname van de zuster van Nathaniël (Nico) Waterman, de bekende arts-onderzoeker van het Antoni van Leeuwenhoekziekenhuis. Waterman sprak zijn contact David Cohen over deze kwestie aan, die zich op zijn beurt in verbinding stelde met Buzaglo. Cohen schetste daarbij de noodzaak van opname, niet zozeer om medische als wel om sociale redenen: 'Dr. N. Waterman, die u zonder twijfel kent, vraagt mij om een aanbeveling voor zijn zuster, die hij gaarne in de Joodsche Invalide opgenomen zou hebben. Ik geef deze gaarne, zowel om zijn verdiensten alsook omdat Dr. Waterman reeds al zijn kinderen kwijt is en zijn eenige zorg nu nog deze zuster is.' 55

Internist Louis Schaap zorgde eveneens voor opname van enkele dierbaren: 'Ook ziekte kon, althans voorlopig nog, deportatie voorkomen. Daarom had ik tante Gusta ziek verklaard en in het Joodsche ziekenhuis laten opnemen, waar zij bij mij op zaal lag. [...] Tante Gatha hadden wij voor haar veiligheid vanuit de Nic. Maesstr. naar de Joodsche Invalide laten verhuizen, wat meer bescherming gaf.' ${ }^{36}$ De Groningse Ans Polak kon door interventie van haar oom en tante Willy en Regina Polak-van Gelder, respectievelijk huis- en oog- 
arts in Amsterdam, als verpleegster bij de JI in dienst treden. Het zou haar redding worden. ${ }^{57}$ Maar ook Ruth Dobschiner, die geen connecties had, was het pand ingekomen: 'Kon het niet als verpleegster, redeneerde ik, dan zou ik proberen patiënt te worden. Als ik maar onder het vurig begeerde dak van het ziekenhuis kon liggen, zou mijn huis tenminste veilig zijn, zolang ik er niet was. Het was het proberen waard.' 58

Via een tussenstap als patiënte in het NIz lukte het haar uiteindelijk als leerling-verpleegster in de Ji terecht te komen, onder het vurig begeerde dak van een ziekenhuis dus. Alleen zou de veiligheid daar niet meer van lange duur zijn.

Zowel bij het NIZ als bij de Ji had de bezetter tegen het einde van 1942 al meer dan eens gemorreld aan de veilige status. Bij het Oudeliedenhuis dat bij het NIz hoorde, werden volgens toenmalig huishoudster Bettie Weijl vrijwel dagelijks oudjes weggehaald, twee per keer.59 Ook bij de Ji stonden er dagelijks Duitsers op de stoep, aldus de beheerder van het gebouw, architect Alain Hartogh. Dankzij het 'tactisch optreden' van Buzaglo en de 'fantastische attesten' van de arts van het instituut, dokter Jo van der Hal, die tevens een huisartspraktijk aan de Nieuwe Herengracht had,waren het in totaal slechts drie patienten die daadwerkelijk op deze manier uit de Ji werden weggehaald. ${ }^{60}$ Men zorgde er in november 1942 echter nog voor dat de opnamecapaciteit vergroot werd met dertig bedden om aan de grote vraag te kunnen voldoen. ${ }^{6}$

De bezetter kreeg ongetwijfeld in de gaten dat ziekenhuizen gebruikt werden als schuilplaats en mogelijkheid om een Sperr te bemachtigen. Voor de Joodse patiënten in niet-Joodse ziekenhuizen zette hij zoekacties op touw in de eerste maanden van I943. Wat betreft de Joodse ziekenhuizen werd eerder ingegrepen. Via de Joodsche Raad kregen de Joodse ziekenhuizen in november I 942 de opdracht om lijsten in te leveren met personalia van alle patiënten en personeelsleden in de verschillende inrichtingen. Hiertoe stuurde de Joodsche Raad een brief naar alle Joodse ziekenhuizen, rusthuizen en inrichtingen. De verklaring van de bezetter was dat deze inventarisatie te maken had met de berekening van de kosten voor de ziekenverpleging. ${ }^{62} \mathrm{Op}$ basis van deze lijsten kon worden opgeteld dat er een totaal aantal verzorgden en verpleegden in Joodse instellingen in heel Nederland verbleef van 55IO. Voor hen zorgden 2753 personeelsleden. Een verhouding van zo goed als één personeelslid op elke twee patiënten. ${ }^{63}$ De Duitse gezagsdragers eisten van dit opvallende feit bij de Joodsche Raad een op schrift gestelde verklaring. ${ }^{64}$ Voorzitter David Cohen legde uit dat dit verschijnsel te verklaren viel door het wegvallen van het niet-Joodse personeel dat vaak vervangen moest worden door onervaren Joodse krachten die het vak nog moesten leren en dus minder werk per persoon konden ver- 
zetten. Als tweede argument droeg hij aan dat er wegens de omstandigheden nieuwe taken waren ontstaan, zoals bodewerk in verband met het verbod op het gebruik van de telefoon. Ook technisch werk was arbeidsintensiever geworden, wegens het gebrek aan machines en hun onderdelen, waardoor veel werk met de hand gedaan moest worden. ${ }^{65}$

Deze verklaring was weliswaar niet bevredigend voor de bezetter, maar die maakte er nog geen halszaak van. In het geheim waren er namelijk al vergevorderde plannen om de Joodse ziekenhuizen binnen afzienbare tijd geheel en al leeg te halen. Dit was mogelijk de echte reden waarom gegevens over de belegging van de bedden in de verschillende Joodse ziekenhuizen nodig waren. In de ziekenhuizen zelf had men door deze gang van zaken al wat argwaan gekregen.

Argwaan wekte ook de bouw van drie nieuwe ziekenbarakken in Westerbork. Zij konden ruimte bieden aan 700 zieken, die vanuit de instellingen in Nederland naar Westerbork zouden gaan, zo werd aan de voorzitters van de Joodsche Raad medegedeeld. Met de besturen van de ziekenhuizen zou overlegd mogen worden over overbrenging van medicatie en dergelijke en over de eventuele verdeling van wie als zware zieke zou mogen blijven en wie als lichtere zieke naar Westerbork zou kunnen reizen. ${ }^{66}$ Dit houdt in dat de Joodsche Raad in december 1942 al wel op de hoogte was van de plannen om ook zieken naar Westerbork te transporteren. Dat de ziekenhuizen daarbij ook geliquideerd zouden worden, bevroedde de Raad nog niet. Volgens de Joodsche Raad waren geruchten over mogelijke liquidatie van de Joodse ziekenhuizen 'ongegrond', hetgeen men meldde op basis van mededelingen van Duitse zijde. ${ }^{67}$ Dat men deze per definitie sterk diende te wantrouwen, bleek echter eens te meer in januari I943. Vanaf die maand bleken de geruchten wel degelijk gegrond: ook zieken bleken niet meer veilig. De status van de ziekenhuizen kwam eensklaps in een totaal ander daglicht te staan.

Dat men tijdens het eerste halfjaar van de deportaties in een illusie had geleefd wat betreft de veiligheid van zieken en ziekenhuizen, werd bewezen door de ontruiming van Het Apeldoornsche Bosch op 21 januari 1943. In één klap werd duidelijk dat de tot dan toe gecreëerde bescherming in de ziekenhuizen niet bestendig zou zijn. De hoop dat zieken en ziekenverzorgers te allen tijde met enig eerbied en respect behandeld zouden worden, en dat zelfs de Duitse bezetter die stelregel zou hanteren, werd door de gebeurtenissen in 'Het Bosch' finaal de grond in geboord. Net als de Sperrenlijsten, die een voor een ongeldig verklaard werden, ofwel 'platzten' volgens het jargon van die tijd, platzte ook de medische uitzonderingspositie. Medische reddingssloepen zonken even onherroepelijk als de andere reddingsopties, een verandering die verstrekkende 
gevolgen had voor geneesheren-directeur en behandelend artsen in Joodse ziekenhuizen. Jacques Lobstein, geneesheer-directeur van Het Apeldoornsche Bosch, zou dit als eerste op hardhandige wijze ondervinden.

\section{HET APELDOORNSCHE BOSCH: BLIJVEN OF VLUCHTEN?}

In het lommerrijke Apeldoorn was sinds 1909 in een statig pand aan de Zutphenschestraat het Joods Psychiatrisch gesticht Het Apeldoornsche Bosch gevestigd. De geesteszieken konden tot rust komen op de 36 hectare bosgrond die het tehuis omgaf. ${ }^{68}$ De Vereeniging Centraal Israëlietisch Krankzinnigenwezen in Nederland (CIK) had tot de bouw van dit gesticht in 1898 het initiatief genomen. In de vooroorlogse decennia hadden er diverse uitbreidingen plaatsgevonden in de vorm van nieuwe paviljoens op het terrein. In januari 1943 bestond het complex uit tien paviljoens. Ook waren er een administratiegebouw, een centrale keuken, een magazijn, een wasgebouw, technische werkplaatsen, een bakkerij en een slagerij, een kolenloods en een bloemenkas, alsmede een metaar-huisje voor de lijkenwassing en een synagoge. Medisch gezien was de instelling goed geoutilleerd; men beschikte over een röntgenkamer, een klinisch-chemisch en een psychologisch laboratorium en sinds I94I over een electroshockapparaat. ${ }^{69}$ Omgevende riante woonhuizen waren gereserveerd als dokterswoningen. ${ }^{70}$ Voor nazorg na ontslag uit 'Het Bosch' diende het Psychiatrisch Paedagogisch Consultatiebureau in Amsterdam. Hier stonden sinds 1925 de te Amsterdam gevestigde oud-patiënten onder toezicht. ${ }^{71}$ Een van de belangrijkste aanwinsten vlak naast het terrein zelf was de kinderafdeling Paedagogium Achisomog geweest. Dit huis voor moeilijk opvoedbare en geestelijk beperkte kinderen, waarvan de naam 'Mijn broeder tot steun' betekent, was in 1935 geopend..$^{72}$ Een jaar later, in 1936, had de niet-Joodse geneesheerdirecteur Jan Kat na 22 jaar trouwe dienst afscheid genomen, waarna hij was opgevolgd door Jacques Lobstein, sedert 1909 in het instituut werkzaam als tweede geneesheer.

Het Apeldoornsche Bosch mocht dan tijdens de eerste maanden van de deportaties bekendstaan als een oase van rust in de geteisterde Joodse gemeenschap van Nederland, de oorlogstoestand en de gevolgen daarvan waren niet geheel aan de Apeldoorners voorbijgegaan. Zo was ook hier in het kader van het verbod voor niet-Joden om in dienst van Joden te werken het niet-Joodse personeel grotendeels vervangen door Joods personeel. De Amsterdamse psychiater Arie Querido, bijvoorbeeld, was in Apeldoorn komen werken omdat 
hij uit zijn functie bij de hoofdstedelijke GGD ontheven was. Hij verving de niet-Joodse psychiater C.H. Simons, die uit de Apeldoornse inrichting had moeten vertrekken. Querido had Simons nog aangeboden te ruilen, zodat Simons zowel Querido's functie bij de GGD zou kunnen overnemen als zijn huis in Amsterdam. Simons wilde echter liever in Apeldoorn blijven wonen. ${ }^{73}$ Of Simons echt niet-Joods was, viel overigens te betwijfelen: hij had een Joodse vader en van zijn moeders familie was de afstamming vanwege Surinaamse wortels moeilijk te bepalen. Hij had zich echter niet aangemeld en viel dus buiten de anti-Joodse maatregelen. Pijnlijk was het ontslag van het niet-Joodse personeel, dat voor de oorlog zo'n 60 procent van de medewerkers had uitgemaakt, zeker geweest, maar men had hen zo goed mogelijk vervangen door Joods personeel. Lobstein had deze opdracht zeer nauwkeurig ter hand genomen, zoals blijkt uit een brief van hem aan het bestuur van de vereniging cıK in Amsterdam. Hierin meldde hij twee geschikte nieuwe artsen gevonden te hebben, weliswaar Joods, maar respectievelijk verloofd met een niet-Joods meisje en niet besneden. ${ }^{74}$ Hierin zag Lobstein kennelijk een mogelijk bezwaar. De benoeming van deze John van Lier en Jaap Spanjaard kon desalniettemin doorgaan. Voor enkele onmisbare niet-Joodse personeelsleden kon bovendien dankzij bemoeienis van de Joodsche Raad een uitzondering gemaakt worden, zij konden voorlopig nog in 'Het Bosch' blijven werken.75

De eerste signalen dat het voortbestaan van Het Apeldoornsche Bosch weleens ter discussie zou kunnen komen te staan, kwamen reeds in november 1942. Historici hebben zich erover verbaasd dat Lobstein naar aanleiding daarvan tussen november 1942 en januari 1943 geen maatregelen trof. ${ }^{6}$ Volgens Presser lag het voor de hand dat Het Apeldoornsche Bosch gevaar liep: 'de nazi's roeiden Joden uit en de nazi's roeiden krankzinnigen uit. Zouden zij dan Joodse krankzinnigen ontzien?'77 Hij vroeg zich dan ook af of er door de afwachtende houding van Lobstein niet meer mensen in de val gelopen waren dan nodig was geweest. ${ }^{78} \mathrm{Had}$ Lobstein zijn patiënten en personeel niet beter kunnen manen weg te gaan en onder te duiken?

Op 6 november 1942 bracht Stabarzt ss-Sturmbannführer E.W.P. Meyer het Apeldoornsche Bosch een bezoek en legde daarbij bijzondere belangstelling aan de dag voor het instrumentarium en de röntgenapparatuur. ${ }^{79}$ Omstreeks diezelfde tijd deelde F. Reuter, hoofd van de Abteilung Volksgesundheit van het Generalkommissariat fur Verwaltung und Justiz, aan de regionaal inspecteur voor het Krankzinnigenwezen, A.G. Audier, mede dat Het Apeldoornsche Bosch uitgekozen was als locatie om 2000 zieken uit West-Duitsland te laten verplegen. ${ }^{80}$ Audier reisde met het nieuws van Reuter af naar Apeldoorn om Lobstein van deze plannen te verwittigen. Enkele dagen later kwam het bericht 
dat van het plan werd afgezien, in verband met vervoersmoeilijkheden. ${ }^{8 \mathrm{r}}$ Een maand later echter herhaalde Audier zijn waarschuwing dat Het Apeldoornsche Bosch zou worden ontruimd. Ook aan secretaris-generaal Frederiks berichtte Audier nu wat hem ter ore was gekomen. Frederiks besprak de zaak in het college van secretarissen-generaal op 22 december. Men vergaderde echter slechts over de vraag welke uit de Hollandse kuststrook te evacueren inrichtingen in de lege paviljoens gehuisvest zouden kunnen worden. Over wat er met de op dat moment nog actuele bewoners van het terrein zou gebeuren, repten de secretarissen-generaal met geen woord. En ook Lobstein ondernam geen actie. ${ }^{82}$ Mogelijk mede omdat Audier hem opnieuw tegenstrijdige berichten gaf. ${ }^{83}$

Vervolgens was het de burgemeester van Apeldoorn die Lobstein alarmeerde. Eind december stuurde hij de geneesheer-directeur een telegram waarin hij aankondigde dat Het Apeldoornsche Bosch was aangewezen voor de huisvesting van een centraal regeringsorgaan. ${ }^{84}$ Die huisvesting zou op korte termijn geschieden en de burgemeester maande Lobstein om alvast voorbereidende maatregelen ter ontruiming te nemen. ${ }^{85}$ Audier stelde Lobstein nu echter gerust. De 'Wehrmachtsbefehlhaber' had Audier immers verzekerd dat medische instellingen slechts voor medische doeleinden gebruikt mochten worden en dat derhalve onderbrenging van een departement op het Bosch-terrein uitgesloten leek. ${ }^{86}$ Dit was slechts ten dele een geruststelling, Audier zei immers niet dat vestiging van een andere médische instelling op het terrein van het $\mathrm{AB}$ uitgesloten was. Lobstein had alsnog reden om argwanend te zijn. Hij hoopte waarschijnlijk echter dat een dergelijke inkwartiering van een andere medische instelling niet gepaard zou gaan met ontruiming van de oorspronkelijke bewoning. Hij geloofde namelijk, volgens Nico Speyer, die als psychiater bij hem in dienst was, in de mogelijkheid dat de Duitsers van Het Apeldoornsche Bosch een 'getto' voor Joodse zieken wilden maken. Dit zou dan betekenen dat er Joodse zieken vanuit het hele land op het terrein gehuisvest zouden worden, naast de al aanwezige patiënten. ${ }^{87}$ Ook toen Ferdinand Aus der Fünten op II januari 1943 in burger naar Apeldoorn afreisde en Lobstein om een rondleiding en een plattegrond vroeg, leek de directeur volgens de bronnen nog niet gealarmeerd. Het bezoek paste voor Lobstein nog steeds bij het idee dat men een getto voor Joodse zieken wilde vormen, aldus ook Arie Querido. ${ }^{88}$ In werkelijkheid beoordeelde Aus der Fünten de geschiktheid van het terrein voor een herstellingsoord voor de Waffen-ss. Aangezien hij de locatie voor dit doel uitermate geschikt achtte, werd er nu haast gemaakt met het ontruimingsplan van de Joodse instelling. ${ }^{89}$ Enkele signalen pleitten er echter nog tot op het laatste moment tegen dat Het Apeldoornsche Bosch voor zijn bestaan zou moeten vrezen. Zo werden er op 27 december 1942 nog dertien patiënten uit 
Westerbork naartoe gebracht. ${ }^{90}$ Dat was al vier maal eerder voorgekomen. Op I7 januari 1943 herhaalde dit zich voor de laatste keer, ${ }^{91}$ toen liefst 2 I mensen van Westerbork naar Apeldoorn werden overgebracht. Dit wekte ook bij het verplegend personeel de indruk dat het voortbestaan van het AB niet ter discussie stond..$^{92}$

Toen op woensdag 20 januari 1943 de Westerborkse kampcommandant Albert Konrad Gemmeker, de Duits-Joodse kamparts Fritz Spanier en honderd mannen van de Joodse Ordedienst (OD) uit Westerbork bij Het Apeldoornsche Bosch aankwamen en de andere Joodse inwoners van Apeldoorn hier bijeenbrachten, was ineens wel degelijk duidelijk wat er stond te gebeuren. Zeker toen de stationsbeambte kwam melden dat er een lange goederentrein gereedstond, was er geen twijfel meer mogelijk. De ontruiming van Het Apeldoornsche Bosch was ophanden. Lobstein gaf het personeel en de mildste patiënten nu de gelegenheid om de instelling te verlaten. Niettemin zou hij volgens Presser nog gerustgesteld zijn door Gemmeker, die hem bezwoer dat hij met zijn groep oD'ers de volgende dag door zou reizen naar Amsterdam. ${ }^{93}$ Echter, loos alarm was het zeker niet. Het personeel was daarvan doordrongen. Eerste verpleger de Groot en zijn vrouw pleegden suïcide en de helft van de personeelsleden en Io procent van zijn patiënten vertrokken met de noorderzon. Lobstein belde Audier, die de volgende morgen om Io uur, nadat het Apeldoornsche Bosch een zeer bewogen nacht had meegemaakt, toesnelde. ${ }^{94}$

Die nacht, van 20 op 2I januari I943, was 'waarschijnlijk de bewogenste nacht in mijn leven', zo schreef verpleger Remi Frank. ${ }^{95}$ Alles moest in gereedheid worden gebracht voor het aanstaande vertrek van de honderden patienten. Pakketten met levensmiddelen en linnengoed en injectiespuiten met het slaapmiddel scopolamine dienden geprepareerd te worden. Leden van de oD maakten tegelijkertijd van de gelegenheid gebruik om personeelsleden te manen het terrein te ontvluchten. Ieder voor zich moest bepalen of hij of zij dat wel of niet zou doen. Deze keuze leverde een levensgroot moreel dilemma voor de betrokkenen op. ${ }^{96}$ Plichtsbesef en het gevoel door de patiënten niet te kunnen worden gemist, moeten door ieders hoofd gespeeld hebben. Een van de OD-mannen noteerde hierover: 'Een groot deel van het personeel had echter teveel plichtsgevoel en wilde de patiënten niet in de steek laten.' 97 Hoewel de oD-er zich er kennelijk over verbaasde, was deze houding niet zo onvoorstelbaar vanuit het perspectief van de norm die voor de artsen en ook voor het verplegend personeel altijd gegolden had: de zorgplicht voor de patiënt. Verpleger Remi Frank ventileerde zijn teleurstelling over de personeelsleden die zich aan deze plicht onttrokken en de benen namen, onder wie volgens hem ook een van de artsen: 'En voor het personeel geldt hier de spreekwijze "Het zinkende 
schip verlaten", al geldt het hier zeker niet allemaal wakkere kapiteinen. Toch bevinden er zich hier vele hoofden onder, zelfs een dokter. Dien zal ik later nooit willen nemen en vertrouwen, omdat ik nu weet, dat hij je niet tot in de uiterste nood zal bijstaan.'98

Naast Lobstein telde Het Apeldoornsche Bosch op het moment van de ontruiming nog acht artsen. Nico Speyer, Arie Querido, Jacob (Jaap) Spanjaard en Elisabeth van der Wal waren de psychiaters, Jonas Mendels nam als internist de somatische behandelingen voor zijn rekening. Daarnaast waren er twee arts-assistenten: John van Lier en David de Vries. Ook was er een vrouwelijke Duits-Joodse psychiater betrokken bij Het Apeldoornsche Bosch. Zij stond niet op de loonlijst, waarschijnlijk omdat zij als Duitse in principe niet in Nederland als arts mocht werken. Haar naam was Weinberg. Een negende, niet-praktiserende arts die op het terrein woonde, was Querido's niet-Joodse echtgenote Tine Querido-Nagtegaal. ${ }^{99}$

Uit de archieven blijkt, in tegenstelling tot Remi Franks verwijt, niet dat er een arts vertrok. Het lijkt erop dat juist geen van hen het zinkende schip verliet. Zij bleven op hun post, met inbegrip van de niet-Joodse psychiater Elisabeth C. van der Wal. ${ }^{100}$ Hiermee is de houding van Lobstein ook te verklaren. Of hij naïef was of niet, is in feite niet relevant. De overtuiging dat het zijn plicht was zijn Apeldoornsche Bosch niet in de steek te laten, gaf waarschijnlijk de doorslag. Zijn verantwoordelijkheid als arts en als geneesheer-directeur schreef immers voor dat hij op zijn post bleef en de zorg voor patiënten en personeel zo veel mogelijk zou continueren. Een kapitein verlaat zijn zinkende schip niet en een geneesheer-directeur zijn ziekenhuis niet. Bovendien was het in Lobsteins specifieke geval onmogelijk geweest om patiënten weg te sturen. Zijn honderden patiënten waren vanwege hun mentale retardatie of ernstige psychiatrische aandoening over het algemeen niet in staat zich zelfstandig buiten de inrichting staande te houden, zeker niet onder de oorlogsomstandigheden die op dat moment golden. Zij waren van Lobstein en zijn staf afhankelijk. Zolang Lobstein de zorg voor zijn patiënten wilde continueren, kon hij daarom ook zijn personeel niet laten gaan. Dat Lobstein zijn artsenplicht als leidraad voor zijn handelen had, beaamden niet-Joodse collegae, die hem in april 1943 probeerden te helpen. Een eerdere poging daartoe was ook ondernomen, maar Lobstein had op dat moment naar verluidt geantwoord die hulp niet te kunnen aannemen 'omdat hij zich met de leiding van het hem toevertrouwde gesticht wenschte te blijven belasten zoolang het belang der patiënten dat wenschelijk maakte. Zoo heeft hij dus de kans op eigen voordeel ten behoeve van zijn patienten afgewezen.' ${ }^{\text {Ior }}$ Ook Elizabeth van der Wal schreef in haar in memoriam: 'Hij vervulde zijn taak totdat de patiënten waren weggevoerd.' ${ }^{\prime 2}$ 
De andere aanwezige artsen dienden, ook al droegen zij niet de immense verantwoordelijkheid van Lobstein, eveneens hun houding te bepalen. Psychiaters Nico Speyer en Arie Querido waren erbij geweest toen Audier in november 1942 Lobstein kwam waarschuwen. Volgens eigen zeggen heeft Speyer vervolgens, anders dan Lobstein, wel actie ondernomen en zo veel mogelijk personeelsleden aangeraden om de instelling te verlaten en onder te duiken. ${ }^{103}$ Dat gebeurde dan ook wel, maar het voelde, volgens een oud-verpleger, 'ten

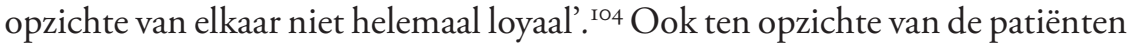
voelde men ook dat men dat eigenlijk niet kon maken. ${ }^{\text {IOS }}$ Van die patiënten was echter eveneens, al voor 20 januari 1943, een deel vertrokken. De Jong schatte dit aantal zelfs op een kleine 200. ${ }^{106}$ Dit zou de invloed van Speyers waarschuwing geweest kunnen zijn. De meesten zullen simulanten ofwel pseudopatiënten of lichtere gevallen zijn geweest die zichzelf buiten de instelling konden redden.

Zijn eigen laatste twijfel over wat er zou gebeuren verloor Speyer pas, en hetzelfde getuigde ook Querido, toen Lobstein hun vertelde dat Aus der Fünten tijdens zijn bezoek van II januari had gevraagd of er een treinstation in de buurt van de instelling was. ${ }^{107}$ Querido en zijn vrouw vertrouwden het nu helemaal niet meer en lieten hun kinderen onderduiken. Zo ook Jonas Mendels en zijn vrouw. Enige dagen voordat de inrichting werd leeggehaald, bracht verpleegster Nuys baby Eljah Mendels en de kinderen Querido naar een onderduikadres. ${ }^{108}$ Hun ouders bleven echter, ondanks de sterke vermoedens wat hun boven het hoofd hing, net als hun directeur, op hun post.

\section{DE ONTRUIMING VAN HET APELDOORNSCHE BOSCH}

Jacques Lobstein probeerde ook op 2I januari 1943, de chaotische en dramatische dag van de ontruiming van zijn instelling, nog als geneesheer-directeur op te treden. Op het nippertje poogde hij iets van zijn instelling te redden: hij maakte een lijst op van verpleegden die niet-vervoerbaar waren. Dit middel, op vele locaties in de voorafgaande maanden met succes ingezet, bleek nu echter van geen enkele waarde meer te zijn. Toen, tegen de avond, Aus der Fünten kwam en de lijst onder ogen kreeg, schoof hij deze onmiddellijk opzij met de redenering dat voor hem alle patiënten 'transportfähig' waren. ${ }^{109}$ Ook voor Lobsteins argument dat sommige patiënten vanwege hun christelijke doop of gemengde huwelijk niet meegevoerd zouden moeten worden, bleek Aus der Fünten niet of nauwelijks gevoelig. ${ }^{\text {IIo }} \mathrm{Hij}$ ging rücksichtslos aan de slag. Audier protesteerde nog tegen de ruwe behandeling van de patiënten, maar 
werd onmiddellijk door Aus der Fünten weggestuurd. Wat volgde, was een afgrijselijk schouwspel. oD'er Ernest Frank vond dit het ergste wat hij ooit had meegemaakt. ${ }^{I I I}$ Een andere oD'er dacht er net zo over: 'Nou Bram [...] als je dit had meegemaakt, dan zou je nooit van zijn leven meer oprecht kunnen lachen. Zoiets verschrikkelijks heb ik nog nooit gezien.' 'II2

Een honderdtal sD'ers dat met Aus der Fünten was gearriveerd, had het terrein van Het Apeldoornsche Bosch afgezet. Paviljoen voor paviljoen joegen zij de patiënten en de kinderen van Achisomog, soms in nachtkleding of dwangbuis, naar buiten. Degenen die niet konden lopen, werden gedragen door de mannen van de Westerborkse Ordedienst. Buiten werden de patiënten in vrachtwagens gepropt en vervoerd naar het rangeerterrein bij het Apeldoornse station, waar 40 goederenwagons met gesloten luchtluiken voor hen gereedstonden. $\mathrm{Nu}$ Lobstein niets meer voor zijn patiënten kon betekenen, poogde hij zich voor zijn personeelsleden in te spannen. Hij probeerde bij het personeel te komen dat uit de paviljoens was gehaald en was opgesloten in een eetzaal van het hoofdgebouw. Ze werden er bewaakt door een Duitser die Lobstein met stokslagen wegjoeg. ${ }^{\mathrm{II}}$ Tenslotte werden de artsen 's avonds zelf ook apart in een zaaltje van sanatoriumafdeling 'Rustoord' opgesloten. Hier stonden bedden en men maande hun om te gaan slapen. Ondertussen gingen de barbaarse taferelen buiten door. Lobstein stond machteloos. Vanuit de kamer waarin hij werd opgesloten, schreef hij in een brief aan de secretaris van de CIK in Amsterdam:

Pogingen om zwaar zieke en niet transportabele patiënten achter te kunnen houden, mochten niet gelukken, alles moest mee. De heele nacht is men met behulp van de OD menschen uit Westerbork bezig geweest onze patiënten naar een gereedstaanden trein uit goederenwagens bestaande over te brengen. De artsen en het administratief personeel werden in de commissiekamer verzameld, mochten er niet uit. Omstreeks half twaalf kregen wij opdracht te gaan slapen op leegstaande bedden op Rustoordmannen, waar ik thans dit krabbeltje zit te schrijven. Hoe het ons te moede was, dat wij onze patiënten zoo in de steek hebben moeten laten, kunt $\mathrm{u}$ u indenken. ${ }^{\mathrm{II}} 4$

En niet alleen hoe zijn patiënten werden weggevoerd moest Lobstein aanzien, ook verloor hij diezelfde nacht zijn zoon:

Zoo juist hoor ik dat nog een aantal van ons verplegend personeel is aangewezen om met het transport patiënten mee naar Duitschland te gaan, 
waaronder o.a. ook mijn zoon Frits. Het is mij moeilijk mijn gedachten te dienen op het oogenblik. Verzend $u$ dit korte briefje om $u$ en den andere heeren even in te lichten. Ik weet niet wanneer 't mij weer mogelijk zal zijn te schrijven. Met beste wenschen en groeten voor het geheele college. J. Lobstein. ${ }^{\mathrm{II}}$

Van de andere artsen is geen notitie van dat moment zelf bewaard gebleven. Nico Speyer schreef later wel een manuscript onder de titel Het drama van het Apeldoornsche Bosch. Zijn persoonlijke gedachten en gevoelens tijdens de gebeurtenissen op 2I januari stelde hij hierin echter niet te boek. Wel noteerde hij hoe er onmiddellijk na de komst van de oD door het personeel met verantwoordelijkheidsbesef op de patiënten gelet werd. Op hen diende de spanning die er onder het personeel heerste, niet overgedragen te worden. Dat lukte aardig, 'zodat het nimmer tot een paniek kwam'. ${ }^{16}$ Voordat de Duitsers waren gekomen, had Speyer de taak op zich genomen om verplegend personeel uit te rusten met voldoende medicamenten en verbandmiddelen voor de reis en had hij Lobstein geholpen met het opstellen van zijn lijst van intransportabele zieken. ${ }^{\text {II7 }}$ Welke criteria zij hierbij precies hanteerden meldde Speyer niet. Zij noteerden op deze lijst volgens hem de namen van ruim 40 verpleegden. ${ }^{\text {II } 8}$ In het proces tegen Aus der Fünten liet Speyer wel iets over de gebruikte criteria los: 'onvervoerbare patiënten, die behalve geestelijk ook lichamelijk ziek waren'. ${ }^{\text {II }}$ Zin had het, zoals eerder vermeld, achteraf bezien geenszins. Eveneens zinloos bleek achteraf de poging die Jonas Mendels met secretaresse Paulina Vomberg waagde om medepersoneelsleden te redden door hun functies op de stamkaarten te veranderen. ${ }^{\text {I20 }}$ Voor een enkele minder zware patiënt had het wel zin om zich in verplegersuniform te hijsen, zoals op de sanatoriumafdeling geschiedde. Deze enkelingen werden niet mee-gedeporteerd. ${ }^{\text {I2I }}$

Arie Querido beschreef de gebeurtenissen tijdens de ontruiming later mi-

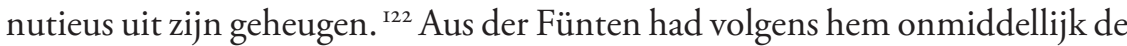
leiding genomen en Audier weggestuurd. De andere artsen hadden in de directeurskamer moeten blijven. Enkelen van hen waren bevolen mee te komen. Querido zelf was gesommeerd mee te lopen om deuren te sluiten en daarna de sleutels af te geven. Nico Speyer had de Duitsers volgens een andere bron moeten rondleiden over het terrein en Jonas Mendels werd verplicht uitleg te geven over de werking van de röntgenkamer. ${ }^{123}$ Speyer protesteerde tegen het niet bewaken van de krankzinnigen. 'Dit protest werd lachend genegeerd.' 124 Toen de artsen vervolgens in 'Rustoord' hadden moeten slapen, was er om een uur 's nachts een Duitser komen vragen naar een arts. Querido sliep nog niet en ging mee als gids. Bij deze gelegenheid zag hij hoe de patiënten werden inge- 
laden. Ook in de ziekenzaal van het personeel wilde Aus der Fünten iedereen inladen. Dit wist Querido echter te voorkomen: 'Ik kon hem bewegen dat ik na zou gaan wie van de zieken in staat waren zich bij het andere personeel te voegen. Hij liet mij toen in het ziekenhuisje achter en ik kreeg de gelegenheid mede te delen, wat Aus der Fünten mij had gezegd. Een aantal broeders en zusters zijn toen opgestaan en hebben zich bij het andere personeel gevoegd.' ${ }^{125}$

De zwaar zieke personeelsleden die dat niet konden, met bijvoorbeeld open tbc of sepsis, gingen onherroepelijk met de patiënten mee. Zij overleden al tijdens het transport, daar was Querido van overtuigd. ${ }^{126}$ De tandarts, die stervende was - hij was septisch door een beet van een patiënt -, had van Querido een injectie gekregen om hem het transport te verlichten, of liever gezegd in de hoop dat hij het transport niet meer zou hoeven meemaken. ${ }^{127}$ Verder mochten verdovende middelen niet worden toegediend. ${ }^{128}$ Volgens getuigenis van secretaresse Paulina Vomberg echter zorgde zij dat haar eigen moeder een grote dosis slaapmiddel toegediend kreeg, waarop deze overleed en deportatie haar bespaard bleef. Of nog meer patiënten op deze manier een zachte dood stierven, was Vomberg niet bekend. ${ }^{129}$ Volgens Querido bleven er veel klaargemaakte injectiespuiten met scopolamine ongebruikt liggen, evenals de voedselpakketten. Al deze geprepareerde reisbenodigdheden bleven achter in de leeggehaalde paviljoens. Querido probeerde Aus der Fünten nog duidelijk te maken dat de kinderen van Achisomog moeilijk opvoedbaar waren en niet krankzinnig. Dat hielp niet, ook de kinderen moesten mee. Zij waren immers volgens Aus der Fünten 'asociale elementen'. ${ }^{130}$ Querido herinnerde zich ook hoe Aus der Fünten, aangekomen in een leeggehaald paviljoen zei: 'Het stinkt hier.' Querido antwoordde dat het de geur van angstzweet was en greep de mogelijkheid aan om te protesteren tegen hetgeen geschiedde: "'een mens heeft niet het recht dat te doen." Waarop Aus der Fünten antwoordde: "Wie zal dat uitmaken?” Ik zeide toen: "Dat wordt hierboven uitgemaakt."” ${ }_{331}$

Over hun eigen lot tastten de artsen in het duister. Aus der Fünten had hun gezegd dat de patiënten naar Duitse lazaretten zouden worden gebracht en dat het personeel in Nederland zou blijven. ${ }^{32}$ Enige scepsis over de betrouwbaarheid van deze woorden zal de artsen niet vreemd geweest zijn. Op vrijdagochtend 22 januari werden de artsen van Het Apeldoornsche Bosch - voor zover zij geslapen hadden - wakker in een leeg gebouw, omringd door lege paviljoens. Veel tijd om hierbij stil te staan kregen ze niet. Om halftwaalf vertrok ook hun trein vanuit Apeldoorn in de richting van Westerbork: Van Lier, Mendels, Spanjaard, Speyer, De Vries en Weinberg en het resterende verplegend personeel gingen mee. ${ }^{133}$ Querido hoefde vanwege zijn gemengde huwelijk niet 
mee. Lobstein bleef met enkele administratieve krachten in het geplunderde gebouw achter. Zij vonden hier tussen de puinhopen nog een dode en een oud vrouwtje dat over het hoofd gezien was. En een rapportenboekje van een afdeling: 'Dit is het laatste rapport. Het AB heeft opgehouden te bestaan. Alle patiënten, morgen emigranten, slapen rustig. Verder geen bijzonderheden. N.B. Patiënt ....heeft nog geen clysma gehad.' 'i34

Op I februari arriveerde ook de plichtsgetrouwe geneesheer-directeur Jacques Lobstein in Westerbork. ${ }^{135}$ Zijn patiënten vond hij daar niet terug, die hadden inmiddels al de dood gevonden in Auschwitz-Birkenau.

\section{'IK VERMOED DAT ZE ZE WEL VAN KANT MAKEN'}

Om zeven uur's ochtends op vrijdag 22 januari waren de 40 goederenwagons met psychiatrisch zieken en een personenwagon met 50 man personeel, van wie er 20 vrijwillig waren meegegaan en 30 na aanwijzing van Aus der Fünten, uit Apeldoorn vertrokken om bij Hengelo de Duitse grens te passeren. De eindbestemming was Auschwitz-Birkenau. Enkele uren later stelden de voorzitters van de Joodsche Raad hun meest nabije collegae van deze gang van zaken op de hoogte. ${ }^{136}$ Een week later hadden Asscher en Cohen een afspraak met Aus der Fünten. $Z$ ij wilden van hem een verklaring van het gebeurde: 'Wij vroegen waarom zieken werden weggehaald en krankzinnigen uit het Apeldoornsche Bosch. Geantwoord werd, dat men deze inrichting nodig had. ${ }^{137}$ Ook wensten zij opheldering omtrent het lot van de gedeporteerde zieken: 'Op onze vraag werd geantwoord, dat de krankzinnigen en de zieken in lazaretten zouden worden opgenomen en verpleegd. ${ }^{{ }^{1} 38}$ Of Cohen en Asscher de verklaring van Aus der Fünten geloofden, wordt in dit verslag niet vermeld.

Anderen hadden op dit moment al een andere, realistischer duiding van het lot dat de gedeporteerden zou treffen. ' $\mathrm{Nu}$, dan kan je wel op je vingers natellen, dat er niet veel van terecht komt. Wat moeten ze daar met die mensen doen? Die zijn nooit in staat om te werken en geloof maar niet, dat ze deze menschen daar nog verplegen. Ik vermoed dat ze ze wel van kant maken, ${ }^{139}$ zo schreef een der oD'ers. Diezelfde overtuiging was Sally de Jong toegedaan toen deze in 1943 in zijn verslag over de toestand van de Nederlandse Joden met betrekking tot de patiënten van Het Apeldoornsche Bosch schreef: 'het valt niet te betwijfelen dat al deze ongelukkigen afgemaakt zijn.' ${ }^{\text {'T40 }}$ Ook Salomon Koster schreef het in zijn dagboek: 
Van de patiënten uit het Joodsch krankzinnigengesticht Het Apeldoornsche Bosch was het al direct zeker, voor zover de directeur hun niet nog bijtijds de vrijheid gaf, hetgeen natuurlijk slechts met weinig patiënten mogelijk was, dat zij allen, bij den overval door de Duitschers op het gesticht, gehaald werden, om afgemaakt te worden, evenals dit met de krankzinnigen in Duitschland, Joden en niet-Joden, gebeurd was. ${ }^{141}$

Lobstein zelf probeerde zich in gevangenschap in Bergen-Belsen, september I944, een voorstelling te maken van het lot dat zijn patiënten hadden ondergaan: 'Wat is er geworden van de patiënten die in den catastrophalen nacht van $2 \mathrm{I} / 22$ januari zijn weggevoerd? De geruchten hieromtrent doen niet veel goeds verwachten en er is helaas maar al te zeer reden om te vermoeden dat deze geruchten waarheid bevatten. Maar zekerheid bestaat er niet. ${ }^{\text {'I42 }}$ Ook de andere artsen van Het Apeldoornsche Bosch schatten, na het aanschouwen van de rücksichtslose behandeling van de patiënten tijdens de ontruiming, hun lot zeer somber in. Jacob Spanjaard schatte in dat ongeveer Io procent van de patiënten lichamelijk te ziek was om zelfs het transport van de instelling naar de trein te overleven. Dat de Duitse leiding zich hier niets aan gelegen liet, was voor Spanjaard genoeg om zijn conclusie te trekken: 'de mensen zouden van kant worden gemaakt.' 'I43 Nico Speyer deelde die visie: 'Ik, voor mij zelf, was daarom niet alleen overtuigd, dat een deel van de zieke patiënten reeds diezelfde nacht moesten zijn overleden, maar ik maakte mij daarbij ook geen enkele illusie over het lot van de overigen, van wie ik moest aannemen, dat zij bestemd waren om te worden vermoord.' ${ }^{\text {'44 }}$

Ook collega Elie Cohen schatte het gruwelijk lot der gedeporteerden juist in, en meende zelfs iets te weten over de methode waarop dit in het geval van de patiënten van Het Apeldoornsche Bosch geschied zou zijn: 'Reeds in I942 had ik geruchten over de vergassing van Poolse Joden vernomen en te Westerbork nam men aan, dat b.v. het transport van zenuwpatiënten van het Joodse krankzinnigengesticht Het Apeldoornsche Bosch dd. 26 januari 1943, hetzelfde lot had ondergaan.' ${ }^{\mathrm{I} 45}$

Het bestuur van de vereniging Centraal Israëlietisch Krankzinnigenwezen, waaronder Het Apeldoornsche Bosch ressorteerde, was gevestigd in Amsterdam, waar geschokt werd gereageerd op de ontruiming, ${ }^{\mathrm{I} 46}$ net als in Apeldoorn zelf. ${ }^{147}$ Tegelijkertijd werd op zakelijke wijze de administratieve afwikkeling ter hand genomen. Op 27 januari stelde het bestuur van het CIK de burgemeester van Amsterdam op de hoogte van de gebeurtenissen. Ook de GGD Amsterdam en de secretarissen-generaal van Binnenlandse Zaken en Justitie werden op dezelfde wijze ingelicht. ${ }^{148}$ Reacties hierop zijn niet bewaard in het CIK-archief. 
Wel bewaard zijn legio brieven van familieleden van patiënten die bij het CIK informeerden naar de verblijfplaats van hun dierbaren. Soms herhaaldelijk en met steeds wanhopiger toon. Het CIK moest hun het antwoord echter schuldig blijven. Dat was althans het officiële antwoord. Ook de bestuursleden van het CIK zullen met grote vrezen gevreesd hebben voor het lot van de gedeporteerde zieken.

De algemene opinie was dat de bezetter deze 'minderwaardigen' wel niet zou sparen. Het vermoeden dat ook de andere zieken, ouden van dagen en kinderen als zodanig beschouwd en behandeld zouden worden, was ook aanwezig, getuige bijvoorbeeld het dagboek van Salomon Koster, die de woorden van een patiënte, zelf verpleegster in het NIZ, weergaf: 'Hoe de Joden gedood worden, door die sadisten, electrisch of met gas, doet eigenlijk weinig ter zake, maar dat dit gebeurt met alle Joden, die niet in staat zijn, om heel hard voor de Duitschers te werken, daarvan is zoo ongeveer iedereen overtuigd.' ${ }^{4} 9$

Het bewijs was geleverd: de bezetter bleek niet terug te deinzen voor het wegvoeren van niet tot enige arbeid in staat zijnde zieken en gehandicapten. Dat gaf te denken voor de andere ziekenhuizen en deed de vraag rijzen of er met medische redmiddelen nog iets te beginnen viel.

\section{REACTIES IN NIET-JOODSE KRING}

De ontruiming van Het Apeldoornsche Bosch bracht ontzetting teweeg in bezet Nederland, en niet alleen in Joodse kring. Het nieuws verspreidde zich razendsnel. ${ }^{150}$ Reacties van verontwaardiging kwamen los. Een morele code voor hoe nu te handelen moest eveneens uitgedacht worden. Het Medisch Contact uitte zijn afgrijzen in een estafettebericht van I maart 1943: 'Een staaltje van Nat.Soc. gezondheidszorg! Op ongelooflijk ruwe wijze zijn de patiënten uit het Isr. K.Z. gesticht het Apeldoornsche Bosch door de bezettingsautoriteiten in goederenwagons, tendeele gebonden, tendeele opeengestapeld, weggevoerd. Men kan het gruwelijk lot dat deze menschen verder getroffen heeft, helaas maar al te goed gissen.' 'II

Een afgevaardigde van het Medisch Contact, de Zutphense arts Paul van Bork, was de avond van de ontruiming poolshoogte gaan nemen en had met Lobstein gesproken. Hij had direct een rapport opgesteld en dit naar de gerechtelijke instantie van de politie Zutphen gezonden. ${ }^{I 52}$ Aan het lot van de patiënten veranderde dat echter niets. Het was wel het eerste teken dat de artsenstand een antwoord trachtte te formuleren op wat er geschied was.

Niet-Joodse artsen hadden door het Medisch Contact en door confronta- 
ties met Joodse patiënten en Joodse collegae zeker enig inzicht in de situatie waarin de Joden zich bevonden. Ook voor niet-Joodse geneesheren-directeur van ziekenhuizen in den lande gold dat. $\mathrm{Zij}$ kregen immers te maken met het weghalen van Joodse patiënten uit hun inrichtingen. Over het verdere lot van die patiënten maakten ook zij zich waarschijnlijk weinig illusies. Had men aanvankelijk nog gedacht of in elk geval gehoopt dat de ouden van dagen die vanaf de herfst van 1942 waren weggevoerd, bijvoorbeeld uit rusthuizen, in door het Rode Kruis gefaciliteerde kampen zouden worden verzorgd, en dat Duitsland op deze manier deviezen in handen kreeg, na de ontruiming van Het Apeldoornsche Bosch kon men niet meer om de donkerste voorspellingen heen. ${ }^{153}$ Het centrum van Medisch Contact sommeerde zijn leden dan ook bij volgende acties zo veel mogelijk tegen te werken: 'Er dreigen thans ook maatregelen tegen andere gestichten. Men zij erop voorbereid, dat hier van ons allen verzet zal worden geeischt, nog verder gaande en nog uitgebreider dan in den Ziekenfondsstrijd.' ${ }^{\text {'54 }}$

Nog verdergaand en uitgebreider dan in de ziekenfondsstrijd: dat betekende nogal wat. Voor de bezetting had de artsenstand immers collectief zeer succesvol weerstand geboden aan hervormingen van het verzekeringsstelsel: de artsen hadden voorkomen dat zij bij ziekenfondsen in loondienst zouden moeten treden en hadden daarmee de door hen essentieel geachte vrije artsenkeuze kunnen verdedigen. De strijd had een heftig vervolg gevonden toen de bezetter voornemens bleek te zijn om alle ziekenfondsen onder te brengen in de Nederlandsche Vereniging voor Ziekenfondsartsen, onderdeel van de door de nationaalsocialististen opgerichte Artsenkamer, om zo de honoraria van ziekenfondsartsen in handen te krijgen. De artsen vreesden dat als dat het geval zou zijn, de artsen wel lid van de NVvZA zouden moeten worden en dat de door hen geboycotte Artsenkamer zo alsnog greep zou krijgen op de artsenstand. Het Medisch Contact was er alles aan gelegen dit te voorkomen. ${ }^{155}$ Een strijd nog feller dan deze ziekenfondsstrijd vond men echter op het moment dat Joodse patiënten dreigden te worden weggehaald geëigend. Dat hield concreet in dat het de MC-leden verboden werd de namen van bij hen opgenomen Joodse patiënten aan de bezetter op te geven. Die vroeg de namen immers bij de instellingen op, zogenaamd met het doel de verpleegkosten te verhalen op de bank Lippmann, Rosenthal \& Co, waar Joden hun geld hadden moeten onderbrengen. Het was voor de artsen niet moeilijk de ware bedoeling achter de maatregel te zien, en dus was het devies: 'Niemand mag hieraan meedoen; ieder bewerke zoo mogelijk administratie of bestuur in deze richting. ' ${ }^{5} 6$

Het Medisch Contact gaf hiermee een duidelijke richtlijn voor de manier 
waarop een arts en in het bijzonder een verantwoordelijk geneesheer-directeur in deze situatie zou moeten handelen. ${ }^{157}$ De ervaring was evenwel dat geneesheren-directeur ook te maken hadden met een bestuur en daarom minder makkelijk rechtstreeks te sturen waren voor het centrum van het MC dan individuele artsen. ${ }^{58}$ Men maakte het de geneesheren-directeur dan ook wat makkelijker door de ziekenhuizen in den lande een voorgedrukte protestbrief aan Seyß-Inquart toe te sturen. De geneesheren-directeur konden middels ondertekening van deze brief collectief tegen wegvoering van Joodse patiënten uit hun instelling protesteren. $\mathrm{Zij}$ lieten de Rijkscommissaris dan met de volgende formulering weten het niet met die gang van zaken eens te zijn: 'Het is in strijd met het gevoel van medemenschelijkheid, dat aan de Joden zal worden onthouden wat aan alle zieken, zelfs wanneer zij misdadigers zijn, als een vanzelfsprekende zaak wordt gegeven: de gelegenheid tot het ontvangen van noodzakelijke geneeskundige hulp en verpleging.' '59

Van de confessionele ziekenhuizen ging 80 procent over tot verzending van dit schriftelijke protest. Met name in katholieke ziekenhuizen, die zich gesteund voelden door het episcopaat, was de respons groot. Protestantse ziekenhuizen waren iets terughoudender in hun protest. In de niet-confessionele ziekenhuizen bestond het bestuur veelal uit ambtenaren in overheidsdienst, die voor hun posities vreesden, waardoor deze ziekenhuizen minder goed vertegenwoordigd waren in deze protestactie. ${ }^{160}$ Voor verschillende ziekenhuisdirecteuren die weigerden gegevens over hun Joodse patiënten prijs te geven of anderszins tegenwerkten, volgde arrestatie. De bezetter viel gewoonweg het ziekenhuis binnen, zocht in de patiëntenadministratie naar persoonsbewijzen met een J erop en nam de betreffende patiënten mee, evenals de geneesheerdirecteur of andere artsen. Zo ook de directeur van de Willem Arntsz Hoeve in Den Dolder, Chr.F. Engelhard, die samen met drie andere doktoren opgepakt werd nadat zij eerst hadden geweigerd namen op te geven en na de eerste razzia in hun psychiatrische kliniek hun ontslag hadden aangeboden. ${ }^{161}$ Ook de Haagse zenuwarts J.W.G. ter Braak was een van de artsen die om deze reden gearresteerd waren. ${ }^{162}$ In Deventer werd P.J. Piebenga, geneesheer-directeur van psychiatrisch ziekenhuis Brinkgreven, tijdelijk in gevangenschap gehouden vanwege het in bescherming nemen van Joodse patiënten. ${ }^{163}$ Gevangenneming van niet-Joodse artsen in Kamp Amersfoort kwam in deze periode geregeld voor, net als gijzeling in Sint-Michielsgestel en Haaren. ${ }^{164}$ Met gevaar voor eigen veiligheid kwamen de artsen op voor wat zij in hun ogen als hun taak en plicht zagen. De voorbeeldfunctie die medici zichzelf toedichtten was bekrachtigd door deze acties. De geneesheren-directeur van Joodse ziekenhuizen zullen zich door de opstelling van zowel Lobstein als de niet-Joodse col- 
legae gesterkt hebben gevoeld en tevens hun overtuiging dat zij hun post niet mochten verlaten hierin bevestigd hebben gezien. Echter, hun situatie werd telkens nijpender. 


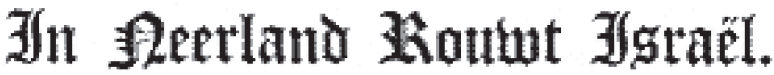

Hierbig verwul ik den traurigen plicht, mede te deolen, dat ik van af 1 Mei 1941 nilet meer te consulteeren ben, ingerolge de opdracht van den Rulkcomminaris voor hot bezalle Nederlandsche gebied, wasbij mil werboden werd, niet-Joodsche pstienten te behandelen.

Loidenas was ik 33 jaren en eventang Dordtensar, huisarts, wasuan

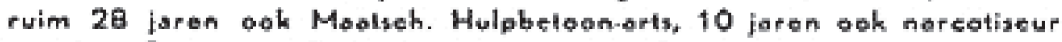
van het Gemeento Ziekenhus en 4 paren Gemeenleraddstid. Ik geloof, dat ik als Joodsche Nederlander en ook als arts, onverveced en getrouwe. den eed heb gehouwen. die th 50 jaren geleden bij mijn ontgroening algelegd hab, n.l. trouw as het liere devies: "Virtus, Concordia, Fides". d. i. Deugd, Samenwerking en Goede Trouw, dat ik etrlị̂t, ftltot: mensetutulitbento. Setroutwbat ds arls en als mensch heb geleefd. In leder goval heb ik daarnaar gestreefd, naar de leidraad; 1 wa Wat ik niet wil dat mij gesehiedf doe ik ook aan een snder nitol en $2^{\text {t* }}$ Wat ik graag voor mexelven wersch, verlang ik ook voor ieder menseh.

Ex-patiēnlen, ik dank $U$ voor Uw vertrouwen on wriendtchap, van

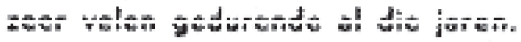

Mijn Collega's Huisartsen en Specialisten, min dank voor hun tleun, hun echte beroeps .ubroudertchap" dia mijn pstienten en mijzelven ten gotede kwam.

Ook aan $\mathrm{HH}$. Tandartsen, Apothekera, Directios en Zusters wan de Ziokentintichtingen, Wijkrusters, Bestuurders en Workers op Philantropisch d. f. menzchmingend, gebied mijn hulde en mijn dank voor do samonwerking.

Hun en hun gexinnen en feder mench wensch th voor hun verdert lovenadagen dol toe, wat hen allen gelukkig maken kan en als weleor in 1574 :

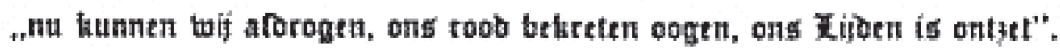

$$
\text { Acad. Lyod But Med Dost O. CAHEN }
$$

Circulaire van de Dordrechtse arts Oscar Cahen (I874-1943) naar aanleiding van het verbod op het behandelen van niet-Joodse patiënten 


\section{MAIXJaAs}

3BRICHT OP SCHRIJVEN VAN 21 Apri1 1941.

BETREFFENDE uitoefening bextoep.
NR. $952 \mathrm{P}$ AFD. Volksgezonaheid.

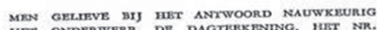

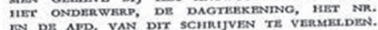

'S-GRAVENHAGE, 29 Apri1 1941 Dyx.

Naax amleiding van Uwen vxaag hoe door $U$ als Joodsch arts gehandela zou moeten worden bif straatongevalien of bij aringende verzoeken om hulp in spoedgevalien, terwijl niet of niet met zekexheid bekend is of de patient een Jood is, moge ik U berichten, dat in die omstandigheden terstond, eventueel ook door U, maatregelen genomen zulien moeten worden, opdat zoo spoedig mogelifk een bevoegde axts aanwezig kan zijn. In afwachting daarvan zult U zelf a1e hulp kannen verleenen, die ook deskundige nlet-artsen (ervaren verpleegstex, E.H.B.O.Ieden) zouden kunnen verleenen, waarbif uiteraexd Uw meerdere kennts van groote waaxde zal zijn.

TE WAARNEMEND SECRETARTS-GEMIRAAI, VAN HET DEPARTEMENT VAN SOCIATE ZAKEN,

$$
\text { w. ¿. Verwey. }
$$

Voor eensluidend afschrift, IE WAARIFNEND SECRETARIS-GEIJPAAI,

$\triangle A N$

den Heex M.R.Hertzberger, Arts, Mozartke de 9, te AMSTKRTAM Z.

In afschrift sezonden aan

den Heer Hoofdinspeoteur v.d.

Volks gezondheid mr.C. Banning, te is-GRA VFIN A

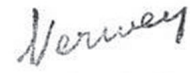

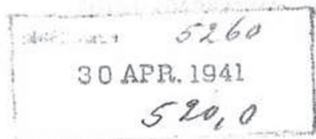

Reactie van secretaris-generaal R.A. Verwey op de vraag van huisarts Meijer Rosier Hertzberger (1900-I984) hoe te handelen bij acute gevallen waarbij men niet wist of de patiënt Joods was of niet 


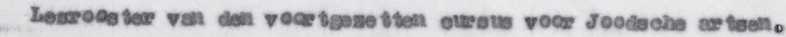

Bagiat6 Dotobers 2043.

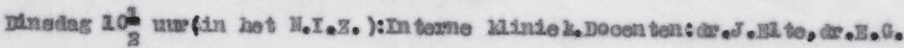

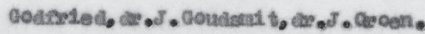

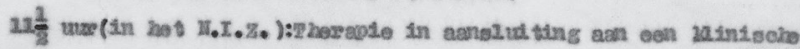

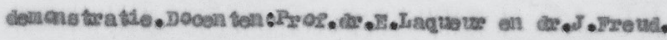
Dese 2es wosat sogeven op nader ash to goven data.

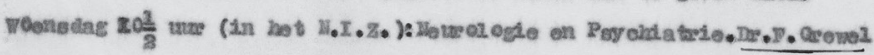

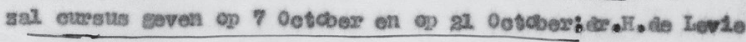

2 Decoltber en as Deceutber.

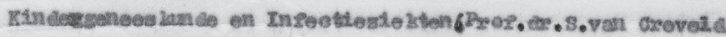

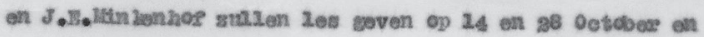
28 16 Doasbes.

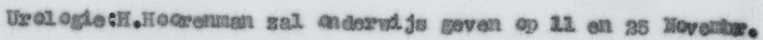

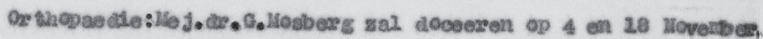

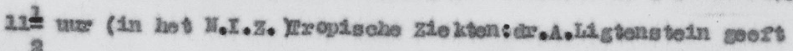
cursug op 7 on 21 0otober, 4 en 18 yoverabes ens en 16 Dooumb

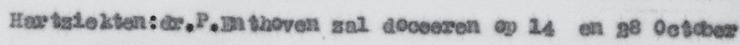
on 23 en 25 llovertbes.

Pathologlacho anatante: dx.J. Ir te goept 2es op 9 en $83 \mathrm{Dem}$ centiber.

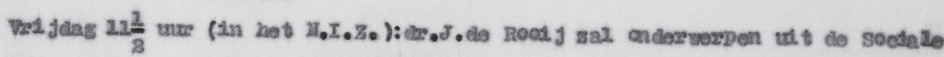

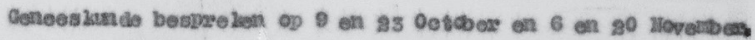

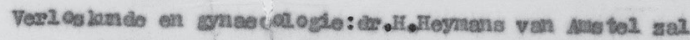
les goven op 16 en 80 Ootcbers on 13 an 37 yorentbes.

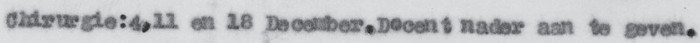

Lesrooster van de voortgezette cursus voor Joodse artsen, 1942 


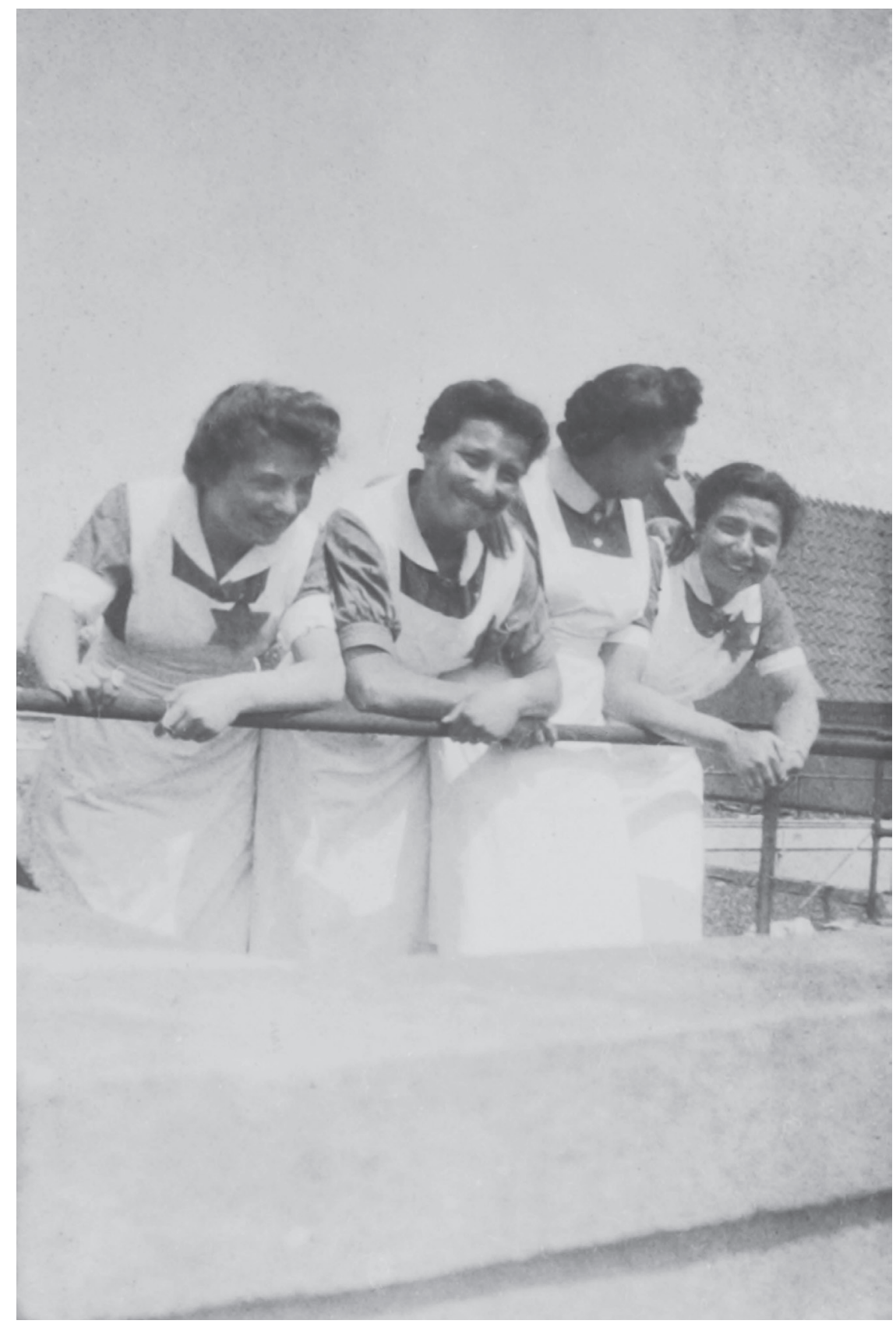

Verpleegsters van het NIZ op het dak van het ziekenhuis, 1942 


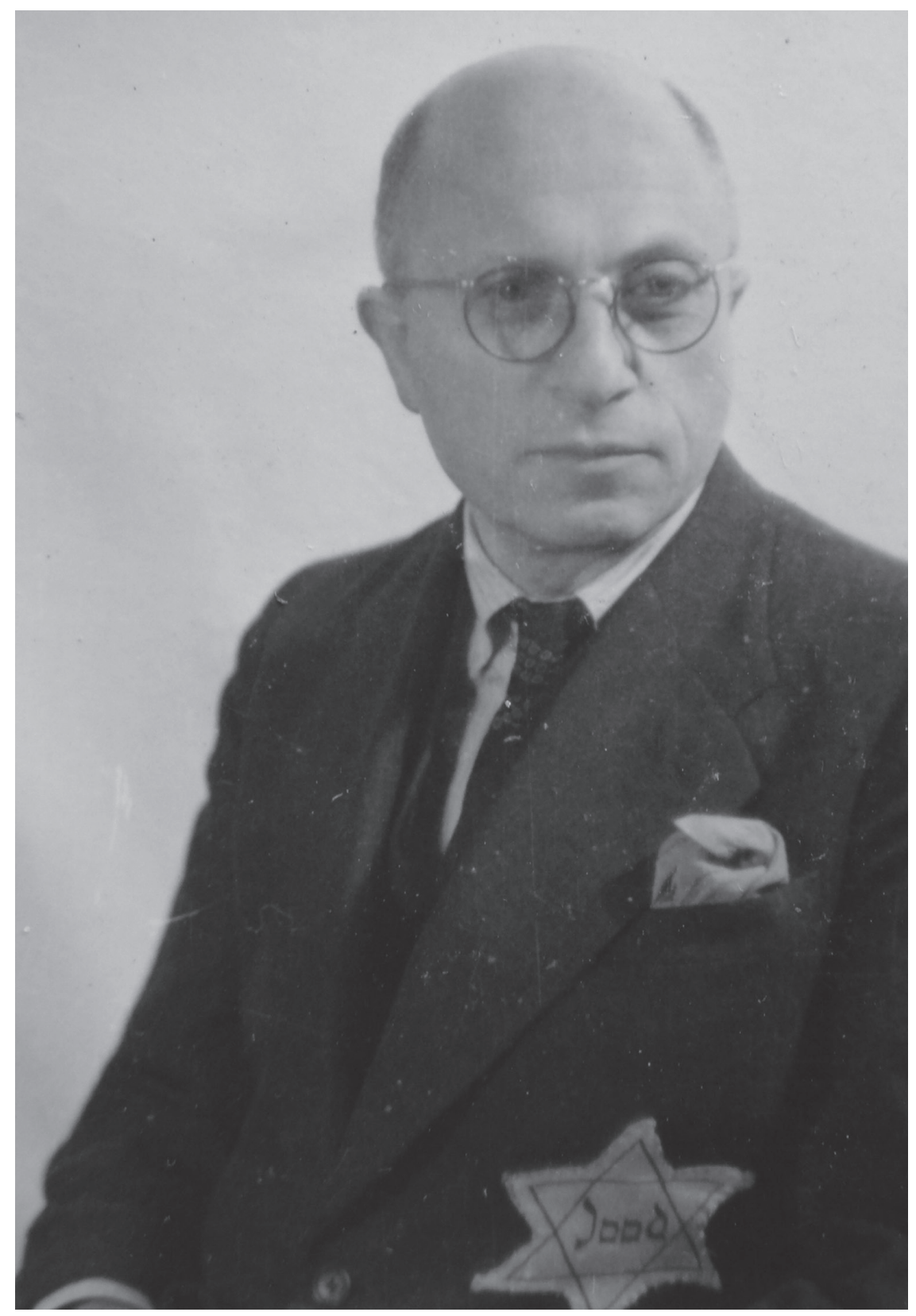

Salomon Kroonenberg (I89I-I96I), geneesheer-directeur van het Nederlandsch Isrälietisch Ziekenhuis, I942 of 1943 


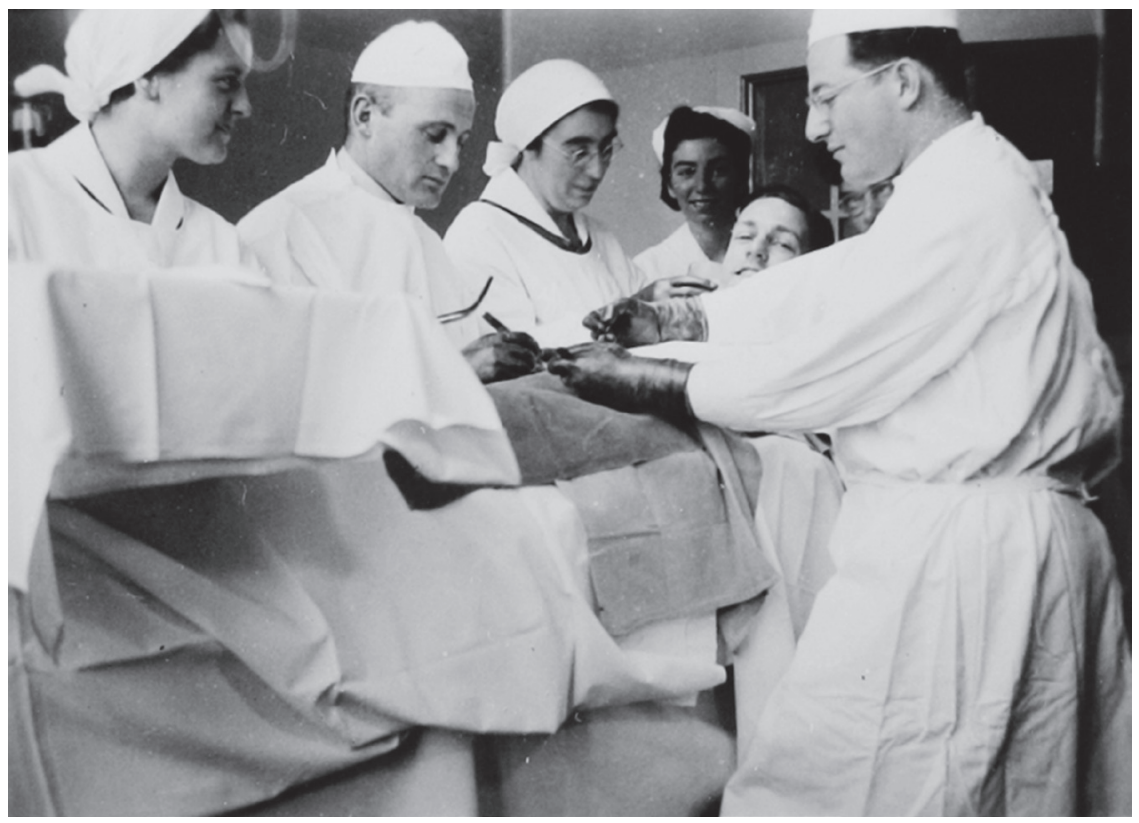

De operatiekamer van het NIZ, met geheel rechts Johnny van Coevorden (19I4-1997) en tweede van links Herman Herschel (I9I0-I999) 


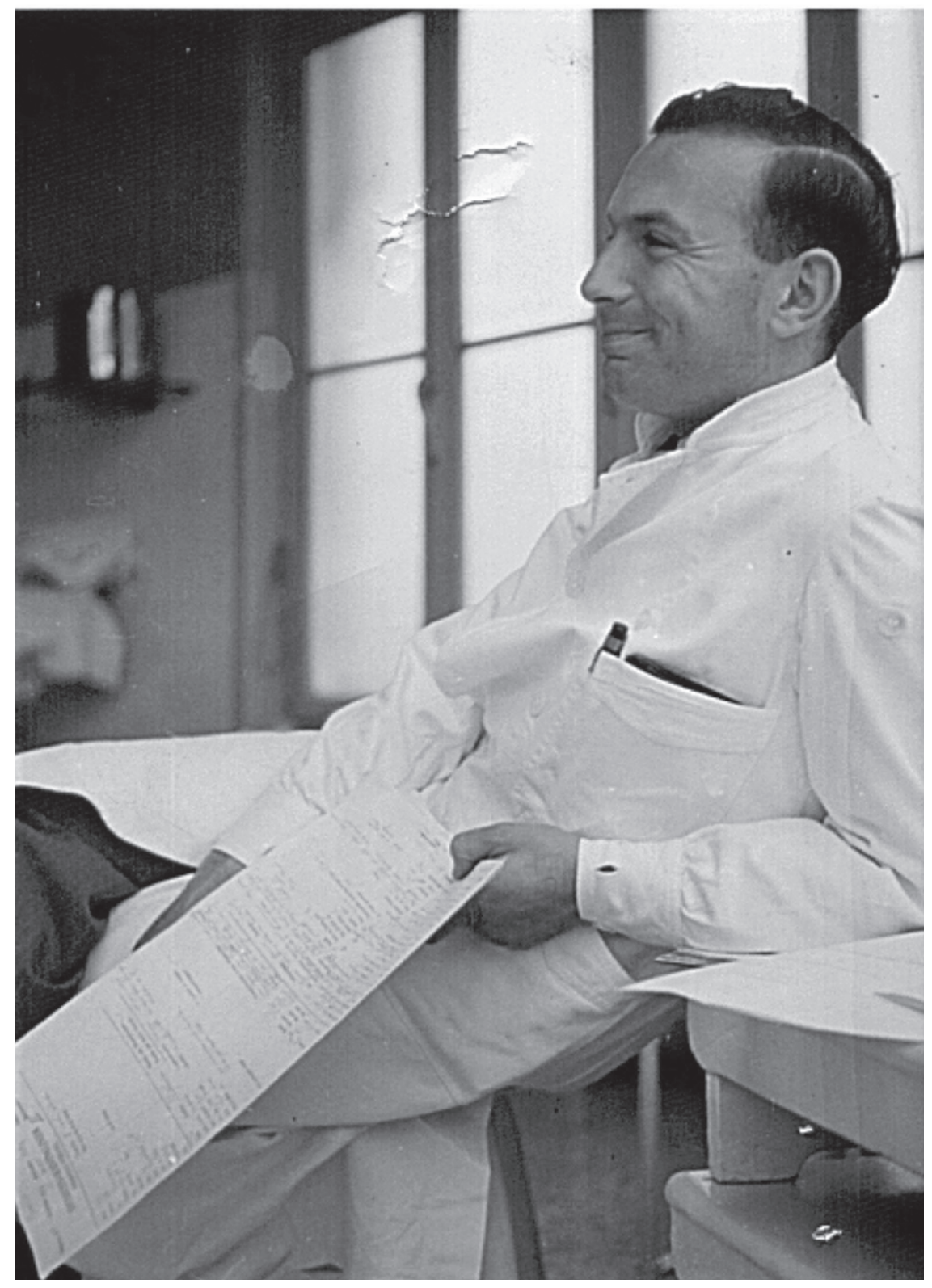

Leo Swaab (1908-1997) 
DR. J. B. POLAK

UITSLUITEND VOOR
HARTZIEKTEN

RÖNTOENOLOGI

\section{AMSTERDAM z., den 7.August . . 4 ?

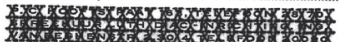

Jacob Obrecht strat 92, Tel.20090

Sehr geehrter Herr Kollege,

$$
16-4 \cdot 110
$$

Bei Herrn P.A.F. Rodrigues Pertira fand ich vor 16 Jahren schon einen Herzfehter.jetzthat er ein typisohes ausgedehntes systolisches Geräusch bei der Pulmonalis, das mit einem deutlichen Decrescendo bis fast über die ganze Diastole hörbar ist; der zweite Ton ist dort kaum hörbar.

Das Herz ist, wie Sie auf dem Orthodia-

gramm sehen, stark vergrössert:die Herzbreite (14.8 cm) ist viel grösser als die Hälfte der Lungenbasis und hat eine deutlich erweiterte Arteria Pulmonalis.Der Blutdruck beträgt $130 / 55$, der diastolische Druck ist also erniedrigt.

fur den offenen Ductus Bies alles ist vollkommen bezeiohnend Ductus Botalli,woran dieser Patient zweifellos leidend ist.

eignet.

Für körperliche Arbeit ist er nicht ge-

Hochachtungsvoll

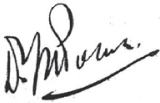

Attest van Joseph Bernard Polak (Rosenberg) (I883-1943)

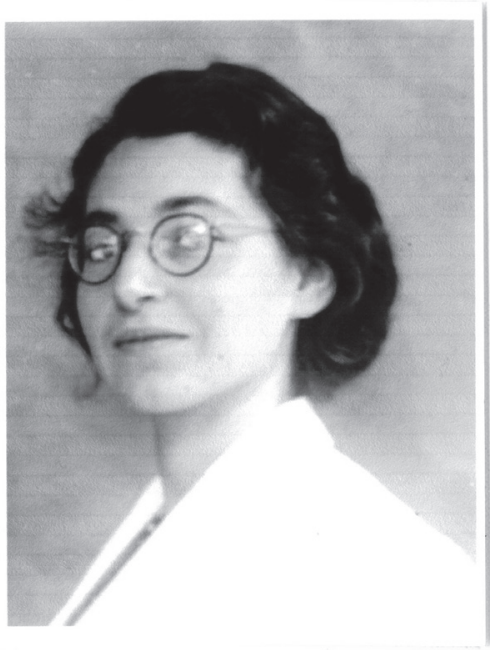

Elsa Jessurun d'Oliveira (1913-1998) 
DR. M. FRANZIE

ARTS 's GRA VENHAGE, A pril 1941 LOUISE DE COLIGNYSTRAAT 51

Ingevolge opdracht van den Rijkscommissaris voor het bezette Nederlandsche gebied, heeft de waarnemend Secretaris-Generaal van het Departement van Sociale $Z_{\text {aken, }}$ bij rondschrijven van 5 Februari j.l., ter kennis gebracht van artsen, tandartsen, apothekers enz., dat personen, voor wie vóór de aanvaarding van hun beroep het afleggen van een eed (belofte) wordt geëischt, en die als Jood moeten worden beschouwd ingevolge Art. 4 van de Verordening No. 189/1940 van den Rijkscommissaris, met ingang van 1 Mei 1941 de waarneming van dit beroep moeten beẽindigen, met dien verstande echter, dat zij de vrijheid behouden, uitsluitend voor Joden werkzaam te zijn.

Tengevolge van dit besluit acht $i k$ mij verplicht $U$ te verwittigen, dat het mij niet meer is toegestaan $U_{W}$ arts en geneeskundig raadsman te mogen zijn.

Terwijl ik met groot leedwezen $U$ deze mededeeling doe, is het mij op dit oogenblik een behoefte, $U$ te danken voor de vele blijken van vriendschap en toegenegenheid, welke ik gedurende de uitoefening van mijn beroep van $U$ heb mogen ondervinden. Ik hoop van harte, dat $U$ aan mij eene aangename herinnering blijft bewaren.

Mijn praktijk zal worden voortgezet door

Dr. E. F. G. van Doorn, Anna Paulownastraat 71, Tel. 115818.

Hem zullen alle gegevens ten dienste staan, die hiervoor nuttig zouden kunnen zijn.

Met vriendelijken groet,

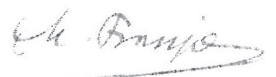

Aan

Brief van Mozes Franzie (I879-1942) aan zijn niet-Joodse patiënten 


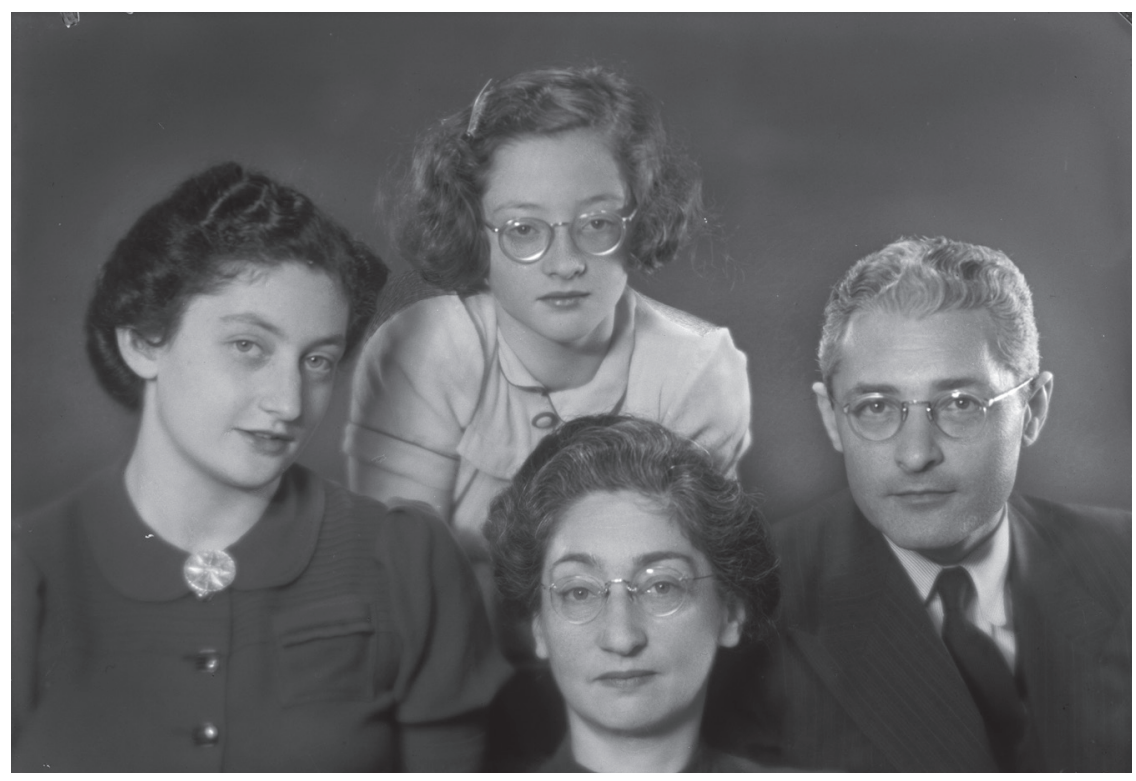

Samuel Poliakoff (I895-I945), geneesheer-directeur van het Portugeesch Israëlietisch Ziekenhuis, met zijn gezin, 1942

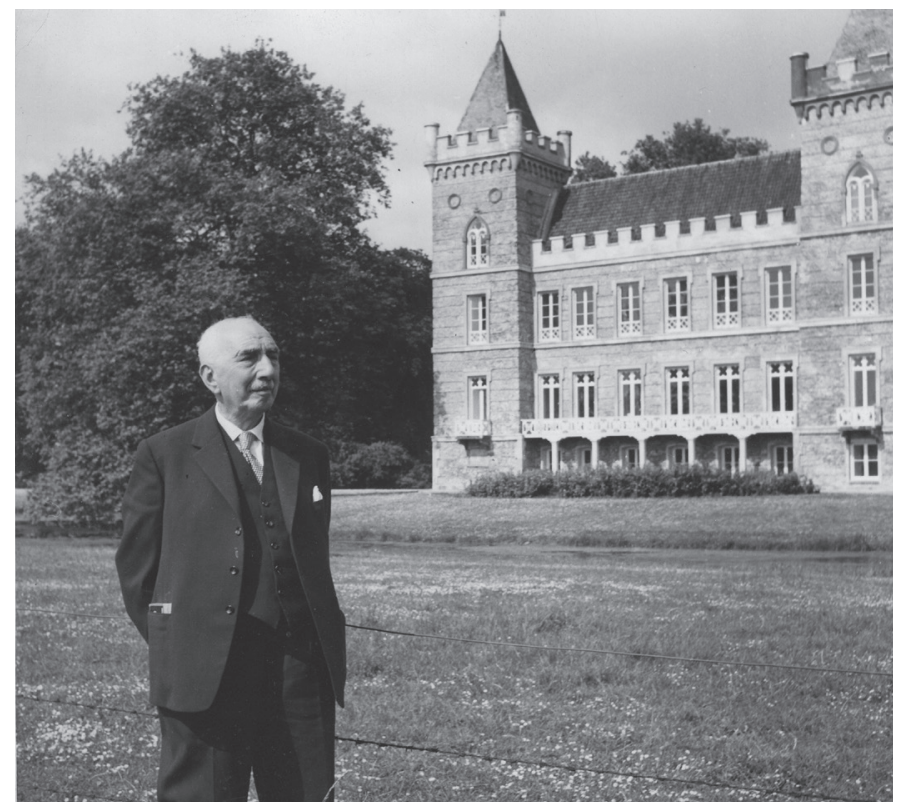

Louis Weijl (I879-1972) in de tuin van kasteel De Schaffelaar, I943 


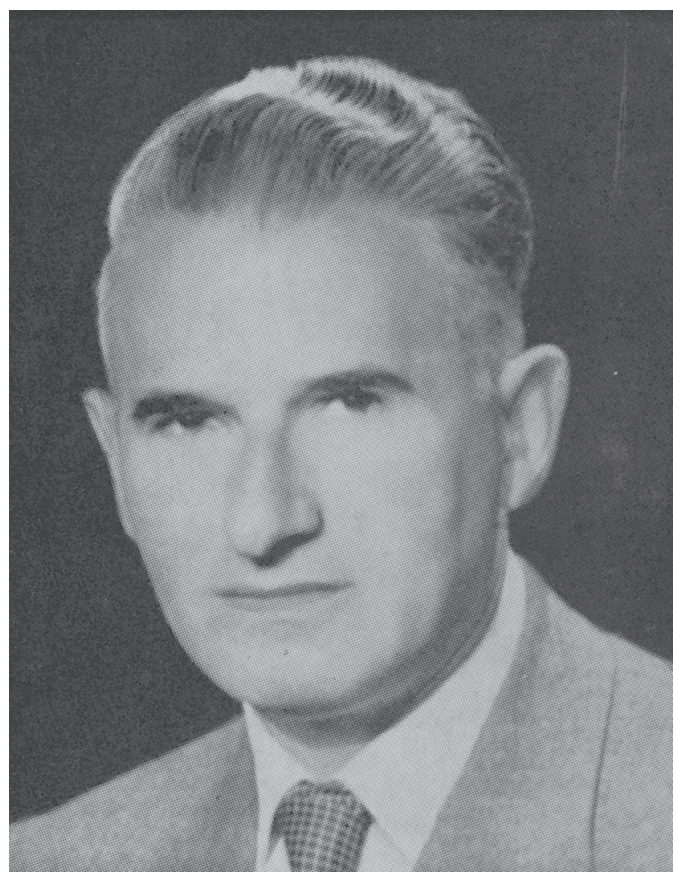

Berthold Stokvis (1906-1963)

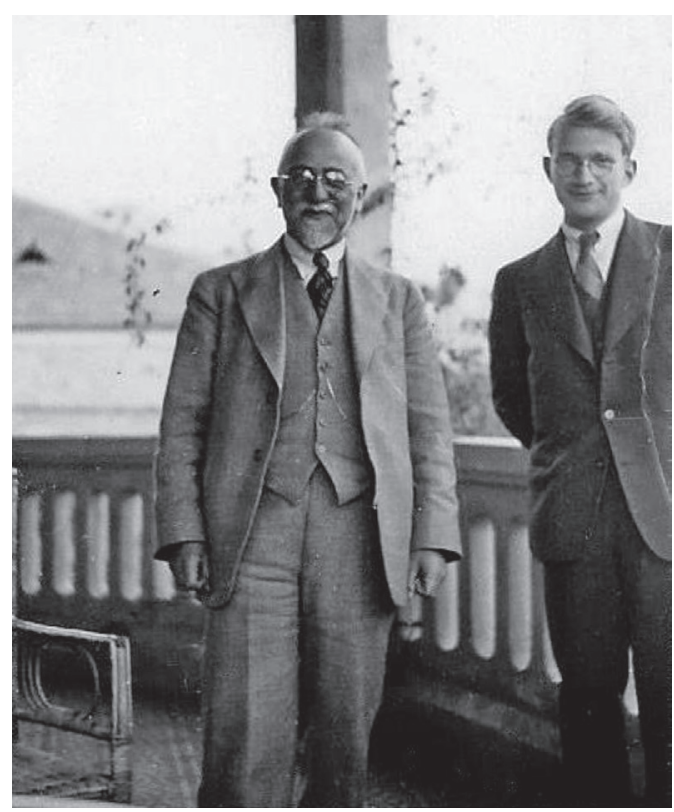

Jacques Lobstein (I883-I945), geneesheer-directeur van Het Apeldoornsche Bosch 


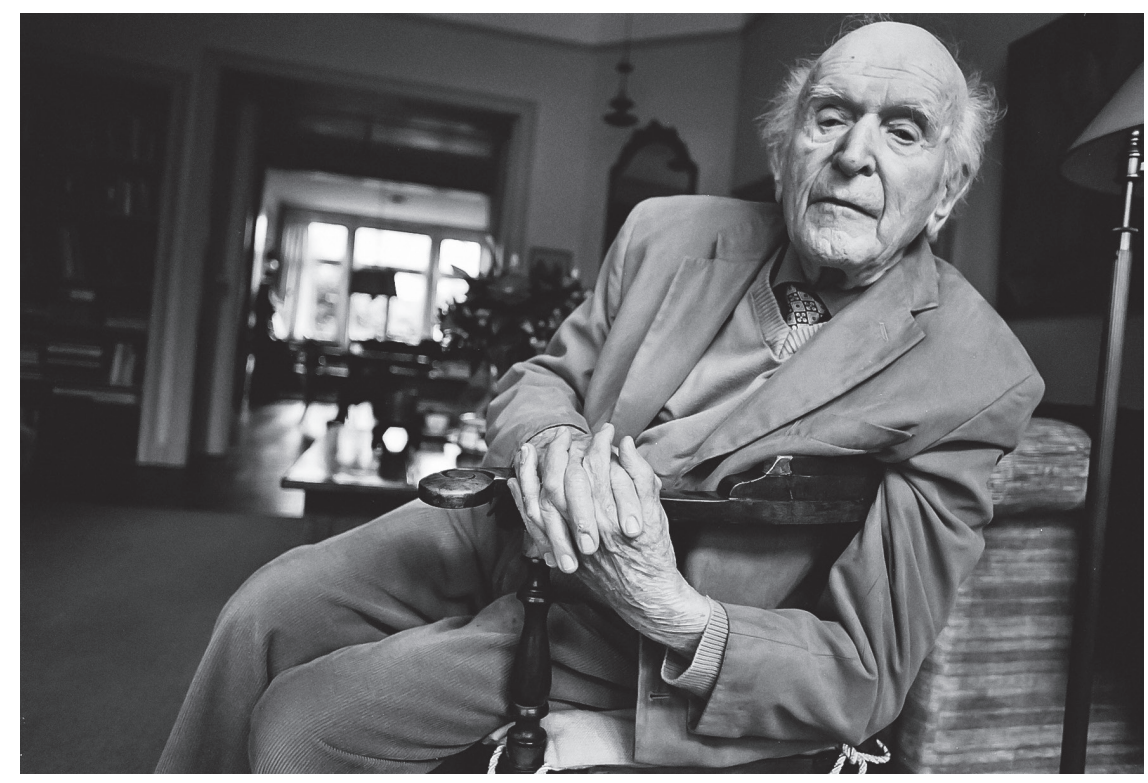

Hans Keilson (I909-20II) (C) JULIE BLIK

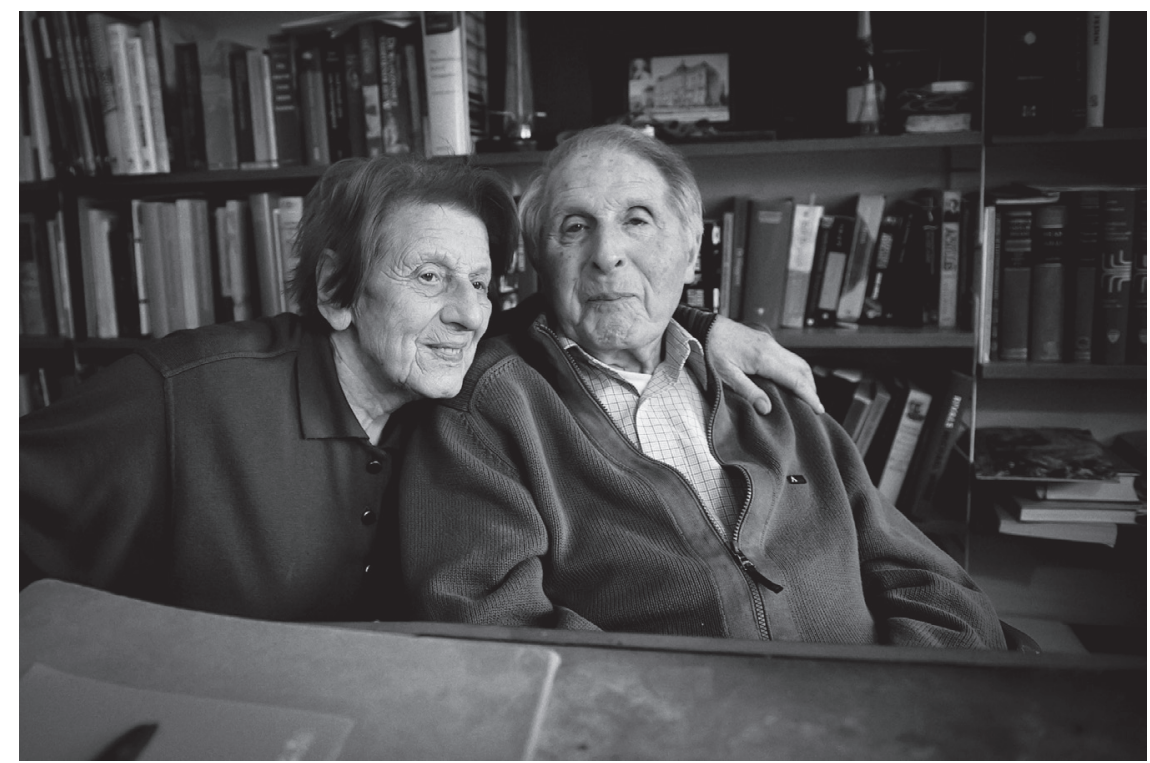

Max Koster (I9I6-20II) en Hannah Koster-Souget (I9I7) (C) JULIE BLIK 


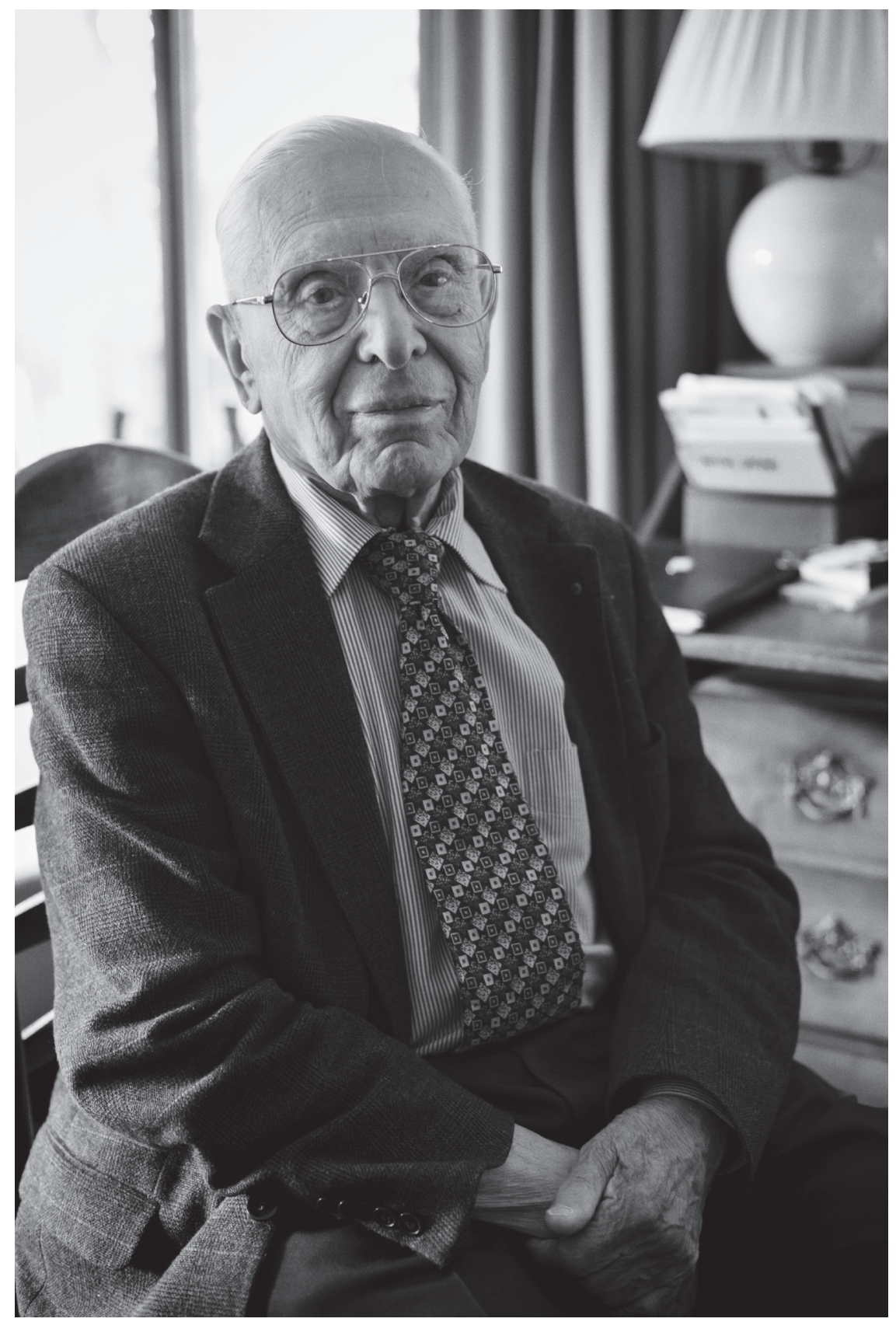

Carel Wolff (I9I4) C JULIE BLIK 


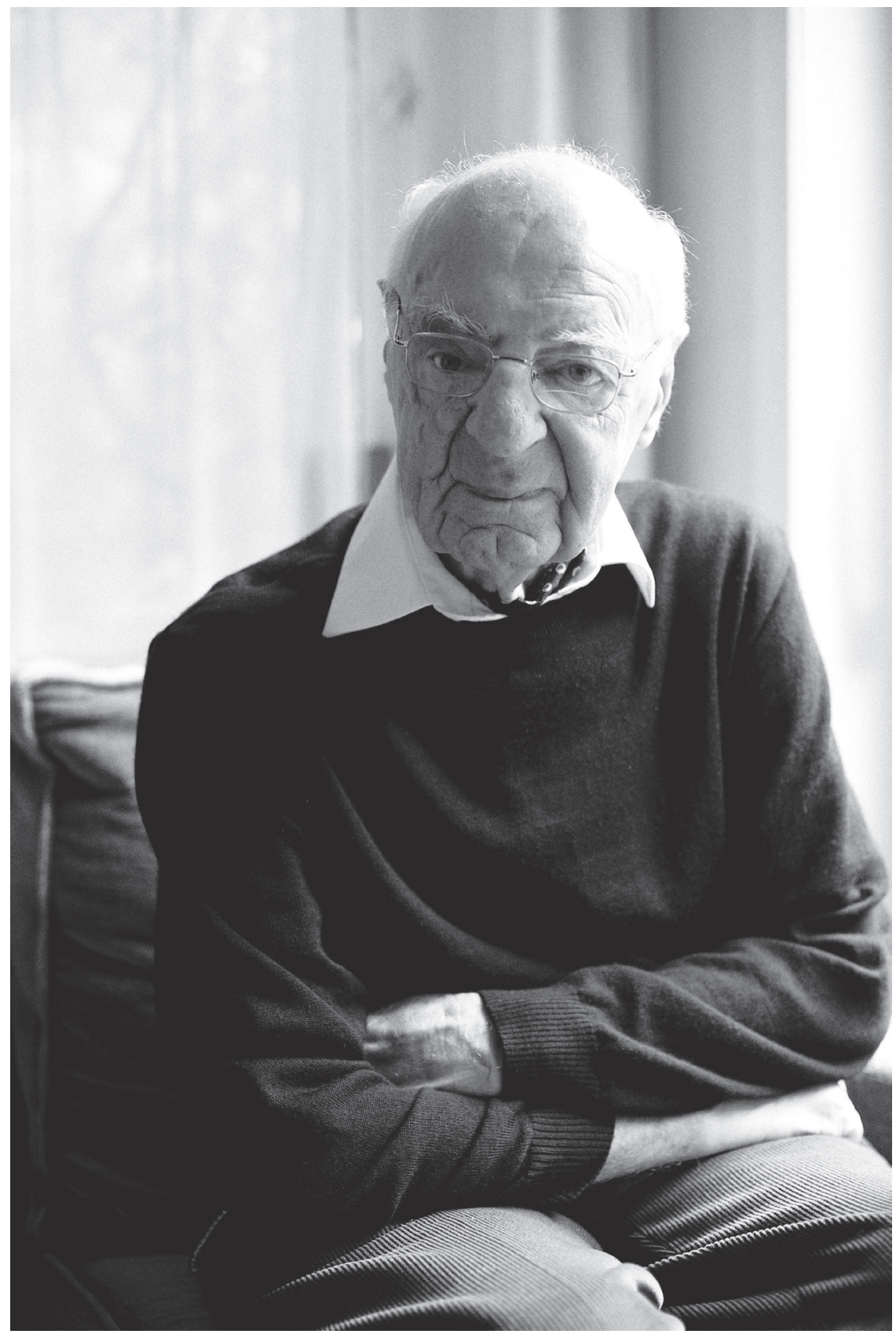

Willy Hijmans (I92I) (C) JULIE BLIK 


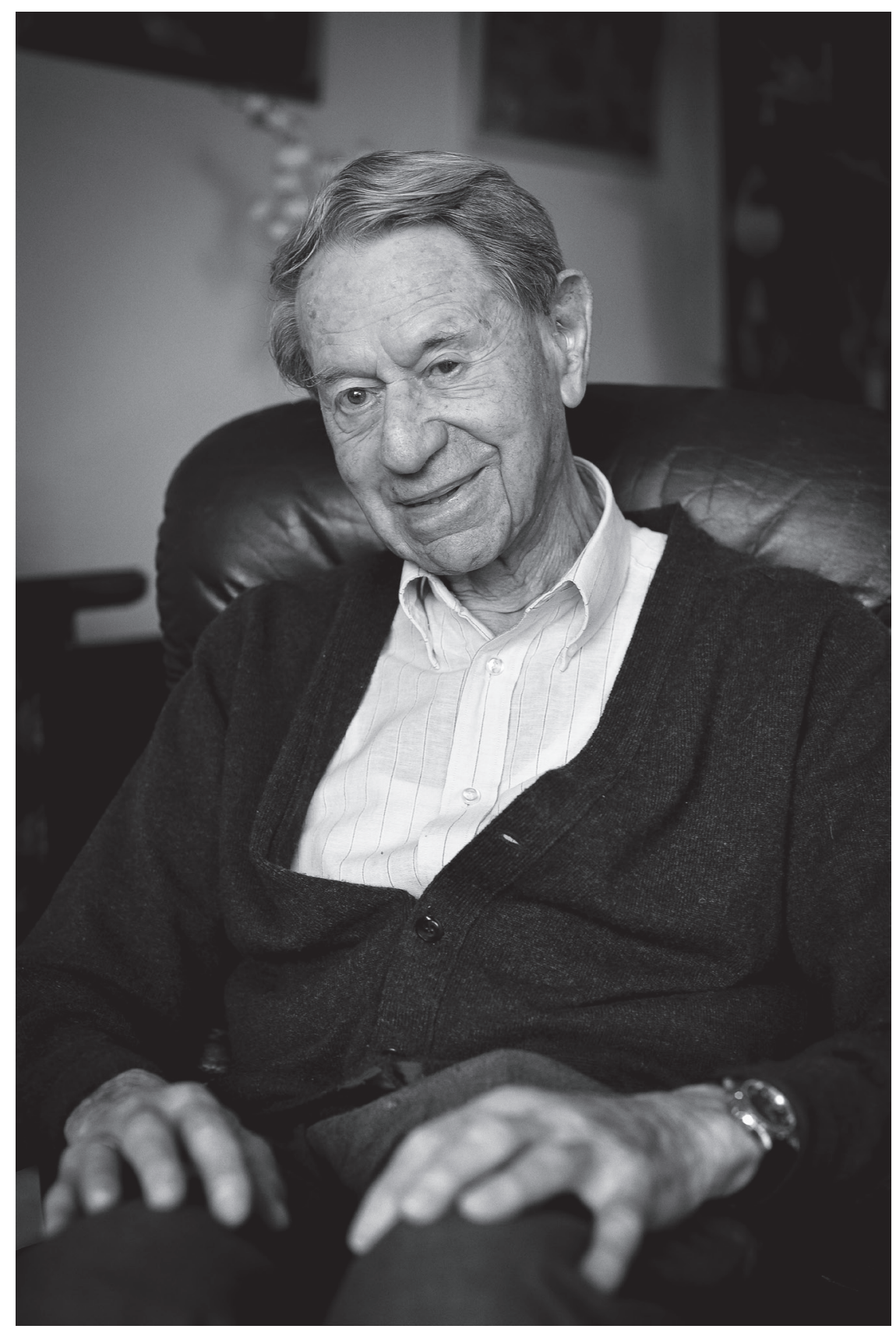

Frits Glaser (I9I6-20I2) C JULIE BLIK 


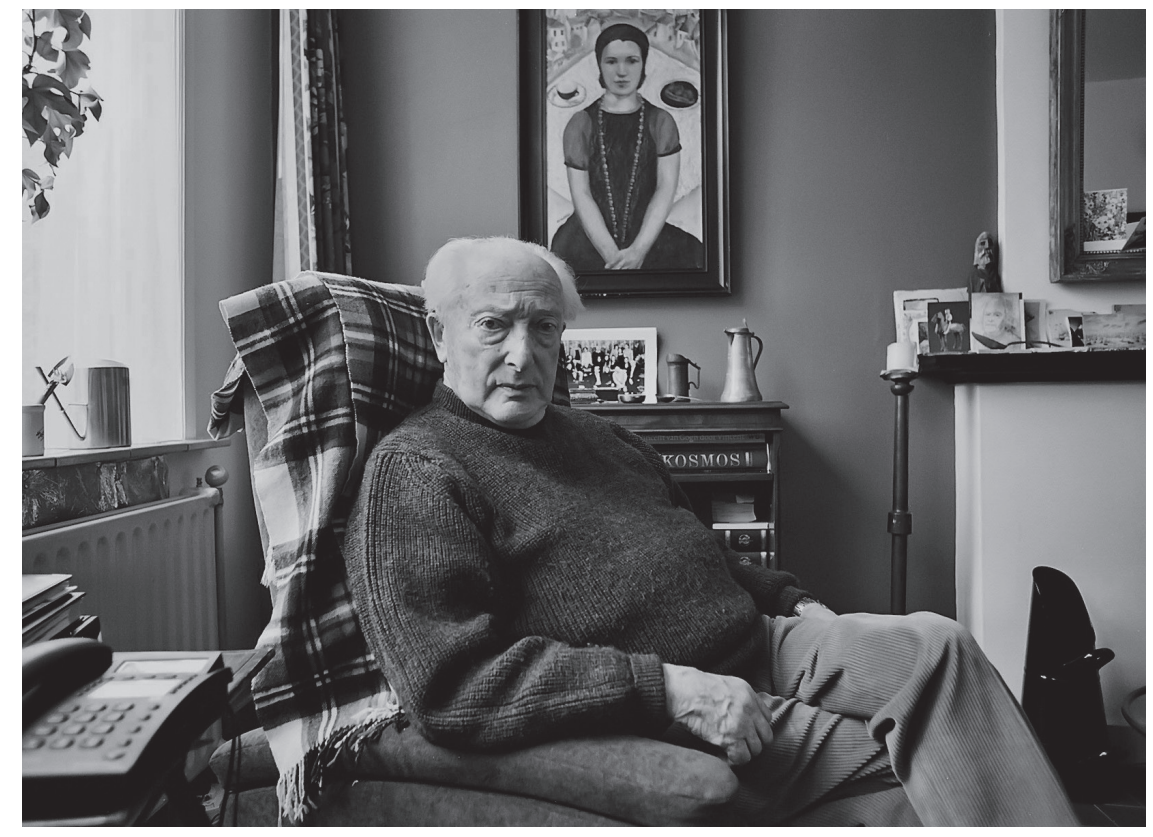

Maurits Frenkel (I9I9-2OI4) (C) JULIE BLIK

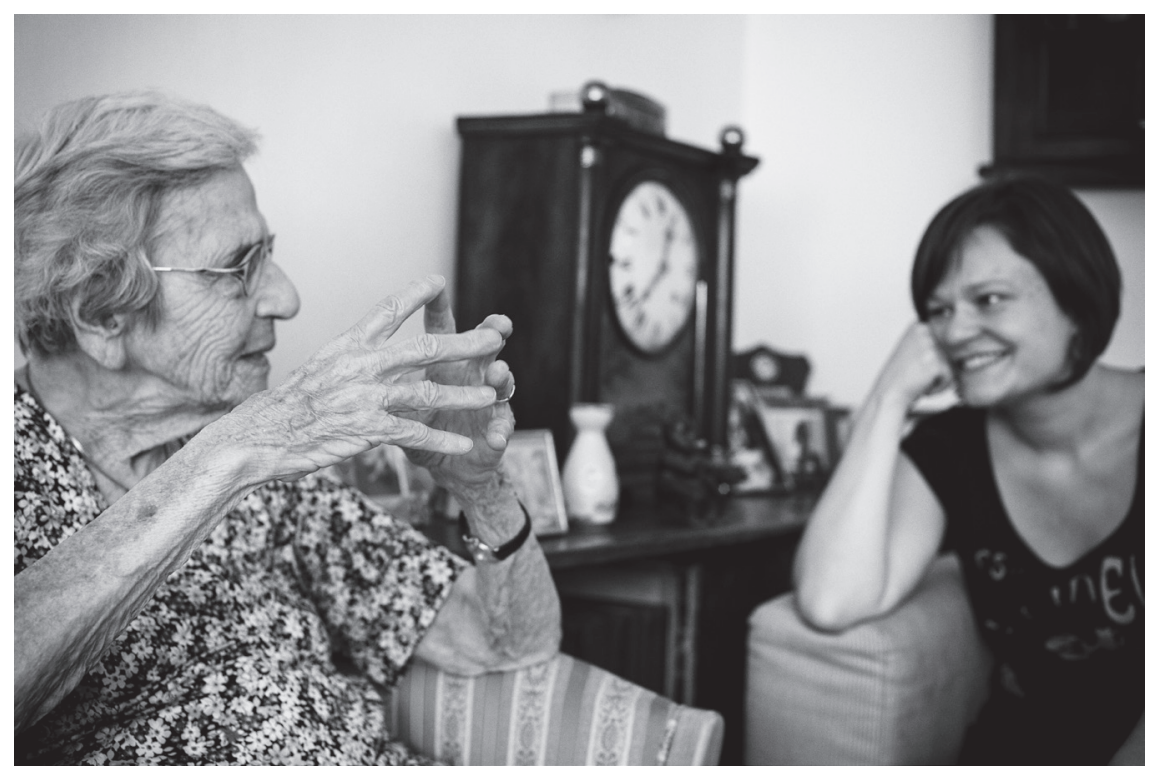

Martha ben Assa/van Esso-Polak (I9I7) in gesprek met de auteur (C) JULIE BLIK 


\title{
6. ALS KAPITEINS OP EEN ZINKEND SCHIP
}

\author{
GENEESHEREN-DIRECTEUR VAN DE BEDREIGDE \\ JOODSE ZIEKENHUIZEN, \\ JANUARI - SEPTEMBER 1943
}

Joods Nederland ging met de ontruiming van Het Apeldoornsche Bosch een nieuwe fase in. Van nu af aan zouden ook zieken niet meer met rust gelaten worden, zo kon men concluderen én ervaren in de weken die erop volgden. Ziekte gold niet langer als bescherming. Sterker nog, juist zieken werden nu het slachtoffer van de deportatiemachinerie. Medische hulp en sabotage in de vorm van (valse) attesten, geënsceneerde ziekten of 'onderduik' in ziekenhuizen leek van weinig waarde meer. Konden de artsen en geneesheren-directeur van de Joodse ziekenhuizen hun patiënten nu nog wel een figuurlijke reddingssloep bieden? En had het voor het medisch personeel nu nog zin om op hun post te blijven? Hoe zat het dan met hun eigen veiligheid?

\section{DE ONTRUIMINGEN GAAN ONVERMINDERD VERDER}

De arrestaties van zieken en de ontruimingen van ziekenhuizen gingen in de maanden februari en maart 1943 gestaag verder. Zieken waren na januari 1943 vogelvrij verklaard en ziekenhuizen waren hun status van onaantastbaarheid kwijt. Sally de Jong beschreef de toestand die hij om zich heen waarnam op de volgende manier:

In de loop van de afgeloopen maanden hadden ongeveer 8000 Joden uitstel van deportatie gekregen op grond van hun ziekzijn. Deze waren nu 
ook aan de beurt om gehaald te worden. [...] iedere avond, reden de overvalauto's door de stad en werden ouden en zieken loopend of op brancards weggehaald. Was men overdag niet thuis, dan maakte men een kans zijn vrijheid nog even te rekken. Wie nog loopen kon sukkelde, hoe oud ook, van's morgens tot's avonds 8 uur, door weer en wind over straat. ${ }^{\text {I }}$

Wrang was dat toen de bezetter zich vanaf januari 1943 actief ging bezighouden met het deporteren van zieken, hij baat had bij de eerdere hulpacties van de artsen. De attesten die hadden gediend om mensen thuis te kunnen houden, werden nu immers een middel om zieken te lokaliseren. Keurig was in de Zentralstelle de administratie van de attesten bijgehouden, waarmee precies bekend was in welk huis welke zieke verpleegd werd. En dus ook uit welk huis die zieke gehaald kon worden. ${ }^{2}$ Met verbijstering moeten de Joodse artsen de nieuwe gebeurtenissen aangezien hebben. Die verbijstering spreekt bijvoorbeeld uit het dagboek van Salomon Koster: 'Wat? Zij ook weggehaald? Ondanks de attesten van mij en van den laboratoriumarts, dat zij aan pernicieuse anemie en aan een ruggemergsziekte lijdt? En dat zij niet getransporteerd mocht worden?'3

Presser somde de acties tegen de zieken na 22 januari 1943 een voor een op. $\mathrm{Al}$ op 23 januari, een dag na 'Apeldoorn', werden 140 zieken uit Westerbork naar het Oosten gedeporteerd. De vrijgekomen plekken in het kampziekenhuis werden een week later ruimschoots opgevuld. Op i februari voerden de Duitsers namelijk 250 Amsterdamse zieken naar de Borneokade om hen vervolgens naar Westerbork te brengen. In Haarlem waren de patiënten van het Jolesziekenhuis, de Joodse vleugel van het Elisabeth Gasthuis, op Is februari naar Amsterdamse Joodse ziekenhuizen overgebracht. Zij konden hier voorlopig nog blijven. ${ }^{4}$ Op I8 en I9 februari werden echter 780 mensen uit Den Haag weggehaald uit rusthuizen en ziekenhuizen, waar slechts 40 'volkomen intransportabelen' achterbleven.' Dit transport werd verder aangevuld met 200 zieken uit Amsterdam. Op protesterende geluiden vanuit de Joodsche Raad antwoordden de Duitse autoriteiten dat men behoefte had aan de huizen van de zieken en dat zij in lazaretten in Westerbork en Duitsland goed verzorgd zouden worden. ${ }^{6}$

Op 26 februari waren het de Rotterdamse zieken die naar het ziekenhuis in Westerbork afgevoerd werden. Het Rotterdamse Israëlietisch Ziekenhuis aan de Schietbaanlaan 42, werd op deze dag ontruimd. 208 patiënten, ook afkomstig uit het bijbehorende Oudeliedengesticht en het Israëlietisch Weeshuis aan de Mathenesserlaan, waren het slachtoffer van deze grondig voorbereide actie. Twee weken eerder al waren de Joodse zieken uit niet-Joodse ziekenhuizen 
in de stad naar het Joodse ziekenhuis overgebracht. ${ }^{7}$ Met de ruim 200 zieken werden ook 6r leden van het medisch en verplegend personeel meegenomen. Enkele leden van het personeel waren familie van David Cohen. Zij moesten mee naar Loods 24, waar de Joden van Rotterdam voorafgaande aan hun deportatie werden verzameld, maar na interventie van Cohen liet men hen vrij. ${ }^{8}$ Geneesheer-directeur Maurits Elzas, die niet in het ziekenhuis aanwezig was op het moment van de Duitse inval, maar zich na waarschuwing onmiddellijk naar het ziekenhuis spoedde, liet zich met zijn patiënten en personeel mee naar Westerbork voeren. ${ }^{9}$

Net als Jacques Lobstein bleef Maurits Elzas daarmee tot het laatst toe op zijn post, trouw aan het verantwoordelijkheidsgevoel ten opzichte van zijn patiënten en personeel, behorend bij zijn positie. $\mathrm{Na}$ de oorlog zou hij zich herinneren: 'Het ziekenhuis werd in beslag genomen: allen die er waren, ook toevallige bezoekers (onze gazzan Rokach!) naar Westerbork gevoerd, zieken, pseudozieken, verpleegsters en verplegers; een onvergetelijke reis was het met mijn beste zusters, één van onze ernstigste patiënten en één van onze beste vrienden. Bijna niemand is hiervan teruggekeerd.'

Anders dan Lobstein zou Elzas echter wel het personeel hebben aangemoedigd onder te duiken, nadat in oktober 1942 een inval in het bij het ziekenhuis behorend Oudeliedengesticht had plaatsgevonden. Volgens Elzas' naoorlogse herinnering hadden zijn waarschuwingen ertoe geleid dat sommige personeelsleden op tijd waren gedoken en de oorlog overleefden. ${ }^{\text {II }}$ Met de kennis van achteraf kan men wel stellen dat dat een zeer verdedigbare handelwijze was, echter op het moment zelf hadden de geneesheren-directeur te maken met een immens dilemma: moest eenieder op zijn post blijven of waren de omstandigheden dusdanig en het vermoeden van wat de bestemming van de deportatie was dermate duister dat het personeel zijn zorgplicht mocht laten varen?

\section{'BIJEEN WAREN DE ALLERTROUWSTE KRACHTEN MET HET MEESTE PLICHTSBESEF'}

$\mathrm{Na}$ het Rotterdamse ziekenhuis zou De Joodsche Invalide in Amsterdam het eerstvolgende slachtoffer worden van een grootschalige ontruimingsactie. Eind februari 1943 telde de JI 4I6 verpleegden, I97 interne en 158 externe personeelsleden. ${ }^{\mathrm{I2}} \mathrm{Op} 26$ februari 1943 was het gerucht dat het gebouw op I maart leeggehaald zou worden al bij het personeel doorgedrongen. Niet nader gedefinieerde 'bevriende bronnen' hadden deze informatie doorgespeeld. ${ }^{13}$ Het gevolg was dat velen die ergens anders naartoe konden gaan, dit spoorslags 
deden. Dit gold met name voor het verplegend personeel. Patiënten waren grotendeels te slecht ter been om te kunnen vluchten. De op 28 februari geplande opvoering van de operette Im Weissen Rössl werd door geneesheer-directeur Jacques Buzaglo geannuleerd. In plaats daarvan voltrok zich een ander schouwspel, opgetekend door A.V. Hartogh:

De laatste nacht waren wij nog slechts met zeer weinig personeel en met 300 patiënten in huis. Voor ieder van hen was een rugzak gereed gemaakt met de nodigste kleding en een broodzak met levensmiddelen en toiletgerei voor enige dagen. Duidelijk zie ik de nacht nog voor mij, toen alle voorbereidingen getroffen waren en wij even uitrustten en voor afscheid bij elkaar zaten. Natuurlijk was onze trouwe hulp, het wijkhoofd der luchtbescherming, de heer Gräper, in ons midden. Bijeen waren de allertrouwste krachten met het meeste plichtsbesef. Helaas, de meesten hebben wij niet weergezien. ${ }^{\mathrm{I}}$

Hetzelfde dilemma als waarmee de medewerkers van Het Apeldoornsche Bosch en die van het Rotterdamse Joodse ziekenhuis waren geconfronteerd, was nu actueel voor het JI-personeel: op je post blijven of vluchten. Een van de personeelsleden die bleven was Chawa Bornsztajn, die in haar memoires over deze beladen nacht optekende dat de verhoudingen tussen de personeelsleden veranderden door de toestand waarin zij bleven doorwerken:

That night of February 28, I943 stands out in my mind with special clarity: I was alone, in charge of an entire department of fifty patients, and during the night I also had to help out on another floor. The sick were lying in bed, terrified, and hardly able to control their tears. [...] When the head nurse came by, I sensed that our relationship had changed - we were like equals in our efforts. ${ }^{\text {Is }}$

De volgende ochtend vond er wederom een uittocht plaats van op het laatste moment vluchtende personeelsleden en mobiele patiënten. De overgeblevenen wachtten op wat stond te gebeuren. Men had vernomen dat de Duitsers om 8.30 uur zouden komen, maar om 8.35 uur was er nog nergens onraad te bespeuren. Abraham Asscher belde nog namens de Joodsche Raad op om te zeggen dat er niets zou gebeuren, maar vijf minuten later stonden de overvalwagens toch voor de deur. De overgebleven rest van de staf verstopte zich grotendeels, onder andere onder de vloer van de toneelzaal, of vluchtte via het dak naar de naastgelegen GGD, maar in totaal werden 256 mensen, voor het groot- 
ste deel bejaarden, meegenomen. ${ }^{16}$ Geneesheer-directeur Buzaglo, die net als Lobstein in Apeldoorn en Elzas in Rotterdam, op zijn post was gebleven, werd gevangengenomen. Ook zijn vrouw Emmy Buzaglo-Coronel, die eveneens arts was, en hun zoontje moesten mee. Het gezin werd een dag later wel weer in vrijheid gesteld, mogelijk omdat beide echtelieden van Portugese afkomst waren. De zogenaamde 'Portugezenlijst' was op dat moment nog beschermd. Daarover later meer.

Ondertussen was het gebouw geplunderd. Hierbij waren de Duitsers ook gestuit op de schuilplaats onder de theaterzaal en op de verzameling antieke wapens van Buzaglo. Hier was koper en zilver bij, dat Buzaglo volgens de Duitse verordeningen allang had moeten inleveren. ${ }^{17}$ Volgens een andere lezing ging het om het synagogezilver van de JI, dat de directeur in veiligheid had willen brengen. ${ }^{18}$ Hoe het ook zij, Buzaglo probeerde weliswaar nog via de Joodsche Raad zijn microscoop terug te krijgen, omdat hij 'zonder deze niet kon werken', ${ }^{19}$ maar hij bevond zich door deze vondst in een hachelijke situatie. Aan Duitse zijde moest men nog bepalen 'was wir mit Dr. Buzaglo zu tun haben wenn er vorspricht', ${ }^{20}$ maar Buzaglo besloot zich hierop vrijwillig te melden. Met zijn gezin werd hij eerst naar kamp Vught en vervolgens naar Westerbork gezonden. ${ }^{2 \mathrm{I}}$

In De Joodsche Invalide bleven na de ontruiming zo'n dertig mensen achter, onder wie architect A.V. Hartogh. Aan hem werd het beheer van het gebouw opgedragen. ${ }^{22}$ De JI-personeelsleden die gevlucht waren en niet waren ondergedoken, hadden zich op I maart verzameld in het NIZ. Ze werden er gastvrij opgenomen, om op te gaan in de grote massa van zich aldaar ophoudende schuilenden. Geneesheer-directeur Salomon Kroonenberg nam de verantwoordelijkheid voor hen over van Buzaglo. Uiteraard konden zij zich, als ervaren personeel, ook daadwerkelijk nuttig maken. Geruchten deden echter al de ronde dat ook de andere Joodse ziekenhuizen ontruimd zouden worden. Jacques Reisel, arts op de interne afdeling van het NIZ, beschreef de onrust om hem heen in zijn dagboek. Enerzijds keek hij neer op de leidende figuren van de Joodsche Raad - van wie hij voorbeeldgedrag verwachtte - die nu vluchtten uit het ziekenhuis: ' $\mathrm{Er}$ is ook wel enige reden voor ons om wat ongerust te zijn. Speyer, dat is de adjunct- directeur van de GGD, haalde zijn moeder halsoverkop uit het ziekenhuis. Zeer ontactvol. Dit is de enige leiding die van de medische commissie is uitgegaan. De kinderen van notaris van de B zijn plotseling verpleegster af, enkele mensen met goede relaties verdwenen.' ${ }^{23}$

Anderzijds schatte hij het dreigende gevaar zodanig groot in dat hij zich ook heel goed kon indenken dat mensen de benen namen: 
Veel mooie alternatieven zijn er nu niet. We hebben het altijd gezegd: de laatste phase zal erg zijn en het ziet er dreigend genoeg uit. Veel illusies over Polen hebben we niet. Speeches van Goebbels en proclamaties van Hitler zijn weer eens vol antisemitisme, met Ausrottungsthemata als vanouds. ${ }^{24}$

Reisels enige hoop was dat de geallieerde invasie vroeg genoeg zou komen om de 'Ausrottungs'-plannen van de bezetter in elk geval nog deels te kunnen dwarsbomen. ${ }^{25}$ Een hoop die bij velen was gegroeid door de Duitse nederlaag bij Stalingrad, eerder die maand. ${ }^{26}$ Ondanks dit lichtpuntje schatte Reisel de situatie dermate zwart in dat medisch personeel de zorgplicht in het ziekenhuis vaarwel mocht zeggen:

In een normale tijd, of tijdens een bombardement respectievelijk brand, zou dit een intolerabele houding geweest zijn, waarop als enige juiste consequentie onmiddellijk ontslag zou volgen, maar nu - onder dit 'unedles Unglück' - en zonder dat iemand ermee geholpen was, zou dit blijven, indien het gerucht juist was, inderdaad niet meer dan donquichotterie zijn of een vorm van overdreven narcisme, namelijk niet door zelfverwijten of die van anderen getroffen te worden en 't besef je 'plicht' gedaan te hebben. ${ }^{27}$

Dat hij zelf in het ziekenhuis bleef, terwijl onder anderen vier artsen verdwenen, was dan ook volgens hem niet ingegeven door heldhaftigheid of plichtsbesef, maar eerder vanuit een rationele inschatting van het risico:

Adler en ik bleven. Niet uit heroïsme dat trouwens, als het heroïsme was, op donquichotterie zou gaan gelijken, maar omdat we het zeer onwaarschijnlijk achtten dat er met het ziekenhuis iets zou gebeuren. Niet waar? Zolang er nog zoveel Joden, 55-60.000, in Amsterdam zijn, zijn we een noodzakelijk instelling, die intact wel zal moeten blijven..$^{28}$

En inderdaad, tijdens de ontruiming van De Joodsche Invalide op I maart was het NIZ ongemoeid en intact gebleven. Een dag later echter leek het noodlot toch onontkoombaar. Een bericht van de Expositur, een invloedrijk bureau van de Joodsche Raad, scheen betrouwbaar: het NIZ zou op 3 maart worden leeggehaald. ${ }^{29}$ De artsen overlegden onderling hoe te handelen, zo tekende Reisel op: 
Eerst wilden we het nog niet geloven, maar na een paar uur bleek het wel zó zeker dat, in overleg tussen dr. G., Kropveld, Adler [vermoedelijk internist Jacob Goudsmit, chirurg Samuel Kropveld en arts-assistent Jacques Adler], Kroonenberg en ik, besloten werd dat de beste en fierste houding was het naar huis zenden van de patiënten, waarop het verplegend personeel zou kunnen doen wat het niet laten kon. Zo gezegd, zo gedaan. Een enorme paniek en chaos natuurlijk het gevolg. ${ }^{30}$

Over de paniek en chaos schreef geneesheer-directeur Salomon Kroonenberg in een naoorlogs kladboekje in steekwoorden enkele herinneringen op:

\section{2 maart 1943}

Paniek in NIZ, omdat bekend was geworden dat de volg dag het zk zou worden leeggehaald. Alle pt vluchten, rekverbanden worden door familie uit elkaar gehaald, de ptn zelf op handwagens naar overal heengebracht. In de namiddag niemand over, ook het personeel gevlucht, met mijn zoons houd ik het bedrijf gaande. ${ }^{31}$

Kroonenberg zelf, als geneesheer-directeur, peinsde kennelijk niet over weggaan. Voor het personeel en voor behandelend artsen als Reisel was er op dit moment weliswaar kennelijk een kentering gekomen in het oordeel over de plicht op je post te blijven, maar voor Kroonenberg zelf was weggaan niet denkbaar. Hij moest de massale uittocht uit zijn ziekenhuis, ook al had hij besloten dat hij zijn personeel zou laten gaan, met lede ogen aanzien. Bettie Weijl, huishoudster van de familie Kroonenberg, was door haar moeder gemaand het ziekenhuis zo snel mogelijk te verlaten. Maar toen zij Salomon Kroonenberg de boodschap wilde geven dat ze zou vertrekken, reageerde de geneesheer-directeur met een indringende blik, over zijn brillenglazen naar zijn beschermelinge toegeworpen, en de woorden: 'Jij ook?' Op dat moment besloot ook Bettie het zinkende schip niet te verlaten en te blijven helpen in het ziekenhuis. $\mathrm{Zij}$ werd bevorderd tot leerling-verpleegster en kon direct beginnen in het leeglopende ziekenhuis. Immers, werk was er genoeg, bij de patiënten die te ziek waren om te vluchten. Zoals psychiater Salomon Koster in zijn dagboek optekende uit de mond van een andere NIZ-verpleegster: 'In ons ziekenhuis zijn vierhonderd en tien van de vierhonderd tachtig patiënten dien dag weggegaan. De stervenden en de zeer ernstige patiënten konden natuurlijk niet weg.' 32

Bij deze zeer ernstige zieken speelden zich onderwijl ongekende taferelen af. Met alle dilemma's van dien voor het medisch personeel. Zo maakte Bettie 
Weijl met coassistent Syl van de Rijn een ronde door de chaos. Onder de nietvervoerbare patiënten was een vrouw die aan kanker leed en in een terminaal stadium verkeerde. Zij klampte Van de Rijn aan en vroeg hem om een extra dosis morfine. De coassistent wist niet wat hij moest doen en vroeg Bettie om raad. Haar devies was: 'Niet doen.' Van de Rijn deed het niet. Gelukkig niet, zoals Bettie later zei. Men kon nog niet weten hoe de situatie zich zou ontwikkelen en hoe en wanneer de oorlog zou aflopen. Bovendien, als men aan dit verzoek zou toegeven, zou men een moord op zijn geweten hebben. ${ }^{33}$ Een andere verpleegster ging er wel toe over en diende haar eigen vader een dodelijke injectie toe. ${ }^{34}$

Salomon Kroonenberg was ondertussen in onderhandeling met enkele Duitse gezagsdragers, onder wie Ferdinand Aus der Fünten. Tegen de middag van 2 maart bereikten de onderhandelaars een akkoord: evacuatie van het ziekenhuis zou alleen geschieden na bericht aan de directeur van de GGD, J.H. Tuntler. Daarnaast zou er een commissie benoemd worden om op dat moment te beslissen welke patiënten niet-vervoerbaar zouden zijn. In deze commissie zaten Kroonenberg zelf, internist Jacob Goudsmit en de Duitse Stabarzt Eduard Meyer. Het functioneren van de "commissie" (de aanhalingstekens zijn van Kroonenberg zelf) zou in de praktijk betekenen dat Kroonenberg en Goudsmit voorstellen mochten doen en Meyer besliste. Dit zou al de volgende dag blijken, want ondanks het akkoord met geruststellende mededelingen van Duitse zijde, die ervoor hadden gezorgd dat er weer wat patiënten het ziekenhuis binnen waren gedruppeld, reden er toch de volgende ochtend om 8 uur al overvalwagens voor. ${ }^{35}$

De Sipo-sD en Grüne Polizei, geholpen door WA en oD uit Westerbork troffen op 3 maart 1943 een halfleeg ziekenhuis aan. Er bevonden zich ongeveer 120 patiënten in het NIZ, verzorgd door een handjevol personeelsleden. ${ }^{36}$ De twee eerder genoemde artsen hadden overnacht in het ziekenhuis, volgens Reisel eerder omdat ze nog steeds vertrouwden op de zekere positie van het ziekenhuis dan omdat ze blijven als hun plicht beschouwden. Ze werden desondanks door het verplegend personeel en de patiënten wel als helden gezien. Zij konden echter niet tegenhouden dat de bezetter het ziekenhuis binnendrong. Stabarzt Meyer wees van de I2O zo'n 40 patiënten aan als transportfähig, waarop die naar Westerbork werden gevoerd. ${ }^{37}$ Daarnaast werd het naastgelegen $\mathrm{Ou}$ deliedengesticht, met nog eens ongeveer 150 bewoners, geheel ontruimd. Over deze gebeurtenis liet Salomon Koster in zijn dagboek een patiënte, verpleegster van het NIZ, aan het woord: 
Dokter, het was zoo een zielig gezicht, al die oudjes, waarvan een deel niet eens begreep, wat er met hen gebeurde; de mannetjes, met hun kalotjes, de vrouwtjes met hun witte mutsjes op, te zien wegvoeren, als gevangenen. Een deel van hun ontbijt was nog blijven staan en de muschjes, die altijd kruimeltjes kregen van de oudjes, waren, nu er niemand meer in den zaal was, brutaal geworden en deden zich aan het ontbijt op de tafel tegoed. Het Bestuur van het ziekenhuis heeft nog gauw, voor veel geld, een vrachtauto met levensmiddelen naar Westerbork gestuurd, maar veel hebben de oudjes daar niet van genoten, want na een paar dagen waren ze al doorgestuurd naar Duitschland en ik denk, dat ze nu al vergast zijn. ${ }^{38}$

Kees Kroonenberg, zoon van de geneesheer-directeur, herinnert zich het tafereel nog goed. Het was de enige keer dat hij zijn vader heeft zien huilen. ${ }^{39}$

De verantwoordelijkheid die Salomon Kroonenberg droeg, was loodzwaar. Niet alleen werden zijn patiënten onder zijn handen weggehaald, ook moest hij in de "commissie" zijn gedachten laten gaan over welke patiënten hij zou trachten te sparen en welke hij moest laten gaan. Een ondoenlijke keuze voor een arts die voor elk van zijn patiënten het beste nastreeft. ${ }^{\circ}$ Of het daadwerkelijk door Kroonenbergs onderhandelingen kwam, of door inmenging van de Joodsche Raad, de GGD en het departement van Volksgezondheid, ${ }^{4 \mathrm{I}}$ ofwel door een tactisch plan van de bezetter, het NIZ werd voorlopig nog in stand gehouden.

Ondertussen had de bezetter ook bij de Centraal Israëlietische Ziekenverpleging voor veel opschudding gezorgd. Ook hier had het gerucht dat ontruiming ophanden was zich als een lopend vuurtje verspreid. Alle tekenen leken erop te wijzen dat dat gerucht op waarheid berustte. Reactie, vergelijkbaar met die in de andere ziekenhuizen, kon niet uitblijven:

Er werden toen onmiddellijk maatregelen genomen, de patiënten, die eenigszins te vervoeren waren, naar huis te laten gaan, en het personeel, zich ten volle van zijn verantwoordelijkheid bewust, werkte hieraan zoveel mogelijk mede. Zij wilden de achtergebleven patiënten tot op het laatst bijstaan en waren derhalve van plan, het ziekenhuis de volgende dag te verlaten. Dezelfde avond echter, nadat de hele dag door, patiënten het ziekenhuis hadden verlaten, werd de inrichting door een Hollandsche politiemacht bezet. De agenten posteerden zich in en om het ziekenhuis, hetgeen echter voor een aantal leden van het personeel geen beletsel was, een poging tot ontvluchten te wagen. ${ }^{42}$ 
Directrice zuster E. Broekman had tijdens deze paniek, volgens herinnering van aanwezige verpleegsters, de vluchtende personeelsleden nogal letterlijk op hun zorgplicht willen wijzen. Zij zou hierbij in de hal zijn gaan zitten en had daar iedereen die wilde vluchten ondervraagd: waar gaat $u$ heen? Wat gaat $\mathrm{u}$ doen? Dit in een poging zo veel mogelijk personeelsleden te behouden. ${ }^{43}$ Deze houding werd haar niet in dank afgenomen door haar personeel. Een andere lezing van de gebeurtenissen is dat niet Broekman, maar voorzitter van bestuur Abraham S. Jacobson een toespraak zou hebben gehouden om te voorkomen dat het personeel het ziekenhuis zou verlaten. ${ }^{44}$ Hoewel Jacobson strikt genomen voorzitter was en geen geneesheer-directeur, stelde hij zich wel als zodanig op. In het licht van de algemene houding van de geneesherendirecteur - trouw op hun post blijvend -, lijkt deze toespraak verklaarbaar. Dat de directeurs eenzelfde houding ook van hun personeel hoopten te zien, is invoelbaar, maar kennelijk was er nadat men steeds meer ervaring met ontruimingen had gekregen een kentering gekomen bij het merendeel van het personeel: zij vonden het niet meer verantwoord te blijven. De norm dat zij op hun post dienden te blijven kon geen stand meer houden, daar waren steeds meer mensen het over eens.

\section{AFBROKKELENDE AUTONOMIE}

De twijfel over de vraag of men aan de zorgplicht moest vasthouden nam ook toe doordat de Joodse artsen en geneesheren-directeur steeds meer autonomie in hun beroepsuitoefening werd ontnomen. Dat kan ook bij de gebeurtenissen in de CIZ een rol hebben gespeeld. De verwachte ontruiming van de CIZ ging, de chaos en verwarring ten spijt, op het laatste moment toch niet door. Aus der Fünten in eigen persoon kwam het personeel melden dat het weer rustig aan het werk kon gaan. De gevluchte personeelsleden konden weer terugkeren. Hieraan gaf men grotendeels gehoor. Enkele dagen later zou Jacobson echter, volgens een naoorlogse getuigenis van een oud-verpleegster, een huldigingsbijeenkomst hebben georganiseerd om de personeelsleden die in de nacht van de omsingeling op hun post waren gebleven voor hun trouwe dienst te bedanken. ${ }^{45} \mathrm{Als}$ die bijeenkomst daadwerkelijk heeft plaatsgevonden, is het des te opvallender dat Jacobson zelf kort erna onderdook, waarschijnlijk in april 1943, hetgeen blijkt uit het feit dat vanaf die tijd chirurg Mau Pimentel als voorzitter van de Ciz optrad. ${ }^{46}$ Was Jacobson zelf ook door zijn personeel overtuigd dat blijven zinloos was geworden? Of was het omdat de leiding over de CIZ overgenomen werd door de commissaris voor niet-commerciële ver- 
enigingen en stichtingen en niet meer onder de Joodsche Vereeniging voor Verpleging en Verzorging viel?

De Joodsche Raad had hieromtrent begin april bericht ontvangen van deze commissaris in Den Haag. Deze was niet gevoelig gebleken voor protest van David Cohen, die te berde had gebracht dat voor het voortbestaan van de CIZ Joods beheer noodzakelijk was. De JVvvv moest vervolgens alle liquide middelen en vermogen van de CIZ inleveren. ${ }^{47}$ Eind april 1943 nam Stabarzt Eduard Meyer zijn intrek in het gebouw van de CIZ aan de Jacob Obrechtstraat. Deze ss-Sturmbannführer had zich tot dan toe als gedetacheerde bij de Zentralstelle beziggehouden met het registreren en in beslag nemen van medische inventarissen van gedeporteerde of te deporteren artsen. ${ }^{48}$ Ook had hij een rol gespeeld bij de eerdere ontruimingen van Joodse ziekenhuizen. $\mathrm{Nu}$ zou hij de leiding van de Ärztliche Dienststelle, de afdeling medische zaken van de Zentralstelle, op zich nemen, en de ciz bood daarvoor de perfecte locatie. Volledige autonomie van de CIZ was daarmee verleden tijd geworden, ook al bleef het ziekenhuis voorlopig gehandhaafd.

Van de gebeurtenissen in het PIZ en de taakopvatting en -uitvoering van geneesheer-directeur Samuel Poliakoff in het vroege voorjaar van I943 zijn geen getuigenissen gevonden, maar het ligt voor de hand te veronderstellen dat ook hier op zijn minst onrust was ontstaan. Het PIz had een andere status dan de CIZ. Het was vermoedelijk, gezien de beschermde status van de Portugese Joden, altijd onder bestuur van de Portugees Israëlietische Gemeente blijven staan en niet onder de JVvvv gaan vallen. ${ }^{49}$ Het was dan ook niet, zoals de CIZ, overgenomen door Duitse gezagsdragers. Dit kan zeker een grotere mate van vertrouwen hebben veroorzaakt dan in de andere ziekenhuizen. Vermoedelijk niet alle medewerkers en patiënten stonden echter op de Portugezenlijst. In elk geval waren er enkele externe personeelsleden op hun huisadres gearresteerd, om wier lot de PIZ-artsen David de Miranda en Emanuel Vas Nunes zich bekommerden. Zij maakten David Cohen erop attent dat in hun beleving werknemers van het ziekenhuis vrijgesteld zouden zijn. Volgens Cohen was dit niet per definitie het geval; vaststond volgens hem alleen dat er niemand van de personeelsleden uit het ziekenhuis gehaald mocht worden. Daarbuiten was men dus niet automatisch net zo veilig. Hij drukte collega Edwin Sluzker van de afdeling Expositur echter op het hart alles in het werk te stellen om de PIZwerknemers uit de Hollandsche Schouwburg te krijgen. ${ }^{\circ}$ Daarmee was hun in elk geval enige veiligheid vergund.

De Joodsche Raad concludeerde dan ook op Io maart 1943 dat de acties tegen de ziekenhuizen weliswaar 'dreigden een ernstig karakter aan te nemen' maar dat dit erg meegevallen was: 'doch thans is de toestand aldus, dat de zie- 
kenhuizen geopend blijven, patiënten kunnen opnemen via den GGD en wat het voornaamste is, de patiënten kunnen na herstel het ziekenhuis wederom onbelemmerd verlaten.' ${ }^{51}$ Er bestond dan wel een relatief gunstige situatie, maar dit citaat toont wel nóg een indamming van de vrijheid van handelen voor de Joodse ziekenhuizen: vanaf maart 1943 werd de opnamemogelijkheid aan banden gelegd.

De GGD diende nu voor alle patiënten te bepalen wie er in de Joodse ziekenhuizen opgenomen mocht worden. Eerst moest het NIZ gevuld worden en daarna het PIZ en de CIZ. ${ }^{52}$ En die twee laatste kleine ziekenhuizen zouden al spoedig nauwelijks nog bereikbaar blijken. Een NIZ-verpleegster: 'Ons ziekenhuis mag nu nog wel patiënten opnemen, maar alleen met goedvinden van den directeur van den Gemeentelijken Geneeskundigen Dienst, de andere twee Joodsche ziekenhuizen mogen niemand meer opnemen. Er is trouwens geen lust meer bij de patiënten, om zich te laten opnemen, behalve natuurlijk bij de zeer ernstige, omdat iedereen de overtuiging heeft, dat, als er weer meer patiënten zijn, de Duitschers toch den een of anderen dag het ziekenhuis weer leeghalen.'53

Deze situatie beperkte de mogelijkheden voor de Joodse artsen om hun patiënten te helpen. Zo beschreef Salomon Koster de moeilijkheden die hij ondervond bij zijn pogingen zijn patiënten opgenomen te krijgen: hij stuitte op bureaucratie en onbegrip bij de dienstdoende GGD-collega. Het overleg met deze GGD-arts kostte Koster zoveel extra tijd dat het in ieder geval één patiënt bijna noodlottig werd. Een andere patiënt werd door een GGD-arts onderzocht na verzoek tot opname. Hem werd na het onderzoek te verstaan gegeven dat hij inderdaad opgenomen kon worden. Op de vraag in welk ziekenhuis dat dan kon geschieden, zei de niet erg fijnzinnige GGD-keuringsarts: 'in de Schouwburg natuurlijk.' 54 Ook het dagboek van Mirjam Bolle vermeldde stroeve onderhandelingen met de GGD over opname van haar grootmoeder in het NIZ. De familie riep daartoe zelfs de hulp in van professor M.N. Roegholt van het Wilhelmina Gasthuis. ${ }^{55}$ Roegholt overlegde met de directeur van de GGD, maar kon uiteindelijk geen opname bewerkstelligen. ${ }^{56}$ Betty Levie, oorspronkelijk radiologe in het Antoni van Leeuwenhoekziekenhuis, nu werkzaam in de CIZ en het NIZ, zag in deze nieuwe beperking de aanleiding om onder te duiken. Zij vond dat zij als behandelend arts zelf moest kunnen beslissen over opname en ontslag van haar patiënten. Daarbij vreesde zij ook dat - in tegenstelling tot de gedane belofte - de patiënten bij ontslag direct zouden worden opgepakt en gedeporteerd. Onder dergelijke omstandigheden, zonder autonomie als arts, kon zij onmogelijk verder werken, zo was haar oordeel. Haar houding, beantwoordend aan de vooroorlogse morele standaard, vond echter nauwe- 
lijks navolging bij haar collegae, zo herinnerde zij zich later. ${ }^{57}$ In de praktijk bleek men de restrictie ten aanzien van opnamen in de eerste weken ook niet zo letterlijk te nemen. De regel bleek niet goed met de GGD afgestemd te zijn. Toen het bestuur van de ciz bijvoorbeeld een verzoek tot opname indiende bij de GGD, antwoordde de onderdirecteur aldaar niets te weten van enige beperkende maatregel. ${ }^{8}$ Er was dus toch nog enige ruimte voor eigen opnames. En de GGD leek ook zeer wel bereid mee te werken aan opname, uitgaande van het patiëntencijfer in het NIZ in juni 1943, dat volgens Kroonenbergs aantekeningen op dat moment weer was gestegen tot boven de 400.59 Op II maart had de Joodsche Raad slechts 84 patiënten in het NIz geteld. ${ }^{60}$ Vele opnamen geschiedden dus tussen maart en juni 1943 met hulp van de GGD.

In het NIZ ging men zo goed en zo kwaad als het ging verder. Men zou zelfs nog een nieuw röntgentoestel aanschaffen. ${ }^{61}$ Gesperrt bleven ook alle medewerkers, net als die in de cIz en het PIz. De voormalige JI-medewerkers vroegen nieuwe legitimatiebewijzen als bewijs dat zij nu in dienst van het NIZ waren. Hun oude JI-Sperr was nu immers waardeloos geworden. In opdracht van de Sipo-sD moesten deze mensen ter beschikking blijven van het NIz. Eventueel mochten zij gedetacheerd worden bij andere instellingen van de JVvVV of de Joodsche Raad en dan hielden zij hun oorspronkelijke papieren. Het personeel van het ontruimde Oudeliedengesticht van het NIZ moest worden beschouwd als Niz-personeel. ${ }^{62}$ Voor hen leek de situatie weer even stabiel. ${ }^{63}$

\section{EEN LAATSTE BASTION VAN VEILIGHEID}

De weer redelijk stabiele situatie voor het Amsterdamse ziekenhuispersoneel was tamelijk uniek. Buiten Amsterdam hadden de acties tegen de ziekenhuizen wel degelijk een ernstig karakter aangenomen. In de vergadering van de Joodsche Raad van Io maart 1943 werd verslag uitgebracht van een reeks ophaalacties van zieken in den lande. In Groningen en Friesland werden in de eerste week van maart in totaal zo'n 500 zieken met gezonde familieleden op transport gesteld. Ook uit Leiden en Den Haag werden op s en 6 maart Joodse patiënten uit de ziekenhuizen gehaald en naar Westerbork overgebracht. ${ }^{64}$ In deze plaatsen mochten weliswaar enkele niet-vervoerbare zieken in Joodse noodziekenhuisjes blijven, maar ook dit zou een tijdelijke maatregel blijken. Begin april waren de oostelijke delen van Nederland aan de beurt. De Joodse zieken uit Arnhem en Zwolle werden weggehaald en naar Westerbork overgebracht. In Arnhem ging het om vijftien zieken, ${ }^{65}$ in Zwolle bleef alleen dokter 
Leo Lezer achter na de ontruiming van het kleine Joodse noodziekenhuis. ${ }^{66}$ Na de oostelijke regio volgden Hilversum, Gouda en Leiden. ${ }^{67}$ Buiten Amsterdam waren de Duitse acties dermate rigoureus dat ze eind april 1943 al zo goed als 'judenrein' waren. Sprake van vluchthavens in de vorm van ziekenhuizen was er allerminst. Binnen Amsterdam was de opnamecapaciteit van zowel CIZ als PIZ beperkt en daarmee werd het NIZ echt het laatste bastion van veiligheid.

Het aantal mensen in het NIZ steeg tussen de ontruiming van het Oudeliedengesticht op 3 maart en medio juni niet alleen door de toename van het aantal patiënten, maar zeker ook door ruim 500 personeelsleden die er hun toevlucht zochten. Op I5 juni waren er 435 patiënten en 530 personeelsleden. ${ }^{68}$ Ondanks de wetenschap dat ook ziekenhuizen verre van onschendbaar waren, en ondanks de restricties omtrent opname, ging er dus nog steeds een aantrekkingskracht van het NIZ uit. Volgens Presser was dit verklaarbaar: 'Het tekent de toestand van de Nederlandse Joden dat er vrij spoedig na deze catastrofe [3 maart ] weer honderden in deze onbruikbare schuilplaats wegdoken, omdat het daarbuiten toch weer nòg gevaarlijker was. ${ }^{69}$

In schipbreuktermen: het NIZ was de minst lekke reddingsboot. Kroonenberg werd echter gedwongen ook in mei 1943 weer lijsten op te stellen van 'onmisbaren', ter schifting van wie van zijn personeel wel en wie niet voor deportatie in aanmerking zou komen. Zowel Benedictus Koopman, co-assistent, die een dagboek bijhield van zijn tijd in het NIZ, als zijn collega co-assistent Arnold Rodrigues Pereira maakten zich zorgen dat zij nu 'misbaar' zouden blijken. Arnold Pereira en zijn kersverse echtgenote werden in voorjaar I943 bijtijds door Kroonenberg gewaarschuwd dat dit inderdaad het geval was: hij had hen niet op zijn lijst gezet. Voor het jonge echtpaar was dit de aanleiding om het ziekenhuis met spoed te verlaten en onder te duiken. ${ }^{70}$ Koopman op zijn beurt had geen idee en schreef op 24 mei dat er door de Joodsche Raad werd 'geknoeid' aan de lijst van Kroonenberg, wat zijn optimisme wat betreft zijn eigen positie niet ten goede kwam. ${ }^{71}$ Ruim een week na deze vertwijfelde notitie zou hij voor het laatst in zijn dagboek schrijven. Wat volgde was zijn arrestatie, deportatie en dood in de gaskamer. ${ }^{72}$

Toch had het NIZ ook nog een functie voor patiënten die ad hoc gered konden worden door een 'medische actie'. Bij de grote razzia op 26 mei 1943 in het centrum van Amsterdam werden 3300 mensen opgepakt en naar Westerbork gezonden. ${ }^{73}$ De rol die de artsen bij een dergelijke razzia konden spelen, wordt duidelijk bij lezing van een brief van orthopedisch chirurg Herman Herschel, waarin hij zijn herinneringen aan deze dag beschreef. ${ }^{74}$ Hij werd 's ochtends vroeg uit zijn bed gehaald door een medewerker van de Joodsche Raad, die hem verzocht medische bijstand te verlenen bij de actie. De Joodse buurt was 
hermetisch afgesloten en mensen werden systematisch uit hun huizen gehaald. Herschel moest zich naar de Hoogduitse Hoofdsynagoge aan het Jonas Daniël Meijerplein (toen Houtmarkt genoemd) begeven, waar men de gearresteerden bijeen zou brengen. Om tien uur kreeg hij een briefje waarmee hij zich vrij mocht bewegen in de Joodse buurt. In het NIZ deed hij verslag van de situatie. Internist Jacob Goudsmit vroeg om een doktersband en ging met Herschel mee terug naar de synagoge. 'Een zeer moedige daad; want in het ziekenhuis was hij safe', aldus Herschel. Nadat Goudsmit de situatie in de synagoge had aanschouwd, verzocht hij Herschel terug te gaan naar het NIZ en daar telefonisch om ambulances te vragen. De GGD-broeders meldden zich met een ambulance aan de zij-ingang van de synagoge, waar zo veel mogelijk mensen in de wagen gepropt werden. Deze gang van zaken herhaalde zich diverse malen. Herschel schatte dat zo'n 80 tot 100 mensen door Goudsmits plan konden worden afgevoerd naar het ziekenhuis, waar ze voorlopig veilig waren. ${ }^{75}$

Een van de gearresteerden was collega-internist Emanuel Godfried. Hij kreeg van Herschel en Goudsmit een doktersband en kon op die manier naar het NIZ worden meegenomen. Ook hielpen zij de twee huisartsen Souget, vader Aron en zoon Max, om ongezien de synagoge uit te glippen. ${ }^{76}$ Deze reddingsactie bleef echter niet onopgemerkt. Toen om halfnegen 's avonds de razzia voorbij was, moesten Herschel, Goudsmit en het ondersteunend Joodse personeel van de Zentralstelle zich verzamelen. Ferdinand Aus der Fünten gaf Herschel en Goudsmit de schuld van de verdwijning van mensen op zijn lijst en hij besloot hen in plaats van vader en zoon Souget op transport te stellen. De medewerkers van de Zentralstelle namen het daarop voor Herschel en Goudsmit op en bezwoeren dat zij onschuldig waren, waarop Aus der Fünten lange tijd zweeg. Volgens Herschel zei Jacob Goudsmit: 'dan gaan we even waardig als velen voor ons. ${ }^{77}$ Herschel zelf had eerder de neiging te ontsnappen, maar Aus der Fünten besloot met: 'Nah, geh schon. ${ }^{3}{ }^{7}$ Voor Herschel was het een van de meest dramatische dagen van zijn leven, maar ook een dag waarop hij 'een moedig mens had leren kennen, die ook nog een briljant idee had, dat zeker mensen gered heeft'. 79 Goudsmit had zijn beroep, de medische trucs en de status van het NIZ succesvol kunnen inzetten om in elk geval een deel van de mensen te hulp te schieten.

Ook de pogingen om het ziekenhuispersoneel te behouden waren tijdens de razzia van 26 mei succesvol. De bezetter had bepaald dat de ziekenhuizen en hun personeel uitgezonderd zouden blijven van deze actie, waarschijnlijk ook door inmenging van Stabarzt Meyer, die de externe personeelsleden van NIZ, PIZ en CIZ plus hun naaste familieleden sommeerde zich naar het gebouw van de Ji te begeven. Aldaar brachten deze ruim 250 personeelsleden de dagen rond 
de grote razzia door, tot Meyer hen op 28 mei kwam vertellen dat degenen onder hen die buiten het leeggehaalde centrum woonden terug naar huis konden keren. Bewoners van het centrum wier huis was leeggehaald en verzegeld, konden in de JI blijven. ${ }^{80}$

\section{SAMENWERKING TUSSEN HET NIZ, DE LEGE JI, DE GGDEN DE HOLLANDSCHE SCHOUWBURG}

Niet alleen de JI, maar ook andere instituten rond het NIZ maakten deel uit van een medische keten van relatieve veiligheid. Tijdens de razzia van 26 mei werd de Hoogduitse Hoofdsynagoge als verzamelplaats voor de gearresteerde Joden gebruikt, maar de meest gebruikte plek voor dit doel was van november 1942 tot september 1943 de Hollandsche Schouwburg op de Plantage Middenlaan. ${ }^{81}$ Zieken werden ook wel via het Lloyd-hotel op transport gezet, ${ }^{82}$ maar de grootste verzamelplaats voor gearresteerde Joden was de Schouwburg. Na een oponthoud van enkele uren of dagen werden zij vervolgens per trein naar Westerbork vervoerd. De Schouwburg was allerminst een prettig oord: 'Wild-wild - in de hel zelf kon het niet wilder zijn dan in de Schouwburg. [...]De brakende kinderen, de wanhopig geworden, gillende volwassenen - voor hen was geen ruimte in de ziekenzaal. Tussen die allen door liepen wij, de paar helpers. ${ }^{83}$

Net als het NIz kon de Hollandsche Schouwburg onder de meest nijpende omstandigheden toch nog een strohalm bieden. Onder de helpers in de wanhoop waren voorjaar 1943 ook vier Nederlandse artsen: Bernard de Vries Robles, die de medische leiding had, en Calmer Roos, Ben Polak en Jo van der Hal. ${ }^{84}$ Hun ziekenverblijf was weliswaar wat rustiger dan de rest van de Schouwburg, maar slecht geoutilleerd en het werk was daarom en vanwege de omstandigheden vaak frustrerend voor de betrokken artsen. ${ }^{85}$ De Vries Robles kon twee meisjes die zichzelf hadden vergiftigd niet redden omdat hij het tegengif niet in huis had. Hij zou zich tegen Salomon Koster hebben laten ontvallen dat de Duitse bezetter de Joden behandelde als een paardenkoopman zijn paarden: zodra ze niet meer voor hem konden werken, werden ze afgemaakt. ${ }^{86}$ Toch waren er voor de artsen in de Hollandsche Schouwburg nog wel enkele mogelijkheden om medische reddingsmiddelen in te zetten.

In de Schouwburg waren verzetsactiviteiten ontstaan, onder leiding van Walter Süsskind. De organisatie die hij leidde wist via de bijbehorende creche, die aan de andere kant van de Plantage Middenlaan gevestigd was, ruim 500 kinderen uit de Schouwburg in veiligheid te brengen. Zij waren met hun ouders in de Schouwburg gevangengezet, voor de nacht in de crèche ondergebracht en 
werden daar, in overleg met de ouders, door studenten weggesmokkeld naar onderduikadressen in Friesland en Limburg. ${ }^{87}$ Ook volwassenen werden vanuit de Schouwburg naar de overkant van de straat gebracht om opgehaald te kunnen worden en in de onderduik te verdwijnen. ${ }^{88}$ De artsen van de Schouwburg verleenden hun medewerking aan deze activiteiten en smokkelden ook via de ziekenzaal mensen weg. ${ }^{89}$ Jo van der Hal herinnerde zich bijvoorbeeld dat de artsen mensen in de behandelkamer opsloten, zij vervolgens de Duitse bewakers dronken voerden en niet veel later de mensen konden laten ontsnappen. ${ }^{90}$ Het huis van de gemengd gehuwde Calmer Roos aan de Weteringschans werd meermaals gebruikt als tijdelijke opvang. Ook zou de in de Schouwburg werkzame Oostenrijks-Joodse arts Jeremias Barth met eigenhandig vervalste sleutels ongeveer een tiental mensen hebben laten ontsnappen. ${ }^{91}$

Een ander voorbeeld van medische hulp via de Schouwburg is opgetekend door Joseph Kater, die zijn functie als arts inzette in een poging zijn eigen vader te redden:

Dankzij een bevriend collega die 'dienst' in de schouwburg had, kreeg $\mathrm{ik}$ het bericht dat mijn vader zich daar bevond, en ging er snel heen. Dat was erg dom, want elke Jood die zich in deze feitelijke gevangenis bevond kwam er bijna nooit meer uit. [...] Er was een soort ziekenkamer met veldbedden en toen ik mijn vader daar vond had ik maar een gedachte: hem eruit halen. Het was twee uur's nachts en ik was dank zij mijn band om de arm waarop 'dokter' stond, zonder moeite langs de wacht in de hal van de schouwburg gekomen, en deze liet mij opnieuw passeren toen ik eruit liep. Een uur later werd mijn vader door de ambulance gehaald als ernstig ziektegeval. Twee broeders tilden hem op de brancard en daarna langs de Duitse wacht in de wachtende ambulance. Eén van die broeders was ik en we reden naar een ziekenhuis, waar ik, dankzij de medewerking van enkele autoriteiten een bed had kunnen krijgen. ${ }^{92}$

Er bestond een samenwerking tussen de artsen van de Schouwburg en die van het NIZ. Oud-verpleegster Janny Moffie-Bolle herinnerde zich hoe zij chirurg Johnny van Coevorden enkele malen vergezelde op zijn tocht door de Hollandsche Schouwburg. 'Soms liep ik mee met Van Coevorden. Hij beoordeelde wie wel en wie niet met ons meekon. Het waren meestal mensen die niet konden lopen. We namen ze mee en zetten ze om de hoek uit de ziekenwagen, want verplegen kon je ze niet. Daar ging het ook eigenlijk niet om - het was een manier om er nog een paar mensen uit te halen.' ${ }^{33}$ Ook Ies Cohen, oudsigarenhandelaar die zich ontpopt had tot manusje-van-alles in het NIZ, liep 
regelmatig naar de Schouwburg om met dergelijke activiteiten een of twee gevangenen naar buiten te helpen en hen vervolgens mee te nemen naar het NIZ. ${ }^{94}$

Dergelijke reddingsacties lukten niet altijd, zelfs niet als de patiënten echt ernstig ziek waren. Zo ondervond ook Salomon Koster:

$\mathrm{Nu}$ fietste ik naar den Joodschen Schouwburg, om dokter De Vries

Robles, chef van de Joodsche doktoren van het ziekenzaaltje, te vragen, of mevrouw de Witte, wegens haar slokdarmaandoening niet vrij kon komen. Ik moest daartoe in de creche wachten, tot hij gelegenheid had om even naar den overkant te komen. [...] Mevrouw de Witte's zuster, die met een valsch persoonsbewijs, zonder ster, rondliep, was al in de Schouwburg geweest en had bij den Joodschen dokter de geneeskundige verklaringen gebracht van Professor de Kleyn en van mij, waarin stond, dat zij dringend een slokdarmoperatie moest ondergaan, om weer zelfstandig te kunnen eten, zonder voedingsslang. ${ }^{95}$

Koster begreep echter al snel van De Vries Robles dat de bezetter zich 'absoluut niets meer' aantrok van attesten, zelfs niet van hoogleraren. Kosters patiënte vertrok naar Vught, alwaar zij 'ook met sonde gevoed kon worden'.96 Deze patiënte was wellicht Klara de Zwarte-Walvisch, die in haar dagboek noteerde:

Misschien was er voor mij nog iets te doen en maakte ik een kleine kans op tijdelijk vrijlating. Tenminste, dat hoopte ik. Eindelijk om drie uur werden we dan bij de dokter in het ziekenzaaltje toegelaten. Daar vertelde ik van mijn kwaal of liever gezegd van hetgeen mij mankeerde, en de doktoren schenen het geval van slokdarmkramp nogal interessant te vinden. Eén beloofde dat hij alles in het werk zou stellen om me vrij te krijgen, maar zijn collega durfde die belofte niet aan. [...] Alles heeft echter niet mogen baten, geen attesten van mijn dokter en van de prof die mij zou opereren. ${ }^{97}$

Voor een andere patiënt, lijdende aan multiple sclerose, kon Koster nog wel arrangeren dat deze een dure behandeling met goudinjecties zou blijven ondergaan, ook in Westerbork. Koster en De Vries Robles vermoedden wel dat het eind van de kuur direct ook het eind van het verblijf in Westerbork zou betekenen en dat deportatie naar het Oosten dan onafwendbaar zou zijn. ${ }^{98}$

Belangrijke hulpfactor voor de artsen in het NIZ en de Hollandsche Schouw- 
burg was de medewerking van werknemers van de GGD aan de reddingsacties: in de eerste plaats door de medewerking bij het opnamebeleid, maar ook door de ambulancebroeders die hielpen bij het wegsluizen van patiënten naar het NIZ. De GGD zetelde in het gebouw aanpalend aan dat van de Joodsche Invalide, op de hoek Weesperplein-Nieuwe Achtergracht. Door deze fysieke nabijheid, de bemoeienis met het opnamebeleid in de Joodse ziekenhuizen en de inzet van ziekenwagens van de GGD bij het ophalen van zieken, waren veel medewerkers van de GGD rechtstreeks geconfronteerd met de misère onder de Joodse bevolking. ${ }^{99}$ De GGD-ambulances hadden in het voorjaar van 1943 , in opdracht van de bezetter, al vele ritjes met Joodse patiënten naar en van de Hollandsche Schouwburg gemaakt. ${ }^{100}$ Dit zat veel ambulancebroeders niet lekker, zoals blijkt uit aantekeningen van Salomon Koster en Berthold Stokvis. De weigering van GGD-broeders om mee te werken zou de reden zijn geweest dat er tijdens de ophaalacties aan huis in januari 1943 troepen oD'ers uit Westerbork waren gehaald. ${ }^{\text {Ior }}$ Voorts makte de GGD-arts H. Peeters, die - als dekmantel? - actief lid van de Artsenkamer was, talloze (valse) attesten waarin hij verklaarde dat gevangenen in de Schouwburg aan een besmettelijke ziekte leden. Deze 'zieken' werden vervolgens overgebracht naar het NIz of de leeggehaalde Joodsche Invalide, via welke adressen zij konden verdwijnen in de onderduik. Als zij geregistreerd waren, vervalste men een overlijdensakte, waarna de onderduik kon beginnen. ${ }^{\text {IO2 }}$

De beheerder van de leeggehaalde Joodsche Invalide, A.V. Hartogh, herinnerde zich ook mensen die door Peeters rechtstreeks vanaf hun huisadres naar de JI werden gestuurd. In totaal schreef Peeters volgens hem honderden attesten. Het hoge sterftecijfer begon op den duur op te vallen, maar de verklaring van Hartogh aan de Duitse autoriteiten dat de zo opwindende tijd voor de Joden hiervan de oorzaak was, werd geloofd. ${ }^{\text {I03 }}$

Ook De Joodsche Invalide zelf stroomde weer vol met vluchtelingen: vol-

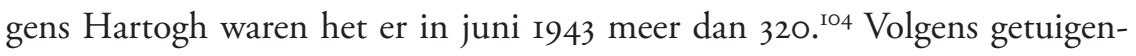
verklaringen werden ook uit De Joodsche Invalide kinderen door het verzet weggehaald nadat zij hier vanuit de Hollandsche Schouwburg naar toe waren gebracht. ${ }^{\text {IO5 }}$ Het grootst en belangrijkst bleef echter het NIZ. Dat ziekenhuis gold, zoals gezegd, nog als allerlaatste redmiddel. Soms kon er zelfs nog iemand uit een gereedstaande deportatietrein naar het NIZ worden overgebracht. Zo verhaalde Berthold Stokvis van een gearresteerde Joodse arts die op het perron nog een lijst met ernstig zieken mocht aanleggen, waarvan een deel naar het NIZ werd overgebracht. ${ }^{106}$ Ans Samama-Polak herinnerde zich hoe psychiater Coen van Emde Boas haar uit de trein die bijna naar Westerbork zou vertrekken, kon halen door te zeggen dat ze ziek was en dringend opgenomen moest 
worden. Ze meldde zich bij het NIZ, waar haar neef Max Hamburger het spel meespeelde. ${ }^{107}$

Het lukte de Joodsche Raad om in juni 1943 de 'Ausnahmebescheinigung', een soort 'super-Sperr' voor de I7o belangrijkste Joodsche Raad-medewerkers, onder wie personeelsleden van de ziekenhuizen, in te voeren. De Raad zag bovendien kans om tijdens Aus der Füntens vakantie bij zijn vervanger Wörlein gedaan te krijgen dat er boven op die I70 stempels nog een heel stel Ausnahmebescheinigungen bij mocht komen. Hieronder vielen onder anderen de 3I artsen van het NIZ, de PIZ en de CIZ, die op hun persoonskaart in de cartotheek van de Joodsche Raad dan ook bovenaan de notitie 'AuBe NIz', 'AuBe PIz', of 'AuBe ciz' vermeld kregen. ${ }^{108}$ Aus der Fünten was furieus toen hij terugkwam van zijn vakantie en stuurde 450 mensen, onder wie Ausnahmebescheinigunghouders, op transport. ${ }^{109}$ Hoelang het NIz het als laatste bastion in het leeggehaalde Joods Amsterdam zou kunnen volhouden was ongewis. Velen richtten zich dan ook in de loop van het voorjaar van 1943 op illegale reddingsmiddelen. Zij doken onder of legden contacten met het georganiseerde verzet.

In het voorjaar van 1943 hadden diverse medewerkers van het NIZ dergelijke contacten gelegd. ${ }^{\text {IIO }}$ De portier van het NIZ, Van Koningsbrugge, zag naar verluidt de hele dag mensen in en uit het kamertje achter zijn portiersloge komen. Hier spraken de werknemers van het NIz en hun illegale contacten van buiten het ziekenhuis elkaar. Laborantes Ellen van Oven en Bep Kaas waren actief in het verzet en konden dat ideaal met hun baan combineren. Iedere ochtend maakten zij een ronde door het ziekenhuis om op alle afdelingen bloed te prikken. Tegelijkertijd konden zij onopvallend allerlei mensen spreken en met patiënten overleggen over het te volgen onderduikplan. Ook verpleger Mau Poons was actief in het organiseren van onderduikmogelijkheden voor NIZ-patiënten en -personeel. Hij was gemengd gehuwd en had ook zelf onderduikers in huis genomen. ${ }^{\text {III }}$ Diverse verpleegsters verleenden hand-en-spandiensten. Ruth Watermann bijvoorbeeld hielp een gezond kind wiens moeder in het NIZ was opgenomen, om onder te duiken. ${ }^{\text {II2 }}$

Een niet-Joods verzetscontact was de jonge Amsterdamse historicus Jan Meilof IJben. Hij was bevriend met de Joodse geneeskundestudent Flip Bloemist, die eind 1942 in het NIZ was opgenomen met tbc. Bloemist wees Meilof IJben op de benarde toestand van de mensen in het NIZ, waarop deze actie ondernam. Hij begon met het zoeken van geschikte onderduikadressen. Die vond hij onder andere in het Overijsselse dorpje Lemele. Meilof IJben haalde de patiënten en personeelsleden uit het NIZ op onder de valse identiteit van de arts dr. Jan Massolt. Hij fietste vrij rond, met een aesculaap op zijn fiets, wat hem soms echter ook de moeilijke situatie opleverde dat hij op straat bij een 
acuut geval geroepen werd. Hij stond in contact met Bernard de Vries Robles in de Hollandsche Schouwburg en ook uit de Ji en later uit het PIZ wist hij mensen te helpen. Via deze constructies en met hulp van directiesecretaris George Ladee van de GGD, wist IJben naar schatting in totaal zo'n 200 mensen aan een onderduikadres te helpen. ${ }^{\mathrm{II} 3}$

\section{HET NIZ 'LOOPT OP Z'N LAATSTE BENEN'}

Dat het einde van het NIz ook onafwendbaar zou zijn, zullen niet veel mensen betwijfeld hebben. Zeker niet nadat in juni en juli 1943 de groep Joden in Nederland wederom drastisch verkleind werd. Op 20 juni werd een 'Grossaktion' in Amsterdam-Zuid en -Oost gehouden. Van de 17 ooo nog legaal in Amsterdam wonende Joden werden er 5550 gearresteerd en gedeporteerd. ${ }^{\mathrm{II}}{ }^{4}$ Opnieuw lukte het Joodse artsen met hulp van GGD-broeders enkele zieken veilig naar het NIZ af te voeren. ${ }^{\text {II }}$ Een voorbeeld was Coen van Emde Boas, die zelf gearresteerd was, maar met zijn echtgenote Magda kans zag op het perron een medische actie te ensceneren, waarbij meerdere mensen onder het mom van ernstige ziekte succesvol naar het NIz konden worden weggesluisd. ${ }^{\mathrm{II}}$ Berthold Stokvis was in deze dagen in het NIZ en beschreef wat hij zag:

Nog steeds ziet men 'sterren', al zijn het er nog maar zeer weinig; nog steeds bevindt zich in het centrum der stad, te midden van wat eens het hartje van den Jodenbuurt is geweest, een concentratie van Joden, te weten in het Nederlandsch Isrälietisch Ziekenhuis. Daags na de groote razzia blijkt het ziekenhuis een verzamelplaats van dakloos geworden gezinnen, die het niet meer wagen huiswaarts te keeren en thans in het ziekenhuis in letterlijken zin een gasthuis vinden. [...] velen houden zich gereed te verdwijnen, zoodra er onraad zal dreigen. ${ }^{\text {II7 }}$

Twee weken later, op 5 juli, was er inderdaad onraad in het Niz zelf: een razzia, waarbij het patiëntental werd teruggebracht tot 300 . Het personeel ontvluchtte voor een groot deel het ziekenhuis. ${ }^{\text {II8 }}$ Zieken werden klaargemaakt voor transport. Sam Bos, broeder op de afdeling, vertelde over een Duitse arts:

Dat was de engel des doods, die mocht beslissen: jij mag blijven, jij moet mee. En ik herinner me dat ik daar alleen stond en luisterde wat er be- 
sproken werd. En dat Van Coevorden zei: 'die heeft een slechte prognose, die maakt het niet lang meer, die gaat dood.' Dan zei die arts: 'Nah, dann kann er bleiben, lass er sich beeilen.' Dat herinner ik me nog altijd. Hij moest snel doodgaan, dan kon hij blijven. ${ }^{19}$

Ook het personeel zou mee moeten, maar gaf zich niet zo snel gewonnen. Via het belendende pand van Nieuwe Kerkstraat 123 zagen enkelen de kans te vluchten. Na een paar passen door de Manegestraat kwamen ze uit op de Nieuwe Prinsengracht. Deze methode van ontvluchten in geval van acute nood in het ziekenhuis was bij eerdere razzia's al uitgevonden en bekend geraakt onder de term 'I-2-3 naar buiten', verwijzend naar het huisnummer van het pand aan de Nieuwe Kerkstraat, waar de linnenkamer van het ziekenhuis gevestigd was. ${ }^{\mathrm{I} 20}$ Ies Cohen, immers officieel hoofd van de radiokamer, had de gewoonte ontwikkeld om het startsein voor een dergelijke vluchtpoging te geven in de vorm van een verborgen radioboodschap. In opdracht van de Duitse agenten moest hij de namen van de personeelsleden op de lijst voorlezen, maar hij voegde daar dan de Jiddische woorden 'wejiwrach' of 'hasjeveinoe' aan toe, oftewel: wegwezen! ${ }^{121}$ Dergelijke trucs hielpen nog even, maar vanaf die 5 de juli liet de bezetter het NIZ niet meer met rust. Jacques Reisel rapporteerde op 3 augustus:

Het ziekenhuis loopt op zijn laatste benen rond, elke dag verdwijnen er vier à vijf mensen, zodat binnenkort hierdoor al alleen de liquidatie van het ziekenhuis te verwachten is. De assistenten, behalve Hamburg, zijn er nog, evenals Goudsmit en Godfried. Het ziekenhuis is een kind met een waterhoofd. Voor de plusminus io ooo Joden, die er nog in Amsterdam zijn, waarvan plusminus 5000 gemengd-gehuwden, zijn drie ziekenhuizen nog in gebruik. De PIZ en CIZ worden voor sterilisatie gebruikt, plusminus vijf per dag. ${ }^{122}$

Terwijl het NIZ op zijn laatste benen liep, was er in het PIZ en in de CIZ een nieuw fenomeen gaande: sterilisaties van gemengd gehuwde Joden. Stabarzt Meyer en zijn bureau, dat van de CIz naar de Joodsche Invalide werd overgeheveld en nog later naar het PIZ, werden belast met de uitvoering van de sterilisaties. ${ }^{123}$ Ook dit vond nu plaats onder de ooit zo felbegeerde daken van de ziekenhuizen. 


\section{STERILISATIE}

Paradoxaal genoeg was Nederland, uitgerekend het land waar de artsen in de jaren dertig zo fel gekant waren geweest tegen de eugenetische sterilisaties die in Duitsland en andere landen plaatsvonden, het enige land waar in 1943 daadwerkelijk sterilisaties van gemengd gehuwde Joden, geheel gezond van lijf en leden, uitgevoerd zouden worden. ${ }^{\text {I24 }}$ Joden met een niet-Joodse huwelijkspartner hadden zich, voor zover zij kinderen hadden, in september 1942 kunnen melden om een Sperre te krijgen. ${ }^{125}$ Nadat er vervolgens desalniettemin maandenlang onzekerheid had bestaan over wat er met hen en met de gemengd gehuwden zonder kinderen, bij elkaar ongeveer 9000 mensen, zou gebeuren, werd hun in voorjaar en zomer 1943 de keuze gegeven: deportatie of sterilisatie. ${ }^{\mathrm{I} 6}$

Ten minste 2059 van de gemengd gehuwden werden tijdens de bezetting naar Westerbork ofwel naar Kamp Vught of verder gedeporteerd. ${ }^{127}$ Met deze vervolging en met de uitvoering van sterilisaties van gemengd gehuwden liepen de Duitse autoriteiten in het bezette Nederland harder dan de machthebbers in Duitsland zelf, waar 'Mischehen' waren vrijgesteld van anti-Joodse maatregelen. Met de zogenaamde 'keuze' voor sterilisatie werd de Nederlandse gemengd gehuwden dan wel een beschermingsmogelijkheid geboden tegen deportatie, maar wel een zeer twijfelachtige. Was hierin nog wel een geëigende 'reddingssloep' te ontwaren? Was het middel sterilisatie niet té drastisch om het doel ervan (bescherming tegen deportatie) te legitimeren? En hoe dienden de Joodse artsen zich in deze kwestie op te stellen?

Op I4 mei 1943 begon de sterilisatiegeschiedenis van de Nederlandse Joden. I03 in Westerbork geïnterneerde gemengd gehuwden met kinderen werden in de registratiezaal van het kamp bijeengeroepen, waar Aus der Fünten het woord tot hen richtte. ${ }^{128} \mathrm{Hij}$ meldde dat hun een halfuur tijd gegund was om te kiezen: deportatie of sterilisatie. Een paniekstemming volgde. De helft van de aanwezigen weigerde de als uiterst vernederend ervaren sterilisatie te ondergaan. ${ }^{\mathrm{I} 9} \mathrm{Zij}$ werden weer het kamp in gestuurd. De andere helft, die sterilisatie toch verkoos boven het vooruitzicht van deportatie, mocht terug naar Amsterdam. Zij werden opgenomen in De Joodsche Invalide. De operaties zouden vervolgens in de CIZ en in het PIZ plaatsvinden. Na de sterilisatie zouden de betrokkenen in plaats van een dikke zwarte $J$ in het persoonsbewijs een opengewerkte J met rode inkt gestempeld krijgen. Zij zouden van deportatie gevrijwaard zijn en ook de Jodenster niet meer behoeven te dragen, ofwel 'Stersteriel-ster af', zoals het rijmpje luidde dat al snel opgang maakte. Voor de 'Sternbefreiten' zou het leven er vervolgens veel rooskleuriger uitzien. Of toch 
niet? $\mathrm{Zij}$ zouden wel een levenslange verminking hebben en onder zware druk tot deze 'keuze' gekomen zijn. Het personeel in De Joodsche Invalide, het PIZ en de ciz kreeg opnieuw een dilemma voorgeschoteld. Mocht of kon het hieraan wel medewerking verlenen?

Verschillende leden van het verplegend personeel en bijvoorbeeld de secretaresse van de CIZ zagen in de aanvang van deze in hun ogen schandelijke en ontoelaatbare toestand aanleiding te gaan onderduiken. ${ }^{130} \mathrm{Zij}$ konden het moreel niet aan zichzelf verantwoorden (indirect) aan deze praktijken mee te werken. Het voorbeeld voor deze principiële houding gaf de vicevoorzitter van de cIz, Mau Henriques Pimentel. Hij was een befaamd chirurg, die weliswaar al 78 jaar oud was, maar nog altijd veel activiteiten ontplooide en als een autoriteit gold. Hij wenste volgens naoorlogse ooggetuigenverklaringen de ontwikkelingen niet verder af te wachten en dook in mei 1943 onder, direct nadat bekend was geworden dat 'zijn' CIZ voor dit doel uitverkoren was. ${ }^{131}$

Geneesheer-directeur Samuel Poliakoff van het PIZ bleef wel aan toen de sterilisaties in zijn ziekenhuis plaatsvonden. Hij moest kiezen tussen twee kwaden: het verlaten van zijn post en het onder zijn dak toelaten van de sterilisaties. Hij woonde de bijeenkomst met vertegenwoordigers van de Joodse ziekenhuizen bij waarbij de aan te nemen houding ten opzichte van het toelaten van de operaties bepaald werd. ${ }^{32}$ Een gemeenschappelijk ontslag werd overwogen, maar dat idee verwierp men weer, omdat een dergelijke vorm van sabotage de Duitsers vermoedelijk tot represailles van rampzalige omvang zou drijven. Men verzocht de Joodsche Raad wel te protesteren bij de Duitse overheid. ${ }^{133}$ Dit deden Cohen en Asscher weliswaar, maar veel effect sorteerde het niet. De sterilisaties gingen door. Wel bedongen de voorzitters dat de ruimtes waarin de sterilisaties plaatsvonden, niet onder verantwoordelijkheid van de Joodsche Raad, maar rechtstreeks onder Duitse verantwoording vielen. ${ }^{134}$ Zodat de ziekenhuizen 'door de Duitsche autoriteiten zijn gevorderd en allen, die daarin werken, dit doen in opdracht dezer autoriteiten, zoodat hiervoor geen verantwoordelijkheid bij den Joodschen Raad of zijn onderdelen noch bij het daarvoor dienstdoende personeel berust'. ${ }^{135}$

Zowel de Joodsche Raad als het ziekenhuispersoneel probeerde afstand te bewaren tot de schandelijk geachte praktijk van de sterilisaties en de verantwoordelijkheid ervoor niet zelf te hoeven dragen. De afdeling van De Joodsche Invalide waar de ter sterilisatie opgenomen mensen lagen, doopte men om tot 'Westerborkheim' en werd bewaakt door NSB'ers. ${ }^{136}$ Het JI-personeel overlegde ook met J.H. Tuntler van de GGD, opperrabbijn Frank en de hoofdcommissaris van politie van bureau Waterlooplein of men de medewerking alsnog moest weigeren. Consensus werd echter bereikt er toch aan mee te doen, 'daar 
de sterilisatie door ons niet kon worden verhinderd en de slachtoffers het minder goed zouden hebben wanneer wij niet medewerkten' ${ }^{137}$ Het aanblijvende personeel van de ziekenhuizen, in totaal zo'n 200 mensen, was na rijp beraad betrokken bij de sterilisaties, maar wel onder de voorwaarde dat het op bevel van de Duitse autoriteiten geschiedde. ${ }^{138}$

Het wel of niet faciliteren van de operaties was een eerste dilemma, het tweede dilemma was nog pregnanter, want betrof de daadwerkelijke uitvoering van de operaties. Mochten artsen dat doen? Van de chirurgisch geschoolde huisarts J.B. Wolff is bekend dat hem het verzoek om te steriliseren werd voorgelegd. Hij weigerde. ${ }^{39}$ Wolff was niet de enige. Aanvankelijk werd er geen enkele Joodse arts gevonden die de sterilisaties wilde uitvoeren. Al op I5 mei I943 had de illegale pers genoteerd: 'Gelukkig hebben de Joodsche doktoren geweigerd hun geloofsgenoten te behandelen.' ${ }^{140}$ Het Medisch Contact volgde niet veel later met een reactie die tegelijkertijd een richtlijn bood. Op 20 mei stelde het in een estafettebericht:

In Amsterdam zijn vier Joden [ 2 mannen en 2 vrouwen] die met een christen in concubinaat leefden, uit welke verhouding kinderen waren voortgekomen, voor de keuze gesteld 'sterilisatie' of naar Polen. Ze zijn door Duitsche artsen gesteriliseerd. Er wachten enkele honderden [kinderloos gemengd-gehuwden, uit Westerbork naar Amsterdam gebracht] in het gebouw van de Joodsche Invalide op dezelfde keuze en hetzelfde lot. Geen arts werke hieraan mede, ook niet op de meest indirecte wijze. ${ }^{4 \mathrm{I}}$

Het was voor het Medisch Contact zo klaar als een klontje: meedoen aan sterilisaties ging recht in tegen de medische beroepseer. Het niet-schadenprincipe, vastgelegd in de eed, werd ermee geschonden. Bovendien was de politieke achtergrond van deze sterilisaties de Nederlandse artsen een gruwel. Alles waar zij voor de oorlog in hadden geloofd, werd door deze praktijk geschoffeerd. Daarnaast was deze maatregel, meer dan andere anti-Joodse bepalingen, in wijde niet-Joodse kringen bekend geworden, omdat ieder van de gedupeerden een niet-Joodse partner en schoonfamilie had. ${ }^{142}$ Ook in kerkelijke kring, waar voor de bezetting al een afkeer van sterilisatie had bestaan, was er snel sprake van wijdverbreid afgrijzen. Op i9 mei zonden de gezamenlijke kerken van Nederland een brief aan Seyß-Inquart om te protesteren tegen de sterilisaties. ${ }^{\text {I43 }}$ De tekst was opgesteld door dominee J. Koopmans en ondertekend door vertegenwoordigers van negen Nederlandse kerkgenootschappen. ${ }^{\text {I44 De }}$ illegale krant Trouw bekritiseerde niet alleen de bedenkers van de 'onchristelijke' maatregel, maar ook degenen die niet voor deportatie, maar voor 'het o.i. 
nog ergere kozen, namelijk de sterilisatie!'145 De afkeer ten opzichte van deze praktijk, zo blijkt uit diverse bronnen, was niet alleen gericht op de bedenkers en uitvoerders van de sterilisatie maar ook op degenen die de operatie ondergingen. ${ }^{146}$ Nederlandse artsen, Joods en niet-Joods, kregen dan ook uit medische en kerkelijke hoek en door de publieke opinie een duidelijke boodschap en moreel kompas mee: uitvoering van sterilisaties was uit den boze.

Geen Nederlandse arts was bereid de operaties uit te voeren en dus had Eduard Meyer twee Duitse militair chirurgen aangetrokken. ${ }^{147}$ Een van hen opereerde de mannen in het PIZ, de ander de vrouwen in de CIZ. In juli 1943 legden zij echter het werk al neer, waarmee Meyer op zoek moest naar andere uitvoerenden. Hij vond een gynaecoloog in Leiden, Henri van der Hoeven, een Nederlandse NsB'er en rabiaat antisemiet, die de operaties op zes Joodse vrouwen met graagte leek uit te voeren. ${ }^{148}$ Voor de operaties van de mannen vond Meyer uiteindelijk toch een Joodse arts: Salomon Lichtenstein. Deze uit Bonn afkomstige bejaarde medicus was een gevangene van Westerbork, die zich bereid toonde om met dit doel van Westerbork naar Amsterdam af te reizen. ${ }^{49}$ Verachting viel hem ten deel. H. Wielek karakteriseerde hem in 1947 als een 'beverige grijsaard, die zelf, en vooral geestelijk, volkomen steriel te noemen

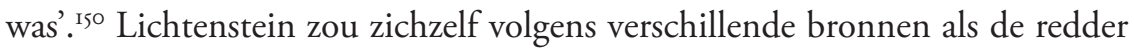
van de Joden hebben gezien en zich daarom met overtuiging van zijn taak gekweten hebben. ${ }^{\text {I5I }}$ 'Hijzelf meent de menschheid hiermede een groote dienst te hebben bewezen,' '52 schreef Cees Banning na de oorlog over hem. Van een Nederlands-Joodse chirurg van het PIZ leeft voorts bij diverse getuigen de overtuiging dat ook hij sterilisaties heeft uitgevoerd. Jacques Reisel was in zijn dagboek glashelder in zijn morele oordeel over deze twee Joodse chirurgen: 'Hopelijk worden beiden hiervoor na de oorlog met hun verdiende loon betaald.' 53

Hoewel het steriliseren in de kern als pertinent ongeoorloofd werd gezien, was er toch nog een uitvlucht voor het geweten van de operateur, zelfs staande aan de operatietafel. Waarschijnlijk is de operatie - mogelijk zelfs met medeweten van Meyer - niet zelden op een manier uitgevoerd die ervoor zorgde dat deze weer ongedaan gemaakt zou kunnen worden. ${ }^{154} \mathrm{Bij}$ de mannen werden de zaadleiders dan wel doorgehaald, maar niet gecauteriseerd (dichtgebrand), waardoor de eindjes van de zaadleiders na de bevrijding weer aan elkaar gezet zouden kunnen worden. Net als bij eerder op zichzelf onoirbaar geachte medische handelingen gaf de medische handeling zelf mogelijkheden om de patiënt in kwestie toch nog te helpen. Medische sabotage kon dus ook hier. Mede omdat de kans van slagen van een hersteloperatie erg klein was, is het de vraag of deze handelwijze veel is voorgekomen.

Medische sabotage werd ogenschijnlijk wel op grote schaal ingezet om ste- 
rilisatie te voorkómen. Men kon 'ontsterd' worden zonder operatie, maar met een bewijs van al bestaande onvruchtbaarheid. Dit gebeurde volgens Benno Stokvis, advocaat en broer van psychiater Berthold, op een dusdanige schaal dat slechts 'maximaal Ioo mannen, daaronder begrepen de schijnoperaties, chirurgisch zijn behandeld, en ten hoogste Io vrouwen'. ${ }^{155}$ Wielek op zijn beurt schatte evenwel dat ongeveer 600 mensen zich hebben laten opereren. ${ }^{156}$ Vergeleken met de officiële Duitse cijfers, die in juni I944 spraken van 2562 gemengd gehuwden die dankzij steriliteit 'Befreiung vom Sterntragen' bereikt hadden, imponeren beide schattingen als zeer laag. Het zou namelijk betekenen dat ofwel circa 2000 , ofwel circa 2400 gemengd gehuwden zonder operatie 'ontsterd' zouden zijn. ${ }^{157}$

Het grootste deel van de vrouwen had de 'sterbevrijding' simpelweg verkregen middels een verklaring van onvruchtbaarheid op grond van gevorderde leeftijd, maar volgens Duitse bronnen had van de II46 mannen het grootste deel wel degelijk een operatie ondergaan. ${ }^{158}$ Hoe dan ook een veelvoud van de 100 die Stokvis noemde en ook beduidend meer dan de 600 van Wielek. Historicus Coen Stuldreher refereerde in zijn proefschrift over de gemengd gehuwden aan een Duitse bron uit november 1943 die sprak van 442 geopereerde mannen, I69 mannen die middels een attest steriel verklaard waren, I9 geopereerde vrouwen, I40 op attest steriel verklaarde vrouwen en II55 vrouwen die op basis van hun leeftijd als steriel waren geregistreerd. ${ }^{59}$ Wat het werkelijke aantal operaties is geweest, is niet te achterhalen. Duidelijk is wel dat in elk geval een substantieel deel van de 'ontsterden' op basis van een medische verklaring van al bestaande onvruchtbaarheid geen operatie hoefde te ondergaan.

Het beeld dat wel overeenkomt in de diverse bronnen is dat men aanvankelijk, in de eerste weken na I4 mei, vrij voortvarend opereerde. Volgens notulen van de Joodsche Raad waren op i8 juni al 36 gemengd gehuwden geopereerd. ${ }^{160}$ In een andere opgave die eveneens uit medio juni I943 stamt, werden de aantallen patiënten in de verschillende instellingen opgesomd: in de CIZ lagen 2 normale ziektegevallen opgenomen plus 2 die voor sterilisatie in aanmerking kwamen, in het PIZ alleen I6 sterilisatiegevallen, in de JI I3 sterilisatiegevallen. ${ }^{16 \mathrm{I}}$ Een maand later was van het voortvarende tempo echter al geen sprake meer: 'De sterilisatie gaat slechts langzaam verder.' ${ }^{\text {I62 }}$ Naast het feit dat de Duitse chirurgen hun werk hadden neergelegd, zou een reden hiervoor kunnen zijn dat men in de tussentijd betere manieren had gevonden om zonder daadwerkelijke sterilisatie toch de 'ontsterring' op grond van onvruchtbaarheidsattesten te verkrijgen. Hiervoor werd weer creativiteit en vervalsing van de artsen gevraagd. 
Met het onderzoek naar de vele honderden verzoeken tot 'on tsterring', liefst zonder operatie, zou de Ärztliche Verbindungsstelle het de volgende maanden druk krijgen. ${ }^{163}$ Deze instantie was een onderdeel van de Joodsche Raad dat de verbinding tussen de Joodse bevolking en de Ärztliche Dienststelle van Meyer vormde. ${ }^{164}$ De Joodse functionarissen van de Verbindungsstelle, ook wel 'Beratungsstelle' genoemd, konden betrokkenen informeren over de gang van zaken rond de sterilisaties en namen ook verzoeken tot sterilisatie of tot sterielverklaring zonder operatie in behandeling. Meyer was de man die, samen met de Zentralstelle, besliste of deze verzoeken wel of niet gehonoreerd werden. Bijzonder was dat Meyer bijna altijd positief besliste en daarmee bewust leek te willen helpen. ${ }^{165}$ Benno Stokvis stond als advocaat ook diverse aanvragers van een steriliteitsverklaring bij en in geen enkele van deze gevallen werd de aanvraag door Meyer afgewezen, ${ }^{166}$ ofschoon de meeste van deze aanvragen gebaseerd waren op medische sabotage.

\section{VALSE STERIELVERKLARINGEN}

De Amsterdamse (niet-Joodse) chirurg M.N. Roegholt claimde de eerste te zijn die valse sterielverklaringen aan gemengd gehuwde Joodse mannen ging afgeven. Hij had hiertoe een truc ontwikkeld, naar eigen zeggen met hulp van Ernst Laqueur, de ontdekker van het testosteron. De aanleiding hiertoe was geweest dat verschillende Joodse gemengd gehuwde mannen hem hadden gesmeekt een sterilisatieoperatie op hen uit te voeren. Deze patiënten hadden kennelijk de strohalm die hun door de sterilisatie werd aangereikt, gegrepen en wilden hun vertrouwde arts als operateur vragen. Roegholt echter voelde er weinig voor deze operatie uit te voeren. Zoals zijn zoon zich herinnerde:

Mijn vader bleef tegenover hun smeekbeden hen te opereren echter onverbiddelijk. De medische ethiek, zoals ik haar als kind heb leren kennen, verbood een medische ingreep zonder medische noodzaak. Dit gold dubbel voor een ingreep als sterilisatie en driedubbel als de ingreep in dienst zou staan van een politiek belang. Dat was wel het allerlaatste waartoe een medicus zich mocht verlagen. ${ }^{167}$

In augustus herhaalde het Medisch Contact nog een keer zijn eerdere moreel appèl: 
Dat de betrokkene sterilisatie verkiest boven 'een ster dragen' en liever geopereerd wordt door een Nederlandschen arts dan door een Duitscher, verandert niets aan het wezen der zaak: operatie om te ontsnappen aan vervolging. Van een vrijwillig besluit is geen sprake. De arts die hierbij behulpzaam is, maakt zich tot uitvoerder van een vonnis, waarmede hij het oneens is, en dat geveld is door een rechter, dien hij disqualificeert. ${ }^{168}$

Roegholt ging dan ook niet over tot operatie, maar verzon een truc om zijn patiënten toch te kunnen helpen. In een brief aan het Medisch Contact in mei I945, waarin hij zijn werkwijze toelichtte, schatte hij dat hij 800 tot Iooo mannen een valse sterielverklaring had kunnen geven. ${ }^{169}$ Stuldreher beargumenteerde echter dat deze schatting te hoog moet zijn geweest. ${ }^{170}$ Hoeveel mensen ermee zijn geholpen is onzeker, maar hoe zij geholpen zijn heeft Roegholt gedetailleerd vastgelegd. Zijn truc hield in dat hij bij zijn patiënten via het rectum de vesiculae seminales (zaadblaasjes) leegdrukte, waardoor er via de penis een écoulement zonder zaadcellen vrijkwam. Immers, de naam vesiculae seminales doet vermoeden dat deze blaasjes de opslagplaats voor zaadcellen zijn, maar Roegholt wist als uroloog wel beter. Zo wist hij enkel ejaculatievocht te verkrijgen, dat - als zijnde sperma - door hem onder de microscoop werd gelegd. Het resultaat van zijn microscooponderzoek was dan een azoöspermie, ofwel een totale afwezigheid van zaadcellen, en dus een bewijs voor onvruchtbaarheid. Hiervan vond hij vervolgens veelvuldig zogenaamd de oorzaak in een eerder doorgemaakte venerische (geslachts)ziekte, zoals gonorrhoe. Een tweede mogelijke oorzaak was de nog niet volledig verworpen theorie van het manlijk climacterium, de mannelijke variant van de vrouwelijke menopauze. Als derde kon hij een vergroting van de prostaat als oorzaak aanwijzen. ${ }^{17 \mathrm{I}} \mathrm{De}$ theorie van prostaathypertrofie als oorzaak voor steriliteit was eigenlijk al verlaten, maar Berthold Stokvis had in Duitse vakliteratuur een artikel ontdekt dat deze theorie juist onderschreef. Ene Hans Zettel, Oberarzt der Luftwaffe, had in 194I in het Zentralblatt für Chirurgie gepubliceerd over 'Der Einfluss der Keimdrusen auf die sogenannten Prostatahypertrophie'. Hierin werd het bewijs geleverd dat een vergrote prostaat een man 'dauernd steril' kon maken. ${ }^{172}$ Stokvis en Roegholt geloofden er zelf niets van, maar konden dit artikel, van de hand van een Duitse arts, goed voor hun eigen doel inzetten.

Roegholt bezocht Meyer, die ook aan de Apollolaan 79 een kantoor had, en besprak, als collegae onder elkaar, de patiëntencasuïstiek. Het argument dat een arts geen medische handeling mocht verrichten als er geen medische noodzaak was, zette Roegholt nu in om Meyer ervan te overtuigen dat er een andere oplossing mogelijk moest zijn dan operatie. Zou een al steriele man 
opereren niet gelijkstaan aan 'het opereren van een glazen oog of het amputeren van een teen van een prothese?' ${ }^{\prime 73}$ zo redeneerde Roegholt volgens zijn zoon. Kennelijk wist Roegholt Meyer te overtuigen, waarmee de deur geopend was voor toepassing van zijn truc. Ook andere artsen gingen zich met deze vorm van medische sabotage bezighouden. Voor vrouwen was de hoogleraar gynaecologie Marius van Bouwdijk Bastiaans de belangrijkste. Van de Joodse artsen moet de naam van Leo Swaab, die vlak bij Meyer aan de Apollolaan 89 praktijk had, genoemd worden. ${ }^{174}$ Swaab was overigens zelf, ook door valse verklaringen, via Calmeyer al niet-Joods verklaard.

Anders dan bij de eerdere vervalsing van keuringen en attesten was de communio opinis onder de artsen over deze kwestie niet onverdeeld enthousiast. Men stelde zich de vraag of men hiermee niet indirect de zo sterk afkeurenswaardige praktijk van sterilisatie in stand hield. Zou men zich niet stelselmatig van iedere medewerking, hoe saboterend ook, moeten onthouden? Het Medisch Contact schreef: 'Er heerscht nu een meeningsverschil onder de collegae, of dit medewerken geoorloofd is.' Er kwam dan ook geen eenduidig advies vanuit het Medisch Contact: 'Wij meenen collegae vrij te moeten laten in hun keuze of zij het principieele danwel menschlievende element hier willen laten overweegen.' '755 Zo gesteld kozen Roegholt, Berthold Stokvis, Leo Swaab en nog een tiental andere (niet-Joodse) artsen voor het menslievende element. Zij achtten het geëigend hun patiënten ook in deze kwestie op onorthodoxe wijze te helpen.

De sterilisatiekwestie zou nog een staartje krijgen in het voorjaar van I944, toen men vijf chirurgen uit Westerbork bereid probeerde te vinden de sterilisaties op zich te nemen, in Amsterdam of mogelijk zelfs in het kamp zelf. ${ }^{176}$ Kamparts Fritz Spanier, gynaecologe Rosalie Wijnberg, de Duits-Joodse arts Kuttner en Generaal Salomon Praag, oud-officier van gezondheid, verzetten zich hier fel tegen met als argument dat het de taak van artsen was om zieken gezond te maken, niet gezonden invalide. Volgens kampcommandant Gemmeker was het een bevel en weigering van een bevel zou op de in het kamp zo bekende manier bestraft worden: met deportatie. Juridisch advies werd ingewonnen bij professor E.M. Meyers, die ook in het kamp gevangenzat. Hij meende dat de artsen gezamenlijk, dus niet alleen de operateurs, verantwoordelijkheid zouden moeten dragen als ze tot behandelen zouden overgaan. Dan zou hun, na de oorlog, strafrechtelijk niets te verwijten zijn, aangezien zij in gevangenschap en niet onafhankelijk zouden hebben gehandeld. Moreel gezien vond hij het wel degelijk verwerpelijk. ${ }^{177}$ De artsen volhardden dan ook in hun weigering. ${ }^{178}$ De chirurg Albert Salomon zegde wel toe toen hij in Westerbork voor deze klus gevraagd werd, maar hij dook onder zodra hij 
met zijn echtgenote in Amsterdam was aangekomen. ${ }^{\text {I79 }}$ Vrouwenarts Rosalie Wijnberg oordeelde later dat zij niet anders had gekund dan pertinent weigeren, omdat zij anders 'niet met zichzelf had kunnen leven'. ${ }^{180}$ In het kamp gaf een tweetal artsen wel voorlichting over het wezen van de ingreep. ${ }^{\text {II }}$ Uit Amsterdam werden mannen gehaald die de operatie reeds ondergaan hadden ter verstrekking van informatie. Zij werden 'mannequins' genoemd. ${ }^{182}$ Over het algemeen werd er op hen neergekeken en werd de ingreep veracht. Journalist Philip Mechanicus, die in het kampziekenhuis was opgenomen, hoorde echter ook de verschillende argumenten in de discussie: 'Onder de artsen is de mening verdeeld: zij zijn het er natuurlijk over eens dat sterilisatie onaangename psychische reacties zal kunnen hebben, maar ik heb de opvatting horen verkondigen: wie zich laat steriliseren, is nog niet verloren: ná de oorlog zal de medische wetenschap zeker het middel vinden om de sterilisatie ongedaan te maken. Over één ding is men het volkomen eens: de maatregel is het toppunt van barbaarsheid.' ${ }^{283}$

\section{'HET GEHELE NIZ ONTRUIMD'}

Terwijl in de zomer van 1943 de JI, CIZ en het PIZ onderdak boden aan de barbaarse praktijk van de sterilisaties, en Meyer er zijn eigen staf, bestaande uit zo'n 80 Joodse medewerkers van de Verbindungsstelle en hun familieleden lange tijd vrijwaarde van deportatie, liep het NIZ op zijn laatste benen. ${ }^{184} \mathrm{Op}$ I3 augustus viel het doek definitief. Op deze dag overkwam geneesheer-directeur Salomon Kroonenberg wat zijn collega Jacques Lobstein ruim een halfjaar eerder in Apeldoorn was overkomen: hij moest machteloos toezien hoe zijn levenswerk, zijn verantwoordelijkheid, zijn patiënten, hem door de vingers glipten. Ook het laatste veilige bastion hield geen stand. In steekwoorden beschreef Kroonenberg wat er gebeurde: 'Het gehele NIZ ontruimd onder leiding van Aus der Fünten. Onvervoerbaren naar gebouw van de Joodse Invalide. Alle personeel gedeporteerd (minder dan 20 in Westerbork aangekomen, rest gevlucht op een tiental mensen na voor de Joodse Invalide). '185

De laatste nog aanwezige personeelsleden en ook artsen vluchtten op deze onheilsdag. Herman Herschel stond op het moment van de omsingeling van het ziekenhuis met Johnny van Coevorden nog te opereren. Herschels vrouw Thea rende naar de operatiekamer en riep: 'Jongens, stop maar.' Herman en Thea verlieten spoorslags het ziekenhuis via Nieuwe Kerkstraat I23 en verdwenen in de onderduik. ${ }^{\text {I86 }}$ Ook Emanuel Godfried wist op I3 augustus onder te duiken. ${ }^{187}$ Anderen trachtten zich in het grote NIZ-gebouw onvindbaar te maken. 
Zelfs in de chaos van de ontruiming slaagde het medisch personeel er nog in om een paar patiënten te helpen te ontkomen. Zo verhaalde Presser van een vrouw die, uit haar door de artsen in scène gezet kraambed, plotseling opstond en het pand kon verlaten. ${ }^{188}$ Ook het jongetje Ed van Thijn, met zijn moeder onder een valse diagnose opgenomen op de afdeling besmettelijke ziekten, ontkwam de I3 de augustus doordat zijn vader met een ziekenauto de gracht op snelde en dwars door de mensenmassa zijn vrouw en zoontje uit het ziekenhuis haalde. Om de hoek werd Eddy uit de handen van zijn moeder gerukt en aan een wildvreemde vrouw meegegeven, richting onbekende onderduikbestemming. ${ }^{189}$

Toen om zes uur 's avonds Aus der Fünten en zijn mannen verdwenen waren, waren er nog een paar onvervoerbare zieken en enkele personeelsleden om hen te verzorgen, en wat mensen die gesperrt waren, overgebleven. Het bericht volgde dat diezelfde avond de overgeblevenen overgebracht moesten worden naar het lege gebouw van De Joodsche Invalide. Er werden bussen voorgereden en iedereen, ook illegaal overgeblevenen als Bettie Weijl, Sam Bos en Ruth Watermann, die zich de hele dag respectievelijk tussen een stapel matrassen en in de lift tussen twee verdiepingen hadden verschanst, stapte in. In de JI richtten zij met de anderen een provisorisch ziekenhuis in, ${ }^{190}$ onder leiding van Kroonenberg, die noteerde: 'In J blijkt dat I5o patiënten zijn overgebracht, Duitsers nijdig. Daar krijgt architect A.V. Hartogh de leiding, ik word "dirigerend geneesheer", dr. Goudsmit internist. In de volgende weken worden nog kleine groepen patiënten gedeporteerd, Joods Amsterdam loopt op zijn einde. ${ }^{\text {'TrI }}$

\section{'ZIJ ALLEN WETEN HET ZWAARD VAN DAMOCLES BOVEN HUN HOOFD'}

Bij de ontruiming van het NIZ op I3 augustus waren de nog aanwezige artsen gevlucht en ondergedoken of gearresteerd. De specialisten Salomon Kroonenberg, Jacob Goudsmit en Johnny van Coevorden en de arts-assistenten Sally Dunner en Jaap Hillesum hadden echter toestemming gekregen mee te gaan met de kleine groep niet-transportabele zieken die naar De Joodsche Invalide werden overgebracht. $\mathrm{Zij}$ trachtten er de medische zorg zo goed mogelijk voort te zetten.

De ongeveer I50 zieken werden verpleegd op de eerste verdieping, waar een geïmproviseerde interne afdeling was gemaakt, en op de derde, de chirurgische afdeling. Al op I6 augustus vond de eerste operatie in de Jı plaats, in een geïm- 
proviseerde operatiekamer. ${ }^{192}$ De personeelsleden hadden het gebouw zo goed mogelijk schoon en geschikt gemaakt, onder andere met spullen uit de opslag op de zesde verdieping, waar door de Duitsers in beslag genomen artseninboedels en instrumenten van gedeporteerde Joodse artsen werden bewaard. ${ }^{93}$ Op de tweede verdieping was op last van de Duitsers een dermatologie- en venereologieafdeling ontstaan, waar de Portugees-Joodse dermatoloog Emanuel Vas Nunes niet-Joodse meisjes met geslachtsziekten behandelde. ${ }^{194}$ Op 4 september werd de Joodsche Invalide officieel als ziekenhuis erkend. ${ }^{195}$ De aanwezige laatste NIZ'ers en JI'ers ontplooiden nog steeds allerlei activiteiten om zo veel mogelijk mensen nog aan een veilig onderduikadres te helpen met hulp van de illegale werkers. ${ }^{196}$ Bastiaan Ader, een predikant uit het Groningse Nieuw-Beerta, schoot de NIZ'ers en JI'ers te hulp en zorgde voor diverse veilige onderduikadressen. ${ }^{197}$

Berthold Stokvis bezocht De Joodsche Invalide in deze dagen en verwonderde zich over hetgeen hij zag, vooral ook aan activiteit en veerkracht van de aanwezigen die trachtten nog het beste van de situatie te maken: 'De Joodsche Invalide. Deze vormt een kapittel op zichzelf, want het is niet gemakkelijk de wondere wereld, waarin de bewoners na deze gebeurtenissen daar leven, te beschrijven. ${ }^{198}$ Co-assistent Max Hamburger herinnerde zich hoe hij met de beperkte middelen die hem ter beschikking stonden een nieuw laboratorium poogde op te zetten. Hij kreeg echter difterie en werd op een isoleerkamer gelegd. Wat hem nog bijzonder helder voor de geest stond, is hoe de beroemde artiesten Johnny en Jones kwamen optreden in De Joodsche Invalide. Deze artiesten zaten al in Westerbork, maar hadden nog permissie gekregen om naar Amsterdam te reizen voor de opname van een nieuwe grammofoonplaat. Deze plaat droeg de veelzeggende titel Westerbork serenade. Bij het optreden van de twee artiesten in de grote zaal van de JI werd via een microfoon verbinding gemaakt met Max Hamburgers kamer en kon hij toch nog meegenieten van liedjes als 'Kusjes voor alle zusjes' en 'io miljoen zoentjes, 't zijn nog maar groentjes'. ${ }^{99}$ Johnny en Jones, Nol van Wesel en Max Kannewasser zouden zelfs een liedje geschreven hebben, speciaal bedoeld voor het ziekenhuis. De eerste regels klonken vermoedelijk als volgt: 'Op de eerste, op de tweede, op de derde, op het lab, daar werken zoveel dokters en die zijn zo knap. Patiënten laten zingen, tja dat kunnen ze toch niet, luister dan dus maar eens naar ons mooie lied.'200

Ook Berthold Stokvis was zeer onder de indruk van de voorstelling die Johnny en Jones op touw zetten:

Wanneer men de prestaties van de medespelenden ziet, kan men inderdaad slechts de grootste bewondering hebben voor het initiatief en 
voor de geestkracht van deze menschen. Zij allen weten het zwaard van Damocles boven hun hoofd. Ieder oogenblik kan het met treffende zekerheid neerdalen, maar desondanks brengen zij onder leiding van twee beroepsartisten, Johnny en Jones, een non-stop revue ten toneele, waarvoor een middelmatig cabaretgezelschap zich niet zou behoeven te schamen. Wij hebben vanmiddag enige wonderlijke uren doorgebracht, waarbij ambivalente gevoelens van onbezorgde vrolijkheid en anderzijds de ervaring van de diepe tragiek, die achter deze schijnbare uitgelatenheid schuilgaat, elkander afwisselen. ${ }^{20 I}$

Hoezeer men ook zelfs nu nog trachtte het moreel hoog te houden en zo normaal mogelijk door te gaan, nu was het moment voor geneesheer-directeur Salomon Kroonenberg aangebroken haast te maken om ook voor zichzelf en zijn familie een onderduikadres te zoeken. Hiertoe sprak hij de niet-Joodse voormalig NIz-ingenieur Mattie Heijligers aan, die de familie inderdaad aan valse persoonsbewijzen kon helpen. Voordat het zover was, werd Heijligers gearresteerd. ${ }^{202}$ Ook De Joodsche Invalide zelf werd niet met rust gelaten: op I7 september werd ook hier weer een razzia gehouden. Nu werden de aanvankelijk niet-vervoerbaar verklaarde NIZ-patiënten alsnog op transport gesteld, iets wat David Cohen zich herinnerde als zo mogelijk nog erger dan de ontruiming van het NIZ zelf. ${ }^{203}$ Dankzij inspanningen van het personeel werd De Joodsche Invalide nog steeds niet helemaal leeggehaald. Nog geen twee weken later echter herhaalde het tafereel zich.

Op 29 september 1943 werd Kroonenbergs voorspelling bewaarheid: Amsterdam werd ‘judenrein'. Zelfs de voorzitters van de Joodsche Raad en de gesperrden met de beste stempels gingen nu op transport. Westerbork was het doel van de reis. Ook het gezin Kroonenberg werd gearresteerd. Salomon, zijn vrouw Sebilla Kroonenberg-Leman, hun beider moeders en jongste zoon Kees kwamen in Westerbork terecht. ${ }^{204}$ Salomon Kroonenberg had zich, als geneesheer-directeur, tot het bittere einde ten dienste gesteld van zijn ziekenhuis, zijn patiënten en zijn personeel. Daarbij zijn eigen veiligheid, volgens zijn naaste collega Louis Schaap, op een tweede plan zettend: 'Hij had elke bescherming afgewezen omdat hij zijn bedreigd ziekenhuis niet vroegtijdig had willen verlaten.' ${ }^{205}$

Internist Goudsmit en de assistenten Dunner en Hillesum bleven voorlopig nog wel in de JI. In het PIZ werd eveneens een razzia gehouden, waarbij geneesheer-directeur Poliakoff meegenomen werd. ${ }^{206}$ De medische middelen die artsen en geneesheren-directeur hun patiënten en personeelsleden ter bescherming konden bieden waren uitgeput. 
Met de meeste geneesheren-directeur liep het niet goed af. Poliakoff zou in 1945 in Duitsland de dood vinden, net als Jacques Lobstein. Beiden overleefden Bergen-Belsen, maar bezweken in de trein die in mei 1945 te Tröbitz door de Russen werd bevrijd. Ook Jacques Buzaglo overleefde de oorlog niet. Hij werd, na deportatie naar Auschwitz, in februari 1945 vermoord bij buitenkommando Bad Warmbrunn. Abraham Jacobsons onderduik zou niet goed aflopen: hij werd ontdekt, gearresteerd en vermoord in Auschwitz. Maurits Elzas overleefde de kampen en keerde terug naar Rotterdam. ${ }^{207}$ Ook Salomon Kroonenberg overleefde internering in Theresienstadt. Alleen Mau Pimentel werd niet gedeporteerd, hij kwam de bezettingstijd door op zijn onderduikadres. ${ }^{208}$ 



\section{BEVOORRECHT?}

TOCH NOG PROFIJT VAN DE ARTSENSTATUS,

JANUARI-SEPTEMBER 1943

Niet alleen de ziekenhuizen, met hun geneesheren-directeur als standvastige kapiteins, waren in de periode januari tot september 1943 in de golven van naziterreur ten onder gegaan, hetzelfde was gebeurd met de andere uitzonderingsgroepen, ofwel 'Sperren', die vanaf het najaar van 1942 in het leven waren geroepen. Ook deze tijdelijk redding biedende lijsten waren een voor een 'geplatzt', volgens het jargon waar men tegen wil en dank maar al te bekend mee werd. Wat een veilige uitzonderingspositie leek, kon van de ene op de andere dag blijken geen enkele bescherming meer te bieden. Joodse artsen konden anderen steeds minder bescherming bieden met de medische middelen die hun ter beschikking stonden. Tegelijkertijd liepen zijzelf ook telkens meer kans om gedeporteerd te worden. Bestonden er toch nog mogelijkheden om, met het artsenberoep, te zorgen dat het zwaard van Damocles voorlopig niet op hen zou neervallen? Kon het medisch beroep voor de artsen zelf nog een voorrecht betekenen?

\section{HET NET SLUIT ZICH}

In 1942 hadden de Joodse artsen voor het overgrote deel nog een relatief bevoorrechte positie bekleed en daardoor ook de mogelijkheid gehad anderen met hun medische middelen tijdelijk soelaas te bieden en zo te volharden in hun medische zorgplicht. Vanaf de deportaties van de zieken in 1943 was daar- 
van echter steeds meer de relativiteit gebleken. 'Ondanks de ellende om ons heen had ik door mijn beroep in een betrekkelijke rust geleefd en over mij een gevoel van veiligheid, zij het ook schijnveiligheid, gekregen.' ${ }^{\prime}$ Zo herinnerde Louis Schaap zich. Achteraf wist hij maar al te goed dat het inderdaad schijnveiligheid was geweest. Immers, in februari 1943 was hij met zijn gezin alsnog gearresteerd, en hij was bij lange na niet de enige arts die dit lot omstreeks diezelfde tijd trof. Het arts-zijn alleen volstond niet meer in de zoektocht naar veiligheid, ook niet voor de beroepsbeoefenaar zelf. Maar wat dán te doen? Op 26 februari schreef Jacques Reisel in zijn dagboek: 'Voor ons is elke dag er één en we twijfelen wel of we het einde van deze gruwelijke oorlog, dat we toch allen zo graag willen meemaken, zullen beleven. Maar we zullen toch met alle macht proberen het hoofd boven water te houden, al is het moeilijk te beoordelen welke methode hiertoe de geschiktste is.' ${ }^{2}$ Begin maart dacht hij dat het einde van de Duitse bezetting nog ongeveer een halfjaar op zich zou laten wachten. ${ }^{3}$ Maar gezien het tempo waarin de deportaties doorgang vonden was dat te lang om af te wachten. Een zoektocht naar de beste manier om het vege lijf te redden volgde.

De meeste Joodse artsen hadden in de loop van 1943 ook niet veel redenen meer om zich verplicht te voelen aan te blijven. Salomon Koster: 'Ik had nu bijna geen praktijk meer. Er waren nog slechts vier van mijn patiënten over, die niet waren weggehaald. Het werd akelig stil in ons groote huis, waar wij vroeger gewend waren den geheelen dag den bel en den telefoon te horen en de kamers met patiënten gevuld te zien.' ${ }^{4}$

Niet alleen nam het aantal patiënten af, ook de praktische benodigdheden voor het voeren van een praktijk werden de Joodse artsen steeds meer onthouden. De telefoon bij Koster zweeg bijvoorbeeld óók omdat hij afgesloten was. In augustus 1942 had de PTT daartoe al bevel gekregen. Op die afsluiting was direct geprotesteerd, door individuele Joodse artsen, vertegenwoordigers van Joodse ziekenhuizen en de Joodsche Raad. 5 De volksgezondheid stond op het spel, zo was het argument. Willem Polak, een pas afgestudeerde arts aan de Nieuwe Prinsengracht te Amsterdam, had in een brief aan de regionaal inspecteur van de Volksgezondheid gesteld dat hij zonder telefoon in geval van een besmettelijke ziekte niet spoedig genoeg aan zijn meldingsplicht zou kunnen voldoen. ${ }^{6}$ Inspelend op de bekende Duitse overgevoeligheid voor besmettelijke ziekten, had secretaris-generaal Verwey vervolgens Seyß-Inquart gemeld dat niet alleen de gezondheid van de Joden, maar die van de gehele bevolking op het spel stond.7 Dit had kennelijk een gevoelige snaar bij de Rijkscommissaris geraakt en sommige Joodse artsen hadden toch weer even een telefoon in gebruik mogen nemen. Louis Schaap bijvoorbeeld kon tot januari I943 over 
een telefoonlijn beschikken. Op 2I januari 1943 wezen de Duitse autoriteiten echter zijn verzoek tot behoud van de telefoonaansluiting af. ${ }^{8}$ Dit tijdelijke voorrecht was de artsen dus weer ontnomen.

Het artsenvoorrecht om 's avonds en 's nachts op straat te mogen was zonder telefoon tamelijk nutteloos geworden. Vanaf 3 juli 1942 had Het Joodsche Weekblad in elk nummer melding gemaakt van de Amsterdamse en Rotterdamse dienstdoende dokters van die week. ${ }^{9}$ Hoe deze dienstdoenden echter melding kregen van een spoedgeval, is een raadsel, met een patiëntengroep die niet de straat op mocht én niet kon opbellen. Salomon Spijer van de medische afdeling van de Joodsche Raad schetste de situatie aan Banning: 'Het komt er practisch op neer, dat Joden, ook voor ernstige ziektegevallen, van 's avonds $8 \mathrm{u}$ tot den volgenden ochtend 6u nauwelijks of niet in staat zijn medische hulp in te roepen.' ${ }^{\text {Io }}$ Voor de Joodse artsen, gewend als zij waren aan een vierentwintiguursbestaan als dokter, met bijbehorende bereikbaarheid en inzetbaarheid, betekende dit dat zij een belangrijk deel van hun praktijk en hun verantwoordelijkheid alleen al praktisch gezien los moesten laten.

In dit verband een lichtpuntje en zeker ook belangrijk voor de praktische uitvoering van hun taken was dat de Joodse artsen wel over een fietsvergunning konden blijven beschikken. ${ }^{\text {II }}$ Visites afleggen was zonder dat vervoersmiddel een onmogelijkheid geworden. De beschikking over een fiets zorgde ervoor dat zij in elk geval overdag nog medische zorg bij de mensen thuis konden bieden. Voor zover er nog patiënten over waren om naartoe te fietsen.

De medische afdeling van de Joodsche Raad trachtte de Joodse gezondheidszorg in stand te houden en publiceerde nog in maart 1943 een lange lijst met 27 verantwoordelijkheden en subcommissies, waarop onder andere de subcommissie inzake tbc-lijders in een sanatorium, het personeel bureau medische sportkeuring, de afdeling masseurs en masseuses, die van assistenten van masseurs en de kraam- en blindenzorg. ${ }^{12}$ Zeker enkele tientallen artsen hebben zich binnen deze organisatie dan ook in het voorjaar van 1943 nog een taak kunnen verwerven. ${ }^{13}$ Echter, dat zou enkel in Amsterdam mogelijk zijn. Vanaf april 1943 was het Joden verboden buiten Amsterdam te wonen. Bovendien was wel duidelijk dat het werk hoogstens een tijdelijk karakter zou kunnen hebben.

Bescherming van de Joodsche Raad hielp bovendien de artsen zelf tot op zekere hoogte, maar hun gezinnen waren niet meer gegarandeerd ook beschermd. Dit ondervond David Nordheim toen hij tijdens de grote razzia van 20 juni 1943 met zijn gezin trachtte naar het veilig geachte PIZ te komen, waar hij op dat moment werkte. Op weg ernaartoe werd het gezin staande gehouden. Alleen David zelf mocht op basis van zijn ziekenhuis-Sperr doorlopen, 
zijn gezin moest mee met de groep gearresteerde Joden. David weigerde zijn vrouw en kinderen in de steek te laten en ging dus mee naar de verzamelplaats op het Daniël Willinkplein en vervolgens naar Westerbork. ${ }^{\mathrm{I}}$

Ook wat financiën betreft waren de Joodse artsen in voorjaar 1943 nauwelijks nog bevoorrecht te noemen. Vanaf januari I943 waren zij geheel en al aangewezen op contante betalingen van patiënten. Van dat geld mochten zij niet meer dan $f 250$ in hun bezit hebben. Indien zij minder dan $f 250$ per maand uit contante gelden ontvingen, konden ze aankloppen bij de Financiële Commissie van de Joodsche Raad, die het bedrag zou aanvullen. Alles wat zij daarentegen meer dan die $f 250$ per maand verdienden of bezaten, dienden zij in te leveren bij de bank Lippmann, Rosenthal \& Co, kortweg LiRo. Bij deze bank hadden de artsen elk een beroepsrekening, waarop sinds mei 1942 bijvoorbeeld ook uitbetalingen van ziekenfondsen dienden te worden gestort. ${ }^{\text {Is }}$ Van deze eigen beroepsrekening mochten de artsen vervolgens enkel geld opnemen dat ter bestrijding van beroepskosten zou dienen. ${ }^{16}$ Salomon Koster gaf in zijn dagboek te kennen zich niet geheel aan alle LiRo-regels te houden en zo nog wel wat extra inkomsten te genereren:

Ik vertelde hem [de LiRo-beambte] dat mijn patiënten mij altijd contant betaalden. 'Dan moet u direct's middags voor vijf uur het ontvangen bedrag, onder aftrek van uw onkosten, hier komen storten' zei hij. Toen ik hem antwoordde dat ik ook's avonds patiënten ontving, zei hij: 'Dan moet $\mathrm{u}$ direct de volgende morgen om negen uur dat geld komen storten.' Ik nam maar de vrijheid om dit niet te doen, maar moest toch elken maand een nauwkeurige opgaaf verstrekken van mijn inkomsten en uitgaven voor de praktijk. Ondanks bedreigingen met helsche straffen, was die nauwkeurigheid natuurlijk niet al te groot. ${ }^{17}$

Hoewel Koster wat wist achter te houden - essentieel bijvoorbeeld om niet veel later zijn onderduik van te kunnen betalen -, werd hem tegelijkertijd geld via LiRo afhandig gemaakt. De roof van Joodse bezittingen sloeg de artsen namelijk allerminst over. Bovendien waren de patiënten net zozeer beroofd van hun geld en goed. Berthold Stokvis noteerde:

En thans is het beroep van Joodschen ziekenverzorger teruggekeerd tot de roeping, zooals die in het ochtendgebed van Maimonides is neergelegd: de ware Charitas; men verwacht thans van den Joodschen arts, dat hij gratis zal helpen; het geld is den Joden immers ontnomen. Het spreekt vanzelf, dat men onder deze omstandigheden moet helpen, waar men kan, geluk- 
kig zijn enkelen nog in staat van achtergehouden gelden hun doktersrekening te voldoen. Het feit doet zich nu voor, dat in deze tijden, nu geen Jood meer dan $f 250$ in zijn bezit mag hebben, door den Joodschen arts geen rekeningen meer worden gestuurd; wie iets te betalen heeft en betalen kan, doet dit spontaan en uiteraard contant 'Via de firma Schwarz' zoals dit heet. ${ }^{18}$

Terug naar de ware caritas dus. Zo verwoordde Stokvis de afbraak van zijn volwaardige artsenbestaan nog vrij positief. Heel basaal probeerde hij nog wat nuttig medisch werk te verrichten, ongeacht of de patiënt daar nog financiële middelen voor had of niet. Gezien de formulering in zijn dagboek putte hij er nog wel eigenwaarde uit. Juist op deze manier werd hij immers gedwongen terug te keren naar de in zijn ogen ware roeping van het artsenberoep. En nog wel zeer specifiek de roeping voor de Joodse arts, wiens leidmotief moest zijn zoals het in het ochtendgebed van Maimonides was vastgelegd: liefdadigheid. Stokvis kon het daarom nog opbrengen zich, ondanks alles, volwaardig arts te voelen. De bezetter had hem weliswaar van maatschappelijk gewaardeerd medicus tot ongewenst, opgejaagd wezen, Untermensch gereduceerd, maar dat betekende nog niet dat hij zich ook waardeloos voelde. Dit bleek ook naar aanleiding van een ervaring in de Zentralstelle, waar hij de sfeer van angst en intimidatie had ondergaan en vervolgens weer opgelucht buiten stond: 'Hier ben ik weer dokter, oftewel ziekenverzorger; ik stap weer op mijn fiets met mijn artsembleem. Binnen ben ik een nummer, of erger: een Jood.' ${ }^{19}$ Vernederd voelde hij zich niet, want inwendig kon hij een gevoel van morele superioriteit aanboren. 'Kunnen deze kerels ons niet vernederen? $Z_{i j}$ vernederen alleen zichzelf. ${ }^{20}$ Of andere Joodse artsen hier hetzelfde over dachten, en evenveel veerkracht en eigenwaarde wisten te behouden, valt te betwijfelen. Koster beschreef in elk geval dat hij zich steeds verder geïsoleerd voelde en als een melaatse behandeld. ${ }^{2 \mathrm{I}}$ Het maatschappelijk aanzien dat Koster gewend was te hebben, viel voor zijn gevoel totaal weg. Daarmee kreeg ook zijn moreel vanzelfsprekend een knauw. Ook Jacques Reisel getuigde in zijn dagboek van een staat van wanhoop, nadat zijn zeventienjarige zusje met dysenterie op transport gesteld was: 'Ad matai. Wat is de hemel rustig en wat zijn de mensen wreed. Wat ben ik kapot van binnen van woede en van leed.' ${ }^{22}$ Zelfs Stokvis werd het op den duur te machtig. Het telkens maar weer nieuwe verliezen incasseren maakte ook hem radeloos en bijna nihilistisch. Ook hij vroeg zich af hoelang nog, maar dan in het Latijn: 
Beheersching, beheersching, be-heer-sching. Ik heb er genoeg van. Ik wil mij niet meer beheerschen. Ik wil niet meer. Quo usque tandem? Die woorden dacht ik vroeger, toen ik iederen morgen over een hooge spoorbrug moest loopen, als ik naar mijn werk ging... Mijn werk was vroeger het belangrijkste van mijn bestaan. Tegenwoordig: onbetekenend. Of neen, toch is het eigenlijk weer het werk, dat mij in dezen tijd staande houdt. Als het mij te machtig wordt, verdiep ik mij in het werk 'le travail pour le travail'. Het werk, waartoe dient het nu? Wat doet alles ertoe?23

Het werk, het artsenberoep, in beter tijden leidend in alles wat Stokvis deed of liet, verloor zijn belang, zijn allesoverheersende rol in Stokvis' leven. In opperste vertwijfeling zocht hij een andere steunpilaar. Hij was een vrome Jood en vond de gezochte steun in de Talmoed: 'In den Talmoed staat "alles ten goede". Ik begrijp het weliswaar niet meer, maar het zal wel zo zijn. Doorgaan, volhouden, innerlijk beheerscht zijn, zo zeg ik het immers mijn patiënten: Hakodousch Boroeghoe, de Heilige, Geloofd zij zijn naam, God zal verlossen.'24

Berthold Stokvis zal hier nog kracht uit hebben kunnen putten, om voort te gaan en vol te houden tot de verlossing zou komen. Bovendien kon hij voor zichzelf met recht nog hoop putten uit zijn Calmeyer-status. Berthold Stokvis was namelijk in december 1942 'gecalmeyerd'. In plaats van de vier Joodse grootouders die hij had opgegeven bij de registratie in januari 194I, had hij er nu op papier slechts twee. Op 8 december 1942 was dit officieel geregistreerd. ${ }^{25}$ Zijn broer Benno, de advocaat, had aannemelijk kunnen maken dat hun beider van origine Russische moeder Margolia Stokvis-Ettlinger een kind van Russische, niet-Joodse ouders was. $\mathrm{Zij}$ zouden vroegtijdig overleden zijn, waarna Margolia door Joodse adoptieouders was grootgebracht. ${ }^{26}$ Met een niet-Joodse moeder werden de beide broers Stokvis vervolgens tot half-Joden verklaard en daarmee vrijgesteld van de verplichting tot tewerkstelling in het Oosten.

Voorstelbaar is dat anderen, die dergelijke hoopgevende factoren ontbeerden, geen enkel lichtpunt in de duisternis meer zagen. Onder dergelijke omstandigheden en in dergelijke geestelijke nood kon de medische zorgplicht dan ook voor velen niet overeind blijven. Vasthouden aan de ethische standaard altijd voor de patiënten klaar te staan kón voor velen eenvoudigweg niet meer. 'De moraal zonk terug tot de belangstelling voor de allernaasten en verder niets dan: ik dood... jij dood. ${ }^{27}$ Zo herinnerde Jaap Spanjaard zich zijn gemoedstoestand in deze periode. ${ }^{28}$ Op het moment van een dergelijke existentiele onzekerheid, waren artsen ook gewoon mensen met 'een normaal en sterk egoïsme [dat] in deze tijd niet alleen verklaarbaar maar ook noodzakelijk is, in deze letterlijke struggle for life', aldus Jacques Reisel. ${ }^{29}$ Het artsenberoep bleek in deze struggle toch nog wel een rol te kunnen spelen. 
In de afweging die de artsen moesten maken, wogen zij uiteraard de kennis die zij hadden over het lot van de gedeporteerden, mee. Zij hadden waarschijnlijk een bovengemiddeld realistisch beeld van wat er in doorgangskamp Westerbork - en ook in Kamp Vught - gebeurde, omdat sommigen van hen de mogelijkheid hadden in die kampen een kijkje te nemen zonder er zelf als gevangene te verblijven.

Sally de Jong was een van de artsen die vrijwillig naar Westerbork waren afgereisd om zich er als arts nuttig te maken. Hij ging nog in voorjaar 1943 over tot een vluchtpoging, nadat hij in Westerbork indringend had kunnen waarnemen wat er met de Joden gebeurde. Hij deed deze poging met zijn echtgenote, nadat zij eerst hun twee zoontjes in veiligheid hadden gebracht op onderduikadressen. Onderweg zag De Jong volgens de overlevering kans een beschrijving van de toestand van de Joden in bezet Nederland in kleine lettertjes op vloeipapier te schrijven en dit manuscript in een uitgeholde scheerkwast naar Engeland te laten smokkelen. Eenmaal bij de regering in ballingschap in Londen aangekomen, kwam het onder ogen van de daar aanwezige tweelingbroer van Sally, de journalist Loe de Jong. ${ }^{30}$ De vluchtpoging zelf mislukte echter jammerlijk: het echtpaar De Jong was de Zwitserse grens al gepasseerd, toen zij werden aangehouden door de Zwitserse grenspolitie. Een nieuwe regel was van kracht gegaan om de instroom van vluchtelingen in te perken: alleen mensen met kinderen werden toegelaten. De Jong en zijn vrouw toonden de fotootjes van hun zoons, die ze bij zich hadden, maar de agenten waren onvermurwbaar: het echtpaar moest terug naar Frankrijk. Daar werden zij gearresteerd en op transport gesteld. Met fatale afloop tot gevolg. ${ }^{3 \mathrm{I}}$

Niet alleen de Westerbork-vrijwilligers hadden de mogelijkheid tot op en neer reizen tussen Westerbork en hun woonplaats, ook andere Joodsche Raadartsen als Emanuel (Mani) Leisen en Bernard de Vries Robles reisden regelmatig met de treinen mee van Amsterdam naar Westerbork en terug. ${ }^{32}$ Ook van de Haagse arts Israël Groen is dit bekend. ${ }^{33}$ Inmiddels hadden ook diverse medisch specialisten Westerbork bezocht om er spreekuur te houden en specifieke patiënten te behandelen. Een specialist die in voorjaar 1943 zowel naar Vught als naar Westerbork afreisde, was de hoogleraar kindergeneeskunde Simon van Creveld, die zijn best deed de medische toestand voor de kinderen in de kampen te verbeteren. ${ }^{34} \mathrm{Na}$ terugkomst in hun woonplaats konden deze medici vervolgens verslag doen van wat zij hadden gezien in het Durchgangslager Westerbork ofwel Judenauffangslager Herzogenbusch. Louis Schaap herinnerde zich dat hij via deze artsen medische contacten in Westerbork kon 
aanspreken, bijvoorbeeld toen zijn schoonmoeder in het kamp terechtkwam. ${ }^{35}$ Er was sprake van collegiaal contact.

Ook Salomon Koster sprak, getuige zijn dagboek, met artsen die in Westerbork waren geweest. Eddy de Wind bijvoorbeeld, als vrijwilliger naar Westerbork vertrokken, trof hij op de bijeenkomsten van het Amsterdamsch Joodsch Psychiatrisch Gezelschap. Thuis deed Koster vervolgens aan zijn vrouw verslag:

Toe man, wees niet zo somber, kom gezellig bij de schemerlamp naast mij zitten en vertel eens wat, want ik spreek ook bijna niemand meer tegenwoordig. Heb je vandaag wat bijzonders gehoord, op jullie maandelijkse bijeenkomst van Joodsche zenuwartsen? Bijzonders? Bijzonders? Dokter Orkaan was juist over uit Westerbork. Je weet, hij is destijds vrijwillig gegaan, waarom weet ik niet. Men zegt, om nog iets voor zijn moeder te kunnen doen, die daarnaar toe gesleept is. ${ }^{36}$

Koster vertelde zijn vrouw over de toestand in Westerbork, zoals De Wind het op zijn beurt aan hem verteld had. Erbarmelijk waren de toestanden ook volgens de informanten van Reisel, die het in zijn dagboek had over artsen die in Westerbork depressief werden omdat zij de wanhoop in het kamp van nabij aanschouwden. ${ }^{37}$

In de kringen van de Joodse artsen was al met al via diverse informatiestromen al het nodige bekend over wat zich in Westerbork afspeelde. Bovendien hadden de artsen zowel contacten met de Joodsche Raad als met 'de gewone man'. Patiënten uit alle lagen van de bevolking consulteerden hun dokters voor een attest of hun specialisten voor een opname in een van de Joodse ziekenhuizen. Ook via die bron konden artsen, meer dan andere beroepsbeoefenaren, informatie verkrijgen over wat zich afspeelde rond de deportaties. $\mathrm{Zij}$ zullen daarom relatief goed geïnformeerd zijn geweest. Wat dat betreft kan men deze artsen nog in zekere zin bevoorrecht noemen: zij waren waarschijnlijk gemiddeld beter in staat dan veel anderen om afwegingen te maken over welke middelen in te zetten voor hun eigen veiligheid.

Sommige artsen echter kozen niet zozeer voor hun eigen veiligheid als wel voor het voortzetten van hun zorgplicht als arts. Leo Lezer, huisarts in Zwollerkerspel, moest zich op I8 mei 1943 melden voor transport naar Vught, maar had van velen het advies gekregen niet te gaan en onder te duiken. Lezer weigerde echter hulp; zijn woorden waren volgens de overlevering: 'Het zal zo'n vaart niet lopen en misschien kan ik me daarginds nog nuttig maken. ${ }^{38}$ Jeanne Bles, kinderarts uit Rotterdam, ging volgens notities op haar Joodsche Raad- 
kaart vrijwillig mee met een transport vanuit de Hollandsche Schouwburg, vermoedelijk om de kinderen onderweg bij te staan. ${ }^{39}$ Van hen en anderen die eenzelfde keuze maakten en met de transporten meegingen, om daar in den vreemde als arts nog iets te kunnen betekenen, kennen we de verhalen niet, omdat zij niet terugkwamen om ze te vertellen.

\section{'DE KIPPEN' LIJKEN VEILIGHEID TE BIEDEN}

Jacques Reisel heeft middels zijn dagboek wel een bron nagelaten waarmee zijn gedachten en afwegingen van voorjaar van 1943 bewaard zijn gebleven. Met zijn vrouw Emmy, dochter van de Utrechtse gynaecoloog Maurits Muller, liet Reisel alle opties die hun enigszins realistisch leken, de revue passeren. Vluchten, onderduiken, toch maar mee naar Westerbork of Vught, of opteren voor het Joods Tehuis in Barneveld ('de kippen'). Een makkelijke keuze was het allerminst.

Maar alles heeft zo zijn risico's, dus nemen we het voorlopig prettigste. Deze week nog een aanbieding voor Zwitserland gehad a frs 7000 . Verleidelijk om in een paar dagen uit de sof te zijn, maar ook dit is nog te riskant. Een mens wil niet graag zelf de strop om de hals doen. In wezen staan we nu weer voor dezelfde beslissing als in juli/september. De dekking van het ziekenhuis zal wel een kwestie van uitermate korte tijd zijn. Misschien houden de kippen ons nog boven water. Voorlopig eten we goed. In Vught schijnt het niet-concentratiekampdeel ongunstiger te zijn dan men voorstelde. Er zijn trouwens mensen naar Duitsland gestuurd, dus ook dat verschil met Westerbork is afwezig. Slecht eten, plagerij, afpakken van de gestuurde levensmiddelen, kleren en zeep, luizen, alles hetzelfde. De oppakkerij neemt's avonds weer flinke vormen aan. Als het zo doorgaat is inderdaad in een halffaar de laatste officiële Jood uit Amsterdam weg. En de ondergedokenen zullen het ook zo prettig niet krijgen nu zoveel Ariërs weg moeten naar Duitsland. Een hopeloze situatie. ${ }^{40}$

De enige hoop die Reisel nog had, putte hij uit de vorderingen van de Sovjettroepen, die na de gewonnen slag om Stalingrad inderdaad aanleiding gaven tot hoop op een Duitse nederlaag. Reisel sloot dan ook bijna ieder dagboekfragment af met een actueel verslag van het Oostfront: 'In Rusland gaat het bij Moskou goed, in de Charkow-sector minder, dus is het wachten weer op de invasie, elke dag weer, zoals de Joden altijd gewacht hebben op de Messias die, ofschoon hij draalt, komen zal.'4r 
Jacques en Emmy Reisel-Muller zouden uiteindelijk proberen de komst van de geallieerde Messias in Barneveld af te wachten. Een ogenschijnlijk zeer betrouwbare en bovendien legale methode om een dreigend deportatielot te ontlopen was namelijk plaatsing op de 'Barneveldlijst'.

De Barneveld-Sperre, voorzien van stempels met nummers beginnend bij 40 ooo, was in het najaar van 1942 ontstaan doordat secretaris-generaal K.J. Frederiks aanvankelijk vijf hem bekende, vooraanstaande Joden voor deportatie wilde behoeden. Nadat Generalkommissar Schmidt hem had toegezegd deze vijf in Nederland te laten, kwam ook secretaris-generaal J. van Dam met een lijstje. Beide lijstjes met vooraanstaanden groeiden, zodra men er in bredere kring van hoorde, in hoog tempo tot lijsten van enkele honderden namen. ${ }^{42}$ Van I8 december 1942 tot 28 augustus 1943 werden in totaal 654 mensen vanwege hun plaatsing op deze lijsten ondergebracht in twee grote huizen, Kasteel De Schaffelaar en Huis De Biezen, in Barneveld. ${ }^{43}$ Artsen maakten als vooraanstaande burgers een gerede kans op deze lijst geplaatst te worden. In totaal 44 Joodse artsen, proportioneel een groot deel van de 654 'Barnevelders', werden door de Barneveldlijst beschermd. Bovendien werden ook ten minste vier weduwen van artsen, met eventuele kinderen, op grond van de verdiensten van hun overleden echtgenoten, op de lijst geplaatst en in Barneveld geïnterneerd. ${ }^{44}$ Ter vergelijking: op de 140 ooo Joden in Nederland was het aantal van 654 te verwaarlozen, ${ }^{45}$ terwijl 44 van de 534 ruim 8 procent is.

De leefomstandigheden in de twee tehuizen waren relatief goed. Voor de Rotterdamse familie Frenkel, bestaande uit vader Lion, die huisarts was, moeder Carolina Frenkel-Wiener, tandarts, en acht van hun negen kinderen, was het alsof zij vanuit de hel in de hemel belandden toen zij in juni 1943 in Barneveld aankwamen. De familie was aanvankelijk naar Vught gedeporteerd, en van daaruit naar Westerbork, waar met name moeder Carolina alles op alles had gezet om op de eigenlijk al gesloten Barneveldlijst te komen. ${ }^{46}$ De Frenkels konden opgelucht hun intrek nemen in kasteel De Schaffelaar, waar zij naast meer veiligheid ook meer vrijheid en beschaving ervoeren dan in Vught en Westerbork.

De gemeenschap in Barneveld was weliswaar noodgedwongen tezamen gebracht en men leefde opeengepakt in gedeelde slaapkamers, wat spanningen opleverde, maar men kreeg wel de kans een waardige manier van leven te behouden, in tegenstelling tot in de kampen. ${ }^{47}$ Daarbij verkeerden de bewoners in interessant gezelschap. De fine fleur van Joodse hoogwaardigheidsbekleders, intellectuelen, musici en industriëlen was hier verzameld. Het intellectuele en culturele klimaat vormde voor velen een aangename atmosfeer. In de Barneveldse cocon, ver weg van het tumultueuze Amsterdam en de dreiging 
van deportatie, kon men relatief ongestoord verder leven. Hier hoopte men de bevrijding te kunnen afwachten. De Middelburgse arts Rachel Weijl-Snuijf schreef in een brief aan vrienden: 'Overigens moet u u onze stemming niet al te somber voorstellen. [...] We klagen dan ook niet om ons persoonlijk, vele anderen hebben meer te dragen.' ${ }^{48}$ Barneveld gold met recht als een voorrecht dat voor relatief veel artsen was weggelegd.

\section{DE AANTREKKINGSKRACHT VAN BARNEVELD}

Dat de Barneveldlijst door de combinatie van veiligheid en relatieve vrijheid een grote aantrekkingskracht had, is goed voorstelbaar. Toch hadden sommigen ook hun bedenkingen bij dit instituut. Er zijn echter aanzienlijk méér voorbeelden van artsen die probeerden zich op de lijsten van Frederiks en Van Dam te laten plaatsen, soms nadat zij over hun aanvankelijke huivering heen waren gestapt. Met de 44 gehonoreerde aanvragen erbij geteld hebben in totaal in elk geval I25 Joodse artsen een plek op de lijst geprobeerd te bemachtigen. $\mathrm{Zij}$ schreven hiertoe hun contacten aan, nu veelal in niet-Joodse kring. Eerste aanspreekpunt was Cees Banning, de geneeskundig hoofdinspecteur, die op zijn beurt zijn invloed bij secretarissen-generaal Verwey, Frederiks en diens ambtenaar S. Kloosterman aanwendde. Een dikke map met brieven over dit onderwerp, afkomstig van Joodse artsen, hun niet-Joodse collegae en Banning zelf, is bewaard gebleven.

Bijvoorbeeld Salomon Kroonenberg, geneesheer-directeur van het NIZ, wendde zich eind november 1942 al tot Banning. Ook hij had op deze manier al wel beveiliging van zichzelf en zijn gezin nagestreefd. Niet om naar Barneveld af te reizen, maar om zijn positie in Amsterdam te bestendigen:

Geachte collega, Onlangs werd mij medegedeeld, dat er een 'lijst Frederiks' bestaat, die bedoelt bepaalde Joden in het land te houden, omdat ze op eenigerlei wijze voor de volkshuishouding van belang geacht worden. Doel van het schrijven is u te vragen of u bereid zoudt zijn uw invloed aan te wenden om mij op deze lijst geplaatst te krijgen. Via een advocaat wordt hetzelfde langs anderen weg voor mij aangevraagd. Als geneesheerdirecteur van het Nederlandsch Israëlietisch Ziekenhuis te Amsterdam (normaal 300 bedden, thans ongeveer 450 patiënten) meen ik een functie te vervullen, die belangrijk genoeg is. ${ }^{49}$ 
Banning antwoordde dat hij nog geen verdere precieze inlichtingen kon geven, maar dat hij zeker zijn best zou doen, net zoals hij had gedaan toen Kroonenberg in mei 1942 krijgsgevangen was gemaakt. ${ }^{50}$

Vervolgens nam Banning ook het initiatief om per inspectieregio te inventariseren welke van de daar werkzame artsen in aanmerking zouden komen voor de Barneveldlijst. Op 2 december 1942 gaf hij opdracht aan zijn regionale inspecteurs om hem lijsten met vooraanstaande Joodse artsen te doen toekomen. 'Ik kan dan met reden voor hen pleiten bij den heer Frederiks, secretaris-generaal van het departement van Binnenlandse Zaken, opdat zij niet gedeporteerd worden.' ${ }^{\prime 1}$ Dit was het startschot voor de regionale inspecteurs, andere bezorgde niet-Joodse collegae en de Joodse artsen zelf om Banning te benaderen met aanvragen voor de Barneveldlijst. Ook advocaten werden daartoe ingeschakeld. In december 1942 en januari I943 dienden zij al verzoekschriften bij Banning in, maar veruit de meeste brieven in zijn archief dateren van februari-maart 1943, toen het water de Joodse artsen echt aan de lippen stond. Ook niet-Joodse collegae hadden daar op dat moment oog voor, getuige hun pogingen Joodse vakgenoten op de lijst te laten zetten. Banning werd in het voorjaar van 1943 overspoeld met aanvragen en steunbetuigingen. F.A. Schalij, voormalig voorzitter van de NMG, vroeg voor zijn gevoel voor zoveel Joodse collegae steun aan bij Banning dat hij er 'het schaamrood op de kaken van kreeg' toen hij opnieuw met een schriftelijk verzoek aankwam, ditmaal voor Jeanne Bles, kinderarts uit Rotterdam..$^{52}$ Banning antwoordde: 'Ik zou het schaamrood op uw kaken maar achterwege laten! Ik kan u mededelen, dat Jeanne Bles reeds is voorgedragen.' 53

Zelfs uit minder voor de hand liggende hoek ontving Banning verzoeken tot bescherming van Joodse medici, zoals van de kinderarts J.C. Schippers, die tegen de ongeschreven regel in de leerstoel in de kindergeneeskunde van de ontslagen Joodse hoogleraar Simon van Creveld had overgenomen, en daarbij ook aanvaard had dat NsB'er Gejus van der Meulen zijn assistent werd. ${ }^{54} \mathrm{Hij}$ sprong in de bres voor de Amsterdamse gemeentearts E.A. Rodrigues Pereira, 'een man, die zijn werk steeds met grote toewijding heeft gedaan'.55

Niet zelden werden de verzoeken vergezeld van uitgebreide biografische gegevens, lijsten van publicaties en opsommingen van maatschappelijke en wetenschappelijke verdiensten. Een indruk van de uiteenlopende redeneringen die men aanvoerde om een bepaalde arts te beschermen ontstaat uit de volgende brieffragmenten:

A.S. Jacobson, geb. I8 october I879, arts sinds I906, van I908-I934 geneesheer aan de Gemeentelijke Lupus Polikliniek (chef Prof. Mendes 
da Costa), ook speciaal voor vervaardigen van prothesen bij aangezichtsdefecten. Herhaaldelijk gaf hij uit eigen beurs de gietvorm en de bijbehorende was voor het vervaardigen van kunstneuzen. ${ }^{56}$

En bijvoorbeeld:

Dr. Hijmans was en is een arts, bij alle artsen in Den Haag bekend en gezien en dit is een gevolg van de wijze waarop hij zijn inzicht inzake Tuberculose-bestrijding bij artsen en patiënten heeft weten ingang te doen vinden. Een erkenning van zijn verdiensten voor de Haagsche bevolking is zeker gerechtvaardigd. 57

Het laatste verzoek bleek niet vergeefs: Marinus Mortier Hijmans' naam verscheen op de Barneveldlijst. Die van Abraham Simeon Jacobson niet, ondanks het feit dat hij voorzitter van het bestuur van de ciz was. Van de geneesherendirecteur van de Joodse ziekenhuizen werd alleen de Rotterdamse Maurits Elzas op de Barneveldlijst geplaatst. Hij was op 26 februari 1943 met de ontruiming van zijn Rotterdams Israëlietisch Ziekenhuis met de patiënten en het personeel meegenomen naar Westerbork, maar zag hier kans zijn contacten aan te boren om naar Barneveld te ontkomen. ${ }^{8}$ Op 9 april 1943 kwam hij er aan, waar zijn oude kennis Gabriël Italie opmerkte: 'Elzas uit Westerbork gearriveerd. Hij is erg oud geworden.' 59 Wat betreft de andere geneesherendirecteur waren de reacties louter afwijzend. Zelfs Salomon Kroonenberg, die er zo vroeg bij was geweest, kreeg geen plek op de lijst. Mogelijk verwachtte men ook dat deze hooggeplaatsten gezien hun functie al een goede protectie genoten. Ook Salomon Spijer, hoofd van de medische afdeling van de Joodsche Raad, werd niet op de lijst geplaatst, ondanks het feit dat Banning hem persoonlijk kende en GGD-directeur Tuntler voor hem pleitte met de woorden: 'onze vriend Spijer, die tot het ontslag der Joden mijn adjunct-directeur was en mij in moeilijke dagen trouw terzijde stond, zou zoo mogelijk gaarne in Barneveld een schuilplaats vinden. ${ }^{\cdot 60}$ Volgens Bannings reactie had hij weliswaar veel moeite voor Spijer gedaan, maar was het in dit stadium, april 1943, al erg moeilijk geworden nog een plaats op de lijst te bemachtigen. ${ }^{61}$

Wrang was het wel dat vooral in voorjaar 1943, toen de behoefte aan een vluchtmogelijkheid juist onder de artsen zo groeide, de kansen op opvang in Barneveld drastisch afnamen. Zo valt ook op te maken uit het verzoek van Israël Bloch, huisarts aan de Amsterdamse Kloveniersburgwal. Professor A. de Kleijn had in december 1942 al een aanvraag voor hem ingediend: 'Het is een dokter wiens lieve dochtertjes van I5 en I7 jaar al naar Polen zijn vervoerd, ter- 
wijl zijn vrouw en hem niet werd toegestaan met dezen mede te gaan.' ${ }^{62}$ Bloch was dus al zwaar getroffen, maar had vanwege zijn beroep zelf een Sperr die tot voorjaar 1943 redelijk veilig leek. Enkele maanden gebeurde er niets met de aanvraag voor Barneveld, totdat Bloch in mei 1943 het vertrouwen in zijn Sperr verloor en zich ten einde raad tot Banning wendde. Bloch en Banning kenden elkaar door hun activiteiten voor de vereniging Asthbro ter bestrijding van astma en bronchitis. Kennelijk had Banning Bloch bij hun laatste ontmoeting, die had plaatsgevonden voor de deportaties een aanvang namen, al beloofd hem te helpen. Zowel daarop als op het grote belang van de vereniging Asthbro kwam Bloch in zijn brief uitgebreid terug teneinde zijn smeekbede kracht bij te zetten.

Ik heb u altijd beschouwd als het proto-type van den stoeren Hollander, als een man op wiens woord men kan bouwen: ik heb op dat woord steeds gebouwd en zal er op blijven bouwen. [...] Nu meen ik (ik ben gedwongen alle bescheidenheid opzij te zetten, troost mij slechts met de gedachte dat iedere pluim die ik mijzelf geef, evenzeer u toekomt) dat de reden, waarom ik voorgedragen ben een zo uitzonderlijke is, dat in Barneveld slechts zeer weinigen zijn, die daar met hetzelfde recht zitten. [...]

Tot deze ophemeling van zijn eigen carrière werd Bloch gedreven door de toestand van wanhoop waarin hij verkeerde en door de angst voor zijn nog overgebleven dierbaren:

Ik wil er de nadruk op leggen, dat ik voor mijzelf niets zou vragen: ik heb de klap beetgehad, mijn geestkracht is ondanks alles niet gebroken, maar mij persoonlijk kan niets meer schelen, mij kan als het ware geen leed meer treffen; wanneer ik iets vraag, dan doe ik dat voor mijn vrouw, die lichamelijk niet sterk is en die geestelijk volkomen gebroken is, en voor mijn kleine jongen. Wanneer een modus gevonden kon worden, waardoor zij beiden hier konden blijven, dan ging ik met een gerust hart naar Polen. [...] Nu is Barneveld wel gesloten, maar de Duitse instanties zijn nu eenmaal almachtig; wanneer $\mathrm{u}$ in overleg met Mr.Dr. Frederiks een Duitse instantie (misschien een medische? $U$ weet zelf het beste wie en op welk moment) weer te overtuigen van de uitzonderlijkheid van mijn geval, dan word ik zeker geplaatst. ${ }^{63}$

Op het nippertje slaagde deze poging: Israël Bloch werd met zijn echtgenote en zoon op I6 augustus I943, terwijl zij al in Westerbork gevangenzaten, op de Barneveldlijst geplaatst. ${ }^{64}$ 
Ook Salomon Diamant zat al in Westerbork toen het in maart 1943 toch nog mogelijk bleek hem naar De Schaffelaar te halen. Hij had in 1907 als huisarts in Hoek van Holland een heldenrol gespeeld toen het stoomschip Berlin schipbreuk leed. Een groot deel van de opvarenden, onder wie leden van een Duits operagezelschap, overleefde de ramp door doortastend optreden van Diamant. Hij werd hiervoor onderscheiden door de Duitse keizer. Deze Duitse onderscheiding was de doorslaggevende reden om hem naar Barneveld te laten gaan. Een echte schipbreuk werd dus Diamants redding tijdens de figuurlijke schipbreuk van de deportaties. ${ }^{65}$

Voor een andere arts die in wanhoop bij Banning aanklopte, en met wie de inspecteur zelfs nauw vriendschappelijk contact onderhield, mislukte de reddingsactie. Deze Jacob (Jaap) Goudsmit, internist en hematoloog in het NIZ, schreef in mei I943: 'Amice Banning, zoals je begrijpen zult, is de toestand voor ons practisch hopeloos. Is er jouwerzijds nog iets te doen? ${ }^{66}$ Nog dezelfde dag telegrafeerde Banning terug. Hij adviseerde een lijst met personalia aan Kloosterman te zenden, met een nadruk op Goudsmits wetenschappelijke staat van dienst. Goudsmit reageerde weer per brief en op 4 juni volgde een persoonlijk briefje van Banning, waarin hij Goudsmit een hart onder de riem probeerde te steken: 'Margot en ik hebben, dat moet je van ons beiden aannemen, heel veel aan jullie gedacht in de laatste tijden! Ik zal doen wat ik kan, maar onze polsstok is verdomd kort! Toch in vredesnaam de moed erin houden. ${ }^{67}$

Ondertussen waagde Banning diverse pogingen bij Frederiks. Voor Goudsmit kwamen zijn inspanningen echter te laat. Barneveld was niet meer bereikbaar voor Jaap en zijn vrouw Jos. Ook een latere poging om een zogenaamde I20 ooo-stempel voor hen te krijgen, waar Banning eveneens zijn best voor deed, mislukte. Het ging om een relatief veilige Sperr, waarbij een stempel hoorde dat een nummer beginnend bij 120 ooo had, en waarvoor per persoon $f 50$ ooo betaald moest worden. Goudsmit zelf had dat idee, als een van vele reddingspogingen, opgeworpen. ${ }^{68} \mathrm{Zijn}$ correspondentie geeft weer welk een uitputtende zoektocht naar redding men kon afleggen. Over de optie Barneveld hadden de Goudsmits blijkens Jaaps brief aan Banning om twee redenen lang geaarzeld: 'Ik heb indertijd geen moeite voor Barneveld gedaan, om verschillende redenen: I. Jos wil het niet, omdat ze dit refugium niet vertrouwt. 2. Ik heb hier nog nuttig werk, als waarnemend directeur van het NIZ en internist. [...] Het komt erop neer dat we eigenlijk niets voelden en voelen voor Barneveld.' ${ }^{6} 9$

$\mathrm{Nu}$, in juni I943, was het beetje veiligheid dat Barneveld in hun ogen leek te bieden, belangrijker geworden dan het wantrouwen van Jos en het plichtsbesef van Jaap. 
Jaap en Jos Goudsmit waren niet de enigen die een afkeer van Barneveld hadden. Enkele artsen deelden die afkeer, om redenen van scepsis of om het principiële standpunt dat ook dit een Duitse instelling was. Een instelling die per definitie gemeden moest worden, net als de Joodsche Raad. Volgens de overlevering gold dit laatste bijvoorbeeld voor de vooruitstrevende Amsterdamse huisarts-seksuoloog Bernard Premsela. ${ }^{70} \mathrm{Hij}$ zou gedeporteerd worden en de dood vinden in Auschwitz. Collega Aron Vedder, huisarts en bacterioloog, had volgens zijn dochter eveneens lang getwijfeld over wel of niet opteren voor Barneveld. Vermoedelijk werd zijn twijfel ingegeven door wantrouwen ten opzichte van de uiteindelijke bedoelingen van de bezetter met het Barneveldse 'tehuis'. ${ }^{11}$ Tijdens een bijeenkomst van Barneveld-genomineerden bij een van hen thuis werd de scepsis ten opzichte van de veiligheid in Barneveld gedeeld: 'Men beschouwt zich dan geheel in de macht der Duitsers. ${ }^{72}$

Ook wat betreft een gevoel van plichtsbesef als obstakel voor Barneveld was Goudsmit niet uniek. Een jongere collega van Goudsmit, de pasafgestudeerde Albert Denekamp, werd eveneens door verantwoordelijkheidsbesef weerhouden van de gang naar Barneveld. Hij was in oktober 1942 als vrijwilliger naar Westerbork afgereisd en praktiseerde hier toen zijn vader, de arts Eliazer Denekamp, op de Barneveldlijst terechtkwam. Ook zoon Albert had nu recht op verblijf in De Schaffelaar. Ondanks aandrang van Banning en Kloosterman in januari en februari I943 dat hij nu toch echt naar Barneveld moest komen, omdat zijn plaats anders aan een ander gegeven zou worden, wilde Albert Denekamp Westerbork pas verlaten als er een opvolger voor hem gevonden was. ${ }^{73}$ 'Het moet als uitgesloten worden beschouwd, dat ik zonder meer mijn arbeid in Westerbork in de steek laat.' ${ }^{74}$ Waarschijnlijk door interventie van Fritz Spanier, chef-arts in Westerbork, en Spijer, hoofd van de medische afdeling van de Joodsche Raad, kon Denekamp toch op i6 februari zijn ontslag bij de Joodsche Raad indienen. Aannemelijk was op dat moment geworden dat collega Nico van Zuiden zijn werk in Westerbork over zou nemen. ${ }^{75}$ Op 27 februari was het zover: de opvolger was geïnstalleerd en Albert kon de reis naar Barneveld ondernemen. ${ }^{76}$

Ook Jacques Lobstein, geneesheer-directeur van Het Apeldoornsche Bosch, had een mogelijke verhuizing naar Barneveld afgewezen 'omdat hij zich met de leiding van het hem toevertrouwde gesticht wenschte te blijven belasten zolang het belang der patiënten dat wenschelijk maakte'. ${ }^{77}$ Pas na de ontruiming van het AB trachtte Lobstein vanuit Westerbork voor Barneveld in aanmerking te komen. Tevergeefs.

Dat het, zelfs onder de grootste dreiging, niet eenvoudig was om patiënten en beroepsplicht achter zich te laten, toont ook het voorbeeld van J. de 
Hartogh jr, huisarts aan de Weesperzijde te Amsterdam. Een anonieme briefschrijver:

Zijn houding is echter deze, dat hij onder geen beding zijn tegenwoordig werk in de steek wil laten. Mocht hij gesteld worden voor de keus: nu naar Barneveld of nooit, dan zou hij zonder aarzelen verkiezen tot den ondergang op het zinkende schip te blijven. Wel zou hij gaarne een reddingsboot gereed zien, als het schip werkelijk in de golven verdwijnt. ${ }^{78}$

Deze aanvraag verdween in de map 'afgewezen'. Succesvol was de poging dus niet. Wel geeft dit weer welke afwegingen bij de artsen gemaakt moesten worden. Voor veel artsen sloeg de balans uiteindelijk, vaak dus in voorjaar I943, door naar: ondanks de bezwaren toch maar een poging wagen. Dit is althans de conclusie die men moet trekken uit het grote aantal aanvragen voor plaatsing op de Barneveldlijst. Of werkelijk alle aanvragen bewaard zijn gebleven is niet eens zeker. In elk geval zijn van ten minste 8I Joodse artsen de aanvragen afgewezen. De meest voorkomende reden van afwijzing was dat de lijsten van Frederiks en Van Dam reeds gesloten waren op het moment dat de betreffende artsen of hun collegae bij Banning aanklopten. ${ }^{79}$

Het merendeel van de 44 Joodse artsen wier aanvraag gehonoreerd was, verhuisde naar Barneveld, in de loop van de periode december 1942 tot zelfs augustus I943, toen het een enkeling als Bloch of Frenkel nog lukte er een plaats te bemachtigen. Vermoedelijk zijn acht van de 44 artsen op de lijsten van Frederiks en Van Dam nooit in Barneveld geweest. Zij waren ofwel gemengd gehuwd en hadden permissie in hun eigen huis te blijven, of zij bevonden zich al in Westerbork en werden op basis van hun Barneveld-Sperr niet verder op transport gestuurd. ${ }^{80}$

\section{'ZUSTER, BRENG MIJ DE CHAMPAGNE'}

De 36 artsen die wel naar Barneveld afreisden, waren dan weliswaar bevoorrecht, zich volledig onttrekken aan de oorlogsomstandigheden konden zij uiteraard niet. De kleine gemeenschap waar zij nu deel van uit gingen maken, kende bovendien haar eigen dynamiek en moeilijkheden. De artsen werden ook in Barneveld weer met problemen geconfronteerd, soms ook gerelateerd aan hun beroep.

Onder de Joodse artsen in Barneveld waren enkele zeer prominente $\mathrm{Ne}$ derlanders, zoals de voormalig rector magnificus van de Groningse universi- 
teit, Alexander Klein, en generaal Salomon Wolfeus Praag. ${ }^{81}$ Eveneens hoge voormalig militairen waren verder de artsen Eliazer Denekamp en Nardus Schrijver, die de rang van luitenant-generaal in de geneeskundige dienst had gehad, en David Stibbe, die er generaal-majoor was geweest. Het waren artsen die hun sporen reeds lang en breed hadden verdiend, maar ook iemand als Andries Querido, een relatief jonge, maar zeer veelbelovende wetenschapper, had met zijn echtgenote en hun zoontje een plaats op de lijst bemachtigd, net als bijvoorbeeld de bekende gynaecologe Rosalie Wijnberg, voormalig bestuurslid van de Geneeskundige Kring van Amsterdam. ${ }^{82}$ Nogal uiteenlopende representanten van de Nederlands-Joodse artsenstand waren er al met al vertegenwoordigd. Ook Jacques Reisel, een eenvoudige arts-assistent van eind twintig, was naar Barneveld gekomen. Dit was mogelijk dankzij de inspanningen van zijn schoonvader Maurits Muller, aan wie er al vroeg een plek was toegezegd.

Niet alleen onder de artsen was een grote variëteit, ook in de rest van de Barneveldse groep waren grote tegenstellingen waarneembaar. Al spoedig na zijn aankomst merkte Reisel hoe gecompliceerd de Barneveldse minimaatschappij in elkaar stak: 'Alras merken we dat het in De Schaffelaar niet alles koek en ei is. Er blijken zeer vele tegenstellingen en groepjes te bestaan, terwijl de toonaangevende mensen sterke assimilanten en, voor een niet onbelangrijk deel, gedoopt zijn. ${ }^{3}$

Reisel, zelf bewust Joods, voelde zich meer thuis bij het niet onbelangrijke aantal zionisten. Een spanning tussen de uiteenlopende gezindten en achtergronden was onmiskenbaar aanwezig. In deze bonte mix van vooraanstaande Nederlandse Joden, met onderlinge spanningen, maar weg van de continue dreiging erbuiten, trachtten de artsen hun beroep nog in ere te houden.

De artsen zetten een kleine medische dienst op, waar zij op vrijwillige basis medische zorg boden. In maart 1943 werd de dienst geleid door drie doktoren: Julius Lankhout uit Den Haag, Aron Vedder uit Amsterdam en Louis Weijl uit Middelburg. ${ }^{84}$ Niet iedereen was evenzeer te spreken over hun aanpak. De jongere artsen stonden te trappelen om ook iets te kunnen doen, zo voelde in elk geval Jacques Reisel:

De geneeskunde staat op een vrij primitief peil. Voor bijzonder beschermde Joden eigenlijk toch wel zielig. De jongeren wensen natuurlijk ook iets te zeggen te hebben maar de ouden geven geen krimp. Een enkel bloedje: goed. Een enkel consult, maar verder: ho maar! Elke veertien dagen oorspronkelijk artsencursus voor plusminus twintig artsen en biologen. Het lukt mij met moeite elke week zo'n bijeenkomst te krijgen, want het 
dweilen en zolder schoonhouden is wel een mooi werk maar het vak blijft toch belangrijker en de behoefte aan medisch werk (al is het theorie) blijft bestaan. $^{85}$

Dat een medische dienst hard nodig was, bleek toen er in april I943 een roodvonkepidemie onder de kinderen uitbrak. Aanvankelijk bracht men de patienten naar het NIZ in Amsterdam over. ${ }^{86}$ Vanaf juni echter was er een apart roodvonkziekenbarakje in Barneveld, speciaal voor dit doel gebouwd op het terrein van De Schaffelaar. Er werden eind juni liefst 28 roodvonkpatiënten en nog twee difteriegevallen opgenomen. De roodvonkepidemie greep behoorlijk om zich heen en werd onmiddellijk gevolgd door een difterie-epidemie. ${ }^{87}$ Een van de patiënten met difterie was Diny Vedder. Haar vader Aron, huisartsbacterioloog, stelde de diagnose aan de hand van een positieve kweek van de difteriebacterie in een kweekbuisje dat in plaats van in de gebruikelijke stoof, in Barneveld niet aanwezig, in de bh van haar moeder was geplaatst. ${ }^{88}$ Van een enigszins primitieve ziekenvoorziening kon men in dit geval met recht spreken. Maar dat er een medische voorziening was, betekende dat de anwezige artsen hun beroep konden uitoefenen en daarmee ook hier de normaliteit zo veel mogelijk konden trachten te behouden, evenals het moreel hooghouden. De gynaecologen Maurits Muller en Rosalie Wijnberg deden anvankelijk nog wat werk op hun eigen gebied, maar leerden zichzelf ook de kneepjes van het pedicurevak. Zo kon het dat de twee gerenommeerde vrouwenartsen in Barneveld ieder een paar uur per dag te consulteren waren voor eksterogen en eeltknobbels. ${ }^{89}$

Maurits Muller, die in 1940 zijn Utrechtse gynaecologische praktijk vanwege hartproblemen had moeten neerleggen, werd echter zelf in Barneveld ernstig ziek. Voor hem was er in het najaar van 1942 overweldigende steun gekomen voor plaatsing op de Barneveldlijst. Zelf had hij reeds op II september 1942 een brief aan de burgemeester van Utrecht gestuurd met het verzoek om hulp. Door de spanning van de oorlog waren Mullers hartklachten verergerd. 'Mij zal men waarschijnlijk, met mijn zieke lichaam, wel niet meer verslepen, maar ik zit in doodsangst, dat men m'n gezin zal wegvoeren. ${ }^{90}$ Reden om de burgemeester te vragen of hij 'een lichtpuntje achter de donkere wolken' kon bieden. ${ }^{91}$ Een groot aantal collegae klopte met dezelfde vraag aan bij de burgemeester, en vervolgens bij Banning en Frederiks. ${ }^{92}$ Wat inspecteur Hemmes over hem schreef, bleek daarmee inderdaad waar: 'In Utrecht en omgeving is Dr. Muller bijzonder populair, terwijl de collegae hem ten zeerste waardeeren. ${ }^{93}$

Muller had zijn vak altijd met groot plezier en toewijding uitgeoefend, blij- 
kens ook zijn memoires. Zijn takkopvatting als arts, geheel in lijn met het geldende ideaal van de paternalistische zorgzame dokter, spreekt uit elke bladzijde van dat werk, en ook uit dit fragment: 'De dokter, hij is een man die het gevoel van machteloosheid, van spanning en benauwenis moet opheffen, die vooral de omgeving van de zieken moet troosten, die een angstige moeder, een liefhebbend echtgenoot, een radeloos gezin van hun gejaagdheid moet verlossen en de rust in de harten moet doen weerkeren.' 94

Die zorgzaamheid en de neiging om de machteloosheid en spanning bij anderen te willen opheffen, kortom de paternalistisch-altruïstische houding die hij zich als arts had eigen gemaakt, bleef Muller houden, ook in Barneveld. $\mathrm{Nu}$ probeerde hij echter de nood van zijn eigen dierbaren en naasten als pater familias zoveel als hij kon te lenigen. Van Muller zijn vele brieven in het archief van Banning terug te vinden, alle bedoeld om familieleden eveneens naar Barneveld te kunnen halen. Allereerst spande hij zich met succes in voor zijn dochter Emmy, getrouwd met Jacques Reisel. Ook zijn oudste en zijn jongste dochter, zijn schoonmoeder, zus en schoonzus konden mee naar Barneveld. ${ }^{95}$ Vervolgens richtte hij zich op de familie van Jacques Reisel, onder wie diens zwager Sal Meijer, huisarts aan de Sarphatistraat te Amsterdam, en op zijn eigen neef Leo Lezer, huisarts te Zwollerkerspel, maar hoeveel moeite Muller zich ook getroostte, deze familieleden werden toch gedeporteerd. Het kringetje dat Muller kon beschermen beperkte zich tot zijn meest nabije familieleden.

Toen Muller eind augustus 1943 een bevalling zou gaan begeleiden in De Biezen, werd hij getroffen door een zwaar hartinfarct. Al snel ging het bergafwaarts met zijn gezondheid. Men nam hem op in de ziekenbarak op het terrrein van De Schaffelaar, waar Maurits Elzas werd aangesteld als zijn behandelend arts. Deze stond echter machteloos en de familie bereidde zich voor op het ergste. Maar 'als hij wakker is maakt hij nog altijd een grapje en is bang iemand lastig te vallen'. ${ }^{96}$ Toen hij zijn einde voelde naderen, viel er dan ook een grote last van zijn schouders. De immense verantwoordelijkheid die hij steeds had gevoeld en waar hij zijn handelen telkens door had laten bepalen, eerder in zijn rol van arts, laatstens in zijn rol van pater familias van een ernstig bedreigde familie, viel nu voorgoed van hem af. De dood kwam voor Muller als een verlossing. Reden om hem, in het bijzijn van schoonzoon Jacques Reisel, te doen uitbrengen: 'Zuster, breng mij de champagne. ${ }^{97}$ Op I3 september I943 overleed Maurits Muller en hij werd begraven op de Joodse begraafplaats in Barneveld, waar dominee G.W. Oberman, een goede vriend van de familie, over Muller zei: 'Hij was een voorbeeld voor zijn collegae in zijn dienen en voor ieder mens in zijn zelfverloochening. ${ }^{9} 9$ 
Het voorbeeld van Maurits Muller toont aan hoe zwaar het verantwoordelijkheidsgevoel en de zorg voor en om anderen onder de gegeven omstandigheden op iemand konden drukken. Op een vader, grootvader, echtgenoot, zoon of oom in het algemeen, en in het bijzonder op iemand die ook zijn beroep had gemaakt van het zorgen voor anderen, op een arts als Maurits Muller. In zijn dagboek had hij in 1940, bij het door gezondheidsproblemen gedwongen neerleggen van zijn praktijk, al genoteerd: 'Dertig jaar met hart en ziel de menschheid gediend en nu ineens basta! Ik heb me ertegen verzet, maar ik moest het opgeven.' ${ }^{99} \mathrm{Nu}$ zijn zorg niet meer de zieke medemens, maar zijn allernaaste dierbaren betrof, kon hij dat net zo min of misschien nog moeilijker opgeven. En hij voelde waarschijnlijk wel dat hij de grip op de situatie volkomen aan het verliezen was.

Het zou dan ook gelukkig kunnen worden genoemd dat Maurits Muller niet meer heeft hoeven meemaken hoe zijn dierbaren twee weken later door Duitse overvalwagens uit hun Barneveldse onderkomen werden weggehaald, om naar Westerbork te worden afgevoerd. Daartegen was hij volkomen machteloos geweest. Nietsontziend als de Duitse aanpak over het algemeen was, maakte de bezetter De Schaffelaar en De Biezen op 29 september, net als Amsterdam, geheel 'judenrein'. De Barnevelders werden via Westerbork gedeporteerd naar Theresienstadt. Zij werden als elitegroep bij elkaar gehouden en veruit de meesten van hen overleefden het 'Vorzugslager' Theresienstadt. Mullers inspanningen waren dus zeker niet vergeefs geweest: zijn meest naaste dierbaren overleefden de oorlog. ${ }^{100}$

Ook van de 44 artsen die op de Barneveldlijst hadden gestaan, overleefde het merendeel. Max Brahn werd echter in Auschwitz vermoord, Carolina Bramson stierf in Bergen-Belsen, de bejaarde David Stibbe overleefde Theresienstadt niet en Nardus Schrijver ten slotte overleed op de terugweg vanuit dat kamp, net na de bevrijding. De 39 andere wisten de oorlog door te komen dankzij hun eigen en Bannings inspanning om op de lijsten van Frederiks en Van Dam te komen.

Op 29 september 1943 wisten de Barnevelders natuurlijk nog niet dat zij een relatief hoge overlevingskans zouden hebben. $\mathrm{Zij}$ waren, net als inmiddels zo goed als iedereen om hen heen, in handen van de Duitsers gevallen, en dat kon van alles betekenen. Jacques en Emmy Reisel-Muller hadden besloten het niet zover te laten komen, maar hun lot in eigen hand te nemen. Zij verstopten zich - met een ander echtpaar - onder de vloer van het kolenschuurtje op het terrein van De Schaffelaar. Met hulp van de half-Joodse arts Joop Wolff, een neef, die in het verzet zat, verdwenen zij vervolgens in een lijkwagen naar hun eerste onderduikadres in Amsterdam. ${ }^{\text {Ior }}$ 
Hadden Jacques en Emmy lang hun bedenkingen gehad bij een onderduikpoging, nu hadden zij geen keus meer. In feite verviel iedere legale mogelijkheid op 29 september: Sperren golden niet meer en zelfs de voorzitters van de Joodsche Raad, die tot het allerlaatst hadden mogen blijven, moesten nu naar Westerbork. En naar Westerbork wilden Jacques en Emmy pertinent niet. Dat betekende dat slechts illegale manieren nog voor hen openstonden: vluchten of onderduiken. Het werd dat laatste, ondanks het feit dat Emmy's zuster geen al te opbeurend verslag had gedaan van haar eigen onderduikervaringen. Jacques' conclusie daarvan was geweest: 'psychisch zeer moeilijk te dragen en inderdaad een remedie tegen het huwelijk. ${ }^{{ }^{102}} \mathrm{Na}$ het wegvallen van de Barneveld-bescherming zagen Emmy en Jacques echter geen andere uitweg meer. 


\title{
8. DE LEGALE EN DE ILLEGALE REST
}

\author{
JOODSE ARTSEN IN BESCHERMDE \\ UITZONDERINGSPOSITIES OF IN DE ONDERDUIK
}

Nadat op 29 september ook de bevoorrechten uit Barneveld waren weggevoerd, was het wel bijna ondoenlijk om enkel met de status van het artsenberoep nog een bevoorrechte positie te vergaren. De elite was weggevoerd en daarmee ook het laatste groepje artsen. Geen andere mogelijkheid restte de artsen nu dan ofwel mee te gaan naar Westerbork of Vught, ofwel onder te duiken. Dit illegale middel tot redding had echter zeer grote bezwaren. Waren er voor sommige artsen niet nog andere mogelijkheden? Konden zij ook legale manieren vinden om niet voor deportatie in aanmerking te komen? En als zij tot onderduiken overgingen: hoe verging hun dat?

\section{'GEARISEERD'}

De enige groep Nederlandse Joden die na 29 september 1943 legaal en in betrekkelijke vrijheid en veiligheid kon verder leven, en dus echt bevoorrecht was, waren de 'gecalmeyerden', ongeveer 3000 mensen die via de Calmeyerprocedure, genoemd naar de door de Generalkommissar 'bevollmächtigte' Duitse ambtenaar Hans Georg Calmeyer waren 'geariseerd'. '

Gecalmeyerden golden niet meer als Joden en hun veiligheid was daarmee stabiel verzekerd. Dat te bereiken was geen sinecure. Men had zich in januari I94I aangemeld als Jood, op basis van het aantal Joodse grootouders. Drie of meer Joodse grootouders betekende dat men als 'vol-Jood' geregistreerd stond. 
Men verdween niet zo makkelijk uit dit registratiesysteem en ook de vette zwarte $\mathrm{J}$ in het persoonsbewijs was letterlijk niet uit te vlakken. Bovendien was iedere Jood van zes jaar of ouder sinds mei 1942 ook op straat herkenbaar door de gele davidster die men in het openbaar te allen tijde, links op de borst, diende te dragen. Daarvanaf komen vereiste een uitputtend en volkomen waterdicht, vervalst, stamboomonderzoek, eventueel aangevuld met een onderzoek van lichaamskenmerken waaruit zou moeten blijken dat een Joodse afstamming - in elk geval voor ten minste twee grootouders - uitgesloten was. Benodigdheden daarvoor waren: een plausibel klinkend verhaal, een goede advocaat, eventueel een rapport van antropometrisch lichamelijk onderzoek en last but not least: de medewerking van Calmeyer. Het was geenszins vanzelfsprekend dat dat allemaal lukte. Van de ruim 5000 afstammingsdossiers die Calmeyer zijn voorgelegd, keurde hij er zo'n 3000 goed, maar dat betekende dat er ook 2000 verzoeken tot arisering werden afgekeurd. ${ }^{2}$ Calmeyers oordelen waren volgens de betrokken advocaten vaak onvoorspelbaar. ${ }^{3}$ Hij leek de dossiers niet altijd te beoordelen op de kwaliteit van het bewijsmateriaal, maar op zijn eigen intuïtie. Dit maakt hem tot op de dag van vandaag een omstreden figuur. Wat zijn intenties waren is een vraag die de gemoederen nog altijd bezighoudt. ${ }^{4}$

Bij Berthold Stokvis slaagde het ariseringstraject. Toen hij in zijn dagboek noteerde dat de Sperren een voor een verdwenen, schreef hij: 'De 30.000 [Sperrstempel-nummers] zijn de Calmeyers, waartoe ook ik heb behoord, voor ik tot half-Ariër werd verklaard. Deze laatsten maken een goede kans, omdat zij een herziening van hun afstamming hebben aangevraagd.'s Stokvis was niet de enige Joodse arts die deze procedure onderging. Ten minste 47 Joodse artsen met asjkenazische wortels trachtten zichzelf, hun echtgenote of kinderen te laten calmeyeren. ${ }^{6} \mathrm{Zij}$ hadden daartoe een advocaat in de arm genomen, die alle mogelijke (valse) documenten over de stamboom verzamelde om het dossier zo overtuigend mogelijk te laten zijn. Vaak werd de tactiek toegepast dat men beweerde dat de voorouders niet getraceerd konden worden, of anders probeerde men overtuigend te maken dat het onderzochte individu een buitenechtelijk kind van een niet-Joodse huisvriend was. ${ }^{7}$ Het wetenschappelijk bewijs voor een dergelijke stelling werd bij een deel van de gevallen vervolgens geleverd door de niet-Joodse artsen Arie de Froe en Cornelis U. Ariëns Kappers. Zij werkten in het anatomisch laboratorium aan de Mauritskade in Amsterdam, pal naast het hoofdkwartier van de Grüne Polizei in het Koloniaal Instituut. Ze waren experts in schedelmetingen en antropometrie, de wetenschap van het opmeten van allerlei lichaamsmaten om antropologische verbanden te kunnen leggen en raciale oorsprong te kunnen aantonen. Onder de 
Nederlandse anatomen was allang gemeengoed dat er geen Joods ras bestond, net zo min trouwens als een Germaans ras. ${ }^{8}$ Deze Duitse rassentheorieën konden echter handig gebruikt worden juist om aan te tonen dat iemand onmogelijk tot het zogenaamde Joodse ras kon behoren. Aldus geschiedde.

In totaal meer dan 2000 Joden meldden zich volgens Ariëns Kappers bij hem en De Froe voor antropometrisch bewijs voor hun arische afstamming. De Froe voerde het onderzoek uit en Ariëns Kappers, die internationale bekendheid genoot, zette vervolgens zijn handtekening onder het onderzoeksverslag. In zo'n 300 gevallen lukte het de betrokken advocaten daarna om Calmeyer met het antropometrisch onderzoek te overtuigen. ${ }^{9}$

Voorbeelden van Joodse artsen bij wie dit inderdaad slaagde, zijn, naast Berthold Stokvis, de Amsterdamse huisarts Ben Swaab en zijn zoon Leo, de gynaecoloog. De bewijzen van arisering kwamen net te laat voor de oudste zoon Juda, tandarts, die met zijn vrouw en dochter al in Westerbork zat. ${ }^{\text {I0 }}$ Ook Jaap Spanjaard zat al gevangen in Westerbork toen de uitslag van zijn afstammingsonderzoek bekend werd. Hij was als psychiater van Het Apeldoornsche Bosch in januari 1943 in Westerbork terechtgekomen, maar kreeg hier in april I943 het bericht dat hij terug naar huis kon. Zijn nieuwe status als half-Jood maakte een wereld van verschil: hij kon zich als psychiater in Utrecht vestigen en relatief ongestoord leven en praktiseren. ${ }^{\text {II }}$ De gecalmeyerde artsen konden nu zowel niet-Joodse patiënten gaan behandelen als zich over hun oude Joodse patiënten blijven ontfermen. Althans, voor zover deze er nog waren.

Bij hoeveel Joodse artsen de Calmeyer-procedure daadwerkelijk slaagde, is niet duidelijk, maar van de 47 artsen wier namen op de in de archieven bewaarde lijsten vermeld staan, hebben 38 de oorlog overleefd. Van die 47 artsen waren er ten minste 17 getrouwd met een niet-Joodse vrouw. Ook dit kan van doorslaggevend belang zijn geweest in de hoge overlevingskans. Calmeyer nam de gemengd gehuwden vaak niet in behandeling omdat hij hen al veilig wist. ${ }^{\mathrm{I}}$ Een rekensom geeft dan - bij benadering - 2I Joodse artsen die door Calmeyer van deportatie gered zijn. Dat is een percentage van bijna 4 , waar in de algemene Joodse bevolking ongeveer 2 procent door Calmeyer gered is. De artsen maakten daarmee meer kans bij Calmeyer dan niet-artsen.

Voor de 47 artsen die overgingen tot een Calmeyer-procedure, kan men veronderstellen dat middelen en contacten vaker dan gemiddeld aanwezig waren om een goede zaak op te zetten. Alhoewel een dergelijk onderzoek veel minder kostbaar was dan veel andere Sperren. ${ }^{\mathrm{I} 3}$ Hun eigen vakkennis kan daarnaast nog bijgedragen hebben aan de uiteindelijke gunstige afloop van het onderzoek. Dit gold in elk geval voor Paul Lopes Cardozo. Hij was assistent geweest bij de anatoom J.A.J. Barge, de hoogleraar die in 1940 op wetenschappelijke 
wijze de rassenleer onderuit had gehaald, en had al in de jaren dertig zijn eigen afstamming onderzocht. Mogelijk mede ingegeven door zijn moeders afkeer van het (Portugese) Jodendom was Lopes Cardozo zijn stamboomonderzoek gestart en daarbij tot de conclusie gekomen dat zijn voorouders van Portugese adel waren geweest en niet Joods. Zijn theorie leverde hem op dat hij als verklaard ariër door het leven kon gaan. Hij vertrok veiligheidshalve wel naar Noord-Groningen en speelde het klaar om daar steeds rondzwervend, door hemzelf poëtisch uitgedrukt 'als vlinder van bloem tot bloem', en als 'Spaanse dokter' onder zijn eigen naam als arts te blijven praktiseren. ${ }^{\mathrm{I}}$

Als Calmeyer gunstig beschikte, betekende dit echter verre van een garantie op overleven. De arts Juda Erwteman, in november 1942 erkend als van gemengden bloede, oftewel 'Gemischt erstes Grades (GI)' kwam in 1943 in Auschwitz-Birkenau aan zijn einde. ${ }^{15}$ Op zijn Joodsche Raadkaart staat 'S-Fall', wat betekent dat hij als strafgeval in Westerbork gevangenzat. ${ }^{16}$ Hij moet dus gearresteerd zijn vanwege een vergrijp. Dat overtrof de Calmeyer-status. Ook de gemengd gehuwde hoogleraar Abraham Albert Hijmans van den Bergh zou de oorlog niet overleven, hoewel hij wel 'vom Tragen des Judensterns befreit' was. ${ }^{17} \mathrm{Bij}$ Calmeyer was zijn procedure aanvankelijk op niets uitgelopen, waarop zijn zoon rechtstreeks bij secretaris-generaal Frederiks had aangeklopt om zijn vader alsnog niet-Joods te laten verklaren. ${ }^{18}$ Frederiks boekte vervolgens pas enkele maanden later succes bij Wimmer en ss-Brigadeführer W. Harster. Zij werden in januari 1943 bereid gevonden Hijmans van den Bergh inderdaad van het dragen van een Jodenster te verlossen. De getergde Hijmans van den Bergh, een van de grote drie van de interne geneeskunde van de jaren dertig, overleed echter kort daarna, verarmd en uit zijn huis gezet, in het huis van zijn opvolger C.D. de Langen. Mogelijk aan suïcide. ${ }^{19}$

De aanvragers van arisering waren er over het algemeen vroeg bij geweest: de meesten stonden al op de Calmeyer-lijst van september 1942. Dat geeft de indruk dat men naast andere Sperrpogingen voor de zekerheid ook alvast een ariseringspoging ondernam. Daarmee stond je naam in ieder geval op de lijst, en zelfs nog zonder definitieve uitslag zou dat uitstel kunnen opleveren. In geval van dreigende arrestatie kon men dan in elk geval de Calmeyerpapieren tonen. Bewijs dat men niet Joods was, had men dan nog niet, maar wel bewijs dat er aan dat Joods-zijn van officiële zijde getwijfeld werd. Het gaf tijd om andere beveiligingsmethoden te zoeken. 
Enkele maanden na het begin van de deportaties had zich nog een extra kans voorgedaan voor de van oorsprong Portugese Joden. Het ging om 375 personen die afstamden van sefardische families, waarin geen of nauwelijks huwelijken met asjkenazim hadden plaatsgevonden. Onder hen waren negentien artsen die net als de andere 'zuivere Portugezen' hun hoop op Calmeyer vestigden. De 'Portugezenlijst' werd opgesteld, en De Froe ging aan de slag om antropometrisch en antropologisch te bewijzen dat deze sefardim, net als zijn eerder onderzochte patiënten, geen Joden waren.

De Froe schreef een rapport getiteld De anthropologie van de zoogenaamde Portugeesche Joden in Nederland, dat in september 1943 verscheen. ${ }^{20}$ In de daaraan voorafgaande maanden had hij de 375 Portugezen die daartoe op een lijst waren gezet, onderworpen aan een zeer nauwkeurig onderzoek, dat bestond uit in die tijd gangbare metingen als bijvoorbeeld middelvingerbreedte, voorhoofdshoogte en haardichtheid. ${ }^{21}$ Ook hun gedrag en psychologie werd beschreven, hun stambomen werden tot de Isde eeuw in Spanje uitgeplozen en van hun bijdrage aan de Nederlandse cultuur werd hoog opgegeven. Alles om tot de volgende conclusie te komen: 'En zoo staan wij dan voor het feit dat in Nederland zich een groep families ontwikkelde, staatkundig van portugeeschen herkomst, raskundig mediterraan, naar religie joodsch, en cultureel en politiek Nederlandsch. ${ }^{22}$

Hans Calmeyer was dezelfde mening toegedaan, zo liet hij al in juli 1943 in een brief aan de Generalkommissar für das Sicherheitswesen weten. ${ }^{23}$ Grote fotoboeken werden nog als bewijsmateriaal aan het onderzoek toegevoegd, opdat zogenaamd aan de beeltenissen van de sefardim onmiddellijk kon worden gezien dat het hier niet om Joden kon gaan. Dankzij deze tactische manoeuvres van De Froe kon bijvoorbeeld dermatoloog Emanuel Vas Nunes redelijk ongestoord doorwerken in de leeggehaalde Joodsche Invalide als behandelend arts van niet-Joodse geslachtszieke vrouwen. Hij kon dat zelfs doen ondanks het verbod voor Joodse artsen om niet-Joodse patiënten te behandelen en ondanks protest van de kant van de NSB. ${ }^{24}$

Dat de Portugezenlijst het eind van de oorlog niet zou halen, was in september 1943 nog allerminst te voorspellen. De ster mocht niet, zoals bij de gecalmeyerden, worden afgelegd, maar in elk geval bood de lijst een manier om weer wat dichter bij de bevrijding te komen. De Portugezen zouden echter met een razzia op I februari 1944 opgepakt worden en naar Westerbork gezonden, alwaar een commissie hen enkele weken later nogmaals bekeek en besloot dat zij toch wel degelijk Joden waren. ${ }^{25}$ Hun doodvonnis was daarmee getekend. 
Enkele dagen later, op 25 februari, transporteerde men hen naar Theresienstadt, vanwaar de meesten naar de gaskamers van Auschwitz-Birkenau werden doorgestuurd. Als door een wonder bleef dit lot de jonge vrouwelijke arts Elsa Jessurun d'Oliveira bespaard. Zij was door de 'stamboekveemonstering' Joods bevonden, ${ }^{26}$ maar op het nippertje, 24 februari, arriveerde haar advocaat Nino Kotting met een afstammingsrapport waarin stond dat haar vader niet haar biologische vader was. De beambte in Westerbork belde naar het kantoor van Calmeyer om bevestigd te krijgen dat Elsa als half-ariër vrijgelaten mocht worden. Calmeyer zelf was in gesprek, maar Kottings collega, Jaap van Proosdij, die bij toeval aanwezig was, nam de telefoon aan en kon met een kort 'Das stimmt' Elsa's lot bezegelen. ${ }^{27}$ Op I april 1944 mocht Elsa uiteindelijk Westerbork verlaten, maar niet dan nadat zij haar echte vader op de trein had moeten zetten. Na die gebeurtenis teruglopend naar haar barak werd zij plotseling overvallen door een hevige pijn in haar arm en maagstreek. Haar eigen diagnose was een maagperforatie, en voorzichtig strompelde ze terug naar de ziekenbarak, waar collega Andries Querido haar opving. Zijn diagnose was echter dat zij een psychosomatische reactie op het gebeurde ervoer. Voor haar latere praktijk heeft Elsa altijd onthouden dat een dergelijke lichamelijke reactie op psychisch trauma dermate heftig kan zijn. ${ }^{28}$

Hoewel de Portugezenlijst langer stand zou houden dan de meeste andere Sperren, bood ook deze geen blijvende bescherming. Van de negentien artsen op de lijst overleefden slechts tien de oorlog. Het voorrecht om op de Portugezenlijst te staan was zeer relatief gebleken.

\section{GEMENGD GEHUWD}

Ook de gemengd gehuwden wisten dat zij, ondanks hun relatief veilige positie, als Jood geregistreerd waren. Ook zij liepen met een gele ster op hun jas. Van de Joodse artsen waren er bijna honderd getrouwd met een niet-Joodse partner. In elk geval 95 namen van artsen kunnen in dit verband gevonden worden, echter bij zeker drie van hen ging het om gecalmeyerde partners. Veiligheidshalve was het weliswaar gunstig om gemengd gehuwd te zijn, maar ook die protectie was niet in alle gevallen afdoende. Iedere keer als zij na 29 september I943 op straat liepen, vormden zij bovendien een bezienswaardigheid en een mikpunt voor Jodenhaat van NsB'ers en Duitse agenten. Velen kozen er dan ook voor de straat niet meer op te gaan en min of meer onder te duiken in hun eigen huis. Van bijvoorbeeld Fritz Fischer is bekend dat hij nauwelijks meer buiten kwam. ${ }^{29}$ 
Dat de gemengd gehuwde Joden zich niet veilig voelden, was niet onterecht, getuige de notitie 'zum Stand des Judenfrage' in Nederland van 5 oktober 1943: 'Jetzige Belegung in Westerbork rund 900o. Wird die Mischehe angefasst, so wächst die Belegung stark an. ${ }^{30}$ Kortom, als men de gemengd gehuwden zou aanpakken, zou de bevolking van Westerbork flink groeien. Het leek de Duitse gezagsdragers kennelijk een kwestie van tijd of dit zou realiteit zijn.

Boven op de angst voor deportatie kwam voor de gemengd gehuwden het dilemma van de sterilisatiekwestie. De bezetter pakte de gemengd gehuwden weliswaar nog niet aan met grootschalige deportatie, maar met de sterilisaties belastte hij hen wel degelijk zwaar. Het vorige hoofdstuk toonde al welk moreel dilemma ze teweegbrachten, zowel onder Joodse en niet-Joodse artsen, als bij de patiënten en ook bij buitenstaanders. Men was over de gehele linie erg afkerig van sterilisaties. Van zes Joodse artsen in een gemengd huwelijk is bekend dat ze zich lieten steriliseren. Drie andere gemengd gehuwde Joodse artsen waren 'sternbefreit', mogelijk eveneens op basis van een uitgevoerde sterilisatie, of anders op basis van een - valse - sterielverklaring. ${ }^{3 \mathrm{I}}$ Volledige veiligheid bood de sterilisatie niet eens. De al jaren niet meer praktiserende Margareta Dekker-Benjamins, die zich volgens de registratie had laten steriliseren, werd op I april I944 door de Duitse politie naar Westerbork gebracht, om haar ruim een week later weer in vrijheid te stellen. ${ }^{32}$ Overigens hadden de 'sternbefreite' gemengd gehuwden ook nog steeds geen burgerrechten. Zij mochten dan ook niet als arts voor niet-Joodse patiënten praktiseren. ${ }^{33}$ Maar alleen al het feit dat zij nog mochten praktiseren en meestal dan ook in hun eigen huis mochten blijven, maakte hen natuurlijk wel relatief bevoorrecht. Iemand als internist Ju Groen - die gemengd gehuwd was, een onderzoek bij De Froe had laten uitvoeren naar zijn eigen afstamming, beschikte over een Ausnahmebescheinigung wegens zijn werk voor de cIz en stond op de Barneveldlijst - kon gedurende de hele oorlog in zijn huis aan het Raphaëlplein in Amsterdam blijven wonen. ${ }^{34}$ Groen had natuurlijk slechts zeer weinig Joodse patiënten, maar had daardoor de tijd om uitgebreide anamnesen bij hen af te nemen. Hij was hierdoor in staat om een nieuwe manier van werken te ontwikkelen, 'biografische anamnese' geheten. Groen raakte er al doende van overtuigd dat voor veel interne aandoeningen bepaalde gebeurtenissen in iemands leven deels de oorzaak konden zijn. Deze ontdekking zou de basis vormen voor zijn latere werk op het gebied van de psychosomatiek. ${ }^{35}$ Het mag een opmerkelijke samenloop van omstandigheden worden genoemd dat de medische wetenschap op dit punt door de situatie waarin Groen verkeerde gestimuleerd werd. Groen wist, vergelijkbaar met bijvoorbeeld de artsen die in het getto van Warschau hongerstudies uitvoerden, nog iets constructief wetenschappelijks te destilleren 
uit zijn ontegenzeggelijk ook benarde toestand. Met dank aan Cees Banning werd zijn boek over voeding en diëten in 1942 nog uitgegeven. ${ }^{36}$ En door zijn positieve wetenschappelijke instelling 'lukte het de Duitsers niet me geheel te breken', aldus Groen zelf. 37

Onder de relatief bevoorrechte, legaal bovengrondse groep van gecalmeyerden, Portugezen en gemengd gehuwden, bevonden zich bij elkaar toch nog zo'n I50 Joodse artsen, bijna een derde van het totaal aantal Joodse artsen. $\mathrm{Zij}$ waren echter niet in deze bevoorrechte positie beland door hun medische werk, maar meer door de mate van assimilatie en integratie die hun beroep en de bijbehorende maatschappelijke positie hun hadden gegeven. Enkele collegae echter mochten als arts nog even doorwerken, ook al vielen zij niet onder een van de drie uitzonderingscategorieën.

\section{IN EEN DESOLAAT MOKUM}

Voor de medische verzorging van de allerlaatste Joden in Amsterdam waren er na 29 september 1943 nog enkele artsen aanwezig, zelfs nog een enkeling die niet in de uitzonderingscategorie van gecalmeyerd, Portugees dan wel gemengd gehuwd viel. Er was namelijk ook nog enige geïnstitutionaliseerde Joodse medische activiteit in Amsterdam. Met name voor de sterilisaties waren CIZ en PIZ nog operationeel. Op i9 oktober echter sloten de deuren van de CIZ. De nog aanwezige patiënten werden naar het PIZ overgebracht. ${ }^{38}$ In De Joodsche Invalide woonden de bijbehorende personeelsleden en hun familieleden. Op ro december stonden nog I 32 mensen op de loonlijst van de JI. ${ }^{39}$ Een deel van hen had mogen aanblijven om op de afdeling van Vas Nunes de 'madeliefjes', de niet-Joodse geslachtszieke vrouwen, te behandelen. Een enkele Joodse patiënt werd ook nog verzorgd. Zo sprak A.V. Hartogh bijvoorbeeld van een 'oudje van IO2 jaar' dat 'pas' in januari 1944 voor Arbeitseinsatz op transport gezet werd. ${ }^{\circ}$ Aangezien Vas Nunes de 'madeliefjes' voor zijn rekening nam, ligt het voor de hand aan te nemen dat de eveneens nog aanwezige internist Jacob Goudsmit het Joodse 'rest'-zaaltje onder zijn hoede had. De arts-assistenten Sally Dunner en Jaap Hillesum zullen hen daarbij terzijde hebben gestaan. Deze vier Joodse artsen werkten nog in Amsterdam door tot ook zij op I2 januari 1944 naar Westerbork werden afgevoerd. ${ }^{4 \mathrm{I}}$ De door hun gemengde huwelijk beschermde Joodse artsen Theodore Philips en Aron en Samuel Kropveld stonden ook nog op de loonlijst, evenals René Fernandes, die gecalmeyerd was. ${ }^{42}$ Goudsmit had middels zijn contacten en uitputtende zoektocht naar veiligheid voor zichzelf en zijn gezin kennelijk kunnen bereiken relatief lang 
in Amsterdam te mogen blijven. Zij hadden zichzelf ook nog trachten te laten ariseren via Calmeyer. ${ }^{43}$ Dit lukte echter niet. Goudsmits positie in de Ji bleek vervolgens ook geen duurzame veiligheid te bieden. Het ging finaal mis in januari I944, toen ook hij opgepakt werd en naar Westerbork afgevoerd. ${ }^{44}$ Vanuit dit kamp werden Jacob Goudsmit en zijn vrouw via Theresienstadt naar Auschwitz gedeporteerd. Zij zouden niet terugkeren. Tegelijk met Goudsmit moesten ook Dunner, Hillesum en Vas Nunes naar Westerbork. Alleen Dunner overleefde de oorlog. ${ }^{45}$

In het PIZ en de Ji beschermde Eduard Meyer de aanwezigen, totdat zijn meerderen hem in maart 1944 wegens verdenking van 'Judenbegünstigung' terug naar Duitsland zonden. Zijn protegés werden naar Westerbork gestuurd. ${ }^{46}$ In de CIZ was inmiddels een geboortekliniek in het leven geroepen voor meisjes die door Duitse soldaten waren bezwangerd. ${ }^{47}$ In het PIZ was nog tot juni I944 enige activiteit, nog altijd in de vorm van de sterilisaties van de gemengd gehuwden. Gewone patiënten waren er niet meer, maar voor de gesteriliseerden was er nog wel personeel aanwezig. Kort voordat zij zouden worden gedeporteerd wist verzetsman Jan Meilof IJben het merendeel van de hier werkzame personeelsleden te redden. ${ }^{48}$

Op ıo januari 1944 haalde men collega Bernard de Vries Robles juist vanuit Westerbork naar Amsterdam. ${ }^{49}$ Het lijkt aannemelijk dat hij de taken van Goudsmit overnam. De Vries Robles verbleef reeds vanaf november 1943 met zijn gezin in Westerbork, maar kreeg via Aus der Fünten, die hij tijdens zijn werkzaamheden in de Zentralstelle en Hollandsche Schouwburg had leren kennen, de mogelijkheid om met zijn artsenfunctie vrijgesteld te worden. Dat zijn vol-Joods-zijn als afstammeling van Surinaamse sefardim in twijfel werd getrokken, zal daarbij ook een factor van betekenis zijn geweest. Het effect van zijn baan als arts in Amsterdam was levensgroot. ${ }^{50} \mathrm{Op}$ i3 september 1944 zaten zijn vrouw en twee kinderen al in de trein die hen naar Bergen-Belsen zou moeten brengen, toen Bernard het vanuit Amsterdam voor elkaar kon krijgen dat zij uit de wagon mochten stappen en in Westerbork mochten blijven. ${ }^{\text {II }}$ In dit bijzondere geval overleefde het artsengezin op legale wijze dankzij het beroep van vader Bernard.

Een ander bijzonder geval was professor Ernst Laqueur. Zijn legale emigratieplannen in het begin van de bezetting waren op niets uitgelopen. Laqueur was geen praktiserend arts maar onderzoeker, en gold, overigens samen met zijn medewerker Janos Freud, als de ontdekker van het testosteron, en had daar grote faam mee verworven. ${ }^{52}$ Ook hij was echter als Jood niet meer welkom aan de universiteit. Hij was wel nog steeds aandeelhouder bij NV Organon in Oss, een bloeiend pharmaceutisch bedrijf waar insuline en andere hor- 
monen werden geproduceerd. De bezetter legde hiervoor zeer veel interesse aan de dag. Hierin leek voor de familie Laqueur een kans te schuilen het land te kunnen verlaten. $\mathrm{Al}$ in 1940 waren er onderhandelingen over een mogelijke ruil: de aandelen voor de bezetter in ruil voor een vrije uittocht naar Amerika voor de hele familie Laqueur. ${ }^{53}$ Simpelweg afpakken, zoals de bezetter over het algemeen met Joods bezit deed, kon in dit geval niet. Het bedrijf zou internationaal reputatieschade lijden en bovendien zouden de overzeese bezittingen van de gevluchte oprichter en grootaandeelhouder Saal van Zwanenberg dan waarschijnlijk afgesplitst worden van het moederbedrijf. ${ }^{54}$ De ruil kwam er echter niet, omdat de nazi's Laqueurs invloed in Amerika vreesden. ${ }^{55}$ Zolang Laqueur in Nederland was zou bovendien Van Zwanenberg mogelijk terughoudender optreden, teneinde Laqueur niet in gevaar te brengen. Laqueur en zijn familie moesten in Nederland blijven. ${ }^{56}$ Ernst Laqueur had zichzelf en zijn familie vervolgens door verschillende advocaten proberen te laten ariseren. ${ }^{57}$ Toen ook dat niet lukte kon hij in elk geval een 40 ooo-stempel voor zijn familie bemachtigen, de stempel die bij de Barneveldlijst hoorde. De Laqueurs gingen echter nooit naar Barneveld, maar kochten in april 1943 een van de zeer zeldzame 120 ooo-stempels. ${ }^{58}$ Ook dit - nog sterkere - stempel verviel echter en de familie moest naar Westerbork en vervolgens naar Bergen-Belsen. Alleen Laqueur zelf was, vanwege zijn verdiensten, volgens persoonlijke bepaling van Franz Fischer 'von der Kennzeichnung der Juden auszunehmen'.59 Hij behoorde hiermee tot de zogenaamde 'Blaue Reiters', een select groepje van zo'n honderd Joden die voor de bezetter van bijzonder belang waren, onder wie ook enkele dubieuze figuren. ${ }^{60}$ Ook dit zou echter geen absolute bescherming bieden: Laqueur zou toch nog op 9 juni 1944 in Westerbork verwacht worden om, samen met zijn echtgenote en hun jongste dochter, voor deportatie naar Theresienstadt in aanmerking te komen. Hij gaf hieraan geen gehoor omdat hij het telegram waarschijnlijk niet op tijd las. Daarna vertrokken er geen transporten meer vanuit Westerbork en bleef Laqueur waar hij was: in Amsterdam. ${ }^{61}$

Een arts die puur vanwege zijn grote verdiensten voor de medische wetenschap in Amsterdam mocht blijven en tot de bevrijding van deportatie was vrijgesteld, was Nico (Nathaniël) Waterman. Deze kankeronderzoeker, verbonden aan het Antoni van Leeuwenhoekziekenhuis, kreeg op I4 augustus I942 een vergunning om zijn onderzoek naar de kankerverwekkende werking van kleurstoffen voort te zetten. Hij legde hiermee de basis voor de latere Warenwet. ${ }^{62}$ Waterman mocht daarvoor in de Ji en het PIZ verblijven en op zeker moment zelfs in zijn eigen huis, en mocht contact hebben met zijn voormalige (niet-Joodse) collegae, omdat de bezetter kennelijk inzag hoezeer deze man 
persoonlijk onmisbaar was. ${ }^{63} \mathrm{Zijn}$ echtgenote moest echter in Westerbork achterblijven en hun volwassen kinderen werden gedeporteerd. Slechts één van de drie kinderen overleefde de oorlog. ${ }^{64}$

Joodse artsen die niet behoorden tot een van de uitzonderingscategorieën, waren inmiddels gedeporteerd of hadden zich tot illegale reddingsmiddelen gewend. De legale middelen hadden hun niet voldoende veiligheid geboden, ondanks alle pogingen die zij hadden gedaan, vaak zelfs meerdere tegelijkertijd. Het voorbeeld van Salomon Koster is typerend. Koster, wiens eerste vrouw niet-Joods was geweest, was begin 1943 nog vrij optimistisch door de diverse beschermingsmaatregelen die hij en zijn Portugees-Joodse tweede vrouw voor zichzelf getroffen hadden:

Onze kansen, om in Amsterdam te mogen blijven, leken zeer gunstig. Ik had het stempel op mijn persoonsbewijs van 'gemengd huwelijk met kinderen, mijn vrouw had, behalve het stempel van den Joodschen Raad als doktersvrouw, bovendien, na een half jaar bemoeienis, via onze advocaten, die ik elke week een of twee malen bezocht, een paar brieven gekregen van het Departement van Binnenlandsche Zaken en van Calmeyer, den Duitschen hoofdambtenaar, die over de plaatsing op de lijsten van de Portugeesche Joden besliste, brieven, waarin stond, dat haar naam op de aanvullende lijst voorkwam. ${ }^{65}$

Ook deze ogenschijnlijk veilige situatie bleek niet stabiel. Voor Koster kwam er een moment waarop hij zijn oude leven en zijn beroepsplichten acuut liet vallen, om voor zijn eigen lijfsbehoud en dat van zijn vrouw te kiezen. Dat was voor hem op Is april 1943, de dag dat tegen alle verwachtingen in zijn schoonmoeder opgepakt was. De Kosters hadden op dat moment het gevoel nog maar één keuze te hebben: wegwezen!

\section{DE ILLEGALE OPTIE: ONDERDUIKEN}

In de loop van 1943 hadden veel artsen, na een uitgebreide zoektocht langs diverse andere (legale) reddingsopties, de stap gezet om onder te duiken. Carel Wolff zag in dat er maar één optie was: 'Je vlucht niet uit je beroep, van arts, maar het wordt je onmogelijk gemaakt om verder je werk te doen. Dus als ik niet uit mezelf hier wegga, dan word ik weggehaald. ${ }^{66}$

Vergeleken met suïcide plegen of het land ontvluchten lijkt onderduiken het minst verregaand. En toch, ook voor deze optie bestonden een zeer hoge 
drempel en grote bezwaren, ${ }^{67}$ waaronder voor artsen het vaarwel zeggen van de patiënten. Dit blijkt bijvoorbeeld uit het verhaal van Antonie Menco, huisarts in de Amsterdamse Plantagebuurt, die aanvankelijk weigerde onder te duiken: 'Uiteindelijk geeft oom Anton [Menco], die tot het laatst voor zijn patiënten klaar wil blijven staan, onder druk van zijn vrouw Jet toe. ${ }^{68}$ Izaäk Jacobs uit Winschoten had naar verluidt eveneens de mogelijkheid om onder te duiken, maar zou hebben geweigerd omdat hij zijn patiënten niet wilde achterlaten. ${ }^{69}$ Voor de artsen golden bovendien ook de bezwaren die golden voor eenieder die overwoog onder te duiken. Presser schetste ze als volgt: 'Men miste de energie, de relaties, het geld, onderschatte de gevaren der wegvoering, overschatte die van het duiken; men was bang, erg bang, verschrikkelijk bang; men wantrouwde de eigen kracht, men wilde solidair blijven met vertrekkende familieleden, onafhankelijk van anderen; men wilde anderen niet in gevaar brengen. Misschien is het dat wel of nog meer, nog veel meer.'70

Bovendien wist men niet hoelang de oorlog nog zou duren en hoelang men het schuilen vol zou moeten houden en was men bang voor ontdekking met de bijbehorende strafmaatregelen. Daar kwam nog bij dat gezinnen meestal gescheiden van elkaar werden ondergebracht en dat ouders hun kinderen dan vaarwel moesten zeggen. Arts Lena Jacobs-Melkman beschreef haar weerstand tegen een gedwongen afscheid van haar kinderen in de eerder geciteerde brief: 'En als ik dus niet absoluut zeker weet dat ze goed terecht komen, kan ik ze niet achterlaten. Het is gemakkelijk in theorie te bedenken, wat het beste is, of wat de beste kansen geeft en misschien is zelfs dat nog niet zo eenvoudig als het lijkt, maar de practijk is nog veel gecompliceerder.' ${ }^{71}$ Een extra complicatie was dat Lena in verwachting was: 'Nu kunnen we onmogelijk onderduiken met zoo'n baby op komst. Onderduiken is op zichzelf al heel moeilijk, maar met een zwart kind erbij wordt dat wel erg lastig. ${ }^{\prime 2}$ Lena en haar man waren al een keer van huis gehaald en naar de Zentralstelle gebracht, terwijl hun kinderen bij de buren waren. Lena had bij de gelegenheid vreselijk in de zenuwen gezeten over het lot van de kinderen. 'Je moet dat een keer zelf gevoeld hebben wat 't zeggen wil je kinderen zoo maar in de steek te laten voor je er goed over kunt oordelen wat dat zeggen wil deze natuurlijke band voor goed te verbreken. De kinderen zijn er te klein voor en ik kan het niet. Tenzij ik zeker weet dat 't zo het beste voor ze is. ${ }^{\prime} 3$

Zeker weten was echter een illusie. Niets kon men echt zeker weten: wat zou er gebeuren na keuze voor de onderduik? Wat zou er gebeuren na keuze voor gehoorzaamheid aan de bevelen van de bezetter? Men kon het niet goed voorspellen noch het zich voorstellen. Lena Jacobs stapte uiteindelijk over haar natuurlijke weerstand, twijfels en angsten heen en dook onder. Haar drie kin- 
deren, onder wie een pasgeboren dochtertje, liet ze ieder op een ander adres onderbrengen. Haar man Jonas Jacobs vertrouwde voorlopig op zijn sterke Joodsche Raad-Sperr en bleef bovengronds. De kinderen zouden de oorlog overleven, hun ouders, beiden op zeker moment gearresteerd, stierven in de kampen. ${ }^{74}$

Het verhaal van Lena Jacobs-Melkman is niet specifiek voor de situatie van de Joodse artsen. Het is exemplarisch voor alle moeders en vaders die de volstrekt onnatuurlijke scheiding van hun kinderen moesten aangaan. Met de onzekerheid of zij elkaar ooit weer zouden zien. Het overkwam ook artsen. Een voorbeeld is de Groningse huisarts Ies van der Hal. Na zeven jaar huwelijk was zijn vrouw Cis in 1942 eindelijk in blijde verwachting geraakt. Ies en Cis konden hun geluk niet op, maar moesten zes weken na de geboorte van hun dochter Henriëtte al afscheid van haar nemen. Ze besloten haar te laten onderduiken. Een onbekende vrouw haalde haar op en reed met haar in de kinderwagen de avondduisternis in. Ies en Cis keken haar na, zonder te weten wie de vrouw was, waar ze met hun kind naartoe zou gaan en of ze Henriëtte ooit terug zouden zien.

Dat was voor ons het ergste moment uit de hele oorlog. Ik kan de gevoelens niet beschrijven. Als ik eraan terugdenk, weet ik nog dat ik hoopte dat er een God bestond. Alles wat ik zag en meemaakte in de concentratiekampen valt in het niet bij dit moment van ellende, wanhoop en verslagenheid. Daarvoor bestond geen gebed.75

Gevoelsmatig moet dit voor alle ouders hetzelfde drama geweest zijn. Echter, dat Ies van der Hal behalve vader ook arts was, vertaalde zich in de manier waarop hij zijn dochter voorbereidde op haar onderduik. Hij riep zijn vriend Max Roeper, chirurg, te hulp en liet hem een ondiepe v-vormige incisie in het babyhuidje maken. Een litteken op Henriëttes buik zou ontstaan en Ies en Cis zouden daaraan een herkenningsteken hebben als zij - mogelijk pas na jaren - na de bevrijding hun dochter zouden zoeken. ${ }^{76}$ Normaal gesproken zou Roeper als rechtgeaard chirurg nooit ofte nimmer in een gezonde baby mogen snijden, maar in dit geval besloot hij het wel te doen. En het had het gewenste effect. Dankzij haar litteken wisten Ies en Cis zeker dat het hun dochter was die ze in 1945 weer in hun armen konden sluiten. Hoewel Ies en Cis de eerste jaren van Henriëttes leven gemist hadden, was hun beslissing achteraf de juiste gebleken.

Achteraf is het makkelijk te stellen dat onderduiken de beste keuze was, maar op het moment zelf kon men dat nog niet overzien. Niet alleen de ge- 
noemde bezwaren en het afscheid moeten nemen van alles, inclusief de kinderen, stond die keuze in de weg, ook het morele bezwaar dat men andere mensen niet in gevaar wilde brengen woog voor sommigen zwaar. Zo oordeelde Joseph Kater, zelfs nog achteraf, toen hij het alternatief kende, over zijn onderduik: 'Achteraf beschouwd heb ik heel verkeerd gehandeld. Iedereen die probeerde met een vals persoonsbewijs zijn leven te redden bracht anderen in gevaar.' 77

En toch, alle bezwaren ten spijt kozen nogal wat artsen uiteindelijk voor de onderduik. Van de 534 Joodse artsen van wie de gegevens bekend zijn, zijn 253 vroeg of laat gedeporteerd. Onder hen waren er ook die aanvankelijk ondergedoken waren maar verraden of ontdekt werden. In ogenschouw nemend dat de gemengd gehuwden meestal niet hoefden onder te duiken, net als degenen bij wie de Calmeyerprocedure of de vlucht naar het buitenland of de suïcide gelukt was, lijken minimaal I 50 onderduikers onder de Joodse artsen een voorzichtige schatting. Dat zou betekenen dat zo'n 28 procent van hen is ondergedoken. Ter vergelijking: het percentage onderduikers onder de totale Nederlandse Joodse bevolking wordt geschat op zo'n 17 procent. ${ }^{78}$ Artsen hadden van oudsher veel contacten, ook bij niet-Joden. Dit zou een verklaring voor het relatief hoge percentage onderduikers onder hen kunnen zijn. Zij vonden bijvoorbeeld bij niet-Joodse patiënten of niet-Joodse collegae onderdak. ${ }^{79}$

\section{COLLEGIALITEIT VERSUS AFHANKELIJKHEID}

De Joodse artsen golden in de ogen van de bezetter weliswaar enkel als 'Untermenschen', voor veel niet-Joodse collegae golden zij nog altijd als medeartsen voor wie de diepgewortelde collegiale loyaliteit nog steeds gevoeld werd. Die collegiale loyaliteit bevorderde hulp van niet-Joodse artsen aan hun Joodse collegae in nood. Professor A.A. Hijmans van den Bergh bijvoorbeeld kon terecht bij zijn Utrechtse leerling en opvolger C.D. de Langen, huisarts H. Rümke regelde een onderduikadres voor zijn Haagse collega Willem van Furth, Rümkes bekende broer, de psychiater H.C. Rümke, nam zijn collega Frits Salomon Meyers in huis, Jacques Reisel dook met zijn vrouw onder bij collegae Van der Valk en Picard in Amsterdam, Herman de Levies en Isaac Dasbergs onderduik werden eveneens door niet-Joodse collegae georganiseerd en Salomon Koster repte in zijn dagboek van zijn onderduikhelper collega Eerdman. ${ }^{80}$

Zeker niet alle niet-Joodse artsen stonden echter klaar om Joodse vakgenoten aan een onderduikadres te helpen. Sommigen waren bang, zoals de collega die eerst aanbood Salomon Kosters microscoop in bewaring te houden, 
en het instrument daarna toch weer terugbracht, angstig voor ontdekking bij een eventuele huiszoeking. ${ }^{81}$ 'Foute' artsen waren er ook, zoals bijvoorbeeld in lijsten aangegeven door de Engelandvaarder-artsen tijdens hun verhoren in Londen en zoals duidelijk blijkt uit hun lidmaatschap van het Medisch Front. De verzetsgeest van het Medisch Contact had echter de overhand in de Nederlandse artsenstand. ${ }^{82}$ Door middel van de estafetteberichten werd het merendeel van de artsen telkens ook aan die verzetsgeest herinnerd en in de eigen afwijzende houding ten opzichte van het antisemitisme van het naziregime gesterkt:

Nederlandsche artsen, tot hoever wilt gij het laten komen? [...] En is het soms niet in strijd met geweten en plichtsbesef dat men de verfoeilijke Joden-maatregelen al dieper laat binnendringen in de medische wereld en dat men door laksheid en slapheid medewerkt aan de vergrooting van den hygienischen nood der verpauperde, arm gestolen en gebroodroofde joodsche landgenoten, die in enkele Amsterdamsche stadswijken worden samengedrongen en die in concentratie- en werkkampen aan de bitterste ellende worden prijsgegeven. ${ }^{83}$

Het Medisch Contact verschafte ook praktische mogelijkheden voor hulp aan ondergedoken collegae. Allereerst door het landelijke netwerk, waardoor hulp ook geboden kon worden door collegae in een verder weg gelegen plaats, collegae aan wie men niet direct via vriendschappelijke of rechtstreekse collegiale banden gelieerd was, maar die wel bewezen betrouwbaar waren, omdat ze deel uitmaakten van het MC-netwerk. Ten tweede kon het Medisch Contact ook financiële steun bieden. In januari I943 was een landelijke steunactie opgezet voor collegae die in gevangenschap verkeerden, om politieke redenen uit hun betrekking ontslagen waren of ondergedoken waren. Ieder draagkrachtig lid van het Medisch Contact droeg maandelijks minstens tien gulden bij aan dit steunfonds. Ook Joodse artsen kon het Medisch Contact uit dit fonds ondersteunen. ${ }^{84}$

Het fenomeen onderduiken was onder artsen ook onontkoombaar bekender dan onder de algemene bevolking. Immers, als er een onderduiker ziek werd of overleed, nam men de plaatselijke huisarts vaak noodgedwongen in vertrouwen. Artsen hadden hun zwijgplicht beroepsmatig al geïncorporeerd en stelden zich dan ook in dit soort gevallen vaak als betrouwbaar en zwijgzaam helper op. Bovendien kon men hen vanwege hun uitzonderingspositie, met onder meer de bijbehorende vergunning om 's avonds te straat op te mogen, wel inzetten voor bepaalde klussen. ${ }^{85}$ Medisch student Sam Bos 
bijvoorbeeld dook onder in een huis waar de plaatselijke huisarts L. Burema, speciaal in verband met het verblijf van de onderduikers, een bord 'Roodvonk' voor op de deur had gemaakt. ${ }^{86}$ Huisartsen kenden hun patiënten en daarmee een hele wijk of dorp goed, en konden een redelijke inschatting maken van wie wel en wie niet te vertrouwen was. Specialisten in ziekenhuizen hadden niet zelden te maken met onderduikers in hun instelling. ${ }^{87}$ Voor de hand liggend is ook dat het artsenberoep an sich het helpen van de medemens bevorderde. Mensen helpen, levens redden: de arts was niet anders gewend en deed het - ook in dit geval - ogenschijnlijk vanzelfsprekend. Al deze factoren droegen ertoe bij dat zij als groep - zowel ideologisch als praktisch - relatief geschikt waren om het onderduiken te faciliteren. ${ }^{88}$

Frits Klein, internist uit Groningen, herinnerde zich hoe hij diepgeraakt was door de vanzelfsprekendheid van de hulp geboden door de hem onbekende collega Lex Kerssemakers uit Veghel, die twee jaar lang zijn dochter verborgen hield:

Ik heb hem en zijn vrouw na de oorlog, voor het eerst in zijn fraaie dokterswoning ontmoet. Te mogen ervaren, dat het voor hen de meest vanzelfsprekende zaak was geweest, dit joodse, voor hen vreemde, kind te verzorgen (en hoe!) en tevens hun oprechte, intense vreugde, dat haar ouders nog leefden, was voor mij een openbaring en een les voor het leven. Zijn vrouw en hij hebben steeds de instelling gehad: wat kunnen wij voor anderen, wie ook, doen. ${ }^{89}$

Niet-Joodse artsen riskeerden met hulp aan Joodse onderduikers veel. Dat artsen als de internist W.F. Noordhoek Hegt en de kinderarts Ph.H. Fiedeldij Dop, om twee belangrijke voorbeelden te noemen, op grote schaal verzet pleegden en onderduikadressen voor Joodse collegae, kinderen en andere Joodse landgenoten organiseerden, vereiste dan ook moed. ${ }^{\circ}$

De keerzijde van de geboden hulp van niet-Joodse collegae was dat het wel een volgende stap was in het statusverlies van de Joodse arts. Onvermijdelijk ontstond een afhankelijkheidssituatie van de Joodse ten opzichte van de nietJoodse beroepsgenoten. Joodse artsen konden, hoe graag men dat ook mocht willen, niet meer als gelijken gezien worden, daarvoor was hun situatie te afwijkend. Een symptoom daarvan was al dat Joodse artsen weliswaar als lid van Medisch Contact werden gezien, maar meestal niet konden deelnemen aan de protestacties. Dit was hun immers vanwege de veiligheid actief afgeraden..$^{9 r}$

Protest tegen de Artsenkamer was de Joodse artsen in dezelfde lijn eveneens ontraden. En zo was het mogelijk dat op een ledenlijst van de Artsenkamer uit 
I943 van de 1327 namen van leden er 208 toebehoorden aan Joodse artsen. ${ }^{92}$ Loe de Jong schatte het aantal Joodse artsen dat het advies van Medisch Contact niet opvolgde en geen lid werd op honderd, ${ }^{93}$ maar dat kunnen er heel goed een stuk meer zijn geweest. Of de gevonden ledenlijst compleet is, is echter niet zeker. Het Medisch Contact adviseerde de Joodse artsen lid van de Artsenkamer te worden. ${ }^{94}$ Medisch Contact voorman W.F. Noordhoek Hegt memoreerde na de bevrijding: 'Van de plm 7000 artsen, hebben waarschijnlijk plm I600 (waaronder 250 NsB'ers en 600 Joodsche artsen, die door ons steeds zijn aangeraden niet deel te nemen aan het verzet) de formulieren [voor de Artsenkamer] ingezonden. '95 Hoe het ook zij, van ten minste 208 Joodse artsen was nu dus, naast al het andere dat hun al ontnomen was, ook hun politieke integriteit afgepakt. De bezetter had hun op alle fronten minderwaardigheid opgelegd, en de acties van Medisch Contact makten het kunstmatige onderscheid tussen Joodse en niet-Joodse collegae nog eens extra pijnlijk voelbaar.

Afhankelijkheid, rechte- en brodeloosheid en een gevoel van minderwaardigheid culmineerden in de onderduiksituatie. Afhankelijker van anderen kon je niet worden. Zo schetste ook de uit Duitsland gevluchte arts Hans Keilson in zijn roman Komedie in mineur de totale afhankelijkheid van de onderduiker:

Al was er niet de geringste aanwijzing in die richting, toch namen de gevreesde gedachten van de anderen hem gevangen: 'Als we hem nu niet hadden, dan konden we...' of: 'Wij hebben toch ook een..., dan is het niet zo eenvoudig. En gevaarlijk ook.' - Dat is een ziekte, de gedachteziekte van de onderduiker. Die vreet aan je vertrouwen, sloopt je onbevangenheid en maakt je een ondankbare hork of slappeling. Bijna niemand blijft dan recht overeind. ${ }^{96}$

Recht overeind blijven, dat was de kunst voor de onderduiker. Onderduiken kon weliswaar je leven redden, maar ten koste van welke prijs? Voor de hoofdpersoon van Komedie in mineur was de psychologische prijs hoog: 'Het betekende zijn vernietiging, zijn vernietiging als mens, ook al redde het zijn leven, misschien.' 97

Onderduiken vroeg nogal wat van iemands mentale reserves. Nooit naar buiten mogen, niet hardop mogen praten, altijd in dezelfde ruimte verkeren, in eenzame opsluiting, of juist altijd met dezelfde mensen op een kluitje, van adres naar adres gesleept worden, weinig mensen zullen alleen al die praktische beperkingen makkelijk geaccepteerd hebben, laat staan met de angst en onzekerheid waarmee onderduikers leefden. Salomon Koster diagnosticeerde zich- 
zelf met een depressie en had suïcidale neigingen. In zijn dagboek noteerde hij: 'Neen, ik houd dit leven niet uit, ik houd het niet uit.' ${ }^{98}$ Zijn vrouw kon hem er, in het belang van de helpers, de kinderen en de patiënten voor wie hij er na de oorlog weer moest zijn, van afhouden om zijn flesje gif in te nemen. ${ }^{99}$ Philip van Blankenstein was naar verluidt 'te rusteloos om onder te duiken'. Hij werd opgepakt en via Westerbork en Theresienstadt naar Auschwitz gevoerd, alwaar hij vermoord werd. ${ }^{\text {Ioo }}$ Collega Herman Musaph, reeds vroeg ondergedoken, probeerde de bij hem opkomende 'negatieve affecten' na de enorme overgang van een drukke huisartspraktijk naar een gedwongen nietsdoen, tegen te gaan door extreem veel te slapen. ${ }^{\text {Ior }}$

Ook Keilsons alter ego vocht tegen zijn eigen sombere gedachten, maar won het meestal niet. Hij moest telkens opnieuw denken aan de treinen die onophoudelijk naar het oosten reden en werd dan overmand door verdriet en angst dat de bevrijding nooit op tijd zou komen voor hemzelf en voor al die anderen. 'Dat was het diepste punt, dieper kon niet. Dat punt bereikte hij vaak - al te vaak.' ${ }^{\text {Iог }}$ Het altijd maar smachten naar de bevrijding, die zo oneindig lang op zich liet wachten, viel de onderduiker zwaar. En elke dag opnieuw loerde het gevaar van voortijdige ontdekking.

... de gruwelijke, hulpeloze angst, die omhoogkomt uit het verdriet en de wanhoop en aan niets meer houvast vindt - de hulpeloze angst die alleen nog het niets vindt. Geen angst of wanhoop om een mens of om een ding, niets, niets, alleen maar overgeleverd zijn, losgeslagen van elke zekerheid, van elke waardigheid, elke liefde. ${ }^{103}$

Losgeslagen van elke zekerheid en volledig overgeleverd, dat waren ook de artsen die zich kort daarvoor nog onmisbaar voor hun patiënten hadden gevoeld, die aanzien hadden genoten en er een hoge moraal op na hielden. Als onderduiker waren zij nu in de eerste plaats vervolgde en niet meer in de eerste plaats (mede)arts. Hun arts-zijn onderscheidde hen niet meer van andere ondergedoken Joden.

De vakliteratuur bijhouden was voor velen een manier om toch nog een beetje arts te blijven. Zij konden zo binding met het vak blijven voelen en de psychologische ondergang tegengaan. Salomon Koster leefde op toen hij een studente medicijnen, bij de buren ondergedoken, les kon geven. ${ }^{\text {IO } 4}$ Voor Herman Musaph werden psychiatrieboeken verzorgd, zodat hij aan zijn proefschrift kon werken. ${ }^{\text {IOS }}$ Het netwerk van artsen en verpleegkundigen uit de kennissenkring van de Joodse internist Leopold Meijler en zijn echtgenote, die verpleegster was, zorgde voor de in Groningen ondergedoken arts Govert de 
Haas. Mevrouw Meijler gold als half-Joodse en hoefde daarom niet onder te duiken. De groep onderduikhelpers waar zij deel van uitmaakte, zorgde ook voor roulatie van medische boeken. ${ }^{106}$ Maar hoe prettig en essentieel die aanvoer van geestelijk voedsel ook was, toch was het natuurlijk alleen medische theorie waar men zich mee bezighield. Het echte medische beroep konden zij niet uitoefenen.

\section{DE DOKTER INCOGNITO}

Van enkele Joodse artsen is bekend dat zij tijdens hun onderduikperiode nog echt praktisch als arts konden werken. Het varieerde van af en toe een klein medisch klusje bij een patiënt van wie de onderduikgevers zeker wisten dat deze volledig betrouwbaar was, zoals bij huisarts Guus Monnickendam uit Rotterdam, tot een volwaardige praktijk onder een valse naam. ${ }^{107}$ De Amsterdamse huisarts David Granaat bijvoorbeeld kreeg het voor elkaar een volledige praktijk te voeren. Hij solliciteerde als 'José van Ingen' naar de functie van waarnemer voor een aan tbc lijdende huisarts in Schoonhoven. Zijn donkere uiterlijk verklaarde hij door een Spaanse grootvader. ${ }^{108}$ Herbert Muller, die in 1942 nog net artsexamen had kunnen doen, nam onder de naam 'Joop van der Meer' waar in de praktijk van zijn studievriend Paul Niks in Rijswijk. ${ }^{\text {Io9 }}$

In het dorpje Halle bij Zelhem kwam in 1944 een waarnemer met zijn gezin wonen, toen de plaatselijke huisdokter Meijering gearresteerd was voor het verstoppen van Joodse onderduikers in zijn huis. De waarnemer luisterde naar de naam Lindekamp. De kinderen Lindekamp gingen naar school in het dorp en de fietsenmaker van het dorp bood de familie onderdak. Pas na de bevrijding werd duidelijk dat dokter Lindekamp eigenlijk dokter Isaak Cohen heette. ${ }^{\text {IIO }}$ Gerard K. Levy uit Amsterdam zou zelfs, volgens de herinneringen van zijn echtgenote en dochter, gedurende een periode onder de naam Jonker in een Utrechts ziekenhuis hebben gefunctioneerd als waarnemend directeur. Een patiënt die hem zonder ster in de trein tegenkwam, zou hem verraden hebben. ${ }^{\text {III }}$

Johnny van Coevorden, die in het NIZ al zijn moed en bravoure had getoond, begon ook aan een zwervend bestaan als onderduiker toen De Joodsche Invalide werd leeggehaald. Met het excuus dat hij zijn operatiekleren nog aanhad en zich eerst wilde verkleden, wist hij aan arrestatie te ontkomen, door via het dak van de JI en de naastgelegen GGD te vluchten. Boekhandelaar van Eijck was zijn contactadres voor de onderduikomzwervingen die volgden. Van Coevorden verbleef in Terneuzen, Den Helder en Winschoten en overal kon 
hij in zijn eigen vak werken. ${ }^{\text {II2 }}$ Zolang hij ver weg bleef van Amsterdam, kon dit blijkbaar goed gaan.

Een dergelijke waarneemsituatie kwam enkele malen meer voor, inderdaad meestal ver weg van het gevaarlijke en tumultueuze Amsterdam, in kleine dorpen of provinciestadjes. Bizarre voorvallen en morele dilemma's kwamen onder deze omstandigheden ook voor.

Allereerst werd het behandelen van niet-Joden weer mogelijk, inclusief NSB'ers en Duitsers. Frits Klein, ondergedoken bij laborant Leegstra van zijn vroegere werkkring, de interne kliniek van het Academisch Ziekenhuis Groningen, kon 's avonds na de thuiskomst van zijn onderduikgever vaak medische casuïstiek bespreken. Op een dag kwam Leegstra, naar verluidt, thuis met een electrocardiogram, dat hij die dag had gedraaid bij NsB-leider Anton Mussert, patiënt van professor Kreuzwendedich von dem Borne. Klein beoordeelde het ecg en kwam tot de conclusie dat Musserts cardiale conditie weliswaar te wensen overliet, maar dat hij niet in levensgevaar verkeerde. ${ }^{113}$ Ook collega Alfred Behrendt kwam in een nogal verwarrende situatie terecht. Hij, weliswaar gemengd gehuwd, gedoopt en gecalmeyerd en daarom zonder ster en niet echt ondergedoken, was in de luwte gaan leven in een dienstgebouw van het jachtslot Sint Hubertus op de Hoge Veluwe. En ook hij kwam daar op een zeker moment als arts in aanraking met de vijand. In april 1945 ontfermde hij zich over een gewonde Duitse soldaat:

Een gewonde - Fischer heet hij - gaat zeker dood. Granaatsplinter in de long, de rug is opengereten en je kan de long van buiten zien. Enorm bloedverlies. Ik troost hem 't Is niet zo erg.' Hij gelooft het gelukkig. ${ }^{\text {II }}$

Bijzonder was het verhaal van Joseph Kater. Op een zekere dag, begin I943, was hij met een vals persoonsbewijs en wat gespaard geld op de fiets gestapt alsof hij een patiënt ging bezoeken. In plaats daarvan ging hij naar een bevriend collega in wiens huis hij de ster van zijn jas haalde. Van tevoren had hij het gerucht laten verspreiden dat hij was opgepakt en als strafgeval op transport gesteld. Zonder ster en met nieuwe naam begon hij een bovengrondse onderduikcarrière als waarnemer in verschillende praktijken. Zogenaamd was hij altijd scheepsarts geweest en had hij door de oorlogssituatie geen werk meer. Het waarnemen ging hem goed af, maar het bracht hem ook in lastige situaties, zoals zijn contact met een Duitse patiënt:

Eén der ss officieren liet mij vragen op zijn kamer te komen, omdat hij ziek was. Nadat ik hem had onderzocht begon hij over de politieke en 
militaire situatie te praten, maar ik zei rustig dat ik me als arts daar nooit mee bemoeide. Toch ging hij door en haalde natuurlijk ook het Judenfrei machen erbij, en de verderfelijke invloed die de Joden hadden uitgeoefend. 'Ein Jude stinkt' hoor ik hem nog zeggen, maar hield wijselijk het advies voor me dat hij dan maar gauw zijn neus moest laten onderzoeken. Zoiets lag dan op het puntje van mijn tong... ${ }^{\text {II }}$

Naast de weerzin die Kater en de andere Joodse artsen waarschijnlijk gevoeld hebben, leverden dergelijke gevallen ook gevaar op. Gevaar dreigde natuurlijk van alle kanten voor de artsen die zich op deze manier door de oorlog probeerden te manoeuvreren. En daarmee wordt een andere mogelijke ingewikkelde situatie onder deze omstandigheden zichtbaar. In de plaats waar Kater aanvankelijk werkte was een groot bedrijf waarvan enkele medewerkers Kater van vroeger bleken te kennen. Dit was aanleiding om zo snel mogelijk een nieuwe betrekking te zoeken. In zijn nieuwe baan in een ziekenhuis overkwam hem iets soortgelijks toen Joodse gevangenen uit een nabijgelegen concentratiekamp op zijn afdeling werden opgenomen. Ook zij kenden hem onder zijn eigen naam, wat direct gevaar op ontmaskering betekende en dus vervolgde Kater zijn zwervend bestaan. Geen eenvoudig bestaan, hoe prettig het ook was dat hij medisch werk kon doen.

E.A. Rodrigues Pereira kreeg op zijn onderduikadres eveneens te maken met een situatie die hem dwong een keuze te maken tussen zijn plichten als arts en zijn eigen veiligheid, zo vertelt de familiegeschiedenis van de onderduikgevers. Vermoedelijk was het in 1944 dat voor het huis in Hellendoorn waar Pereira, zijn vrouw en zijn dochter als zogenaamde evacués uit Den Haag verbleven, een ongeluk plaatsvond waarbij een Duitse soldaat gewond raakte. De soldaat werd in het grote huis - zowel bakkerij, winkel als boerderij -, binnengedragen. Rodrigues Pereira ging in Hellendoorn weliswaar als meneer Starkenburg, beslist geen dokter, door het leven, maar besloot op dit moment toch als arts op te treden. Hij verbond de wond. Echter, de toegesnelde jonge Hellendoornse huisarts R. ter Borg zag onmiddellijk dat deze wond niet door een leek kon zijn verzorgd. Hij doorzag de situatie waarschijnlijk, aangezien hij de zoon van de onderduikgever, E.J. Teesselink, hierop waarschuwde dat de 'evacué dit nooit meer mocht doen, daar hij hierdoor zijn werkelijke beroep en identiteit verraadde. ${ }^{\mathrm{II} 6}$ Geheimhouding was van het allergrootste belang. Enerzijds hielp het Joseph Kater in mentaal opzicht dat hij zijn eigen werk kon blijven doen, anderzijds drukte het grote geheim zwaar op hem. Vooral de verantwoordelijkheid ten opzichte van degenen om hem heen, die hij potentieel in gevaar bracht, bezwaarde hem: 
Mijn leven was dubbelslachtig. Door normaal als arts te praktiseren stond ik midden in het gewone dagelijkse bestaan, zowel sociaal als in mijn beroep. [...] Maar elke seconde leefde ik onder de druk dat het mis kon gaan, waarbij ik me ook steeds afvroeg of de collega in wiens praktijk ik werkte en die van mijn Joodse identiteit niets afwist, gevaar zou lopen als dit aan het licht kwam. ${ }^{\mathrm{II}}$

Zozeer zelfs drukte dit op hem dat hij achteraf oordeelde dat hij verkeerd had gehandeld.

In dit relaas heb ik al eerder gezegd dat ik er achteraf spijt van heb gehad als arts te hebben doorgewerkt, dankzij een goed nagemaakt persoonsbewijs zonder de fatale letter J erop. Het ging er toen voor iedereen in de eerste plaats om het vege lijf te redden, en direct daarna ook het leven van anderen. ${ }^{\text {II } 8}$

Zijn eigen vege lijf probeerde Kater inderdaad te redden, met nog een beetje extra erbij: zijn menselijke waardigheid als gewaardeerd deel van de samenleving, als arts. Zijn autonomie als gerespecteerd medicus, zoals hij die voor de bezetting gekend had, had hij zo graag willen behouden:

Geen enkele Nederlander die zijn hele leven als een volwaardig mens in ons landje had gewoond en gewerkt, kon zich schikken in de ontmenselijking waaraan hij ten prooi viel. Wanneer je van de ene op de andere dag vogelvrij wordt, terwijl je in de volle kracht van je leven staat en tot op dat ogenblik als een geheel volwaardig en nuttig mens een bestaan hebt opgebouwd, probeer je alles om je vrijheid te behouden. ${ }^{\text {II }}$

En hoewel vrijheid, zelfs in de relatief gunstige positie van Kater, een utopie was, had hij wel de mogelijkheid arts te blijven en kon hij met zijn beroep het leven van anderen blijven redden.

\section{VERZET}

Andere Joodse artsen vonden ook nog manieren om zich nuttig te maken voor een hoger doel dan alleen hun eigen veiligheid. Ook zij vonden, net als Kater, methoden om het eigen vege lijf te redden en tegelijkertijd iets voor anderen te betekenen. In feite zou men kunnen stellen dat iedere Jood die niet gehoor- 
zaamde aan de Duitse order om mee te gaan met de deportaties, zich verzette, ook onderduikers en vluchtelingen. Sommigen gingen verder door ook de algemene goede zaak en het welzijn van anderen te willen dienen.

Zo konden Joodse artsen die in maart 1943 nog praktiseerden, zich openlijk verzetten door mee te doen aan de zogenoemde bordjesactie. Deze actie van het Medisch Contact behelsde het symbolisch afstand doen van de artsentitel door op naambordjes aan de deur het woord 'arts' door te halen of af te plakken. Hetzelfde gebeurde met receptpapiertjes en briefpapier. Doel van dit al: voorkomen dat men automatisch, door het voeren van de artsentitel, als lid van de Artsenkamer gezien zou worden. Die regel was ingevoerd vanwege de geringe respons van de artsen op eerdere mildere pogingen tot ledenwerving van de Artsenkamer. De bijbehorende brief aan Seyß-Inquart, waarin men aangaf afstand te doen van de bevoegdheid tot uitoefening van het artsenberoep, werd uiteindelijk door 6200 artsen ondertekend en opgestuurd. Dit aantal was dus nog hoger dan de 5000 die aan de meeste MC-acties meededen. Vermoedelijk waren enkele Deutschfreundliche artsen mee gaan doen omdat zij bij het publiek, dat onder de indruk was van deze 'artsenstaking', niet als NSB'er te boek wilden staan. ${ }^{120}$ Gezien het hoge aantal ondertekenaars is het zeker dat er ook Joodse artsen bij waren.

De bordjesactie, door de bezetter min of meer smalend 'Klebe-aktion' (pleisteractie) genoemd, oogstte bewondering van bijvoorbeeld de jonge Mirjam Levie, secretaresse bij de Joodsche Raad, die in een passage in haar dagboek schreef:

Ongeveer alle doktoren hebben dat gedaan, zodat er, theoretisch dan altijd, bijna geen 'dokter' meer bestaat, doch alleen kwakzalvers. Ze mogen natuurlijk geen recepten schrijven, geen doodsakten tekenen enz enz. En het ergste is dat de meesten niet thuis slapen, omdat ze vrezen gehaald te worden en als iemand dus's nachts een dokter nodig heeft, bv voor een bevalling, dan is het reuze beroerd. We zijn erg nieuwsgierig wat er zal gebeuren, want zo zonder doktoren kunnen ze toch niet. Het is wel een mooie houding, hoor. ${ }^{\text {I2I }}$

Joseph Kater vond het indrukwekkend, maar was, in zijn specifieke situatie, tegelijkertijd ook bang voor represailles op artsen. Niet ten onrechte, want inderdaad werden er na de bordjesactie diverse artsen gearresteerd. ${ }^{122}$ Door de grote saamhorigheid van de actie was het voor de bezetter echter moeilijk om adequaat te reageren. Iedereen arresteren die mee had gedaan zou immers de volksgezondheid ernstig in gevaar brengen. Inbinden restte hem dus en de art- 
sen boekten succes met de actie: zij hadden eens te meer getoond nazificering van hun beroep niet te dulden. ${ }^{\mathrm{I} 3}$ De Artsenkamer werd een grote mislukking en de artsenstand had een duidelijk statement gemaakt, niet alleen richting bezetter, maar ook naar de rest van de bevolking. Salomon Koster zag een rechtstreeks verband tussen de bordjesactie en het hoge aantal studenten medicijnen dat even later de loyaliteitsverklaring weigerde te tekenen. ${ }^{\mathrm{I} 4}$ Hierna weigerden op hun beurt de assistenten in academische ziekenhuizen, die een belangrijke taak vervulden in het onderwijs aan medisch studenten, nog les te geven aan hen die zich wel loyaal hadden verklaard. ${ }^{\mathrm{I} 25}$ Dit 'assistentenverzet' duurde van augustus tot december 1943 en viel samen met het 'hooglerarenverzet', waaraan ook medici deelnamen, zoals hoogleraar interne geneeskunde J.G.G. Borst. ${ }^{\mathrm{I} 6}$

In verband met de verzetsgeest verdient de houding van de medisch studenten een vermelding. Hoewel ook onder de studenten NsB' ers waren, waren er relatief veel studenten actief in het verzet. Met name in Amsterdam waren dat Joodse en niet-Joodse studenten, die hechte contacten onderhielden. Met elkaar en met verzetsgroeperingen, bijvoorbeeld in de groep die een aanslag pleegde op het bevolkingsregister. ${ }^{\text {I27 }}$ Nog enkele voorbeelden: Max Hamburger was betrokken bij het vervalsen van persoonsbewijzen in de groep van Lau Mazirel, Willy Hijmans smokkelde mensen over de grens via de lijn DutchParis, Izak Baruch werkte voor verzetsman Koos Vorrink en zorgde ook voor vlucht-opties naar Frankrijk. ${ }^{\mathrm{I} 28}$

Ook onder de afgestudeerde Joodse artsen waren er die bereid waren nog extra risico's te nemen en zich aansloten bij verzetsorganisaties. Ben Polak schreef voor het illegale blad Vrije Katheder en was actief in het communistische verzet, samen met onder anderen de Haagse (niet-Joodse) zenuwarts Gerrit Kastein. ${ }^{\text {I29 }}$ Frits Grewel en David de Miranda waren betrokken bij de groep rond het illegale blad Het Parool, waarbij De Miranda bovendien persoonsbewijzen vervalste en kinderen uit de crèche van de Hollandsche Schouwburg hielp smokkelen in het kader van de organisatie van Joop Woortman. ${ }^{130}$ David Granaat nam met zijn niet-Joodse echtgenote een Joods kind als onderduiker op, ${ }^{13 \mathrm{I}}$ Bernard Premsela zou kinderen van patiënten naar onderduikadressen hebben laten brengen, ${ }^{\mathrm{I} 2}$ Abraham Gans stond in Leiden bekend als verzetsman, ${ }^{\mathrm{I} 33}$ Margaret Danby in Oss, Jo Kalker werd als zodanig genoemd in de verhoren van de Engelandvaarders en Max Roeper werd gearresteerd vanwege verzetsactiviteiten, Mani (Emanuel) Leisen raakte betrokken bij de persoonsbewijzencentrale van Gerrit van der Veen, en arts en componist Nico Richter was al in I94I in het georganiseerde verzet gegaan. ${ }^{134}$ Coen van Emde Boas, door een Calmeyerprocedure 'ontjoodst', organiseerde in zijn huis bijeenkom- 
sten van het verzet en gaf berichten door van de Engelse radio die hij op zijn zolder verstopt had. ${ }^{135}$ Van Norbert Neufeld is bekend dat hij antifascistische propaganda verspreidde. ${ }^{136}$ Simon van Creveld schreef in het illegale blad De Keten in het Gooi. ${ }^{137}$ Betty Levie raakte diep verzeild in de verzetsgroep rondom Philips-ingenieur Hajo Bruining, die zij kende door haar contact met stralendeskundige Daniël den Hoed en haar eigen werk in de röntgenologie, waarvoor de techniek veelal door Philips geleverd was. ${ }^{138}$ Isaak Cohen hielp bij het wegsluizen van Amerikaanse piloten. ${ }^{139}$ De Engelandvaarders ten slotte zijn al eerder genoemd, maar passen zeker ook in dit verband van zich actief verzettende Joodse artsen.

In elk geval eén van de Joodse artsen in het georganiseerde verzet kon zijn arts-zijn zelfs in zijn illegale rol goed gebruiken. Sterker nog, dat arts-zijn was aanleiding geweest voor het verzet om juist hem voor de klus te vragen. Het ging om Hans Keilson, de gevluchte Duits-Joodse arts en specialist in de kinderpsyche, die via zijn onderduikgevers in aanraking kwam met de Vrije Groepen Amsterdam. Deze organisatie verzorgde onder andere onderduikadressen voor Joodse kinderen in heel Nederland. In de praktijk bleek dat dit onderduiken voor kinderen regelmatig problemen opleverde, bijvoorbeeld als een kind niet aardde in het gezin waar het terechtkwam, raar gedrag ging vertonen, heel stil was of juist veel ruziemaakte. Om te voorkomen dat een dergelijk geval uit de hand zou lopen, werd dokter Keilson, alias dokter Van der Linden, naar deze gezinnen gestuurd om met het kind te praten en te bemiddelen tussen het kind en de onderduikouders. Zodoende reisde Keilson het land door, van het ene kind in geestelijke nood naar het andere. Hij wist het zelfs klaar te spelen over de problemen die hij tegenkwam een manuscript te schrijven, dat hij voor de veiligheid in de tuin begroef, om het na de bevrijding uit te werken tot een proefschrift. ${ }^{140}$ Daarmee leefde hij hetgeen hem door zijn vader op het hart gedrukt was na: hij vergat niet dat hij arts was. 



\title{
9. ARTS IN GEVANGENSCHAP
}

\author{
JOODSE ARTSEN IN DE KAMPEN IN NEDERLAND
}

Artsenvoorrechten en zoektochten naar reddingssloepen en vluchtwegen ten spijt, ten minste 253 Joodse artsen werden op zeker moment slachtoffer van de deportatiemachinerie. Net als de circa 107 ooo Nederlandse Joden - ruim driekwart van alle Joden in Nederland - die dat lot deelden, waren zij weerloos tegenover de terreur die ook hun ten deel viel. Ook zij belandden in nazigevangenschap, waar zij werden blootgesteld aan vernedering, mishandeling en ten slotte vernietiging in Oost-Europese moordkampen. Dat zij arts waren had dat niet kunnen voorkomen. Kon het beroep van arts onder deze omstandigheid, van gevangenschap en levensbedreiging in een van de nazikampen, überhaupt nog een rol spelen?

\section{KAMPEN OP NEDERLANDSE BODEM}

De meesten van de 253 gedeporteerde Joodse artsen belandden eerst in het Polizeiliches Durchgangslager Westerbork, vanwaar zij verder naar concentratiekampen in bezet Polen en Duitsland werden gevoerd. Vanaf januari 1943 bestond er ook in Vught een Durchgangslager voor Joden, hoewel dit kamp anvankelijk aan de Joodse bevolking was voorgesteld als een permanente verblijfplaats, een 'Auffangslager'. Voorts bestonden er nog drie kampen op Nederlands grondgebied waar Joden gevangen werden gehouden, te weten Amersfoort, Schoorl en Ommen. Ommen is al genoemd in verband met de 
voorbereiding voor de werkkampen voor Joodse mannen die in de eerste helft van 1942 in gebruik werden genomen. Kamp Erika, zoals het concentratiekamp in Ommen genoemd werd, kende uiteindelijk echter slechts twaalf Joodse gevangenen. Zij arriveerden in augustus 1942 en werden er blootgesteld aan ernstige mishandeling, alvorens ze naar Westerbork werden gebracht. ${ }^{\text {I }}$ Voor zover bekend was onder deze twaalf geen arts. In kamp Schoorl heeft na Jacques Reisel, die dankzij zijn beroep en zijn contacten in de medische wereld snel na zijn internering in juni I94I vrij was gekomen, geen Joodse arts meer gevangengezeten.

In Amersfoort, Vught en Westerbork zaten meerdere Joodse artsen en in al deze kampen was een bepaalde vorm van medische verzorging voorhanden. Tussen de kampen bestonden echter grote verschillen in het aanbod aan medische zorg en ook in de mate waarin Joodse artsen een bijdrage aan die zorg konden leveren. Daarmee samenhangend is ook een verschil waarneembaar in de mate waarin de artsen zelf nog profijt hadden van hun beroep. Kortom, in hoeverre het artsenberoep een rol kon spelen verschilde per kamp.

\section{KAMP AMERSFOORT}

Kamp Amersfoort, ofwel Polizeiliches Durchgangslager Amersfoort, geopend in de zomer van 194I, ressorteerde onder de Befehlshaber der Sicherheitspolizei und des SD. Met name illegale werkers en andere in de ogen van de bezetter politiek gevaarlijke elementen, maar ook eenvoudige zwarthandelaren of clandestiene slachters, kwamen hier terecht terwijl hun zaak in onderzoek was bij de Sicherheitspolizei. Uitkomst van een dergelijk onderzoek kon betekenen dat zij een bepaalde periode in 'Schutzhaft' opgelegd kregen, die in concentratiekampen in Duitsland moest worden uitgezeten. Vanaf januari 1943 konden veroordeelden hun Schutzhaft echter ook uitzitten in Nederland en wel in het Konzentrationslager Herzogenbusch, ofwel Kamp Vught. Zowel in Amersfoort als in Vught zijn Joodse gevangenen onder deze Schutzhäftlinge geweest. $^{2}$

Amersfoort was een berucht kamp. De loodzware arbeid, de bar slechte voeding en de sadistische mishandelingen van bij uitstek de Joodse gevangenen kon de ongelukkigen ter plaatse fataal worden. ${ }^{3}$ Ongeveer een op de tien gevangenen in Kamp Amersfoort was, in de periode tot de opening van Kamp Vught in januari I943, als Jood geregistreerd. ${ }^{4}$ Onder de in totaal 35000 Häftlinge die er gedurende de hele bezetting verbleven, waren in elk geval twaalf Joodse artsen, van wie er twee de oorlog overleefden. Hun exacte ver- 
grijpen zijn niet bekend, maar Joden kwamen over het algemeen in Amersfoort terecht als zij de voor hen geldende bepalingen hadden overtreden of als zij beschuldigd werden van verzetsactiviteiten. ${ }^{5}$ Richard Bromberg was naar Amersfoort gevoerd als vergelding voor de protestactie van de katholieke kerk in juli 1942. Wat de misdaad dan ook was die de andere Joodse artsen gepleegd zouden hebben, voor de meesten stond er de doodstraf op. Bijna 800 van de in Amersfoort geïnterneerde Joden werden naar Mauthausen gedeporteerd. De andere honderden gingen, meest via Westerbork, hun ondergang in OostEuropa tegemoet. $\mathrm{H}$. Wielek schreef over de anblik van de mannen in het transport vanuit Amersfoort dat op I6 juli 1942 via Westerbork naar Auschwitz reed en waar de Joodse artsen De Wit en Zeehandelaar deel van uitmaakten: 'Dat deze vermagerde, uitgeputte mannen, die, hoe oud of hoe jong ook, oude mannen waren met vaak iets verwilderds in hun gezichten, een paar weken of maanden geleden nog volwaardige mensen waren geweest, vroeger veel gepresteerd hadden... Dat dit alles op Nederlandse bodem kon gebeuren...!'

De jonge Amsterdamse arts Willem Polak vond al in Kamp Amersfoort zelf de dood. Hij leed aan moeilijk instelbare diabetes mellitus en had in Amsterdam, in hypoglycemische toestand (te laag bloedsuiker), met de daarbij passende verwardheid, de bezetter op straat klaarblijkelijk dusdanig geërgerd dat hij was gearresteerd. ${ }^{7}$ Hij werd naar Amersfoort gestuurd, waar hij op 27 november 1942 omkwam, zogenaamd 'auf der Flucht erschossen', een doodsoorzaak die de kampartsen te pas en te onpas inzetten, ook als heel andere oorzaken aan het overlijden ten grondslag lagen, zoals mishandeling of het onthouden van noodzakelijke medicamenten. ${ }^{8}$ De kampartsen van Amersfoort, NSB'ers, genoten een buitengewoon slechte reputatie. De leidinggevende arts N. van Nieuwenhuysen verdacht al zijn patiënten ervan hun klachten te simuleren en trad uitermate wreed tegen hen op. Zijn opvolger J.H. Klomp leek iets humaner, maar was in de praktijk nauwelijks beter dan zijn voorganger. De gevangenen van Amersfoort hadden niet tot nauwelijks de mogelijkheid behoorlijke medische verzorging te krijgen. Medici onder de gevangenen konden daarop praktisch geen invloed uitoefenen. Zij kregen niet de kans iets met hun beroep te doen. Slechts een enkele uitzondering is bekend. De gevangen Amsterdamse niet-Joodse hoogleraar J.G.G. Borst had nog enig overwicht over Van Nieuwenhuysen en kon soms iets ten positieve beïnvloeden door hem van behandeladviezen te voorzien. ${ }^{9}$

In elk geval twee Joodse artsen probeerden als medicus iets te doen. Van Elie Cohen is de meeste informatie overgeleverd, omdat hij overleefde en na de oorlog uitvoerig van zijn ervaringen getuigd heeft. Hij arriveerde in Amersfoort op 23 oktober 1942, nadat hij met zijn vrouw en zoontje een vluchtpoging had 
ondernomen en verraden was. Ze waren regelrecht in de val gelopen. Cohen werkte in Amersfoort aanvankelijk in het Judenkommando, het zwaarste commando. Dankzij zijn beroep kreeg hij het voor elkaar tot de uitzonderingen onder de Joodse gevangenen te gaan behoren. Hij kwam in contact met de hoofdbroeder, die zorgde dat hij clandestien avonddiensten kon doen, in ruil voor wat extra eten. Later ondervond hij nogmaals voordeel van dit contact toen hij bij een commando kon werken dat de taak had de lijken op te ruimen, klaarblijkelijk een lichter commando. ${ }^{\text {IO }}$ Cohen zei nadien over deze ontwikkeling in zijn bestaan als gevangene: 'Hier begint de invloed van het arts-zijn. 'I

Het arts-zijn betekende vanaf dit moment voor Cohen volgens zijn eigen analyse echter niet zozeer dat hij het medische peil in Amersfoort ten behoeve van de andere gevangenen wilde verbeteren, als wel in de eerste plaats dat hij zijn eigen omstandigheden kon opvijzelen. Dit was zijn belangrijkste doel geworden sinds hij de eerste blik had geworpen op de verschrikkingen in Amersfoort. Anderen helpen met zijn beroep was een gepasseerd station, het ging hem nu in eerste instantie om zijn eigen lijfsbehoud. Terwijl hij op zijn eerste dag in het kamp getuige was van de mishandeling van een medegevangene, had Cohen namelijk al een gevoel van verlies van empathie meegemaakt, iets wat hij later duidde als 'depersonalisatie'. 'Mijn reactie was dat ik het van buitenaf bekeek als door een kijkgat, ik maakte er geen deel van uit, ik had er niets mee te maken.' ${ }^{2}$

Elie Cohen was niet de enige die als Amersfoorts gevangene een dergelijke ervaring en bijbehorende houding ten opzichte van andere gevangenen had. Er heerste, ook volgens andere ooggetuigen, over het algemeen een 'ieder voor zich'-mentaliteit in het kamp. ${ }^{13}$ Toch waren er nog enkele gevangenen die het wel opbrachten aan een ander te denken. Een niet-Joodse getuige, vanaf juli 1942 in het kamp aanwezig, herinnerde zich drie voorbeelden van buitengewone menselijkheid: het gedrag van twee jonge dominees en 'een edele Joodse arts', ${ }^{14}$ vermoedelijk Herman de la Parra, die in Amersfoort was beland vanwege het in bewaring geven van huisraad en omdat hij in het bezit was van een radio. Hij stond van jongs af aan bekend als hulpvaardig en werd daarom ook geschikt geacht voor het artsenberoep. Deze hulpvaardigheid toonde hij ook in Amersfoort, toen hij erin slaagde om bij de ss opium te stelen voor de zieke medegevangene Frans Goedhart, voorman van de Parool-groep. Zonder deze medische interventie had hij Amersfoort niet overleefd, zo herinnerde Goedhart zich later. ${ }^{15}$ Herman de la Parra zelf zou echter op 6 oktober 1942, enkele weken nadat hij Goedhart het leven had gered, in Mauthausen aan zijn tragisch einde komen. ${ }^{16}$ 


\section{KAMP VUGHT}

Toen Kamp Vught in januari 1943 werd geopend, bracht men de Schutzhäftlinge uit Amersfoort hierheen. Dit nieuwe kamp behelsde naast het Schutzhaftlager, het Frauenlager, het Geisellager, het Polizeiliches Durchgangslager en het SD-Lager ook een Judenlager. Het gehele complex viel, in tegenstelling tot Amersfoort en ook Ommen en Schoorl, niet onder de SiPo-SD, maar onder de ss. ${ }^{17}$

De Schutzhäftlinge - Joods en niet-Joods - ondervonden net als in Amersfoort een sadistische behandeling en ook de geïnterneerden van het Judenlager kregen het zwaar te verduren. In totaal telde deze laatste groep zo'n I2 000 mensen. Het grootste deel van hen arriveerde in april 1943 vanuit hun woonplaatsen, een tweede grote groep bestond uit zogenaamde 'Rüstungsjuden' uit Amsterdam, zij die wegens werkzaamheden voor de Wehrmacht en andere Duitse opdrachtgevers gesperrt waren geweest. Dat de belofte dat zij in dit Auffangslager zouden mogen blijven en er in een groot industriecentrum zouden worden tewerkgesteld, op niets gebaseerd bleek, werd hun al snel duidelijk. ${ }^{18}$ Op 8 mei 1943, nadat al enkele kleinere transporten van Vught naar Westerbork hadden plaatsgevonden, moesten I280 mensen vertrekken naar Westerbork. Daarmee was kamp Vught van een Auffangslager in een Durchgangslager veranderd. ${ }^{19}$

Dat Vught te verkiezen was boven Westerbork bleek daarmee een illusie. In beide kampen was de angst doorgestuurd te worden naar kampen in het Oosten reëel en groot, ook al gold in Vught dat de transporten die vanhier vertrokken eerst nog Westerbork aandeden, waar nog een kans was verdere deportatie uit te stellen. ${ }^{20}$ De leefomstandigheden in het Judendurchgangslager Vught waren harder dan in Westerbork. ${ }^{2 \mathrm{II}}$ De medische voorzieningen waren er zeer beperkt, zeker voor de Joodse gevangenen, maar toch konden Joodse artsen hier al vaker dan in Amersfoort hun beroep inzetten en proberen het medisch peil in positieve zin te beïnvloeden. Of dit ook al gold voor Benno Friedberg, die als Schutzhäftling van Amersfoort naar Vught was overgebracht, is zeer twijfelachtig. Hij was als arts verbonden geweest aan de Zentralstelle in Amsterdam en eind 1942 opgepakt vanwege het vervalsen van persoonsbewijzen. Via de gevangenis in Scheveningen was hij in Amersfoort terechtgekomen. ${ }^{22}$ De enkele tientallen Joden die met de Amersfoortse groep Schutzhäftlinge in het Schutzhaft-deel van Vught waren overgebracht, hadden het nog zwaarder dan de honderden die tegelijkertijd in het Judendurchgangslager-deel waren ondergebracht. ${ }^{23} \mathrm{Zij}$ werden blootgesteld aan zware mishandeling en vernedering. Friedbergs persoonlijke ervaringen zijn niet geboekstaafd, maar wel is 
bekend dat hij in november 1943, via een tweede tussenstop in het heropende kamp Amersfoort, in Auschwitz belandde, waarvandaan hij niet zou terugkeren. ${ }^{24}$

Jacob Bramson, psychiater uit Franeker, kon wel iets met zijn beroep betekenen. Hij kwam in februari 1943 in het Vughtse Judenlager aan en kreeg de opdracht er een medische dienst te organiseren. Deze opdracht vervulde hij samen met huisarts Sylvain Winkel uit Rotterdam. Ze liepen echter tegen grote moeilijkheden aan: 'Er bleek niets te zijn. Er waren geen geneesmiddelen en geen instrumenten. Tevens was er geen ziekenverblijf en was er ook geen verplegend personeel. ${ }^{25}$

Niet alleen was er gebrek aan alles wat een basale medische verzorging vereiste, ook werden de beide Joodse artsen in hun werk moedwillig tegengewerkt door de kampleiding, die daarbij vernedering en mishandeling niet schuwde:

Dr. Winkel kreeg van een Duitse arts een klap in het gezicht, omdat hij bij een gevangene roodvonk had vastgesteld. Deze Duitse arts kwam op deze melding, naar hij zeide, in vliegende vaart uit Den Haag naar het kamp terug 'voor niets'. Een in het kamp aanwezige Sanitäter, een Duitser en naar mij uit zijn uitlatingen bleek, een student in de geneeskunde, controleerde ons 'werk'. Daarbij maakte hij bijv uit een prima zittende beenfractuur van een dame met zeer weinig bloeding, één met flinke dislocatie en grote bloeduitstortingen. ${ }^{26}$

Bramson concludeerde dan ook dat de medische dienst in Vught 'beneden elke critiek was'. ${ }^{27}$ Het ergst was nog wel de slechte verzorging van kinderen en zuigelingen. Infectieziekten als mazelen en roodvonk tierden daardoor welig en ziekte en sterfte onder de kinderen was een groot probleem..$^{28}$ Klaartje de Zwarte-Walvisch, gevangene van het Judendurchgangslager Vught, schreef in mei 1943 in haar dagboek: 'Baby's smolten weg als sneeuw voor de zon. Voor kinderen beneden de twee jaar was het leven absoluut niet houdbaar. ${ }^{29}$ Het anderhalf jaar oude dochtertje van dokter Betty Poppers-Prins uit Winterswijk stierf reeds een week na aankomst in Vught, op I9 april 1943. ${ }^{30}$ Vervolgens zou Poppers zelf als arts in het kinderkamp en in de barak voor besmettelijke ziekten gaan werken, waar zij de toestand kenschetste als 'onhoudbaar', vanwege de zeer slechte hygiëne en voeding. In een naoorlogs verslag herinnerde zij zich dat er medicamenten en instrumenten aanwezig waren, maar dat Joodse artsen hierover niet mochten beschikken. Hun was zelfs bij binnenkomst een verklaring voorgelegd waarop zij dienden te ondertekenen dat zij al hun medicamenten hadden afgegeven..$^{31}$ 
De Joodsche Raad trachtte aan deze erbarmelijke toestanden iets te verbeteren met hulp van de ontslagen Joodse hoogleraar kindergeneeskunde Simon van Creveld. Hij reisde tien keer af naar Vught en deed er zijn best de toestand voor de kinderen iets te verbeteren. ${ }^{32}$ Op ro mei 1943 stuurde hij de kampcommandant, ss-Hauptsturmführer Karl Chmielewsky, een voorstel voor reductie van de ziekte- en sterfgevallen onder de kinderen in Vught, dat de volgende punten bevatte: I. Reductie van het aantal kinderen in de bedden. 2. Grotere afstanden tussen de bedden. 3. Scheidingswanden. 4. Separaat houden van waslappen ed, faciliteren daarvan. 5. Wasinrichting in de zaal om handen wassen mogelijk te maken. 6. Afsluitbare emmers voor verbandmateriaal. 7. Vergroting van de ramen: lucht en licht. 8. Ziekenbezoek beperken tot bepaalde tijden. 9. Ondergetekende wil graag lezingen voor personeel geven over kindergeneeskunde. Io. Minstens Ix per week een ervaren kinderarts op consult. ${ }^{33}$ Hoewel Van Creveld de Joodsche Raad op 20 mei 1943 liet weten 'niet ontevreden' te zijn over de gezondheidstoestand van de kinderen, vergeleken bij zijn eerste bezoek een paar weken eerder, had zijn interventie volgens andere getuigen niet veel effect, vooral ook omdat de Duitse gezagsdragers geenszins bereidwillig waren Van Crevelds aanwijzingen op te volgen. ${ }^{34}$

Ook de Groningse arts Ies van der Hal, vanaf Is april 1943 in Vught geïnterneerd, herinnerde zich een uitgesproken non-coöperatieve opstelling van de kampleiding. Apparatuur, medicamenten en voedsel, door Van Creveld uit Amsterdam naar het kamp gestuurd, werden door de ss in beslag genomen en niet aan de kinderen ter beschikking gesteld. Dit resulteerde erin dat Van Creveld zelf, met gevaar voor eigen leven, hulpgoederen het kamp binnensmokkelde en buiten het bereik van de ss liet bewaren. ${ }^{35}$ Zelfs Van Crevelds pogingen de voedselvoorziening voor de zuigelingen te centraliseren, werd geboycot, terwijl de benodigde pannen en kachels wel aanwezig waren. Er was slechts één kachel in de ziekenbarak, waarop alles gekookt moest worden. 'De moeders hebben formele vechtpartijen moeten leveren om slechts voor een enkele keer het flesje voor hun baby's te kunnen verwarmen. ${ }^{36} \mathrm{Als}$ zelfs een hooggeplaatst en internationaal bekend medicus als Van Creveld al tegen een muur van onwil aanliep, was er voor een huisarts als Ies van der Hal al helemaal niets te beginnen. Toch spande hij zich in medische verzorging in de ziekenbarak te bieden, waarbij hij specialistische ingrepen als het doorprikken van trommelvliezen bij de veelvuldig optredende oorontstekingen ten gevolge van de mazelenepidemie zelf op zich nam. 'Zoiets zou in een normale maatschappij of bij een normale medische verzorging tot de onmogelijkheden behoren. ${ }^{37}$

Ook Jacob Bramson merkte, zelfs toen hij al niet meer in Vught zelf maar in Westerbork verbleef, dat pogingen om in Vught de medische zorg te verbe- 
teren op niets uitliepen. Hij zond zijn opvolger in de Vughtse Joodse ziekenbarak, de Duits-Joodse arts H. Levie, een stel reageerbuizen om urineonderzoek mee te doen. Deze kwamen echter nooit aan. En zelfs al waren ze aangekomen, urineonderzoek doen was Levie door de kampleiding verboden. 'Na mijn vertrek uit Vught, is de toestand van de medische dienst aldaar nog veel erger geworden, 38 concludeerde Bramson.

Het beeld van een volstrekt ontoereikende en door de ss geboycotte medische verzorging blijkt ook uit de in het Judendurchgangslager bijgehouden dagboeken van Klaartje de Zwarte-Walvisch en David Koker. De eerste schreef bijvoorbeeld in mei I943: 'Medische hulp is er praktisch nog steeds niet. Enige weken geleden zijn hier enige doktoren en tandartsen gekomen. Zij allen hadden hun instrumenten meegebracht, in de hoop zich in het kamp te kunnen vestigen en zodoende toch nog iets voor hun medemensen te zijn. Maar jawel, alles is hun afgenomen.' 39

Toen David Koker op zeker moment zelf was opgenomen in de ziekenbarak, merkte hij dat de verzorging eigenlijk geheel op hemzelf aankwam. ${ }^{40}$ Ondanks het tekort aan medisch personeel mochten niet eens alle aanwezige Joodse artsen als zodanig werken. Louis Schaap bijvoorbeeld moest zware betonnen palen sjouwen, prikkeldraad vlechten en stenen voor huizenbouw vervoeren. In het commando waar hij werkte was het uit den boze je ziek te melden. 'Als het bleek dat er niets bijzonders was, werd je afgeranseld. Gevolg was dat bijna niemand zich ziek meldde, tenzij dat hij erbij neer viel.' ${ }^{4 I}$ Van enig respect jegens artsen was geen sprake, aldus de ervaringen van Schaap, die zelf zwaar mishandeld werd en ook zag dat hetzelfde gebeurde met Joachim Schrijver. 'Toen de oude maagdarmarts Schrijver eens een minuut te laat op appèl verscheen, omdat hij diarree had, werd het gezicht van dezen 70 jarige bont en blauw geslagen.' ${ }^{2}$

En toch, ook enkele in Vught geïnterneerde Joodse artsen wisten nog iets van de oude betekenis van hun beroep vast te houden en in te zetten. Max Roeper dacht onderweg naar Vught al met zijn functie als arts op een bepaalde mate van extra veiligheid te kunnen rekenen. Toen hij van het Huis van Bewaring in Groningen werd overgebracht naar Vught schreef hij naar huis: 'Als men nu maar niet vergeet erbij te zeggen dat ik arts ben, want dat scheelt een stuk natuurlijk.' Kennelijk lukte het hem inderdaad een functie als arts te bemachtigen, want hij schreef niet veel later: 'Heb voor mij geen zorg. Zoolang ik deze betrekking houd, is er geen gevaar voor mij en is er geen enkele reden tot ongerustheid.' ${ }^{43}$ Ook voor enkele andere Joodse artsen had hun beroep in Vught nog betekenis en nut. Zo schreef David Koker over de arts die de scepter zwaaide over het Joodse ziekenzaaltje, de Duits-Joodse Levie, dat deze iets 
bijzonder menselijks over zich had en zijn patiënten als zijn eigen kinderen tegemoet trad. Hij gaf hun, bij gebrek aan medicijnen, in elk geval menselijke aandacht. ${ }^{44}$ Ook Klaartje de Zwarte schreef over de steun die zij ontving van een arts, die bij haar in de barak woonde. Deze arts, mogelijk Betty Poppers, trachtte De Zwartes gemis van haar behandelend psychiater (Koster) enigszins te verlichten door uitgebreide gesprekken met haar te voeren over de slokdarmkrampen die haar zo kwelden..$^{45}$ Deze zelfde arts werd op een nacht geroepen bij een medegevangene die ernstig vloeide. Afgaande op het dagboek van Klaartje de Zwarte was het bloedverlies dusdanig dat de vrouw dreigde dood te bloeden. Het vloeien was niet te stelpen, maar op het laatste moment bedacht de arts een mogelijkheid om de patiënte te helpen: 'Machteloos stonden we erbij en plotseling holde de dokter naar de slaapzaal, trok haar mantel van het bed en ging de straat op. We wisten niet waar ze heen ging, maar na een uur kwam ze terug met een injectiespuit. Goddank kon er tenminste iets gedaan worden.' ${ }^{46}$

Midden in de nacht had deze arts de wachtpost weten te passeren en in het mannenkamp kunnen komen, waar ze het medicijn had bemachtigd. ${ }^{47} \mathrm{Na}$ enkele kritieke uren leek de patiënte inderdaad op te knappen.

Een soortgelijk voorbeeld van zorgzaamheid en beroepstoewijding toonden de artsen Johanna Aronsohn en Eljakim Ricardo door mee te gaan met de kindertransporten die op 6 en 7 juni vanuit Vught vertrokken. Deze transporten, de droevigste uit de droevige geschiedenis van Kamp Vught, bestonden vrijwel alleen uit zieke kinderen, met of zonder hun vaders en moeders. Elja Ricardo, die in het kamp als arts werkte en in de ziekenbarak bekendstond als een opgewekte verschijning, die altijd met een tennisballetje rondliep om zijn korfbaltalenten te onderhouden, achtte het kennelijk zijn plicht deze kinderen te begeleiden op hun transport. Zijn precieze beweegredenen zijn niet meer te achterhalen, maar zijn zoon Benjamin vermoedde dat hij het bij zijn taakopvatting als arts vond horen. Hij was menslievend en had een groot verantwoordelijkheidsgevoel, zo meenden ook verpleegsters die met hem werkten. ${ }^{4}$ Een van zijn patiënten in Vught, Jacques Furth, zei over Ricardo's besluit met het kindertransport mee te gaan: 'Je zou hem een heel vroege arts zonder grenzen kunnen noemen.' ${ }^{49}$ Alleen vanwege het geluk dat hij op de Portugezenlijst stond, werd Ricardo aanvankelijk vanuit Westerbork niet verder gezonden. Uiteindelijk zou hij bij de dodenmarsen vanuit Auschwitz-Birkenau bezwijken. ${ }^{50}$

Ook Johanna Aronsohn bleek een 'arts zonder grenzen'. Voorzitter David Cohen van de Joodsche Raad, die aanwezig was bij de transporten in Vught, zag op 6 juni hoe chaotisch een en ander verliep. Hij vroeg daarop voor de 
volgende dag enkele artsen uit Amsterdam te mogen meenemen om met hen vrijstellingen te kunnen verkrijgen voor de zieke kinderen. Die toestemming werd hem verleend en een van de vier artsen die op 7 juni naar Vught afreisden, was Johanna Aronsohn. Zij toonde zich, net als Ricardo, bereid de kinderen in de trein te begeleiden, hoewel zij niet eens hun behandelend arts was geweest. Toen zij in Westerbork vervolgens protesteerde tegen het voorgenomen doorzenden van dit transport met zieke kinderen naar Sobibor, duwde de Westerborkse kampcommandant Gemmeker haar wederom de trein in. Zij werd, met de kinderen, op II juni 1943 in Sobibor vermoord. s $^{\text {I }}$

\section{KAMP WESTERBORK}

In Kamp Westerbork troffen de Joodse artsen in het voorjaar van 1943 een totaal andere toestand wat betreft het medisch peil dan in Amersfoort of Vught. Jacob Bramson, die de situatie vergeleek met die in Vught, zei dan ook: 'De medische dienst in het kamp Westerbork was boven elke lof verheven en functioneerde niet minder goed dan de beste geneeskundige dienst in Nederland, terwijl ook ruim voldoende hulpmiddelen, geneesmiddelen en verplegend personeel aanwezig was. ${ }^{52}$

Ook Abel Herzberg noemde het ziekenhuis in Westerbork 'voortreffelijk'.53 Presser was eveneens zeer te spreken over de kwaliteit van de medische zorg in Westerbork. ${ }^{54}$ Voordat het peil van de medische zorg in Westerbork zo hoog was gestegen was er echter wel het nodige aan voorafgegaan. Het Polizeiliches Durchgangslager Westerbork bestond officieel pas sinds I juli i942. Voor die tijd was er al wel een barakkenkamp op de Drentse hei, alleen heette dat toen nog Centraal Vluchtelingenkamp Westerbork. Dit kamp was in I939 gebouwd, met het doel zo'n 800 Joodse vluchtelingen uit Hitler-Duitsland op te kunnen vangen. Het kamp was zo veel mogelijk zelfvoorzienend en dus was ook bij de bouw al rekening gehouden met de opvang van zieken. Hiertoe was een barak ingericht als 'ziekenhuis' voor lichte gevallen. Leden bewoners van het kamp aan een ernstiger ziekte, dan konden zij worden opgenomen in het Wilhelminaziekenhuis te Assen of het Academisch Ziekenhuis in Groningen. 55

De vluchtelingartsen van het eerste uur hadden de ziekenbarak in gebruik genomen. Het ging aanvankelijk om vier artsen, twee tandartsen en twee apothekers, aangevuld met twee Hollandse verpleegsters. ${ }^{56}$ Zo was de situatie zoals de Duits-Joodse Arthur Bial die aantrof toen hij op 9 maart 1940 in Westerbork aankwam. Hij was er benoemd tot hoofd van de polikliniek, een nieuw op te 
bouwen onderdeel van de medische dienst. Bial begon vanuit het niets. Slechts een pincet en een schaar had hij in het begin tot zijn beschikking. ${ }^{57}$ Benodigde medicamenten werden betrokken bij het Rijksmagazijn voor Geneesmiddelen in Amsterdam, maar waren ook nog niet in overvloed aanwezig..$^{88}$ Toen op Io mei 1940 de Duitsers Nederland binnenvielen, stond het ziekenhuis in Westerbork dan ook nog in de kinderschoenen.

Nadat de Duitse bezetting een feit was geworden, bleef de organisatie van het kamp aanvankelijk onder Nederlands toezicht. De financiering kwam voor rekening van het Joodse Vluchtelingencomité. ${ }^{9}$ De Nederlandse leiding van het kamp bleef voorlopig ook nog in functie. In het ziekenhuis bleef J.H. Boezeman, huisarts in een nabijgelegen dorp, 'kamparts'. ${ }^{60} \mathrm{Hij}$ kwam daarvoor drie keer per week naar het kamp. ${ }^{6} \mathrm{Hij}$ had er met name een controlerende taak, zoals blijkt uit een kampverordening van commandant Jacques Schol, die tot juli 1942 de algemene leiding over het kamp had. ${ }^{62}$

Belangrijker voor de dagelijkse gang van zaken dan de Nederlandse toezichthouders was en bleef de interne Duits-Joodse kamporganisatie, een hierarchische structuur die bestond uit een aantal afdelingen met elk een eigen leider en plaatsvervangende leiders, onder een eindverantwoordelijke 'Erste Dienstleiter'. De gezondheidsdienst, Dienstbereich IV, was onderverdeeld in ziekenhuis, polikliniek, tandartsendienst, apotheek en hygiënische dienst. Overkoepelend Dienstleiter was de uit Düsseldorf gevluchte medicus Fritz Spanier. Collega Arthur Bial was zijn 'Stellvertreter' (vervanger). ${ }^{63}$

Hoewel de organisatie in handen van de bewoners zelf en die van de Nederlandse kampleiding bleef, viel de verantwoordelijkheid voor het kamp vanaf I6 juli 1940 niet meer onder het ministerie van Binnenlandse Zaken. Het gezag over het kamp werd overgenomen door het departement van Justitie. ${ }^{64}$ In- en uitlopen was verboden en het aantal bewakers werd opgevoerd. Echter, in het jaar 194I, toen in de rest van Nederland de anti-Joodse maatregelen duidelijk voelbaar werden, leefden de vluchtelingen in Westerbork nog in relatieve rust. De voorzieningen, de houten huisjes en barakken waren primitief, maar een zekere basisverzorging was aanwezig. Getuige de verordeningen van Schol konden vrouwen de benodigde maandverbandmiddelen krijgen en zo nodig een maïzena-toelage voor baby's. ${ }^{65}$ Dat kennelijk ook aan de behandeling van luieruitslag aandacht werd besteed, bevestigt het beeld dat aan hygiëne en lichamelijke verzorging belang werd gehecht. ${ }^{66}$ Er was in 194I en de eerste helft van 1942 ook nog wel eens iets extra’s mogelijk. Zo werd er een kapper speciaal voor het ziekenhuis aangesteld ${ }^{67}$ organiseerde men een concert voor de zieken en medische cursussen voor belangstellenden. ${ }^{68}$ Het beeld ontstaat dan ook van een gedisciplineerde organisatie die een fatsoenlijke medische dienst als een basisbehoefte zag. 
Was de groei van het kamp, en dus van het ziekenhuis, aanvankelijk beperkt gebleven tot de komst van enkele Duitse Joden, vanaf juli I942, de start van de grootschalige deportaties, raakte Westerbork steeds meer bevolkt door Nederlandse Joden. Of althans, deden steeds meer Nederlandse Joden Westerbork kortstondig aan, op weg naar de verder oostwaarts gelegen deportatieoorden. Met de eerste twee transporten van in totaal 2030 mensen, de meesten uit Amsterdam, die op I5 en I6 juli vanuit Westerbork naar Auschwitz vertrokken, had Westerbork duidelijk de functie van Durchgangslager gekregen. Per i juli I942 viel het kamp dan ook niet meer onder het departement van Justitie maar onder de Befehlshaber der Sicherheitspolizei und des SD. ${ }^{69}$ Het was het begin van een episode waarin wekelijks vertrekkende transporttreinen het leven in kamp Westerbork zouden bepalen en eenieder die er verbleef in hun greep zouden houden. Tot I oktober I942 waren er al I8 918 mensen via Westerbork naar onbekende bestemming in het Oosten gedeporteerd. ${ }^{70}$ Nog bijna 90000 zouden hen volgen.

Het nieuwe karakter van Kamp Westerbork werd visueel gekenmerkt door meer prikkeldraad en wachttorens. Doordat de omheining in juli 1942 veranderde, kwam de ziekenbarak buiten het eigenlijke kampterrein te liggen en moest daarom worden verplaatst. ${ }^{71}$ Naast de Nederlandse commandant Jacques Schol werd nu ook een ss-commandant aangesteld. Nadat Erich Deppner en Josef Hugo Dischner voor deze functie ongeschikt bleken te zijn, de laatste omdat hij te inhumaan optrad, wat in de ogen van de Duitse verantwoordelijken in Nederland niet tactisch was, werd in oktober 1942 ss-Obersturmführer Albert Konrad Gemmeker aangewezen. ${ }^{72} \mathrm{Hij}$ stond bekend als een 'gentleman-boef', iemand die in zijn persoonlijk contact met de gevangenen geen schrikbewind voerde, maar uiteindelijk wel het vertrek van veruit het grootste deel van de 93 transporten vanuit Westerbork naar de concentratiekampen in het Oosten leidde. Onder hem ontstond de bizarre situatie dat de gevangenen een uitmuntende medische behandeling konden krijgen om vervolgens, geheel genezen verklaard, hun dood in de gaskamer tegemoet te gaan. ${ }^{73}$

\section{UITDIJENDE ZIEKENZORG}

ss-commandant Gemmeker droeg de eindverantwoordelijkheid voor de kamporganisatie die, net als voordien, praktisch in handen bleef van de Duitse Joden. Deze 'Alte Kampinsassen' waren degenen die de belangrijke posities bekleedden en taken uitvoerden, zodat er weinig werkzaamheden overbleven voor de nieuw aangekomen Nederlandse Joden. Voor diverse Nederlandse 
Joodse artsen bleek echter dat zij hun beroep in Westerbork goed konden gebruiken en inzetten. Het ziekenhuis zou groeien door de groei van het kamp en door de toenemende behoefte aan medische verzorging. Ook de kwaliteit van de geboden medische zorg verbeterde tijdens de deportatiefase.

Onder de Alte Kampinsassen bevonden zich elf Duits-Joodse artsen die voor 15 juli 1942 in het kamp waren gekomen. ${ }^{74}$ Deze Duits-Joodse medische staf werd al snel aangevuld met Nederlandse collegae. Zo kwam de Groningse arts Nico van Zuiden uit een van de werkkampen op ro juli in het kamp aan. Hij werd niet doorgestuurd, maar kon aan de slag in het ziekenhuis. ${ }^{75}$ Hetzelfde gold voor de internist Simon Izak de Vries uit Amsterdam, die op Io augustus, na zijn arrestatie tijdens de razzia in Amsterdam-Zuid op 9 augustus, met zijn gezin arriveerde in kamp Westerbork. ${ }^{76}$ De op dezelfde dag gearresteerde artsen Emanuel Roselaar, Moritz Gomperts , Jacques Gompertz, Hugo Salvendi en Jacob Roos werden wel meteen doorgestuurd naar Auschwitz. ${ }^{77}$

Ook de Utrechtse arts Martin de Jong, in augustus 1942 verraden en gearresteerd wegens verzetsactiviteiten in de groep rond dominee G.W. Oberman, was het niet vergund in Westerbork te blijven. ${ }^{78}$ Dat hij volgens zijn Joodsche Raad Cartotheek-kaart gesperrt was en men in Westerbork hem 'tracht als kampdokter te houden', bleek op 16 oktober 1942 kortweg 'onvoldoende'.79 De Jong werd in Auschwitz vermoord. Van nog eens dertien collegae is bekend dat ook zij in het najaar van 1942 al naar Auschwitz gedeporteerd werden. ${ }^{80}$

De pasafgestudeerde Isaac Cohensius kreeg evenmin de mogelijkheid in Westerbork als arts te werken en zichzelf en zijn echtgenote op die manier voor deportatie te behoeden. Hij werd al met een van de eerste transporten vanuit Westerbork weggevoerd. Zijn kersverse echtgenote was namelijk medio augustus opgeroepen en Cohensius besloot haar te vergezellen naar Westerbork. Vandaaruit werd het hem geoorloofd terug te reizen naar Amsterdam om er zijn artsexamen af te leggen. In ruil voor deze gunst moest hij echter bij terugkomst in het kamp meteen mee met een transport naar het Oosten. Hij overleefde de concentratiekampen en getuigde na de oorlog:

Op 28 augustus 1942 om precies I2 uur zweer ik den alouden eed van Hippocrates. Om 5 uur wenscht een gelukkige jonge vrouw haar man geluk in het Jodenkamp te Westerbork, na twaalf jaren van wachten, strijden en werken... Met een paar nieuwe bekenden vieren we een heel klein feestje, in de vrouwenbarak. Dan weten we, dat we gaan moeten - ik heb moeten beloven, dat ik geen aanspraken op in het kamp blijven, zal maken, zoals oudere artsen. Wie als arts werkt, wordt niet gedeporteerd - welke kans heeft dan een jonge arts, zonder kruiwagen! ${ }^{8 \mathrm{r}}$ 
Cohensius maakte deel uit van een van de achttien Koseltransporten, die in de periode augustus tot december 1942 stopten in Kosel, zo'n 80 kilometer voor Auschwitz en waar de jonge mannen tussen is en 50 jaar bevel kregen uit te stappen. Zij werden tewerkgesteld in werkkampen in de buurt, terwijl hun gezinnen doorgingen naar Auschwitz. ${ }^{82}$ Cohensius zelf overleefde zijn gevangenschap, maar zijn op 28 augustus nog 'gelukkige jonge vrouw' Esther Cohensius-van der Hoeden werd op 3 september 1943 vergast in Auschwitz. ${ }^{83}$ Ook de artsen Isidore Bak, René Kahn en Alfred Kropveld (opgepakt in Frankrijk tijdens zijn vluchtpoging) belandden via een van de Koseltransporten in de concentratiekampen om nooit meer terug te keren. ${ }^{84}$

Andere artsen waren - aldus Cohensius - ofwel ouder, of hadden 'een kruiwagen', ofwel domweg geluk. Zij mochten in elk geval in Westerbork blijven. Dat had ook te maken met de groeiende behoefte aan medisch personeel, als gevolg van de groei van het kamp net na het vertrek van de Koseltransporten.

Met name begin oktober 1942 veranderde er dusdanig veel dat de vraag naar medisch personeel in één klap enorm toenam. Dit was het gevolg van de aankomst van de tewerkgestelden uit de werkkampen en hun familieleden die tegelijkertijd uit hun huizen waren gehaald. Bij de circa 2000 bewoners die kamp Westerbork op dat moment telde, kwamen er opeens meer dan 12000 bij. ${ }^{85}$ Men kan zich de grote aanpassingsproblemen indenken. De latere verpleger Bob Cahen schetste de situatie in het kampziekenhuis in oktober 1942:

Als gevolg van deze omvangrijke aanwas van nieuwe gevangenen werd het ziekenhuis uitgebreid met noodbarakken en extra personeel. Maar deze maatregelen waren niet afdoende. Er was een tekort aan alles. Het was een enorme chaos. En in deze ellende kwamen ook nog eens mensen te overlijden of deden zelfmoordpogingen. ${ }^{86}$

Werner Stertzenbach, een jonge gevangene, schreef na zijn vlucht uit het kamp in een verklaring voor de regering in ballingschap over de toestand in het kampziekenhuis in oktober 1942: 'de benaming "ziekenhuis" zou o.i. een verkeerde indruk wekken, het was meer een verzamelplaats van zieken, want ook hier lagen de menschen, i.c. de patiënten in ijzeren kribben gedeeltelijk tweehoog boven elkaar in grote zalen van Ioo, soms I35 patienten bij elkaar.' ${ }^{\text {'7 }}$ Weer een andere getuige ervoer als patiënt dat er te weinig thermometers en medicijnen waren en dat hygiëne ver te zoeken was. ${ }^{88}$

Met de tewerkgestelden van de werkkampen kwamen de twee Groningse artsen Maurits van der Reis en Benjamin Pais mee naar Westerbork. Zij hadden in Norg deel uitgemaakt van de groep Groningers die er ontginningswerk- 
zaamheden had verricht. Zij zouden beiden bij aankomst in Westerbork direct het medisch team versterken. ${ }^{89}$ Toevalligerwijs kwam uit Rotterdam, ook op 3 oktober, eveneens een nieuwe arts aan, de bacterioloog Ellis Hertzberger, in september in de tram gearresteerd omdat hij geen ster droeg. Toen hem naar zijn persoonsbewijs was gevraagd, had men zijn vergrijp ontdekt. Nadat hij enige weken in de gevangenis had doorgebracht, werden hij en zijn echtgenote naar Westerbork overgebracht. De Joodsche Raad in Rotterdam gaf hem medische instrumenten, waaronder een stethoscoop, mee. ${ }^{\circ}$ Over zijn aankomst in Westerbork schreef Hertzberger:

We moesten ons eerst bij de administratie inschrijven. Daar werd ook naar mijn beroep gevraagd. Ik was één van de eerste artsen die daar kwam. Artsen hadden in Nederland over het algemeen een Sperre waarmee ze uitstel van deportatie kregen. Ze waren in de Nederlandse maatschappij onmisbaar. Maar ja, voor mij geen Sperre: ik was gepakt in de tram. ${ }^{9 \mathrm{r}}$

Inderdaad was in het kamp het aantal artsen nog altijd ontoereikend, omdat dezen grotendeels gesperrt waren. Daarom ging de Joodsche Raad, zoals eerder vermeld, over tot het werven van vrijwilligers. De artsen die zich hiertoe beschikbaar toonden, Sally de Jong, Albert Denekamp, Eddy de Wind, Paul Stibbe en mogelijk ook Juda Buys, kwamen in oktober en begin november in Westerbork aan. ${ }^{92}$ Ook Salomon Diamant, die door de Sicherheitspolizei voor de functie van kamparts was benaderd, is in elk geval tijdelijk, in najaar 1942, in Westerbork geweest. ${ }^{93}$ Eduard Zeldenrust was in het najaar van 1942 gearresteerd en op I4 oktober naar Westerbork gebracht, alwaar ook hij een baan kreeg als kamparts. ${ }^{94}$ In november kwamen Izaak van Esso en zijn echtgenote in het kamp aan. Dankzij interventie van de Joodsche Raad kreeg Van Esso een baan als arts in het ziekenhuis. ${ }^{95}$ Een andere arts, die volgens getuigenis van Arthur Bial aanvankelijk ondanks zijn beroep op de transportlijst stond om direct doorgezonden te worden maar toch in het ziekenhuis kon worden vastgehouden, was de Amsterdamse Maurits de Levie. ${ }^{96}$ Hij was aanvankelijk als patiënt opgenomen, maar toen hij genezen was, kon hij als arts in het ziekenhuis blijven. ${ }^{97}$

Nadat de drukte van oktober met de arbeiders uit de werkkampen achter de rug was - bijna allemaal werden ze vrijwel meteen doorgestuurd -, konden de artsen zich richten op de in november en december binnenkomende groepen sterk verzwakte arbeiders uit werkkamp Ellecom en mishandelde gevangenen uit Amersfoort. ${ }^{98}$ Sally de Jong schreef over de Ellecommers: 'De eerste groep, ongeveer veertig man, kwam daar in begin November aan: zeer velen hadden 
etterende wonden aan handen of voeten, waren vermagerd tot op het been en een tiental had in sterke mate hongeroedeem.' ${ }^{99}$ Ook de mannen die in concentratiekamp Amersfoort gevangen hadden gezeten, waren er slecht aan toe. ${ }^{100}$ Een van hen was de journalist Philip Mechanicus, die de blijdschap van de mannen bij aankomst in het ziekenhuis van Westerbork, waar hun eindelijk een humane behandeling ten deel viel, beschreef: 'hoevelen hebben niet liggen schreeuwen van pijn én vreugde tegelijk, toen eindelijk een dokter met vaderlijke zorg onder vriendelijke woorden hun etterende wonden kwam behandelen.' ${ }^{\prime}$ I

Er was nogal wat werk aan de winkel voor de artsen in het kamp. De verhouding tussen de Duitse en de Nederlandse Joden in het kamp was van meet af aan gespannen: de Duitse Joden verweten de Nederlandse Joden ongastvrijheid in de jaren dertig en de Nederlanders bekeken de Duitsers met argusogen omdat zij zich zozeer als kampelite gedroegen. ${ }^{102}$ Hierdoor verliep de samenwerking tussen de Duits-Joodse medici en de nieuw aangekomen Nederlandse niet vlekkeloos. Sally de Jong: 'Er werkten vrij veel oude duitsche artsen die sinds jaren geen praktijk meer hadden uitgeoefend. ${ }^{103}$ Des te meer reden voor de over het algemeen relatief jonge Nederlandse garde om hard aan de slag te gaan. Een van hun eerste doelen was het verbeteren van de hygiëne en infectiepreventie, ook al omdat de sterftecijfers in het najaar van 1942 sterk waren gestegen. Waren er in de maand september nog vijf sterfgevallen te betreuren, in oktober waren het er dertig. Vooral onder zuigelingen was de sterfte groot. Sally de Jong deed verslag van ongeveer tien zuigelingen die in de maanden juli tot november door de slechte hygiënische toestanden aan de gevolgen van infecties of ten gevolge van tekort aan zuigelingenvoeding overleden. ${ }^{104} \mathrm{Men}$ vatte het plan op om de epidemieën van infectieziekten, die het gevolg waren van de erbarmelijke hygiëne, te bestrijden met behulp van vaccinatiecampagnes. Campagnes tegen pokken, difterie, tyfus en paratyfus werden ontworpen. ${ }^{\text {.05 }}$ Met de Joodsche Raad in Amsterdam onderhield de Westerborkse medische staf nauwe contacten. Ook in Amsterdam werd de slechte hygiënische toestand in Westerbork namelijk met zorg gevolgd. De Joodsche Raad poogde zo veel mogelijk levensmiddelen en - deels 'zwart' ingekochte - medicijnen naar Westerbork te zenden om de ergste nood te lenigen. ${ }^{106}$ Salomon Spijer, leider van de medische afdeling, bezocht het kamp in november 1942 om overleg te plegen. ${ }^{\text {IO7 }}$

De verbetering van de gezondheidszorg in het kamp werd grondig aangepakt. In de staten van aantallen medewerkers van het kampziekenhuis is terug te zien hoe het medische apparaat in rap tempo uitdijde. Was het totaal aantal 'Beschäftigten' in het ziekenhuis op I9 september 1942 nog 25, in de polikliniek 
I6, op een totaal van 363I kampingezetenen, twee maanden later was het personeel in het ziekenhuis al 345 man sterk. In de polikliniek waren op deze datum nog eens 30 mensen in dienst. Deze laatste cijfers, van de telling van 16 november 1942, hoorden bij een totaal aantal kampingezetenen van 6795 mensen. Slechts één week eerder, op, 9 november, leverde de telling maar 4I personeelsleden in het ziekenhuis op, en 20 in de polikliniek, hoewel er al bijna evenveel kampbewoners waren: 6042 mensen. De groei van het ziekenhuispersoneel liep daarmee weliswaar achter op de explosieve groei van het kamp zelf, maar kon in één week net zo explosief groeien. In december 1942 leek er een stabiele situatie te zijn ontstaan met zo'n 450 man personeel in het ziekenhuis en 28 in de polikliniek op een totaal van ruim 8000 gevangenen. De artsen onder hen kregen de kans het ziekenhuis en de daar geboden zorg verder vorm te geven, zodat zij in het jaar 1943 daadwerkelijk goede medische zorg konden bieden.

\section{'OOGENSCHIJNLIJK NORMALE' \\ GEZONDHEIDSZORG...}

In 1943 nam de vraag naar medische zorg in Westerbork enorm toe, vanwege de aanwas aan patiënten afkomstig uit de Joodse ziekenhuizen die vanaf januari van dat jaar werden ontruimd. Plannen tot overbrenging van zieken naar Westerbork waren eind 1942 al bij de Joodsche Raad en bij de Joodse vertegenwoordiging in Westerbork doorgedrongen. ${ }^{108}$ Uitbreiding van het aantal ziekenbarakken in het kamp bereidde men dan ook in december 1942 al voor. ${ }^{\text {I09 }}$ Er moesten drie extra ziekenbarakken worden ingericht voor de ongeveer 700 verwachte extra patiënten boven op de 700 die er al werden verpleegd. ${ }^{\text {IIo }}$

De benodigdheden voor de drie nieuwe ziekenzalen kon de Joodsche Raad deels verkrijgen uit de boedels van mensen die al naar Westerbork of Duitsland waren vertrokken. ${ }^{I I I}$ Voorzitter David Cohen opperde nog een paar andere methoden. Zo stelde hij de Zentralstelle voor dat de Joodse ziekenhuizen zo veel mogelijk spullen uit hun eigen inventaris zouden afstaan ten behoeve van de ziekenzalen in Westerbork, een geste waartoe de bij de JVvVv aangesloten instellingen al bereid waren gevonden. Verder zou er een inzamelingsactie bij de gehele Joodse gemeenschap worden gehouden en tevens zou de mensen die in de ziekenbarak werden opgenomen, worden verzocht zelf het nodige aan beddengoed en dergelijke mee te nemen. Als laatste noemde Cohen de mogelijkheid om door inkoop aan de juiste spullen te komen. ${ }^{\mathrm{II}}$ Maurits de Levie werd er vanuit Westerbork op uitgestuurd om boeken, instrumenten en medicamenten uit Amsterdam op te halen. ${ }^{\mathrm{II} 3}$ De Levie was niet de enige arts 
die zich met dit doel buiten het kamp begaf. Simon de Vries verwierf eveneens verlofpassen om in Amsterdam inkopen te doen voor het ziekenhuis: eenmaal in november 1942 en driemaal in januari-februari 1943. Hij mocht ook buiten

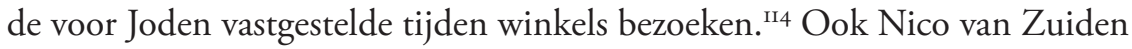
had een reisvergunning, waardoor hij ook familie buiten het kamp kon bezoeken. ${ }^{\text {II }}$ Paul Stibbe reisde op 27 december nog naar Het Apeldoornsche Bosch, om er een groep psychiatrische patiënten onder te brengen die niet in Westerbork behandeld konden worden. ${ }^{\text {II6 }}$ Dit was vanaf augustus 1942 vijf keer voorgekomen, maar de ontruiming van de instelling op 21 januari 1943 maakte er een einde aan. Vanaf dat moment stroomden er enkel zieken vanuit het hele land het kampziekenhuis ín.

Schommelde het aantal patiënten in het kampziekenhuis in de laatste week van november 1942 nog rond de 540 op ruim 8000 gevangenen, op 16 maart I943 telde het ziekenhuis precies I40o patienten op een totale kampsterkte van rond de 8500 mensen. ${ }^{\text {II }}$ De Joodsche Raad hield er rekening mee dat het ziekenhuis nog verder zou moeten uitbreiden om uiteindelijk opnamecapaciteit voor 2500 patiënten te hebben. Westerbork zou dan, in tegenstelling tot het zogenaamde industriecentrum Vught voor gezonde Joden, de verzamelplaats voor zieken en ouden van dagen worden, 'hoewel dit natuurlijk voor velen een "doorgangsziekenhuis" zal moeten zijn, waarna zij het met bestemming Duitschland zullen moeten verlaten'. ${ }^{\text {I18 }}$ Wekelijks zouden 200 zieken met hun 400 à 500 familieleden op transport worden gesteld, samen met Straf- ofwel S-gevallen, mensen die bijvoorbeeld hadden getracht onder te duiken. ${ }^{119}$ Met de grote stroom patiënten vanaf januari 1943 kwamen medisch personeel en medisch specialisten, die eveneens gearresteerd werden, ook in steeds groteren getale naar Westerbork.

De artsen van Het Apeldoornsche Bosch waren alle naar Westerbork vertrokken, met uitzondering van de gemengd gehuwde Arie Querido en de niet-Joodse Elisabeth van der Wal. Tussen haar en haar collegae in Westerbork en ook met het Centraal Israëlietisch Krankzinnigengesticht, waarvan het bestuur nog in Amsterdam was, ontstond een correspondentie. De artsen van het Bosch konden aan de slag in het kampziekenhuis. Zo stuurde artsassistent John van Lier op I2 februari een brief, vermoedelijk naar mr. Parser, voorzitter van het bestuur van het CIK: 'Ik werk in één van de barakken en heb een afdeling van 35 bedden, waar werk genoeg is. De verpleging is behoorlijk al ontbreken door de omstandigheden tal van geneesmiddelen en hulpmiddelen.' ${ }^{20}$

Ook geneesheer-directeur Lobstein werd nadat hij enkele dagen langer met wat administratief personeel had mogen blijven, op i februari op de trein naar 
Westerbork gezet, waar ook hij in het ziekenhuis een aanstelling kreeg om er zijn psychiatrische werkzaamheden zo goed en zo kwaad als het ging voort te zetten. Van deze periode is zijn patiëntenadministratie bewaard gebleven. Enkele patiënten die hij ooit in Het Apeldoornsche Bosch had behandeld, zag hij hier terug, naast vele nieuwe gevallen. In zijn documentatie zijn 229 patiënten terug te vinden. Nauwkeurig hield hij diagnoses en behandelingen bij en deed zelfs eenvoudig statistisch onderzoek op de casuïstiek die hij tegenkwam. Ook hield hij zich, net als voor de oorlog, nog bezig met erfelijkheidsonderzoek, getuige de vele stambomen van psychiatrische patiënten die hij in zijn aantekeningen bijhield. ${ }^{\mathrm{I}}$ Lobstein kon daarmee tot op zekere hoogte zijn medisch wetenschappelijke werk ook in het kamp voortzetten.

Een bijzonder medisch geval voor de Westerborkse artsen was de twintigjarige zwaargehandicapte patiënt, blind, doofstom, mentaal geretardeerd en slechts $80 \mathrm{~cm}$ groot, die op 30 juni 1943 in Westerbork stierf. Hij blies zijn laatste adem uit nog voor men hem voor 'tewerkstelling' naar Polen had kunnen doorsturen. Na zijn overlijden besloten de artsen in het kamp deze mogelijk leerzame casus nader te onderzoeken. Zij gingen over tot obductie van het lijkje. Deze werd uitgevoerd door Paul Stibbe, samen met Lobstein en professor Van Creveld, die naast Vught ook Westerbork bezocht om de kindergeneeskundige zorg te verbeteren. Oogarts Regina Polak-van Gelder had bij leven van de patiënt reeds een rode punt in het netvlies gezien, typerend voor de ziekte van Tay-Sachs. ${ }^{\text {I22 }}$ Daarmee was de diagnose al duidelijk, maar zoals het artsen in de vooroorlogse periode ook had betaamd, namen de kampartsen de gelegenheid te baat hun medische kennis te vergroten. En zij kregen hiertoe de gelegenheid. Kampcommandant Gemmeker, kennelijk zelf ook nieuwsgierig, was zelfs persoonlijk aanwezig bij de hele procedure.

Hoewel er steeds meer medische expertise in het kamp aanwezig was, konden patiënten met ingewikkelde aandoeningen nog steeds naar het Academisch Ziekenhuis in Groningen. Van de periode 30 oktober 1942 tot 28 juni 1943 zijn ontslagpapieren bewaard gebleven van I6o patiënten die in het AZG waren behandeld, voor aandoeningen variërend van een beklemde liesbreuk tot M. Basedov (schildklierziekte) en ablatio retinae (netvliesloslating). ${ }^{123}$

Een voorbeeld van een medisch specialist die in Westerbork zelf kwam, was de zojuist genoemde Regina Polak-van Gelder, die samen met haar echtgenoot Willy Polak, eveneens arts, aan de slag kon in het ziekenhuis. ${ }^{24}$ De bekende vrouwenarts Herman Heymans van Amstel deed de bevallingen in de Westerborkse kraamafdeling. Internist Louis Schaap van het NIz kwam in maart 943 als strafgeval vanuit Vught naar Westerbork. Nadat hij hersteld was van zijn 
verwondingen en uitputting, werd hij van patiënt in het ziekenhuis gepromoveerd tot arts en van zijn ' $S$ ' verlost. ${ }^{\text {I25 }}$

De Amsterdamse kno-arts Fie Velleman-Pinto werd in de gelegenheid gesteld op en neer te reizen tussen haar woonplaats en Westerbork, om in het kamp specialistische ingrepen op keel-, neus- en oorgebied te verrichten. ${ }^{26}$ Dergelijke gerenommeerde specialisten konden niet alleen worden geconsulteerd, maar hielden ook voordrachten. Zo hield Simon van Creveld lezingen op de artsenbijeenkomsten in het kamp. De artsen ontvingen zelfs medische vaktijdschriften. Wielek vroeg zich af: 'welk plaatsje met I6 ooo inwoners heeft zoveel prominente doktoren ter beschikking als Westerbork?'I27 'Op medisch gebied was het ideaal', was dan ook het naoorlogse oordeel van Elie Cohen, die in het voorjaar van 1943 vanuit Amersfoort naar Westerbork kwam. ${ }^{128} \mathrm{De}$ van oorsprong Duitse kinderarts Max Benjamin vond de medische verzorging, toen hij in juni vanuit Amsterdam in het kamp arriveerde: 'goed, net als in een gewoon ziekenhuis. [...] De ziekenbarakken bleven natuurlijk barakken, maar alles bij elkaar genomen was het er naar omstandigheden heel best.' ${ }^{29}$ In februari was begonnen met de bouw van een eigen operatiezaal in het voormalige schoolgebouw, die in mei gereed zou zijn, en ook was er een röntgenapparaat aangeschaft. De aanvoer van medicatie werd in de loop van 1943 ook toereikend. Ellis Hertzberger had als kamparts de beschikking over urotropine, sulfa en Prontosil, en verder over efedrine, nitroglycerine, aspirine, Luminal (fenobarbital), morfine, opiumdruppels, gorgeldrankjes met permangaan en tannalbine. Dit kwam overeen met wat er elders in Nederland aan medicatie beschikbaar was. Het stond de apotheker van het kamp vrij om te bestellen wat hij nodig achtte en vaak werd de voorraad medicijnen nog uitgebreid door zendingen van familieleden in den lande. ${ }^{30}$ Psychiater Jacques Tas oordeelde: 'Het ziekenhuis was zeer uitgebreid en uitstekend georganiseerd, zoowel poliklinisch als klinisch, de medische verzorging was daar in ieder geval veel beter dan die van de ziekenfondspatiënten in Amsterdam.' ${ }^{\text {I3I }}$ En Presser schreef over de 'Medicina Westerborkiana':

Een ziekenhuis op de Drentse hei met, op zijn hoogtepunt, zeventienhonderdvijfentwintig bedden, honderdtwintig artsen en meer dan duizend man personeel. Met alle mogelijke specialisten. Met (ik som opzettelijk maar wat kriskras op) isolatiekamertjes, een afdeling voor geesteszieken, een prachtige apotheek, een aparte dieetkeuken, allerlei magazijnen, tekenaars, orthopedisten, kappers, fotografen, laboratoria, sociale voorzorg, pastorale dienst, Енво-posten, hygienische dienst, tandheelkundige klinieken, estafetten, portiers, postdienst, operatiekamer, een polikliniek 
met vaste spreekuren, doorlichting van alle kampbewoners op tuberculose, immunisering tegen tyfus en paratyfus, vaststelling van bloedgroepen. Met wekelijkse artsenvergaderingen, waarop behandeling van wetenschappelijke en klinische onderwerpen - als men bij dit alles iets mist, ligt het aan mij. ${ }^{132}$

Al met al staat vast: er was goede medische zorg in Westerbork. De artsen die het voor elkaar kregen in Westerbork in het kampziekenhuis te gaan werken, konden daar dan ook echt weer arts zijn.

\section{... MAAR TOCH OOK WEER GEEN PARADIJS}

Simon van Creveld zag het verschil tussen Vught en Westerbork zeer duidelijk, tijdens zijn missie om de kinderen in beide kampen onder humane omstandigheden te laten verzorgen en verplegen. De toestand op de kinderafdeling in Westerbork noemde hij in I946 dan ook 'oogenschijnlijk normaal', terwijl hij Dantes hel een paradijs vond vergeleken met kamp Vught. ${ }^{133}$ Desalniettemin diende de medische situatie in Westerbork niet geïdealiseerd te worden. Massale infecties kwamen er vanwege de matige hygiëne in het kamp steeds veelvuldig voor, onder de kinderen met name (gecompliceerde) oorontstekingen: otitiden en mastoïditiden. ${ }^{134}$ In december 1942 werden ongeveer 600 kinderen getroffen door een grote mazelenepidemie. In februari 1943 brak er een roodvonkepidemie uit, en evenals de eerdere mazelenpatiëntjes werden de geïnfecteerden geïsoleerd, dit keer zo'n honderd. Verder leed bijna iedereen volgens het verslag van Sally de Jong na aankomst aan buikloop. ${ }^{135}$ Ellis Hertzberger vermeldde ook veel gevallen van hepatitis $A$, kinkhoest, oogontsteking en een 'epidemie' van blaasontsteking. Deze had echter een niet-medische grondslag: de tegen blaasontsteking voorgeschreven urotropinetabletten bleken prima geschikt voor het maken van een vuurtje om iets op te verwarmen. ${ }^{136}$

Naast de matige hygiëne in het kamp, die de gezondheid van de inwoners in negatieve zin kon beïnvloeden, was ook de medische zorg niet voor iedereen even goed. Het kon uitmaken in welk deel van het kampziekenhuis men patiënt werd. In totaal bestond het ziekenhuis medio I943 uit negen barakken, waarover de patiënten verdeeld waren. Vier daarvan, die bij het oude kamp behoorden, hadden volgens Sally de Jong een betere levensstandaard dan de vijf nieuwere. In de vier beter uitgeruste barakken werden acuut zieken opgenomen, maar ook protegés van kampprominenten en enkele speciale categorieën, zoals kraamvrouwen en hun borelingen, onrustige psychiatrische 
patiënten en mensen met besmettelijke aandoeningen. In de vijf minder goed bekendstaande barakken werden vooral de zieken uit de aankomende transporten opgenomen, waar zij in stapelbedden werden gelegd. ${ }^{137}$ Aangezien in I943 grote groepen zieke, oude en zwakke mensen binnenstroomden, verbaast het niet dat ondanks het goed geoutilleerde ziekenhuis de sterftecijfers hoog waren. In april I943 werd het hoogste aantal sterfgevallen in één maand gemeten, namelijk 89. Pas na augustus 1943 zou het sterftecijfer weer onder de 30 zakken. ${ }^{138}$ Onder de gestorvenen in Westerbork was Herman Pinkhof, een van de meest invloedrijke, productieve en gerespecteerde medici die Nederland had gekend. Nadat ook hem als Jood alles ontnomen was, blies deze eerbiedwaardige tachtigjarige op I6 juli 1943 zijn laatste adem uit in gevangenschap, als 'slachtoffer van door een Duitsche furie bezetenen, van wie de beste nog niet waardig zou geweest zijn Pinkhof de schoenriemen te ontbinden'. ${ }^{139}$ Zo mogelijk nog erger - vergassing in Polen - is Pinkhof bespaard gebleven.

Dat was immers wat Westerbork, ondanks welke goede medische zorg dan ook, een plek des onheils maakte. De sterftecijfers daalden in augustus I943 in Westerbork weliswaar, maar dat kwam ook en misschien vooral omdat op dat moment de meeste zieken, zwakken en ouden van dagen doorgestuurd waren naar de gaskamers. De sterfte vond plaats buiten het zicht van de 'ogenschijnlijk normale' wereld van Kamp Westerbork en zijn ziekenhuis. De toestand in Westerbork was dan ook uiteraard verre van daadwerkelijk normaal. Altijd en immer was daar, als een zwaard van Damocles dat boven de Westerborkse bevolking hing, de kans op transport. De geïnterneerden leefden in het ritme van de wekelijks aanzwellende angst met het volgende transport mee te moeten. ${ }^{140}$ Dat is ook waarom Pressers jubelende woorden over het ziekenhuis een sarcastische ondertoon hebben: als het doel was mensen te vernietigen, waarom werden zij dan eerst nog zo goed medisch opgelapt?

Simon van Creveld ondervond de absurditeit van de Westerborkse gezondheidszorg aan den lijve in de casus van zijn patiënt Michieltje. Dit jongetje, voluit Machiel Prins geheten, was uit kamp Vught, waar hij op 3I mei 1943 geboren was, met een van de kindertransporten naar Westerbork gebracht. De te vroeg geboren baby, met een geboortegewicht van slechts I350 gram, werd bij aankomst in Westerbork door Gemmeker met alle zorg omringd. ${ }^{{ }^{14} \mathrm{I}} \mathrm{Hij}$ liet een couveuse uit Groningen komen, ontbood Van Creveld en volgde nauwgezet diens instructies op. Hij stelde twee verpleegsters aan om voor Michieltje te zorgen en hem sondevoeding te geven, aangevuld met kleine beetjes cognac. Machiel groeide zienderogen en sterkte aan. Toen hij zes pond woog, vond Gemmeker hem 'transportfähig' en werd hij voor de tweede keer in een trein geladen. Ditmaal richting de gaskamer van Auschwitz, waar hij op 24 september 1943 vermoord werd. ${ }^{142}$ 
De geschiedenis van de 'Medicina Westerborkiana' gaat dus enerzijds over een - zuiver medisch gezien - knap staaltje werk. In weinig tijd en met weinig middelen wist de medische staf een enorm, goed functionerend en medisch volwaardig ziekenhuis uit de grond te stampen. Maar ze gaat ook en vooral over de absurde praktijk waarbij het nazisysteem mensen eerst liet genezen om hen vervolgens te vermoorden. Voor de artsen die in dit perverse systeem werkten, kan dat niet anders dan bizarre situaties hebben opgeleverd. Arts zijn in Westerbork was verre van eenvoudig. Zo ervoer ook Maurits van der Reis, zoals opgetekend door zijn patiënt Philip Mechanicus: 'De arts liet zich drijven op zijn sentiment en verloor alle objectiviteit uit het oog, barstte tenslotte in snikken uit en sloeg zijn vuist op tafel. Overspannen. Geen wonder.' ${ }^{433}$ Het verlangen naar een einde aan de waanzin die Westerbork heette en de teleurstelling dat de geallieerden voor zijn gevoel niets deden om de Joden te helpen, bracht Van der Reis tot deze inzinking.

\section{'MEDICINA WESTERBORKIANA'}

Het ziekenhuis in kamp Westerbork maakte deel uit van de verre van normale subwereld die het kamp was. Verschillende historici hebben zich gebogen over de vraag hoe de bewoners van deze subwereld een gemeenschap vormden en hoe zij zich ten opzichte van elkaar gedroegen. Presser waagde zich niet aan een oordeel of men ook in Westerbork al een 'depersonalisatie' doormaakte, zoals bijvoorbeeld Elie Cohen in Amersfoort al ervaren had. Wel stelde hij dat 'een zekere persoonlijkheidserosie' dreigde, 'een afneming van energie, een aflaten van initiatief, een inboeten aan denkkracht, een afglijden naar een meer mechanisch bestaan'. ${ }^{444}$ Gevangene Rosa van der Hal-Prins kenschetste haar mentaliteitsverandering tijdens haar gevangenschap in Westerbork op poëtische wijze:

Hier leerde ik, dat ik een ander ben

Dan die ik altijd dacht te wezen

En dikwijls moet ik voor mijzelve vrezen,

Als ik mijn eigen ik niet meer herken. ${ }^{\text {I45 }}$

Van een zekere mate van depersonalisatie lijkt hiermee in het geval van Rosa van der Hal wel sprake. Wielek ging verder en bespeurde een vrij algemeen verlies van solidariteit: 'Van gemeenschapsleven was in Westerbork [...] niet veel te bespeuren. Hier heerste een wreed egoïsme, dat slechts aan zichzelf en 
zijn eigen gezin dacht. Hier was het belangrijkste er voor te zorgen, dat men niet mee moest met de volgende trein. ${ }^{\text {I46 }}$ Eva Moraal zag echter ondanks de doodsangst en de overheersende drijfveer om van de wekelijkse transportlijst af te blijven, toch ook een zeker 'normaal' gemeenschapsleven. Westerbork was 'een gedwongen kampgemeenschap met haar eigen zeden en gewoonten, die toch ook weer verdacht veel op de gewone maatschappij daarbuiten leek'. ${ }^{47}$ Mogelijk was dit ook ingegeven door de niet-aflatende hoop dat men spoedig uit deze benarde situatie bevrijd zou worden. Zo herinnerde ook psychiater Jacques Tas zich hoe belangrijk hoop was voor alle gevangenen, arts of geen arts: 'Bijna unaniem was het optimisme, wat den oorlog betrof. Nog een paar weken, nog een paar maanden, was de hoogste wijsheid, die men over het te verwachten verloop van den oorlog te hooren kreeg; iedereen had natuurlijk de hoop, dat de oorlog net zou zijn afgeloopen, voordat hij op transport zou moeten.' ${ }^{\text {I } 48}$

Hoewel deze hoop volgens Tas vrijwel unaniem gedeeld werd, kan er verder weinig generaliserends over dé mentaliteit in Westerbork geconcludeerd worden. In deze gemeenschap, gedwongen bijeengebracht uit alle lagen van de samenleving en met een verblijfsduur variërend van enkele uren tot jaren, was van alles mogelijk. "'Alles” kon in Westerbork...' zo besloot dan ook Presser. ${ }^{\text {I49 }}$ Welke rol kon het artsenberoep dan spelen in deze rijk geschakeerde gemeenschap van in het nauw gedrevenen?

In Westerbork gold voor de artsen net zo goed als voor alle andere gevangenen dat het primaire streven was niet doorgestuurd te worden. In Westerbork ging het zoeken naar een 'reddingsboot' onverminderd, zo niet verhevigd, door:

Het vreselijke van Westerbork was de doodsangst voor de eenmaal of tweemaal per week vertrekkende transporten naar plaatsen, waaruit nooit berichten van aankomst of andere tekenen van leven kwamen. Dat was het grote duivelse mysterie. Om de transporten te ontlopen deed men alles. $^{\text {I50 }}$

Ook voor artsen bestond allerminst garantie dat zij in het kamp konden blijven. Net als toen zij nog in hun eigen huizen waren en deportatie naar Westerbork probeerden tegen te gaan middels allerlei lijsten en Sperren, trachtten zij ook in Westerbork weer een 'Zurückstellung' te krijgen. Daarop maakten zij dankzij hun beroep een relatief grote kans. Jacques Tas herinnerde zich dat hij direct de dag na zijn aankomst werk maakte van een mogelijke aanstelling in het kampziekenhuis. 
Den volgenden ochtend in Westerbork was mijn eerste gang naar het ziekenhuis om contact met de collegae te zoeken. Ik kreeg daar te doen met collega Waterman, die hoofd was van het ziekenhuis en zelf ook als internist hoofd was van een afdeling. Er waren reeds drie collegae zenuwartsen, t.w. N. Spijer, Lobstein en Landauer, in het kamp. Landauer moest internistisch werk doen, Spijer deed de neurologie en Lobstein de psychiatrie; het was dus moeilijk voor mij een werkkring te vinden. Men was echter zeer welwillend en Waterman heeft er direct voor gezorgd dat $\mathrm{ik}$, zij het dan voorloopig slechts formeel, als medicus ingeschakeld werd, zoodat men mij geen ander onaangenaam werk op den hals kon schuiven. Dit kwam er dus op neer, dat ik niets te doen had. ${ }^{\text {II }}$

Tas hoefde dus niets te doen, was eigenlijk als arts boventallig, maar had alleen dankzij zijn beroep meer zekerheid voor zichzelf, zijn vrouw en zoon bereikt. ${ }^{152}$ Het was Tas gelukt steun van zijn al aanwezige collegae te krijgen, iets wat volgens Jacques Reisel niet vanzelfsprekend was:

De artsen staan in een moeilijke positie maar hebben ook hun eigen psychologie: die van sterke jaloersheid op de collegae die nog niet van huis en hof verdreven zijn. En levend van de hoop dat zij, de artsen van Westerbork, het desondanks langer zullen uithouden, als eerst aangekomenen, dan de anderen die doorgestuurd zullen worden. Omdat zij komen als het kamp oververzadigd aan artsen is. En Polen, Birkenau, schreeuwt om artsen, al zullen deze niet veel werkelijke hulp kunnen bieden. ${ }^{153}$

Dat Reisel een vrij accuraat beeld schetste, ook al was hij niet zelf in Westerbork geweest, blijkt uit de verslagen van Elie Cohen over zijn gevoel van wroeging ten opzichte van nieuwelingen: 'Mijn gedachte was: Jullie hebt zoveel langer dan wij in de vrijheid (die geen vrijheid was, maar dat wilde ik niet laten meetellen) geleefd, je hebt het zoveel langer beter gehad dan wij, je hebt je toen niet om ons bekommerd, red je nu ook maar.' 54

Reisel bestempelde deze denkwijze als 'de merkwaardige psychologie van Westerbork' en verklaarde haar als volgt: 'In deze gemeenschap, die het primitiefste naast het hoogst ontwikkeldste kent aan menselijke reacties, de honger en de sexuele problemen niet te vergeten, kan natuurlijk niet normaal gereageerd worden.' 'ss In dit 'Hollandse Massada', in deze 'collectieve neurose', kon men bovendien nergens van op aan, want zelfs als een arts een baan bemachtigd had in het kampziekenhuis, was het nog allerminst zeker dat dat tot daadwerkelijke 'Zurückstellung' leidde. Op de kaarten van vele artsen in de 
Joodsche Raad-cartotheek zijn dan ook diverse verzoeken tot Sperrung op een of andere nog waardevol ogende lijst terug te vinden. ${ }^{56}$

Naast zichzelf helpen konden artsen met hun beroep - net als vóór Westerbork - een rol spelen in het vertragen van deportatie van patiënten. Ook hier konden ziekte en verblijf in het ziekenhuis, net als eerder, een strohalm vormen, een methode om verdere deportatie nog uit te stellen. Reeds bij de registratie bij aankomst in het kamp kon men bij de hier aanwezige registratiearts opgeven ziek te zijn en behandeling of verpleging te behoeven. Deze arts kon de zojuist aangekomen patiënt vervolgens rechtstreeks vanuit de registratiezaal in het ziekenhuis laten opnemen. ${ }^{157}$ In het ziekenhuis zelf was dan vervolgens de stationsarts, vergelijkbaar met een zaalarts in een ziekenhuis, verantwoordelijk voor de verdere medische behandeling in zijn ziekenbarak en voor de duur van de opname. Ook de polikliniekartsen en de 'transportartsen' konden een rol spelen in het opnemen of opgenomen houden van patiënten. De transportartsen hadden de taak om tijdens het vertrek van een transport medische assistentie te verlenen en bovendien de nacht voor het transport dienst te doen voor gevallen die op het laatste moment transportunfähig bleken te zijn.

Transportunfähig: dat was ook hier het sleutelwoord. Net als vóór Westerbork kon de medische verklaring van niet-vervoerbaarheid soms nog een redding zijn en (verdere) deportatie voorlopig voorkomen. ${ }^{158}$ En net als vóór Westerbork kon hierbij ook gesaboteerd worden.

Getuige dankbare woorden, na de oorlog gewijd aan het optreden van verschillende artsen in Westerbork, hadden sommige medici middels medische sabotage in Westerbork iets zeer wezenlijks voor hun individuele patiënten kunnen betekenen. De artsen waren weliswaar niet bij machte het systeem van de deportatiemachinerie te beïnvloeden, maar voor de individuele overlevenden was in retrospectief het optreden van de dokter bepalend geweest. Zo zorgde vrouwenarts Heymans van Amstel dat een patiënte die hij voor de oorlog had behandeld en die binnenkwam met een straftransport, rechtstreeks opgenomen werd in het ziekenhuis. Deze vrouw had in de trein naar Westerbork continu op één been gestaan, waardoor zij bij aankomst dit rood aangelopen been kon tonen bij wijze van trombosebeen. Of Heymans van Amstel dit bedrog dadelijk doorzag, vertelt het verhaal niet, maar in elk geval kon zij direct naar het ziekenhuis, wat haar uiteindelijk opleverde dat haar ' $S$ ', die haar eigenlijk in de strafbarak en vervolgens in de eerstvolgende trein naar Auschwitz zou hebben gebracht, 'weggewerkt' kon worden. Hierdoor kon zij vijftien maanden in Westerbork blijven. ${ }^{159}$ Een andere erkentelijke patiënte was Letty Rudelsheim, die in haar memoires Albert Elgenant Denekamp dankte, die 
volgens haar herinnering tot op het laatste moment probeerde haar naam via contacten van de transportlijst af te krijgen. ${ }^{160}$

Philip Mechanicus noteerde in september 1943 dat er operaties waren geschied die medisch niet verantwoord konden worden, net zoals in Amsterdam was voorgekomen. ${ }^{16 r}$ Ook abortus was een reden om transportunfähig te worden verklaard. Er werd geen openlijke abortus provocatus gepleegd, maar er werd gezegd dat een zwangere vrouw vloeide (dus een spontane abortus had) en gecuretteerd diende te worden. Dit 'schoonmaken' van de baarmoeder werd volgens Ellis Hertzberger regelmatig ingezet. ${ }^{162}$ Herbert Kruskel werd door de eveneens oorspronkelijk uit Frankfurt afkomstige arts Neuburger geholpen doordat die zijn echtgenote opnam met een 'akuten Gallenanfall', waardoor de hele familie 'zurückgestellt' werd. Vervolgens zorgde Neuburger er ook voor dat mevrouw Kruskel, zelf ook arts, een baan in het Westerborkse ziekenhuis kreeg. ${ }^{163}$ Een in juli 1942 voor een werkkamp opgeroepen jongeman, Paul Hertz, was in Amsterdam al geholpen door Jacob Goudsmit en Marietje Stoppelman, die attesten voor hem hadden geschreven. In Westerbork wendde hij zich tot Simon de Vries. Deze zei hem dat hij hem niet in Westerbork kon houden, maar adviseerde hem om in elkaar te zakken en zo opname in het ziekenhuis af te dwingen. ${ }^{164}$ Dezelfde De Vries zorgde er ook voor dat een van de leidsters van het Westerborkse weeshuis, Betsy Vromen-Snapper, werd aangesteld als secretaresse der specialisten. ${ }^{65}$ In het weeshuis waar zij gewerkt had, waren ook verschillende artsen actief in hun pogingen de kinderen te behoeden voor de wekelijkse transporten. De leider van het weeshuis, Otto Birnbaum, herinnerde zich na de oorlog hoe voormalig geneesheer-directeur van het NIz Salomon Kroonenberg altijd bereid was om te helpen door een bewijs van hoge koorts voor een bepaald kind af te geven, waardoor het kind nog niet op transport hoefde. Meestal leverde dit slechts uitstel van een paar weken op. Toch roemde Birnbaum Kroonenberg om deze handelwijze, omdat hij andere artsen had meegemaakt die dergelijke verklaringen weigerden af te geven. $\mathrm{Zij}$ vreesden bij ontdekking van valse attesten hiervoor met transport te moeten boeten. ${ }^{166}$

Een geval waarbij dit daadwerkelijk gebeurd is, is niet overgeleverd, maar artsen die wel aan deze medische sabotage meewerkten, riskeerden ongetwijfeld in elk geval voor hun gevoel hun bevoorrechte positie. Dit merkte ook Jacques Tas op, die in de strafbarak terechtkwam naar aanleiding van het illegaal posten van een brief naar Amsterdam. Toen hij daar een vervelende kaakholteontsteking kreeg, werd hem toegestaan ter poliklinische behandeling naar kno-arts Alexander Roozendaal te gaan. 'Toen het gevaar voor straf transport voor mij acuut werd, heeft collega Roozendaal mij aangeboden, mij aan een 
of andere uitgebreide radicale operatie te onderwerpen, om op deze wijze de zaak te rekken; ook daar was van zijn kant eenige moed toe noodig, zoodat ik deze houding zeer heb gewaardeerd. ${ }^{1}{ }^{167}$ Medewerking van het hoofd van de medische dienst, Fritz Spanier, kreeg Tas niet. Integendeel, Spanier was huiverig een collega op te laten nemen in het ziekenhuis, omdat hij vreesde 'dat de commandant zou denken, dat dit een doorgestoken kaart van de collegae onder elkaar was'. ${ }^{168}$ Elie Cohen herinnerde zich na de oorlog daarentegen dat Spanier vaak wel bereid was mee te werken aan het transportunfähig verklaren van patiënten. De transportartsen moesten namelijk een verzoek indienen bij Spanier om een patiënt transportunfähig te laten verklaren. Cohen wist dat de artsen zo zwaar mogelijke diagnosen stelden en de meest onwaarschijnlijke ziekten meldden. Spanier lachte daar dan wel eens om, net als de artsen zelf. Zo legde Cohen Spanier ook eens het geval van vier zwangere vrouwen in de strafbarak voor, die allen getuige het lichamelijk onderzoek niet verder dan omstreeks de vijfde maand van hun zwangerschap waren. De grens om teruggesteld te worden was een zwangerschapsduur van zeven maanden. Cohen dacht een poging te kunnen wagen met een verklaring bij Spanier dat de vrouwen alle vier ongeveer zes maanden in verwachting waren. Spanier bleek volgens Cohen in een goede bui en speelde het spel mee door te zeggen dat hij duidelijk kon zien dat de vrouwen allang in de zevende maand van hun termijn zaten en niet op transport konden. ${ }^{69}$

Cohen kon ook helpen door melkinjecties of tyfusvaccinaties te geven, zodat er koorts ontstond. Bij 40 graden koorts konden zijn patiënten dan worden opgenomen en vervolgens transportunfähig worden verklaard. ${ }^{170}$ Dat kon zelfs nog op het allerlaatste moment, namelijk in de nacht voor het transport, na het bekendmaken van de transportlijst. Cohen had op maandagavond vanaf negen uur samen met een collega 'transportdienst' voor het hele kamp. De twee artsen sliepen in de polikliniek, maar kwamen nauwelijks aan hun nachtrust toe omdat er voortdurend meldingen kwamen uit het hele kamp, waar mensen zich van hun driehoog-bedden gooiden om een hersenschudding te krijgen of zichzelf met messen verwondden:

Tot twee uur waren er voortdurend meldingen, dan was er dit, dan dat. Negen van de tien gevangenen lieten je roepen om klachten, die niets te betekenen hadden en het waren meestal pogingen om uit het transport te komen. De thermometer was hierbij het belangrijkste instrument en we werden vaak gewaarschuwd of we direct bij iemand wilden komen, die 40 graden koorts had. Maar meestal was er niets aan de hand. ${ }^{171}$ 
$\mathrm{Zij}$ poogden tegen beter weten in omdat dit het enige was wat hun nog restte. 'De wanhoop die op hun gezichten lag en de hoop, die ze hadden dat je ze nog kon helpen!'r72 Dat bleef Cohen maar al te zeer bij. Hij besefte dat hem op deze manier een bepaalde macht in handen was gegeven, die ook de verleiding tot machtsmisbruik met zich meebracht. 'Wat voor verleidingen ik niet gehad heb! Wat ze me hebben aangeboden om de temperatuur niet te nauw te nemen!' ${ }^{173}$ Hij moest bepalen wie wel te helpen en wie niet, en om welke redenen. Hét grote probleem was daarbij dat de transportcijfers gehaald moesten worden. Voor iedere zieke die door Cohens toedoen niet op transport ging, moest er een ander de trein in.

\section{VITAMINER}

Etty Hillesum, als vrijwillig verpleegster naar Westerbork gekomen, moest aanzien hoe ook haar ouders en broer hier belandden. Het leed en de angst voor de deportaties die zij om zich heen meemaakte, gingen haar zeer aan het hart, maar het allermeest trof haar het ongeluk van haar dierbaren. ${ }^{174} \mathrm{Om}$ hen maakte zij zich de meeste zorgen: 'De zorg om de aller-, allernaasten vreet erger aan je dan wat ook.' ${ }^{175}$

Als je in Westerbork enige invloed had, lag het dan ook voor de hand eerst dierbaren en bekenden te helpen. Ook in de schipbreuk die Westerbork heette was het hemd nader dan de rok bij het verdelen van de 'reddingsboten'. 'Als het familieleden waren of vrienden deed je je best om te trachten de mensen te helpen', aldus Cohen, die als arts 'prominent' geworden was. Sally de Jong schreef over het beïnvloeden van de transportlijsten door de artsen: 'Ook dit is niet alleen een medische aangelegenheid; familieleden, vrienden en vrienden van vrienden worden, ook al zijn zij "transportfähig" van de lijst verwijderd. '

Gevangene Sieg van den Bergh, zelf geen medicus, zag dat het kon helpen een arts in de vriendenkring te hebben: 'Mijn schoonmoeder werd in het ziekenhuis opgenomen en enige weken achter elkaar verklaarde een bevriende dokter haar "transportunfähig"' Philip Mechanicus schreef eind augustus I943 in zijn dagboek over een arts die zijn vader en schoonvader als patiënt opgenomen hield, zodat zijn ziekenbarak de bijnaam 'het familiehotel' kreeg. ${ }^{\text {.77 }}$ Elie Cohen getuigde van een dergelijke handelwijze: 'Mijn neef kwam bij mij en zei: "Pa moet vandaag in het ziekenhuis." Dus pa kwam erin op zondag.' ${ }^{178}$

Het inzetten van contacten, relaties, ook wel vitamine $\mathrm{R}$ genoemd, was typerend voor de gang van zaken in Westerbork. Dat sommige 'prominenten', mensen met enige macht om de transportlijst te beïnvloeden, hierbij ook 
omkoopbaar of chantabel bleken is niet verwonderlijk. De meest prominente arts, met de meeste relaties en de grootste invloed in Westerbork, was zonder twijfel Fritz Spanier. Nadat de kampcommandant van het bureau Iv B4 in Den Haag het aantal gevangenen had opgekregen dat hij op een bepaalde datum per trein diende te laten vertrekken, riep deze Spanier en de dienstleiders Kurt Schlesinger en Hans Ottenstein bijeen. Deze drie zochten aan de hand van de cartotheekkaarten vervolgens de mensen uit die in aanmerking kwamen om op transport gestuurd te worden. Dit aantal Transportfähigen lag altijd zo'n Io tot 20 procent boven het vereiste aantal. Hierna volgde namelijk de grote jacht op 'Zurückstellungen', hetzij door op het laatste moment ingediende verzoeken, hetzij door interventie van de Joodsche Raad of zijn Contact Commissie of door de kampcommandant zelf. De allerlaatste mogelijkheid was dat men door een arts, met de toestemming van Spanier, van 'transportfähig' naar 'transportunfähig' getransformeerd werd. ${ }^{179}$

Toen Mechanicus Spanier op 3I juli 1943 had ontmoet, beschreef hij hem als een charmante man met goede manieren en een weemoedige glimlach, een scepticus die het leven kende. ${ }^{180}$ Sally de Jong vond Spanier weliswaar 'in meenig opzicht voor zijn taak berekend; hij kende zijn vak en had veel invloed op den commandant', maar hij bevoordeelde Duitse boven de Nederlandse Joden. Bovendien had De Jong vermoedens, maar geen bewijzen, dat Spanier omkoopbaar was. ${ }^{\text {I8I }}$ Deze kritiek stond niet op zichzelf. Zowel tijdens als na de oorlog bestond er nogal wat rancune onder (oud-)gevangenen over de houding van onder anderen Spanier. Vrij algemeen was de verontwaardiging van Nederlandse gevangenen over het gedrag van de Duitse Joden. De Alte Kampinsassen hadden alle belangrijke baantjes in handen, waardoor Nederlanders nauwelijks een kans kregen om ook een zekerder positie in het kamp te bereiken. Van Dienstleiter Spanier zijn getuigenissen bewaard gebleven die zeer negatief over hem spreken. Tegelijkertijd zijn er getuigenissen van mensen die door hem gered werden en hem daarom de hemel in prezen. ${ }^{182}$ Elie Cohen, die zelf had ervaren wat het betekende om 'prominent' te zijn, schreef eerlijk dat ook hij beïnvloedbaar was:

Dat ging ongeveer zo. Maandagmiddag kwamen ze op de polikliniek vragen hoe ik het maakte, of ik een cigaret wilde opsteken. Dat wilde je graag, want meestal had hij goede, die hiervoor speciaal bewaard waren. Dan begon een praatje over het weer en de belangrijkste dingen uit het kamp om dan eindelijk bij het doel van het bezoek te belanden, nl: 'Heb je vanavond dienst? Zou je mij misschien een plezier willen doen?' 'Als het kan graag.' Dan bleek dat er een familielid, een vriend of vriendin kwam en of ik die door zou willen sturen naar het ziekenhuis. 
Cohen was over het algemeen bereid zijn medegevangenen op deze wijze te helpen. Uitzondering was als hij net zelf hard was getroffen door het vertrek van een eigen dierbare: 'Waren er de week tevoren goede vrienden van je doorgestuurd, dan verdomde je het om wat te doen. Ik betaal ook gelag, dacht je dan, waarom moeten zij er wel uit? ${ }^{3}{ }^{3} 3$ Wanneer hij deze mensen vervolgens op het perron zag, kon hij wel spijt krijgen van zijn optreden: 'Voor een enkele wagon was nog een plaatsje voor het raam met prikkeldraad vrij en daar stond een kennis voor, die me toeriep: 'Ik kom terug!' Dan had je een gevoel van wroeging, dat je toch niet meer je best had gedaan, dat je geen goede bui had gehad. ${ }^{\text {184 }}$

In zijn naoorlogse beoordeling van zijn eigen gedrag spaarde Cohen zichzelf niet. Hij vond zijn houding achteraf gezien egoïstisch. In een interview refereerde hij aan een in Westerbork tot hem gerichte vrouwenstem aan welke hij nog vaak dacht: "UU blijft rustig hier, maar wij moeten weg", en aan de haat die uit haar ogen op mij toekwam'. ${ }^{185}$ Het was hem gelukt zo lang in Westerbork te blijven door het spel mee te spelen, zo zei hij. 'Ook ik stond hakken te klappen, ook ik deed 'stramm' en riep luid: "Jawohl Doktor Spanier, Jawohl Herr Schlesinger" en ik deed net zo hard mijn "plicht" als de anderen opdat de treinen iedere dinsdag met het vereiste aantal Joden naar het Oosten konden vertrekken. Ik werkte mee uit egoïstisch eigenbelang. ${ }^{3} 86$

Wellicht had zijn ervaring in Amersfoort bij Cohen al een dermate vergaande depersonalisatie teweeggebracht dat hij moeilijk nog een ander dan zijn eigen belang kon dienen. Toch kan het aandikken van diagnoses, kunstmatig verhogen van koorts en verlengen van de zwangerschapsduur teneinde patiënten uitstel van deportatie te bezorgen, kortom de medische sabotage die ook Cohen toepaste, niet louter uit egoïstische motieven verklaard worden. Cohen zette hiermee zijn reputatie bij Spanier op het spel en daarmee zijn veiliggestelde positie in Westerbork. In I993 zei Cohen hier dan ook over: 'Je deed wat je kon. ${ }^{\text {' } 87}$

Maar ook hier bleken de medische reddingsmiddelen maar zeer tijdelijk respijt te bieden. Zieken werden in 1943 gewoon meegedeporteerd. ${ }^{188}$ Sally de Jong zag met lede ogen aan hoe een groep zieken op transport werd gestuurd:

Het is, op een transportochtend, een droeve uittocht uit de ziekenhuisbarakken: lopend, meestal ondersteund, op brancards gaat het naar de trein. Voor patiënten die niet kunnen zitten zijn een honderdvijftig primitieve britsen getimmerd, twee boven elkaar. Daarop gelegen, worden verlamden, blinden, tachtig-, negentigjarigen naar Duitschland vervoerd. ${ }^{189}$ 
Transportunfähig verklaren had steeds minder zin. Sterker nog, een 'kroongetuige' had zich afgevraagd of het niet zinvoller zou zijn juist de ouderen, zwakkeren en zieken, kortom de transportunfähigen, te deporteren:

Een kroongetuige komt bovendien met een bericht, dat een schel licht werpt op de onmenselijke situatie waarin het kamp verkeerde: de meest rationele en humane methode van selectie voor de wegvoering leek deze artsen de aanwijzing van de meest hopeloze gevallen: gingen die de veewagens in, dan kregen de lichtere zieken de kans, in de gunstiger kampsituatie te herstellen (de lezer geve zich rekenschap van het karakter van een systeem, dat zulke situaties wist te scheppen). ${ }^{190}$

Tegen een dergelijk systeem was geen enkel medisch sabotagemiddel opgewassen. De deportatiemachinerie ging onverstoorbaar verder en ging de een niet mee, dan wel de ander. In feite waren de prominenten en dus ook de artsen volstrekt machteloos. Transportfähig of niet, iedereen moest eraan geloven. Net als alle eerdere bleek ook deze strohalm geen reële strohalm, maar een manier om slachtoffers tegen elkaar uit te spelen. Ellis Hertzberger merkte dan ook terecht op: 'Je kon niets doen.' ${ }^{\text {I9I }}$

\section{MACHTELOOS?}

Ellis Hertzberger had ervoor gekozen zo min mogelijk verklaringen van 'Transportunfähigkeit' af te geven. ${ }^{192} \mathrm{Hij}$ had zich niet willen begeven in het morele dilemma van keuzes maken tussen mensen. En hij was niet de enige die er zo over dacht. Jacques Reisel had immers al in zijn dagboek genoteerd: 'Ziekentransportlijsten maken, een werk dat geen mens, geen Jood en zeker geen arts mag doen. Hands off!' ${ }^{193}$ Hij had gezien dat de vrijwillig naar Westerbork afgereisde Joodse artsen hier deels idealistische motieven voor hadden gehad, maar ook zij 'moeten lijsten maken van transportfähige zieken, dat hoort nu eenmaal bij het werk van de Joodsche Raad. Dus óók slavenarbeid, evenals de Expositur van Westerbork. Werk dat als mens, als Jood en als arts niet kan en mag verricht worden.' ${ }^{294}$

Ook in Westerbork zelf was kritiek hoorbaar op artsen die keuzes maakten tussen mensen. De stationsarts die in zijn ziekenbarak een 'familiehotel' had opgezet, viel zware kritiek ten deel van zowel patiënten als collegae. Hij had immers het deel van zijn patiënten met een ' $S$ ', de strafgevallen, opeens ontslagen uit zijn barak, omdat hij verantwoordelijk was gesteld voor een eventuele 
ontsnapping in hun gelederen. Met deze houding had hij, aldus Mechanicus 'zijn reputatie als mens verspeeld'. ${ }^{195}$

En toch was juist het ziekenhuis in de herinnering van verschillende getuigen een kleine oase van menselijkheid. Presser tekende bijvoorbeeld uit de mond van een ooggetuige op: 'En toch, juist in het ziekenhuis ontmoette men mensen, artsen en verpleegsters, die, hun eigen zorgen en noden vergetend, dag en nacht met toewijding al het mogelijke deden wat in hun macht was, om hun lijdende medemensen te helpen. ${ }^{196}$ John van Lier, arts-assistent uit Het Apeldoornsche Bosch, kreeg weliswaar een zaal met 35 patiënten toegewezen, maar daar was voor hemzelf geen bestendige verblijfsbelofte bij. ${ }^{197}$ Desondanks besloot hij zijn brief aan het Centraal Israëlietisch Krankzinnigengesticht met de woorden: 'Uit dit relaas blijkt, dat wij het hier wel kunnen stellen. Wij hebben een bevoorrechte positie boven velen, die met ons uit Apeldoorn zijn gekomen en zijn hier dankbaar voor en doen ons best in onze positie talrijken naar vermogen te helpen.' ${ }^{\text {'98 }}$

Naar vermogen helpen, dat was wat de Westerborkse artsen nog konden doen. Ook Elsa Jessurun d'Oliveira werkte in Westerbork in haar vak, haalde daar voldoening uit en kon daarmee ook Westerbork even vergeten, zoals zij aan haar verloofde in Amsterdam schreef: 'Het werken in m'n eigen vak bevalt me wel goed. Er zijn hier ontroerend lieve babies.' ${ }^{999}$ En ook: 'ik heb vandaag reuze hard gewerkt, er waren een heel stel bijzondere gevallen. Dan kan ik heel W vergeten, wel heerlijk.' ${ }^{200}$ Haar werkdagen zagen er eigenlijk heel normaal uit, zoals zij gedetailleerd aan haar geliefde beschreef:

Ik eet op het ziekenhuisterrein iedere dag. [...] Ik sta \pm om 7 uur op (maar om 5 uur begint men al op klompen door de barak te klossen) en ben dan om ong 8 uur klaar. Ga ontbijten in de Ior d.i. de ziekenhuiscantine, met Han. Verder's morgens werken op zaal, soms druk, soms heel weinig te doen. Om half I ga ik in Ior eten en dan een uurtje naar huis (!). Dan ga ik m'n bed opmaken, soms wassen of boodschappen doen. Dan weer naar zaal en wat lezen (in de med bibliotheek) om half 7 brood halen in de IoI en naar huis. 's Avonds ben ik meest weg, op zoek naar licht en gezelligheid. $^{201}$

De artsen konden, zoals Elsa beschreef, in het goede ziekenhuis dat voorhanden was, hun beroep op min of meer normale wijze voort- en inzetten. Daarmee konden zij een dosis normale medemenselijkheid overbrengen in een onmenselijke wereld.

Ook een arts die zelf niet eens een aanstelling in het ziekenhuis had, maar 
daar als patiënt verbleef, kon nog een dergelijke humane hulp bieden. Zo hielp David Meijer Levy uit Eefde de patiënt naast hem: het jongetje Louis van Vollenhoven. Hij voerde hem zijn eten en zorgde dat hij zijn pillen nam. ${ }^{202}$ Mechanicus beschreef de artsen in het kamp ook als algemeen hulpvaardig, bijvoorbeeld toen zij trachtten de buiklooppatiënten zo veel mogelijk te ontzien en te laten rusten. ${ }^{203}$ Jacques Tas had aanvankelijk niets te doen, maar bedacht toen zelf dat hij zich nuttig kon maken door spreekuur te houden voor kinderen die door de omstandigheden weer in bed waren gaan plassen. ${ }^{204}$ Arts Ellis Hertzberger deed zijn medische werk eenvoudigweg zo goed mogelijk. In een interview in de jaren negentig zei hij in alle bescheidenheid: 'Ik denk niet dat ik mensen het leven heb gered daar'; hooguit had hij weleens iemand opgelapt in het ziekenhuis. Totdat diegene ook weer op transport ging. ${ }^{205}$

Een kans om ook op het laatst nog iets voor de vertrekkenden te betekenen, al was het niet echt medische hulp, vond de Dordrechtse arts Oscar Cahen, die ook vaak bij de transporten aanwezig was. Hij was erin geslaagd een schuilplaats in de trein te maken voor het deponeren van briefjes. Hij sprak met de gedeporteerden af dat hij hun briefjes bij terugkeer van de trein zou verzamelen en zou doorsturen naar de geadresseerden, hetgeen hem ook daadwerkelijk lukte. ${ }^{206}$

Onder de vertrekkenden bevonden zich in toenemende mate artsen; ook zij kwamen onherroepelijk aan de beurt. Op 7 juli 1943 kwam er zelfs ontstellend nieuws voor de oude kampingezetenen: de 'Stammliste' was 'geplatzt', oftewel niet meer geldig. Iedereen werd ontsperd. Er zou een nieuwe stamgroep gevormd worden van ten hoogste 1623 mensen, van wie niet meer dan 300 medewerkers van de gezondheidsdienst mochten zijn. Alleen doktoren, verplegend personeel en dringend noodzakelijk administratiepersoneel kwamen in aanmerking voor deze status. ${ }^{207}$ Nog geen week later, op 13 juli, was er volgens Mechanicus al sprake van een 'grote slachting' onder het ziekenhuispersoneel, van wie een groot aantal op transport moest. Onder hen zestien artsen. ${ }^{208}$ Oudgedienden Eddy de Wind en Elie Cohen moesten mee met het transport van I4 september. De Wind kwam niet in aanmerking om bij de 300 bevoorrechten te komen, omdat hij op de personeelslijst van de Joodsche Raad stond: hij was destijds bij de Joodsche Raad in dienst gekomen en niet bij Dienstbereich IV zelf. Spanier was oprecht boos, maar kon er niets aan veranderen. ${ }^{209}$ Elie Cohen daarentegen was uit de gratie geraakt bij Spanier, waardoor hij geen bescherming meer genoot.

De vertrekkende artsen konden als treinarts tijdens het transport nog helpen, al was dat gezien het gebrek aan middelen in de treinen, zeer minimaal. De jonge Amsterdamse arts David Moffie, die op 3I augustus 1943 uit Wes- 
terbork vertrok in de richting van Auschwitz-Birkenau, was met drie collegae tot treinarts gebombardeerd en droeg ten teken daarvan een band om de arm. Enkele malen werd hij tijdens stops naar een andere wagon geroepen, waar iemand onwel was geworden, maar dit alles had geen enkele betekenis: hij kon niets voor deze mensen doen. ${ }^{210}$ Immers, aannemelijk is dat als zelfs voedsel al uitermate schaars was in de treinen, medicamenten al helemaal niet of nauwelijks aanwezig waren. Medische instrumenten waren er alleen dan als de arts ze zelf had meegebracht. Zo namen F.C. de Leeuw-Bernard, medisch doctoranda, en haar man, arts, samen een 'mooie verzameling' instrumenten en enkele medische handboekjes mee in de trein teneinde op de plaats van bestemming zich wederom in een ziekenhuis nuttig te kunnen maken. Met dit transport, dat uit Westerbork vertrok op 26 augustus I943, reden vijf artsen mee, die niet veel meer konden doen dan bij aankomst helpen bij het uit de wagons dragen van de zieken die per brancard de trein in waren gekomen. ${ }^{21}$ Toch nog een klein artsengebaar, terugverwijzend naar normalere tijden.

\section{TRANSPORTSTOPEN WETENSCHAPPELIJK WERK}

In oktober 1943 was er in het kamp een polio-epidemie uitgebroken. Op I9 oktober vertrok er nog een trein die vanwege besmettingsgevaar hermetisch was gesloten met loodjes, maar op dat moment was Gemmeker al ingegaan op het advies van Spanier om een quarantainetoestand uit te roepen. In het kamp zelf werden hygiënische maatregelen getroffen om de kinderverlamming in te dammen, maar het belangrijkste was: de transporten werden lamgelegd. In de hele periode van 29 oktober 1943 tot 26 januari 1944 vertrokken er geen treinen, met uitzondering van één transport. ${ }^{212}$ Spanier voelde zich, in zijn streven de quarantaine in te voeren en zo lang mogelijk vol te houden, gesteund door Stabarzt Eduard Meyer. Deze kwam verschillende malen op bezoek in Westerbork en sprak dan kort met Spanier. Spanier op zijn beurt had de indruk dat Meyer hem relatief gunstig gezind was. ${ }^{213}$ Welke machten achter de schermen ook mochten meespelen, het effect, een transportstop van drie maanden, was een ongekende luxe. Een luxe die men aangreep om de normaliteit ten enemale te trachten te bewaren.

In het Westerborkse ziekenhuis was november-december 1943, door de afwezigheid van de wekelijkse spanning, een periode van relatieve rust. Niet alleen de uitgaande treinen vertrokken niet, ook de inkomende transporten waren min of meer opgedroogd. Immers, Amsterdam was op 29 september ‘judenrein’ verklaard. Iedereen die niet ondergedoken zat, was inmiddels naar 
Westerbork of verder oostwaarts gebracht. Met het 'laatste transport' was de Barneveldgroep in Westerbork gearriveerd. De artsen in deze groep gaven een nieuwe impuls aan het wetenschappelijk niveau in het kamp.

Dat in deze periode hier de eerste antibiotica in Nederland geproduceerd en gebruikt werden, lijkt stug, maar zou toch, hoewel nog zeer amateuristisch, het geval kunnen zijn geweest. De hygiënische afdeling van Dienstbereich IV was immers steeds beter en geavanceerder geworden. De veelvuldig voorkomende infectieziekten dienden ingedamd te worden en daarvoor waren, zeker na de komst van de artsen uit Barneveld, diverse experts aanwezig. In augustus 1943 was men al, na maanden van voorbereiding, daadwerkelijk begonnen met een vaccinatieprogramma. Allereerst werd men verplicht tegen tyfus en paratyfus ingeënt, waarna difterie- en pokkeninentingen volgden in de maanden erna. ${ }^{214}$ Ook werd er een grootscheepse campagne opgezet om de enorme vliegenplaag die in het kamp heerste te bestrijden. ${ }^{215}$ De hygiënische dienst had tevens een taak in de voorkoming van verspreiding van geslachtsziekten, aangezien de seksuele moraal in Westerbork stukken losser was dan ze in de gewone burgermaatschappij was geweest. ${ }^{216}$ Tevens moest elk sterfgeval gemeld worden bij de hygiënische dienst teneinde de crematie spoedig te kunnen afhandelen. ${ }^{217}$ Zeker tijdens de quarantaine werd zeer veel belang gehecht aan deze afdeling.

Jacobus Heimans en Aron Vedder waren begin 1944 de twee artsen die de staf van de hygiënische dienst vormden en zij werkten samen in hun bacteriologisch-parasitologisch laboratorium. ${ }^{218}$ Aron Vedder had in zijn huisartspraktijk aan de Amsterdamse Weesperzijde ook reeds een bacteriologisch lab gehad, alvorens hij naar Barneveld was vertrokken. Volgens zijn dochter zette hij zijn bacteriologische werkzaamheden in Westerbork voort, waar hij samen met zijn collega Hans Schrijver en zijn vrouw, die bacteriologisch laborante was, op proef zelfs penicilline maakte. Hij had volgens de getuigenis van zijn dochter een Amerikaans artikel over de zeer recente ontwikkelingen op het gebied van de productie en toepassing van dit revolutionaire medicijn mee naar het kamp genomen. Dit stelde hem in staat om in gevangenschap, in het laboratoriumpje van twee bij twee meter, een poging te wagen tot productie van het antibioticum. Twee soorten maakten Vedder en Schrijver naar verluidt: Moppine en Grappine, verwijzend naar de zeer experimentele fase waarin deze 'medicijnen' verkeerden. Niettemin: een man met schotwonden in de thorax zou dit middel ook daadwerkelijk toegediend hebben gekregen toen hij een longontsteking kreeg. Hij genas. ${ }^{219}$ Dit zou zelfs de Delftse hoogleraar Hein Waterman geweest zijn, eveneens een oud-Barnevelder. Op 30 mei 1944 was hij gewond geraakt tijdens een beschieting van een Engels jachtvliegtuig. Een granaatscherf had zich in zijn linkerlong geboord, vlak bij het pericard (hart- 
zakje), waar deze onmogelijk chirurgisch verwijderd kon worden. ${ }^{220}$ Het verhaal zou kunnen kloppen, aangezien ook Andries Querido, arts-onderzoeker die tot 1939 in het Institut Pasteur in Parijs had gewerkt, in het kamp aanwezig was. Hij had permissie om vanuit Westerbork op en neer te reizen naar de Gist- en Spiritusfabriek in Delft, waar men ook al - in het diepste geheim - experimenteerde met de fabricage van penicilline, onder de codenaam Bacinol. Querido had bij een toevallige ontmoeting op het station van Simon van Creveld een exemplaar van het Schweizerische Medizinische Wochenschrift gekregen dat volledig gewijd was aan penicilline en toonde hoe het gefabriceerd kon worden. ${ }^{221}$ Dat dit voor de Gist- en Spiritusfabriek zeer bruikbaar was staat vast, of Querido en de zijnen er ook in Westerbork iets mee deden is niet zeker, maar het is niet ondenkbaar. Als het echt zo is dat in kamp Westerbork voor het eerst op Nederlandse bodem een patiënt met penicilline is behandeld, is dit zeer opmerkelijk. Het toont andermaal het hoogstaand medisch peil in het kamp aan, maar doet tegelijkertijd enigszins surrealistisch aan, met in het achterhoofd wat de functie van het kamp verder behelste.

\section{HET'SCHICKSAL IM OSTEN'}

De primaire functie van kamp Westerbork bleef het deporteren van zo veel mogelijk Joden naar hun vernietiging. Eind januari 1944 was het gedaan met de relatieve rust van de quarantaine. De treinen sleepten weer als tevoren grote hoeveelheden mensen weg. Bij uitstek zieken waren nu aan de beurt. Het ziekenhuis was immers 'het waterhoofd' van het kamp geworden, zoveel mensen werkten of verbleven er. Op 4 februari 1944 stuurde Gemmeker het volgende telegram aan ss-Sturmbannführer Wilhelm Zöpf van het Haagse Reichssicherheitshauptamt IV B4, belast met de deportaties van Joden, om een voorstel te doen voor een oplossing:

Nachdem der Lagerbestand auf 6500 Juden herabgesunken ist, das

Krankenhaus andererseits aber immer noch etwa 900 kranke Juden aufweist, halte ich es für dringend notwendig, ohne Rücksicht auf Infektions- und Fieberkrankheiten, den Abtransport der kranken Juden durchzuführen. Infolge der hohen Zahl von Kranken ist auch eine entsprechend hohe Zahl von Krankenhauspersonal notwendig, was sich auf die Durchführung der Transporten nach Auschwitz hemmend auswirkt. Auch bei den Transporten nach Theresienstadt und Bergen-Belsen hat sich gezeigt, dass die Zahl der nichttransportfähigen erheblich war und eine starke verringerung der Transportzahle brachte. 
Gemmeker geloofde dat hij hard moest optreden:

Ich habe den Eindruck, dass die Juden, wenn ein radikaler Abtransport von Kranken durchgeführt wird, sehr schnell gesund werden und nicht mehr im Krankenhaus zuflucht suchen. Ich schlage deshalb vor, ausser den Transportfreien alle kranke Juden, die nicht zur Barneveld-, Protestanten-Gruppen und zur Stammliste gehoeren, nach Auschwitz auf Transport zu stellen. Auf diese Weise würde das Krankenhaus sicherlich um 400-500 kranke Juden entlastet. ${ }^{222}$

Zo gezegd, zo gedaan. Het grote ziekentransport werd op 8 februari 1944 een feit. De artsen stonden machteloos: Transportunfähigkeit bestond niet meer. Uiteindelijk gingen met dit transport 268 zieken mee, begeleid door een even groot aantal verplegers en artsen. ${ }^{223}$ Chirurg Izak Manheim en co-assistent Max Hamburger, die met zijn vrouw slechts enkele weken eerder was aangekomen, waren bij de vertrekkenden. ${ }^{22}$ Van hetgeen hunzelf en de zieken te wachten stond, zullen ze een sombere voorstelling hebben gehad. In het kamp was namelijk, zeker onder artsen, volgens getuigenissen, wel enige kennis van het 'Schicksal im Osten'. Arts Andries Kaas, half-Jood en in januari 1944 gepakt wegens hulp aan Joden, was gevangene in Westerbork op het moment dat hier de sterilisatiekwestie actueel was. Hij sprak erover met diverse mensen.

Een van de artsen, een doorgaans zeer goed ingelichte figuur van de 'oude garde', deelde me toen mee, dat diegenen die de bevelen tot sterilisatie niet zouden opvolgen, direct naar Auschwitz gedeporteerd zouden worden. En hij voegde daaraan toe, dat geen van de gedeporteerde artsen dat zou overleven. ${ }^{225}$

Kaas verbaasde zich over deze stelligheid en de blijkbaar gedetailleerde kennis van de arts over wat deportatie precies in zou houden.

Ook nu weet ik nog niet, of hij iets van selectie of gaskamers afwist. Wel bleek bij een andere gelegenheid, dat hij precies wist hoe de controle bij aankomst in een concentratiekamp verliep. ${ }^{226}$

Wat wisten de gevangenen in Westerbork precies van hun lot in het Oosten? Dat geïndustrialiseerde vernietiging het einddoel van de reis zou kunnen zijn, was moeilijk te geloven. ${ }^{227}$ Een arts die het wel geloofde, was Ies van der Hal. 
Hij had lang in Vught gevangengezeten en had er de Hongaarse apotheker Leo Laptos leren kennen, die al in Auschwitz geweest was. Hoewel de bezetter angstvallig probeerde de kennis over wat daar gebeurde binnenskamers te houden, was Laptos toch, door een administratieve fout binnen de Nederlandse landsgrenzen gekomen. Hij stelde Van der Hal op de hoogte van hetgeen hij in Auschwitz had gezien. Van der Hal werd op 3 juni 1944 naar Westerbork gezonden, om al een week daarna met zijn echtgenote doorgestuurd te worden naar Birkenau. Daar zag hij met eigen ogen het onvoorstelbare. ${ }^{228}$

Van der Hals verhaal toont dat artsen in sommige gevallen door hun contacten goed geïnformeerd konden zijn. In Westerbork riep hij zijn collegaartsen bijeen, omdat hij vond dat hij zijn kennis met hen moest delen. Onder anderen Spanier, Nico Speyer en Els Jessurun d'Oliveira waren bij dit gesprek aanwezig. Van der Hal meende dat Spanier goed op hoogte was en wellicht zelfs met Gemmeker over Polen sprak. Speyer was door de informatie van Van der Hal ook ingelicht. ${ }^{229}$ Echter, welk verdringings- of geheugenmechanisme er ook aan ten grondslag lag, na de oorlog kon Speyer zich deze bijeenkomst niet meer heugen. Hij zei zelfs tegen een andere collega dat hij er een bewijs voor had dat hij dacht dat de getransporteerden ook weer terug zouden komen: toen Van der Hal met de trein mee moest had Speyer hem een van zijn twee pakken meegegeven. Hij zou daarbij gezegd hebben: 'Kijk eens, Ies, dit is een heel goed pak. Dat geef ik je omdat je nu eenmaal doorgaat, maar ik heb wel een belangrijk verzoek. Als je terugkomt, moet ik het terug hebben, anders heb ik geen pak. ${ }^{230}$ Els d'Oliveira daarentegen kon zich na de bevrijding wel nog exact voor de geest halen wat Van der Hals boodschap was geweest. Toen hij zich aan haar wilde voorstellen op een medisch congres, jaren na de oorlog, meldde zij dat dat niet nodig was. Zij kende hem en zijn toenmalige onheilstijding nog maar al te goed, zo bevestigde zij hem ook per brief. ${ }^{23 \mathrm{I}} \mathrm{Bij}$ andere artsen leefden op zijn minst ook vermoedens, zoals Mechanicus uit de mond van een van hen optekende:

Van optimisme kan geen sprake zijn. Wie zich optimist noemt, geeft zich over aan luchthartigheid. Die heeft nog niets geleerd van de harde feiten. Wat horen wij uit Polen? Zo goed als niets. [...] Wie naar Polen gaat, is afgeschreven. ${ }^{232}$

En toch, als arts hoefde je niet helemaal afgeschreven te zijn. Zelfs in de vernietigings- en concentratiekampen in het Oosten kon het artsenberoep nog een rol spelen. Max Roeper schreef vanuit Vught aan zijn (niet-Joodse) echtgenote dat hij dankzij zijn beroep minder vrees koesterde voor zijn dreigende de- 
portatie naar het Oosten. Hij redeneerde immers: 'waarschijnlijk heb ik kans door mijn beroep daar in den vreemde weer een functie te krijgen. ${ }^{233}$ Roepers hoop bleek ijdel, want twee maanden later werd hij in Auschwitz-Birkenau vermoord. Toch had hij wel gelijk met zijn opmerking: artsen hadden dankzij hun beroep relatief betere kansen. Zelfs in Sobibor, waar vrijwel iedereen direct na aankomst vergast werd, hadden de twee Nederlandse artsen Tobias Soubice en Benjamin Nink nog even als arts mogen werken, alvorens ook hen de dood in de gaskamer wachtte. ${ }^{234}$

Ondanks het feit dat vele Joodse artsen op soortgelijke wijze van het leven beroofd werden, sommige al vroeg 'werden gestorven' in Mauthausen en andere nog in mei 1945 stierven aan vlektyfus in de trein met gevangenen uit Bergen-Belsen die in Tröbitz door de Russen bevrijd werd, waren de Nederlandse Joodse artsen als groep toch relatief bevoorrecht. Van de 534 Joodse artsen over wie dit boek gaat, overleefden er 2II de Duitse bezetting niet. Dat zijn huiveringwekkend veel verloren levens, maar in vergelijking met de 75 procent van de totale Nederlandse Joodse bevolking die de oorlog niet overleefde, is die 2 II een opvallend laag getal. Terwijl van de Nederlandse Joden 25 procent overleefde, bleef van de Nederlandse Joodse artsen ruim 60 procent in leven. Dit percentage is ook iets gunstiger dan de overlevingskans in een andere elitegroep, die van de Joodse advocaten. Daar overleefde iets meer dan 50 procent van de ruim 200 betrokkenen. ${ }^{235}$ In de artsengroep was het overlevingspercentage van de gedeporteerden ook opvallend hoog. Van de 253 gedeporteerde artsen overleefden volgens de gevonden gegevens 86 de oor$\log .{ }^{236}$ Hoewel alsnog de overgrote meerderheid van de gedeporteerde artsen in de kampen de dood vond, was deze overlevingskans van I op de 3 relatief gezien bijzonder hoog. Van de circa IIo ooo gedeporteerde Nederlandse Joden overleefden er slechts 5000: I op de 22.

De oorzaak voor dit laatste grote verschil lijkt drieledig. Allereerst golden volgens getuigen vaak betere leefomstandigheden in de kampen voor diegenen die als arts in een kampziekenhuis konden werken. Zo was het mogelijk dat I4 van de 87 naar Auschwitz(-Birkenau) gedeporteerde artsen na de oorlog naar Nederland konden terugkeren, vaak omdat zij er als arts hadden kunnen werken. Ellis Hertzberger bijvoorbeeld had in Auschwitz als bacterioloog gewerkt, wat betekende dat hij niet in de barre kou fysiek uitputtende arbeid in een commando hoefde te verrichten, maar warm binnen achter zijn microscoop kon zitten. ${ }^{237}$ In Westerbork had hij bovendien als arts de keuze gekregen of hij naar Auschwitz of Theresienstadt 'wilde'. Theresienstadt stond bekend als een 'Vorzugslager', waar betere leefomstandigheden zouden zijn. Hertzberger koos dus voor dit kamp. ${ }^{238}$ Ook de Barnevelders zouden naar Theresienstadt 
gaan. Degenen onder hen met Palestinapapieren (met name zionisten hadden een dergelijke 'Sperr') konden echter ook voor een Austauschlager in het kamp Bergen-Belsen kiezen. Jacob Bramson was de enige die hiertoe overging. ${ }^{239}$ Hoewel er inderdaad uitwisselingen hebben plaatsgevonden was deze keuze in retrospectief waarschijnlijk de verkeerde voor de familie Bramson. Carolina Bramson-Klein, echtgenote van Jacob en zelf ook arts, stierf in Bergen-Belsen. ${ }^{240}$ Nog 69 andere artsen, een relatief grote groep, zouden naar Theresienstadt afgevoerd worden. In dit kamp voor 'bevoorrechten' golden inderdaad hogere kansen op overleving dan in de vernietigingskampen Auschwitz en Sobibor, net als in het eveneens beter bekendstaande Bergen-Belsen, waar ook relatief veel artsen naar werden afgevoerd. Van de 29 artsen die in Bergen-Belsen terechtkwamen, overleefden er I5. Van de 70 naar Theresienstadt gevoerden kwamen er 4I terug. Nog altijd hoge sterftecijfers, maar van de 26 artsen die naar Sobibor werden gedeporteerd, overleefde niemand. Relatief veel artsen werden dus naar de 'betere' kampen afgevoerd. Dit geldt als de tweede reden voor hun hogere overlevingskans. Dat velen van de artsen vanuit Theresienstadt, onder wie ook Hertzberger, alsnog naar Auschwitz zouden worden getransporteerd konden zij van tevoren niet bevroeden. Hun verblijf in Theresienstadt, een kamp met hemeltergend erbarmelijke omstandigheden, maar in elk geval nog zonder gaskamer, had hun aankomst in vernietigingskamp Auschwitz wel iets vertraagd. Vertraging was dan ook een derde belangrijk voordeel voor beoefenaars van het medisch vak. In Nederland zelf was vooral het ziekenhuis van Durchgangslager Westerbork voor veel artsen een - levensreddende - vertragende factor geweest.

Het artsenberoep speelde al met al in de kampen nog wel degelijk een rol van betekenis. Het was een van de weinige beroepen, misschien wel het enige, waaraan men in de kampen nog echt iets kon hebben. 'Werkelijk, arts was het beroep voor de kampen,' zei Elie Cohen dan ook met een cynische ondertoon, maar zeker niet onterecht. ${ }^{24 I}$

De daadwerkelijke invulling van het artsenberoep in de kampen in OostEuropa valt buiten het bestek van dit boek, maar een citaat van de Frans-Joodse arts Albert Haas geeft weer dat zodra men de mogelijkheid had om als arts te werken automatisch niet alleen de voorrechten, maar ook de plichten van het arts-zijn weer opspeelden:

Een wezenlijk deel van mijn kampervaring was dat ik mij verantwoordelijk voelde voor de medische zorg voor mijn medegevangenen. Niemand kon in de dagelijkse - en vaak primitieve - strijd om het bestaan een heilige zijn. Maar ik werd vaak verscheurd door de tegenstelling tussen 
de principiële waarden van mijn beroep - die ik innig koester - en mijn instinctieve reactie op de wil tot overleven, de onoplosbare morele strijd die ik moest leveren. ${ }^{242}$ 


\section{SAMENVATTING EN CONCLUSIE}

Kon aan het imperatief 'Vergeet niet dat je arts bent' te allen tijde gehoor worden gegeven tijdens de Tweede Wereldoorlog? ${ }^{\text {? }}$ Met deze vraag begon dit boek. $\mathrm{Na}$ de ervaringen te hebben bestudeerd van 534 Joodse artsen in Nederland die onder het nazi-juk trachtten arts te blijven, kan het antwoord niet anders luiden dan: nee, niet te allen tijde. Er hebben zich, onder de krankzinnige, levensbedreigende omstandigheden van de Shoah, situaties voorgedaan waarbij het artsenberoep voor de beoefenaar zijn betekenis verloor. Heel vaak, onder de meeste omstandigheden en voor de meesten van de hier beschreven 534 Joodse artsen in het bezette Nederland, bleef het beroep echter wel van belang. Dat men arts was en daarbij behorende plichten en voorrechten had, was in vele situaties van grote betekenis.

\section{SAMENVATTING}

Voorafgaande aan de Duitse bezetting speelde het arts-zijn voor Nederlandse Joodse medici een zeer belangrijke rol: vóór al het andere was men arts. Het beroep was meer dan zomaar een baan: het was een roeping. Men stond in de traditie van de arts met de status van een bij uitstek deugdzaam, moreel hoogstaand en altruïstisch mens. De arts diende de zorgen van de schouders van de patiënt te nemen. Een paternalistische houding ten opzichte van de patiënt was dan ook volslagen normaal. Men diende zich als arts bevoogdend, zorgend en vaderlijk op te stellen, zo werd dit ingevuld. Collegialiteit was door dit ideaal eveneens vanzelfsprekend: men vormde gezamenlijk een elitair, boven het 
lekenpubliek verheven genootschap. Of men Joods of niet-Joods, katholiek of protestant was, gold in de artsenstand in het verzuilde Nederland als minder relevant. In de eerste plaats was men collega. De Nederlandse Joodse artsen hadden zich in de decennia voor de Tweede Wereldoorlog een gelijkwaardige positie binnen de artsenstand verworven en niet zelden hadden ze zowel in medische kring als maatschappelijk carrière gemaakt. Met name in Amsterdam, waar zo'n 40 procent van de artsen Joods was, woonden en praktiseerden vele vooraanstaande Joodse medici. Maar ook in de algemene artsenstand en in de samenleving was sprake van verregaande emancipatie en integratie van de Joodse artsen, vergemakkelijkt door het feit dat de Joodse en de neoromantische niet-Joodse medische ethiek vrijwel naadloos op elkaar aansloten. Ook de Joodse medische ethiek, gesymboliseerd door het Ochtendgebed voor de arts van Maimonides, stond immers - kort samengevat - het ideaal van een paternalistisch altruïsme voor. In de gids Medische ethiek die door de beroepsvereniging NMG als leidraad werd gebruikt en mede met inbreng van Joodse medici tot stand was gekomen, kan men hetzelfde ideaal ontwaren. Dat de Joodse en de algemene medische 'zedenleer' zo goed bij elkaar pasten, maakte het ook voor bewust Joodse artsen makkelijk zich volledig thuis te voelen in de Nederlandse artsenstand. De volledige integratie van de Joodse artsen in de artsenstand betekende dan ook niet dat zij volledig geassimileerd moesten leven. Allerlei uitingen van verbondenheid met de Joodse achtergrond kwamen voor. Religie, traditie, zionisme en antisemitisme konden in positieve of negatieve zin het besef Joods te zijn beïnvloeden of bepalen. Ook een 'rasbewustzijn', een in deze tijd gebruikelijke term, kon een verbondenheid met het Jodendom ingeven. Over de definitie van het begrip 'ras' bestond in de Nederlandse medische wetenschap evenwel scepsis, zeker in verband met het Jodendom. Anders dan in Duitsland sloegen theorieën van rassenhygiëne en eugenetica nauwelijks aan onder de medici in de Lage Landen. Hoewel de Nederlandse artsen in meerderheid niets wilden weten van nationaalsocialistische medische wetenschap en ook protesteerden toen de Joodse artsen in Duitsland een beroepsverbod opgelegd kregen, had de opkomst van het nationaalsocialisme bij de oosterburen toch zijn weerslag op de Nederlandse artsenstand en de Nederlandse Joodse artsen. Antisemitisme en de angst daarvoor namen in de jaren na Hitlers Machtübernahme en de vluchtelingenstroom die de grens over kwam, toe. Joodse artsen werden hierdoor, ook in Nederland, al meer dan voorheen op hun eigen Jodendom gewezen. Vooropstond echter, tot to mei I940, het arts-zijn. 
De bezetting van Nederland door de Duitse troepen zette dit onmiddellijk op losse schroeven en leidde er al in de meidagen van 1940 toe dat sommigen huis, haard en verantwoordelijkheid ten opzichte van patiënten vaarwel zeiden en vluchtten of zelfs zelfmoord pleegden. Verhoudingsgewijs waren zelfs veel suïcideplegers in de eerste zelfmoordgolf in mei 1940 medisch geschoold. Bij deze elf artsen was, hoewel hun precieze gedachtegang onbekend zal blijven, waarschijnlijk de angst voor het nazibewind sterker dan de wens vast te houden aan het arts-zijn. Dat hiervoor ondanks het drastische karakter van de daad, veel begrip bestond, bleek uit de collegiale reacties. Kennelijk bestond er al een breed gedeelde consensus dat onder deze omstandigheden alles anders was.

De meeste Joodse artsen probeerden na mei 1940 wél hun beroep vast te houden en op ongeveer gelijke voet verder te gaan met de plichtsbetrachting zoals zij die hadden geïncorporeerd, ook al werden zij al snel beroofd van de status en daarmee van bepaalde voorrechten die zij als arts gewend waren te genieten. Binnen een jaar na het begin van de bezetting waren deze Joodse artsen namelijk al losgeweekt uit de Nederlandse artsenstand door zowel het ambtenarenverbod als het beroepsverbod. Nadat de ontheffing en vervolgens het ontslag van circa honderd ambtenaar-artsen begin 194I doeltreffend was geëffectueerd, volgde per I mei 194I het verbod voor alle Joodse artsen om niet-Joodse patiënten te behandelen. De gevolgen waren voelbaar op praktisch, financieel en moreel gebied. Om met Berthold Stokvis te spreken: de Joodse artsen werden hierdoor gedegradeerd tot ziekenverzorgers. De Nederlandse artsenstand, hoe weinig behept met nazisympathieën ook, al waren er wel diverse voorbeelden van antisemitisme bij artsen, bleek bij dit al niet in staat de Joodse collegae binnenboord te houden. In het medisch establishment overheerste een gebrek aan daadkracht op dit punt, terwijl men juist wel duidelijk stelling nam tegen de opgelegde nazificering van de geneeskunde met de vorming van de artsenverzetsgroep Medisch Contact. Gevolg was dat de Joodse artsen moesten proberen verder te werken in een om hen heen gecreëerd isolement, alleen voor Joodse patiënten en zonder de vertrouwde collegiale context. Het oude houvast aan de gebruiken en handelwijzen van de medische stand was daardoor niet meer zo vanzelfsprekend als het ooit was.

Het Joodse geïsoleerde volksdeel stond vanaf februari 194I onder leiding van de door de bezetter in het leven geroepen Joodsche Raad. Via dit orgaan wist de bezetter de Nederlandse Joden te laten gehoorzamen aan de steeds verder ingevoerde discriminerende maatregelen. Daarbij zorgde de bezetter dat de angst er goed in zat door enkele grootscheepse razzia’s te houden waarbij Joodse burgers werden opgepakt en in gruwelkampen vermoord. Bij dergelijke 
acties, bijvoorbeeld de Twentse razzia in september I94I, werden ook enkele artsen gearresteerd en weggevoerd. Deze vroeg gearresteerde artsen handelden volgens getuigenissen vaak nog geheel en al beantwoordend aan de plichten die zij als medici geïncorporeerd hadden. Zij leken daarbij soms ook nog te vertrouwen op een fatsoenlijke behandeling vanwege hun status als arts. Bij andere artsen sloeg de twijfel toe, wat ertoe leidde dat zij op hun beurt hun medische zorgplicht opzegden en op de vlucht sloegen. Dit werd in de meeste bekende gevallen vergemakkelijkt door het feit dat hun zorgplicht al tot een minimum gereduceerd was, aangezien hun het merendeel van hun (niet-Joodse) patiënten was afgepakt.

De meeste Joodse artsen bleven echter en zetten ook nu weer hun werkzaamheden zo goed en zo kwaad als het ging voort. Artsen en de Joodsche Raad poogden de normaliteit te behouden middels de voortgezette Joodse artsencursus, bedoeld om vakinhoudelijk bij te blijven en zinnig medisch werk te blijven doen. Hoewel ogenschijnlijk normaal, was al het werk dat onder de vlag van de Joodsche Raad werd verricht, al besmet met een politieke lading: mocht men zijn medewerking verlenen aan dit door de bezetter opgelegde instituut? Was dat niet een teken van collaboratie, hoezeer men ook mocht proberen 'tegenwerkend mee te werken'? Deze vraag werd voor de medici extra pregnant ten tijde van de medische keuringen voor de werkkampen in Nederland, begin 1942. Het verrichten van deze keuringen zou ten dienste van de bedoelingen van de bezetter zijn en was daarmee politiek bezwaarlijk. Diverse artsen weigerden principieel iedere medewerking, soms na een slechte eerste indruk, zoals bij de artsen die de eerste keuringen in Amsterdam verrichtten, soms van meet af aan en in collectief verband, zoals bij de Groningse artsen.

Vele Joodse artsen gingen echter wel tot keuren over, en maakten daarmee een politieke keuze meer in de lijn van de Joodsche Raad, die vreesde dat overname door NSB-artsen dermate ernstige gevolgen zou hebben dat men het vuile werk dan maar beter zelf op kon knappen. De voorwaarde die de Joodse keuringsartsen zichzelf stelden, was dat zij deze keuringen op onorthodoxe wijze dienden uit te voeren. De plicht van objectiviteit die in de vooroorlogse medische ethiek vanzelfsprekend was geweest, was nu niet meer gewenst. Het principe van eerlijk keuren en naar waarheid medische verklaringen afgeven werd verlaten. Het werd de norm dat men zo veel mogelijk mensen probeerde af te keuren, zo niet op feitelijke gronden, dan wel op grond van verzonnen en geënsceneerde diagnoses. Hoewel een enkeling toch vasthield aan de oorspronkelijke ethiek en weigerde valse verklaringen af te geven, ging de meerderheid van de artsen, net zoals de betrokken niet-Joodse collegae, over tot het verdraaien, aandikken of volledig verzinnen van diagnoses. 
Met het verdraaien, aandikken of verzinnen van diagnoses, kortom, met het plegen van valsheid in geschrifte, ofwel medische sabotage, bleef men doorgaan nadat de grootschalige deportaties van de Nederlandse Joden in juli $\mathbf{1 9 4 2}$ een aanvang hadden genomen. Het simuleren van ziekten met hulp van de medische stand werd niet alleen schriftelijk maar ook met geënsceneerde ziekbedden uitgevoerd. De geneeskunde kon aldus de functie van 'reddingssloep in de schipbreuk van de deportaties' gaan vervullen en mensen - tijdelijk van deportatie vrijwaren. Dit gold kennelijk voor de meeste artsen als van groter belang dan het handhaven van vooroorlogse medisch ethische normen. Vervalsing werd immers nu breed geaccepteerd en in Joodsche Raad-verband zelfs geïnstitutionaliseerd.

Het artsenberoep vervulde tegelijkertijd steeds meer de functie van reddingsmiddel voor de arts zelf. In het eerste halfjaar van de deportaties waren al ten minste 54 artsen gearresteerd. Een bewijs dat het arts-zijn geen absolute bescherming tegen deportatie bood. Het medisch beroep kón echter wel dienen als beschermingsmiddel, zoals voor de Joodsche Raad-artsen of voor de vrijwilligers voor Westerbork die door hun beroep een bevoorrechte positie bekleedden. Deze medici zetten hun beroep voort ten behoeve van anderen, zoals hun oude beroepsplicht hun ook voorschreef, maar hadden dan wel weer te maken met het politieke dilemma of zij via hun binding aan de Joodsche Raad - hoe indirect ook - mee zouden werken aan de vervolging. Ook in deze fase waren er diversen die een radicale uitvlucht uit de morele dilemma's kozen, ofwel via een vluchtpoging naar een onbezet buitenland, ofwel in de dood. Suïcide kwam nu onder de artsen getalsmatig minder vaak voor dan tijdens de eerste zelfmoordgolf, maar beroepsmatig kwamen zij er zeker veelvuldig mee in aanraking. De vraag drong zich aan hen op of zij suïcidanten volgens vooroorlogs medisch ethisch principe moesten behandelen en moesten trachten te redden of dat zij er beter aan deden niet te interveniëren en hen te laten sterven. Het was een ingewikkeld dilemma, voor iedere individuele arts die ermee in aanraking kwam en bij iedere individuele casus opnieuw. Het Amsterdamsch Joodsch Psychiatrisch Gezelschap boog zich over deze thematiek en zette een studie op naar de geestelijke toestand van de Amsterdamse Joden onder de gegeven omstandigheden. De deelnemende psychiaters bemerkten dat hun vak als gevolg van de omstandigheden verregaande veranderingen had ondergaan. Zogenoemde 'reactieve toestanden' kwamen veel voor, terwijl anderen, die voorheen een zwak geestelijk gestel hadden gehad, plotseling zeer veerkrachtig bleken. Suïcide kwam nu voor bij geestelijk volkomen gezonde, stabiele en hoogstaande individuen. Andere suïcidepogingen bleken nu echter 
evenwel juist niet bedoeld om daadwerkelijk te sterven, maar om opname in een ziekenhuis te bewerkstelligen, wat tijdelijk een veilige manier leek om van deportatie gevrijwaard te zijn.

Net zoals ziek zijn een andere klank had gekregen in het licht van de dreiging van deportatie, kreeg opname in een ziekenhuis ook een totaal andere betekenis dan in vredestijd. Het was plotseling zeer wenselijk om ziek te zijn en nóg wenselijker om in een ziekenhuis te liggen. Daarmee kon men immers, net als in de door andere auteurs beschreven ziekenhuizen in Berlijn en Parijs, aan deportatie ontkomen. De opnameaantallen van de verschillende Joodse ziekenhuizen stegen dan ook aanzienlijk in de maanden na juli 1942. De ziekenhuizen en de leiding en artsen daar maakten dit mogelijk, niet geheel zonder risico. Pseudopatiënten en pseudopersoneel vonden een veilig heenkomen in ziekenhuizen. In die ziekenhuizen namen artsen ook de nodige risico's in hun streven patiënten te ziek voor deportatie - ofwel 'transportunfähig' - te maken. Enkelen gingen hierin verder dan de sabotagemiddelen die inmiddels al gemeengoed waren geworden: de attesten en ensceneringen. Zij besloten nog meer van de oude ethiek te herzien door nu daadwerkelijk in gezonde lichamen te gaan snijden, waarbij ze van het aloude principe primum-nonnocere (allereerst niet schaden) weinig heel lieten. De medische sabotage ging aldus wederom een stapje verder. Men handelde echter nog altijd in het belang van de individuele patiënt, een vertrouwd medisch ethisch beginsel. In plaats van een deontologische ethiek was men hier alleen naar een meer teleologische benadering van de medische ethiek overgegaan. De normen werden weliswaar overschreden, maar de overkoepelende waarden van het medische vak werden nog wel in het oog gehouden. Dit was zeer zeker niet het geval bij een patiënt, een verrader, die bewust niet juist behandeld werd, met fatale gevolgen. Hier overheerste het politieke belang de medische ethiek. Of dit vaker dan één keer is voorgekomen, is niet bekend. De geneesheren-directeur van diverse Joodse ziekenhuizen leken zich daarentegen juist wel aan de aloude medisch ethische beginselen te blijven houden op de cruciale momenten waarop zij voor de keuze stonden voor hun eigen veiligheid te kiezen of bij hun patiënten te blijven. Zij volgden daarmee het voorbeeld van Jacques Lobstein, geneesheerdirecteur van Het Apeldoornsche Bosch, dat op 2I januari 1943 als eerste grote Joodse medische instelling op brute wijze werd leeggehaald.

De ontruiming van het Apeldoornsche Bosch vormde een cesuur: nu was geen enkel Joods ziekenhuis en geen enkele Joodse zieke meer veilig, zo was de overtuiging. Bovendien vermoedde men van de deportatie nu al helemaal 
weinig goeds. $\mathrm{Nu}$ ook volstrekt ongeschikte arbeidskrachten naar de zogenaamde Arbeitseinsatz waren versleept, ging men ervan uit dat deze 'wel van kant gemaakt' zouden worden. Onder deze omstandigheden nog meewerken aan een verachtelijke nazipraktijk als de sterilisaties van gemengd gehuwden, hoe tegenwerkend dan ook, werd door veel artsen als onacceptabel gezien en ook collectief door het Medisch Contact afgewezen. De omvang en de ernst van de ramp die zich voltrok, werd immers steeds duidelijker zichtbaar. Dit betekende ook dat niet alleen de patiënten of pseudopatiënten hun strohalm kwijtraakten, maar dat ook de artsen zelf almaar meer doordrongen van hun eigen kwetsbaarheid raakten. Het artsenberoep zou geen bescherming meer bieden, geen voorrecht meer inhouden en net als alle andere uitzonderingscategorieën ofwel Sperren als zeepbellen uiteenspatten. Het net sloot zich in het voorjaar van 1943 steeds meer om de artsen. Hun praktische en financiële mogelijkheden werden hun telkens meer ontnomen en bij velen nam ook de mentale veerkracht af. Meer dan gemiddeld konden zij zich, door hun onderlinge contacten en informatiestromen, inmiddels een beeld vormen van de interneringskampen Westerbork en Vught, en dat bevorderde voor velen hun zoektocht naar een veiliger alternatief. Barneveld, ofwel de lijsten van Frederiks en Van Dam, was dan ook bijzonder populair onder de artsen. I25 Joodse medici poogden via deze weg voorlopig deportatie naar Westerbork te voorkomen. Hoofdinspecteur van gezondheid Banning, die ijverig had meegewerkt aan het ontslag van de ambtenaar-artsen en de instelling van het beroepsverbod, toonde zich nu van een andere kant en stelde alles in het werk om zo veel mogelijk Joodse artsen in Barneveld te krijgen. Bij 44 van hen had dat tot resultaat dat zij tot 29 september onder protectie van de Barneveldse enclave konden blijven. Ook hier, en in het kleine Barneveldse ziekenhuisje, werden zij echter nog met de plichten die hun beroep met zich meebracht geconfronteerd. Een ouderwetse arts als Maurits Muller, die de zorgplicht als tweede natuur meedroeg, projecteerde deze nu op zijn familie, voor wie hij niet-aflatende pogingen deed ook hen naar Barneveld te halen. Hij was opgelucht dat hij bij zijn dood die verantwoordelijkheid eindelijk niet meer hoefde te dragen. Slechts een paar weken later werd ook Barneveld ontruimd en werden de bewoners naar Westerbork overgebracht.

Op 29 september 1943 was Nederland weliswaar officieel 'judenrein' verklaard, maar er leefden nog kleine aantallen legale en illegale Joden in het land. Ten minste 2I Joodse artsen bijvoorbeeld waren geariseerd via de zogenoemde Calmeyer-procedure. De artsen hebben hiertoe procentueel gezien meer toegang gehad dan de Joodse groep in zijn algemeen. Op de Portugezenlijst stonden 
ook enkele Joodse artsen; echter, deze lijst zou in februari I944 alsnog 'platzen'. Gemengd gehuwde Joden konden legaal tot het eind van de oorlog in hun eigen leefomgeving blijven, al vormden zij een kwetsbare groep. Bijna honderd Joodse artsen vielen in deze categorie, eveneens een verhoudingsgewijs hoog percentage. Een enkele Joodse arts had een dermate belangrijke functie bekleed dat deze afdoende bescherming bood. Zij leefden en werkten door aan hun wetenschappelijke arbeid, in een desolaat Mokum, in afwachting van de bevrijding.

De overige niet-gedeporteerden zaten ondergedoken, soms bij patiënten, soms bij niet-Joodse collegae. Onderduiken was een allerminst aanlokkelijk alternatief voor deportatie: men ging evenzeer een ongewisse toekomst tegemoet, vol angst en afhankelijkheid van anderen, geestelijke afstomping en verveling. Toch gingen relatief veel artsen hier uiteindelijk toe over. Het geschatte percentage van de artsen die onderdoken is 28 procent, afgezet tegen 17 procent van de totale Joodse populatie is dit een groot deel. Enkele artsen konden toch nog iets met hun artsenberoep doen. $\mathrm{Zij}$ werkten ofwel incognito, ofwel konden op hun onderduikadres iets met hun medische kennis betekenen. Dit leverde echter wederom gevaarlijke situaties op en soms een moreel conflict. Moest men bijvoorbeeld Duitse soldaten of collaborateurs behandelen? Men deed het vaak wel. Tegelijkertijd zagen diverse artsen kans zich in het georganiseerde verzet te mengen.

Uit de bronnen blijkt dat in elk geval 253 Joodse artsen werden gedeporteerd. Dat is relatief weinig in vergelijking met de algemene Nederlandse Joodse bevolking. En ook de gedeporteerde Joodse artsen waren over het geheel genomen beter af dan de niet-artsen: i op de 3 overleefde de kampen, in tegenstelling tot de I op de 22 van de totale groep gedeporteerden. Arts-zijn had alleen al daarom zeer zeker betekenis tot in de kampen. Maar ook voor anderen kon men nog weleens iets doen als arts. In Amersfoort ging dit moeilijk, vanwege de bar slechte medische voorzieningen en de onmogelijkheid als gevangene dit te beïnvloeden. Toch zijn van Amersfoort twee voorbeelden overgeleverd van artsen die nog iets voor zichzelf (E.A. Cohen) of anderen (H. de la Parra) hebben kunnen betekenen middels hun beroep. In Vught bestonden er al meer mogelijkheden iets met het medische beroep te doen, hier met name in het belang van andere gevangenen. Men trachtte en kreeg de gelegenheid de medische toestand er (iets) te verbeteren. In Westerbork ten slotte was het medisch peil veel hoger. Er was hier zelfs, na een aanloopfase, sprake van een goed geoutilleerd en groot ziekenhuis. Ogenschijnlijk normale medische zorg werd hier geboden. Artsen trachtten ook medisch gezien de 
normaliteit hier te bewaren door patiënten te voorzien van de beste zorg die zij konden bieden. De 'Medicina Westerborkiana' hield echter ook in dat men met de directe dreiging van de deportaties andere normen ging hanteren dan ooit voor mogelijk gehouden. Ook hier was sprake van medische sabotage, maar op het redden van één gevangene volgde onmiddellijk transport van een andere. De keuze wie wel en wie niet geholpen moest worden, was ondoenlijk en het nettoresultaat was uiteraard hetzelfde. Sommige artsen zijn, niet geheel onmenselijk, gezwicht voor de verleiding van de macht om in elk geval de eigen familie en vrienden te trachten te redden. Andere artsen concludeerden dat zij zich van het kiezen van levens boven andere verre moesten proberen te houden en beseften dat ze machteloos stonden. Iéts konden zij nog wel doen: het naar vermogen helpen van patiënten. De normaliteit trachten te bewaren, medisch goede zorg leveren en een beetje menselijke aandacht schenken: dat hield het moreel nog enigszins hoog. Even gloorde er ook weer hoop toen er een transportstop werd gehouden wegens een epidemie. Tijdens deze rustige periode verrichtten artsen in Westerbork wetenschappelijk werk door te experimenteren met het nieuwe medicijn penicilline. Op 8 februari 1944 werd echter met een grootschalig ziekentransport de droom van de transportstop ruw verstoord. Het 'Schicksal im Osten' gingen de artsen, die de barbarij van het nationaalsocialisme via hun patiënten zo intens hadden meebeleefd, met bovengemiddeld accurate vermoedens en daarom met grote huiver tegemoet.

\section{CONCLUSIES}

Alles overziend valt allereerst op hoezeer de Nederlandse Joodse artsen er tijdens de bezetting alleen voor stonden. Ieder voor zich moesten zij hun handelen vormgeven onder de moeilijkste omstandigheden denkbaar. Zij stonden goeddeels buiten het Medisch Contact en er bestond geen Joodse tegenhanger van deze contactgroep. Er bestond grote inter-individuele variatie in handelwijzen, zo bleek dan ook. In schril contrast met de collegiale sfeer van voor de bezetting - zo duidelijk anders dan het protectionisme in de Franse artsenstand en de discriminatie onder artsen in het Duitsland van de jaren dertig - stond het isolement van de Joodse groep ten opzichte van de niet-Joodse artsenstand. Gezien de grote waarde die oorspronkelijk aan collegialiteit werd gehecht, is het tempo waarmee de bezetter dit isolement in de Nederlandse artsenstand kon bewerkstelligen ontluisterend. De indruk die achterblijft is er een van eenzaamheid, machteloosheid en wanhoop. Het is een indruk die past 
bij wat al bekend is van deze geschiedenis, maar die toch door de persoonlijke voorbeelden hard aankomt.

Ondanks de eenzaamheid en de inter-individuele verschillen kunnen er toch ook generaliserende conclusies getrokken worden. Het is gerechtvaardigd te stellen dat de Joodse artsen als groep een relatief bevoorrechte positie bekleedden. Met nadruk: relatief, maar toch ook duidelijk: bevoorrecht. Medici konden hun beroep inzetten voor het redden van eigen huis en haard. Meer dan gemiddeld hadden zij toegang tot 'Sperren', de juiste contacten in elitekringen, Barneveld en onderduikadressen. Aan de relatief hoge overlevingscijfers van de artsen is te zien dat het medisch beroep, zoals artsen als Elie Cohen en Ellis Hertzberger na de oorlog getuigden, inderdaad een duidelijk voordeel boven Joden in andere beroepsgroepen inhield. Maar ook in vergelijking met de Joodse artsen in Frankrijk en Duitsland blijken de Nederlandse Joodse artsen bevoorrecht te zijn geweest. Zij konden immers door blijven werken in hun eigen beroep, al was het dan slechts voor Joodse patiënten. De status verbonden aan het artsenberoep raakten zij daardoor niet geheel kwijt, terwijl dat voor de meeste Joodse artsen in de twee andere landen wel gebeurde. Met de status die zij nog tot op zekere hoogte behielden konden de Nederlandse Joodse artsen ook blijven vasthouden aan het principe van 'noblesse oblige', dat ze gewend waren te huldigen. Zowel naar hun eigen geweten als naar buiten toe gaf het beroep hun daarmee plichten die anderen niet hadden. Zij trachtten hun beroep daarom over het algemeen op de vertrouwde paternalistisch altruïstische wijze te blijven uitvoeren, zij het vaak op een totaal andere manier praktisch ingevuld. In de nieuwe manieren van het inzetten van het medisch beroep en het daarbij vervormen van de vertrouwde medische ethiek vallen verschillende gradaties te ontwaren.

Er waren artsen die hun aloude artsenplichten ongeacht de omstandigheden bleven huldigen en geheel en al handelden in de geest van de vertrouwde medische ethiek. Zij behielden de normaliteit op medisch-ethisch gebied en deden hierin geen concessies. Dit bracht henzelf echter niet zelden in levensgevaar en is ook daarom, parallel aan de collegae in het getto van Warschau, heroïsch te noemen. Zo waren er de geneesheren-directeur die weigerden hun patiënten en personeel aan hun lot over te laten. Artsen die meegedeporteerd wilden worden met hun patiënten, stelden zich dermate verantwoordelijk op dat zij het belang van hun patiënten lieten prevaleren boven hun eigen belang. Zelfs in de kampen kon dat voorkomen, zoals bij de artsen die medicijnen voor patiënten stalen. Deze handelingen van zelfopoffering vallen dan ook onder de definitie van Joods verzet, ofwel 'Amidah'. Ook in de Nederlandse historio- 
grafie, waar tegenwoordig van 'helden' gesproken mag worden, zouden dezen in die categorie vallen. Immers, zij tartten het kwaad, niet in hun eigen belang, maar 'om niet', omdat zij dat handelen 'gewoon' vonden. ${ }^{2}$

Ook artsen die de medische wetenschap vooruit trachtten te helpen en daarmee eveneens vasthielden aan een traditionele invulling van het artsenberoep, kunnen gecategoriseerd worden als bewakers van de normaliteit. Men denke hierbij aan de voortgezette Joodse artsencursus, de psychiaters van het Amsterdamsch Joodsch Psychiatrisch Gezelschap, Juda Groen met zijn ontwikkeling van de psychosomatiek en de artsen die in Westerbork zo goed mogelijke medische zorg leverden of proeven deden met penicilline. Ook zij hielden met de normaliteit zoveel mogelijk het moreel hoog. Men zou dit, parallel aan voorgaande en aan hetgeen over de gettoartsen in Warschau is gesteld, eveneens een heroïsche of constructieve manier van het inzetten van het artsenberoep kunnen noemen. Bauer omschreef dit werk als 'the work of doctors, nurses, and educators to consciously maintain health and moral fiber to enable individual and group survival'. ${ }^{3}$ Aan deze werkzaamheden waren ook meestal geen politieke haken en ogen verbonden. Hun werkzaamheden brachten hen echter - anders dan de eerder genoemde voorbeelden - niet direct zelf in levensgevaar en waren daarom - zo men wil - minder uitgesproken heroïsch te noemen.

Persoonlijk gevaar was wel verbonden aan de opstelling van de Groningse artsen die in het geval van de keuringen voor de werkkampen principieel hun medewerking weigerden. Deze opstelling is zowel medisch ethisch als politiek onverzettelijk te noemen, maar de uitwerking ervan was dermate ongunstig dat men achteraf betwijfelde of dit de juiste keuze was geweest. Dit voorbeeld bewijst dat behoud van de normaliteit niet altijd tot de beste uitkomst leidde en verklaart waarom er voor vele artsen een acceptatie ontstond ten opzichte van aanpassing van de medische ethiek naar een meer teleologische benadering. Medisch-ethische beginselen, uitgangspunten oftewel deugden, werden voor velen ondergeschikt aan het uiteindelijke beoogde einddoel, het resultaat van een handelwijze. Artsen gingen de omstandigheden meewegen in hun beslissingen, zowel politieke als medisch-ethische. Bijvoorbeeld de artsen die voor de Joodsche Raad gingen werken, konden daarmee hun beroep vaak weer op de traditionele manier voortzetten. Op die manier trachtten ook zij de medische normaliteit te bewaren, zij het door het doen van een aanzienlijk geachte politieke concessie. De artsen die het pad van medische sabotage gingen bewandelen, door ofwel valse verklaringen af te geven ofwel door patiënten zieker te laten lijken dan ze waren, deden daarentegen geen politieke concessie, 
maar zeker wel een medisch-ethische. Zij kneedden de medische ethiek waarin zij waren opgeleid tot een nieuwe, onder de gegeven omstandigheden meer bruikbare ethiek. Concrete normen uit de vertrouwde ethiek vervaagden, terwijl zij daarbij wel de waarde van het individuele belang van de patiënt in het oog hielden. Er was hiermee wel sprake van een verschuiving van een deontologische naar een meer teleologische benadering, maar niet van werken in het belang van de staat, zoals bij het perverse 'utilitarisme' van de nazi-artsen. Of men alle vormen van medische sabotage vervolgens als 'Amidah' mag beschouwen, is discutabel. Immers, in het geval van een 'healing-killing-paradox', zoals ook de Nederlandse Joodse artsen die tegenkwamen, bijvoorbeeld in het geval van abortus of hulp bij suïcide, kan men moeilijk aanvoeren dat er sprake was van 'sanctification of life'.

Hoever men ging in de aanpassing van de ethiek, varieerde per arts. Waar kan worden gesteld dat het uitschrijven van valse attesten door zo goed als iedere arts geaccepteerd werd, was dat allerminst het geval voor het meewerken aan de sterilisaties. Zelfs het maken van valse sterielverklaringen, in feite niet zo heel anders dan het uitschrijven van een vals attest met andere inhoud, werd slechts door enkele artsen als oirbaar beschouwd. En bijvoorbeeld over het snijden in gezonde lichamen was meer onderling verschil van mening dan over het ensceneren van een ziekbed. De individuele verschillen daargelaten, lijkt een algemeen gedeelde grens te zijn geweest het verrichten van sterilisatieoperaties, waartoe dan ook slechts twee Joodse artsen overgingen. Ook zijn in Nederland geen gevallen bekend zoals de operaties in Warschau om mensen een minder geprononceerd 'Joods' uiterlijk te geven. Een andere grens was het verkrijgen van geldelijk gewin door medische sabotage, waarvan eveneens slechts twee voorbeelden overgeleverd zijn. Ook de beschreven medische moord in het NIz kan medisch ethisch op geen enkele manier gebillijkt worden. Dit was medisch handelen in primair politiek belang. Goedbeschouwd was dit eveneens het geval, hoewel van een veel onschuldiger orde, bij het voor militaire dienst ongeschikt maken van Duitse soldaten op basis van een valse oogheelkundige diagnose. Met deze voorbeelden worden de dilemma's van de Joodse artsen extra pregnant voelbaar, want invoelbaar is het zeker dat men politieke vijanden liever niet wilde behandelen. Los van de medische ethiek zou men dit onder 'Amidah' kunnen scharen, maar het lijkt erop dat veruit de meeste artsen deze grens niet overschreden. Voor hen woog het arts-zijn zwaarder dan het politieke belang. 
Hoezeer de meeste artsen ook vast trachtten te houden aan dat arts-zijn en dat op zo goed mogelijke manier, met of zonder aanpassing van de gebruikelijke handelwijzen en normen, vorm probeerden te geven, het werd hun gedurende de vervolging waarvan ook zij het slachtoffer waren, telkens moeilijker gemaakt. Omdat ook hun alles werd afgenomen, bereikten velen op een zeker moment het punt waarbij zij voelden dat zij het arts-zijn moesten loslaten, meestal om nog te pogen het eigen leven en dat van hun meest nabijen te redden. In termen van medisch-ethisch legitiem handelen was dit loslaten van artsenplichten echter het meest extreem en ongewenst wat men als arts kon doen. Als men vluchtte of onderdook, moest men bereid zijn die drempel over te gaan. Wanneer de verschillende artsen zover kwamen varieerde sterk. Er waren successievelijk kleine aantallen artsen die alles vaarwel zeiden en voor hun eigen veiligheid kozen, totdat in het voorjaar van 1943 de meeste artsen het water echt tot aan de lippen stond en zij in groten getale deze stap zetten. Desalniettemin, de artsen die onderdoken of vluchtten lieten dan wel hun patiënten en verantwoordelijkheden als arts in hun vaste omgeving los (NB: voor zover die nog aanwezig waren), maar konden zich tijdens vlucht of onderduik wel weer als arts inzetten. Daarvan zijn legio voorbeelden. Echt het beroep loslaten deden dus ook zij vaak niet. Dat gold natuurlijk wel voor de artsen die suïcide pleegden. Zij waren het die de toekomst zó duister inschatten dat geen enkele ethische richtlijn meer geldig leek. Alle voorheen gehanteerde ethiek had haar waarde verloren onder de gegeven omstandigheden. Zij braken volledig en radicaal met de medische ethiek waar zij jaren naar geleefd hadden, en dat soms zelfs al in het allereerste stadium van de bezetting. En wie kon en kan hun ongelijk geven? 'Onder de gegeven omstandigheden' is hier het sleutelbegrip: de omstandigheden waren van dien aard dat een dergelijke radicale breuk met alles wat voorheen vanzelfsprekend was, invoelbaar wordt. Zo komt de empathie die in het begin genoemd werd hier weer terug. De bronnen die zijn gebruikt, de egodocumenten en oral history, maken inleving mogelijk. Waarschijnlijk hebben Stokvis, Koster en de andere auteurs van de dagboeken en memoires hun gevoelsleven ook met dat doel op papier gezet. Deze bronnen zijn goedbeschouwd apologetische geschriften met een didactische inslag. Ze zijn vermoedelijk geschreven om uit te leggen waarom de schrijvers bepaalde keuzen maakten en om ons als lezers erover na te laten denken wat wíj zouden doen. 


\section{GESCHIEDENIS ALS MORELE LES}

Chelouche claimde al dat het lesgeven over de geneeskunde van de Holocaust voor medisch studenten van nu een 'curriculum enhancing' effect kan hebben. ${ }^{4} \mathrm{Zij}$, en met haar andere medisch historici wereldwijd, zien net als Stokvis en de andere dagboekschrijvers dat de geschiedenis als morele les kan dienen. Als dat zo is, welke lering valt er dan te trekken uit dit boek?

Allereerst is voor de medici van nu een relevant onderdeel het paternalistisch altruïsme alhier beschreven. In de 534 levensverhalen van Joodse artsen tijdens de Tweede Wereldoorlog in Nederland troffen we ondanks de eigen levensbedreiging nogal wat blijken van medemenselijkheid en een bevoogdende houding. Zorgen voor de patiënten was de ultieme artsenplicht en bleef dat voor veel artsen ook onder de meest extreme omstandigheden. Het artsenberoep bevorderde altruïsme, zo lijkt het. Zelfs wanneer men verstoken leek van mogelijkheden om altruïstisch te zijn omdat men het eigen vege lijf moest zien te redden, toonden artsen zorg voor een ander. Grodin en zijn medewerkers ontwaarden dit verschijnsel ook en zien daarin het belang van hun studie:

Grodin, a psychiatrist and a bioethicist, says the project goes beyond bearing witness, venturing deep into the moral belly of the beast, where self-preservation and altruism wrestle [...] Rachelle Rubin: They felt a responsibility because of their profession, that's what I found interesting, says Rubin. For others it was just out of the goodness of their hearts, but the reason these people gave that care was because they were doctors. That set them apart. ${ }^{5}$

Bioloog Frans de Waal heeft in zijn onderzoek bij primaten aangetoond dat altruïsme een biologische eigenschap is, in weerwil van het potentiële evolutionaire nadeel ervan. Loet Micheels ondervond dat als arts in Auschwitz aan den lijve:

Ik kwam tot de conclusie dat het in wezen was: ieder voor zich - met belangrijke uitzonderingen. [...] Toch is ook het omgekeerde waar; onder welke omstandigheden ook, menselijke eigenschappen als medeleven en altruïsme kunnen niet volledig worden uitgewist. ${ }^{6}$

Maar hoever strekt die medemenselijke zorg voor de ander dan? De Waal gebruikte de metafoor van de drijvende piramide. ${ }^{7}$ Op de top van de 'altruïsmepiramide' staat men zelf, daar direct onder bevinden zich de meest nabije dier- 
baren, daaronder de andere familieleden, vervolgens vrienden, kennissen en de rest van de wereldbevolking. Altruïsme strekt zich naar gelang de opwaartse druk van het water, oftewel de welstand waarin men zelf verkeert, uit tot alleen het bovenste topje, of helemaal tot de bodem. In het geval van de Joodse vervolgden in het bezette Nederland waren de middelen tot het bieden van altruïsme steeds schaarser. Ook Presser en Herzberg hebben, in verband met de geschiedenis van de Joodsche Raad, het menselijke fenomeen besproken dat bij schaarste de eerste zorg automatisch gaat naar de meest nabijen, en pas daarna naar familie, vrienden, kennissen en onbekenden. In die volgorde. Het is een universeel verschijnsel in tijden van catastrofe, zo stelt ook Evelien Gans, in navolging van Sem Dresden. ${ }^{8}$ Voor artsen was er echter nog een andere laag: de laag van de patiënten. Waar deze laag zich in de piramide bevond, zal per arts verschillend zijn geweest. Echter, de bevoogdende, paternalistische artsencultuur zal hebben gestimuleerd dat deze laag op aanzienlijke hoogte in de piramide zat, voor sommigen zelfs helemaal op de top.

Waar paternalisme in de nationaalsocialistische geneeskunde een zeer negatieve uitwerking had - want het betekende daar dat artsen alles met hun patiënten konden doen -, kon het dus ook juist een positief, altruïsme bevorderend effect hebben. Afhankelijk van welke definitie men hanteert zou het gedrag van de nazi-artsen niet eens meer paternalistisch genoemd kunnen worden. Immers, vaderlijk was dat allerminst. Bij artsen die medische experimenten uitvoerden die ernstige schade toebrachten aan de proefpersonen was sprake van een goedbeschouwd geperverteerd paternalisme: het belang van de patiënt werd totaal overruled door wat de arts wilde. De paradigmaverschuiving van paternalisme naar autonomie voor de patiënt, die in de medische ethiek gedurende de tweede helft van de twintigste eeuw plaatsvond, was mede ingegeven door de wens nooit meer tot een ontsporing te komen zoals de naziartsen die hadden getoond. Paternalisme als zodanig heeft dan ook een zeer negatieve connotatie gekregen, waarmee een pleidooi voor een bepaalde mate van paternalisme direct in een kwaad daglicht kan worden geplaatst. ${ }^{9}$ Dat het paternalistisch altruïsme uit de neoromantische traditie en het Ochtendgebed voor de arts van Maimonides daarmee óók in de vergetelheid raakten, is een ongewenst bijeffect. Bewustzijn hiervan zou een 'curriculum enhancing' effect van dit boek kunnen zijn. Uiteraard zijn autonomie en 'informed consent' voor patiënten van onschatbare waarde, maar een te eenzijdige focus hierop zou kunnen leiden tot onverschilligheid. ${ }^{10}$ Dit terwijl het artsen bij uitstek gegeven is zich te bekommeren om de zieke, afhankelijke medemens: op vaderlijke, of steeds vaker, moederlijke wijze. 
Breder gezien is de lering die uit dit boek getrokken kan worden, dat ethiek verregaand vervormd kan worden door de omstandigheden. In elk geval voor de medische ethiek is dat ook hier, net als bij Chelouche, gebleken. Uiteraard kan uniformiteit in de medische ethiek nagestreefd worden, zodat alle artsen wereldwijd zich in principe aan dezelfde basisregels houden. Dit is een goed en noodzakelijk streven en helpt zeker om een barrière tegen algemeen als immoreel beschouwd handelen op te werpen, zo blijkt ook uit deze casestudy. Maar men dient de realiteitszin te behouden dat als de omstandigheden veranderen, de ethiek meeverandert. Van schuiven met wat praktische, heel concrete, minder belangrijke normen tot het overboord gooien van basale waarden: het kan en het gebeurt als de omstandigheden er aanleiding toe geven. Het besef van de pluriformiteit van ethiek noopt mij er ook toe mijn eigen verteltrant met een kritisch oog te beschouwen. Immers, ook mijn ethiek is ge- of vervormd door mijn tijd, cultuur, omgeving, kortom mijn omstandigheden. Bovendien heb ik onder mijn omstandigheden makkelijk praten: 'No moral judgement whatsoever is possible from conditions of safety on the behaviour of human beings in conditions of danger,' zo zei de Britse politieke filosoof Isaiah Berlin al terecht. ${ }^{\text {II }}$ Vanuit de leunstoel veroordelen van handelingen van mensen in levensgevaar is ongepast. Maar laten we de uitnodiging van Stokvis, Koster en de andere getuigen wel aannemen en de discussie over ethiek blijven voeren. 


\section{NOTEN}

\section{INLEIDING}

I Dagboek Berthold Stokvis, NIOD, 244, inv. nr. II49, I22.

2 Naar de antisemitische filosoof G.J.P.J. Bolland (1854-1922).

3 Voor meer informatie over Sarphati, zie: Lydia Hagoort, Samuel Sarphati I813-1866. Van Portugese armenarts tot Amsterdamse ondernemer (Amsterdam 2012).

4 http://www.verzetsmuseum.org/museum/nl/tweedewereldoorlog/achtergrond/ achtergrond,amsterdam/straatnamen 2-II-2OI3.

5 Dagboek Berthold Stokvis, NIOD, 244, inv. nr. II49, 50.

6 Ibidem, IOI.

7 Dagboek Jacques Reisel, notitie van 7-2-I943, privécollectie familie Reisel.

8 Gesprek met Maurits Frenkel, d.d. 22-2-2009; Henk Pelser, Vluchtweg Zwitserland. Verhalen uit een ondergronds verleden (Amsterdam 1996) 47.

9 Dagboek Salomon Koster, NIOD 244, inv. nr. 996, 208.

IO Dagboek Berthold Stokvis, NIOD, 244, inv. nr. II 49,232

II Gesprekken met Hans Keilson, d.d. 20-II-2008 en $\mathrm{I} 5-\mathrm{I}-2009$

I2 J.C.P. Eeftinck Schattenkerk, 'Variaties op het thema der medische ethiek', in: C.D.J. Brandt (red.), Onderdrukking en verzet. Nederland in oorlogstijd. Deel 2 (Arnhem/Amsterdam 19491954) 377-383; Peter Voute, Only a Free Man. War Memories of Two Dutch Doctors 1940-I945 (Santa Fe I982) 67.

I3 Henk M. van Randwijk, In de schaduw van gisteren. Kroniek van het verzet 1940-1945 (Amsterdam 1967) I70; Voor meer informatie over het artsenverzet: Philip De Vries, M.C. I94I-I945 Geschiedenis van het verzet der artsen in Nederland (Haarlem 1949).

I4 Annet Mooij, Doctors of Amsterdam. Patient Care, Medical Training and Research I650-2000 (Amsterdam 2002) 263. De eerbaarheid van hun bijzondere beroep was in gevaar en daarom kónden zij niet anders dan stelling nemen, aldus medischhistorica Annet Mooij. Zie ook: Joost Visser, Ben Crul e.a., Witte jassen en bruinhemden. Nederlandse artsen in de Tweede Wereldoorlog. Bijzondere getuigenissen van artsen en geneeskundestudenten 1940-1945 (Breda 20I0) 23. 
I5 Frits Baltesen, 'Een arts helpt, ook in de oorlog. 20II)

Oorlogsverhalen op eerste veteranendag voor oudartsen in Utrecht', NRC 25-3-2009.

I6 Loe de Jong, Het Koninkrijk der Nederlanden in de Tweede Wereldoorlog, I4 dln. (Den Haag/Leiden 1969-I994) deel zes, tweede helft, 700: dit zou geen laakbare vorm van discriminatie zijn geweest, maar een houding ingegeven door veiligheidsoverwegingen.

I7 Abel J. Herzberg, Kroniek der Jodenvervolging 1940-1945 (5e herziene druk; Amsterdam 1985, eerste druk 1950) I9.

I8 Conny Kristel, Geschiedschrijving als opdracht. Abel Herzberg, Jacques Presser en Loe de Jong over de Jodenvervolging (Amsterdam 1998) 20.

I9 De Vries, MC I94I-I945.

20 Madelon de Keizer en Marije Plomp, Een open zenuw. Hoe wij ons de Tweede Wereldoorlog herinneren (Amsterdam 20IO) I4-I5; Rob van Ginkel, Rondom de stilte. Herdenkingscultuur in Nederland (Amsterdam 20II) I8.

2I Ido de Haan, $\mathrm{Na}$ de ondergang. De herinnering aan de Jodenvervolging in Nederland 1945-1995 (Den Haag 1997) 2; Frank van Vree, In de schaduw van Auschwitz. Herinneringen, beelden, geschiedenis (Groningen 1995) 9-Io; Rob van der Laarse, De oor$\log$ als beleving. Over de musealisering en enscenering van Holocaust-erfgoed (Amsterdam 20II) IO-II; Rob van der Laarse en Frank van Vree, De dynamiek van de herinnering. Nederland en de Tweede Wereldoorlog in een internationale context (Amsterdam 2009) 7.

22 De Haan, Na de ondergang, 2.

23 Hans Mulder, Kunst in crisis en bezetting. Een onderzoek naar de houding van Nederlandse kunstenaars in de periode 1930-1945 (Utrecht 1978); Pauline Micheels, Muziek in de schaduw van het Derde Rijk. De Nederlandse symfonie-orkesten, I933-1945 (Zutphen 1993); Derk Venema, Rechters in oorlogstijd. De confrontatie van de Nederlandse rechterlijke macht met nationaal socialisme en bezetting (Den Haag 2007); Joggli Meihuizen, Smalle Marges. De Nederlandse advocatuur in de Tweede Wereldoorlog (Amsterdam 20Io);

Klaas van Berkel, De stem van de wetenschap. Geschiedenis van de Koninklijke Nederlandse Akademie van Wetenschappen deel 2 I9I4-2008 (Amsterdam
24 Gesprekken met Max Hamburger, d.d. 28-I0-2008, I4-5-2009, I6-7-2009; David Moffie, naoorlogse getuigenis 1948, NIOD 250d, inv. nr. 700; Elie. A. Cohen, naoorlogse getuigenis, NIOD 25od, inv.nr. 475; Eddy de Wind, Eindstation Auschwitz (Amsterdam 198I) I2.

25 De Jong, Koninkrijk, deel acht, deel een, 408.

26 Ingrid Lutke Schipholt, 'Dankzij mijn beroep leef ik nog. Bacterioloog Hertzberger overleefde zes concentratiekampen', Medisch Contact 6I (2006) 38, I494-I497; I. Sitniakowsky, 'Overleven leidde vaak tot schuldgevoel. Sober relaas over hel van Sobibor', De Telegraaf I2-5-1979, 86ste jaargang; Elie A. Cohen, Beelden uit de nacht. Kampherinneringen (Baarn 1992) 5 .

27 Naoorlogs verslag Elie A. Cohen, NIOD, 250i, inv.nr. I085.

28 John M. Efron, Medicine and the German Jews (New Haven 200I) 3.

29 Sherwin B. Nuland, Maimonides (New York 2005) I6.

30 Samuel Krauss, Geschichte der Jüdischen Ärzte. Vom fruhesten Mittelalter bis zus Gleichberechtigung (Wenen 1930).

3I Zoals die aangewakkerd was door medischhistorici als Henry Sigerist. Zie: Robert Baker en Laurence B. Mc Cullough (red.), The Cambridge World History of Medical Ethics (New York 2008) 8.

32 Fred Rosner en Frank Heynick, Jews and Medicine. An Epic Saga (2002); Natalia Berger, Jews and Medicine. Religion, Culture, Science (Tel Aviv 1995); Efron, Medicine and the German Jews; Michael Nevins, Jewish Medicine. What It Is and Why It Matters (New Jersey 2006); Michael Nevins, The Jewish Doctor. A Narrative History (New Jersey 1996).

33 Nevins, The Jewish Doctor, I; Nuland, Maimonides, 23.

34 Fred Rosner, Biomedical Ethics and Jewish Law (New Jersey 200I) 6; Marcel Poorthuis, 'Het concept van genezen in de Joodse traditie', Maatschappij en gezondheid, 1982, I5-42, 32.

35 Nevins, The Jewish Doctor, I3; Berger, Jews and Medicine, 16.

36 Hindle Hes, Jewish Physicians in the Nether-

lands 1600-1940 (Assen I980) XII. 
37 J.H. Coppenhagen, Anafiem Gedoe’iem. Overleden joodse artsen uit Nederland I940-I945 (Rotterdam 2000) 44.

38 De Jong, Koninkrijk, resp. deel vier, deel twee, 745 (bijna 70o); deel vijf, deel een, 433 (370); 545 (677); deel zes, deel twee, 704 (bijna 70o); deel twaalf, deel een, 465-466 (ca 370).

39 Berger, Jews and Medicine, 27; Michael Kater, 'A Historical and Contemporary View of Jewish Doctors in Germany' in: John J. Michalczyk, Medicine, Ethics and the Third Reich. Historical and Contemporary Issues (Kansas City 1994) I6I-I66; Eduard Seidler, Jüdische Kinderärzte 1933-1945. Entrechtet, geflohen, ermordet (Basel 2007) 9. 40 Efron, Medicine and the German Jews, 4. $4 \mathrm{I}$ De Jong, Koninkrijk, deel een, 458.

42 Kater, 'A Historical and Contemporary View', I6I; Sara J. Bloomfield, Deadly Medicine. Creating the Master Race. United States Holocaust Memorial Museum (Washington 2004) 193.

43 Michael Kater, Doctors under Hitler (Chapel Hill 1989) 22I.

44 John Cornwell, Hitler's Scientists. Science, War, and the Devil's Pact (New York 2003) I55.

45 Saul Friedländer, Nazi-Duitsland en de Joden. Deel I: de jaren van vervolging 1933-I939 (New York 1997) 263.

46 Udo Benzenhöfer, Jüdische Ärzte in Hanover I933 bis I945 (Wetzlar 2000); Barbara Becker-Jakli, Das jüdische Krankenhaus in Köln (Keulen 2004); Daniel Silver, Refuge in Hell. How Berlin's Jewish hospital Outlasted the Nazis (Boston 2003).

47 Eduard Seidler, Jüdische Kinderärzte 1933-1945. Entrechtet, geflohen, ermordet. (Basel 2007) 9.

48 Bijvoorbeeld de oogartsen J.M. Rohrbach e.a.. 'Jüdische Augenärzte im Nationalsozialismus. Eine Gedenkliste', Klinisches Monatsblat Augenheilkunde 20II; 228: 70-83; Barbara Frey, 'Als Mensch und Ärztin hervorragend. Die Jüdische Ärztin Gertrud Mosberg (1903-1945)', Frauen in der Bielenfelder Geschichte, 2010, 280-29I.

49 Silver, Refuge in Hell, 2II-228.

50 Henri Nahum, La médécine Francaise et les Juifs 1930-1945 (Parijs 2006); Bruno Halioua, Blouses blanches, étoiles jaunes. L'exclusion des médecins juifs en France sous l'Occupation (Parijs 200o); Chantal
Beauchamp schreef op I0-3-2007 een kritische recensie voor La Cliothèque: http://clio-cr.clionautes. org/la-medecine-francaise-et-les-juifs-I930-I945. html\#.VADhahZwvgI, 29-8-20I4.

5I Friedländer, Nazi-Duitsland en de Joden, 257.

52 Zie hiervoor ook: Donna Evleth, 'The Ordre de Médécins and the Jews in Vichy France, 1940I944' in: www.fh.oxfordjournals.org 30 maart 2006.

53 Nahum, La médécine Francaise et les Juifs, 260.

54 Halioua, Blouses blanches, 199.

55 Nahum, La médécine française et les Juifs, 298.

56 Ibidem, 300, 305.

57 Daniel Nadav, 'Jewish Medicine During the Holocaust in the Ghettos and Forests', in: Berger, Jews and Medicine, 205-219; Shaul M. Shasha,

'Medicine in the Ghettos during the Holocaust', Harefuah Medical Journal, Vol I4I, no. 4 (2002): 318-323.

58 Adina Szwajger, I Remember Nothing More: The Warsaw's Children's Hospital and the Jewish Resistance (Londen 1990); Mordechai Lensky, A Physician Inside the Warsaw Ghetto (Jeruzalem 2009).

59 Charles G. Roland, 'Creativity in the Face of Disaster: Medicine in the Warsaw ghetto' in: Michalczyk, Medicine, Ethics, and the Third Reich, I53-I60; Charles G. Roland, Courage under Siege. Starvation, Disease, and Death in the Warsaw ghetto (New York 1992).

60 Roland, 'Creativity in the Face of Disaster', I53-I60; Myron Winick (red.), Hunger Disease. Studies by the Jewish Physicians in the Warsaw Ghetto (New York 1979).

6I Roland, Courage under Siege, 196.

62 Ibidem, 196.

63 Yehuda Bauer, Rethinking the Holocaust (New Haven 200I) I2O.

64 Roland, Courage under Siege, 20I.

65 Ibidem, 66.

66 Tessa Chelouche, 'Some Ethical Dilemmas Faced by Jewish Doctors during the Holocaust', in: Medicine and Law 24 (2005) 4, 703-716, passim.

67 Bauer, Rethinking the Holocaust, I2I.

68 Roland, Courage under Siege, I79-180.

69 Ibidem, 227.

70 Henk A.M.J. ten Have, R.H.J. ter Meulen, E. van Leeuwen, Medische ethiek (Houten 2000) 22-23; 
Tom L. Beauchamp, James F. Childress, Principles of Biomedical Ethics (New York 1983) 19-20.

7I Dana Lewis, A Forgotten Medicine: an Examination of Medical Practice by Jewish Physicians in the Warsaw ghetto, I940-1942. History of Medicine IBSc Dissertation University College London (Londen: z.u. 20I2) collectie Wellcome Library, HMED 3002 .

72 Ibidem.

73 Michael Katz in: Winick (red.), Hunger Disease, 66.

74 Michael E. Grodin (red.), Jewish Medical Resistance in the Holocaust (New York 2014) 273.

75 Johannes C.H. Blom, In de ban van goed en fout? Wetenschappelijke geschiedschrijving over de bezettingstijd in Nederland (Rede uitgesproken bij de aanvaarding van het ambt van gewoon hoogleraar in de Nederlandse geschiedenis sedert de middeleeuwen aan de Universiteit van Amsterdam op I2 december 1983 (Bergen I983).

Jan Bank, Oorlogsverleden in Nederland (Rede uitgesproken bij de aanvaarding van het ambt van buitengewoon hoogleraar in de maatschappijgeschiedenis, in het bijzonder de overdracht van historische kennis via de massamedia, aan de Erasmus Universiteit Rotterdam op 27 oktober 1983 (Baarn 1983).

76 Kristel, Geschiedschrijving als opdracht, 24-25.

77 De Jong, Koninkrijk, deel veertien, deel twee, I073: reactie van Abram de Swaan NRC 23 dec 1988. De Swaans recentste werk Compartimenten van vernietiging. Over genocidale regimes en hun daders (Amsterdam 20I4) vecht het paradigma van de 'banaliteit van het kwaad' aan, dat sinds Hannah Arendts beschrijving van Adolf Eichmann en de Milgram-experimenten wereldwijd is overgenomen.

78 Evelien Gans, 'Iedereen een beetje slachtoffer, iedereen een beetje dader', Groene Amsterdammer 27-I-20IO.

79 Chris van der Heijden, Grijs verleden.

Nederland en de Tweede Wereldoorlog (Amsterdam/ Antwerpen 200I) I6.

80 De Haan, Na de ondergang, 232.

8I Bas Kromhout en Frans Smits, 'Weg met grijs, bewonderen mág', Historisch Nieuwsblad
(2009) 8, op http://www.historischnieuwsblad. $\mathrm{nl} / \mathrm{nl} /$ artikel/26025/schwegman-en-withuis-overoorlogshelden.html.

82 Marjan Schwegman, 'Uitzonderlijk of juist heel gewoon. Aantekeningen bij het ongemakkelijke begrip "heldendom", in: Jaap Cohen en Hinke Piersma (red.), Moedige mensen. Helden in oorlogstijd (Amsterdam 20I4) 22-27, 23 en 27.

83 Jolande Withuis, Weest manlijk, zijt sterk. Pim Boellaard (1903-200I) Het leven van een verzetsheld (Amsterdam 2008) I7.

84 Bauer, Rethinking the Holocaust, ix.

85 Shmuel Reis, 'Learning from the past: Medicine and the Holocaust', The Lancet, vol 374, issue 9684, IIO-III, II juli 2009.

86 http://www.bumc.bu.edu/oma/michael-agrodin-md/ I september 20I3; Persoonlijke mededeling Tessa Chelouche, d.d. 8-5-20I2.

87 Chelouche, 'Some Ethical Dilemmas', passim.

88 A. Jotkowitz, 'The Holocaust and Medical

Ethics: the Voices of the Victims', Journal of Medical Ethics 2008;34:869-870. 870.

89 Medisch-historicus Leo van Bergen e.a. benadrukten in 2009 in het Nederlands Tijdschrift voor Geneeskunde het belang van aandacht voor oorlog en de bijbehorende medisch ethische dilemma's: Leo van Bergen e.a., 'Schenk in het medisch onderwijs aandacht aan oorlog', Nederlands Tijdschrift voor Geneeskunde I53 (2009) 35, I737-I739.

90 Jotkowitz, 'The Holocaust and Medical Ethics', 869-870; M.M. Cohen JR, 'Overview of German, Nazi, and Holocaust Medicine', American Journal of Medical Genetics Part A 2010, I52A:687707.687.

9I Cohen JR, 'Overview', 688.

92 R. Baker, 'The History of Medical Ethics', in : W.F. Bynum, Roy Porter e.a., Companion Encyclopedia of the History of Medicine Vol.2 (Londen I993) 849-887; Ludwig Edelstein (Owsei Temkin and Lilian Temkin red.), Ancient Medicine: Selected Papers of Ludwig Edelstein (Baltimore 1967).

93 Baker, 'The History of Medical Ethics', 849887.

94 Baker e.a., The Cambridge World History of Medical Ethics, 4.

95 Jotkowitz, 'The Holocaust and Medical 
Ethics', 869 .

96 Barron H. Lerner, David J. Rothman, 'Medicine and the Holocaust: Learning More of the Lessons', Annals of Internal Medicine I22 (1995) IO, 793-794.

97 Paul Weindling, Health, Race and German Politics Between National Unification and Nazism I870-1945 (Cambridge 1989) 6; Claudia Koonz, The Nazi Conscience (Cambridge MA, Londen 2003) 3. 98 L. Alexander, 'Medical Science Under Dictatorship', New England Journal of Medicine 1949; 24I:39-47 July I4, I949. 39.

99 Arthur Caplan (red.), When Medicine Went Mad. Bioethics and the Holocaust (New Jersey 1992) 76-77; Michael H. Kater, 'Criminal Physicians in the Third Reich. Toward a Group Portrait', in: Frances R. Nicosia, Jonathan Huener (red.), Medicine and Medical Ethics in Nazi Germany. Origins, Practices, Legacies (New York 2002) 77-92, 82. Ioo De Jong, Koninkrijk, deel acht, deeleen, 67. IoI Christopher Browning, The Origins of the Final Solution. The Evolution of Nazi Jewish Policy, September 1939-March 1942 (Jeruzalem 2004) I84I85; Koonz, The Nazi Conscience, 6-9.

IO2 Ernst Klee, Euthanasie im NS-Staat. Die Vernichtunglebenswerten Lebens (Frankfurt 1983) 24-26; Ernst Klee, Auschwitz, die NS-Medizin und ihre Opfer (Frankfurt 1997); Henry Friedlander, The Origins of Nazi Genocide: from Euthanasia to the Final Solution (Chapel Hill 1995) 216-245.

IO3 Robert Lifton, Nazi Doctors. Medical Killing and the Psychology of Genocide (New York 1986) 422-427. Vooral onder invloed van Christopher Browning's Ordinary Men is dit een gangbare visie geworden. Ook Arthur Caplan, in zijn When Medicine Went Mad hing deze visie aan. Hij benadrukte daarom het belang van kennisname van dit mechanisme, opdat we onszelf kunnen wapenen tegen dergelijke ontsporing.

Zie: Christopher Browning, Ordinary Men. Reserve Police Batallion Ior and the Final Solution in Poland (New York 1992).

IO4 Weindling, Health, Race and German Politics; Paul Weindling, Nazi Medicine and the Nuremberg Trials. From Medical War Crimes to Informed Consent (Londen 2004); Friedlander, The Origins of Nazi Genocide; Daniel Jonah Goldhagen Hitler's Willing Executioners. Ordinary Germans and the Holocaust (New York 1996); Fridolf Kudlien, Ärzte im Nationalsozialismus (Keulen 1985).

I05 Kudlien, Ärzte im Nationalsozialismus.

Io6 Ibidem, II7; Cohen JR, 'Overview', 687-707. I07 George J. Annas en Michael A. Grodin, The Nazi Doctors and the Nuremberg Code: Human Rights in Human Experimentation. (New York 1992).

IO8 Cornwell, Hitler's Scientists, I52.

Io9 Omar Haque, Julian de Freitas e.a., 'Why Did So Many German Doctors Join the Nazi Party Early?' International Journal of Law and Psychiatry 35 (2012) 473-479; Friedlander, The Origins of Nazi Genocide, 217; Annas, The Nazi Doctors and the Nuremberg Code.

IIo Haque e.a., 'Why Did So Many German Doctors Join the Nazi Party Early?', 473-479. III Michael Kater, 'Professionalization and Socialization of Physicians in Wilhelmine and Weimar Germany.' Journal of Contemporary History, 20 (4) (1985) 677-70I.

II2 Tessa Chelouche, 'Medicine and the Holocaust - Lessons for present and future physicians', in: Medicine and Law 27 (2008) 4, 787-804, 804. II3 De belangrijkste bronnen voor deze database zijn: NIOD 77, archief Höhere ss- und Polizeiführer, Referat IVB4 en Zentralstelle für jüdische Auswanderung; Nationaal Archief 2.I5.38, archief Geneeskundige Hoofdinspectie I902I952; Nationaal Archief 2.I5.37, archief ministerie Sociale Zaken, afdeling Volksgezondheid; Joodsche Raad cartotheek, Rode Kruis Den Haag; Medisch Contact Artsendatabank http://medischcontactartsendatabankwoii.artsennet.nl/MC/index.jsp; Joods Biografisch Woordenboek http://www. joodsbw.nl; Joods digitaal monument http://www. joodsmonument.nl.

II4 Peter Friedlander, 'Theory, Method and Oral History' in: Robert Perks, Alistair Thomson, The Oral History Reader (Londen 1998) 318.

IIs Raphael Samuel, Theatres of Memory (Londen I994) I:x

II6 Paul Thompson, Voice of the Past: Oral History (Oxford 20003 ). 
II7 Mary A. Larson, 'Research Design and Strategies' in: T. L. Charlton, L.E. Myers, R. Sharpless, Handbook of Oral History (Oxford 2006) I05-I34; 'Oral History Evaluation Guidelines', Oral History Association Pamphlet Number 3, http://www.baylor. edu/ OHA/EvaluationGuidelines.html\#Principles and Standards 3-6-20I2.

II8 Lawrence Langer, Holocaust Testimonies: the Ruins of Memory (New Haven I99I) I48.

II) Naomi Rosh White, 'Holocaust Testimony and History', in: Perks e.a., The Oral History Reader, $\mathrm{I} 74$.

I20 Ibidem, I76.

I2I Selma Leijdesdorff, Wij hebben als mens geleefd. Het Joodse proletariaat van Amsterdam I900-I940 (Amsterdam 1987) 36-40. Op zich is dit een voor de hand liggende aanname. Andere visies bestaan echter ook. Zoals die van Langer, die meent dat er bij overlevenden vaak een strikte scheiding is tussen de vooroorlogse, de 'oorlogse', en de naoorlogse identiteit. De 'ik' van in de oorlog is een andere 'ik' dan die van nu. Hij meent dat hieruit voortvloeit dat tijdens het vertellen van de ervaringen in de oorlog, deze ervaringen volledig los staan van latere ervaringen of opgedane kennis en dus niet geïnterpreteerd of bereflecteerd zijn. (Langer, Holocaust Testimonies, 42.) Op basis van de interviews die ik zelf heb afgenomen kan ik zijn visie niet geheel delen. Het lijkt mij onvermijdelijk dat wel degelijk alles wat men aan kennis over de loop van de gebeurtenissen en de verbanden tussen de historische feiten in de loop der jaren heeft opgedaan, de herinneringen in een bepaald perspectief plaatsen. Dat perspectief kan niet meer hetzelfde zijn als destijds, in een uitermate verwarrende, onvoorspelbare en bedreigende situatie. Het meest aannemelijk lijkt mij dat de kennis van achteraf de herinnering, hoe onbewust ook, enigszins gekleurd moet hebben.

I22 Brief Sieg Gitter, Herzliyah, aan auteur, 16-3-2009.

I23 Hermann W. von der Dunk, Inleiding, in: M.C. Brands, H.W. von der Dunk, H.H. Zwager (red.), Egodocumenten. Een bijzonder genre van historische bronnen (Groningen 1970) I.

I24 Ibidem, I5.

I25 Peter Romijn in inleiding oorlogsdagboek van Kees Tetteroo: Cornelis L.F. Tetteroo, Mijn dagboek, oorlogskroniek van Kees Tetteroo (Zaltbommel 2007); Eva Moraal, http://www.isgeschiedenis. $\mathrm{nl} /$ archiefstukken/ieder-zijn-eigen-oorlog-egodocumenten-over-de-tweede-wereldoorlog/3-4-20I4; Marieke Meeuwenoord, Mensen, macht en mentaliteiten achter prikkeldraad: een historisch-sociologische studie van concentratiekamp Vught (I943-I944), proefschrift UvA, (Amsterdam: z.u. 20II). I26 Eva Moraal, Als ik morgen niet op transport ga, ga ik's avonds naar de revue. Kamp Westerbork in brieven, dagboeken en memoires (1942-2010), proefschrift UvA, (Amsterdam: z.u. 2013) 58.

I27 Ibidem, 6o.

I28 Leijdesdorff, Wij hebben als mens geleefd, 40.

I29 Samuel D. Kassow, Wie schrijft onze geschiedenis, Het dramatische verhaal van het verborgen archief van het getto van Warschau (Amsterdam 2009) 30. I30 Bart van der Boom, 'Wij weten niets van hun lot'. Gewone Nederlanders en de Holocaust (Amsterdam 20I2) II3.

I3I Arianne Baggerman en Rudolf Dekker, 'De gevaarlijkste van alle bronnen. Egodocumenten, nieuwe wegen en perspectieven', Tijdschrift voor Economische en Sociale geschiedenis I (2004) 4, 3-22. I32 David J. Rothman, Strangers at the Bedside. A History of How Law and Bioethics Transformed Medical Decision Making (New York I99I) 8.

\section{GEWONE HOLLANDSE ARTSEN}

I Gerrit A. Lindeboom, Hippocrates (Amsterdam 1948) 36 .

2 Mart J. van Lieburg, 't Is geen baan,'t is een bestaan. Het sociale en economische leven van de me- dische beroepsbeoefenaren in Nederland weerspiegeld in 75 jaar VVAA (Rotterdam 2000).

3 Toespraak, gehouden op I3-9-I943 ter gelegenheid van de begrafenis van Dr. Maurits L. Muller, 
door Dr. G.W. Oberman, ned. Herv. Predikant te Utrecht. Kopie in bezit Hannah van den Ende. Uit collectie privécollectie familie Muller, Driebergen. 4 J. van Arkel Zegwaard (pseudoniem voor Stephan Sturkop), Vrouwenarts (Amsterdam 194I); J. van Arkel Zegwaard, Vrouwenzaal (Amsterdam I946); J. Van Arkel Zegwaard, Herinneringen van een huisarts (Amsterdam 1947); Maurits L. Muller, Aan de poort van het leven (Utrecht 1947).

5 Dagboek Berthold Stokvis, NIOD, 244, inv. nr. II49, 57 .

6 Ben Sajet, 'Am I a hero?', I, manuscript in Ben Sajet archief, ongenummerd, IISG Amsterdam.

7 Ben Sajet, Een leven lang. Verteld aan Hans Fels (Baarn I977) 7-24 en 50-70.

8 Jaap Meijer, Zij lieten hun sporen achter. Joodse bijdragen tot de Nederlandse beschaving (Utrecht I964) 53; David E. Cohen, 'De Joodsche geneeskundigen in de noordelijke Nederlanden vóór ı60о', Nederlandsch Tijdschrift voor Geneeskunde 78 (1934) 535; David E. Cohen, 'De vroegere Amsterdamsche Joodsche doctoren', Nederlandsch Tijdschrift voor Geneeskunde 7I (1927) I388.

9 Joseph Michman, Hartog Beem, Dan Michman, Pinkas, Geschiedenis van de joodse gemeenschap in Nederland (Amsterdam 1992) 67; Salvador Bloemgarten, Hartog de Hartog Lémon, I755-I823. Joodse revolutionair in Franse tijd (Amsterdam 2007).

IO Hagoort, Samuel Sarphati I8I3-I866.

II Michman e.a., Pinkas, 83.

I2 Hagoort, Samuel Sarphati I8I3-I866, 2II-2I2;

Henne van der Kooy en Justus de Leeuwe, Sarphati. Een biografie (Amsterdam 200I) 236.

I3 Stefan van der Poel, Tussen zieken, boeken en kikkers. De fysiologie van een leven: Izaac van Deen (I804-I869) (Groningen 20I2) 20; Michman e.a., Pinkas, II3.

I4 http://www.historici.nl/Onderzoek/Projecten/ BWN/lemmata/bwn4/stokvis, II-II-2OI3; Hes, Jewish Physicians in the Netherlands, 157-I58.

I5 Mineke Bosch, Een onwrikbaar geloof in rechtvaardigheid. Aletta Jacobs (I854-I929) (Amsterdam 2009) 70.

I6 Eddy S. Houwaart, De Hygiënisten. Artsen, staat en volksgezondheid in Nederland I840-I890
(Groningen I99I).

I7 Han Israëls en Annet Mooij, Aan de Achtergracht. Honderd jaar GGD Amsterdam (Amsterdam 200I) 138 .

I8 Ibidem, 94.

I9 Ibidem, I20 en 139; Arie Querido Doorgaand verkeer. Autobiografische fragmenten (Lochem 1980) I22.

20 De Vries, $M C_{194 I-I 945}$, I.

2I Marius Tausk, Organon. De geschiedenis van een bijzondere Nederlandse onderneming (Nijmegen I978) II-I5; Nelly Oudshoorn, Beyond the natural body: an archeology of sex hormones (London 1994) 68-7I.

22 Tausk, Organon, 45.

23 Mart J. van Lieburg, 'Joodse medici in Nederland tijdens de Tweede Wereldoorlog', in: J.H. Coppenhagen, Anafiem Gedoeiem. Overleden joodse artsen uit Nederland 1940-1945 (Rotterdam 2000) 33. 24 Hans Daalder, 'Joden in verzuilend Nederland' in id., Politiek en Historie: Opstellen over Nederlandse politiek en vergelijkende wetenschap (Amsterdam I990) IO2.

25 Statistisch jaarboek der gemeente Amsterdam, uitgegeven door het bureau van statistiek der gemeente, 29ste jaargang 1940-I94I. Stadsarchief Amsterdam, 022.2, inv. nr. 8. 137.

26 Interview van Oeke Hoogendijk met David

Moffie, 2-II-200O, typoscript collectie Joods Historisch Museum Amsterdam.

27 Van Lieburg, 'Joodse medici in Nederland', 3I.

28 Mart J. van Lieburg, 'Bevorderlijk voor de

kunst en nuttig voor de maatschappij'. De geschiedenis van het Genootschap ter bevordering van Heel-en Verloskunde (I857-I929) en van het Amsterdams Geneeskundig Genootschap (I925-I988) (Amsterdam I988) 62, 74 .

29 Hes, Jewish physicians in the Netherlands, I68;

Het Joodsche Weekblad, 2e jaargang, nr. 44, 5 februari 1943, I.

30 www.joodsbw.nl, 4-9-20I4.

3I Leijdesdorff, Wij hebben als mens geleefd, 77.

Verwijst naar een verslag bij het YIVO, door Gertrud van Tijn in 1935 geschreven; J.P.Kruyt, 'Het Jodendom in de Nederlandse samenleving', in H.J. Pos (red.), Anti-semitisme en Jodendom: een bundel 
studies over een actueel vraagstuk (Arnhem 1939) 215. 32 Johannes Th.M. Houwink ten Cate, 'Het jongere deel', Demografische en sociale kenmerken van het jodendom in Nederland tijdens de vervolging.' In: Jaarboek van het Rijksinstituut voor Oorlogsdocumentatie 1989 (Zutphen 1989) 9-66, 15.

33 Daalder, 'Joden in verzuilend Nederland', Io6.

34 Leijdesdorff, Wij hebben als mens geleefd, 77.

35 Michman e.a., Pinkas, Io8.

36 Corjo Jansen en Derk Venema, De Hoge Raad en de Tweede Wereldoorlog. Recht en rechtsbeoefening in de jaren 1930-1950 (Amsterdam 20II); Meihuizen, Smalle Marges, 167.

37 Eduard Jacobs werd in 1893 burgemeester van Lonneker. http://javapost.nl/20I2/03/27/alettajacobs-en-de-indische-connectie/ 3-4-20I4.

38 Geert J. Bremer, Huisarts zijn in het interbel-

lum (Rotterdam 2006) 58.

39 Vereniging ten behoeve van het ziekenhuiswezen, Nationaal Archief, 2.I9.IIo.oI, inv.nr. 62; Map documenten Salomon Kroonenberg, privécollectie familie Kroonenberg.

40 Elsa Pereira-d'Oliveira, Vrouwen feministen die van genezen wisten (Amsterdam 1973); Klazien Kruisheer, De dokter dat ben ik. 65 jaar Vereniging van Nederlandse Vrouwelijke Artsen (Zutphen 1998).

4I Bremer, Huisarts zijn in het interbellum, 49-50.

42 Ibidem, 95.

43 Salomon Biegel, Handleiding der gezond-

heidsleer. In verband met de Nederlandse wetgeving

(Gorinchem 1927), vijfde herziene druk.

44 Herman Pinkhof, Het beroep van arts (Dordrecht I9I2), no. 7 in de serie Morks' beroepsbibliotheek.

45 Joël van der Kous, 'Wat een huisdokter er van vindt', Radiorede door den heer J. van der Kous, arts, op 29 januari 1932 voor de AVRO-schooluitzending gehouden, in: Joël van der Kous e.a., $\mathrm{Zal}$ $i k$ medicus worden? no. I. in de serie 'Wat zal ik worden?' (Baarn I932).

46 Bernard Premsela, Geslachtelijke voorlichting van de rijpere jeugd (Amsterdam I934); Bernard Premsela, Geboorteregeling (Amsterdam 1934); Bernard Premsela, Moeilijkheden in het huwelijk: mededeelingen uit en voor de practijk, mede ontleend aan het Dr. Aletta Jacobshuis te Amsterdam (Amster- dam 1936); Bernard Premsela, De ongehuwde man

(Amsterdam 1939); Bernard Premsela, Sexuologie in de praktijk (Amsterdam 1940); Bernard Premsela,

Ochtend defilé (Amsterdam I946) postuum uitgegeven; Hugo Röling, 'Bernard Premsela, Pionier van de seksuologie: beminnelijk en inconsequent', Ons Amsterdam 46 (I994) 240-244; Henny Brandhorst, 'From neo-Malthusianism to sexual reform: the Dutch section of the World League for Sexual Reform', Journal of the History of Sexuality, I2 (2003) I, 38-67.

47 Coen van Emde Boas, De periodieke onvruchtbaarheid en haar beteekenis voor de regeling van het kindertal: beschouwingen over de grondslagen, de betrouwbaarheid en de practische bruikbaarheid van de zoogenaamde "periodieke onthouding" (Amsterdam 1934).

48 Van Lieburg, 'Joodse medici in Nederland', 32. Zie bijv. de Geneeskundige Gids.

49 Izaak van Esso, Aesculaap, propagandanummer, januari 1938. Privécollectie familie Spanjaard. so Gerard van Rijnberk, 'H. Pinkhof, I888-25 februari-I929. Een medisch journalistiek jubilaeum', Nederlands Tijdschrift voor Geneeskunde 73 (1929) 898-900.

5 I P. A. de Wilde, 'Gouden artsjubileum Dr. H. Pinkhof', Nederlands Tijdschrift voor Geneeskunde 79 (1935) I029-30.

52 Een erkenning van zijn Talmoedkennis, hem toegekend door opperrabbijn J.H. Dünner in 1904. 53 P. Muntendam, 'Het vraagstuk der lijkopening in een joodsche gemeenschap', Nederlands Tijdschrift voor Geneeskunde 68 (1924) 2406-7. I. van Esso, 'Dr. Hermanus Pinkhof', http://www. genootschapjoodsewetenschap.nl/bijdragen-enmededeelingen levensberichten 1956, 27-8-20I4 54 'Lijkopening in Joodsche ziekenhuizen', de Telegraaf, 19-4-1939, jaargang 47. Aankondiging van lezing van Kroonenberg over dit onderwerp, in het NIZ. Ook in 'Lijkopening nuttig voor de medische wetenschap. Ondanks verbod van het Israelietisch geloof toch toepassing noodig'. Het Vaderland, staat-en letterkundig nieuwsblad, 26-4-I939. Dit kwam ook overeen met wat in de gids 'medische ethiek' over dit onderwerp geschreven stond, namelijk dat in sommige gevallen sectie op Israëlitische 
gestorvenen was toegestaan, en dat men daartoe overleg kon plegen met een rabbijn. Zie: A. ten Bokkel Huinink, C. Fehmers, Th. Hammes red., Medische ethiek (tweede druk NMG I94I) II9.

55 Van Rijnberk, 'Dr. H. Pinkhof, I888-25 februari-I929', 898-900.

56 Herman Pinkhof, 'Over sterilisatie en castratie in het Jodendom', Boschblaadjes, 4 (I935) 5, 34. In privécollectie familie Kroonenberg.

57 Ibidem.

58 Hes, Jewish Physicians in the Netherlands, II6.

59 Fred Rosner, Medicine in the Bible and the Talmud: selections from classical jewish sources (New Jersey 1995 2e druk) I82. Er bestonden en bestaan specifiek Joodse medische ethische beginselen. In I959 schreef rabbijn Immanuel Jakobovits een tot op de dag van vandaag gebruikt standaardwerk over Joodse medische ethiek: Immanuel Jakobovits, Jewish Medical Ethics (New York 1959).

60 Gerrit A. Lindeboom, 'Het (aan Maimonides toegeschreven) ochtendgebed van een arts', Nederlands Tijdschrift voor Geneeskunde II5 (I97I) 924-7.

6I Nevins, The jewish doctor, I8-27.

62 Lindeboom, 'Het (aan Maimonides toegeschreven) ochtendgebed van een arts', 924-7.

63 Jacques Z. Baruch, 'Bij het graf van Maimonides', Nederlands Tijdschrift voor Geneeskunde 96 (I952) I543. Bijvoorbeeld van de vooroorlogse zionistische arts Meyer Premsela is overgeleverd dat hij tijdens zijn geneeskundestudie door zijn medestudenten wel met Maimonides vergeleken werd: Meyer J. Perath, Tussen Jeruzalem en Amsterdam (Baarn I975), achterblad.

64 Nevins, Jewish medicine.

65 Max Nassauer, De goede dokter. Een nuttig prentenboek voor jong en oud. Uit het Duits vertaald door dr. Kaas (Arnhem 1909), Inleiding.

66 Th. Hammes, 'De pijlers van onze ethiek', openingsrede uitgesproken in de 86e Algemeene Vergadering der Maatschappij. Nederlands Tijdschrift voor Geneeskunde 79 (I935) 3375.

67 Frank Huisman, J.H. Warner, Locating medical history. The stories and their meanings (Baltimore 2004) 507.

68 G.B. Ughetti, Artsen en patiënten. Herinneringen van een geneesheer. Naar de ze Hoogduitse vertaling door A.K.W. Arntzenius ('s-Gravenhage I900) 7 .

69 Hector Treub, Patiënt en geneesheer. Klinische les (Leiden 1892) 4.

70 Hector Treub, Medische fatsoensleer (Amsterdam 1903).

7I J.L.C. Wortman, De ethica aan het ziekbed

(Haarlem 1929) 84.

72 Ibidem, 74.

73 W.B. Huddleston Slater, Dokter en publiek.

Een reeks actuele vraagstukken (Rotterdam I929) I4.

74 Ten Bokkel Huinink e.a., Medische ethiek, 9.

75 Ibidem.

76 Ibidem, 6.

77 H. Burger, Geneesheer en maatschappij (Amsterdam 1919) 3.

78 Van der Kous e.a., Zal ik medicus worden?, II.

79 Carola J.E. Kaandorp, Jannes J.E. Van

Everdingen, Annet Mooij (red.), Erflaters van de geneeskunde, beroemde Nederlandse artsen beschreven door hun (kinds)kinderen (Overveen 2002).

80 Gerard van Rijnberk, 'Medische ethiek', Nederlands Tijdschrift voor Geneeskunde 80 (1936) 299I. 8I Van Rijnberk, 'Dr. H. Pinkhof, I888-25 februari-I929', 898-900.

82 De Vries, $M C_{1941-I 945, \text { I. }}$

83 Querido Doorgaand verkeer, 353.

84 Van Rijnberk, 'Medische ethiek', 2991.

85 Henk Boonstra, 'Is er nog plaats voor de oude idealen in de nieuwe zorgmarkt?' in: Vincent Kirkels (red), Oude idealen in de nieuwe zorgmarkt (Nijmegen 2008) 86.

86 Pinkhof, Het beroep van arts, I9.

87 E.S. Houwaart, 'De modernisering van de gezondheidszorg en de geneeskunde in de negentiende eeuw' in: B.J.M. Aulbers, G.J. Bremer (red), De huisarts van toen. Een historische benadering

(Rotterdam 1995) 9-33, 26-27.

88 Hammes, 'De pijlers van onze ethiek', 3375.

89 Ibidem.

90 Ibidem.

9I Ibidem.

92 Ibidem.

93 Ten Bokkel Huinink e.a., Medische ethiek, I2

94 Ibidem, I3.

95 Ibidem, II4. 
96 Ibidem, 72.

97 T.C. Winkler, Dokter en patiënt ('s-Hertogenbosch I880) 3 .

98 Ten Bokkel Huinink e.a., Medische ethiek, I8.

99 De schrijvers leken deze paragraaf bijna letterlijk te hebben overgenomen van Hector Treubs colleges over medische fatsoensleer uit 1903: Treub, Medische fatsoensleer, 33 .

Ioo Ten Bokkel Huinink e.a., Medische ethiek, 7. Ior Johannes C.H. Blom, Joël J. Cahen, 'Joodse Nederlanders, Nederlandse joden en joden in $\mathrm{Ne}$ derland (1870-1940)' in: Johannes C.H. Blom, Rena G. Fuks-Mansfeld, Ivo Schöffer (red.), Geschiedenis van de joden in Nederland (Amsterdam I995) 248. IO2 Sigmund Seeligmann, 'Die Juden in Holland. Eine Characteristik' in: Festskript i Anledning af Professor David Simonsens 70-aarige Fødselsdag (Copenhagen I923) 253-257.

IO3 Blom en Cahen, 'Joodse Nederlanders, Nederlandse joden en joden in Nederland', 250.

IO4 Leijdesdorff, Wij hebben als mens geleefd, I04.

Ios Houwink ten Cate, 'Het jongere deel', ro.

Io6 Michman e.a., Pinkas, I30.

IO7 Zie daarvoor: Bernard Wasserstein, On the

Eve. The Jews of Europe Before the Second World

War (Londen 20I2). Wasserstein meent dat deze assimilatoire neiging in de meeste landen vooral ingegeven werd door (angst voor) antisemitisme. Io8 Wout Ultee en Ruud Luijkx, 'Jewish-Gentile Intermarriage in Six European Cities I900-I940. Explaining Differences and Trends' in: The Netherlands Journal of Social Sciences 34 (1998) 2, I65-I93.

Io9 Emanuel Boekman, 'Demografie van de Joden in Nederland', Nederlands Tijdschrift voor Geneeskunde 80 (1936) 3957.

IIO Michman e.a., Pinkas, I3I.

III Interview met Juda J. Groen, internist, door Philo Bregstein, in serie interviews I969-1975, typoscript Joods Historisch Museum, inv. nr. 00005027. II2 Michman e.a., Pinkas, I30.

II3 M.C. Croockewit, Het exlibris der Nederlandse medici (Den Haag I950).

II4 De meeste van deze ex librissen waren voor de oorlog ontworpen en konden daarmee nog niet beïnvloed zijn door de gebeurtenissen tijdens de bezetting.
II5 Gesprekken met Max Hamburger, d.d. 28-IO2008, 14-5-2009, 16-7-2009.

II6 Dagboek Joseph Kater, NIOD DOC I, inv. nr. 868A.

II7 www.joodsbw.nl 9-4-20I4; B. Quispel, 'M. Elzas 50 jaar Doctor Medicinae', Nederlands Tijdschrift voor Geneeskunde IIO (I966) I206-7 II8 Stefan van der Poel, Joodse stadjers. De Joodse gemeenschap in de stad Groningen (I796-I945) (Assen 2004) 8I.

II9 A.M. van der Woel, 'Dr. Hausdorff I90I-I990' http://rjb.x-cago.com/GARJB/I99I/I2/I99II23I/ GARJB-I99II23I-OI47/story.pdf 9-4-20I4.

I2O Gesprek met Lea Dasberg, d.d. I4-2-20II.

I2I Henriette Boas, Bewust-joodse Nederlandse vrouwen. Veertien portretten (Kampen 1992) I05-I06. I22 Dagboek Maurits Muller Micha.reisel.net/ memor/dagboek.htm I7-IO-I9I3.

I23 Manuscript O. Cahen november I94I aan het Medisch Dispuut Dordrecht, Dordrechts Archief DIEP, 489, inv. nr. 20430.

I24 Ibidem.

I25 Jaap Spanjaard, Brieven I931-1985 (Amsterdam 1993) I0.

I26 Ibidem.

I27 Dienke Hondius, Terugkeer. Antisemitisme in Nederland rond de bevrijding (Den Haag 1998) 57. I28 Blom en Cahen, 'Joodse Nederlanders, Nederlandse joden en joden in Nederland', 284-287. I29 Ongedateerde brief van Celine Lopes Cardozo-Rodrigues Pereira aan haar zoon Paul in Leiden, dertiger jaren. Prive-collectie familie Lopes Cardozo.

I30 Gesprek met Lida en Ada Lopes Cardozo,

d.d. I-9-20I2, resp. 26-5-20I2.

I3I De Jong, Koninkrijk, deel acht, deel twee, 955

I32 Klazien Laansma, Eindstation Tröbitz (Kampen 1996) 23.

I33 Ibidem.

I34 Blom en Cahen, 'Joodse Nederlanders, Nederlandse joden en joden in Nederland', 286: Joden werden bijvoorbeeld geweerd bij elitaire gezelschappen als de Grote Club in Amsterdam.

I35 Laansma, Eindstation Tröbitz, I4. I36 Jansen en Venema, De Hoge Raad en de Tweede Wereldoorlog, 32. 
I37 Dagboek Jeltje Eckert-Stroink, NIOD 244, inv. nr. II92, november I940; Van der Boom, ' Wij weten niets van hun lot', $3 \mathrm{O}$.

I38 Van der Boom, 'Wij weten niets van hun lot', 3OI-306.

I39 N.K.C.A. in 't Veld, De zuivering van artsen en advocaten ('s-Gravenhage I983) 28. In december I942 waren er 2IO Nederlandse artsen lid van het Medisch Front. Dat cijfer stamt echter van tijdens de bezetting en hoeft dus geen een-op-een relatie met het antisemitisme in de Nederlandse artsenstand in het interbellum te hebben. NSB staat voor 'Nationaal-Socialistische Beweging'.

I40 Dick van Galen Last, 'Rassenhygiëne: de dodelijke omhelzing van wetenschap en nationaal socialisme' in: Martijn Eickhoff, Barbara Henkes, Frank van Vree (red), Volkseigen. Ras, cultuur en wetenschap in Nederland I900-I950 (Zutphen 2000) 217: 'Het geloof in het ras als bepalende factor van beschavingsniveau was sinds het midden van de I9e eeuw algemeen verbreid geraakt onder de geletterden van de meeste Europese naties.'

I4I Jan Noordman, Om de kwaliteit van het nageslacht. Eugenetica in Nederland I9oo-I95o (Nijmegen I989) I28.

I42 www.kb.nl bijv. Nieuw Israëlitisch Weekblad 22-I2-1933, jaargang 69, nr 33; L.K.W. 'Medische Kroniek', Algemeen Dagblad 2I-9-1933.

I43 E.D. Wiersma, 'Sterilisatie en castratie', Nederlands Tijdschrift voor Geneeskunde 79 (1935) I074-7; Ca. M. Schenck, 'De sterilisatie op eugenetische indicatie en het geldende recht', Nederlands Tijdschrift voor Geneeskunde 79 (1935) 2266-8; E. D. Wiersma, 'Sterilisatie, een onderzoek naar de mogelijkheid eener wettelijke regeling der geslachtelijke onvruchtbaarmaking in Nederland', Nederlands Tijdschrift voor Geneeskunde 77 (1933) 5002.

I44 L.F. Driessen, 'Therapeutische sterilisatie in de verloskunde', Nederlands Tijdschrift voor Geneeskunde 72 (1928) 6294-6; J.J. van Loghem, 'Eugenetische sterilisatie', Nederlands Tijdschrift voor Geneeskunde 75 (193I) 6207. De auteur spreekt in een dergelijk geval van 'unlawful wounding'. I45 Herman Pinkhof, 'Sterilisatie van erfelijk blinden', Nederlands Tijdschrift voor Geneeskunde 78 (1934) 826
I46 L.J.J. Muskens, 'Aanteekeningen omtrent de sterilisatie in Duitschland', Nederlands Tijdschrift voor Geneeskunde 79 (1935) 78-79.

I47 U.G. Bijlsma, 'Sterilisatie', Nederlands Tijdschrift voor Geneeskunde 78 (1934) 5172-5173.

I48 Stephen Snelders en Toine Pieters, 'Van degeneratie tot individuele gezondheidsopties', Gewina 26 (2003) 203-2I5, 209-2IO.

I49 Herman Pinkhof, 'Sterilisatie zonder geneeskundige indicatie', Nederlands Tijdschrift voor Geneeskunde 77 (1933) 3402.

I50 In hetzelfde jaar stuurde de afdeling Dordrecht van de NMG aan het Pruisische Staatsbaden Verbond een verontrust verzoek om opheldering omtrent uitspraken over het antisemitische sterilisatiebeleid: 'Het Nederlanderschap geëerd', Nieuw Israëlitisch Weekblad 23-6-I933.

I5I Noordman, Om de kwaliteit van het nageslacht, $\mathrm{I} 6$.

I52 Van der Poel, Tussen zieken, boeken en kikkers, 58.

I53 Noordman, Om de kwaliteit van het nageslacht, I30.

I54 Zie bijv: Leonard Polak Daniëls, 'Over de pathologie van het endocrine stelsel bij de Joden', Nederlands Tijdschrift voor Geneeskunde 74 (1930) 289-9I; E. Sluiter, 'Suikerziekte bij Joden', Nederlands Tijdschrift voor Geneeskunde 73 (1929) II66; Herman Pinkhof, 'De vruchtbaarheid der Joden voorbij', Nederlands Tijdschrift voor Geneeskunde 72 (I928) 585 I.

I55 G.J. Bremer, 'Jacob Sanders I887-I945, joods huisarts en geleerde. Zijn aandeel in de ontwikkeling van de erfelijkheidsleer in Nederland' Misjpoge I7 (2004) 2, 50-53 en document 0ooI2315, Joods Historisch Museum.

I56 Samuel Poliakoff schreef in de jaren 1920 een serie artikelen over raskenmerken van Joden in de Vrijdagavond: bijv: 2 (1925), 5, deel I, 78-80.

I57 Frits Grewel en Coen van Emde Boas 'De Joden in Amsterdam', Mens en Maatschappij, 3 (I955) 298 en 304.

I58 Van Lieburg, 'Joodse medici in Nederland', 35.

I59 Typoscript van M.H. Pimentel, 'De geneeskundige verzorging en ziekenverpleging der Joden 
in Amsterdam van I804-I940', ca. I950, Joods Historisch Museum, document ooor3988; Dr. J. de Hartogh JR., 'Het Nederl. Isr. Armbestuur in de laatste 50 jaar', Gedenkboek ter gelegenheid van het 50-jarig bestaan van het Centraal Blad voor Israëlieten in Nederland I935, 55-58, Joods Historisch Museum, 927 Gede b.; Typoscript over de geschiedenis van het Joodse ziekenhuis in Rotterdam door M. Elzas, ca. I950, Joods Historisch Museum, document ooor3990; Typoscript over het voormalige Joles-ziekenhuis in Haarlem, auteur mogelijk S.L. Anholt, ca. I950, Joods Historisch Museum, document ooor3989; Wim de Wagt, Joods Haarlem. Een topografie van hoop en herinnering (Wormer 2005) 27; Wim de Wagt, 'Thuis en nietthuis in het Huis van Joles. Het Joles Ziekenhuis aan het Groot Heiligland (1930-1949)', in: K. v.d. Linden e.a., Kom ga sjoelen! Bijdragen over de geschiedenis van de joodse gemeenschap in Haarlem (Haarlem 1999) 83-I06.

I60 Dr. Jan Kat (187I-1957).

I6I Dick Houwaart, Kehillo kedousjo Den Haag. Een halve eeuw geschiedenis van Joods Den Haag (Den Haag 1986) I8; A. Bartels en A. Polak, 'De verzorging van Joodse zieken te 's-Gravenhage tot 1943', Studia Rosenthaliana 3 (1969) 2, 202-207. I62 Vestigingsboek, Nationaal Archief KNMG 2.19.053.OI, inv. nr. 272.

I63 Michael E. Grodin (red.), Jewish Medical Resistance in the Holocaust (New York 20I4) preface xiv; http://www.holocaust-history.org/klarsfeld/ Frenchprocent2oChildren/html\&graphics/Too95. shtml 26-II-2OI3.

I64 Briefwisseling Izaak van Esso met dr.med.

L. Glesinger in Zagreb 1937, Joods Historisch Museum, documenten 0002633 en 0002634 ; En voor Pinkhof: De Wilde, 'Gouden artsjubileum Dr. H. Pinkhof', I029-30.

I65 Typoscript van M.H. Pimentel, 'De geneeskundige verzorging en ziekenverpleging der Joden in Amsterdam van I804-I940', ca. I950, Joods Historisch Museum, document ooor3988. I66 http://www.genootschapjoodsewetenschap. $\mathrm{nl} /$ bijdragen-en-mededeelingen levensberichten I956, 9-4-20I4.

Ook de Amsterdamse Joodse artsen Emanuel Vas
Nunes, Meijer Premsela en Herman Pinkhof waren eind jaren dertig lid van dit genootschap.

I67 Catalogus tentoonstelling op het gebied van Amsterdamsch-Joodsche artsen en besnijders, in het Amsterdamsch Historisch Museum op de Nieuwmarkt, catalogus nr.I; november 1926- maart I927, Joods Historisch Museum 995.9.

I68 Izaak van Esso, 'Het aandeel der Joden in de natuurwetenschappen in Nederland' in: Dr. Hk.

Brugmans en Drs. A. Frank, Geschiedenis der Joden in Nederland (Amsterdam I940) Ie deel, 643-679. I69 Izaak van Esso, 'Geschiedenis der Geneeskunde', Aesculaap, propagandanummer, januari I938, I5.

I70 Izaak van Esso, 'De Jood als patiënt' in: De Vrijdagavond, I (1925) 44, 283-285.

I7I Ibidem.

I72 Van Esso, 'Het aandeel der Joden in de natuurwetenschappen in Nederland', 643.

I73 Brugmans en Frank, Geschiedenis der Joden in Nederland, verantwoording.

I74 Ivo Schöffer, 'Nederland en de Joden in de jaren dertig in historisch perspectief', in Kathinka Dittrich en Hans Würzner (red.) Nederland en het Duitse Exil I933-I940: Achttien essays (Amsterdam I982) 88.

I75 Kruyt, 'Het Jodendom in de Nederlandse samenleving', 227.

I76 Michman e.a., Pinkas, ro8 en I63; Blom en Cahen, 'Joodse Nederlanders, Nederlandse joden en joden in Nederland', 296; Frank van Vree meldde dat in de confessionele Nederlandse pers antisemitisme doorklonk ten opzichte van de 'ontaarde', niet meer gelovige Jood: Frank van Vree, De Nederlandse pers en Duitsland 1930-1939. Een studie over de vorming van de publieke opinie (Groningen 1989) 35I; De Jong, Koninkrijk, deel vier, deel twee, 746: antisemitisme was mild in vergelijking met andere landen.

I77 Houwink ten Cate, 'Het jongere deel', II. I78 Ludy Giebels, De zionistische beweging in Nederland I899-I94I (Assen 1975) I7I.

I79 Ibidem; Zie voor socialistisch zionisme ook: Evelien Gans, De kleine verschillen die het leven uitmaken. Een historische studie naar joodse sociaaldemocraten en socialistisch-zionisten in Nederland 
(Amsterdam 1999).

I80 Blom en Cahen, 'Joodse Nederlanders, Nederlandse joden en joden in Nederland', 29I.

I8I Ibidem, 277.

I82 Jaap Meijer, Hoge hoeden, lage standaarden. De Nederlandse Joden tussen 1933 en 1940 (Baarn 1969) 53: citaat uit een brief van o.a. Menno Hertzberger (en J. Samuel, I.E. Drievoet, L. Prins, Colaco Osorio, Goldenberg, Frits van Raalte, L. Levin enz.) aan David Cohen nav zionistische discussie in Centraal Blad voor Israëlieten in Nederland 2I maart 1935.

Zie ook: Giebels, De zionistische beweging in Nederland, 174 .

I83 David Cohen, Zwervend en dolend. De joodse vluchtelingen in Nederland in de jaren 1933-1940 (Haarlem 1955); Bob Moore, Refugees from Nazi Germany in the Netherlands, 1933-1940 (Dordrecht 1986).

I84 Hondius, Terugkeer, 43.

I85 Joods Historisch Museum, Spielberg-interview Boes Lankhout.

I86 Bob Moore, Victims and Survivors. The Nazi Persecution of the Jews in the Netherlands 1940-1945 (Londen 1997) 33; Wasserstein, On the Eve, IO3; Pim Griffioen en Ron Zeller, Jodenvervolging in Nederland, België en Frankrijk 1940-I945. Overeenkomsten, verschillen, oorzaken (Amsterdam 20II) IOI3; Schoffer: 'Nederland en de Joden', 9r; Hondius, Terugkeer, 5I.

I87 Plakboek Jacob Goudsmit, privécollectie familie Goudsmit, Amsterdam.

I88 Iki Freud, Mijn naam is Freud, Iki Freud.

Bekentenissen van een psychoanalytica (Amsterdam 2004) I8.

I89 Correspondentie met Bart de Cort, onderzoeker, die de geschiedenis schrijft van de Stichting tot Verdediging van de Culturele en Maatschappelijke Rechten der Joden, kortweg: Stichting Joodse

Rechten (SJR), januari 2013.

I90 Praag, Salomon Wolfeus (I876-I96r),

Generaal-majoor inspecteur Geneeskundige dienst Koninklijke Landmacht I933-I939, medisch adviseur van het ministerie van Binnenlandse Zaken, afdeling armwezen/vluchtelingen.

I9I Brief van M. Hertzberger aan S.W. Praag, 7-I2-I939, Nationaal Archief 2.04.58, inv.nr. I6o.
192 Brief van M.L. van der Heijden aan S.W.

Praag, 14-6-1939, Nationaal Archief 2.04.58, inv. nr. 97 .

I93 Brief van H. Peeters aan S.W. Praag, 3I-71939, Nationaal Archief 2.04.58, inv.nr. 97.

194 Brief van J.E. Hartogs aan S.W. Praag, 5-31939, Nationaal Archief 2.04.58, inv.nr. 97.

I95 Correspondentie S.W. Praag, Nationaal

Archief 2.04.58, inv.nr.I6o.

I96 Gesprek met Ralph van Furth, d.d. 27-I-20II.

I97 Brief Haagsch Vluchtelingencomité aan S.W. Praag. Het ging om de artsen M. Witkamp, N.J. Teijler, Dr. H. Rümke, C.M. Veenhuyzen, H.A.N. Vechtmann; Dr. W.F. Noordhoek Hegt, J. Knoop; Dr. A.W.H. Mak v. Waay; H.A.A. Struycken en S.J. Weg. 4-8-I939, Nationaal Archief 2.04.58, inv. nr. 97 .

198 'Een oproeping ten behoeve van de Joodsche artsen in Duitschland', Nederlands Tijdschrift voor Geneeskunde 77 (1933) 2247; L.L. Posthuma, 'Nieuwe bedreiging der Joodsche artsen te Berlijn', Nederlands Tijdschrift voor Geneeskunde 79 (1935) 4697; L.L. Posthuma, 'Geen Joodsche artsen meer in Duitsland', Nederlands Tijdschrift voor Geneeskunde 82 (1938) 4746-4747.

199 Th. A. Blom, 'Joodsche artsen in Duitschland', Nederlands Tijdschrift voor Geneeskunde 82 (1938) 4936.

200 Cohen, Zwervend en dolend, II9.

2OI Blom en Cahen, 'Joodse Nederlanders, Nederlandse joden en joden in Nederland', 25 I. 202 'Statistische gegevens over immigranten van Joodsen bloede in Nederland', I oktober I94I, NIOD 20, inv.nr. I5OI.

203 Carolus Reijnders, Van 'Joodsche natiën' tot Joodse Nederlanders (Amsterdam 1970) 52. 204 Van Lieburg, 'Joodse medici in Nederland', I9.

205 'Rapport betreffende de overvulling van het medische beroep', Nederlands Tijdschrift voor Geneeskunde 83 (1939) 299I-3172.

206 Zoals bijvoorbeeld de vluchtelingen die bij de familie Hausdorff in Rotterdam werden opgevangen: Gesprek met Dov Hausdorff (telefonisch) d.d. I6-2-20II.

207 Van Lieburg, 'Joodse medici in Nederland', 
28.

208 Ina Boudier-Bakker, Met de tanden op elkaar.

Dagboeknotities '40-'45 (Amsterdam 1965) I3.

\section{AFSTAND VAN DE ARTSENSTAND}

I Dagboek Berthold Stokvis, NIOD, 244, inv. nr. II49, 44: beschrijving I4 mei I940.

2 Van Vree, De Nederlandse pers en Duitsland 1930-1939, 356.

3 Michman e.a., Pinkas, I70; Exact hetzelfde wordt gesteld in: Blom en Cahen, 'Joodse Nederlanders, Nederlandse joden en joden in Nederland', 247.

4 Van Lieburg, 'Joodse medici in Nederland', 4I.

5 Joods Historisch Museum, Spielberg-interviews Edward Vas Nunes, Juliette van Cleeff-Fernandes, Ellis Hertzberger; allen kinderen van artsen; Ellis en Jenny Hertzberger, Door de Holocaust verbonden. Westerbork, Theresienstadt en Auschwitz als basis voor een huwelijk (Laren 2009) 48.

6 Frank Kouwenhoven, 'Voetlicht. Professor Groen: van kleine Napoleon tot wetenschappelijk vorser', Centrum. Academisch Ziekenhuis en Medische Faculteit Leiden I4 (1984) 4, 88-92, 90.

7 Fritz Fischer, memoires, genoteerd in 1945 , privécollectie familie Fischer.

8 http://www.joodsmonument.nl/person/546473/nl 9-4-20I4.

9 Van Lieburg, 'Joodse medici in Nederland', 43.

IO Ibidem, 4I.

II Jacques Presser, Ondergang. De vervolging en verdelging van het Nederlandse Jodendom 1940-1945 2 dln ('s-Gravenhage 1965) deel een, I3.

I2 Joods Historisch Museum, Spielberg-interviews Marianne van der Poorten-Stokvis, Diny Boas-Vedder, Benno Premsela, Louis Micheels, Ima Shalom Spanjaard-van Esso; gesprek met Martha ben Assa/van Esso-Polak, d.d. I3-2-20II; gesprekken met Rob Goudsmit, d.d. 19-2-2009, 23-4-2009; gesprekken met Willy Hijmans, d.d. I7-6-20IO, 2I-8-20IO.

I3 Joods Historisch Museum, Spielberg-interview Tons Katzenstein-Hartogs.

I4 L.W. de Bree, Zeeland I940-I945. Deel I (Middelburg 1979) 293.
I5 http://www.holywellhousepublishing.co.uk/Zeemanshoop_voyage.html 9-4-20I4 en gesprek Herman van Praag, d.d. 5-2-2009.

I6 Frank van Tubergen, Wout Ultee en Ruud Luijkx, 'The Unwholesome Theme of Suicide', in Chaja Brasz (red.), Dutch Jews As Percieved By

Themselves and By Others (Leiden 200I) 340; Karin Dangermond, 'Het heft in eigen handen. Een kwalitatief onderzoek naar Joodse zelfmoorden in Nederland tijdens de Tweede Wereldoorlog', scriptie bij de master Holocaust- en genocidestudies, (Amsterdam: z.u. 20II). Dit wordt vermeld in: J.J. van Loghem, 'Nederlandsche statistiek van den zelfmoord', Nederlands Tijdschrift voor Geneeskunde 85 (194I) 574-5. 574.

I7 Gesprek met Arnold Rodrigues Pereira, d.d. 4-IO-2OII.

I8 Dagboek Berthold Stokvis, NIOD, 244, inv. nr. II49, 50 .

I9 Briefwisseling familie Frijda over de suïcide van familieleden Willy en Lena Levy-Frijda, I7-51940, NIOD DOC II, inv.nr. I390.

20 In april I940 stierf er ook een Joodse arts door suïcide: R.P. Belinfante.

2I Zo vermoedt ook Van Lieburg in: Mart J. van Lieburg, 'De burgergeneeskundige dienst in mobilisatie- en bezettingstijd', Gewina I4 (I99I) 4 , I77-I92, I85.

22 Hammes, 'De pijlers van onze ethiek', 3375.

23 Herman Pinkhof, 'Verklaring van overlijden bij zelfmoord', Nederlands Tijdschrift voor Geneeskunde 76 (1932) 4464-5; Nico Speyer, Overzicht van den geschiedenis van den zelfmoord in Nederland', Nederlands Tijdschrift voor Geneeskunde 82 (1938) I599-I605, I602.

24 Dagboek Salomon Koster, NIOD 244, inv. nr. 996, 57 .

25 Klaas van Berkel, Academische illusies. De

Groningse universiteit in een tijd van crisis, bezetting en herstel, 1930-I950 (Amsterdam 2005) I55. 
26 W.A. Kuenen, 'In Memoriam L. Polak

Daniels', Nederlands Tijdschrift voor Geneeskunde 84 (I940) 20I2-4.

27 G.C. van den Heuvel, 'In memoriam M.

Hertzberger', Nederlands Tijdschrift voor Geneeskunde 84 (1940) 2174.

28 H. Burgerhout, 'In memoriam Dr. J. van den Borg', Nederlands Tijdschrift voor Geneeskunde 84 (I940) 2078.

29 W.P.C. Zeeman, 'In memoriam dr. E. Marx, arts geworden 1906, doctorstitel 1925', Nederlands Tijdschrift voor Geneeskunde 84 (I940) 2075-6, 2075. 30 Burgerhout, 'In memoriam Dr. J. van den Borg', 2078.

3I Maurits Muller, 'In memoriam dr. E.H.B. van Lier', Nederlands Tijdschrift voor Geneeskunde. 84 (1940) 2076-2077, 2076.

32 Gesprek met Sam en Ruth Bos-Watermann d.d. 26-2-2009.

33 Cornelia de Lange, 'In memoriam dr. M. de Bruin, overleden I8 mei 1940', Nederlands Tijdschrift voor Geneeskunde 84 (1940) 1996.

34 Documentatie suïciden onder Nederlandse Joden, NIOD DOC II, inv.nr. I390; Chr. van Gelderen, 'In memoriam W.A. Levy', Nederlands Tijdschrift voor Geneeskunde 84 (I940) 2276; Th. E. de Jonge-Cohen, 'In memoriam Dr. E. Sanders', Nederlands Tijdschrift voor Geneeskunde 84 (I940) 2078-9.

35 Het hem door zijn vader voorgeschreven, ongebruikte recept is nog altijd in het bezit van zijn zoon, de schrijver L.H. Wiener: L.H. Wiener, Wegens mensenkennis gesloten (Amsterdam 1988) 5-Io. 36 N. Knapper, 'In Memoriam E. Wiener, overleden I4 mei 1940', Nederlands Tijdschrift voor Geneeskunde 84 (1940) 2079.

37 Van Bernard Aa werd wel in de (onvolledige) dataset van de doodsoorzaken in mei 1940 in het CBS een beweegreden voor de zelfmoord genoemd: allereerst 'drank en drugs' en daarnaast 'oorlogstoestand': Dangermond, 'Het heft in eigen handen', 49. De enige andere arts van deze elf die ook in het CBS geregistreerd werd is Maurits Hertzberger, bij wie exact dezelfde beweegredenen vermeld worden. 38 http://www.joodsmonument.nl/person/536785, 2I-II-20I3. Van Ludwig Pincus verscheen geen in memoriam in het NTvG.

39 De Leidse hoogleraar keel-, neus- en oorheelkunde Pieter Kan stierf, hoewel waarschijnlijk niet door suïcide, ook aan de oorlogstoestand, toen hij, die al tijden met hartfalen kampte, collabeerde op de dag van de capitulatie. Op I5 mei overleed hij hieraan, aldus collega P.C. Flu. Zie: Gerard van Rijnberk, 'I940-Mei-I945, Aanvullingen en verbeteringen', Nederlands Tijdschrift voor Geneeskunde 89 (1945) 264-267, 265.

40 Dagboek Salomon Koster, NIOD 244, inv. nr. 996, 57 .

4I Kwitantie apotheek Surinamestraat, NIOD DOC II, inv.nr. I390.

42 Van de I63 kaartjes zijn er 86 met gas. Andere mogelijkheden: vergif, schotwond, verdrinking, ophanging, cyaankali, veronal, uit het raam gesprongen, morphine, atropine.

43 Emile Durkheim, Le suicide, étude de sociologie (I897).

44 Wout Ultee en Ruud Luijkx, 'De schaduw van een hand. Joods-gojse huwelijken en joodse zelfdodingen in Nederland 1936-1943' in: Henk Flap en Wil Arts(red.), De organisatie van de bezetting (Amsterdam 1997) 68.

45 Dangermond, 'Het heft in eigen handen', 43; Van Tubergen e.a., The Unwholesome Theme of Suicide', 345 .

46 Te weten: Eugen Marx, Ludwig Pincus,

Maurits Hertzberger, Maurits de Bruin en Leonard Polak Daniëls.

47 Nechama Tec, Resilience and Courage: Women, Men, and the Holocaust (Londen 2003) 347-48.

48 Dagboek Berthold Stokvis, NIOD, 244, inv. nr. II49, 44 .

49 Ultee en Luijkx, 'De schaduw van een hand', 55-76.

50 Frank van Tubergen en Wout Ultee, 'Political integration, war and suicide: the Dutch paradox?' in: International sociology 2I (2006) 223.

$5 \mathrm{I}$ Kater, Doctors under Hitler, 22I.

52 E.A.D.E. Carp, 'Voorbehoeding tegen zelfmoord', Nederlands Tijdschrift voor Geneeskunde. 85 (I94I) 52-56, 55 .

53 Speyer, 'Overzicht van den geschiedenis van den zelfmoord', I599-I605; Carp, 'Voorbehoeding 
tegen zelfmoord', 52-6.

54 A.M.Meerloo, 'Zelfmoord en arts', Geneeskundige Gids I8 (1940) 500. Deze Meerloo [zijn moeder was Joods, maar hij gold volgens de Neurenberger wetten als half-Joods ] had overigens in een eerder artikel over zelfmoord wel gesteld dat er verschillend over zelfmoord gedacht kon worden: A.M. Meerloo, 'De beoordeeling van zelfmoordneiging', Nederlands Tijdschrift voor Geneeskunde. 77 (1933) 3I-37.

55 Meerloo, 'Zelfmoord en de arts', 462.

56 Joods Historisch Museum, Spielberg-interview Ellis Hertzberger; Gesprek met Jenny HertzbergerGold d.d. 27-3-20II; Hertzberger, Door de Holocaust verbonden, 48 .

57 Presser, Ondergang, deel een, I4.

58 Sally de Jong, 'De Ondergang van het Nederlandsche Jodendom', NIOD I87, inv.nr. I.I3 5s, I.

59 De Jong, Koninkrijk, deel drie, 450-45I.

60 Ibidem.

6I Dagboek Berthold Stokvis, NIOD, 244, inv. nr. II49, 47. Vermoedelijk wordt dezelfde arts ook genoemd in De Jong, Koninkrijk, deel veertien, deel een, I08: reactie van Isaac Kisch in Studia Rosenthaliana.

62 Van Berkel, Academische illusies, I55.

63 Elie A. Cohen, De Afgrond. Amersfoort, Westerbork, Auschwitz (Amsterdam I97I) 6.

64 Joost A.M. Meerloo, Een mond vol spijkers (Wassenaar 1975) 84-85.

65 Gesprek met Jaap Klein d.d. 20-8-20I2; Zie ook de stukken van leider van het Medisch Front te Groningen L.M. ter Horst in Nationaal Archief KNMG 2.I9.053.OI, inv. nr. 279. G. Timmer en L.M. ter Horst.

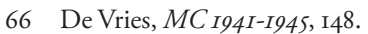

67 Herman C. van der Hoeven, Ziekenfondsen en de Duitse bezetting (Den Haag 1989) 85 .

68 Notulen bestuursvergaderingen, juni en juli 1940, archief Stichting Historie Ziekenfondsen, AZH, inv.nr. IOOII2OI3.

69 Brief van Joh. Verzendaal, hoofdagent Ned Ziekenfonds te Hilversum, 3-8-I940, Nationaal Archief 2.I9.053.0I, inv.nr. 62. Mr. R. van Genechten was een NsB-kopstuk.

70 Notulen bestuursvergadering, 24-7-I940, archief Stichting Historie Ziekenfondsen, AZH, inv. nr. IOOII2OI3.

7I Notulen dagelijks bestuur NMG, augustus 1940, Nationaal Archief 2.I9.053.0I, inv.nr. 34.

72 http://medischcontact-artsendatabankwoii. artsennet.nl/MC/DoC.jsp?scannr=MC-058_oor42 \&dockey=EL63KvVWDC\&bioid $=24707$ \&biokey $=$ JjcPphMENA 3-8-20I3.

73 Brief van Reuter aan Departement van Sociale Zaken afdeling Volksgezondheid, II-IO-I94O,

Nationaal Archief Geneeskundige Hoofdinspectie, 2.15.38, inv.nr. 35 .

74 Brief van Cees Banning, hoofdinspecteur, aan provinciale inspecteurs van de Volksgezondheid, 17-IO-I940, Nationaal Archief 2.15.38, inv.nr. 35 .

75 De Jong, Koninkrijk, deel vier, deel twee, 760.

76 Brief L.A. Veeger aan Banning I8-IO-I940,

Nationaal Archief 2.15.38, inv.nr. 35 .

77 Brief van C. Banning aan alle provinciale inspecteurs 2I-IO-I940, Nationaal Archief 2.I5.38, inv.nr. 35 .

78 Opgave van Joodse artsen in gemeentedienst van B\&W van Amsterdam 20-II-I940, Nationaal Archief 2.15.37, inv.nr. I219.

79 Correspondentie van inspecteurs voor de Volksgezondheid H. Hemmes, P. Muntendam, A. in 't Veld, V.v.d. Brekel en L.A.Veeger aan C. Banning, Hoofdinspecteur, oktober 1940, Nationaal Archief 2.15.38, inv.nr. 35

80 Opgave van Joodse artsen in gemeentedienst van B\&W van Amsterdam 20-II-I940, Nationaal Archief 2.15.37, inv.nr. I219.

8I Brief van A.H.J. Nord aan Hemmes 25-I-I94I, Nationaal Archief 2.15.38, inv.nr. 35.

82 De Jong, Koninkrijk, deel vier, deel twee, 875 .

83 Verordening 189, 22 oktober 1940, Verordnungsblatt.

84 De Jong, Koninkrijk, deel vier, deel twee, 780.

85 Israëls en Mooij, Aan de Achtergracht, I38-I39.

86 De Jong, Koninkrijk, deel vier, deel twee, 762.

87 Peter Romijn, 'Boosaardig bestuur', rede uitgesproken bij de aanvaarding van het ambt van gewoon hoogleraar met als leeropdracht Geschiedenis van de 20 ste eeuw, in het bijzonder betreffende het openbaar bestuur in tijden van oorlog en crisis aan de Universiteit van Amsterdam, 2I november 
2002, I6; De Jong, Koninkrijk, deel vier, deel twee, 866.

88 De Jong, Koninkrijk, deel vier, deel twee, 78I.

89 Dagboek J.A. Eckert-Stroink, NIOD 244, inv. nr. II92.

90 Brief van de voorzitter van de gemeentelijke raad van beroep aan college van burgemeester en wethouders Utrecht 30-I2-I940, Yad Vashem, M68, Stukken uit het Gemeente-archief Utrecht, inv. nr. I75.9.

9I Gesprekken met Willy Hijmans, d.d. I7-620IO, 2I-8-20IO; Jolanda Hendriksen en Willy Hijmans, 'De rassencolleges van Barge. Een leemte in de geschiedenis van de Leidse universiteit', in: Overdruk Leids Jaarboekje I995.

92 Hendriksen en Hijmans, 'De Rassencolleges van Barge'.

93 De Jong, Koninkrijk, deel vier, deel twee, 80o8oI; Peter Jan Knegtmans, Een kwetsbaar centrum van de geest. De Universiteit van Amsterdam tussen I935 en I950 (Amsterdam 1998) I02. Reeds een maand eerder hadden 229 hoogleraren een manifest ondertekend namens de Nederlandse wetenschap, waarin zij bij Seyß-Inquart blijk hadden gegeven van hun afkeuring van het eerder uitgevaardigde verbod op benoeming of promotie van Joodse ambtenaren. Deze hoogleraren, onder aanvoering van de Amsterdamse jurist Paul Scholten, ageerden tegen het opgelegde onderscheid tussen Joodse en niet-Joodse wetenschappers. Voor de hoogleraren was het van geen belang of de beoefenaren der wetenschappen Joods of niet-Joods waren, zo hielden zij Seyß-Inquart voor. De 229 ondertekenaars van deze verklaring vertegenwoordigden ongeveer de helft van het totale hooglerarencorps. Men kon echter aan de ontheffing van de Joodse ambtenaren slechts enkele weken later meteen zien dat de bezetter zich allerminst iets aantrok van dergelijk protest. 94 In Leiden werd medicus Abraham Gans uit zijn functie ontheven: P.J. Idenburg, De Leidse universiteit 1928-1946. Vernieuwing en verzet (Leiden 1978) I83 en 362.

95 Presser, Ondergang, deel een, 44; Knegtmans, Een kwetsbaar centrum van de geest, I06.

96 Dagboek Berthold Stokvis, NIOD, 244, inv. nr. II $49,57$.
Kouwenhoven, 'Voetlicht. Professor Groen', 90.

98 B.P. Tammeling, Honderd vijfenzeventig jaar

AZG (Groningen I978) 274. Gesprek met Jaap Klein d.d. 20-8-20I2.

99 Strekkend tot heil der lijdende menschheid. 75 jaar ziekenhuis Heerenveen (Drachten I988) 27.

Ioo Brief van Muntendam aan Banning 30-IO-

1940, Nationaal Archief 2.I5.38, inv.nr. 35; gesprek met Bettine Polak, d.d. Io-Io-20II.

IOI Querido, Doorgaand verkeer, I80.

IO2 Dagboek Berthold Stokvis, NIOD 244, inv.

nr. II49, 59.

IO3 De Jong, Koninkrijk, deel vier, deel twee, 868-869.

IO4 Ibidem.

IO5 Sander van Walsum, Ook al voelt men zich gewond (Utrecht 1995) 29.

Io6 Presser, Ondergang, deel een, 49.

IO7 Piet Schrijvers, Rome, Athene, Jeruzalem. Leven en werk van prof.dr. David Cohen (Groningen 2000) I2O. Aan de Amsterdamse universiteit bedroeg het jaarsalaris voor een hoogleraar zo'n $f$ 7500,-; aan andere universiteiten lag het bedrag wat hoger, rond de $f$ 9000,--

Io8 Opgave van uitgekeerde bedragen in de oorlogjaren aan het Joodse personeel van de GGD Amsterdam I2-6-1947, Stadsarchief Amsterdam 30I40, inv.nr. 2936. Collega Elazar Aäron Rodrigues Pereira bleef in de jaren I94I, I942, I943 en I944 hetzelfde salaris ontvangen, namelijk $f 3324,96$. Hij was een uitzonderlijk geval, want na zijn ontslag opnieuw aangesteld, via de Joodsche Raad. Dit omdat zijn opvolger niet bleek te functioneren. Daarnaast had ook hij een eigen (particuliere) praktijk, waaruit hij een inkomen genereerde van vermoedelijk maandelijks zo'n $f$ 30,-.

I09 Notulen voorzitter de heer de Graaff 29-II94I, Stadsarchief Amsterdam, Algemeen Ziekenfonds Amsterdam Ioor, inv. nr. 190.

IIO Van Berkel, Academische illusies, 289.

III Notulen Ooglijders Gasthuis. Privécollectie familie Fischer.

II2 Gesprek en correspondentie met M.M.

Wagenaar-Fischer, I5-II-20II. Fischer was ook nog enigszins actief voor het gasthuis. Hij begeleidde 
assistenten en promovendi en beantwoordde vakinhoudelijke vragen.

II3 Freud, Mijn naam is Freud, 23; dagboek Janos Freud, I80: 23-9-45, privécollectie familie Freud, Amsterdam. Het ging om S.E. de Jongh, J.C. Pompe, W. Schraffordt Koops en G.F. Gaarenstroom.

II4 'Ik ben niet onderscheiden omdat ik de oorlog heb overleefd.' De Tijd, I3 jan I984: I6-I8. Interview met Elsa Rodrigues Pereira-Jessurun d'Oliveira, naar aanleiding van haar pensionering en Koninklijke onderscheiding.

IIs Thera Wijsenbeek, Zieke lieverdjes. I2s jaar kinderzorg in het Emma Kinderziekenhuis (Amsterdam 1990) II6.

II6 Notulen vergadering dagelijks bestuur AvL I4-2-I940, Archief Antoni van Leeuwenhoekziekenhuis Amsterdam.

II7 Testimony Betty Levie, janı975, Yad Vashem Archives 0.3, file number 3968.

II8 De Jong, Koninkrijk, deel vier, deel twee, 874 .

II9 Presser, Ondergang deeleen, 62.

I2O De Jong, Koninkrijk, deel vier, deel twee, 94I.

I2I Pim Griffioen en Ron Zeller in: Romijn e.a., Comparing the Persecution of the Jews in the Netherlands, France and Belgium, 1940-1945: Similarities,

Differences, Causes (Amsterdam 20II) 78.

I22 Notitie van Verwey 27-2-I94I, Nationaal Archief 2.15.37, inv.nr. II6.

I23 Brief van het hoofdbestuur van het Rode Kruis aan Verwey 27-2-194I, Nationaal Archief 2.15.37, inv.nr. II6.

I24 Meihuizen, Smalle marges, I68.

I25 Ibidem, I70-I7I.

I26 Briefwisseling tussen Lankhout en Verwey 8 tot IO-2-I94I, Nationaal Archief 2.I5.37, inv.nr. I219.

I27 Brief van J. de Hartogh, huisarts Plantage Middenlaan 84 aan Verwey IO-2-I94I, Nationaal Archief 2.15.37, inv.nr. I219.

I28 Reactie van het Departement op brieven van Levy's advocaat 9-2-I94I, Nationaal Archief 2.I5.37, inv.nr. I219.

I29 Brief van Rijkscommissaris aan secretarisgeneraal van het departement van Sociale Zaken over de zaak Batavier 3-5-I94I, Nationaal Archief 2.15.37, inv.nr. I219.
I30 Correspondentie van Th. Heimans en N.T. Carsten aan Verwey IO-2 tot 27-2-I94I, Nationaal Archief 2.15.19, inv.nr. I219.

I3I Correspondentie Verwey-Banning 26-3-I94I, I6-4-I94I, Nationaal Archief 2.I5.37, inv.nr. I219. Zie ook: notulen vergadering inspecteurs van de volksgezondheid I6-4-I94I, Nationaal Archief 2.15.38, inv.nr. 5 .

I32 Brief aan Verwey 28-4-I94I, Nationaal Archief 2.15.37, inv.nr.I219.

I33 Brief namens de bevolking van Boskoop aan Verwey, februari 194I, Nationaal Archief 2.I5.37, inv.nr. I2I9

I34 Het ging hier om dokter Jules Drukker (1903-1982), huisarts te Amsterdam. Ook voor dr. I. Goslinski in Leeuwarden is een dergelijk verzoek van een zwangere patiënte bewaard gebleven. Brief aan Verwey van D. de Leijer uit de Jasonstraat te Amsterdam, I3-2-I94I, Nationaal Archief 2.I5.37, inv.nr. I2I9.

I35 Correspondentie Verwey- Zwaap I7-3-I94I, Nationaal Archief 2.15.37, inv.nr. I219. Zie voor Zwaap ook; Werkgroep Hilversums Verzet 19401945, Hilversum in onderdrukking en verzet 1940I945 (Hilversum 1985) 72.

I36 De Jong, Koninkrijk, deel vier, deel twee, 874 .

I37 Mart J. van Lieburg, Bronovo, I865-199o

(Kampen 1990) Ior: 'Zonder veel ophef vertrok op I april I94I de 'arts des huizes' dr. H.M. Hijmans, na ruim dertig jaar in Bronovo praktijk te hebben gevoerd. Officieel werd zijn pensionering als reden van vertrek opgegeven, waarmee gemaskeerd werd dat hij anders om zijn joodse afkomst had moeten aftreden.'

I38 Notitie van Verwey 27-2-194I, Nationaal Archief 2.15.37, inv.nr. I219.

I39 Correspondentie Verwey met M. Polano Io tot 27-2-I94I, Nationaal Archief 2.I.5.37, inv.nr. I2I9.

I4O Correspondentie Verwey-Volharding 26-2194I, Nationaal Archief 2.15.37, inv.nr. I219.

I4I Brief van J.A. Putto aan In 't Veld, die deze vraag doorstuurde naar Verwey 23-6-I94I, Nationaal Archief 2.15.37, inv.nr. I219.

I42 Correspondentie Banning-Verwey-Premsela I5-2-I94I tot 25-2-I94I, Nationaal Archief 2.I5.38, 
inv.nr. 35 .

I43 Brief Verwey-van Emde Boas 19-5-I94I, Nationaal Archief 2.15.37, inv.nr. I219.

I44 Gesprek met Lea Dasberg, d.d. I4-2-20II.

I45 Jan van Eijck, Barend Haeseker e.a. (red.),

Canon van de huisartsgeneeskunde (Haarlem 2013) Ioo.

I46 Brief van A.S. de Wit aan geneeskundig inspecteur van Noord-Brabant I3-2-I94I, Nationaal Archief 2.15.38, inv.nr. 35 .

I47 Houwink ten Cate, 'Het jongere deel', I3.

I48 Gesprek met schoondochter Martha ben

Assa/van Esso-Polak, d.d. I3-2-20II.

I49 Mr. A.F. Gaarlandt-Kist (red.), 40o jaar St.

Elisabeth's of Groote Gasthuis te Haarlem (Haarlem I98I) 47.

I50 Testimony Betty Levie, janı975, Yad Vashem Archives 0.3, file number 3968.

I5I Rob Teeuwen, Het ziekenfondsbestel in historisch perspectief. Onderscheidene kenmerken van Nederlandse ziekenfondsen (Zeist 1998) 26.

I52 Zie bijv. Stadsarchief Amsterdam, IOOI, AZA, en: Stichting Historie Ziekenfondswezen AZH IOOII2OI3, notulen bestuursvergadering I2-3-I94I: hier waren de Joodse artsen S. Zwaap en Amalia Frank gecontracteerd.

I53 Privécollectie dhr. H.F.B. Keijzer te Oudewater.

I54 O. Cahen, 'In Neerland rouwt Israël', DIEP Dordrechts Archief 489, inv.nr. 20430. Waarschijnlijk door deze protestactie werd Cahen niet veel later gearresteerd: Verklaring Henricus Maria Evers, no I08, CABR, BG Den Bosch 2338, inv.nr. 748.

I55 Nationaal Archief 2.I5.37, inv.nr. I219.

I56 Correspondentie Banning, Nationaal Archief 2.I.5.38, inv.nr. 35 .

I57 Dagboek Berthold Stokvis, NIOD, 244, inv. nr. II49: n.a.v. I mei-verordening.

I58 Robert Cohen, emailcorrespondentie d.d. feb. 20Ir: 'Ik herinner mij heel goed dat in eind april I94I ons huis vol was met boeketten en taarten.'; Joods Historisch Museum, Spielberg-interview Marjon Koolhoven-Kalker.

I59 H. Blok, K.A. Deurloo ea (red.), Om voor te lezen-miqra. Feestbundel voor Frits Hoogewoud. (Maastricht 2005) I.
I6o Jenny Hertzberger-Gold, De familie Hertzberger in Nederland, een familiekroniek (Baarn 1996)

77.

I6I Dagboek Salomon Koster, NIOD 244, inv. nr. 996, 169 .

I62 NIOD-dagboeken 244, II49, Berthold Stokvis, mei I94I.

I63 Zoals David Nordheim, volgens zijn zoon Moshe: Moshe Nordheim, From Rebuke to Rejoicing (Victoria 2004) I7I; Gesprek met Moshe Nordheim, d.d. 24-II-20Io.

I64 Hetty Fortuin-Blitz uit Den Haag volgde een cursus fysiotherapie (toen heilgymnastiek en massage), maar mocht hierin uiteindelijk geen examen meer doen. Ies van der Hal uit Groningen volgde de opticiensopleiding.

I65 Zie voor beide: correspondentie Verwey,

Nationaal Archief 2.15.37, inv.nr. I219.

I66 Brief burgemeester van Hellendoorn aan Verwey 7-4-I94I, Nationaal Archief 2.15.37, inv.nr. I219. Gevolg van de eerlijkheid van de burgemeester om een en ander te melden was overigens wel dat de subsidie aan het sanatorium werd ingetrokken.

I67 Notulen vergadering hoofdbestuur NMG 8-6194I, Nationaal Archief 2.19.053.0I, inv.nr. 30.

I68 Betalingen aan doktoren, archief Stichting Historie Ziekenfondswezen, I00225304, inv.nrs. 05, 06, 07 .

I69 Betalingen aan doktoren, archief Stichting Historie Ziekenfondswezen, I00225304, inv.nrs. 05, 06, 07.

I70 Notulen vergadering hoofdbestuur NMG 274-I94I, Nationaal Archief 2.19.053.0I, inv.nr. 30. I7I Ten Bokkel Huinink e.a., Medische ethiek, 73; L.S. Wildervanck, Het overnemen van een practijk', Nederlands Tijdschrift voor Geneeskunde 8I (1937) 4870-4874. zogenaamde 'goodwill'.

I72 Gesprekken met Carel Wolff, d.d. 30-IO-

2008, 25-4-2009, 2-II-2009.

I73 Brief van Banning aan alle inspecteurs 30-IO1940, Nationaal Archief 2.15.38, inv.nr. 274.

I74 Cohen, De afgrond, I5.

I75 Ibidem.

I76 Nordheim, From Rebuke to Rejoicing, 165; G.J. Veerman, Wijhe voor en tijdens de Tweede Wereldoorlog (Wijhe, 1992) 86: Dr. Leo Lezer gaf 
zijn praktijk over aan dr. D. Hoogendoorn, die terugkeer van Lezer nastreefde. Zie ook: Joods Historisch Museum, Spielberg-interview Marjon Koolhoven-Kalker.

I77 Gesprek met Bettine Polak, d.d. IO-IO-20II. I78 Dagboek Berthold Stokvis, NIOD, 244, inv. nr. II49, 50: n.a.v. I mei 194I.

I79 Ruben Bollegraaf, De Joden te Oss tijdens de bezetting door Duitsland (Amsterdam I993) Io.

I80 Notulen vergadering hoofdbestuur 27-4-I94I, Nationaal Archief 2.19.053.01, inv.nr. 30.

I8I 'Mededeelingen', I2-4-I94I Nederlands Tijdschrift voor Geneeskunde 85 (I94I) I5.

I82 Herman Pinkhof, 'Rechterlijk oordeel aangaande het overnemen van practijk', Nederlands Tijdschrift voor Geneeskunde 85 (I94I) 2853.

I83 L. Onderdijk, Ioo Jaar Algemeen Middelburgsch Ziekenfonds (Middelburg 1948) II4; Brief A.C.H. de Nooijer aan de Ned. Ver. Voor Ziekenfondsartsen, 26-II-I942, http://medischcontactartsendatabankwoii.artsennet.nl/MC/profiel.jsp?bi oid=30225\&biokey=Ejg8z7iweX I6-4-20I4.

I84 Overnamecontract van voormalige praktijk van W. de Torres, 30-II-I942, http://medischcontact-artsendatabankwoii.artsennet.nl/MC/DoC. jsp?scannr=MC-074_oor77\&dockey=GQW 5xHTl If \&bioid=2IO40\&biokey $=\mathrm{Ax} 5 \mathrm{OVnK} 4 \mathrm{~m} 2$ I6-4-20I4. I85 Wildervanck, 'Het overnemen van een practijk', 4870-74.

I86 Schrijven van de medische commissie, jan I942, NIOD I82, inv.nr. I2C.

I87 Cohen, De afgrond, I6.

I88 G. Groenhuis, Emmen in bezettingstijd

(Emmen 1990) I40.

I89 Dagboek Berthold Stokvis, NIOD, 244, inv. nr. II49: n.a.v. I mei I94I.

I90 Brief van M.R. Hertzberger Mozartkade 9, aan Verwey 2I-4-I94I, Nationaal Archief 2.I5.37, inv.nr. I219.

I9I Dagboek Berthold Stokvis, NIOD, 244, inv. nr. II49: n.a.v. I mei I94I.

I92 Testimony Betty Levie, janı975, Yad Vashem Archives 0.3, file number 3968.

I93 Brief van M.B. Bloch aan Banning 28-5-I94I, Nationaal Archief 2.15.38, inv.nr. 35 .

I94 Gesprek en correspondentie met M.M.
Wagenaar-Fischer, d.d. I5-II-20II.

I95 Dagboek Salomon Koster, NIOD 244, inv. nr. 996, I69.

I96 Brief van J. Ailjon aan Verwey I3-2-I94I,

Nationaal Archief 2.15.37, inv.nr. I219.

I97 Meihuizen, Smalle Marges, I85-186.

198 De Jong, Koninkrijk, deel vier, deel twee, 756.

I99 Bijvoorbeeld met Salomon Spijer en Jacob

Goudsmit, zie correspondentie in Nationaal

Archief 2.15.38, inv.nr. 35 .

200 Brief van Banning aan F.A. Schalij, voorzitter van de NMG I9-2-I94I, Nationaal Archief 2.I5.38, inv.nr. 35 .

201 Brief van F.A. Schalij aan Banning I7-2-I94I,

Nationaal Archief 2.15.38, inv.nr. 35 .

202 Brief van de Amsterdamse Geneeskundigen Kring aan het Hoofdbestuur der NMG 15-3-194I, Stadsarchief Amsterdam 687, NMG afdeling Amsterdam, inv. nr. 20.

203 Notulen vergadering hoofdbestuur NMG 2-2194I, Nationaal Archief 2.I9.053.0I, inv.nr. 30.

204 Cohen, De afgrond, I5.

205 Notulen vergadering dagelijks bestuur NMG I-4-I94I, Nationaal Archief 2.19.053.0I, inv.nr. 30. 206 Een maatregel die per 6 april I94I inging. 207 Notulen vergadering dagelijks bestuur NMG I-4-I94I, Nationaal Archief 2.I9.053.OI, inv.nr. 30. 208 Geheime notulen van de bespreking tijdens de vergadering van het dagelijks bestuur NMG 3O-II1940, Nationaal Archief 2.19.053.0I, inv. nr. 30.

209 Notulen vergadering hoofdbestuur NMG I59-I940, Nationaal Archief 2.19.053.0I, inv.nr. 30. 2IO Notulen vergadering dagelijks bestuur NMG 29-6-I94I, Nationaal Archief 2.19.053.0I, inv.nr. 34. 2II De Vries, MC 194I-I945, II.

2I2 Correspondentie NMG juni I94I, Nationaal Archief 2.19.053.0I, inv.nr. 255. Geschreven door Dr. Pannekoek, zie ook: De Vries, MC I94I-I945, I5-I6.

2I3 Stenografisch verslag van de vergadering NMG 20-IO-I940, Nationaal Archief 2.19.053.OI, inv.nr. IO.

$2 \mathrm{I} 4$ De Jong, Koninkrijk, deel vijf, deel een, 433. 2I5 Ie estafettebericht, website Medisch Contact, http://medischcontact.artsennet.nl/kennis-I/dossiers/geschiedenis/tweede-wereldoorlog/archieven- 
en-documenten/estafetteberichten.htm I6-4-20I4. 216 Beschouwing 4 maart 1942, website Medisch Contact, http://medischcontact.artsennet.nl/kennis-I/dossiers/geschiedenis/tweede-wereldoorlog/ archieven-en-documenten/estafetteberichten.htm I6-4-20I4.

2I7 Eerste landelijke conferentie, I4 of 24 sept I94I, website Medisch Contact, http://medischcontact.artsennet.nl/kennis-I/dossiers/geschiedenis/ tweede-wereldoorlog/archieven-en-documenten/ estafetteberichten.htm I6-4-20I4.
2I8 Gesprek Bettine Polak d.d. IO-IO-20II, en gesprek met Ralph van Furth, d.d. 27-I-20II. 2I9 Zoals in ieder geval de Amsterdammers Louise Kaiser en Carl Izaak de Vries Robles: brief Dr. E. Devivere, KNO-arts aan Medisch Contact 20-I-I947, Nationaal Archief MC 2.19.053.02, inv.nr. 47. 220 Cohen, De afgrond, 15. 22I Brief van dr. J. van Woerden aan Medisch Contact 2-2-1947, Nationaal Archief 2.19.053.02, inv.nr. 47.

\section{GOEDGEKEURD?}

I II49: n.a.v. I mei I94I.

2 Presser, Ondergang, deel een, 203.

3 Ibidem, 391, 452.

4 De Jong, Koninkrijk, deel vijf, deel twee, IO44.

5 Presser, Ondergang, deeleen, 8I.

6 Herzberg, Kroniek, Io6.

7 Notulen gemeentebestuur nav brief van

Tuntler, directeur GGD 9-2-I94I, NIOD DOC II, inv. nr. $36 \mathrm{I}$.

8 De Jong, Koninkrijk, deel vier, deel twee, 885 . 9 Ibidem, 886.

IO Presser, Ondergang, deel een, 88.

II Gesprek met Rosetta Musaph-Andriesse, d.d. 23-IO-2008.

I2 Moore, Victims and Survivors, 69.

I3 Presser, Ondergang, deel een, 513-517. Enkele publicaties die bijdroegen aan de discussie verschenen in de jaren I980 en I990: Hans Knoop, De Joodsche Raad: het drama van Abraham Asscher en David Cohen (Amsterdam 1983); Nanda van der Zee, Om erger te voorkomen (Amsterdam I997).

I4 Presser, Ondergang, deeleen, $5 \mathrm{I} 3$.

I5 Coppenhagen, Anafiem Gedoe'iem, resp. 78 en I39-I4O; www.joodsmonument.nl, I6-4-20I4.

I6 De Wind, Eindstation Auschwitz, achterflap; Herzberg, Kroniek, I25.

I7 Marjolein Schenkel, De Twentse paradox. De lotgevallen van de joodse bevolking van Hengelo en Enschede tijdens de Tweede Wereldoorlog (Zutphen 2003) 65; De Jong, Koninkrijk, deel vijf, deel een,
558.

I8 Zie ook: Koos Groen, Als slachtoffers daders worden. De zaak van de joodse verraadster Ans van Dijk (Amsterdam 1994) 85.

I9 H.E. Dominicus, Mauthausen. Een gedenkboek (Amsterdam 1999) II8; De Jong, Koninkrijk, deel acht, deel twee, 6or.

20 Dominicus, Mauthausen, I48; Aantekeningen van Magda van Emde Boas-Starkenstein, privécollectie familie van Emde Boas.

2I Joodsche Raad cartotheek, Rode Kruis Den Haag.

22 Joodsche Raad cartotheek, Rode Kruis Den Haag.

23 Brief van Salomon Zwaap aan Verwey, wnd hoofd dep. 17-3-194I, Nationaal Archief 2.15.37, inv. nr. I219.

24 Lijst van 40 medici die als gijzelaar in het Groot Seminarium Haaren zitten, augustus 1942, Nationaal Archief Geneeskundige Hoofdinspectie 2.15.38, 40; Brief van Mevrouw Mendes de Leon aan Banning 26-8-1942, Nationaal Archief Geneeskundige Hoofdinspectie 2.15.38, 40.

25 Rik Valkenburg 'Gedreigd door het vuur', I26: getuigenis van Betty de Haas-Boekbinder, Lohamei Hagettaot, Holland Section, inv.nr. 2I48.

26 Dominicus, Mauthausen, op 29 juni 1942 stierf hij.

27 Joods Historisch Museum, Spielberginterview Martha Edersheim-de Vries; Dominicus, Mauthausen, 96. 
28 Gesprekken met Frits Glaser, d.d. 24-2-2009 en I3-5-20IO.

29 Dominicus, Mauthausen; Coppenhagen, Anafiem Gedoe’iem, 9I.

30 De Bree, Zeeland 1940-1945, 297.

3I Brief van dr. F. Wibaut aan burgemeester van Amsterdam I5-6-I94I, Nationaal Archief 2.19.053.02, inv.nr. 22; Ongedateerd verslag door Louis Schaap over belevenissen, vermoedelijk geschreven aan broer Adolf Schaap, privécollectie familie Schaap.

32 Dagboek Jacques Reisel, 8-2-I943, privécollectie familie Reisel, Amsterdam.

33 Van Lieburg, 'Joodse medici in Nederland', 4I.

34 Joodsche Raad Cartotheek, Rode Kruis Den Haag.

35 Dossier S. Prins, Nationaal Archief ministerie van Justitie te Londen, I2162.

36 Dossier van mej. S. Joles Nationaal Archief ministerie van Justitie te Londen, I0383.

37 Notulen 25-6-194I Algemeen Ziekenfonds Amsterdam Stadsarchief Amsterdam AZA IOoI, inv. nr. I90.

38 Artikel in Grand Rapids Press over een lezing van Ben Sajet in Amerika op I4-8-1942, dossier Ben Sajet, ongenummerd, IIsG Amsterdam; Jan Bruin en Jan van der Werff, Vrijheid achter de horizon (Houten I998) 49.

39 Londen, 6 november I94I, verklaring van overhandiging Bronzen Kruis aan Benedictus Herschel Sajet, dossier Ben Sajet, ongenummerd, IISG Amsterdam.

40 Manuscript van Ben Sajet, getiteld 'Am I a hero?', dossier Ben Sajet, ongenummerd, IISG Amsterdam.

4I Dossier van Sam Ritmeester Nationaal Archief Ministerie van Justitie te Londen, I2I76.

42 Hanny S.R. Meijler, Ik zou wéér zo gek zijn.

Mannen van de Irenebrigade (Amsterdam 1992) 246.

43 Nationaal Archief Justitie te Londen, I2I76, verslag verhoor Sam Ritmeester, 8-2-I944.

44 Jan A.M. van Eijck, 'Freddie de Wit, huisarts in Tilburg 1936-I94I. Een jonge huisarts, een vergeten slachtoffer van de Holocaust', Tilburg. Tijdschrift voor geschiedenis, monumenten en cultuur 3I (2013) 3, 72-77.
45 Brief van A.S. de Wit aan gen. inspecteur voor Noord-Brabant, doorgestuurd aan C. Banning I3-2194I, Nationaal Archief geneeskundige hoofdinspectie 1902-I952 2.15.38, inv.nr. 35 .

46 Vijf Brieven van Alfred Samuel (Freddie) de Wit uit Kamp Amersfoort, februari tot juli 1942 (collectie Joost Niepoth, Amsterdam); Joods Historisch Museum, Spielberg-interview Mary de Wit; Ad de Beer en Gerrit Kobes, Het leven gebroken. De geschiedenis van de Tilburgers die als gevolg van de strijd tegen Duitsland en de bezetting om het leven kwamen (Tilburg 2002) 37.

47 Joods Historisch Museum, Spielberg-interview Anne Bodenheimer; Bruin en van der Werff, Vrijheid achter de horizon, IOI-IO2; http://www. engelandvaarderskatwijk.nl/poging-9 I6-4-20I4. 48 Bruin en van der Werff, Vrijheid achter de horizon, IO3.

49 Gesprekken met Frits Glaser, d.d. 24-2-2009 en I3-5-20IO.

50 Bruin en van der Werff, Vrijheid achter de horizon, 75-76.

5I Het Joodsche Weekblad, Ie jaargang no. 26, 27-6-I94I.

52 Van Lieburg, 'Joodse medici in Nederland', 49.

53 Oktober 194I, brief van Onderwijscommissie van de medische subcommissie van de Coördinatiecommissie, bestaande uit S. Van Creveld, J. Groen, S. Kroonenberg, E. Laqueur en E. Godfried. privécollectie familie Schaap, Amsterdam.

54 Het Joodsche Weekblad, re jaargang no. 30, 3I-IO-I94I.

55 Het Joodsche Weekblad, Ie jaargang no. 37, I9-I2-I94I.

56 I8-I2-I94I, NIOD I82, inv.nr. 8d.

57 29-I-I942, NIOD I82, inv.nr. IC.

58 Commissie voor geldelijk beheer Joodsche Raad, salarissen afdeling medische zaken I7-II-I942, NIOD I82 inv.nr. 4c; Gesprek met Dik Jacobs, d.d. i6-ii-20io.

59 Brief van burgemeester Voûte aan voorzitter Joodsche Raad voor Amsterdam 2-7-I942, NIOD archief 182 , inv.nr. $7 \mathrm{C}$

60 Brief van Burgemeester Voûte aan Beauftragte Böhmcker I7-II-I94I, NIOD DOC II, inv.nr. 36I.

6I Van Lieburg, 'Joodse medici', 49. 
62 Notulen vergadering Joodsche Raad 25-2-1942, NIOD archief I82, inv.nr. Ic.

63 Presser, Ondergang, deel een, 486. Nieuw personeel werd bijvoorbeeld door de instellingen zelf gerecruteerd, zoals blijkt uit verschillende advertenties in het Joodsche Weekblad, waarin advertenties voor (para)medisch personeel verschenen; Het Joodsche Weekblad, Ie jaargang, no. 52, I-4-1942.

64 Jacques Reisel, dagboek, 8-2-I943, privébezit familie Reisel.

65 Sieg Gitter, Herzliyah, brief aan auteur 3-I2009.

66 Gesprekken met Frits Glaser, d.d. 24-2-2009 en I3-5-20IO; gesprekken met Hans Keilson, d.d. 2O-II-2008 en I5-I-2009.

67 Emailwisseling met Bart de Cort, onderzoeker Canada, 28-2-20I3. Op basis van informatie van dochter Leisen.

68 Brief van dr. H. Böhmcker aan voorzitters Joodsche Raad I6-7-I94I, NIOD I82, inv.nr. 6c.

69 Presser, Ondergang, deel een, I80.

70 De Jong, Koninkrijk, deel vijf, deel twee, I053; Niek van der Oord, Jodenkampen (Kampen 2003) passim.

7I Notulen vergadering Joodsche Raad 27-III94I, NIOD I82, inv.nr. IC.

72 Presser, Ondergang, deel een, I84.

73 Het Joodsche Weekblad, re jaargang, no. 40, 9-I-I942.

74 3-I-I948, NIOD I8Ij, inv.nr. Id.

75 De Jong, 'De Ondergang van het Nederlandsche Jodendom', 6-7.

76 De Jong, Koninkrijk, deel vijf, deel twee, I054.

77 Knoop, De Joodsche Raad, I63; Nordheim,

From Rebuke to Rejoicing, I79. De vierde arts zou mogelijk Benjamin Juda Gomperts geweest kunnen zijn: Joods Historisch Museum, Spielberg-interview Alice Gomperts.

78 Erik Somers, Voorzitter van de Joodse Raad. De herinneringen van David Cohen I94I-I943 (Zutphen 2010) I22.

79 Presser, Ondergang, deel een, I88.

80 Somers, Voorzitter van de Joodse Raad, I22.

8 I Ibidem.

82 Ibidem.

83 Emailwisseling met Mirjam Bolle-Levie, september 2009.

84 Nordheim, From Rebuke to Rejoicing, I80;

Gesprek met Moshe Nordheim, d.d. 24-II-20Io.

85 www.joodsewerkkampen.nl I6-4-20I4.

86 De Jong, 'De Ondergang van het Nederland-

sche Jodendom', 6-7.

87 Ibidem.

88 Presser, Ondergang, deel een, I85 en I89.

89 De Jong, 'De Ondergang van het Nederlandsche Jodendom', 6-7.

90 Ibidem.

9I Gesprek met Ilse de Haas-Vyth, d.d. I9-I-2009 en gesprek met Maurits Frenkel, d.d. 22-2-2009; Joods Historisch Museum, Spielberg-interview, Govert de Haas.

92 Brief van S. Spijer, medisch adviseur Joodsche Raad, aan L. Schaap 27-I-I942, privécollectie familie Schaap.

93 Ongedateerde brief van Louis Schaap, vermoedelijk vlak na de bevrijding geschreven aan zijn broer Adolph Schaap in Amerika, privécollectie familie Schaap.

94 Zeventiende nota van Meyer de Vries aan onderscheidene personen betreffende werkverruiming 29-I-I942, NIOD I82, inv.nr. 8c.

95 Zeventiende nota van Meyer de Vries aan onderscheidene personen betreffende werkverruiming 3-3-I942, NIOD I82, inv.nr. 8c.

96 Notulen van de 39ste vergadering van de Centrale Commissie 23-3-I942, NIOD I82, inv.nr. 9b.

97 I4-4-I942, NIOD I82, inv.nr. I2l.

98 Ben Sijes, De arbeidsinzet. De gedwongen arbeid van nederlanders in Duitsland 1940-1945 (Den Haag 1966) II5. Niet-NSB'ers die voor de oorlog dit soort keuringen hadden uitgevoerd hadden grotendeels bedankt.

99 Sijes, De arbeidsinzet, II3.

IOO Ibidem.

IOI Ten Bokkel Huinink e.a., Medische ethiek, 6I.

IO2 De Jong, 'De Ondergang van het Nederlandsche Jodendom', 6-7.

IO3 Dagboek Berthold Stokvis, NIOD, 244, inv.

nr. II49, IOI.

I04 Presser, Ondergang, deel een, I99.

IO5 Dagboek Berthold Stokvis, NIOD, 244, inv.

nr. II49, IOI. 
Io6 Dagboek Salomon Koster, NIOD, 244, inv. nr. 996, I6I.

IO7 Ook in de gesprekken met respectievelijk Ilse de Haas-Vyth, d.d. I9-I-2009, en Maurits Frenkel, d.d. 22-2-2009, kwam deze truc ter sprake.

I08 Gesprek met Julius en Carel Roos, d.d. I3II-2008.

I09 Dagboek J. Zwaaf, NIOD 244, inv.nr. I624, 5. IIO Max Cahen, Ik heb dit alles opgeschreven... ('sHertogenbosch 2010) 35 .

III Dagboek Berthold Stokvis, NIOD, 244, inv. nr. II49, IOI.

II2 Dagboek Salomon Koster, NIOD 244, inv. nr. 996, I4I.

II3 Ongedateerde brief van Louis Schaap, vermoedelijk vlak na de bevrijding geschreven aan zijn broer Adolph Schaap in Amerika, privécollectie familie Schaap.

II4 De Jong, 'De Ondergang van het Nederlandsche Jodendom', 6-7.

IIs Zoals ook blijkt uit de naoorlogse beoordeling in het zuiveringsproces van de Nederlandse artsen, waarin ook de keuringspraktijken, zoals ook later uitgevoerd voor de Arbeitseinsatz, ter sprake kwamen: In 't Veld, De zuivering van artsen en advocaten, 27: Keuringen voor tewerkstelling in Duitsland werden door de 'goede' artsen betamelijk geacht - en ook vaak door henzelf verricht- op voorwaarde dat een onevenredig hoog percentage van de onderzochte werkkrachten werd afgekeurd. Er is een geval bekend van een Joodse keuringsarts die ofwel teveel mensen goedkeurde ofwel te veel geld vroeg voor de keuringen, en zich hiervoor na de bevrijding voor de Joodse Ereraad moest verantwoorden: NIW 78 (I945) I.

II6 De Jong, 'De Ondergang van het Nederlandsche Jodendom', 6-7.

II7 Ibidem.

II8 Ongedateerde brief van Louis Schaap, vermoedelijk vlak na de bevrijding geschreven aan zijn broer Adolph Schaap in Amerika, privécollectie familie Schaap.

II9 De Jong, 'De Ondergang van het Nederlandsche Jodendom', 6-7.

I2O Gesprek met Max en Hannah Koster-

Souget, d.d. I-2-2009; Joods Historisch Museum,
Spielberg-interview Max Koster.

I2I Groenhuis, Emmen in bezettingstijd, I46.

I22 Presser, Ondergang, deel een, 196; Herman van Rens, Vervolgd in Limburg. Joden en Sinti in Nederlands-Limburg tijdens de Tweede Wereldoorlog (Hilversum 2013) 372.

I23 Bollegraaf, De Joden te Oss, I9.

I24 Ibidem.

I25 Ibidem.

I26 Ibidem.

I27 Ibidem, 20.

I28 Ibidem, 20.

I29 Notulen van de 42 ste vergadering van de Centrale Commissie van de Joodsche Raad 22-4I942, NIOD I82, inv.nr. 9b.

I3O 23-4-I942, NIOD I8Ij, inv.nr. Ik.

I3I 2Iste nota van Meyer de Vries over de werkverruiming I-4-I942, NIOD I82, inv.nr. 8c; Brief van S.

Cohen aan Meyer de Vries over verschillende werkkampen 26-6-I942, NIOD I82, inv.nr. 8c.

I32 Verslag van A. Levie uit Stadskanaal aan Meyer de Vries over de toestand in Sellingerbeetse 7-6-I942, NIOD I82, inv.nr. 8c.

I33 Notulen van de 49ste vergadering van de Centrale Commissie van de Joodsche Raad Io-61942, NIOD I82, inv.nr. 9b; Notulen van de 5oste vergadering van de Centrale Commissie van de Joodsche Raad 17-6-1942, NIOD I82, inv.nr. 9b. I34 Brief van dr. I. van der $\mathrm{Hal}$ aan Prof. D. Cohen 22-II-I947, NIOD I8Ij, inv.nr. Id.

I35 Ongedateerde naoorlogse verklaring van E.A. Cohen aan ir. R.C. Broek van het RIOD noemt dr. v.d. Horst en dr. Kuppen, NIOD 25od, inv.nr. 475. I36 Notitie van Meyer de Vries inzake werkverruiming Groningen 24-6-I942, NIOD I82, inv.nr. 8c.

I37 Brief van burgemeester Cort van der Linden van Groningen aan de secretaris-generaal van het departement van Binnenlandse Zaken 26-6-I942, NIOD IOIb, inv.nr. 86 .

I38 Notitie van Meyer de Vries inzake werkverruiming Groningen 24-6-I942, NIOD I82, inv.nr. 8c. I39 http://bdi.memorialdelashoah.

org/internet/jsp/core/MmsRedirector. jsp?id=58I79 \& type=VICTIM 7-IO-20I3. I4O Naoorlogs verslag E.A. Cohen, NIOD, 250i, inv.nr. 1085 . 
I4I Isidor van der Hal, Het mesje. De oorlog van een joods Groninger arts (Groningen 1994) I4. I42 Notulen van de vergadering van de Centrale Commissie van de Joodsche Raad op 29-6-1942, 7-7-I942, NIOD I82, inv.nr. 9b.

I43 H.J. van Baalen, Joods leven Deventer en omstreken (Deventer 1998) I66; Hartog Beem, De Joden van Leeuwarden. Geschiedenis van een Joods cultuurcentrum (Assen 1974) 266; Uit: E.P. Boon en J.J.M. Lettinck, De Joodse Gemeente in Winschoten en omgeving 1683-1964 (Zuidbroek 2010) 329, blijkt dat in Winschoten in juli 1942 een keuring in het Groene Kruisgebouw plaatsvond; onduidelijk is wie deze keuring uitvoerde. Uit: Leonard Kasteleyn, Joden in Leiden en omgeving 1933-1945. Vervolging en bescherming, joden in Leiden 1933-1945 (Leiden 2003) 30, blijkt dat er in juni 1942 vier Joodse Leidenaren in werkkamp Vledder arriveerden, over keuring hieraan voorafgaande wordt niets vermeld; Uit: Hans Kooger, Het oude volk. Kroniek van joods leven in de Achterhoek, Liemers en het grensgebied (Doetinchem 200I) 78, blijkt dat er op I2 augustus uit de Achterhoek in elk geval ca. 50 Joden naar het werkkamp Lievelde werden overgebracht. Over een hieraan voorafgaande keuring wordt niet gerept. Uit: Geert C. Hovingh, Joods leven in Zuidlaren (Bedum 200o) 43, blijkt dat er uit Zuidlaren I6 Joden in juli 1942 werden opgeroepen.

In de volgende regionale studies wordt in het geheel geen melding gemaakt van keuringen en/of werkkampen: Lous de Brouwer, De Joodse Gemeente Alphen aan den Rijn I792-I964 (Amsterdam 2002); Tammo Bakker, De kehille Veendam, Veendam,
Wildervank, Muntendam (eigen uitgave Veendam I998); R.C. Hage en J.H. de Vey Mestdagh, De Joodse gemeenschap van Veendam-Wildervank, Muntendam en Meeden (Groningen 1985); Annette Evertzen en Stevine Groenen, Ontduiken en onderduiken, verhalen van Joden in Borne (Borne 2013); L.M. van der Hoeven en E.M. Bánki, Joods leven in Maassluis I688-1942 (Maassluis 2000); Ad van den Oord, Vervolgd en vergeten. Duitse en Nederlandse Joden in Oisterwijk 1933-I945 (Oisterwijk 1998); W.J. Fecken, De Joodse gemeenschap in 's-Graveland en Kortenhoef I730-1945 (Kortenhoef I995); Peter Lurvink, De joodse gemeente te Aalten. Een geschiedenis I630-I945 (Zutphen I99I).

I44 Brief van dr. I. van der $\mathrm{Hal}$ aan prof. D.

Cohen 22-II-I947, NIOD I8Ij, inv.nr. Id.

I45 Van der Hal, Het mesje, I5.

I46 Naoorlogse verklaring van Israel de la Penha I5-9-I9O7 over transport van 6-II-I942, NIOD 250i, inv.nr. 1056 .

I47 Van der Hal, Het mesje, 2I.

I48 Ibidem.

I49 Kooger, Het oude volk, 78; Thijs J. Rinsema, Joden in Meppel I940-I945 (Zutphen 2004) 204. I5O Van der Hal, Het mesje, 42. Brief Ies van der $\mathrm{Hal}$ aan neef en nicht Bram en Betsie, 4-IO-I945, privécollectie familie Van der Hal.

I5I Gesprek met Leo van der Reis (telefonisch), d.d. 2-IO-2OII.

I52 Presser, Ondergang, deel een, I89.

I53 Van der Boom, 'Wij weten niets van hun lot',

I89.

I54 Presser, Ondergang, deeleen, I89.

\section{GENEESKUNDE ALS REDDINGSSLOEP}

I Debórah Dwork en Robert Jan van Pelt, $\mathrm{De}$ Holocaust. Een geschiedenis (Amsterdam 2002) 293-294.

2 Presser, Ondergang, deeleen, 247-25I.

3 Ibidem, 287.

4 Ibidem, 252.

5 Bob Moore, Survivors. Jewish Self-Help and Rescue in Nazi-Occupied Western Europe (Oxford 20IO) 210.

6 Frank van Vree, Hetty Berg (red.), De Holland- sche Schouwburg. Theater, deportatieplaats, plek van herinnering (Amsterdam 20I3); Presser, Ondergang, deeleen, 286.

7 Presser, Ondergang, deel een, 264.

8 Ibidem.

9 Ibidem, 29I.

IO Ibidem, 253 .

II Ibidem, 29I.

I2 Raymund Schütz, Vermoedelijk op transport 
(masterscriptie archiefwetenschappen) (november 20IO, update juni 20II) http://www.joodsebibliotheek.nl/auteur/Noo/Raymund-Schutz/boek/Igo/ Vermoedelijk-op-transport/I/txt/; Presser, Ondergang deel een, 289-290.

13 Moore, Victims and Survivors, 96; Houwink ten Cate, 'Het jongere deel', I6.

I4 Van der Boom, 'Wij weten niets van hun lot', I9I.

I5 Herzberg, Kroniek, 208-209.

I6 Notulen van de 47ste vergadering van de Centrale Commissie op do. 2I mei 26-5-I942, NIOD I82, inv.nr. $9 \mathrm{~b}$.

I7 Brief van Kroonenberg aan Banning 25-II1942, Nationaal Archief geneeskundige hoofdinspectie 2.I5.38, inv.nr. $4 \mathrm{I}$.

I8 Brief Ned. Isr. Armbestuur aan L. Schaap I8 juni I942, privécollectie familie Schaap: dat Kroonenberg weer terug was en op 22 juni zijn werkzaamheden zou hervatten. Dankzegging voor moeite gedaan door Schaap; Verslag bespreking Asscher met Lages, I3-9-I942, NIOD I82, inv.nr. Id. I9 Somers, Voorzitter van de Joodse Raad, I42. 20 Brief van Hanna Schaap aan een zekere Jo, Io juni 1945, privécollectie familie Schaap. Rita Simons werd op 30 september 1943 in Auschwitz vermoord.

2I Zij vonden allen de dood in Auschwitz(Birkenau).

22 Verslagen besprekingen met Lages 5-II-I942, I7-II-I942 en 29-II-I942, NIOD I82, inv.nr. Id.

23 Joods Historisch Museum, Spielberg-interview Ima Spanjaard-van Esso. Voor haar en haar verloofde was dit gebeuren aanleiding direct op de vlucht te slaan.

24 Brief van David Cohen en Abraham Asscher aan Lages I9-II-I942, NIOD I82, inv.nr. Id.

25 In Westerbork zelf wisten zij hun Palestinapapieren rond te krijgen, waardoor zij niet naar Auschwitz, maar naar Bergen-Belsen werden gedeporteerd. Zie ook: Joodsche Raad cartotheek. In Theresienstadt hoorden zij bij de kleine groep mensen die met de Palestina-groep uitgewisseld werden en in Zwitserland terechtkwamen. Hun dochter Ima werd echter met haar verloofde Loet Micheels, een jonge dokter, bij hun vluchtpoging verraden, in België gevangengezet en vandaar gedeporteerd. Zij overleefden Auschwitz ternauwernood. Zoon Ben van Esso bereikte met zijn verloofde Martha Polak - beiden waren eveneens arts - na diverse omzwervingen het vrije Engeland. De jongste zoon, Flip, ondernam evenzeer een vluchtpoging, met de groep van Joop Westerweel, die echter fataal afliep. Via Drancy belandde hij in Auschwitz, waar hij vergast werd.

26 Joodsche Raad Cartotheek, Rode Kruis Den Haag; Coppenhagen, Anafiem Gedoe'iem; www. joodsmonument.nl; www.medischcontact.nl/ geschiedenis artsendatabank.

27 H.J.J.M. van der Bruggen, 'Dr. mr. R.R.L.M. Bromberg. Voorzitter Raad van Beroep en Ambtenarengerecht 1939-1940 en 1945-1956' in: A.M.J.A. Berkvens, H.J.J.M. van der Bruggen en R.M.L.M. Magnée (red.), Rechtspraak in Roermond. Van Soevereine Raad naar Rechtbank Limburg (I580-2012) (Hilversum 2013); Van Rens, Vervolgd in Limburg, 207.

28 Dagboek Berthold Stokvis, NIOD, 244, inv. nr. II49, I6I.

29 De Jong, 'De Ondergang van het Nederlandsche Jodendom', 9 .

30 Op de Joodsche Raad cartotheek-kaart van Max Ziekenoppasser staat bijvoorbeeld aangetekend: 'Arts afd Zentralstelle. Bestuurslid van de Ver. Centraal Isrälietsiche Ziekenverpleging.'

3I Gids van den Joodschen Raad voor Amsterdam, I5 maart I943, NIOD I82.

32 I-3-I942, NIOD I82, inv.nr. I2a.

33 5-6-I942, NIOD I82, inv.nr. I2d.

34 Het Joodsche Weekblad, 2 (1942) I7. Volgens opgaven van 9 september 1942 werden er op dat moment 2030 mensen verzorgd in deze rusthuizen, door 720 man personeel (NIOD I82, inv.nr. IIa, 9-91942). Met name na het begin van de deportaties van de Nederlandse Joden in juli 1942 werd dat een belangrijke taak. Rusthuizen schoten toen immers als paddenstoelen uit de lucht, omdat men verwachtte daar veilig te zijn voor de zogenaamde tewerkstelling in Oost-Europa.

35 Het Joodsche Weekblad, 2 (1942) I7; Geneeskundig Jaarboekje 1939.

36 Ook Raymund Schütz van het Rode Kruis te 
Den Haag kan vooralsnog geen uitsluitsel geven over deze notities.

37 Dagboek Salomon Koster, NIOD 244, inv. nr. 996, I44.

38 Dagboek Salomon Koster, NIOD 244, inv. nr. 996, I70.

39 Dagboek Joseph Kater, NIOD DOC I, inv. nr. 868A.

40 Privécollectie familie Goudsmit, Amsterdam, en privécollectie familie Schaap.

4I Privécollectie familie Denekamp: A.E. Denekamp werd in sept 1942 nog voor keuring opgeroepen, verklaring van mr. H. Edersheim van JR Den Haag dat hij als arts onmisbaar was, ongedateerd. 27 okt.: oproep om Sperr te komen halen.

42 Verklaring van de Joodsche Raad van lidmaatschap van de Joodsche Centrale voor Beroepsopleiding en medisch adviseur, getekend door Abraham Assscher en David Cohen 24-7-I943, verklaring van lidmaatschap van de financiële commissie van de JCB t.b.v. David Hausdorff daarvan A.M. Cohen 22-7-1942, brief van Zentralstelle 29-9-I942, alles afkomstig uit: Pinchas Bar Ze'ev, 'Het verhaal van zeven oorlogsdocumenten en...één persoon', Aleh, april 2009, Jom Hashoa, I8-20.

43 Marcel Prins en Peter Henk Steenhuis, Andere achterhuizen. Verhalen van joodse onderduikers

(Amsterdam 2010) I6I, I64.

44 Gesprek met Dik Jacobs, d.d. I6-II-20Io.

45 Lena Jacobs-Melkman, brief I9-IO-I942, via dhr. Wim Westerhoff. De 'beroemde Bolle' aan wie gerefereerd wordt, betreft Max Bolle, Joodsche Raad prominent.

46 Dagboek Berthold Stokvis, NIOD, 244, inv. nr. II49, I70.

47 Ibidem, I25.

48 Ibidem, I3I.

49 Ibidem, 158.

50 Joods Historisch Museum, Spielberg-interview Hetty Fortuin-Blitz.

5I Brief van Bernard de Vries Robles, I965 aan de WUV, privécollectie familie de Vries Robles.

52 Dagboek Joop Voet, aangehaald in Van der Boom, 'Wij weten niets van hun lot', $3 \mathrm{I} 8$.

53 Notulen van de 64ste vergadering van de Contact Comissie van de Joodsche Raad, I4-IO-I942:
'Donderdag j.l. werden van den Haag uit 4 doktoren voor het kamp aangevraagd. Heden hebben wij de vrijwilligers gevonden, doch wij wachten thans op nadere berichten.' NIOD I82, inv.nr. 9b.

54 Gesprek met Arnold Rodrigues Pereira, d.d. 4-IO-20II; Fragmenten uit interview Jaap Cohen met Arnold Rodrigues Pereira d.d. 5-3-20Io.

55 Gesprekken met Carel Wolff, d.d. 30-IO-2008, 25-4-2009, 2-II-2009.

56 De Wind, Eindstation Auschwitz, 8.

57 Naoorlogse verklaring van Abraham Wittenburg, geboren II-9-I9IO, ook arts en bevriend met Sally de Jong, NIOD 250i, inv.nr. I094.

58 Joodsche Raad cartotheek, Rode Kruis Den Haag; Rinsema, Joden in Meppel, 297.

59 Herinneringen van Paul Dagobert Stibbe 1992 Joods Historisch Museum, document 12624.

60 Brief mr. H. Edersheim aan A.E. Denekamp 8-IO-I942: bevestiging van dienstverband voor JR, privécollectie familie Denekamp, Amsterdam. 6I Joodsche Raad cartotheek, Rode Kruis Den Haag. Er staat op Buys' kaart vermeld: wegens verdiensten Judenrat.

62 Dagboek Jacques Reisel, 7-2-I943, privécollectie familie Reisel, Amsterdam.

63 Gesprek met Maurits Frenkel, d.d. 22-2-2009; Pelser, Vluchtweg Zwitserland, 47.

64 Gesprek met Max en Hannah Koster-Souget, d.d. I-2-2009.

65 Dossier B.J. van Esso en mej. M. Polak, Nationaal Archief ministerie van Justitie te Londen, II988.

66 Levensbeschrijving van Benjamin Juda van Esso, door hemzelf geschreven te Praia das Macas 6-6-I943, Nationaal Archief ministerie van Justitie te Londen, II988.

67 Voor deportatie uit Mechelen zie: Maxime Steinberg, La Persécution des Juifs en Belgique (19401945) (Brussel 2004) 234.

68 Joods Historisch Museum, Spielberg-interview Ima Spanjaard-van Esso.

69 Louis J. Micheels, Dokter II764I. Herinneringen aan de Holocaust (New Haven 1989) 66. Hier worden drie i.p.v. twee kinderen genoemd. 70 Joodsche Raad cartotheek, Rode Kruis Den Haag. De data en beschrijving komen overeen. 
7I www.joodsmonument.nl

72 www.joodsmonument.nl: Algemeen politieblad, nr 43, 29 oktober 1942, I220, bericht 2598.

73 Correspondentie en gesprekken met Sieg en Leah Gitter, d.d. jan.- mei 2009. De Spaanse collega heette dr. Ricardo Horno Allorta.

74 Van Tubergen e.a., 'The Unwholesome Theme of Suicide', 340 .

75 In 1942 overleden Jakob Pinkhof, Bernard

Eisendrath en Salomo Bendien door suïcide, in I943 Benoit Catz en Willem van Furth en mogelijk ook A.A. Hijmans van den Bergh.

76 Herman Pinkhof, 'Geneeskundige hulp bij zelfmoord', Nederlands Tijdschrift voor Geneeskunde 3I (1933) 3603 .

77 F.S. Meyers, 'Van de zelfmoorden', verslag voor Amst. Joodsch Psychiatrisch Gezelschap, NIOD DOC II, inv. nr. 3 OB.

78 Ibidem.

79 Ibidem.

80 Gegevens over zelfmoorden Joden, 23-9-I942: brief van Joodsche Raad aan Lages, NIOD 77, inv.nr. I465. Zie ook: Joods Historisch Museum, Jacob Pinkhof, inv.nr. 20040075.

8I Clara Asscher-Pinkhof, Danseres zonder benen (Den Haag 1966) I57.

82 Ibidem, I57.

83 Ongedateerd, naoorlogs verslag F.S. Meyers over het Amsterdamsch Joodsch Psychiatrisch gezelschap, NIOD DOC II, inv.nr. $30 B$.

84 Pim Ligtvoet, 'I $k$ heb een heel tijdje niets van me laten horen', Joden in de Zaanstreek (1940-1945)

(Wormer 2007) 34; www.joodsmonumentzaanstreek.nl/pagina-2Io-Eisendrath-Bernard.htm 9-4-20I4.

85 Correspondentie geneeskundige inspectie over ongeoorloofde productie van kankerserum door $S$. Bendien, Nationaal Archief 2.15.37, inv.nr. 2268.

86 www.joodsmonument.nl

87 Gesprek met Maurits Frenkel, d.d. 22-2-2009; Pelser, Vluchtweg Zwitserland, 46.

88 Ongedateerd naoorlogs verslag F.S. Meyers, vermoedelijk 1945, Amsterdamsch Joodsch Psychiatrisch Gezelschap, NIOD DOC II, inv.nr. 30B.

89 Gesprekken met Willy Hijmans, I7-6-20Io, 2I-8-20IO; Job Degenaar, 'Het blonde overbuur- meisje en de onbekende Jood', Vrij Nederland 30 april 2005, 45; Voor Polak Daniëls, zie ook: J. Roos en W. Hijmans, 'In Memoriam dr. A. Polak Daniëls', Nederlands Tijdschrift Geneeskunde I30 (I986) I297-I298.

90 Toestand van levensbedreigend laag suikergehalte in het bloed.

9I Gesprek met Carel Wolff, d.d. 30-IO-2008,

25-4-2009, 2-II-2009.

92 Muller, Aan de poort van het leven, 227

93 Dagboek Salomon Koster, NIOD 244, inv. nr. 996, I59.

94 Liliane Pelzman, En verder geen leed. Een moeder, haar dochter, hun oorlog (Amsterdam 2009) 66. Tevens gesprek met informante, d.d. aug. 2012. 95 Gesprek met Benjamin Ricardo, d.d. 4-52009; Joods Historisch Museum, Spielberg-interview Sera Schrijver.

96 Dagboek Joseph Kater, NIOD DOC I, inv. nr. 868A.

97 Presser, Ondergang, deel een, 29I.

98 Dagboek Joseph Kater, NIOD DOC I, inv. nr. $868 \mathrm{~A}$.

99 Ibidem.

IOO Dagboek Berthold Stokvis, NIOD, 244, inv. nr. II49, IoI; Gesprek met Julius en Carel Roos, d.d. I3-II-2008.

IOI Gesprek met Diny Boas-Vedder, d.d. 5-II2011.

IO2 Dagboek Berthold Stokvis, NIOD, 244, inv. nr. II49, 39 .

I03 Ongedateerd: 'De Amsterdamsche Joden gedurende de jaren I940-I943, een sociaal-psychiatrische studie, door Dr. F.S. Meyers met medewerking van dr. B. Stokvis en dr. J. Tas, NIOD DOC II, inv.nr. $30 B$.

I04 Agenda Andries Blok 1942, Joods Historisch Museum, document 13235 .

IO5 Ten Bokkel Huinink e.a., Medische ethiek, II.

Io6 Gesprek met Carel Wolff, d.d. 30-IO-2008, 25-4-2009, 2-II-2009.

Io7 A.E. Denekamp en G. Dekker (red.), Besluit en rapport inzake geneeskundige verklaringen. KNMG (1949) 9; Paul Denekamp, Van Boezeman tot Denekamp, een korte familiegeschiedenis (Amsterdam 1989) 50. 
IO8 Joden-Nederland, Artsen, NIOD Knipselarchief, KA II, inv.nr. 979.

I09 Dagboek Joseph Kater, NIOD DOC I, inv. nr. 868 A.

IIO Presser, Ondergang, deel een, afbeelding 2, 3 I2.

III Ibidem.

II2 Brief van G. van Tijn aan mej. Elisabeth

Zwarts 26-7-I942, NIOD I82, inv.nr. Iof. De twee artsen waren vermoedelijk Max Bloch en Norbert

Neufeld. Max Ziekenoppasser was volgens zijn Joodsche Raad cartotheek-kaart eveneens als arts bij de Zentralstelle werkzaam.

II3 H. Wielek, De oorlog die Hitler won (Amsterdam 1947) I46.

II4 Presser, Ondergang, deel een, 3I2.

II5 H. Wielek, De oorlog die Hitler won, I46.

II6 Archief van Centraal Voorlichtingsbureau

7-9-I942, NIOD I82, inv.nr. 9g.

II7 Bollegraaf, De Joden te Oss, 23.

II8 Dagboek Berthold Stokvis, NIOD, 244, inv. nr. II49, I28.

II) Ibidem.

I2O Bollegraaf, De Joden te Oss, 23.

I2I Dagboek Berthold Stokvis, pag. I28, NIOD, 244 , inv. nr. II49.

I22 Gesprek met Diny Boas-Vedder, d.d. 5-II2011.

I23 Dagboek Berthold Stokvis, NIOD, 244, inv. nr. II49, I39-I4O.

I24 Ongedateerde brief van Louis Schaap, vermoedelijk vlak na de bevrijding geschreven aan zijn broer Adolph Schaap in Amerika, privécollectie familie Schaap.

I25 Dagboek Berthold Stokvis, NIOD, 244, inv. nr. II49, I44.

I26 De Jong, 'De Ondergang van het Nederlandsche Jodendom', I2. en: NIOD I82, inv.nrs. 34b, 34c en $34 \mathrm{~d}$.

I27 Mark Schellekens, Walter Süskind, Hoe een zakenman honderden Joodse kinderen uit handen van de nazi's redde (Amsterdam 20II) 85 .

I28 Dagboek Berthold Stokvis, NIOD, 244, inv. nr. II49, I46.

I29 Ibidem.

I30 Emailcorrespondentie Paul Hertzberger, januari 2010.
I3I Brief van Henriette A. Lohr, arts voor inwendige ziekten I8-3-1947, Nationaal Archief 2.19.053.02, inv.nr. 47.

I32 Dagboek Berthold Stokvis, NIOD, 244, inv. nr. II49, I62.

I33 Notulen van de 7Oste vergadering van de CC, vrij 20 nov. 23-II-I942, NIOD I82, inv.nr. 9b.

I34 Dagboek Salomon Koster, NIOD 244, inv. nr. $996, \mathrm{I} 42$.

I35 Ibidem, I49.

I36 Dagboek Berthold Stokvis, NIOD, 244, inv. nr. II49, 39; De Jong, 'De Ondergang van het Nederlandsche Jodendom'.

I37 NIOD I82, inv.nr. IOa. En begeleidende brieven in NIOD I82, inv.nr. $9 \mathrm{~h}$.

I38 Dagboek Berthold Stokvis, NIOD, 244, inv. nr. II49, IOI.

I39 Te weten: H. de Levie, F.S. Meyers, J. Tas, B. Stokvis, A.M. Meerloo, K. Landauer, E. de Wind, B. Polak, C. van Emde Boas, M.L.A.S. Ali Cohen, S. Koster, A. Muller, F. Grewel.

I40 Brief M. Ali Cohen over bijzondere omstandigheden van de tijd die hun weerslag hebben op het Joodsch Psychiatrisch Consultatiebureau en het Joodsch Medisch-Opvoedkundig Bureau 27-9I942, NIOD DOC II, inv.nr. 30B.

I4I Presser, Ondergang, deel een, 283: B. Stokvis over wonderbaarlijk sterke houding Joden in deportatiefase. NIW I7 aug 1945.

I42 Herman de Levie, voordracht 27-9-I942. En ook: Brief 28-9-I942 van Dr. S. Koster aan Dr. F.S. Meijers NIOD DOC II, inv.nr. $30 B$.

I43 Brief van Herman de Levie aan Meyers I8-IOI946, NIOD DOC II, inv.nr. 30B.

I44 Naoorlogs verslag van F.S. Meyers, NIOD DOC II, inv.nr. $30 B$.

I45 Ibidem.

I46 Brief M. Ali Cohen over bijzondere omstandigheden van de tijd die hun weerslag hebben op het Joodsch Psychiatrisch Consultatiebureau en het Joodsch Medisch-Opvoedkundig Bureau 27-91942, NIOD DOC II, inv.nr. 30B.

I47 Notulen van de bijeenkomst van 28 maart I943, ten huize van Dr. J. Tas. Aanwezig alle leden behalve Dr. B.S. Polak en Dr. E. de Wind, Dr. M.L.A.S. Ali Cohen: Vervolg van rede van Basch- 
witz met daaropvolgende discussie, NIOD DOC II, inv.nr. $30 \mathrm{~B}$.

I48 Naoorlogs verslag van F.S. Meyers, NIOD DOC II, inv.nr. $30 \mathrm{~B}$.

I49 Ibidem.

I5O Brief van Dr. S. Koster aan Dr. F.S. Meijers

28-9-I942, NIOD DOC II, inv.nr. $30 B$.

I5I Ben W. de Vries, Remi. Portrait of a Young Dutch Jew in the Holocaust (Herzliya 2003) 54.

I52 Manuscript 'Het drama van het Apeldoornsche Bosch' door N. Speyer, pag.4, NIOD DOC II inv. nr. 1337 .

I53 Psychiater Arie Querido meldde overigens na de oorlog dat het niet om grote aantallen simulanten uit de maatschappij ging, maar met name om mensen die op die manier uit Westerbork probeerden weg te komen. Proces tegen Aus der Fünten, 'Het einde van het Apeldoornsche Bosch' door Dr. A. Querido, artikel uit 'mededelingen van de nationale federatie voor de geestelijke volksgezondheid' no. 2. dec I945, NIOD DOC I, inv.nr. 500, Ai3.

I54 Van Tubergen e.a., 'The Unwholesome Theme of Suicide', 336; Dangermond, 'Het heft in eigen handen', 5 .

I55 Dagboek Salomon Koster, NIOD 244, inv. nr.

$996,146$.

I56 Ibidem.

I57 Naoorlogs verslag van F.S. Meyers, NIOD Doc II, inv.nr. 3oB; Janneke de Moei, Het leven niet waard. Een geschiedenis van rassenwaan (Hooghalen 20II) 50.

I58 Leesha Rose, The Tulips Are Red (Jeruzalem I978) 87 .

I59 Gesprek met Philippine van der Feltz- Muller, d.d. 3-I2-2OII.

I60 Joods Historisch Museum, Spielberg-interview Betsy Gezang-van Praag.

I6I Joods Historisch Museum, Spielberg-interview Boes Lankhout; De Lang, Het oorlogsdagboek van Dr. G. Italie, 315, 3 nov 1942: 'tal van Joden vertoeven in Ramaerkliniek'.

I62 Van Rens, Vervolgd in Limburg, 77.

I63 Notulen vergadering Joodsche Raad 5-7-I942, NIOD I82, inv.nr. Ic.

I64 Bollegraaf, De Joden te Oss, 27.

\section{5. 'ONDER HET VURIG BEGEERDE DAK VAN HET ZIEKENHUIS'}

I Ongedateerd: 'Belegung in jüdischen Anstalten', vermoedelijk september-oktober 1942, NIOD I82, inv.nr. 33e.

2 Ibidem.

3 Suzette Wyers, Als ik wil kan ik duiken. Brieven van Claartje van Aals, verpleegster in de joods psychiatrische inrichting Het Apeldoornsche Bosch 1940-1943 (Amsterdam 1995).

4 Ibidem, 93.

5 Ongedateerd: 'Belegung in jüdischen Anstalten' vermoedelijk september-oktober 1942, NIOD I82, inv.nr. 33e.

6 Presser, Ondergang, deel een, 343.

7 Notulen vergadering bestuur en comm. financiën JVvVV Joodsche Raad 23-II-I942, NIOD I82, inv. nr. $33 \mathrm{~d}$.

8 Isaac Lipschits, Tsedaka. Een halve eeuw Joods

Maatschappelijk Werk in Nederland (Zutphen 1997)
52.

9 Het Joodsche Weekblad, 2e jaargang, no. 32, I3-II-I942; Typoscript van M.H. Pimentel, 'De geneeskundige verzorging en ziekenverpleging der Joden in Amsterdam van I804-I940', ca. I950, 5, Joods Historisch Museum, document ooor 3988. IO 4-I-I943, NIOD I82, inv.nr. 33e.

II I3-I-I943, NIOD I82, inv.nr. 33d.

I2 4-II-I942, NIOD I82, inv.nr. 33C.

I3 7-I2-I942, NIOD I82, inv.nr. IC.

I4 M. Poons, 'Bij de sloop van het voormalig Ned. Isr. Ziekenhuis', Hakehilla 24 (1979) 7, 2I-23. I5 Typoscript van M.H. Pimentel, 'De geneeskundige verzorging en ziekenverpleging der Joden in Amsterdam van I804-1940', ca. I950, Joods Historisch Museum, inv.nr. ooor3988; Dr. J. de Hartogh JR., 'Het Nederl. Isr. Armbestuur in de laatste 50 jaar', Gedenkboek ter gelegenheid 
van het 50-jarig bestaan van het Centraal Blad voor Israëlieten in Nederland 1935, 55-58, Joods Historisch Museum, 927 Gede b; Typoscript over de geschiedenis van het Joodse ziekenhuis in Rotterdam door M. Elzas, ca. I950, Joods Historisch Museum, document ooor3990; Typoscript over het voormalige Joles-ziekenhuis in Haarlem, ca. I950, auteur mogelijk S.L. Anholt. Joods Historisch Museum, document ooor3989.

I6 Gesprekken met Carel Wolff d.d. 30-IO-2008, 25-4-2009, 2-II-2009.

I7 J. Exalto en J.C. Tummers, 'De behandeling van den opengebleven ductus Botalli', Nederlands Tijdschrift voor Geneeskunde 86 (1942) 45, 27722778, 2775; J. Wieberdink, 'Dr. S.M. Kropveld; het begin van de Nederlandse hartchirurgie', Nederlands Tijdschrift voor Geneeskunde I33 (1989) 45, 2238. De patiënte, Annie Walg, ten tijde van de operatie elf jaar oud, zou de operatie, een jaar ziekenhuisopname nadien en de Duitse concentratiekampen overleven: Joods Historisch Museum, Spielberg-interview Annie Reinfeld-Walg.

I8 6-IO-I942, Joods Historisch Museum, document 00000906.

I9 Het Joodsche Weekblad, 2 (I942) 32, I, I3 november.

20 Joods Historisch Museum, Spielberg-interview Herman Herschel.

2I Bijvoorbeeld bij Kitty Fonteijn: gesprek met Sally van Coevorden d.d. 13-8-2009.

22 Gesprekken met Max Hamburger, d.d. 28-Io2008, I4-5-2009, I6-7-2009.

23 Gesprek met Sam en Ruth Bos-Watermann, d.d. 26-2-2009.

24 Joods Historisch Museum, Spielberg-interview Max Cohen; gesprek met Maurits Frenkel, d.d. 22-2-2009.

25 Philip Mechanicus, In Dépôt. Dagboek uit Westerbork (Amsterdam 1964) I49.

26 Joods Historisch Museum, Spielberg-interview Herman Herschel.

27 Ibidem.

28 Longontsteking ontstaan door niet goed ophoesten bij een verzwakte patiënt. Iets overeind zitten helpt om dit te voorkomen.
29 Gesprekken met Kees Kroonenberg, d.d. I2-32009, 2-4-2009, 23-4-2009.

30 Dagboek Joseph Kater, NIOD DOC I, inv. nr. 868A.

3I Emailwisseling met Bart de Cort, o.b.v. gesprek met dochter Leisen, 28-2-20I3; Heleen Pronk, 'Zoals ik het mij herinner. levensverhaal van Geertrui Hingst. deel I: I927-I945.' manuscript (Wassenaar/Amsterdam/Voorthuizen; z.u. 20II) kopie in bezit van auteur.

32 Gesprekken met Bettie Weijl, d.d. 9-I2-2009 en I-4-20IO; gesprekken met Sally van Coevorden, d.d. 2I-I-2009 en 13-8-2009, gesprekken met Max Hamburger, d.d. 28-I0-2008, I4-5-2009, I6-7-2009; gesprekken met Kees Kroonenberg, d.d. I2-3-2009, 2-4-2009, 23-4-2009.

33 Joods Historisch Museum, Spielberg-interview Johnny van Coevorden; Gesprekken met Bettie Weijl, d.d. 9-I2-2009 en I-4-20IO.

34 Gesprekken met Sally van Coevorden, d.d. 2I-I-2009 en I3-8-2009; Sally van Coevorden, Zoals $i k$ het beleefd heb (Amsterdam; z.u. zonder datering) 13. Kopie in bezit auteur.

35 Esther Göbel, Een hemel zonder vogels. Het aangrijpende levensverhaal van Janny Moffe-Bolle (Amsterdam 20IO) 38.

36 Joods Historisch Museum, Spielberg-interview Herman Herschel.

37 Louis Schaap, 'In memoriam Dr. S. Kroonenberg', Nederlandsch Tijdschrift voor Geneeskunde Io6 (I962) I, 49.

38 NIOD archief I82 Ic, I8-9-I942 notulen vergadering Joodsche Raad.

39 Joods Historisch Museum, Doooo7833, Brief Ben Wessels 2O-II-I942, aan zijn vriend Johan Schipper in Oostvoorne.

40 Gesprek met Sam en Ruth Bos-Watermann, d.d. 26-2-2009.

4I Joods Historisch Museum, Spielberg-interview Elly Pruikenmaker-Monnickendam.

42 Dr. M.H. Pimentel over Zr. Broekman Joodse Ereraad ongedateerd, Stadsarchief cIZ 795, inv.nr. 24. Zie ook: Sajet, Een leven lang, I45.

43 Joodse Ereraad, Zr. Broekman, Stadsarchief CIZ 795, inv.nr. 24 
44 Typoscript over de geschiedenis van het Joodse ziekenhuis in Rotterdam door M. Elzas, ca. I950, Joods Historisch Museum, document ooor3990; Typoscript over het voormalige Joles-ziekenhuis in Haarlem, ca. I950, auteur mogelijk S.L. Anholt, Joods Historisch Museum, 00013989.

45 Dagboek Salomon Koster, NIOD 244, inv. nr. 996,147 .

46 Joods Historisch Museum, Spielberg-interview Abraham van der Sluijs.

47 Ben Braber, Zelfs als wij zullen verliezen. Joden in verzet en illegaliteit 1940-I945 (Amsterdam 1990) 83 .

48 Dit blijkt bijvoorbeeld uit de enorme afname van advertenties voor vrije plaatsen in rusthuizen in Het Joodsche Weekblad.

49 Rose, The Tulips Are Red; Gesprek met Ans Samama-Polak, d.d. I6-Io-2orI.

50 Het Joodsche Weekblad I (I94I) 26, 3 oktober.

5I Brief van Buzaglo (dir JI), Van Santen en Smit aan voorzitter Joodsche Raad I4-9-I942, NIOD I82, inv.nr. 3c.

52 Brief van Ji aan voorz JR: J.H. Buzaglo (geneesheer-directeur), A van Santen vice-voorzitter, K. Rozenberg penningmeester 25-IO-I942, NIOD I82, inv.nr. 3e.

53 Ibidem.

54 Joods Historisch Museum, Spielberg-interview Maurits Coronel. Neef van Buzaglo.

55 Brief David Cohen aan J.H. Buzaglo, gen. dir. JI I7-2-I943, NIOD I82, inv.nr. 4d.

56 Verslag van oorlogsgebeurtenissen door Louis Schaap, ongedateerd, privécollectie familie Schaap.

57 Gesprek met Ans Samama-Polak, d.d. I6-Io2011.

58 Johanna-Ruth Dobschiner, Te mogen leven! (Franeker 1974) 44.

59 Gesprekken met Bettie Weijl, d.d. 9-I2-2009 en I-4-20Io.

60 Alain V. Hartogh, De Joodsche Invalide in oorlogstijd (Amsterdam: z.u. 1946) 2, manuscript in bezit van NIOD, Ned 9.I Har.

6I Brief van Ji aan voorz. JR: voorz Mr. M. Levie, secr. L. Smit II-II-I942, NIOD I82, inv.nr. 3 e. 62 Brief David Cohen aan de Joodse ziekenhuizen, weeshuizen, oudeliedengestichten, krank- zinnigengestichten, rusthuizen, tehuizen voor kinderverzorging enz. 26-II-I942, Joods Historisch Museum, document 00000249 ; Notulen vergadering Joodsche Raad 30-II-I942, NIOD I82, inv.nr. Ic. In maart 1942 was ook al een poging ondernomen de Joodse patiënten in den lande in kaart te brengen, onder het mom van dat er een afzonderlijk sanatorium voor Joden zou worden opgericht: brief van S. Spijer aan ziekenhuisdirecteuren, medische afdeling J.R. I2-3-I942, NIOD I82, inv.nr. I2C.

63 Presser, Ondergang, deel een, 313. Interne Informatie Joodsche Raad, 3-4 dec. 1942.

64 Onderhoud tussen Rombach en Prof.Dr. D. Cohen 3-I2-I942, NIOD I82, inv.nr. Id.

65 Brief van Prof.Dr. D. Cohen aan Rombach IO-I2-I942, NIOD I82, inv.nr. 7 b.

66 Notulen vergadering Joodsche Raad I7-I2I942, NIOD I82, inv.nr. IC.

67 Bericht centr voorl bureau I4-I2-I942, NIOD I82, inv.nr. 9c.

68 S. Laansma, De Joodse gemeente te Apeldoorn en het Apeldoornsche Bosch (Zutphen 1979) 40.

69 Hanneke Oosterhof, Het Apeldoornsche Bosch. Joodse psychiatrische inrichting 1909-I943 (Heerlen 1989) I2.

70 Correspondentie t.b.v. de ingebruikname van het leegstaande complex van het voormalig Apeldoornsche Bosch 14-2-1947, Nationaal Archief ministerie van Sociale Zaken, inv.nr. IIo8.

7I Oosterhof, Het Apeldoornsche Bosch, II.

72 Rena Fuks-Mansfeld, Wie in tranen zaait...

Geschiedenis van de Joodse Geestelijke Gezondheidszorg in Nederland (Assen 1997).

73 Zeer vertrouwelijk verslag aan het college van regenten van het AB 7-4-I94I en 8-3-I94I: briefje van Querido aan Simons, Stadsarchief Amsterdam cIK Io66, inv.nr. I47.

74 Brief van Lobstein aan voorzitter cıK 22-4194I, Stadsarchief Amsterdam cIK IO66, inv.nr. I47. 75 Conceptbrief in het Nederlands van David Cohen aan Arauner over vervanging van Joods personeel in de verschillende ziekenhuizen 24-2-1942, NIOD I82, inv.nr. 6d.

76 Moore, Victims and Survivors, Ioo; De Jong, Koninkrijk, deel zes, deel een, 32I; Presser, Ondergang, deel een, 324; Oosterhof, Het Apeldoornsche 
Bosch, 27.

77 Presser, Ondergang, deel een, 322.

78 Ibidem.

79 Proces tegen Aus der Fünten, verhoor Nico Speyer, I949, NIOD DOC I, inv.nr. 500, a8.

80 De Jong, Koninkrijk, deel zes, deeleen, 320. Deze Audier was een eigenaardige figuur, die, ondanks zijn NSB-lidmaatschap, in zijn eigen psychiatrische praktijk in Assen gevangenen van Westerbork behandelde, onder wie de echtgenote van Dr. Spanier, de Duits-Joodse kamparts. Zie daarvoor: Notitie van behandeling van Mw. Babette Spanier door Dr. Audier Assen 2-7-I942, NIOD 250i, inv. nr. 459 .

8I Proces tegen Aus der Fünten, verklaring Arie Querido, 1949, NIOD DOC I, inv.nr. 500, a8.

82 De Jong, Koninkrijk, deel zes, deeleen, $32 \mathrm{I}$.

83 Oosterhof, Het Apeldoornsche Bosch, 27.

84 Weergave van telegram en telefoonverkeer geneesheer-directeur 24-I2-I942, Stadsarchief Amsterdam, CIK I066, inv.nr. 153.

85 Ibidem.

86 Ibidem.

87 Proces tegen Aus der Fünten, verklaring Nico Speyer, 1949, NIOD DOC I, inv.nr. 500, a8.

88 Presser, Ondergang, deel een, 324; Proces tegen Aus der Fünten, verklaring van Arie Querido, NIOD Doc I, inv.nr. 500, a5.

89 De Jong, Koninkrijk, deel zes, deel een, 32I.

90 Staten met patiëntenaantallen, NIOD 250i, inv. nr. 459 .

9I Manuscript 'Het drama van het Apeldoornsche Bosch' door N. Speyer, NIOD DOC II, inv.nr. I337.

92 Sal van Son, documentaire. http://www.xs4all. $\mathrm{nl} / \sim$ tfursten/apeldoornscheboschdoc/.

93 Presser, Ondergang, deel een, 324.

94 De Jong, Koninkrijk, deel zes, deel een, 32I.

95 De Vries, Remi, 73.

96 Ibidem, 74-75; Wyers, Als ik wilkan ik duiken, Io6.

97 Ongedateerd en anoniem geschreven verslag van een OD-man vanaf gang naar werkkamp, NIOD 250i, inv.nr. 493.

98 De Vries, Remi, 74.

99 Artsendatabank www.medischcontact.nl
I6-4-20I4.

Ioo Oosterhof, Het Apeldoornsche Bosch, 31: Zij vertrok pas op de 2iste januari, toen zij daartoe gedwongen werd.

IOI Brief van A. Rombach en N. Muller van het

Ned. Gen. tot zedelijke verbetering der gevangenen tbv Lobstein 7-4-I943, NIOD IOIb, inv.nr. 3IO.

IO2 E.C. van der Wal, 'Jacques Lobstein', http:// www.genootschapjoodsewetenschap.nl/bijdragenen-mededeelingen 1956, 27-8-20I4.

I03 Presser, Ondergang, deel een, 323; Proces tegen Aus der Fünten, verklaring Arie Querido, NIOD Doc I, inv.nr. 500, A8.

IO4 Gesprek met Eli Asser, d.d. 26-2-2009.

I05 De Vries, Remi, 7I.

Io6 De Jong, Koninkrijk, deel zes, deeleen, 32I.

IO7 Manuscript 'Het drama van het Apeldoornsche Bosch' door N. Speyer, pag. 7, NIOD DOC II, inv.nr. 1337 .

Io8 Bij de familie A.D. Posthumus-Jansen te Leeuwarden. E-mailcorrespondentie met Eljah Mendels, maart en april 20II. Ejah Mendels en de kinderen Querido overleefden de oorlog.

I09 Apeldoornsche Bosch, Getuigenis van Arie Querido, op I2 feb 1946, NIOD DOC II, inv.nr. 1337. IIO Getuigenis Paulina Vomberg tegen Aus der Fünten 1949, NIOD DOC I, inv.nr. 500, a8.

III Joods Historisch Museum, Spielberg-interview Ernest Frank.

II2 Ongedateerd en anoniem geschreven verslag van een OD-man vanaf gang naar werkkamp, NIOD 250i, inv.nr. 493.

II3 Oosterhof, Het Apeldoornsche Bosch, 36.

II4 Brief van Lobstein aan Parser 22-I-I943,

Stadsarchief CIK I066, inv.nr. I53.

IIs Ibidem.

II6 Manuscript 'Het drama van het Apeldoornsche Bosch' door N. Speyer, pag. 7, NIOD DOC II inv.nr. 1337.

II7 Ibidem.

II8 Proces tegen Aus der Fünten, verklaring Nico Speyer 1949, NIOD DOC I, inv.nr. 500, a8.

II) Proces tegen Aus der Fünten, verklaring Nico Speyer, I3-I2-I949, NIOD DOC I, inv.nr. 500, g2. I20 Oosterhof, Het Apeldoornsche Bosch, 36. I2I Manuscript 'Het drama van het Apeldoorn- 
sche Bosch' door N. Speyer, NIOD DOC II, inv.nr. I337, I3.

I22 Getuigenis van Arie Querido, I2-2-I946, NIOD DOC II, inv.nr. 1337.

I23 Briefje van C. van Emde Boas, zenuwarts I4-6-I945, Nationaal Archief Medisch Contact 2.19.053.02, inv.nr. 19.

I24 Proces tegen Aus der Fünten, verklaring Nico Speyer 1949, NIOD DOC I, inv.nr. 500, a8.

I25 Getuigenis van Arie Querido, arts op I2 feb. I946, NIOD DOC II, inv.nr. I337.

I26 Ibidem.

I27 Briefje van C. van Emde Boas, zenuwarts I4-6-I945, Nationaal Archief Medisch Contact 2.19.053.02, inv.nr. 19. Verklaring Arie Querido in proces tegen Aus der Fünten, NIOD DOC I, inv.nr. 500, a5. Koert Reurmann was de naam van deze tandarts.

I28 Artikel in Algemeen Handelsblad 'Hoe het AB werd geliquideerd. Zeer bezwarende getuigenverklaring tegen Aus der Fünten voor het Bijzondere Gerechtshof te Amsterdam' I4-I2-I949, NIOD 250i, inv.nr. 1065 .

I29 Paulina Vomberg in proces tegen Aus der Fünten, NIOD DOC I, inv.nr. 500, G3.

I30 Eigen verklaring Ferdinand Aus der Fünten 1949, NIOD DOC I, inv.nr. 500, a8.

I3I Proces tegen Aus der Fünten, verklaring Arie Querido, NIOD DOC I, inv.nr. 500, a8.

I32 Artikel in Algemeen Handelsblad 'Hoe het АВ werd geliquideerd. Zeer bezwarende getuigenverklaring tegen Aus der Fünten voor het Bijzondere Gerechtshof te Amsterdam' I4-I2-I949, NIOD 250i, inv.nr. 1065 .

I33 Briefje van C. van Emde Boas, zenuwarts 14-6-1945, Nationaal Archief Medisch Contact 2.19.053.02, inv.nr. I9.

I34 Manuscript 'Het drama van het Apeldoornsche Bosch' door N. Speyer, pag. II, NIOD DOC II inv.nr. I337.

I35 Joodsche Raad cartotheek, Rode Kruis Den Haag.

I36 Aan de leden van de JR, prov hoofdvertegenwoordigers en afdelingschefs van David Cohen en Abraham Asscher 22-I-I943, NIOD I82, inv.nr. 4d. I37 Aus der Fünten en Abraham Asscher, David
Cohen, Edwin Sluzker 28-I-I943, NIOD I82, inv. nr. Id.

I38 Ibidem.

I39 Ongedateerd verslag van een OD-man vanaf gang naar werkkamp, NIOD 250i, inv.nr. 493.

I4O De Jong, 'De Ondergang van het Nederlandsche Jodendom', I2.

I4I Dagboek Salomon Koster, NIOD 244, inv. nr. 996, I43.

I42 Dagboek Jacques Lobstein, september I944, Stadsarchief Amsterdam CIK I066, inv.nr. 196.

I43 Proces tegen Aus der Fünten, verklaring Jacob Spanjaard I949, NIOD DOC I, inv.nr. 500.

I44 Proces tegen Aus der Fünten, verklaring Nico Speyer I949, NIOD DOC I, inv.nr. 500, a8.

I45 Elie A. Cohen, 'Het Duitse concentratiekamp. Een medische en psychologische studie' (Amsterdam 1952) 98-99.

I46 Diverse mondelinge bronnen vermelden dat zij hoorden van het nieuws uit Apeldoorn. Het schokeffect dat dit nieuws teweegbracht, was volgens hen groot.

I47 Verklaring Hermannus Kalkema in het proces tegen Aus der Fünten I949, NIOD DOC I, inv. nr. 500, a8.

I48 Brief van bestuur CIK aan Burgemeester van A'dam 27-I-I943, Stadsarchief Io66 CIK, inv.nr. I78. I49 Dagboek Salomon Koster, NIOD 244, inv. nr. 996, I54-I55.

I50 Van der Boom, 'Wij weten niets van hun lot', 205 .

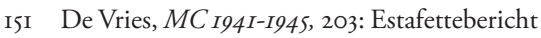
I maart 1943

I52 Verklaring Paul van Bork, proces tegen Aus der Fünten, I949, NIOD DOC I, inv.nr. 500, a8.

I53 De Jong, 'De Ondergang van het Nederlandsche Jodendom', II.

I54 De Vries, MC I94I-I945, 203.

I55 De Vries, MC I94I-I945, 36-37. Zie voor de vooroorlogse ziekenfondsstrijd bijv. ook: Herman Pinkhof, 'De ziekenfondsstrijd te Utrecht', Nederlands Tijdschrift voor Geneeskunde. 78 (I934) 9II-9I2. I56 Ongedateerd, vermoedelijk februari 1943, Nationaal Archief Medisch Contact 2.19.053.02, inv.nr. 22.

I57 J.J. Brutel de la Rivière, 'Het artsenverzet', 
in: C.D.J. Brandt (red.), Onderdrukking en verzet. Nederland in oorlogstijd. Deel 2 (Arnhem/Amsterdam 1949-1954) 347-376, 370.

I58 De Vries, MC I94I-I945, 68.

I59 Ongedateerd, Nationaal Archief Medisch Contact 2.19.053.02, inv.nr. 22. I60 De Vries, MC I94I-I945, 69. I6I NIOD DOC I, inv.nrs. 248, I86I; Zie ook: Harry Oosterhuis en Marijke Gijswijt-Hofstra, Verward van geest en ander ongerief. Psychiatrie en geestelijke gezondheidszorg in Nederland (I870-2005) (Houten 2008) 490; De Moei, Het leven niet waard, 57-58; Cecile aan de Stegge, Gekkenwerk. De ontwikkeling van het beroep psychiatrisch verpleegkundige in Nederland I830-1980 (Maastricht 2012) I046. I62 De Lang, Het oorlogsdagboek van Dr. G. Italie. Den Haag, 345, 2I februari 1943.

I63 Van Baalen, Joods leven in Deventer, I63.

I64 De Vries, MC I94I-I945, 89.

\section{ALS KAPITEINS OP EEN ZINKEND SCHIP}

I De Jong, 'De Ondergang van het Nederlandsche Jodendom', II.

2 Dagboek Berthold Stokvis, NIOD, 244, inv. nr. II49, 245; Wielek, De oorlog die Hitler won, I46.

3 Dagboek Salomon Koster, NIOD 244, inv. nr. 996, I62.

4 Typoscript over het voormalige Joles-ziekenhuis in Haarlem, auteur mogelijk S.L. Anholt, ca. I950, Joods Historisch Museum, document ooor3989. 5 Aus der Fünten en Abraham Asscher, David Cohen, Edwin Sluzker 28-I-I943, NIOD 182, inv. nr. Id.

6 Ibidem.

7 Notulen van de 75ste vergadering van de CC, vrijdag 8 januari, I3-I-I943, NIOD I82, inv.nr. 9 b.

8 Somers, Voorzitter van de Joodse Raad, I46.

9 Quispel, 'M. Elzas 50 jaar doctor medicinae', I206-I207. De patiënten werden allen vergast in Sobibor. Omdat Elzas op de Barneveldlijst stond, kwam hij met een deel van zijn gezin in Theresienstadt terecht, waar zij, op een dochter na, de oorlog wisten te overleven. http://rotterdam.joodsamsterdam.nl/gebjoodsziekenhuis.htm

Io M. Elzas, 'Een en ander uit de geschiedenis van het Joodse ziekenhuis te Rotterdam', 7, Joods Historisch Museum, document 13990.

II Ibidem.

I2 Presser, Ondergang, deel een, 34I.

I3 Hartogh, De Joodsche Invalide, 2; Ook in:

Dagboek Jacques Reisel, 26-2-I943, privécollectie familie Reisel.

I4 Hartogh, De Joodsche Invalide, 2.

I5 Rose, The Tulips Are Red, 94.
I6 Hartogh, De Joodsche Invalide, 3.

I7 In het Duits geschreven briefje van 4 maart I943, onbekende afzender en aangeschrevene, in inventaris Joodsche invalide, NIOD DOC II, inv.nr. I2I4.

I8 Rena Fuks-Mansfeld, so jaar Ji I9II-I96I (Amsterdam I96I) 65.

I9 Notitie voor David Cohen van Max Plotske 4-3-I943, NIOD I82, inv.nr. 4d.

20 In het Duits geschreven briefje van 4 maart 1943, onbekende afzender en aangeschrevene in inventaris Joodsche invalide, NIOD DOC II, inv.nr. I2I4.

2I Daar beviel zijn vrouw Emmy op 7 juli 1943 van hun tweede zoon Victor Jochanan, zie: Het Joodsche Weekblad, 3 (1943) I5, 2, I6 juli. Dit jongetje zou slechts I5 maanden oud worden. In oktober I944 werd hij met zijn moeder en broer Aron Joost in Auschwitz-Birkenau vergast. Het werk van hun vader als arts bij de Ji en in Westerbork, de poging van professor Cohen om het gezin op de Barneveldlijst te krijgen, alsmede de Portugese afstamming van zowel Jacques als Emmy zouden niet afdoende blijken om het gezin te redden. Jacques Buzaglo kwam op 28 februari 1945 om in een extern kommando bij Bad Warmbrunn, zie: www.joodsmonument.nl; Somers, Voorzitter van de Joodse Raad, I60. 22 Joodsche invalide I3-3-I943, NIOD DOC II, inv. nr. I2I4.

23 Dagboek Jacques Reisel, 26-2-I943, privécollectie familie Reisel.

24 Ibidem.

25 Ibidem. 
26 Van der Boom, 'Wij weten niets van hun lot', I3O.

27 Dagboek Jacques Reisel, 5-3-I943, privécollectie familie Reisel.

28 Ibidem.

29 Ibidem.

30 Ibidem.

3I Dagboekje Salomon Kroonenberg, privécollectie familie Kroonenberg, Amsterdam.

32 Dagboek Salomon Koster, NIOD 244, inv. nr. 996, I54.

33 Gesprekken met Bettie Weijl, d.d. 9-I2-2009 en I-4-20IO.

34 Gesprekken met Kees Kroonenberg, d.d. I2-32009, 2-4-2009, 23-4-2009. Ook in: samenvatting inlichtingen Dr. de Vries Robles en broeder Poons Amsterdamsch Joodsch Psychiatrisch gezelschap, 2I-8-I946, NIOD DOC II, inv.nr. 30B.

35 Dagboekje Salomon Kroonenberg, privécollectie familie Kroonenberg, Amsterdam.

36 Ibidem.

37 Dagboek Jacques Reisel, 5-3-I943, privécollectie familie Reisel, Amsterdam.

38 Dagboek Salomon Koster, NIOD 244, inv. nr. 996, I54.

39 Gesprekken met Kees Kroonenberg, d.d. I2-32009, 2-4-2009, 23-4-2009.

40 Louis Schaap, 'In memoriam Dr. S. Kroonenberg', Nederlands Tijdschrift voor Geneeskunde. 1962 (I06 I.) nr. I, 49.

4I Dagboek Jacques Reisel, 5-3-I943, privécollectie familie Reisel.

42 Joodse Ereraad, zr. Broekman, getuigenis van

zr. Cohen, Stadsarchief cIz 795, inv.nr. 24.

43 Ibidem.

44 Joodse Ereraad, ongedateerd, onbekende schrijver, 'puntsgewijze beantwoording van de zoogenaamde "aanklacht”, Stadsarchief cIz 795, inv.nr. 24, Desalniettemin werd directrice Broekman in 1946 door de Joodse Ereraad berispt om haar optreden. zie: NIW 20-I2-I946, bekendmakingen Joodse Ereraad.

45 Joodse Ereraad, ongedateerd, onbekende schrijver, 'puntsgewijze beantwoording van de zoogenaamde "aanklacht”, Stadsarchief CIZ 795, inv.nr. 24 .
46 Pimentel zelf dacht na de oorlog dat Jacobson al in 1942 ondergedoken was, zie: Typoscript van M.H. Pimentel, 'De geneeskundige verzorging en ziekenverpleging der Joden in Amsterdam van I804-I940', ca. I950, I5, Joods Historisch Museum, document 0oor3988. Dat zou echter niet kunnen kloppen met de getuigenissen in Stadsarchief cIz, 795. Volgens gegevens Claims Resolution Tribunal: http://www.crt-II.org/_awards/_apdfs/JacobsonGranaat_Rosa.pdf zat Jacobson ondergedoken op een boerderij, waar hij werd verraden en opgepakt. I6-4-20I4.

47 Correspondentie David Cohen met comm. voor niet-commerc. ver. en stichtingen, NIOD I82, inv.nr. 6a.

48 De Jong, Koninkrijk, deel zeven, deel een, 294.

49 Huispost Jvvvv: lijst met alle inrichtingen

I7-2-I943, NIOD I82, inv.nr. 4C.

50 Brief van David Cohen aan Edwin Sluzker 8-3-I943, NIOD I82, inv.nr. 6 .

5I Notulen van de 83ste vergadering van de CC, vrij 3 maart, IO-3-I943, NIOD I82, inv.nr. 9b.

52 7-4-I943 en IO-3-I943 notulen JVvVV, NIOD I82, inv.nr. $33 \mathrm{~d}$.

53 Dagboek Salomon Koster, NIOD 244, inv. nr. 996, I54.

54 Ibidem, I87, NIOD 244.

55 Wilhelmina Gasthuis, door de bezetter omgedoopt tot 'Wester Gasthuis'.

56 Mirjam Bolle-Levie, Ik zal je beschrijven hoe een dag er hier uitziet. Dagboekbrieven uit Amsterdam, Westerbork en Bergen-Belsen (Amsterdam, 2003) 77, I8-3-1943.

57 Testimony Betty Levie, janı975, Yad Vashem Archives 0.3, file number 3968.

58 IO-3-I943, notulen JVvvv, NIOD I82, inv.nr. 33d.

59 Dagboekje Salomon Kroonenberg, privécol-

lectie familie Kroonenberg.

60 Notulen vergadering Joodsche Raad II-3-I943, NIOD I82, inv.nr. IC.

6I IO-3-I943: notulen JVvVV, NIOD I82, inv.nr. 33d.

62 Ibidem.

63 Ongedateerd, vermoedelijk maart I943: notulen Joodsche Vereniging voor Verpleging en Verzorging, NIOD I82, inv.nr. 33d: besloten werd dat het aan hoogleraar kindergeneeskunde Simon 
van Creveld zou worden toegestaan een nieuwe kinderkliniek op te richten voor Joodse kinderen in Amsterdam-Oost. De Jvvvv zou de kosten hiervoor, met name de huur van een polikliniekruimte aan de Pretoriusstraat nummer i8, a $f$ 40,- per maand, op zich nemen. In deze kliniek zou, behalve Van Creveld zelf, ook arts Karel de Leeuw gaan werken, ondersteund door verpleegster Mientje Speyer-Leon. Zij werden hierdoor allen gesperrt. 64 IO-3-I943: notulen JVvVV, NIOD I82, inv.nr. $33 \mathrm{~d}$.

65 7-4-1943, notulen JVvvv, NIOD I82, inv.nr. 33d.

66 Veerman, Wijhe, 86.

67 Brief van David Cohen aan de Beauftragte I2-4-I943, NIOD I82, inv.nr. 7c.

68 Brief van G. Czaczkes van de Aerztliche Verbindungsstelle aan de voorzitters van de Joodsche Raad I5-6-I943, NIOD I82, inv.nr. 5a. waarvan 435 patiënten en 530 personeelsleden.

69 Presser, Ondergang, deel een, 344.

70 Gesprek met Arnold Rodrigues Pereira, d.d. 4-IO-2OII; Dagboek Benedictus Koopman, NIOD 244 , inv.nr. 1160 .

7I Dagboek Benedictus Koopman, maandag 24 mei I943, NIOD 244, inv.nr. II60.

72 Op I6 juli 1943 werd hij vermoord in Sobibor: http://www.joodsmonument.nl/person/482777/ nl 9-4-20I4.

73 De Jong, Koninkrijk, deel zeven, deel een, 302.

74 Brief Herman Herschel gericht aan Rob Goudsmit, Amsterdam, 24-7-I994, privécollectie familie Goudsmit.

75 Ibidem.

76 Joods Historisch Museum, Spielberg-interview Sophie Souget-Blindeman.

77 Brief Herman Herschel gericht aan Rob

Goudsmit, Amsterdam, 24-7-I994, privécollectie familie Goudsmit.

78 Ibidem.

79 Ibidem; gesprekken met Rob Goudsmit, d.d. 19-2-2009, 23-4-2009.

80 Mededeling van de heer Aberle van de Ji 28-5I943, NIOD I82, inv.nr. 5a.

8I In een kasoverzicht van de Hollandsche Schouwburg werd voor de balans van januari 1943 nog geen medische dienst opgenomen; pas toen de zieken uit hun huizen waren gehaald, werd deze dienst waarschijnlijk in het leven geroepen, NIOD I82, inv.nr. 34c.

82 Dagboek Berthold Stokvis, NIOD, 244, inv. nr. II49, 249.

83 Asscher-Pinkhof, Danseres zonder benen, I49.

84 Joods Historisch Museum, Spielberg-interview Virrie de Vries Robles.

85 Van Vree en Berg (red.), De Hollandsche Schouwburg, I39.

86 Dagboek Salomon Koster, NIOD 244, inv. nr. 996, I82.

87 Alex Bakker, Dag pap, tot morgen. Joodse kinderen gered uit de crèche (Hilversum 2005) 9.

88 Dagboek Salomon Koster, NIOD 244, inv. nr. 996, I82.

89 Bert Jan Flim, Omdat hun hart sprak. Geschiedenis van de georganiseerde hulp aan Joodse kinderen in Nederland 1942-1945 (Kampen 1996) I38; Bakker, Dagpap, tot morgen, I8; Joods Historisch Museum, Spielberg-interview Virrie de Vries Robles.

90 Joods Historisch Museum, Spielberg-interview Jo van der Hal.

9I Van Vree en Berg (red.), De Hollandsche

Schouwburg, I39. Gesprek met Jacques Barth, dd.

IO-O2-2015

92 Dagboek Joseph Kater, NIOD DOC I, inv. nr. 868A.

93 Göbel, Een hemel zonder vogels, 42.

94 Gesprekken met Bettie Weijl, d.d. 9-I2-2009 en I-4-20IO; Gesprekken met Kees Kroonenberg, d.d. 12-3-2009, 2-4-2009, 23-4-2009.

95 Dagboek Salomon Koster, NIOD 244, inv. nr. 996, I82.

96 Ibidem.

97 Klaartje de Zwarte-Walvisch, Alles ging aan flarden (Amsterdam 2009) 35-36.

98 Dagboek Salomon Koster, NIOD 244, inv. nr. 996, 173 .

99 Manuscript: 'De GG en GD en de oorlog van I940-I945, niet gedateerd, onbekende schrijver, Stadsarchief Amsterdam GG en GD 30I4O, inv.nr. 5I; Verklaring Charlotte Ruys 4 juni I945, NIOD 284 artsenzuivering, inv.nr. 5.2. Van directeur Tuntler is bekend dat hij geen lid was van het Medisch Contact, wat hem na de oorlog verdacht maakte. 
Hij werd dan ook aan een zuiverings-onderzoek onderworpen. Hoogleraar Charlotte Ruys kwam echter voor hem op en meende dat hij altijd een anti-Duitse houding had gehad, maar had gemeend dat zijn eigen methoden effectiever waren dan de methode die het Medisch Contact hanteerde; Hartogh, De Joodsche Invalide, 8.

IOo Thijs Gras en Gerrit Rottink, De broeders van de Breukendienst. Ioo jaar eerste hulp en ziekenvervoer door de GGD Amsterdam I908-2008 (Amsterdam 2008) 94-95.

IOI Dagboek Berthold Stokvis, NIOD, 244, inv. nr. II49, 247; Dagboek Salomon Koster, NIOD 244, inv. nr. 996, I80.

IO2 Hartogh, De Joodsche Invalide, 8.

IO3 Ibidem.

IO4 Ibidem.

Ios Gesprek met Ans Samama- Polak, d.d. I6 oktober $201 \mathrm{I}$.

Io6 Dagboek Berthold Stokvis, NIOD, 244, inv. nr. II49, 272.

IO7 Gesprek met Ans Samama-Polak, d.d. I6IO-2OII. Komt ook overeen met herinneringen van Magda van Emde Boas, manuscript in privéarchief familie van Emde Boas, Amsterdam.

Io8 Joodsche Raad cartotheek, Rode Kruis Den Haag.

Io9 Schütz, Vermoedelijk op transport, 49.

IIo Gesprekken met Bettie Weijl, d.d. 9-I2-2009

en I-4-20IO; gesprek met Sam en Ruth Bos-

Watermann, d.d. 26-2-2009; gesprek met Maurits Frenkel, d.d. 22-2-2009; gesprekken met Kees

Kroonenberg, d.d. 12-3-2009, 2-4-2009, 23-4-2009; gesprekken met Max Hamburger, d.d. 28-IO-2008, I4-5-2009, I6-7-2009; gesprek met Arnold Rodrigues Pereira, d.d. 4-IO-20II.

III Gesprekken met Bettie Weijl, d.d. 9-I2-2009 en I-4-20IO.

II2 Gesprek met Sam en Ruth Bos-Watermann, d.d. 26-2-2009.

II3 Bob Reinalda, 'Jan Meilof IJben I9I3-I989: leraar geschiedenis met een verzetsverleden' (Leur: z.u. I mei 20II) 7, kopie manuscript in bezit auteur. Refereert aan de Yad Vashem onderscheiding die Meilof IJben kreeg.

II4 Presser, Ondergang, deel een, 376.
II5 Dagboek Berthold Stokvis, NIOD, 244, inv. nr. II49, 272.

II6 Manuscript Magda van Emde Boas-Starkenstein, privécollectie familie van Emde Boas.

II7 Dagboek Berthold Stokvis, NIOD, 244, inv. nr. II49, 277.

II8 Dagboekje Salomon Kroonenberg, privécollectie familie Kroonenberg.

II9 Gesprek met Sam en Ruth Bos-Watermann, d.d. 26-2-2009; Joods Historisch Museum, Spielberg-interview Johnny van Coevorden. I2O Gesprekken met Kees Kroonenberg, d.d.

I2-3-2009, 2-4-2009, 23-4-2009.

I2I Ibidem; gesprek met Sam en Ruth Bos-

Watermann, d.d. 26-2-2009; gesprekken met Max Hamburger, d.d. 28-IO-2008, I4-5-2009, I6-7-2009; gesprekken met Bettie Weijl, d.d. 9-I2-2009 en I-4-20IO; gesprekken met Sally van Coevorden, d.d. 2I-I-2009 en I3-8-2009; Joods Historisch Museum, Spielberg-interview Elly PruikenmakerMonnickendam; Dagboek Berthold Stokvis, NIOD, 244, inv. nr. II49, 277.

I22 Dagboek Jacques Reisel, 3-8-I943, privécollectie familie Reisel.

I23 Somers, Voorzitter van de Joodse Raad, I79.

124 De Jong, Koninkrijk, deel zeven, deel een, 285.

I25 Coen Stuldreher, De legale rest. Gemengd gehuwde Joden onder de Duitse bezetting (Amsterdam 2007) 277.

I26 Ibidem, 292.

I27 Ibidem, 398.

I28 De Jong, Koninkrijk, deel zeven, deel een, 287.

I29 Verklaring W.L. Loeb, NIOD, 25oi, inv.nr. 475.

I30 Testimony Juutje Duitscher in I990, Yad

Vashem $\mathrm{O}_{3}$, inv.nr. 5832.

I3I Joodse Ereraad verslag Zr. Broekman, Stadsarchief Amsterdam CIZ 795, inv.nr. 24.

132 Presser, Ondergang, deel een, 360.

I33 Ibidem.

I34 Correspondentie David Cohen en Rombach 22-5-I943, NIOD I82, inv.nr. Id; brief David Cohen aan Beauftragte 3I-5-I943 en 7-6-I943, NIOD I82, inv.nr. 7c; brief van David Cohen aan bestuur JI 3-6-I943, NIOD I82, inv.nr. 5a; Moore, Victims and Survivors, I25. De betrokkenen moesten zelf voor hun behandeling betalen. Als zij de kosten voor 
operatie en ziekenhuisverpleging niet zelf konden dragen, konden zij zich wenden tot de Joodsche Raad. Deze declareerde de kosten dan bij de Beauftragte voor de stad Amsterdam. Op deze manier hoefde de Joodsche Raad ook niet de financiële verantwoordelijkheid te dragen.

I35 Brief van David Cohen aan Jvvvv 20-5-I943, NIOD I82, inv.nr. 5a; Vergadering JR 20-5-I943, NIOD I82, inv.nr. Ic.

I36 Hartogh, De Joodsche Invalide, 5; Verklaring van Barend Kroonenberg, kok in de Joodsche Invalide I947, NIOD 250i, inv.nr. IIO2.

I37 Hartogh, De Joodsche Invalide, 5.

I38 Brief van G. Czaczkes van de Aerztliche Verbindungsstelle aan de voorzitters van de Joodsche Raad I5-6-I943, NIOD I82, inv.nr. 5a.

I39 Gesprek met Carel Wolff, d.d. 30-IO-2008, 25-4-2009 en 2-II-2009.

I40 www.kb.nl De Vrije Stem I5-5-I943.

I4I Estafettebericht 20 mei I943, Nationaal Archief Medisch Contact 2.19.053.02, inv.nr. 8.

I42 Moore, Victims and Survivors, I26.

I43 www.kb.nl 15-7-1943: De Stem van Vrij Nederland; voor God, Koningin en Vaderland, brief van de kerken van Nederland aan de Rijkscommissaris. I44 De Jong, Koninkrijk, deel zeven, deel een, 289. De Rooms-Katholieke kerk en diverse protestantse kerkgenootschappen.

I45 www.kb.nl 3-6-43 'Jodenleed in Nederland', Trouw, I (I943) 6.

I46 Göbel, Een hemel zonder vogels, 47; BolleLevie, Ik zal je beschrijven, I54, 20-7-1943; Joods Historisch Museum, Spielberg-interview Jetty van Geens.

I47 De Jong, Koninkrijk, deel zeven, deeleen, 293. I48 Visser e.a., Witte jassen en bruinhemden, 22I.

I49 In Coppenhagen/Van Lieburg wordt in dit verband ten onrechte de Nederlandse arts Abraham Ligtenstein genoemd. Een en ander geschiedde overigens nadat het Salomon Lichtenstein in Westerbork niet gelukt was zich niet-Joods te laten verklaren en zo de dans te ontspringen. Op zijn Joodsche Raad cartotheek-kaart staat genoteerd dat Lichtenstein hiertoe een verzoek indiende op 29 april 1943 .

I50 Wielek, De oorlog die Hitler won, 315.
I5I Presser, Ondergang, deel een, 359.

I52 Brief van Banning aan min. van Sociale Zaken 4-9-1945, Nationaal Archief min van Sociale Zaken afdeling Volksgezondheid 2.I5.37, inv.nr. II47. Deze correspondentie werd gevoerd in het kader van de vraag of Lichtenstein zijn bevoegdheid als arts mocht behouden. Banning was tegen. De minister volgde Bannings advies en Lichtenstein mocht niet meer praktiseren.

I53 Dagboek Jacques Reisel, 3-8-I943, privécollectie familie Reisel.

I54 De Jong, Koninkrijk, deel zeven, deel een, 296.

I55 Benno Stokvis, in bezettingstijd (Amsterdam I967) I7.

I56 Wielek, De oorlog die Hitler won, 317.

I57 Moore, Victims and Survivors, I25.

I58 Stokvis, Advocaat in bezettingstijd, I7; Moore, Victims and Survivors, I25; Stuldreher, De legale rest, 293.

I59 Stuldreher, De legale rest, 304-305.

I60 Notulen van de 98ste vergadering van de CC I8-6-I943, NIOD I82, inv.nr. 9b.

I6I Brief van G. Czaczkes van de Aerztliche Verbindungsstelle aan de voorzitters van de Joodsche Raad I5-6-I943, NIOD I82, inv.nr. 5a; In de Ji: plus 26 familieleden of direct personeel dat in de JI verblijf hield wegens onbewoonbaarheid van hun eigen woningen of die vielen onder de categorie van personen die door hun oponthoud in de JI beschermd waren.

I62 Notulen van de 99ste vergadering van de CC I6-7-I943, NIOD I82, inv.nr. 9b.

I63 Ibidem.

I64 Notulen van de Iooste vergadering van de CC 20-7-I943, NIOD I82, inv.nr. 9b.

I65 De Jong, Koninkrijk, deel zeven, deel een, 296; Somers, Voorzitter van de Joodse Raad, I80; Stuldreher, De legale rest, 300.

I66 Stokvis, Advocaat in bezettingstijd 26.

I67 Richter Roegholt, 'Steriel bedrog tegen de ster', Het Parool 22-I-I998, pag. I5, NIOD DOC II, inv. nr. 1007.

I68 Augustus 1943, estafettebericht, Nationaal Archief Medisch Contact 2.19.053.02, inv.nr. 22. I69 Brief van M.N. Roegholt Nationaal Archief 26-5-1945, Nationaal Archief Medisch Contact 
2.19.053.02, 22 .

I70 Stuldreher, De legale rest, 306.

I7I Richter Roegholt, 'Steriel bedrog tegen de ster', Het Parool 22-I-I998, pag. I5, NIOD DOC II, inv. nr. 1007 .

I72 Stokvis, Advocaat in bezettingstijd, 2I; Richter Roegholt, 'Steriel bedrog tegen de ster', Het Parool 22-I-I998, pag. I5, NIOD DOC II, inv.nr. IOO7.

I73 Richter Roegholt, 'Steriel bedrog tegen de ster', Het Parool 22-I-I998, pag. I5, NIOD DOC II, inv. nr. I007; het verhaal van Roegholt wordt bevestigd in: Maaike Meijer, M. Vasalis. Een biografie (Amsterdam 2OI2) $33 \mathrm{I}$

I74 Stokvis, Advocaat in bezettingstijd, 28.

I75 Verslag 22 maart 1944, Nationaal Archief Medisch Contact 2.I9.053.02, inv.nr. 45.

I76 De Lang, Het oorlogsdagboek van Dr. G. Italie, 458: 20 april I944.

I77 Bericht van een onderhoud met Dr. Fritz Spanier 23-5-I946, NIOD 250i, inv.nr. 5II.

I78 Verklaring van Barend Kroonenberg, kok in de Joodsche Invalide, I947, NIOD 250i, inv.nr. IIO2. I79 Herinneringen van Prof.dr. Albert Salomon, NIOD DOC II, inv.nr. I007; Wielek, De oorlog die Hitler won, 3I5.

I80 Pereira-d'Oliveira, Vrouwen feministen, 62.

I8I Mechanicus, In Dépôt, 38, I2-6-I943.

I82 Verslag van dr. Ottenstein, NIOD 250i, inv. nr. $5 \mathrm{IO}$.

I83 Mechanicus, In Dépôt, 40.

I84 Joods Historisch Museum, Spielberginterview Anita Leeser-Gassan. Een van hen was het jonge meisje Anita Gassan, dat zich Meyer herinnert als een 'hele goede Duitser'. Zij voelde zich in de CIz en later in de Ji beschermd tegen razzia's die buiten plaatshadden; Moore, Victims and Survivors, I53.

I85 Dagboekje Salomon Kroonenberg, privécollectie familie Kroonenberg.

I86 Joods Historisch Museum, Spielberg-interview Herman Herschel.

I87 Joods Historisch Museum, Spielberg-interview David Moffie.

I88 Presser, Ondergang, deel een, 385 .

I89 Gesprek met Ed van Thijn, d.d. 27-2-20I2;

Ed van Thijn, Achttien adressen (Amsterdam 2004)
23-24.

I90 Gesprekken met Bettie Weijl, d.d. 9-I2-2009 en I-4-20Io; gesprek Sam en Ruth Bos-Watermann d.d. 26-2-2009.

I9I Dagboekje Salomon Kroonenberg, privécollectie familie Kroonenberg, Amsterdam; De schatting van het aantal patiënten volgens Israëls en Mooij, Aan de Achtergracht, I37, is dus aan de krappe kant.

I92 Gesprek met Margot Plesser-Dunner, d.d. 6-2-20II; Dagboekje Salomon Kroonenberg, privécollectie familie Kroonenberg, Amsterdam.

I93 Hartogh, De Joodsche Invalide, 7.

I94 Gesprekken met Bettie Weijl, d.d. 9-I2-2009 en I-4-20IO.

I95 Hartogh, De Joodsche Invalide, 9.

I96 Joods Historisch Museum, Spielberg-interview Johnny van Coevorden; Hartogh, De Joodsche Invalide, Io; Rose, The Tulips Are Red.

I97 J.A. Ader, Een Groningse pastorie in de storm (Franeker I947); gesprek Sam en Ruth Bos-

Watermann d.d. 26-2-2009: Ruth Watermann was afkomstig uit het Groningse Hogeland en op verzoek van vrienden van haar ouders ging dominee Bastiaan Ader haar uit Amsterdam halen. Ader zou echter gearresteerd en gefusilleerd worden; Moore, Victims and Survivors, I54-I55, verwijst er ook naar. I98 Dagboek Berthold Stokvis, NIOD, 244, inv. nr. II49, 286.

I99 Gesprekken met Max Hamburger, d.d. 28-IO2008, I4-5-2009, I6-7-2009. 200 Gesprek met Kees Kroonenberg, d.d. 25-52010.

2OI Dagboek Berthold Stokvis, NIOD, 244, inv. nr. II49, 286.

$2 \mathrm{O} 2$ Dagboekje Salomon Kroonenberg, privécollectie familie Kroonenberg; Gesprekken met Kees Kroonenberg, d.d. I2-3-2009, 2-4-2009, 23-4-2009. 203 Somers, Voorzitter van de Joodse Raad, I83. 204 Dagboekje Salomon Kroonenberg, privécollectie familie Kroonenberg. De twee oudste jongens, Sal en Lex, hadden kans gezien het huis tijdens de arrestatie te ontvluchten. In Westerbork kon Kroonenberg zelf weliswaar een functie als arts bekleden, maar hij kon daarin niet voorkomen dat zowel zijn eigen moeder als zijn schoonmoeder 
gedeporteerd en vergast werden. Zoon Kees, 20 jaar, werd op is februari 1944 alleen naar BergenBelsen gedeporteerd, terwijl Salomon en Sebilla op 4 september 1944 naar Theresienstadt werden gevoerd. Hier overleefden zij de oorlog, om na de bevrijding met hun ondergedoken zoons Sal en Lex en hun gevluchte dochter en haar gezin herenigd te worden. Wonder boven wonder keerde ook zoon Kees levend uit Tröbitz terug.

205 Schaap, 'In memoriam Dr. S. Kroonenberg',
49.

206 Joodsche Raad cartotheek, Rode Kruis Den

Haag; Hes, Jewish physicians in the Netherlands, I28-I29.

207 Hij verloor zijn jongste dochter tijdens hun verblijf in Theresienstadt, zie: De Lang, Het oorlogsdagboek van Dr. G. Italie, 534, I5 feb 1945. 208 www.joodsmonument.nl; Hes, Jewish physiscians in the Netherlands; Joodsche Raad cartotheek, Rode Kruis Den Haag.

\section{BEVOORRECHT?}

I Ongedateerd naoorlogs verslag van Louis Schaap over oorlogservaringen, vermoedelijk aan broer A. Schaap, privécollectie familie Schaap.

2 Dagboek Jacques Reisel, 26-2-I943, privécollectie familie Reisel.

3 Dagboek Jacques Reisel, 5-3-I943, privécollectie familie Reisel.

4 Dagboek Salomon Koster, NIOD 244, inv. nr. 996, 193 .

5 Brief van arts W. Polak aan geneeskundig inspecteur I-9-I942, Nationaal Archief Geneeskundige Hoofdinspectie 2.I5.38, inv.nr. 35. Men schreef Banning en Verwey aan en dezen namen op hun beurt contact op met de directeur-generaal en de Rijkscommissaris.

6 Brief van arts W. Polak aan geneeskundig inspecteur I-9-I942, Nationaal Archief Geneeskundige Hoofdinspectie 2.15.38, inv.nr. 35 .

7 Brief van Verwey aan Reichskommissar I9-91942, Nationaal Archief Geneeskundige Hoofdinspectie 2.15.38, inv.nr. 35 .

8 Brief van J. Brandon, JRvA aan Schaap 2I-II943, privécollectie familie Schaap.

9 Het Joodsche Weekblad vanaf juli I942. Op 2 oktober wordt de laatste vermelding van telefoonnummers van Rotterdamse artsen gevonden.

Io Brief van Spijer aan Banning 4-9-1942,

Nationaal Archief Geneeskundige Hoofdinspectie 2.I5.38, inv.nr. 35 .

II Dagboek Berthold Stokvis, NIOD, 244, inv. nr. II49, 232.

I2 Geen datering, waarschijnlijk tweede helft maart 1943, NIOD I82, inv.nr. Ia.

I3 Bijvoorbeeld Frits Grewel, getuige de stukken in zijn persoonlijk archief: Stadsarchief I5OI, inv. nr. 84; Annemiek Onstenk, Annemarie Grewel. Een portret (Amsterdam 2008) I9-20.

I4 Nordheim, From Rebuke to Rejoicing, 240.

I5 Brief van LiRo aan Deutsche Krankenkasse 24II-I942, NIOD 09I Deutsche Krankenkasse, inv.nr. 2 d. Per verordening 58/42 van 23 mei 1942 mochten ziekenfondsen geen rechtstreekse betalingen aan Joodse artsen meer doen, maar moesten de bedragen overgemaakt worden op een algemene rekening van de bank Lipmann en Rosenthal. Dit weliswaar met 'nauwkeurige specificatie' en onder vermelding van de namen en adressen van de desbetreffende doktoren, maar of de vergoeding dan ook daadwerkelijk bij hen terechtkwam moet men betwijfelen. I6 Mapje met correspondentie afdeling medische zaken; 'Betaling van onkosten voor medische hulp aan Joden', NIOD I82, inv.nr. I2C; Zie ook: NIOD I82, 32c,32d en 9 h.

I7 Dagboek Salomon Koster, NIOD 244, inv. nr. 996, I28.

I8 Dagboek Berthold Stokvis, NIOD, 244, inv. nr. II49, 57 .

I9 Ibidem, I99.

20 Ibidem.

2I Ibidem, I93.

22 Dagboek Jacques Reisel, I9-7-I943, privécol-

lectie familie Reisel. 'Ad matai' is hebreeuws voor: hoelang nog?

23 Dagboek Berthold Stokvis, NIOD, 244, inv. nr. 
II49, 232.

24 Ibidem.

25 Map Stokvis Calmeyer-archief, Centraal

Bureau voor Genealogie Den Haag.

26 Stokvis, Advocaat in bezettingstijd, 33. Dit

fragment gaat waarschijnlijk over hemzelf, ook al vermeldt hij dat niet expliciet.

27 Brief van Jaap Spanjaard aan de hoofdredacteur van De Groene, n.a.v. arrestatie Cohen en Asscher, IO-II-I947, privécollectie familie Spanjaard. 28 Overigens lukte het ook Jaap Spanjaard om uiteindelijk te worden gecalmeyerd.

29 Dagboek Jacques Reisel, 7-2-I943, privécollectie familie Reisel.

30 Boudewijn Smits, Loe de Jong I9I4-2005.

Historicus met een missie (Amsterdam 20I4) II9-I2O en 150 .

3 I Smits, Loe de Jong, I44-I47. Sally de Jong stond overigens ook op de Calmeyerlijst van 27-IO-I942, NIOD 77, inv.nr. I429. Kennelijk had hij ook daartoe een poging ondernomen.

32 Emailwisseling met Bart de Cort, 28-2-20I3, op basis van gesprek met dochter Mani Leisen, en tevens gesprek met Virrie de Vries Robles, d.d. 28 augustus 2012.

33 De Lang, Het oorlogsdagboek van Dr. G. Italie, 344: 2I feb i943.

34 Presser, Ondergang, deel twee, 400-40r; Verslag van bezoek JR aan Vught, 4 mei I943, Joods Historisch Museum, document 00000784; Notulen vergadering JR 4-5-I943, NIOD I82, inv.nr. IC; Aanvragen voor reisvergunningen voor $\mathrm{S}$. van Creveld, NIOD I82, inv.nrs. 4C en 5a; Simon van Creveld,

" Kindergeneeskunde" in een concentratiekamp', Nederlands Tijdschrift voor Geneeskunde 90 (I946) $225-227,226$.

35 Ongedateerd naoorlogs verslag van Louis Schaap over oorlogservaringen, vermoedelijk aan broer A. Schaap, privécollectie familie Schaap, Amsterdam.

36 Dagboek Salomon Koster, NIOD 244, inv. nr. 996, I91.

37 Dagboek Jacques Reisel, II-2-I943, privécollectie familie Reisel, Amsterdam.

38 Veerman, Wijhe, 86.

39 Joodsche Raad cartotheek, Rode Kruis Den
Haag.

40 Dagboek Jacques Reisel, I2-3-I943, privécollectie familie Reisel, Amsterdam.

4I Ibidem.

42 Presser, Ondergang, deel een, 439.

43 Cijfers Barneveld: De Schaffelaar en De Biezen, NIOD Barneveld 25ob, inv.nr. 70.

44 Namenlijst Barneveld I5-5-I943, NIOD 25ob, inv.nr. 67 en Barneveld administratie, NIOD IOIb, inv.nr. 764 .

45 De Munnick, Uitverkoren in uitzondering? inleiding.

46 Joods Historisch Museum, Spielberg-interview Simon Frenkel, zoon van Lion en Carolina Frenkel.

47 Boris de Munnick, Uitverkoren in uitzondering?, Het verhaal van de Joodse 'Barneveld-groep' I942-I945 (Barneveld I99I) 32; gesprek met Herman van Praag, d.d. 5-2-2009.

48 Brief Rachel Weijl-Snuijf aan familie van Leverink 7-7-I943, privécollectie familie de Beer.

49 Brief van Kroonenberg aan Banning 25-III942, Nationaal Archief Geneeskundige Hoofdinspectie $2 . \mathrm{I} 5.38$, inv.nr. 4I.

50 Brief van Banning aan Kroonenberg 27-II1942, Nationaal Archief Geneeskundige Hoofdinspectie 2.15 .38 , inv.nr. 4I.

$5 \mathrm{I}$ Brief van Banning aan regionale inspecteurs 2-I2-I942, Nationaal Archief Geneeskundige Hoofdinspectie, 2.I5.38, inv.nr. 4I.

52 Brief van FA Schalij aan Banning I2-4-I943, Nationaal Archief Geneeskundige Hoofdinspectie, 2.I5.38, inv.nr. $4 \mathrm{I}$.

53 Brief van Banning aan FA Schalij I5-4-I943, Nationaal Archief Geneeskundige Hoofdinspectie, 2.I5.38, inv.nr. 4I.

54 Knegtmans, Een kwetsbaar centrum van de geest, II6.

55 Brief van J.C. Schippers aan Banning 2-3-I943, Nationaal Archief Geneeskundige Hoofdinspectie, 2.I5.38, inv.nr. 4I.

56 Brief van inpecteur In 't Veld van Zuid-

Holland aan Banning 3-I2-I942, Nationaal Archief Geneeskundige Hoofdinspectie, 2.I5.38, inv.nr. 4I; Abraham Jacobson werd niet op de lijst geplaatst. Hij dook onder, maar op 3 september 1944 werd 
ook hij gedeporteerd en vermoord in AuschwitzBirkenau.

57 Brief van inspecteur v.d. Brekel van NoordHoll aan Banning 27-I-I943, Nationaal Archief Geneeskundige Hoofdinspectie, 2.15.38, inv.nr. 4I; Marinus Mortier Hijmans kreeg inderdaad een vermelding op de lijst Frederiks. Vanwege zijn huwelijk met een niet-Joodse vrouw kon hij in zijn eigen huis in Den Haag blijven wonen, waar hij het bombardement op het Bezuidenhout en de oorlog zou overleven.

58 CEC-cartotheek, Rode Kruis Den Haag.

59 De Lang, Het oorlogsdagboek van Dr. G. Italie, 362, 9 april 1943 .

60 Brief van Tuntler aan Banning I7-4-I943,

Nationaal Archief Geneeskundige Hoofdinspectie, 2.I5.38, inv.nr. 4I.

6I Brief van Banning aan Tuntler 2I-4-I943,

Nationaal Archief Geneeskundige Hoofdinspectie, 2.I5.38, inv.nr. 4I.

62 Brief van Prof.dr. A. de Kleijn aan Banning I3-I2-I942, Nationaal Archief Geneeskundige Hoofdinspectie, 2.I5.38, inv.nr. 4I.

63 Brief van I. Bloch aan Banning 23-5-1943,

Nationaal Archief Geneeskundige Hoofdinspectie, 2.I5.38, inv.nr. $4 \mathrm{I}$.

64 Joodsche Raad cartotheek, Rode Kruis Den Haag.

65 www.thuisinbrabant.nl/personen/d/diamantprocent2c-salomon. 9-4-20I4. http://www. boschboom.nl/Download/columns/Deprocent2oBoschboomprocent20I5042007procent20I4procent2oTheoprocent2oHoogbergen.pdf 9-4-20I4.

66 Brief van J. Goudsmit aan Banning 29-5-1943, Nationaal Archief Geneeskundige Hoofdinspectie, 2.15.38, inv.nr. 4I.

67 Brief van Banning aan Goudsmit 4-6-I943, Nationaal Archief Geneeskundige Hoofdinspectie, 2.15.38, inv.nr. 4I.

68 Brief van Goudsmit aan Banning 25-8-1943, Nationaal Archief Geneeskundige Hoofdinspectie, 2.I5.38, inv.nr. 4I; Afgewezen aanvraag voor Barneveld voor Goudsmit, NIOD Iorb, inv.nr. 303.

69 Brief van Goudsmit aan Banning I-6-I943,

Nationaal Archief Geneeskundige Hoofdinspectie, 2.I5.38, inv.nr. 4I.
70 Joods monument Zaanstreek, Benedictus

Premsela: http://www.joodsmonumentzaanstreek. nl/pagina-I435-Wessel-Max.htm 9-4-20I4.

7I Gesprek met Diny Boas-Vedder, d.d. 5-II-20II.

72 Ongedateerd verslag van bijeenkomst bij

Generaal Praag, Niod Iorb, inv.nr. I68.

73 Brief van dep. BiZa aan A.E. Denekamp barak 35 Westerbork 19-2-I943, NIOD 25ob, inv.nr. 74.

74 Brief van A.E. Denekamp aan Kloosterman

9-I-I943, NIOD IOIb, inv.nr. 330.

75 Privécollectie familie Denekamp, Amsterdam.

76 Joodsche Raad cartotheek, Rode Kruis Den

Haag.

77 Verzoek van A. Rombach en N. Muller van het Ned Gen tot zedelijke verbetering der gevangenen t.b.v. Lobstein 7-4-I943, NIOD IOIb, inv.nr. 3IO. 78 Verzoek voor J. de Hartogh JR. zonder afzender 5-7-I943, NIOD IOIb, inv.nr. 304.

79 Blijkens de dossiers in Nationaal Archief 2.15.38, inv.nr. 4I en NIOD Barneveld Iorb.

80 Ibidem.

8I Verslag van een bezoek aan Generaal Praag door een medewerker van het Riod 26-2-I952, NIOD 25ob, inv.nr. 78 .

82 Brief van Banning aan Kloosterman I6-4-I943, Nationaal Archief Geneeskundige Hoofdinspectie 2.I5.38, inv.nr. 4I.

83 Dagboek Jacques Reisel, 4-5-1943, privécollectie familie Reisel.

84 Rapport over medische en hygiënische toestand De Schaffelaar en De Biezen, door inspecteur L.A. Veeger maart I943, NIOD IoIb, inv.nr. I79.

85 Dagboek Jacques Reisel, 4-5-I943, privécollectie familie Reisel.

86 Cartotheek Barneveld, NIOD Iorb, inv.nr. 764; Opnamen van roodvonk-patiënten uit Barneveld in het NIZ, NIOD IOIb, inv.nrs. 443-446.

87 Brief van Wolthuis aan Beauftragte I-6-I943, NIOD IoIb, inv.nr. 447.

88 Gesprek met Diny Boas-Vedder, d.d. 5-II-20II. 89 Ruth van der Meij, Hartelijke groeten. Berichten uit concentratiekampen (Uithoorn 20I2) 37: brief van M.L. Muller aan huishoudster Adry, I8-7-I943. 90 Brief van M.L. Muller aan burgemeester Utrecht II-9-I942, NIOD IOIb, inv.nr. 3I2. 9I Ibidem. 
92 Brief van gynaecoloog Dr Heyster aan Frederiks 26-9-I942, NIOD IOIb, inv.nr. 3I2; Steunvraag voor Muller van dr. F.C. van Tongeren en Prof.

Michael 24-IO-I942, NIOD IOIb, inv.nr. 3I2; Poging voor Muller van vijftien leden van de medische faculteit Utrecht I4-II-I942, NIOD IoIb, inv. nr. 328; Poging van Banning voor Muller I5-I2-I942, NIOD Iorb, inv. nr. 328; Van der Meij, Hartelijke groeten, I6-I8.

93 Verzoek van Hemmes aan Banning om Muller voor te dragen 25-II-I942, Nationaal Archief Geneeskundige Hoofdinspectie 2.15.38, inv.nr. 4I.

94 Muller, Aan de poort van het leven, 79.

95 http://micha.reisel.net/memor/dagboek.htm 9-4-20I4.

96 Van der Meij, Hartelijke groeten, 43: brief van Rebekka Muller-Wolff aan huishoudster Adry I2-9-I943.
97 Gesprek met Philippine van der Feltz-Muller, d.d. 3-I2-2OII.

98 Toespraak, gehouden op 13-9-I943 ter gelegenheid van de begrafenis van Dr. M.L. Muller, door Dr. G.W. Oberman, ned.-herv. predikant te Utrecht. Kopie in bezit auteur. Uit privécollectie familie Muller.

99 Dagboek Maurits Muller, 7-9-1940, http:// micha.reisel.net/memor/dagboek.htm 3-9-20I4. IOO www.joodsmonument.nl Oudste dochter Ina Muller stierf echter in december 1945, waarschijnlijk ten gevolge van gezondheidsproblemen opgelopen tijdens de oorlog.

IOI Gesprek met Philippine van der Feltz-Muller, d.d. 3-I2-2OII.

IO2 Dagboek Jacques Reisel, I2-3-I943, privécollectie familie Reisel.

\section{DE LEGALE EN DE ILLEGALE REST}

I Moore, Victims and Survivors, I2I.

2 Geraldien von Frijtag Drabbe Künzel, Het geval Calmeyer (Amsterdam 2008) 9.

3 Ibidem, I58-I59.

4 Von Frijtag Drabbe Künzel, Het geval Calmeyer;

Ruth van Galen-Hermann, Calmeyer, dader of mensenredder? Visies op Calmeyers rol in de Jodenvervolging (Soesterberg 2009); Stuldreher, De legale rest; Stokvis, Advocaat in bezettingstijd, 36 .

5 Dagboek Berthold Stokvis, NIOD, 244, inv. nr. II49, 269.

6 Joodsche Raad cartotheek, Rode Kruis Den Haag en Stadsarchief Amsterdam, Uva faculteit geneeskunde 30265 , inv.nrs. 647-654 en 950 en NIOD 77 , inv.nr. I429 en NIOD 20, inv.nr. I507.

7 Schütz, Vermoedelijk op transport, 40.

8 Laurens de Rooy, Snijburcht. Lodewijk Bolk en de bloei van de Nederlandse Anatomie (Amsterdam 2OII) 234 .

9 Cornelius U. Ariëns Kappers, Reiziger in breinen. Herinneringen van een hersenonderzoeker (Amsterdam 200I) 2II.

IO Juda Swaab, Hansje Marchand en hun dochter zouden de oorlog niet overleven. www.joodsmo- nument.nl.

II Documenten in privécollectie familie Spanjaard.

I2 Stuldreher, De legale rest, 217.

I3 Bepaling over heffing bij afstammingsonderzoek 24-5-I943, NIOD 20, inv.nr. 18I6: 'er is een recht verschuldigd van a. $f$ 3,50 voor de afgifte van een afstammingsbewijs, waarvoor de afstamming tot de grootouders wordt onderzocht. B. $f \mathrm{I}, 50$ voor de afgifte van een voorlopig afstammingsbewijs. Het onder a bedoelde recht wordt bij uitbreiding van het onderzoek tot verdere voorouders vermeerderd met $f$ 0,25 voor iedere ten behoeve daarvan te controleeren akte.'

I4 Privécollectie familie Lopes Cardozo, Cambridge.

Is Calmeyerlijst, aanvulling 2I-II-I942, NIOD 77, inv.nr. 1429 .

I6 Joodsche Raad cartotheek, Rode Kruis Den Haag.

I7 Brief van Pol. Angestellte 9-I-I943, NIOD 77, inv.nr. I308.

I8 Brief van mr. L.J. Hijmans van den Bergh aan Frederiks 27-IO-I942, NIOD IoIb, inv.nr. 5 I. 
I9 J.H. Pannekoek, 'De clinicus, onderzoeker en leermeester Abraham Albert Hijmans van den Bergh (I869-1943)' Nederlands Tijdschrift voor Geneeskunde. 1993; 137:1982-7; Hes, Jewish physicians in the Netherlands.

20 NIOD 2O, inv.nr. I532; Von Frijtag Drabbe Künzel, Het geval Calmeyer, I37.

2I Dossiers De Froe Stadsarchief Amsterdam 30265 , inv.nr. 647-654 en 950.

22 Arie de Froe, De anthropologie van de zoogenaamde Portugeesche Joden in Nederland (Amsterdam 1943).

23 Brief van Calmeyer aan Generalkommissar fur das Sicherheitswesen IO-7-I943, NIOD 77, inv. nr. 1262 .

24 Correspondentie Caspary oktober en november 1943 met General Kommissar Wimmer, Beauftragte van Amsterdam en Reichskommissar NIOD 20, inv.nr. 355 .

25 Von Frijtag Drabbe Künzel, Het geval Calmeyer, I38-139; Joods Historisch Museum,

Spielberg-interview Elsa Rodrigues Pereira-Jessurun d'Oliveira.

26 Elsa Jessurun d'Oliveira, agenda 20 feb I944, privécollectie familie Rodrigues Pereira, Amsterdam.

27 Meihuizen, Smalle marges, II8-II9; Von Frijtag Drabbe Künzel, Het geval Calmeyer, I39-I40.

28 Joods Historisch Museum, Spielberg-interview Elsa Rodrigues Pereira-Jessurun d'Oliveira.

29 Gesprek en correspondentie met M.M. Wagenaar-Fischer, d.d. I5-II-20II.

30 'Vermerk zum Stand der Judenfrage am 5.IO.I943' 5-IO-I943, NIOD 20, inv.nr. I492.

3I Opgaven van sternbefreite en gesteriliseerde Joden, NIOD 77, inv.nrs. I438 en I444.

32 Joodsche Raad cartotheek, Rode Kruis Den Haag.

33 Stuldreher, De legale rest; Stokvis, Advocaat in bezettingstijd, 282.

34 Ongedateerde lijst van op Barneveldlijst geplaatsten Joodsche Raad cartotheek kaart, NIOD Iorb, inv.nr. I6o; Marjo J.G.W. van Daal en Annemarie de Knecht-van Ekelen, Joannes Juda Groen (I903-I99o), een arts op zoek naar het ware welzijn (Rotterdam I994) 84.
35 Joannes J. Groen, Asthma bronchiale seu nervosum, een psychosomatische studie (Amsterdam I950); Joannes J. Groen, Psychogenese en psychotherapie van colitis ulcerosa (Amsterdam 1947); H.G.M. Rooijmans, 'Stokvis en de psychosomatiek', in: Nederlands Tijdschrift voor Geneeskunde. 138 (1994) 52, 26II-26I4.

36 Van Daal en de Knecht-van Ekelen, Joannes Juda Groen, 79.

37 Ibidem, 82.

38 Herzberg, Kroniek, I55.

39 Loonlijst Ji 3-Io december 1943, Stadsarchief Amsterdam Joodsche Invalide I213, inv.nr. 63; B. Heyl spreekt van ongeveer 70 Joden in de Joodsche Invalide: B. Heyl, Het vergeten hoofdstuk binnen de geschiedenis van de gezondheidszorg (Nieuwerkerk a/d IJssel 2006) 285.

40 Hartogh, De Joodsche Invalide, Io.

4I Verslag van verhoor Josefine Goudsmit door Hauptsturmbannführer Moehse in Theresienstadt I944, privécollectie familie Goudsmit, Amsterdam; biografische schets van Sally Dunner, Yad Vashem en privécollectie familie Dunner, Jeruzalem; Joodsche Raad cartotheek, Rode Kruis Den Haag. 42 Loonlijst Ji 3-Io december 1943, Stadsarchief Amsterdam Joodsche Invalide I2I3, inv.nr. 63.

43 Brief van Goudsmit aan Banning I-6-I943, Nationaal Archief Geneeskundige Hoofdinspectie, 2.I5.38, inv.nr. 4I.

44 Verslag van verhoor Josefine Goudsmit door Hauptsturmbannführer Moehse in Theresienstadt I944, privécollectie familie Goudsmit, Amsterdam. 45 Gesprek Margot Plesser-Dunner, d.d. 6-2$20 I I$.

46 Wielek, De oorlog die Hitler won, 317.

47 CIZ archiefstukken, Stadsarchief Amsterdam 795 , inv.nr. 67.

48 Reinalda, 'Jan Meilof IJben', 8.

49 Joodsche Raad cartotheek, Rode Kruis Den Haag.

50 Isidoor de Vries, De vreemde waarheid: herinneringen van een joodse jongen (I92I-I948) (Apeldoorn 1995) 88-89; De Vries Robles stond op de Calmeyerlijst van 8-9-42 NIOD 77, inv. nr. I429. 5I Gesprek met Virrie de Vries Robles, d.d. 28 augustus 2012. 
52 Freud, Mijn naam is Freud, I24-I25.

53 Brief van Schering A.G. Berlin aan Befehlshaber der SiPo und SD I-II-I940, NIOD 77, inv.nr. I307.

54 Tausk, Organon, 210.

55 Saskia Goldschmidt, Verplicht gelukkig (Amsterdam 2OII) III-II3.

56 Peter Jan Knegtmans, Geld, ijdelheid en

hormonen. Ernst Laqueur, hoogleraar en ondernemer (Amsterdam 20I4) 230.

57 Felix Hermann Oestreicher, Ein jüdischer Arztkalender. Durch Westerbork und Bergen-Belsen nach Tröbitz. Konzentrationslager-Tagebuch I943-I945 (Konstanz 2000) 36.

58 Ongedateerd verslag door E. Laqueur, op verzoek van P. Goldschmidt opgeschreven, NIOD 77, inv.nr. 1307

59 Verklaring höhere ss- und Polizeiführer I6-2I944, NIOD 77, inv.nr. I307.

60 Matthias Middelberg, Judenrecht, Judenpolitik und der Jurist Hans Calmeyer in den besetzten Niederlanden 1940-1945 (Göttingen 2005) 347-353. 6I Brief van Zöpf aan Befehlshaber der SiPo und SD 8-6-1944, NIOD 77, inv.nr. 1307; Knegtmans, Geld, ijdelheid en hormonen, 249-252.

62 N. Waterman, correspondentie betreffende Watermans particuliere laboratorium tijdens de oorlogsjaren 1940-I945, correspondentie van zijn vrouw in Westerbork, Boerhaave Museum, Leiden, MB, a 264, met dank aan mw. Mieke de Mots en het Boerhaave Museum te Leiden; http:// www.historad.nl/nl/\#!/nl/Ioo-jaar-radiotherapieantoni-van-leeuwenhoek-oorlogsjaren/joodsemedewerkers-ontslagen-op-last-van-bezetter/ I7-4-20I4; J.W. Duyff, 'N. Waterman 50 jaar doctor in de geneeskunde', Nederlands Tijdschrift voor Geneeskunde. I957, I0I, 374.

63 Brief van Burgemeester Amsterdam aan Böhmcker 24-II-I94I, NIOD DOC II, inv.nr. 36I.

64 N. Waterman, correspondentie, Boerhaave Museum te Leiden.

65 Dagboek Salomon Koster, NIOD 244, inv. nr. 996, 194.

66 Gesprek met Carel Wolff 20I2, filmopname in bezit van Joods Historisch Museum Amsterdam.

67 Moore, Survivors, $2 \mathrm{I} 2$.
68 Pelzman, En verder geen leed, 63-64.

69 www.joodsmonument.nl

70 Presser, Ondergang, deel twee, 260.

7I Brief Lena Jacobs-Melkman, I9-IO-I942, via dhr. Wim Westerhoff.

72 Ibidem.

73 Ibidem.

74 Hans Ziekenoppasser, 'Stem uit het verleden', NIW 27, 3-4-20I2, 69-7I.

75 Van der Hal, Het mesje, 45.

76 Gesprek met Henriëtte Ophir-van der Hal I4II-20Io, en met Bettine Polak, d.d. IO-IO-20II.

77 Dagboek Joseph Kater, NIOD DOC I, inv. nr. $868 \mathrm{~A}$.

78 Moore, Victims and Survivors, I46. Zie ook: Herzberg, Kroniek, 318.

79 Zoals bijvoorbeeld van de Amsterdamse huisarts Willem Cohen bekend is dat deze bij een patiënte onderdook: mail Robert Cohen 19-220II; of bijvoorbeeld Joods Historisch Museum, Spielberg-interview, Julius Leydesdorff; Spielberginterview Sijze Schortinghuis: deze bood zijn huisarts Jacob Hamburger uit Boskoop een onderduikplek; Spielberg-interview Abraham Querido: deze dook onder bij een Utrechtse collega met wie hij gestudeerd had.

80 Gesprekken met Ralph van Furth d.d. 27-I20II; Philip Rümke d.d. 4-2-20I4; Wanda Reisel d.d. 6-8-2013; Johannes Wagenaar 2-2-2013; Lea Dasberg, d.d.I4-2-20II; Joods Historisch Museum, Spielberg-interview Lowina de Levie; Dagboek Salomon Koster, NIOD 244, inv. nr. 996, 2 I2. 8I Dagboek Salomon Koster, NIOD 244, inv. nr. 996, 193 .

82 De Jong, Koninkrijk, deel zes, deel twee, 704. 83 Artsenverzet, ongedateerd estafettebericht: 'De Nederlandsche Volksgezondheid in gevaar'. Vermoedelijk in begin I943 geschreven, NIOD DOC II, inv.nr. 64

84 Nationaal Archief Medisch Contact

2.19.053.02, inv.nr. 44.

85 Visser e.a., Witte jassen en bruinhemden, I4; Voute, Only a Free Man, 64-65; Joop D. Kila, De kille aan het Marsdiep (Den Helder I999) II9. 86 Gesprek met Sam Bos en Ruth Bos-Watermann d.d. 26-2-2009: Burema zou later directeur 
van de Rotterdamse GGD worden.

87 Moore, Victims and Survivors, I8O-I8I.

88 Ingrid Lutke Schipholt, 'We waren onmis-

baar. Dokterstitel boodt huisarts Gerritsma een zekere bescherming', Medisch Contact 64 (2009) I8, 80o-8or.

89 F. Klein, 'In Memoriam A.A. Kerssemakers', Nederlands Tijdschrift voor Geneeskunde I07 (1963) 3IO-I.

90 W.S. Cost, J. Eeftinck Schattenkerk, J.

Roos, 'In Memoriam Dr. W.F. Noordhoek Hegt', Nederlands Tijdschrift voor Geneeskunde I27 (1983) 235I; Moore, Victims and Survivors, I82; Visser e.a., Witte jassen en bruinhemden, 94; Charley Fiedeldij Dop, 'Bruggen Bouwen', Auschwitz Bulletin 58 (20I4) I, 8-9.

9I De Jong, Koninkrijk, deel zes, deel twee, 700: stelt dat dit geen laakbare vorm van discriminatie is, maar ingegeven door veiligheidsoverwegingen.

92 Nederlandsche Artsenkamer, ledenlijst I943, NIOD DOC II, inv.nr. 498.

93 De Jong, Koninkrijk, deel zes, deel twee, 704.

94 Notulen vergadering dagelijks bestuur NMG I3-9-I94I, Nationaal Archief 2.I9.053.0I, inv. nr. 30. 95 Rede gehouden op de eerste plechtige bijeenkomst van 'Medisch Contact' te 's-Gravenhage door Dr W.F. Noordhoek Hegt 3I-5-I945, Nationaal Archief 2.I9.053.02, inv.nr. 46.

96 Hans Keilson, Komedie in Mineur (herziene versie, uit het Duits vertaald) (Amsterdam 20Io) 38. 97 Ibidem, 63.

98 Dagboek Salomon Koster, NIOD 244, inv. nr. 996, 208.

99 Ibidem.

Ioo Elisabeth van Blankenstein, Dr. M. van Blankenstein, een Nederlands dagbladdiplomaat I880-1964 (Leiden 1999).

IOI Presser, Ondergang, deel een, 267, citeert

Herman Musaph: 'Doodsdrift, castratie-complexen en depressie', 1948 .

IO2 Keilson, Komedie in Mineur, 39.

IO3 Ibidem, 42.

IO4 Dagboek Salomon Koster, NIOD 244, inv. nr. 996, 208.

IO5 Gesprek met mw. Rosetta Musaph-Andriesse, d.d. 23-I0-2008. Naar later bleek waren het boeken die door het verzet geleend werden van professor van der Hoop, die na de bevrijding Musaphs eerste analyticus zou worden.

Io6 Gesprek met mw. Ilse de Haas-Vyth, d.d.

19-I-2009.

IO7 Emailcorrespondentie met dhr. M. Monnickendam.

Io8 Gesprek met Lydia Granaat-ten Doeschot,

d.d. II-9-20Io.

I09 Gesprek met familie Muller, d.d. 29-I-20I3, vals persoonsbewijs in bezit van de familie.

II Emailwisseling met Jan Oonk, september 20I2; Hans Cohen, 'The Book Nathan', manuscipt van zoon, kopie in bezit van auteur; Jan Oonk, 'Dokter Isaak Cohen in Halle. Joodse arts in de oorlog', Kronyck 37, nr.I48, juni 2013, 2-I2.

III Gesprek met Helene Levy, d.d. IO-4-20I2.

II2 Gesprekken met Sally van Coevorden, d.d.

2I-I-2009 en I3-8-2009.

II3 Gesprek met Jaap Klein, d.d. 20-8-20I2.

II4 NIOD Dagboeken, 244, I547: Alfred Behrendt, I5-4-I945.

II5 Dagboek Joseph Kater, NIOD DOC I, inv. nr. 868A.

II6 Gesprek met mw. A.W. Everts-Kuik, kleindochter van J. Teesselink, d.d. I4-7-20I4; emailcorrespondentie met mw. A.W. Everts-Kuik d.d. juli 2014 .

II7 Ibidem.

II8 Ibidem.

II) Ibidem.

I2O De Vries, M.C. I94I-I945, 47.

I2I Bolle-Levie, Ik zal je beschrijven, 90, 28-3-I943.

I22 Dagboek Joseph Kater, NIOD DOC I, inv. nr.

868A; NIOD 20, Generalkommissar fur Verwaltung und Justiz, inv.nr. 368; Brief van Schröder aan de Gen Komm fur Verwaltung und Justiz over artsen die zich inzake de artsenstaking 'besonders negativ hervorgetan haben' I-4-I943, NIOD 86, inv.nr. 55. I23 Mart J. van Lieburg, 'De echo van een eersaluut. Medisch contact en de manifestatie van collectiviteit en moraliteit in bezettingstijd', Medisch Contact 50 (I995) 48, I557-I559, I558.

I24 Dagboek Salomon Koster, NIOD 244, inv. nr. 996, 108.

I25 Archiefstukken Prof.dr. J.G.G. Borst, NIOD 
$2 \mathrm{I} 2 \mathrm{k}$, inv.nr. $2 \mathrm{~d}$.

I26 Archiefstukken Prof.dr. J.G.G. Borst, NIOD $2 \mathrm{I} 2 \mathrm{k}$, inv.nr. $2 \mathrm{a}$.

I27 Zo is daar het voorbeeld van Maurits Frenkel, die zich als Joods student volop gesteund voelde door zijn niet-Joodse vrienden en uiteindelijk ook door hen over de grens geholpen werd, waarna hij heelhuids in Zwitserland aankwam. Hij herinnerde zich van eerder de toespraak van Suze Taets van Amerongen, die als studente het woord richtte tot de ontslagen docent Juda Groen; haar ongenoegen daarover uitte en tegelijkertijd Groen alle lof gaf voor zijn verdiensten als docent: Gesprek met Maurits Frenkel, d.d. 22-2-2009; Van Daal en de Knecht-van Ekelen, Joannes Juda Groen, 77.

De Joodse studente Hanny Levie had eenzelfde moed getoond toen zij de dag na de invoering van de Jodenster in de collegezaal pal naast een NSBstudent was gaan zitten, gekleed in een lange jurk, van boven tot onder volgenaaid met de gehate gele sterren. Na aanvang van de deportaties was zij ondergedoken, werd gepakt, ontsnapte uit Westerbork en sloot zich aan bij het georganiseerde verzet. Haar verloofde Rudi Bloemgarten, eveneens medicijnenstudent en Joods, werd gefusilleerd vanwege betrokkenheid bij de overval op het bevolkingsregister. Bij deze overval waren ook de Joodse medisch studenten Leo Frijda en Wim de Rooij betrokken. Peter Brusse, 'Een verdwaalde kunstenares', Vrij Nederland, I4 november 2009; www.joodsmonument. $\mathrm{nl}$,; Braber, Zelfs als wij zullen verliezen, IIo en I23. I28 Gesprekken met Max Hamburger, d.d. 28-IO-2008, I4-5-2009, I6-7-2009; gesprekken met Willy Hijmans, d.d. I7-6-20IO, 2I-8-20IO; Identiteitsbewijs Frans verzet, I944 van 'Jacques Baruch, médécin’, privécollectie familie Baruch,
Amsterdam, kopie in het bezit van auteur. I29 Gesprek met Freek Polak, d.d. dec. 2008; http://resources.huygens.knaw.nl/bwn/BWN/lemmata/bwn6/polak I8-9-20I4. I30 Madelon de Keizer, Frans Goedhart. Journalist en politicus (I904-I9go) (Amsterdam 20I2) I09; David de Miranda stond model voor dokter Jacques Berger in: Maurits Dekker, De laars op de nek. Roman 1939-1945 (Leiden 1945). Hierin worden ook zijn activiteiten in de Hollandsche Schouwburg beschreven.

I3I Gesprek met Lydia Granaat-ten Doeschot, d.d. II-9-20Io.

I32 Gesprek met Joop Scheerman, wier moeder met Premsela zou hebben samengewerkt, d.d.

27-4-20I4.

I33 Gesprek met Selma Velleman, d.d. 4-II-2OI2. I34 www.joodsbw.nl; Emailwisseling met Bart de Cort,jan.- feb. 2013; Juul Muller, Nico Richter I9I5-I945 (Amsterdam z.u. 2003) digitale kopie in bezit van auteur.

I35 Hanna en Walter Kohner, Hanna en Walter, een liefdesgeschiedenis (Amsterdam 1985) 98; Aantekeningen van Magda van Emde Boas-Starkenstein, privécollectie familie van Emde Boas, Amsterdam; Julia Guttmann, 'My early life I9r9-1946 manuscript, privécollectie familie van Emde Boas. I36 Magda van Emde Boas-Starkenstein, 'Dokterchen', aantekeningen, privécollectie familie van Emde Boas.

I37 Braber, Zelfs als wij zullen verliezen, 87. I38 Testimony Betty Levie, janı975, Yad Vashem Archives 0.3, file number 3968.

I39 Oonk, 'Dokter Isaak Cohen in Halle', 2-I2, II.

I40 Joods Historisch Museum interview van

Philo Bregstein met Hans Keilson 29-3-I969.

\section{ARTS IN GEVANGENSCHAP}

I De Jong, Koninkrijk, deel acht, deel twee, 636.

2 Ibidem, 579-697.

3 Ibidem, 606.

4 Geraldien von Frijtag Drabbe Kunzel, Kamp Amersfoort (Amsterdam 2003) 78.
5 De Jong, Koninkrijk, deel acht, deel twee, 59I.

6 Wielek, De oorlog die Hitler won, I5o.

7 Gesprek met Martha ben Assa, 13-2-20II.

8 Von Frijtag Drabbe Kunzel, Kamp Amersfoort, II5; Cohen, Beelden wit de nacht, I4. 
9 Von Frijtag Drabbe Kunzel, Kamp Amersfoort, II2.

IO Ibidem, IO7.

II Cohen, Beelden uit de nacht, I2.

I2 Cohen, Beelden uit de nacht, I2.

I3 De Jong, Koninkrijk, deel acht, deel twee, 6I4-6I5.

I4 Ibidem, 6I4, verwijst naar het verslag van mededelingen van G. Tuynenburg Muys (7-II-I947) I3. I5 Ibidem, 6oI.

I6 Joodsche Raad cartotheek, Rode Kruis Den Haag; Dominicus, Mauthausen, II8; http://www. bevrijdingintercultureel.nl/bi/surijoods.html, I6 oktober 2013.

I7 Meeuwenoord, Mensen, macht en mentaliteiten achter prikkeldraad, 405.

I8 Ibidem, 406-407.

I9 Ibidem, I25.

20 Presser, Ondergang, deel twee, 39I; Meeuwenoord, Mensen, macht en mentaliteiten achter prikkeldraad, $\mathrm{I} 34$.

2I De Jong, Koninkrijk, deel 8, deel twee, 652.

22 www.joodsmonument.nl/community, Joods

Historisch Museum, document 7868; NIOD Erelijst Verzet en Koopvaardij, database made by J.W. de Leeuw; Coppenhagen, Anafiem Gedoe'iem, 93.

23 De Jong, Koninkrijk, deel acht, deel twee, 646

24 Joodsche Raad cartotheek, Rode Kruis Den Haag.

25 Verhoor Jacob Bramson, proces-verbaal gemeentepolitie Franeker 5-9-I947, NIOD 250g Vught, inv.nr. 397

26 Ibidem.

27 Ibidem.

28 Meeuwenoord, Mensen, macht en mentaliteiten achter prikkeldraad, II2 en I26-I27; Janneke de Moei, Joodse kinderen in het kamp Vught (Vught 1999) 55 .

29 De Zwarte-Walvisch, Alles ging aan flarden, 68. 30 Verslag B. Poppers-Prins 24 oktober 1945, NIOD 250g Vught, inv.nr. 708; De Moei, Joodse kinderen in het kamp Vught, 55 .

3I Verslag B. Poppers-Prins 24 oktober I945, NIOD $250 \mathrm{~g}$ Vught, inv.nr. 708.

32 Presser, Ondergang, deel twee, 400-40I;

Verslag van bezoek JR aan Vught 4 mei I943, Joods
Historisch Museum document 00000784; Notulen vergadering JR 4-5-I943, NIOD I82, inv.nr. IC; Aanvragen voor reisvergunningen voor $S$. van Creveld, NIOD I82, inv.nrs. 4c en 5 a.

33 Brief van Simon van Creveld over kindersterfte in Vught Io mei 1943 aan Kommandant ss- Hauptsturmfuhrer Chmielewsky, NIOD 25og Vught, inv. nr. 398 .

34 Somers, Voorzitter van de Joodse Raad, I6I.

35 Van der Hal, Het mesje, 52-53.

36 Ibidem, 53.

37 Ibidem, 52 .

38 Verhoor Jacob Bramson, proces-verbaal gemeentepolitie Franeker 5-9-I947, NIOD 25og Vught, inv.nr. 397.

39 De Zwarte-Walvisch, Alles ging aan flarden, 9I.

40 David Koker, Dagboek geschreven in Vught

(Amsterdam 1977) 79.

4I Ongedateerde brief van Louis Schaap, vermoedelijk vlak na de bevrijding geschreven aan zijn broer Adolph Schaap in Amerika, privécollectie familie Schaap, Amsterdam.

42 Ibidem.

43 Max Roeper, resp. brief uit het Huis van Bewaring in Groningen, okt. 1943 aan zijn echtgenote Louise Roeper-Piekema, en: Vught 3-II-I942 aan Ciel en Tom Verkade-Piekema. Joods Historisch Museum, 00008430 en 00008434.

44 Koker, Dagboek geschreven in Vught, 82.

45 De Zwarte-Walvisch, Alles ging aan flarden, 75.

46 Ibidem, 70-7I.

47 Mogelijk bij de Utrechtse niet-Joodse gynaecoloog Steyns, die veel hulp aan de Joodse collegae bood, volgens Ies van der Hal.

48 Gesprek met Judith Gobits en Benjamin Ricardo d.d. 4-5-2009; Gesprek met Ted van der Sluis-Springer en Meyer van der Sluis 4-IO-2009. 49 J.I. Furth, Auschwitz Bulletin 45, no.I, 45, op http://www.jodeninnederland.nl/id/P-I973, 20-8-20I3.

50 Gesprek met Arnold Rodrigues Pereira, d.d. 4-IO-2OII.

$5 \mathrm{I}$ Somers, Voorzitter van de Joodse Raad, I64. noot 277; Notulen 97ste vergadering CC van de JR vrijdag II juni I943, NIOD I82, inv.nr. 9 b. 52 Verhoor Jacob Bramson, proces-verbaal ge- 
meentepolitie Franeker 5-9-I947, NIOD $250 g$ Vught, inv.nr. 397.

53 Herzberg, Kroniek, 262.

54 J. Presser, Inleiding in: Mechanicus, In Dépôt, 7; Ook in: Somers, Voorzitter van de Joodse Raad.

55 Guido Abuys en Dirk Mulder, Genezen verklaard voor... een ziekenhuis in kamp Westerbork, 1939-1945 (Assen, 2006) 27.

56 Artsen van het allereerste begin waren Spanier, Praag, Weinberg en Nussbaum. Daarnaast waren er twee tandartsen, Schneemann en Rothschild, en twee apothekers, Rosenberg en Altmann.

57 Verklaring van dr. A. Bial opgenomen op IO-4I946, NIOD 250i, inv.nr. 496.

58 Verklaring van dr. A. Bial opgenomen op IO-4I946, NIOD 250i, inv.nr. 496.

Bericht van een onderhoud met Dr. F. Spanier op 23 mei 1946, NIOD 250i, inv.nr. 512.

59 De Jong, Koninkrijk, deel vier, deel twee, 754.

60 Jan Hendrik Boezeman, 09-7-1908,

Wildervank, zich in 1940 gevestigd hebbende in

Westerbork.

6I Verklaring van dr. A. Bial opgenomen op IO-4I946, NIOD 250i, inv.nr. 496.

62 Verordening van commandant Schol juli I940, NIOD 250i, inv.nr. 68

63 Verklaring van dr. A. Bial opgenomen op Io-4I946, NIOD 250i, inv.nr. 496.

Spanier was gevlucht uit Düsseldorf en in Westerbork terechtgekomen toen een deel van de opvarenden van het vluchtelingenschip de St. Louis, dat nergens welkom was en waarop Spanier scheepsarts was, in Westerbork was opgevangen.

64 De Jong, Koninkrijk, deel acht, deel twee, 725.

65 Verordening van Schol, 9-7-I94I, NIOD 250i, inv.nr. 78 .

66 Verordening van Schol, I9-II-I94I, NIOD 250i, inv.nr. 82 .

67 Verordening van Schol, 27-5-I94I, een zeker Lipinski, NIOD 250i, inv.nr. 76.

68 Verordening van Schol, 2-3-I94I, NIOD 250i, inv.nr. 73 .

69 Moraal, Als ik morgen niet op transport ga, 267. 70 Gerhard Hirschfeld, 'Niederlande', in: Wolfgang Benz, Dimension des Völkermords: die Zahl der jüdischen Opfer des Nationalsozialismus (München
I99I) I37-I67, I62.

7I Abuys en Mulder, Genezen verklaard voor...,

28 .

72 De Jong, Koninkrijk, deel acht, deel twee, 734

73 Abuys en Mulder, Genezen verklaard voor..., 7.

74 Dr. Arthur Bial, Dr. Heinrich Bierer, Dr.

Siegfried Ledermann, Dr. Herbert Manheim, Dr. Friedrich Neubürger, Dr. Julius Nussbaum, Dr.

Werner Petzal, Dr. Franz Pick, Dr. Fritz Spanier, Dr. August Waterman, Dr. Meier Weinberg, NIOD 250i, inv.nr. 20.

75 Joodsche Raad cartotheek, Rode Kruis Den Haag, www.jhm.nl.

76 M.M. Hilfman, 'In Memoriam Dr. S.I. de

Vries', Nederlands Tijdschrift voor Geneeskunde II7 (I973) I44I-2. Hierin wordt ook vermeld dat De Vries zijn vrouw en kinderen tijdens de oorlog verloor.

77 Joodsche Raad cartotheek, Rode Kruis Den Haag.

78 Herinneringen van Paul Stibbe i992, Joods Historisch Museum, document I2624; Pronk,

'Zoals ik het mij herinner'.

79 Joodsche Raad cartotheek, Rode Kruis Den Haag, Martin de Jong.

80 Joodsche Raad cartotheek, Rode Kruis Den

Haag. Benjamin Frank ging direct door in nov. 42, Mozes Franzie in dec. 42, Pal Haasz al in sept., Lodewijk Meijers in aug. door, Lisamaria Meirowsky 2 aug. door, Arnold Norden nov. door, Marcus Samson in nov. gekomen, in dec. door, Leonard van Straten, Michel van Straten, Jacob van Veen, Hartog Vorst, Salomon Kottek, Joseph Abas.

8I Dr. I. Cohensius, geboren Oude-Tonge, I4II-I9IO, Lohamei Hagettaot, Holland Section, inv. nr. $4 \mathrm{I} 6$.

82 De Jong, Koninkrijk, deel acht, deel twee, 7OI.

83 www. joodsmonument.nl

84 Joodsche Raad cartotheek, Rode Kruis Den

Haag, www.joodsmonument.nl.

85 De Jong, Koninkrijk, deel acht, deel twee, 733.

86 Abuys en Mulder, Genezen verklaard voor..., 9.

87 Verklaring van Werner Stertzenbach voorjaar I945, NIOD 250i, inv.nr. 493.

88 Naoorlogs verslag van B. Chits, NIOD 25oi, inv. nr. III2. 
89 Joodsche Raad cartotheek, Rode Kruis Den Haag; Joods Historisch Museum, Spielberg-interview Mina Friedländer-Marcus.

90 Joods Historisch Museum, Spielberg-interview Ellis Hertzberger.

9I Hertzberger, Door de Holocaust verbonden, 55.

92 Joodsche Raad cartotheek, Rode Kruis Den Haag.

93 Joodsche Raad cartotheek, Rode Kruis Den Haag; overleg Aus der Fünten, David Cohen en Edwin Sluzker, I9-IO-I942, NIOD I82, inv. nr. Id; Cahen, Ik heb dit alles opgeschreven, 53 .

94 http://www.jodeninnederland.nl/id/P-82II, Joodsche Raad cartotheek, Rode Kruis Den Haag. 95 Verslag van onderhoud van beide voorzitters van de Joodsche Raad met Lages en Blumenthal op I7-II-I942, NIOD I82, inv.nr. Id; Brief van Abraham Asscher en David Cohen aan Lages I9-II-I942, NIOD I82, inv.nr. 6b.

96 Maurits de Levie (I898-I945) woonde en praktiseerde aan het Daniel Willinkplein 52 Amsterdam in: Coppenhagen, Anafiem Gedoe’iem, III.

97 Verslag van Dr. A. Bial over Westerbork, opgetekend op IO-4-I946, NIOD 250i, inv.nr. 496.

98 Presser, Ondergang, deel een, 430.

99 De Jong, 'De Ondergang van het Nederlandsche Jodendom', 7 .

Ioo De Jong, 'De Ondergang van het Nederlandsche Jodendom', 24.

IOI Mechanicus, In Dépôt, I9.

IO2 Zie bijv. Moraal, Als ik morgen niet op transportga, 304 .

IO3 De Jong, 'De Ondergang van het Nederlandsche Jodendom.

IO4 Ibidem.

IO5 Verordening van waarnemend commandant

J.I.M.J. Haan op 30-I2-I942, NIOD 250i, inv.nr. 95.

Io6 De Jong, 'De Ondergang van het Nederlandsche Jodendom'.

IO7 Notulen van de 67ste vergadering van de Contact Commissie op 30-IO-I942, NIOD I82, inv. nr. 9 b.

Io8 Notulen van de vergadering van de Contact Commissie van de JRvA, IO-I2-I942, NIOD I82, inv. nr. 9 b.

Io9 Notulen van de7Iste vergadering van de
Contact Commissie van de JRvA, 27-II-I942, NIOD I82, inv.nr. 9 b.

IIO Notulen vergadering Joodsche Raad, I7-I2I942, NIOD I82, inv.nr. Ic. De eerste van de drie barakken kwam gereed in januari 1943: Notulen van de vergadering van de Joodsche Raad I4-I-I943, NIOD I82, inv.nr. Ic.

III Notulen van de vergadering van de Contact Commissie van de JRvA, IO-I2-I942, NIOD I82, inv. nr. 9 b.

II2 Brief van Prof. dr. D. Cohen aan de Zentralstelle, I6-I2-I942, NIOD I82, inv.nr. 6b.

II3 Reisvergunning van twee dagen, NIOD 250i, inv.nr. 865 .

II4 Reisvergunningen van Simon Izak de Vries I-5-I9O2 te Hoorn, NIOD 25oi, inv.nr. 867.

II5 Verzoek en reisvergunningen van Dr. Nathan van Zuiden I6-I2-I942, NIOD 250i, inv.nr. 867.

II6 Mededelingen van kampcommandant augustus tot december I942, NIOD 250i, inv.nr. 459.

II7 Vermelding aantal patiënten in het ziekenhuis, tellingen kampsterkte, 28-II-I942 en 20-3I943, NIOD 250i, inv.nrs. 455 en 456.

II8 Notulen van de vergadering van de Joodsche Raad 25-I-I943, NIOD I82, inv.nr. IC.

II) Notulen van de vergadering van de 77 ste Contact Commissie van de JRvA 22-I-I943, NIOD I82, inv.nr. 9b. Zie ook: notulen van de 78 ste vergadering van de Contact Commissie van de JRvA 29-I-I943, NIOD I82, inv.nr. 9b.

I2O Brief van John van Lier uit Westerbork I2-2I943, Stadsarchief I066 CIK, inv.nr. I53.

I2I Westerbork 250i, inv.nr. 478.

I22 Sectieverslag door P. Stibbe I-7-I943, NIOD 250i, inv.nr. 48I.

I23 Ontslagpapieren van patiënten terugkerend naar Westerbork, getekend door wnd. geneesheer A. Bolt, gericht aan arts L.M. ter Horst, Heeresingel 2 en aan de kampcommandant van Westerbork van de periode 3O-IO-I942 tot 28 juni I943, NIOD 250 i, inv.nr. 45 I.

Onder de patiënten waren met name veel kinderen en volwassenen met infectieuze aandoeningen en mensen met ongespecificeerde buikklachten, maar ook 12 patiënten met maligne tumoren, Io met oogheelkundige problemen als cataract, 
glaucoom en netvliesloslating, 9 met maagklachten waarvan I overleed aan een maagperforatie, 7 met fracturen en 3 met schotwonden. Eén patient met een depressie werd behandeld, alsmede een patiënt met multiple sclerose. Ook mochten in enkele gevallen gevangenen voor een nieuwe bril naar Assen of voor een gehoorapparaat naar Groningen.

Zie: Mededelingen van kampcommandant augustus tot december 1942, NIOD 250i, inv.nr. 459. I24 Notulen van de 84ste vergadering van de Contact Commissie van de JRvA, I2-3-I943, NIOD I82, inv.nr. 9 b.

I25 Brief van Hanna Schaap aan onbekende geadresseerde I0-6-I945, privécollectie familie Schaap Amsterdam; Etty Hillesum, Het denkende hart van de barak. Brieven van Etty Hillesum (Haarlem 1982) 43, 23-6-I943.

I26 Joods Historisch Museum, Spielberg-interview Jetty en Renée Pinto.

I27 Wielek, De oorlog die Hitler won, 233.

I28 Naoorlogs verslag E.A. Cohen, NIOD, 250i, inv.nr. 1085 .

I29 Naoorlogse verklaring van Dr. Max Benjamin, geboren 16 mei 1889 te Schermbeck, gewoond hebbende Retiefstraat 48II, gepakt bij razzia op 20 juni 1943 in Oost, NIOD 250i, inv.nr. I085.

I30 Hertzberger, Door de Holocaust verbonden, 57-58.

I3I Verslag kampbelevenissen door Jacques Tas, privécollectie D. van Loggem, Amsterdam.

132 J. Presser, Inleiding in: Mechanicus, In Dépôt, 7.

I33 Van Creveld, "“Kindergeneeskunde” in een concentratiekamp', 226.

I34 Ibidem. Otitis is oorontsteking, mastoïditis is ontsteking van het processus mastoideus, het bot achter het oor, meestal een gevolg van otitis.

I35 De Jong, 'De Ondergang van het Nederlandsche Jodendom', 22-23.

I36 Hertzberger, Door de Holocaust verbonden, 57-58.

I37 Dit waren de barakken met de nummers 8I tot 85 , volgens: De Jong, 'De Ondergang van het Nederlandsche Jodendom', 22-23.

I38 Rapport over het aantal sterfgevallen in

Westerbork van 15-7-I942 tot I2-4-I945, NIOD 250i, inv.nr. 488.

I39 Th. Hammes, 'Dr. Hermanus Pinkhof. Een levensschets', Nederlands Tijdschrift voor Geneeskunde. 89 (1945) 25I-252, 25I; Zie ook: Het Joodsche Weekblad 3 (1943) I6, 2, 23 juli.

I4O Moraal, Als ik morgen niet op transport ga, 527. I4I Willy Lindwer, Kamp van hoop en wanhoop: getuigen van Westerbork 1939-I945 (Amsterdam 1990) 194: interview met Trudel Reemst-de Vries; Abuys en Mulder, Genezen verklaard voor..., 86-87. I42 De Moei, Joodse kinderen in het kamp Vught, 90-9I; Van Creveld, "Kindergeneeskunde” in een concentratiekamp', 226; Bestelbon voor Rijksmagazijn voor geneesmiddelen Amsterdam voor 'Maagsonde voor zuigelingen I, Maagsonde fur kleine Kinder I, Electr. Sterilisator $(220 \mathrm{~V})$ circa $32 x_{4} 4 \mathrm{~cm}$ I, Zuigcurette vlg. Dr. De Vink (Fabrikant: Loth te Utrecht) I, Gistingsbuisjes vlg. Einhorn (saccharometers) 6.' I4-8-I944, NIOD 250i, inv.nr. I77.

I43 Mechanicus, In Dépôt, I3-I4, 28-5-I943.

I44 Presser, Ondergang, deel twee, 337-338.

I45 Rosa van der Hal-Prins, de latere levenspartner van arts Sieg Emmering, in: Laansma, Eindstation Tröbitz, 64.

I46 Wielek, De oorlog die Hitler won, 197.

I47 Moraal, Als ik morgen niet op transport ga, 423.

I48 Verslag kampbelevenissen door Jacques Tas, privécollectie D. van Loggem, Amsterdam.

I49 Presser, Ondergang, deel twee, 338.

I50 Sieg van den Bergh, Deportaties. Westerbork,

Theresienstadt, Auschwitz, Gleiwitz (Bussum 1945) I3.

I5I Naoorlogs verslag Jacques Tas, privécollectie D. van Loggem, Amsterdam.

I52 Eveneens: gesprek met Louis Tas, d.d. okt. 2008.

I53 Dagboek Jacques Reisel, II-2-I943, privécollectie familie Reisel, Amsterdam.

I54 Cohen, Het Duitse concentratiekamp, I54-I55.

I55 Dagboek Jacques Reisel, II-2-I943, privécollectie familie Reisel, Amsterdam.

I56 Joodse Raad cartotheek, Rode Kruis Den

Haag; Herinneringen van Paul Stibbe I992, Joods

Historisch Museum, document I2624.

I57 Cohen, Het Duitse concentratiekamp, I54-I55.

I58 Mechanicus, In Dépôt, 70. 
I59 Joods Historisch Museum, Spielberg-interview Josephine Benninga-Warendorf. I60 Letty Ben Heled-Rudelsheim, Gesprekken met mijzelf in Auschwitz (Kampen 2003) 91; Albert Elgenant Denekamp (19I4-I979). Denekamp zou later directeur van het Sophia Ziekenhuis te Zwolle worden, zie: A.G.P. Cremers, 'In Memoriam A.E. Denekamp', Nederlands Tijdschrift voor Geneeskunde. I23 (1979) 768.

I6I Mechanicus, In Dépôt, I48-I49, 4-9-I943. I62 Joods Historisch Museum, Spielberg-interview Ellis Hertzberger.

I63 Herbert Kruskel, 'In Westerbork und BergenBelsen, September 1942-juli I944', NIOD 250i, inv. nr. 509, pag. I3.

I64 Naoorlogse verklaring van Paul Hertz, NIOD 250 i, inv.nr. I044.

I65 Naoorlogse verklaring van mw. VromensSnapper, NIOD 250i, inv.nr. 5I5.

I66 Lindwer, Kamp van hoop en wanhoop, I04: Interview met Jehoshua H. (Otto) Birnbaum en Hennie Birnbaum-Szaja.

I67 Verslag Jacques Tas, privécollectie D. van Loggem, Amsterdam.

I68 Verslag Jacques Tas, privécollectie D. van Loggem, Amsterdam.

I69 Naoorlogs verslag E.A. Cohen, NIOD, 250i, inv.nr. 1085 .

I70 De Volkskrant 27-IO-I993, artikel over E.A. Cohen.

I7I Naoorlogs verslag E.A. Cohen, NIOD 250i, inv.nr. 1085 .

I72 Ibidem.

I73 Ibidem.

I74 Zoals dat nu eenmaal een algemeen menselijk verschijnsel is.

I75 Hillesum, Het denkende hart van de barak, 46: zonder datum, omstreeks 26-6-I943.

I76 De Jong, 'De Ondergang van het Nederlandsche Jodendom', 25 .

I77 Mechanicus, In Dépôt, I46, 3I-8-I943.

I78 Naoorlogs verslag E.A. Cohen, NIOD, 250i, inv.nr. 1085 .

I79 Naoorlogse verklaring Alexander Holländer die werkte bij de Registratur, I4-9-I945, NIOD 250i, III8.
I80 Mechanicus, In Dépôt, I03, 31-7-I943.

I8I De Jong, 'De Ondergang van het Nederlandsche Jodendom', 22-23.

I82 Naoorlogs verslag E.A. Cohen, NIOD 250i, inv.nr. I085; Verslag in Londen bekend 20-8-43, NIOD 250i, 516, 527: zeer negatief t.o.v. houding Spanier; Verslag Werner Stertzenbach, jan 45, NIOD 250i, 493 en 5I3: zeer negatief t.o.v. houding Spanier; Positief over hem zijn: Sam Stern, Ziekenbroeder in kamp Westerbork (Westerbork 2004) 25, Verslag Birnbaum weeshuis, NIOD 250i, inv.nr. 497. I83 Naoorlogs verslag E.A. Cohen, NIOD, 250i, inv.nr. 1085 .

I84 Ibidem.

I85 Interview met E.A. Cohen in Algemeen Handelsblad, 24-I-I970, knipselarchief NIOD KB I 9388. I86 Interview met E.A. Cohen in Nieuw Israëlitisch Weekblad, 2-5-1970, knipselarchief NIOD KB I 9388.

I87 Interview met E.A. Cohen in De Volkskrant, 27-IO-I993, knipselarchief NIOD KB I 9388.

I88 Details over uitgaande transporten gebaseerd op gegevens van de OD, NIOD 250i, inv.nr. 208.

I89 De Jong, 'De Ondergang van het Nederlandsche Jodendom', 23.

190 Presser, Ondergang, deel twee, 319.

I9I Joods Historisch Museum, Spielberg-interview Ellis Hertzberger.

192 Ibidem.

I93 Dagboek Jacques Reisel, 7-2-I943, privécollectie familie Reisel, Amsterdam.

194 Dagboek Jacques Reisel, II-2-I943, privécollectie familie Reisel, Amsterdam.

I95 Mechanicus, In Dépôt, I46-I47, 3I-8-I943.

196 Presser, Ondergang, deel twee, 319.

I97 Brief van John van Lier uit Westerbork I2-21943, Stadsarchief Amsterdam I066 CIK, inv.nr. I53. I98 Ibidem.

I99 Brief van Elsa Jessurun d'Oliveira in Westerbork aan verloofde Paul Rodrigues Pereira 23-2-I944, privécollectie familie Rodrigues Pereira, Amsterdam.

200 Brief van Elsa Jessurun d'Oliveira in Westerbork aan verloofde Paul Rodrigues Pereira I5-3-I944, privécollectie familie Rodrigues Pereira, Amsterdam. 
20I Brief van Elsa Jessurun d'Oliveira in

Westerbork aan verloofde Paul Rodrigues Pereira 25-2-I944, privécollectie familie Rodrigues Pereira, Amsterdam.

202 Gesprek met Louis van Vollenhoven, Amsterdam 2009.

203 Mechanicus, In Dépôt, 123.

204 Verslag Jacques Tas, privécollectie D. van Loggem, Amsterdam.

205 Joods Historisch Museum, Spielberg-interview Ellis Hertzberger.

206 Brief van Haagse RIOD aan afwikkelingsbureau concentratiekampen 2-IO-I946, NIOD 250i, inv. nr. 332 .

207 Lagerbefehl Gemmeker 7-7-I943, NIOD 25oi, inv.nr. IIO; Mechanicus, In Dépôt, 75, 8-7-I943.

208 Mechanicus, In Dépôt, 8I, 13-7-1943.

209 De Wind, Eindstation Auschwitz, 9.

2IO David Moffie, naoorlogse getuigenis 1948, NIOD 25od, inv. nr. 700.

2II Naoorlogse verklaring van mw. F.C. de Leeuw-Bernard, NIOD 250i, inv.nr. I079.

2I2 Lagerbefehl Gemmeker I9-IO-I943 en 4-III943, NIOD 250i, inv.nrs. II3 en II4.

Naoorlogs verslag van Dr. Ottenstein, NIOD 250i, inv.nr. 510; Mechanicus, In Dépôt,185, I9-IO-I943.

2I3 Getuigenis Dr. Fritz Spanier, Landeskriminalamt, process Wilhelm Zöpf, 28-4-I960, NIOD.

2I4 Kommandanturbefehl Gemmeker, I-9-I943, NIOD 250i, inv.nr. I2I; Briefje van onbekende arts aan Dr. Pick, 23-IO-I943, NIOD 250i, inv.nr. 33; Verklaring van inentingsstatus, 8-7-I944, NIOD 250i, inv.nr. 473.

215 Mechanicus, In Dépôt, 94, 25-7-I943.

2 I6 20 aug 1943: verslag in Londen bekend, NIOD 250i, inv.nrs. 516 en 527.

2I7 Reglement voor barakkenleiders door waarnemend commandant Haan, I2-I2-I943, NIOD 25Oi, inv.nr. 126 .

2I8 Zeepverdelingslijst, I3-4-I944, NIOD 250i, inv. nr. 644 .

219 Joods Historisch Museum, Spielberginterview Diny Boas-Vedder; Gesprek met Diny Boas-Vedder, d.d. 5-II-20II.

220 Zie ook vermelding van de ziekenhuisopname van Hein Waterman en het contact met (latere hoogleraar biochemie) Max Gruber in de brieven van de echtgenote van Nathaniël Waterman vanuit Westerbork naar haar man in Amsterdam, Museum Boerhaave, Leiden. In een telefoongesprek d.d. 26-2-20I2, met A. Waterman, zoon van Prof. $\mathrm{H}$. Waterman, gaf deze aan zich niet te kunnen herinneren dat zijn vader tijdens de opname met experimentele antibiotica behandeld is. Wel was er volgens hem sprake van contact tussen zijn vader en Querido, ook over het penicillineonderzoek. 22I Marlene Burns, 'Wartime Research to Post-War Production: Bacinol, Dutch Penicillin, 1940-1950, in: Circulation of Antibiotics: Journeys of Drug Standards, I930-I970 (Madrid 2009) I8-I9; Ad Maas en Hans Hooijmakers, Scientific Research in World War II: What Scientists Did in the War (New York 2009) 57-60.

222 Telegram Gemmeker aan Zöpf, 4-2-I944, NIOD 250i, inv.nr. 335 .

223 Lindwer, Kamp van hoop en wanhoop, 44.

224 Göbel, Een hemel zonder vogels, 63; Verslagen van transport van 8-2-1944 na de oorlog opgegeven aan het RIOD, NIOD, 250i, inv.nr. I094.

225 Andries Kaas, Buchenwald. Conclusies na twintigjaar (Arnhem 1968) 25.

226 Kaas, Buchenwald, 25.

227 Van der Boom, 'Wij weten niets van hun lot',

325 .

228 Lijst van mensen die op 3-6-44 van Vught naar Westerbork werden getransporteerd, NIOD 250i, inv.nr. 196.

229 Van der Hal, Het mesje, 56; Abuys en Mulder, Genezen verklaard voor..., 97-98.

230 Abuys en Mulder, Genezen verklaard voor..., 2I-22.

23I Brief van Elsa Rodrigues Pereira-Jessurun d'Oliveira aan Ies van der Hal, I8-II-I984, privécollectie familie van der Hal, Herzliyah.

232 Mechanicus, In Dépôt, 59, 27-6-1943.

233 Brief van Max Roeper aan zijn echtgenote Louise Roeper-Spiekema, Vught I4-II-I943, JHM 00008436 .

234 Jules Schelvis, Vernietigingskamp Sobibor (Amsterdam 1993) I06.

235 Meihuizen, Smalle Marges, $27 \mathrm{I}$.

236 Gecombineerde verzamelde data uit o.a.: 
Joodsche Raad cartotheek, Rode Kruis Den Haag, www.joodsmonument.nl; Coppenhagen, Anafiem Gedoe'iem.

237 Hertzberger, Door de Holocaust verbonden, 70.

238 Ibidem, 63.

239 De Lang, Het oorlogsdagboek van Dr. G. Italie,
426: 22 november 1943 .

240 www.joodsmonument.nl

24I Naoorlogs verslag E.A. Cohen, NIOD, 250i, inv.nr. 1085 .

242 Albert Haas, Arts achter prikkeldraad (Amsterdam/Brussel I986, vertaling uit het engels) 9 .

\section{SAMENVATTING EN CONCLUSIE}

I Gesprekken met Hans Keilson, d.d. 2O-II-2008 en I5-I-2009.

2 Schwegman, 'Uitzonderlijk of juist heel gewoon', 27.

3 Bauer, Rethinking the Holocaust, I2O.

4 Chelouche, 'Medicine and the Holocaust', 804. 5 http://www.bu.edu/bostonia/winter-springı/ holocaust-doctors/ 20-03-20I4.

6 Micheels, Dokter II764I, 63-64.

7 Frans de Waal, Van nature goed. Over de oorsprong van goed en kwaad in mensen en andere dieren (Amsterdam 1996 vertaling uit het engels) 246.

8 Evelien Gans, Jaap en Ischa Meijer, een joodse geschiedenis I9I2-1956 (Amsterdam 2008) I9I.
9 Tom L. Beauchamp, James F. Childress, Principles of Biomedical Ethics (New York 1979) 209-222. Io T.R.V. Nys, 'Paternalisme en autonomie in de geestelijke gezondheidszorg', Tijdschrift voor psychiatrie 47 (2005) 8, 519-528, 527.

II Michael Ignatieff, Isaiah Berlin. A Life (Londen 1998) 253. 



\section{LITERATUUR EN BRONNEN}

Abuys, Guido en Dirk Mulder, Genezen verklaard voor... een ziekenhuis in kamp Westerbork, I939I945 (Assen 2006)

Ader, J.A., Een Groningse pastorie in de storm

(Franeker 1947)

Alexander, L., 'Medical Science Under Dictatorship', New England Journal of Medicine (1949) 24I, 39-47

Annas, George J. en Michael A. Grodin, The Nazi Doctors and the Nuremberg Code: Human Rights in Human Experimentation (New York 1992)

Ariëns Kappers, Cornelius U., Reiziger in breinen. Herinneringen van een hersenonderzoeker (Amsterdam 200I)

Arkel Zegwaard, J. van (ps. van S. Sturkop), Herinneringen van een huisarts (Amsterdam 1947)

Arkel Zegwaard, J. van, Vrouwenarts (Amsterdam I94I)

Arkel Zegwaard, J. van, Vrouwenzaal (Amsterdam I946)

Asscher-Pinkhof, Clara, Danseres zonder benen ('sGravenhage 1966)

Baalen, H.J. van, Joods leven in Deventer en omstreken (Deventer 1998)

Baggerman, Arianne en Rudolf Dekker, 'De gevaarlijkste van alle bronnen. Egodocumenten, nieuwe wegen en perspectieven', Tijdschrift voor Economische en Sociale geschiedenis I (2004) 4, 3-22

Baker, Robert en Laurence B. McCullough (red.), The Cambridge World History of Medical Ethics (New York 2008)

Baker, Robert, 'The History of Medical Ethics', in: W.F. Bynum, Roy Porter e.a., Companion Encyclopedia of the History of Medicine 2 (Londen 1993) 849-887

Bakker, Alex, Dag pap, tot morgen. Joodse kinderen gered uit de crèche (Hilversum 2005)

Bakker, Tammo, De kehille Veendam. Veendam, Wildervank, Muntendam (Veendam I998)

Baltesen, Frits, 'Een arts helpt, ook in de oorlog. Oorlogsverhalen op eerste veteranendag voor oud-artsen in Utrecht', NRC Handelsblad 25-3-2009

Bank, Jan, Oorlogsverleden in Nederland. Rede uitgesproken bij de aanvaarding van het ambt van buitengewoon hoogleraar in de maatschappijgeschiedenis, in het bijzonder de overdracht van historische kennis via de massamedia, aan de Erasmus Universiteit Rotterdam op 27 oktober 
I983 (Baarn I983)

Bartels, A. en A. Polak, 'De verzorging van Joodse zieken te 's-Gravenhage tot 1943', Studia Rosenthaliana 3 (1969) 2, 202-207

Baruch, Jacques Z., 'Bij het graf van Maimonides', Nederlands Tijdschrift voor Geneeskunde 96 (I952) I543

Bar Ze'ev, Pinchas, 'Het verhaal van zeven oorlogsdocumenten en... één persoon', Aleh, Jom HaShoah uitgave, april 2009, I8-20

Bauer, Yehuda, Rethinking the Holocaust (New Haven 200I)

Beauchamp, Tom L., James F. Childres, Principles of Biomedical Ethics (New York/Oxford 19832 )

Becker-Jakli, Barbara, Das jüdische Krankenhaus in Köln (Keulen 2004)

Beer, Ad de en Gerrit Kobes, Het leven gebroken. De geschiedenis van de Tilburgers die als gevolg van de strijd tegen Duitsland en de bezetting om het leven kwamen (Tilburg 2002)

Ben Heled-Rudelsheim, Letty, Gesprekken met mijzelf in Auschwitz (Kampen 2003)

Benz, Wolfgang, Dimension des Völkermords. Die Zahl der jüdischen Opfer des Nationalsozialismus (München I99I)

Benzenhöfer, Udo, Jüdische Ärzte in Hannover 1933 bis 1945 (Wetzlar 2000)

Bergen, Leo van e.a., 'Schenk in het medisch onderwijs aandacht aan oorlog', Nederlands Tijdschrift voor Geneeskunde I53 (2009) 35, I737-I739

Berger, Natalia, Jews and Medicine. Religion, Culture, Science (Tel Aviv 1995)

Bergh, Sieg van den, Deportaties. Westerbork, Theresiënstadt, Auschwitz, Gleiwitz (Bussum 1945)

Berkel, Klaas van, Academische illusies. De Groningse universiteit in een tijd van crisis, bezetting en herstel, 1930-I950 (Amsterdam 2005)

Berkel, Klaas van, De stem van de wetenschap. Geschiedenis van de Koninklijke Nederlandse Akademie van Wetenschappen deel 2 I9I4-2008 (Amsterdam 20II)

Berkvens, A.M.J.A., H.J.J.M. van der Bruggen en R. M.L.M. Magnée red., Rechtspraak in Roermond. Van Soevereine Raad naar Rechtbank Limburg (I580-2012) (Hilversum 2013)

Biegel, Salomon, Handleiding der gezondheidsleer.
In verband met de Nederlandse wetgeving (Gorinchem 1927 5)

Bijlsma, U.G., 'Sterilisatie', Nederlands Tijdschrift voor Geneeskunde 78 (1934) 5172-5173

Blankenstein, Elisabeth van, Dr. M. van Blankenstein, een Nederlands dagbladdiplomaat 1880 1964 (Leiden 1999)

Bloemgarten, Salvador, Hartog de Hartog Lémon, I755-I823. Joodse revolutionair in Franse tijd (Amsterdam 2007)

Blok, H., K.A. Deurloo e.a. (red.), Om voor te lezen - miqra. Feestbundel voor Frits Hoogewoud (Maastricht 2005)

Blom, J.C.H., In de ban van goed en fout? Wetenschappelijke geschiedschrijving over de bezettingstijd in Nederland. Rede uitgesproken bij de aanvaarding van het ambt van gewoon hoogleraar in de Nederlandse geschiedenis sedert de middeleeuwen aan de Universiteit van Amsterdam op I2 december 1983 (Bergen 1983)

Blom, J.C.H., J.J. Cahen, 'Joodse Nederlanders, Nederlandse joden en joden in Nederland (I870-1940)' in: J.C.H. Blom, R.G. FuksMansfeld en I. Schöffer (red.), Geschiedenis van de joden in Nederland (Amsterdam I995)

Blom, J.C.H., R.G. Fuks-Mansfeld, I. Schöffer (red.), Geschiedenis van de joden in Nederland (Amsterdam 1995)

Blom, Th.A., 'Joodsche artsen in Duitschland', Nederlands Tijdschrift voor Geneeskunde 82 (I938) 4936

Bloomfield, Sara J., Deadly Medicine. Creating the Master Race. United States Holocaust Memorial Museum (Washington 2004)

Boas, Henriette, Bewust-joodse Nederlandse vrouwen. Veertien portretten (Kampen 1992)

Boas, Jacob, Boulevard des Misères. The story of Transit Camp Westerbork (Hamden 1985)

Boekman, E., 'Demografie van de Joden in Nederland', Nederlands Tijdschrift voor Geneeskunde 80 (1936) 3957

Bokkel Huinink, A. ten, C. Fehmers, Th. Hammes red., Medische ethiek (NMG I94I 2)

Bolle, Mirjam, Ik zal je beschrijven hoe een dag er hier uitziet. Dagboekbrieven uit Amsterdam, Westerbork en Bergen-Belsen (Amsterdam 2003) 
Bollegraaf, Ruben, De Joden te Oss tijdens de bezetting door Duitsland (Amsterdam 1993) Boom, Bart van der, 'Wij weten niets van hun lot'. Gewone Nederlanders en de Holocaust (Amsterdam 20I2)

Boon, E.P. en J.J.M. Lettinck, De Joodse Gemeente in Winschoten en omgeving I683-I964 (Zuidbroek 20IO)

Bosch, Mineke, Een onwrikbaar geloof in rechtvaardigheid. Aletta Jacobs (I854-I929) (Amsterdam 2009)

Boudier-Bakker, Ina, Met de tanden op elkaar. Dagboeknotities '40-'45 (Amsterdam 1965)

Braber, Ben, Zelfs als wij zullen verliezen. Joden in verzet en illegaliteit 1940-I945 (Amsterdam I990)

Brandhorst, Henny, 'From Neo-Malthusianism to Sexual Reform: the Dutch Section of the World League for Sexual Reform', Journal of the History of Sexuality, I2 (2003) I, 38- 67

Brands, M.C., H.W. von der Dunk, H.H. Zwager (red.), Egodocumenten. Een bijzonder genre van historische bronnen (Groningen 1970)

Brandt C.D.J. (red.), Onderdrukking en verzet. Nederland in oorlogstijd. Deel 2 (Arnhem/Amsterdam 1949-I954)

Brasz, Chaja (red.), Dutch Jews as Percieved by Themselves and by Others (Leiden 200I)

Bree, L.W. de, Zeeland I940-I945. Deel I (Middelburg 1979)

Bremer, Geert J., 'Jacob Sanders I887-I945, joods huisarts en geleerde. Zijn aandeel in de ontwikkeling van de erfelijkheidsleer in Nederland', Misjpoge 17 (2004) 2, 50-53

Bremer, Geert J., Huisarts zijn in het Interbellum (Rotterdam 2006)

Brouwer, Lous de, De Joodse Gemeente Alphen aan den Rijn I792-I964 (Amsterdam 2002)

Browning, Christopher, Ordinary Men. Reserve Police Batallion Ior and the Final Solution in Poland (New York 1992)

Browning, Christopher, The Origins of the Final Solution. The Evolution of Nazi Jewish Policy, September 1939-March 1942 (Jeruzalem 2004)

Brugmans, Hk. en A. Frank, Geschiedenis der Joden in Nederland (Amsterdam I940)

Bruggen, H.J.J.M. van der, 'Dr.mr. R.R.L.M.
Bromberg. Voorzitter Raad van Beroep en Ambtenarengerecht 1939-1940 en 1945-1956', in: A.M.J.A. Berkvens, H.J.J.M. van der Bruggen en R.M.L.M. Magnée (red.), Rechtspraak in Roermond. Van Soevereine Raad naar Rechtbank Limburg (I580-2012) (Hilversum 2013)

Bruin, Jan en Jan van der Werff, Vrijheid achter de horizon. Engelandvaart over de Noordzee 1940I945 (Houten I998)

Brusse, Peter, 'Een verdwaalde kunstenares', Vrij Nederland, I4-II-2009

Brutel de la Rivière, J.J., 'Het artsenverzet', in: C.D.J. Brandt (red.), Onderdrukking en verzet. Nederland in oorlogstijd. Deel 2 (Arnhem/Amsterdam I949-1954) 347-376

Burger, H., Geneesheer en maatschappij (Amsterdam I919)

Burgerhout, H., 'In memoriam Dr. J. van den Borg', Nederlands Tijdschrift voor Geneeskunde. 84 (1940) 2078

Burns, Marlene, 'Wartime Research to Post-War Production: Bacinol, Dutch Penicillin, 1940I950', in: Circulation of Antibiotics: Journeys of Drug Standards, I930-1970 (Madrid 2009)

Bynum, W.F., Roy Porter e.a., Companion Encyclopedia of the History of Medicine 2 (Londen 1993)

Cahen, Max, Ik heb dit alles opgeschreven... ('sHertogenbosch 20Io)

Caplan, Arthur (red.), When Medicine went Mad. Bioethics and the Holocaust (New Jersey 1992)

Carp, E.A.D.E., 'Voorbehoeding tegen zelfmoord', Nederlands Tijdschrift voor Geneeskunde 85 (I94I) $52-56$

Charlton, T.L., L.E. Myers, R. Sharpless, Handbook of Oral History (Oxford 2006)

Chelouche, Tessa, 'Some Ethical Dilemmas Faced by Jewish Doctors during the Holocaust', Medicine and Law 24 (2005) 4, 703-716

Chelouche, Tessa, 'Medicine and the Holocaust - Lessons for Present and Future Physicians', Medicine and Law 27 (2008) 4, 787-804

Cohen, David, Zwervend en dolend. De joodse vluchtelingen in Nederland in de jaren 1933- 1940 (Haarlem 1955)

Cohen, David E., 'De Joodsche geneeskundigen in de noordelijke Nederlanden vóór I60o', 
Nederlandsch Tijdschrift voor Geneeskunde 78 (I934) 535

Cohen, David E., 'De vroegere Amsterdamsche Joodsche doctoren', Nederlandsch Tijdschrift voor Geneeskunde 7I (1927) I388

Cohen, Elie A., 'Het Duitse concentratiekamp. Een medische en psychologische studie', (Amsterdam I952)

Cohen, Elie A., De Afgrond. Amersfoort, Westerbork, Auschwitz (Amsterdam 197I)

Cohen, Elie A., De negentien treinen naar Sobibor (Amsterdam 1979)

Cohen, Elie A., Beelden uit de nacht. Kampherinneringen (Baarn 1992)

Cohen, Jaap en Hinke Piersma (red.), Moedige mensen. Helden in oorlogstijd (Amsterdam 20I4)

Cohen, Michael M., 'Overview of German, Nazi and Holocaust Medicine', American Journal of Medical Genetics (2010) I52A, 687-707

Coons, Christian en Michael Weber (red.), Paternalism. Theory and practice (Cambridge 2013)

Coppenhagen, J.H., Anafiem Gedoe’iem. Overleden joodse artsen uit Nederland 1940-1945 (Rotterdam 2000)

Cornwell, John, Hitler's scientists. Science, War, and the Devil's Pact (New York 2003)

Cost, W.S., J. Eeftinck Schattenkerk en J. Roos, 'In Memoriam Dr. W.F. Noordhoek Hegt', Nederlands Tijdschrift voor Geneeskunde I27 (1983) 235I

Cremers, A.G.P., 'In Memoriam A.E. Denekamp', Nederlands Tijdschrift voor Geneeskunde $\mathrm{I} 23$ (1979) 768

Creveld, Simon van, “"Kindergeneeskunde” in een concentratiekamp', Nederlands Tijdschrift voor Geneeskunde 90 (1946) 225-227

Croockewit, M.C., Het exlibris der Nederlandse medici ('s-Gravenhage 1950)

Daal, Marjo J.G.W. van, en Annemarie de Knechtvan Ekelen, Joannes Juda Groen (1903-199o), een arts op zoek naar het ware welzijn (Rotterdam 1994)

Daalder, Hans, 'Joden in verzuilend Nederland' in id., Politiek en historie. Opstellen over Nederlandse politiek en vergelijkende wetenschap (Amsterdam 1990)

Dangermond, Karin, 'Het heft in eigen han- den. Een kwalitatief onderzoek naar Joodse zelfmoorden in Nederland tijdens de Tweede Wereldoorlog', scriptie bij de master Holocausten genocidestudies (Amsterdam 20II)

Degenaar, Job, 'Het blonde overbuurmeisje en de onbekende Jood', Vrij Nederland, 30-4- 2005

Dekker, Maurits, De laars op de nek. Roman I939I945 (Leiden I945)

Denekamp, Albert E., en G. Dekker (red.), Besluit en rapport inzake geneeskundige verklaringen. K.N.M.G. (KNMG 1949)

Denekamp, Paul, Van Boezeman tot Denekamp, een korte familiegeschiedenis (Amsterdam 1989)

Dittrich, Kathinka, en Hans Würzner (red.) Nederland en het Duitse Exil 1933-1940. Achttien essays (Amsterdam 1982)

Dobschiner, Johanna-Ruth, Te mogen leven! (Franeker 1974)

Dominicus, H.E., Mauthausen. Een gedenkboek (Amsterdam 1999)

Driessen, L.F., 'Therapeutische sterilisatie in de verloskunde', Nederlands Tijdschrift voor Geneeskunde 72 (1928) 6294-6296

Durkheim, Emile, Le suicide, étude de sociologie (I897)

Dwork, Debórah, en Robert Jan van Pelt, De Holocaust. Een geschiedenis (Amsterdam 2002)

Edelstein, Ludwig (Owsei Temkin en Lilian Temkin red.), Ancient Medicine. Selected Papers of Ludwig Edelstein (Baltimore 1967)

Eeftinck Schattenkerk, J.C.P., 'Variaties op het thema der medische ethiek', in: C.D.J. Brandt (red.), Onderdrukking en verzet. Nederland in oorlogstijd. Deel 2 (Arnhem/Amsterdam I9491954) $377-383$

Efron, John M., Medicine and the German Jews (New Haven 200I)

Eickhoff, Martijn, Barbara Henkes en Frank van Vree (red.), Volkseigen. Ras, cultuur en wetenschap in Nederland I900-I950 (Zutphen 2000) Eijck, Jan van, Barend Haeseker e.a. (red.), Canon van de huisartsgeneeskunde (Haarlem 2013)

Eijck, Jan A.M. van, 'Freddie de Wit, huisarts in Tilburg 1936-I94I. Een jonge huisarts, een vergeten slachtoffer van de Holocaust', Tilburg. 
Tijdschrift voor geschiedenis, monumenten en cultuur 3I (2013) 3, 72-77

Emde Boas, Coen van, De periodieke onvruchtbaarheid en haar beteekenis voor de regeling van het kindertal. Beschouwingen over de grondslagen, de betrouwbaarheid en de practische bruikbaarheid van de zoogenaamde 'periodieke onthouding' (Amsterdam 1934)

Esso, Izaak van, 'De Jood als patiënt' De Vrijdagavond $\mathrm{I}$ (1925) 44

Esso, Izaak van, 'Geschiedenis der Geneeskunde', Aesculaap, propagandanummer (januari 1938)

Esso, Izaak van, 'Het aandeel der Joden in de natuurwetenschappen in Nederland' in: Hk. Brugmans en A. Frank, Geschiedenis der Joden in Nederland. Deel I (Amsterdam 1940) 643-679

Everdingen, J.J.E. van, en H.F.J. Horstmanshoff, 'De nieuwe Nederlandse artseneed', Nederlands Tijdschrift voor Geneeskunde 149 (2005) I062-I067

Evertzen, Annette, en Stevine Groenen, Ontduiken en onderduiken. Verhalen van Joden in Borne (Borne 20I3)

Exalto, J., J.C. Tummers, 'De behandeling van den opengebleven ductus Botalli', Nederlands Tijdschrift voor Geneeskunde 86 (I942) 45, 2772- 2778

Fecken, W.J., De Joodse gemeenschap in 's-Graveland en Kortenhoef I730-I945 (Kortenhoef I995)

Fiedeldij Dop, Charley, 'Bruggen Bouwen', Auschwitz Bulletin 58 (20I4) I, 8-9

Flap, Henk, en Wil Arts (red.), De organisatie van de bezetting (Amsterdam 1997)

Flim, Bert Jan, Omdat hun hart sprak. Geschiedenis van de georganiseerde hulp aan Joodse kinderen in Nederland 1942-1945 (Kampen 1996)

Freud, Iki, Mijn naam is Freud, Iki Freud. Bekentenissen van een psychoanalytica (Amsterdam 2004)

Frey, Barbara, 'Als Mensch und Ärztin hervorragend. Die jüdische Ärztin Gertrud Mosberg (1903-1945)', Frauen in der Bielenfelder Geschichte (2010) 280-29I

Friedlander, Henry, The Origins of Nazi Genocide: from Euthanasia to the Final Solution (Chapel Hill 1995)

Friedlander, Peter, 'Theory, Method and Oral
History' in: R. Perks, en A. Thomson, The Oral

History Reader (Londen 1998) 3II-3I9

Friedländer, Saul, Nazi-Duitsland en de Joden. Deel I, de jaren van vervolging I933-I939 (New York I997)

Frijtag Drabbe Künzel, Geraldien von, Kamp Amersfoort (Amsterdam 2003)

Frijtag Drabbe Künzel, Geraldien von, Het geval Calmeyer (Amsterdam 2008)

Froe, Arie de, De anthropologie van de zoogenaamde Portugeesche Joden in Nederland (Amsterdam I943)

Fuks-Mansfeld, Rena, Wie in tranen zaait... Geschiedenis van de Joodse Geestelijke Gezondheidszorg in Nederland (Assen 1997)

Gaarlandt-Kist, Mr. A.F. (red.), 400 jaar St. Elisabeth's of Groote Gasthuis te Haarlem (Haarlem I98I)

Galen-Hermann, Ruth van, Calmeyer, dader of mensenredder? Visies op Calmeyers rol in de Jodenvervolging (Soesterberg 2009)

Galen Last, Dick van, 'Rassenhygiëne: de dodelijke omhelzing van wetenschap en nationaal- socialisme' in: Martijn Eickhoff, Barbara Henkes en Frank van Vree (red.), Volkseigen. Ras, cultuur en wetenschap in Nederland I9oo-I95o (Zutphen 2000)

Gans, Evelien, De kleine verschillen die het leven uitmaken. Een historische studie naar joodse sociaal-democraten en socialistisch-zionisten in Nederland (Amsterdam 1999)

Gans, Evelien, Jaap en Ischa Meijer. Een joodse geschiedenis 19I2-I956 (Amsterdam 2008)

Gans, Evelien, 'Iedereen een beetje slachtoffer, iedereen een beetje dader', Groene Amsterdammer, 27-I-20IO

Gelderen, Chr. van, 'In memoriam W.A. Levy', Nederlands Tijdschrift voor Geneeskunde 84 (I940) 2276

Giebels, Ludy, De zionistische beweging in Nederland I899-I94I (Assen I975)

Ginkel, Rob van, Rondom de stilte. Herdenkingscultuur in Nederland (Amsterdam 20II)

Göbel, Esther, Een hemel zonder vogels. Het aangrijpende levensverhaal van Janny Moffie-Bolle (Amsterdam 20Io) 
Goldhagen, Daniel Jonah, Hitler's Willing Executioners. Ordinary Germans and the Holocaust (New York 1996)

Goldschmidt, Saskia, Verplicht gelukkig (Amsterdam 2OII)

Goldworth, Amnon, The collected works of Jeremy Bentham. Deontology, together with a table of the springs of action and article on utilitarianism (New York 1984)

Gras, Thijs, en Gerrit Rottink, De broeders van de Breukendienst. I0o jaar eerste hulp en ziekenvervoer door de GGD Amsterdam 1908-2008 (Amsterdam 2008)

Grewel, Frits, en Coen van Emde Boas 'De Joden in Amsterdam', Mens en Maatschappij, 30 (1955) 298

Griffioen, Pim, en Ron Zeller, Jodenvervolging in Nederland, Belgie en Frankrijk 1940-1945. Overeenkomsten, verschillen, oorzaken (Amsterdam 2OII)

Griffioen, Pim, en Ron Zeller in: Peter Romijn e.a., Comparing the Persecution of the Jews in the Netherlands, France and Belgium, 1940-I945: Similarities, Differences, Causes (Amsterdam 20II)

Grodin, Michael E. (red.), Jewish Medical Resistance in the Holocaust (New York 20I4)

Groen, Joannes J., Psychogenese en psychotherapie van colitis ulcerosa (Amsterdam I947)

Groen, Joannes J., Asthma bronchiale seu nervosum, een psychosomatische studie (Amsterdam 1950)

Groen, Koos, Als slachtoffers daders worden. De zaak van de joodse verraadster Ans van Dijk (Amsterdam 1994)

Groenhuis, G., Emmen in bezettingstijd (Emmen 1990)

Haan, Ido de, Na de ondergang. De herinnering aan de Jodenvervolging in Nederland 1945- 1995. (Den Haag 1997)

Haas, Albert, Arts achter prikkeldraad (Amsterdam/ Brussel I986)

Hage, R.C., en J.H. de Vey Mestdagh, De Joodse gemeenschap van Veendam-Wildervank, Muntendam en Meeden (Groningen 1985)

Hagoort, Lydia, Samuel Sarphati I813-1866. Van Portugese armenarts tot Amsterdamse ondernemer (Amsterdam 20I2)
Hal, Isidor van der, Het mesje. De oorlog van een joods Groninger arts (Groningen 1994)

Halioua, Bruno, Blouses blanches, étoiles jaunes. L'exclusion des médecins juifs en France sous l'Occupation (Parijs 2000)

Hammes, Th., 'De pijlers van onze ethiek. Openingsrede uitgesproken in de 86e Algemeene Vergadering der Maatschappij', Nederlands Tijdschrift voor Geneeskunde 79 (1935) 3375

Hammes, Th., 'Dr. Hermanus Pinkhof. Een levensschets', Nederlands Tijdschrift voor Geneeskunde. 89 (I945) $25 \mathrm{I}-252$

Haque, Omar, Julian de Freitas et al., 'Why Did So Many German Doctors Join the Nazi Party Early?' International Journal of Law and Psychiatry 35 (2012) 473-479

Hartogh, Alain V., 'De Joodsche Invalide in oorlogstijd' (Amsterdam i946) manuscript in bezit van NIOD

Have, H.A.M.J. ten, R.H.J. ter Meulen, en E. van Leeuwen, Medische ethiek (Houten 2000)

Heijden, Chris van der, Grijs verleden. Nederland en de Tweede Wereldoorlog (Amsterdam/ Antwerpen 200I)

Hendriksen, Jolanda, en Willy Hijmans, 'De rassencolleges van Barge. Een leemte in de geschiedenis van de Leidse universiteit', Overdruk Leids Jaarboekje 1995

Hertzberger-Gold, Jenny, De familie Hertzberger in Nederland, een familiekroniek (Baarn 1996)

Herzberg, Abel J., Kroniek der Jodenvervolging I940I945 (Amsterdam I9855 (1950))

Hes, Hindle, Jewish Physicians in the Netherlands I600-1940 (Assen 1980)

Heuvel, G.C. van den, 'In memoriam M. Hertzberger', Nederlands Tijdschrift voor Geneeskunde 84 (I940) 2174

Heyl, B., Het vergeten hoofdstuk binnen de geschiedenis van de gezondheidszorg (Nieuwerkerk a/d IJssel 2006)

Hilfman, M.M., 'In Memoriam Dr. S.I. de Vries', Nederlands Tijdschrift voor Geneeskunde II7 (I973) I44I-I442

Hillesum, Etty, Het denkende hart van de barak. Brieven van Etty Hillesum (Haarlem 1982)

Hirschfeld, Gerhard, 'Niederlande', in: Wolfgang 
Benz, Dimension des Völkermords. Die Zahl der jüdischen Opfer des Nationalsozialismus (München I99I) I37-I65

Hoeven, Herman C. van der, Ziekenfondsen en de Duitse bezetting (Den Haag 1989)

Hoeven, L.M. van der, en E.M. Bánki, Joods leven in Maassluis I688-1942 (Maassluis 2000)

Hondius, Dienke, Terugkeer. Antisemitisme in Nederland rond de bevrijding (Den Haag 1998)

Houwaart, Dick, Kehillo kedousjo Den Haag. Een halve eeuw geschiedenis van joods Den Haag (Den Haag 1986)

Houwaart, Eddy S., De Hygiënisten. Artsen, staat en volksgezondheid in Nederland I840-I890 (Groningen 199I)

Houwink ten Cate, J.Th.M., “"Het jongere deel”, Demografische en sociale kenmerken van het jodendom in Nederland tijdens de vervolging', in: Jaarboek van het Rijksinstituut voor Oorlogsdocumentatie I989 (Zutphen 1989) 9-66.

Hovingh, Geert C., Joods leven in Zuidlaren (Bedum 2000)

Huddleston Slater, W.B., Dokter en publiek. Een reeks actuele vradgstukken (Rotterdam 1929)

Huisman, Frank, en J.H. Warner, Locating Medical History. The Stories and Their Meanings (Baltimore 2004)

Hulst, F.J., en H.M. Luning, De Joodse gemeente Assen. Geschiedenis van een behoorlijke kille, I740-I976 (Assen 199I)

Idenburg, P.J., De Leidse universiteit 1928-1946. Vernieuwing en verzet (Leiden 1978)

Ignatieff, Michael, Isaiah Berlin. A Life (Londen I998)

Israëls, Han, en Annet Mooij, Aan de Achtergracht. Honderd jaar GG S.GD Amsterdam (Amsterdam 200I)

Jakobovits, Immanuel, Jewish Medical Ethics (New York 1959)

Jansen, Corjo, en Derk Venema, De Hoge Raad en de Tweede Wereldoorlog. Recht en rechtsbeoefening in de jaren 1930-I950 (Amsterdam 20II)

Jong, Loe de, Het Koninkrijk der Nederlanden in de Tweede Wereldoorlog, I4 dln (Den Haag/Leiden 1969-1994)

Jonge-Cohen, Th.E. de, 'In memoriam Dr. E. San- ders', Nederlands Tijdschrift voor Geneeskunde 84 (I940) 2078-2079

Jotkowitz, A., 'The Holocaust and Medical Ethics: the Voices of the Victims', Journal of Medical Ethics 34 (2008) 869-870

Kaandorp, Carola J.E., Jannes J.E. van Everdingen, en Annet Mooij (red.), Erflaters van de geneeskunde, beroemde Nederlandse artsen beschreven door hun (kinds)kinderen (Overveen 2002)

Kaas, Andries, Buchenwald. Conclusies na twintig jaar (Arnhem 1968)

Kassow, Samuel D., Wie schrijft onze geschiedenis. Het dramatische verhaal van het verborgen archief van het getto van Warschau (Amsterdam 2009)

Kastein, G.W., Het rassenvraagstuk (Amsterdam 1938)

Kasteleyn, Leonard, Joden in Leiden en omgeving 1933-1945. Vervolging en bescherming, joden in Leiden 1933-1945 (Leiden 2003)

Kater, Michael, 'Professionalization and Socialization of Physicians in Wilhelmine and Weimar Germany', Journal of Contemporary History 20 (I985) 4, 677-70I

Kater, Michael, Doctors under Hitler (Chapel Hill 1989)

Kater, Michael, 'A Historical and Contemporary View of Jewish Doctors in Germany' in: John J. Michalczyk, Medicine and the Third Reich. Historical and Contemporary Issues (Kansas City 1994) I6I-I66

Kater, Michael, 'Criminal Physicians in the Third Reich. Toward a Group Portrait', in: Frances R. Nicosia, en Jonathan Huener (red.), Medicine and Medical Ethics in Nazi Germany. Origins, Practices, Legacies (New York 2002)

Keilson, Hans, Komedie in Mineur (Amsterdam 2010)

Keizer, Madelon de, Frans Goedhart. Journalist en politicus (1904-1990) (Amsterdam 20I2)

Keizer Madelon de, en Marije Plomp, Een open zenuw. Hoe wij ons de Tweede Wereldoorlog herinneren (Amsterdam 20IO)

Kila, Joop D., De kille aan het Marsdiep (Den Helder 1999)

Klee, Ernst, Euthanasie im NS-Staat. Die Vernichtung unlebenswerten Lebens (Frankfurt 1983) 
Klee, Ernst, Auschwitz, die NS-Medizin und ihre Opfer (Frankfurt 1997)

Klein, F., 'In Memoriam A.A. Kerssemakers', Nederlands Tijdschrift voor Geneeskunde IO7 (I963) 3IO-3II

Knapper, N., 'In Memoriam E. Wiener, overleden I4 mei 1940', Nederlands Tijdschrift voor Geneeskunde 84 (1940) 2079

Knegtmans, Peter Jan, Een kwetsbaar centrum van de geest. De Universiteit van Amsterdam tussen I935 en 1950 (Amsterdam 1998)

Knegtmans, Peter Jan, Geld, ijdelheid en hormonen. Ernst Laqueur, hoogleraar en ondernemer (Amsterdam 20I4)

Knoop, Hans, De Joodsche Raad: het drama van Abraham Asscher en David Cohen (Amsterdam I983)

Kohner, Hanna en Walter, Hanna en Walter, een liefdesgeschiedenis (Amsterdam 1985)

Koker, David, Dagboek geschreven in Vught (Amsterdam I977)

Kooger, Hans, Het oude volk. Kroniek van joods leven in de Achterhoek, Liemers en het grensgebied (Doetinchem 200I)

Koonz, Claudia, The Nazi Conscience (Cambridge MA/Londen 2003)

Kooy, Henne van der, Justus de Leeuwe, Sarphati. Een biografie (Amsterdam 200I)

Kous, Joël van der, e.a., Zal ik medicus worden? no.I. in de serie 'Wat zal ik worden?' (Baarn 1932)

Kouwenhoven, Frank, 'Voetlicht. Professor Groen: van kleine Napoleon tot wetenschappelijk vorser', Centrum. Academisch Ziekenhuis en Medische Faculteit Leiden I4 (1984) 4, 88-92

Krauss, Samuel, Geschichte der jüdischen Ärzte. Vom frühesten Mittelalter bis zur Gleichberechtigung (Wenen 1930)

Kristel, Conny, Geschiedschrijving als opdracht. Abel Herzberg, Jacques Presser en Loe de Jong over de Jodenvervolging (Amsterdam I998)

Kromhout, Bas, en Frans Smits, 'Weg met grijs, bewonderen mág', Historisch Nieuwsblad 8, (2009) op http://www.historischnieuwsblad.nl/ $\mathrm{nl} /$ artikel/26025/schwegman-en-withuis-overoorlogshelden.html

Kruisheer, Klazien, De dokter dat ben ik. 65 jaar
Vereniging van Nederlandse Vrouwelijke Artsen (Zutphen 1998)

Kruyt, J.P., 'Het Jodendom in de Nederlandse samenleving', in H.J. Pos (red.), Anti-semitisme en Jodendom. Een bundel studies over een actueel vraagstuk (Arnhem 1939)

Kudlien, Fridolf, Ärzte im Nationalsozialismus (Keulen i985)

Kuenen, W.A., 'In Memoriam L. Polak Daniels', Nederlands Tijdschrift voor Geneeskunde 84 (I940) 20I2-20I4

Laansma, Klazien, Eindstation Tröbitz (Kampen I996)

Laansma, S., De Joodse gemeente te Apeldoorn en Het Apeldoornsche Bosch (Zutphen 1979)

Laarse, Rob van der, De oorlog als beleving. Over de musealisering en enscenering van Holocausterfgoed (Amsterdam 20II)

Laarse, Rob van der, en Frank van Vree, De dynamiek van de herinnering. Nederland en de Tweede Wereldoorlog in een internationale context (Amsterdam 2009)

Lang, Wally M. de, Het oorlogsdagboek van Dr. G. Italie. Den Haag, Barneveld, Westerbork, Theresienstadt, Den Haag 1940-I945 (Amsterdam 2009)

Lange, Cornelia de, 'In memoriam dr. M. de Bruin, overleden I8 mei 1940', Nederlands Tijdschrift voor Geneeskunde 84 (1940) 1996.

Langer, Lawrence, Holocaust Testimonies: the Ruins of Memory (New Haven I99I)

Larson, Mary A., 'Research Design and Strategies' in: T.L. Charlton, L.E. Myers, R. Sharpless, Handbook of Oral History (Oxford 2006)

Leijdesdorff, Selma, Wij hebben als mens geleefd. Het Joodse proletariaat van Amsterdam, I900-1940 (Amsterdam 1987)

Lensky, Mordechai, A Physician Inside the Warsaw Ghetto (Jerusalem 2009)

Lerner, Barron H., David J. Rothman, 'Medicine and the Holocaust: Learning More of the Lessons', Annals of Internal Medicine I22 (I995) IO, 793-794

Lewis, Dana, 'A Forgotten Medicine: an Examination of Medical Practice by Jewish Physicians in the Warsaw Ghetto, I940-I942', University 
College London, History of Medicine IBSc

Dissertation: HMED 3002, 27-4-2012

Lieburg, Mart J. van, 'Bevorderlijk voor de kunst en nuttig voor de maatschappij' De geschiedenis van het Genootschap ter bevordering van Heel-en Verloskunde (I857-1929) en van het Amsterdams Geneeskundig Genootschap (I925-1988) (Amsterdam I988)

Lieburg, Mart J. van, Bronovo, I865-I99o (Kampen 1990)

Lieburg, Mart J. van, 'De burgergeneeskundige dienst in mobilisatie- en bezettingstijd', Gewina, I99I, vol. I4 (4), I77-I92

Lieberg, Mart J. van, 'De echo van een eersaluut. Medisch Contact en de manifestatie van collectiviteit en moraliteit in bezettingstijd', Medisch Contact 50 (1995) 48, I557-I559

Lieburg, Mart J. van, 't Is geen baan, 't is een bestaan. Het sociale en economische leven van de medische beroepsbeoefenaren in Nederland weerspiegeld in 75 jaar VVAA (Rotterdam 200o)

Lieburg, Mart J. van, 'Joodse medici in Nederland tijdens de Tweede Wereldoorlog', in: J.H. Coppenhagen, Anafiem Gedoe'iem. Overleden joodse artsen uit Nederland 1940-1945 (Rotterdam 2000)

Liek, Erwin, Der Arzt und seine Sendung. Gedanken eines Ketzers (München 1926)

Lifton, Robert, Nazi Doctors. Medical Killing and the Psychology of Genocide (New York 1986)

Ligtvoet, Pim, 'Tk heb een heel tijdje niets van me laten horen'. Joden in de Zaanstreek (I940-1945) (Wormer 2007)

Lindeboom, Gerrit A., Hippocrates (Amsterdam I948)

Lindeboom, Gerrit A., 'Het (aan Maimonides toegeschreven) ochtendgebed van een arts', $\mathrm{Ne}$ derlands Tijdschrift Geneeskunde II5 (I97I) 924-7

Linden K. v.d., e.a., Kom ga sjoelen! Bijdragen over de geschiedenis van de joodse gemeenschap in Haarlem (Haarlem 1999)

Lindwer, Willy, Kamp van hoop en wanhoop. Getuigen van Westerbork 1939-I945 (Amsterdam 1990)

Lipschits, Isaac, Tsedaka. Een halve eeuw Joods Maatschappelijk Werk in Nederland (Zutphen 1997)
Loghem, J.J. van, 'Eugenetische sterilisatie', Nederlands Tijdschrift voor Geneeskunde 75 (193I) 6207

Lurvink, Peter, De joodse gemeente te Aalten. Een geschiedenis I630-I945 (Zutphen I99I)

Lutke Schipholt, Ingrid, 'Dankzij mijn beroep leef ik nog. Bacterioloog Hertzberger overleefde zes concentratiekampen', Medisch Contact 6I (2006) 38, I494-I497

Lutke Schipholt, Ingrid, 'We waren onmisbaar. Dokterstitel bood huisarts Gerritsma een zekere bescherming', Medisch Contact 64 (2009) I8, 800-80I

Maas, Ad, en Hans Hooijmakers, Scientific Research in World War II. What Scientists Did in the War (New York 2009)

Mechanicus, Philip, In Dépôt. Dagboek uit Westerbork (Amsterdam 1964)

Meerloo, A.M., 'De beoordeeling van zelfmoordneiging', Nederlands Tijdschrift voor Geneeskunde 77 (1933) 3I-37

Meerloo, A.M., 'Zelfmoord en arts', Geneeskundige Gids I8 (1940) 500

Meerloo, Joost A.M., Een mond vol spijkers (Wassenaar 1975)

Meeuwenoord, Marieke, Mensen, macht en mentaliteiten achter prikkeldraad. Een historischsociologische studie van concentratiekamp Vught (1943-1944), proefschrift UvA, (Amsterdam 2OII)

Meihuizen, Joggli, Smalle marges. De Nederlandse advocatuur in de Tweede Wereldoorlog (Amsterdam 20I0)

Meij, Ruth van der, Hartelijke groeten. Berichten uit concentratiekampen (Uithoorn 20I2)

Meijer, Jaap, Zij lieten hun sporen achter. Joodse bijdragen tot de Nederlandse beschaving (Utrecht 1964)

Meijer, Jaap, Hoge hoeden, lage standaarden. De Nederlandse Joden tussen 1933 en 1940 (Baarn 1969)

Meijer, Maaike, M. Vasalis. Een biografie (Amsterdam 20I2)

Meijler, Hanny S.R., Ik zou wéér zo gek zijn. Mannen van de Irenebrigade (Amsterdam 1992)

Melkman-de Paauw, Fré, Hoe het verder gaat weet niemand. Na-oorlogse brieven uit Amsterdam naar Palestina (Amsterdam/Antwerpen 2002) 
Micheels, Louis J., Dokter II764I. Herinneringen aan de holocaust (New Haven 1989)

Micheels, Pauline, Muziek in de schaduw van het Derde Rijk. De Nederlandse symfonie- orkesten, I933-I945 (Zutphen 1993)

Michman, Joseph, Hartog Beem, en Dan Michman, Pinkas, Geschiedenis van de joodse gemeenschap in Nederland (Amsterdam 1992)

Middelberg, Matthias, Judenrecht, Judenpolitik und der Jurist Hans Calmeyer in den besetzten Niederlanden 1940-1945 (Göttingen 2005)

Mill, John Stuart, en Jeremy Bentham, Utilitarianism and Other Essays (New York 1987)

Michalczyk, John, Medicine, Ethics, and the Third Reich: Historical and Contemporary Issues (Kansas City 1994)

Moei, Janneke de, Joodse kinderen in het kamp Vught (Vught 1999)

Moei, Janneke de, Het leven niet waard. Een geschiedenis van rassenwaan (Hooghalen 20II)

Mooij, Annet, Doctors of Amsterdam. Patient Care, Medical Training and Research I650-2000 (Amsterdam 2002)

Moore, Bob, Refugees from Nazi Germany in the Netherlands 1933-1940 (Dordrecht 1986)

Moore, Bob, Victims and Survivors. The Nazi Persecution of the Jews in the Netherlands 1940-1945 (Londen 1997)

Moore, Bob, Survivors. Jewish Self-Help and Rescue in Nazi-Occupied Western Europe (Oxford 2010)

Moraal, Eva, Als ik morgen niet op transport ga, ga $i k$ 's avonds naar de revue. Kamp Westerbork in brieven, dagboeken en memoires (1942-2010), proefschrift UvA (Amsterdam 2013)

Mulder, Hans, Kunst in crisis en bezetting. Een onderzoek naar de houding van Nederlandse kunstenaars in de periode 1930-1945 (Utrecht I978)

Muller, Juul, Nico Richter I9IS-I945 (Amsterdam 2003), digitale kopie in bezit van auteur

Muller, Maurits L., 'In memoriam dr. E.H.B. van Lier', Nederlands Tijdschrift voor Geneeskunde 84 (I940) 2076-2077

Muller, Maurits L., Aan de poort van het leven (Utrecht 1947)

Munnick, Boris de, Uitverkoren in uitzondering? Het verhaal van de Joodse 'Barneveld-groep' 1942-
I945 (Barneveld I99I)

Muntendam, P., 'Het vraagstuk der lijkopening in een joodsche gemeenschap', Nederlands Tijdschrift voor Geneeskunde 68 (I924) 2406-2407

Muskens, L.J.J., 'Aanteekeningen omtrent de sterilisatie in Duitschland', Nederlands Tijdschrift voor Geneeskunde 79 (1935) 78-79

Nadav, Daniel, 'Jewish Medicine during the Holocaust in the Ghettos and Forests', in: Natalia Berger, Jews and Medicine (Jeruzalem I995) 205-219

Nahum, Henri, La médécine Francaise et les Juifs 1930-1945 (Paris 2006)

Nassauer, Max, De goede dokter. Een nuttig prentenboek voor jong en oud (Arnhem 1909)

Nevins, Michael, Jewish Medicine. What it Is and Why it Matters (New Jersey 2006)

Nevins, Michael, The Jewish Doctor. A Narrative History (New Jersey I996)

Nicosia, Frances R., en Jonathan Huener (red.), Medicine and Medical Ethics in Nazi Germany. Origins, Practices, Legacies (New York 2002)

Noordman, Jan, Om de kwaliteit van het nageslacht. Eugenetica in Nederland I9oo-I950 (Nijmegen 1989)

Nordheim, Moshe, From Rebuke to Rejoicing (Victoria 2004)

Nuland, Sherwin B., Maimonides (New York 2005)

Nys, T.R.V., 'Paternalisme en autonomie in de geestelijke gezondheidszorg', Tijdschrift voor psychiatrie 47 (2005) 8, 519-528

Oestreicher, Felix Hermann, Ein jüdischer Arztkalender. Durch Westerbork und Bergen-Belsen nach Tröbitz. Konzentrationslager-Tagebuch I943-I945 (Konstanz 2000)

Onderdijk, L., Ioo Jaar Algemeen Middelburgsch Ziekenfonds (Middelburg 1948)

Onstenk, Annemiek, Annemarie Grewel. Een portret (Amsterdam 2008)

Oonk, Jan, 'Dokter Isaak Cohen in Halle. Joodse arts in de oorlog', Kronyck 37 (2013) I48, 2-I2

Oord, Ad van den, Vervolgd en vergeten. Duitse en Nederlandse Joden in Oisterwijk 1933- 1945 (Oisterwijk 1998)

Oord, Niek van der, Jodenkampen (Kampen 2003)

Oosterhof, Hanneke, Het Apeldoornsche Bosch. 
Joodse psychiatrische inrichting I909-I943 (Heerlen i989)

Oosterhuis, Harry, Marijke Gijswijt-Hofstra, Verward van geest en ander ongerief. Psychiatrie en geestelijke gezondheidszorg in Nederland (I8702005) (Houten 2008)

Oudshoorn, Nelly, Beyond the Natural Body. An Archeology of Sex Hormones (Londen 1994)

Pannekoek, J.H., 'De clinicus, onderzoeker en leermeester Abraham Albert Hijmans van den Bergh (I869-I943)', Nederlands Tijdschrift voor Geneeskunde 137 (1993) 1982-1987

Pelser, Henk, Vluchtweg Zwitserland. Verhalen uit een ondergronds verleden (Amsterdam 1996)

Pelzman, Liliane, En verder geen leed. Een moeder, haar dochter, hun oorlog (Amsterdam 2009)

Perath, Meyer J., Tussen Jeruzalem en Amsterdam (Baarn I975)

Pereira-d'Oliveira, Elsa, Vrouwen feministen die van genezen wisten (Amsterdam 1973)

Perks, Robert, en Alistair Thomson, The Oral History Reader (Londen 1998)

Pinkhof, Herman, Het beroep van arts, no. 7 in de serie Morks' beroepsbibliotheek (Dordrecht I9I2)

Pinkhof, Herman, De eubiotiek van het Joodsche volk (Amsterdam 1908)

Pinkhof, Herman, 'De vruchtbaarheid der Joden voorbij', Nederlands Tijdschrift voor Geneeskunde 72 (I928) $585 \mathrm{I}$

Pinkhof, Herman, 'Verklaring van overlijden bij zelfmoord', Nederlands Tijdschrift voor Geneeskunde 76 (1932) 4464-4465

Pinkhof, Herman, 'Geneeskundige hulp bij zelfmoord', Nederlands Tijdschrift voor Geneeskunde 3I (1933) 3603

Pinkhof, Herman, 'Sterilisatie zonder geneeskundige indicatie', Nederlands Tijdschrift voor Geneeskunde 77 (1933) 3402

Pinkhof, Herman, 'Sterilisatie van erfelijk blinden', Nederlands Tijdschrift voor Geneeskunde 78 (1934) 826

Pinkhof, Herman, 'De ziekenfondsstrijd te Utrecht', Nederlands Tijdschrift voor Geneeskunde 78 (I934) 9II-9I2

Pinkhof, Herman,'Over sterilisatie en castratie in het Jodendom', Boschblaadjes, 4 (I935) 5, 34

Pinkhof, Herman, 'Rechterlijk oordeel aangaande het overnemen van practijk', Nederlands Tijdschrift voor Geneeskunde 85 (I94I) 2853

Poel, Stefan van der, Joodse stadjers. De Joodse gemeenschap in de stad Groningen (I796- I945) (Assen 2004)

Poel, Stefan van der, Tussen zieken, boeken en kikkers. De fysiologie van een leven. Izaac van Deen (I804-1869) (Groningen 2012)

Polak Daniëls, Leonard, 'Over de pathologie van het endocrine stelsel bij de Joden', Nederlands Tijdschrift voor Geneeskunde 74 (1930) 289-29I

Poliakoff, Samuel, 'Raskenmerken bij Joden', de Vrijdagavond 2 (I925) 5, 78-80

Poons, M., 'Bij de sloop van het voormalig Ned. Isr. Ziekenhuis', Hakehilla 24 (I979) 7, 2I-23

Poorthuis, Marcel, 'Het concept van genezen in de Joodse traditie', Maatschappij en gezondheid (I982) I5-42

Pos, H.J. (red.), Anti-semitisme en Jodendom. Een bundel studies over een actueel vraagstuk (Arnhem I939)

Posthuma, L.L., 'Nieuwe bedreiging der Joodsche artsen te Berlijn', Nederlands Tijdschrift voor Geneeskunde 79 (I935) 4697

Posthuma, L.L., 'Geen Joodsche artsen meer in Duitsland', Nederlands Tijdschrift voor Geneeskunde 82 (1938) 4746-4747

Premsela, Bernard, Geslachtelijke voorlichting van de rijpere jeugd (Amsterdam 1934)

Premsela, Bernard, Geboorteregeling (Amsterdam 1934)

Premsela, Bernard, Moeilijkheden in het huwelijk. Mededeelingen uit en voor de practijk, mede ontleend aan het Dr. Aletta Jacobshuis te Amsterdam (Amsterdam 1936)

Premsela, Bernard, De ongehuwde man (Amsterdam 1939)

Premsela, Bernard, Sexuologie in de praktijk (Amsterdam 1940)

Premsela, Bernard, Ochtend defilé (Amsterdam 1946)

Jacques Presser, Ondergang. De vervolging en verdelging van het Nederlandse Jodendom 1940-1945 2 dln ('s-Gravenhage I965) 
Prins, Marcel, en Peter Henk Steenhuis, Andere achterhuizen. Verhalen van joodse onderduikers (Amsterdam 20IO)

Pronk, Heleen, 'Zoals ik het mij herinner. Levensverhaal van Geertrui Hingst. Deel I: 1927- 1945.' (Wassenaar/Amsterdam/Voorthuizen 20II) kopie in bezit van auteur

Querido, Arie, Doorgaand verkeer. Autobiografische fragmenten (Lochem 1980)

Quispel, B., 'M. Elzas 50 jaar Doctor Medicinae', Nederlands Tijdschrift voor Geneeskunde IIO (I966) I206-I207

Randwijk, H.M. van, In de schaduw van gisteren. Kroniek van het verzet 1940-1945 (Amsterdam 1967)

Reinalda, Bob, 'Jan Meilof IJben I913-I989: leraar geschiedenis met een verzetsverleden' (Leur 20II), kopie in bezit auteur

Reis, Shmuel, 'Learning from the Past: Medicine and the Holocaust', The Lancet 374 (2009) 9684, IIO-III

Rens, Herman van, Vervolgd in Limburg. Joden en Sinti in Nederlands-Limburg tijdens de Tweede Wereldoorlog (Hilversum 2013)

Reijnders, Carolus, Van 'Joodsche natiën' tot Joodse Nederlanders (Amsterdam 1970)

Rinsema, Thijs J., Joden in Meppel 1940-I945 (Zutphen 2004)

Rohrbach, J.M. e.a., 'Jüdische Augenärzte im Nationalsozialismus. Eine Gedenkliste', Klinisches Monatsblat Augenheilkunde 228 (201I) 70-83

Röling, Hugo, 'Bernard Premsela, Pionier van de seksuologie: beminnelijk en inconsequent', $O n$ Amsterdam 46 (1994) 240-244

Roland, Charles G., Courage under Siege. Starvation, Disease, and Death in the Warsaw Ghetto (New York 1992)

Roland, Charles G., 'Creativity in the Face of Disaster: Medicine in the Warsaw Ghetto', in: John J. Michalczyk, Medicine, Ethics, and the Third Reich: Historical and Contemporary Issues (Kansas City 1994) I53-I60

Romijn, Peter, Boosaardig bestuur. Rede uitgesproken bij de aanvaarding van het ambt van gewoon hoogleraar met als leeropdracht Geschiedenis van de 2oste eeuw, in het bijzonder betreffende het openbaar bestuur in tijden van oorlog en crisis aan de Universiteit van Amsterdam op 21 november 2002 (Amsterdam 2002)

Romijn, Peter, 'Inleiding', in: C.L.F. Tetteroo, Mijn dagboek, oorlogskroniek van Kees Tetteroo (Zaltbommel 2007)

Romijn, Peter e.a., Comparing the Persecution of the Jews in the Netherlands, France and Belgium, 1940-1945: Similarities, Differences, Causes (Amsterdam 20II)

Romijn, Peter, Bart van der Boom e.a., The Persecution of the Jews in the Netherlands 1940-1945. New Perspectives (Amsterdam 20I2)

Rooijmans, H.G.M., 'Stokvis en de psychosomatiek', Nederlands Tijdschrift voor Geneeskunde I38 (I994) 26II-26I4

Roos, Julius, en Willy Hijmans, 'In Memoriam dr. A. Polak Daniëls', Nederlands Tijdschrift voor Geneeskunde I30 (1986) I297-I298

Rooy, Laurens de, Snijburcht. Lodewijk Bolk en de bloei van de Nederlandse Anatomie (Amsterdam 20II)

Rose, Leesha, The Tulips Are Red (Jeruzalem 1978)

Rosh White, Naomi, 'Holocaust Testimony and History', in: Robert Perks en Alistair Thomson, The Oral History Reader (Londen 1998)

Rosner, Fred, Medicine in the Bible and the Talmud: Selections from Classical Jewish Sources (New Jersey 1995 2)

Rosner, Fred, Biomedical Ethics and Jewish Law (New Jersey 200I)

Rosner, Fred, Frank Heynick, Jews and Medicine. An Epic Saga (New Jersey 2002)

Rothman, David J., Strangers at the Bedside. A History of how Law and Bioethics Transformed Medical Decision Making (New York 199I)

Rijnberk, Gerard van, 'H. Pinkhof, I888-25 februari-I929. Een medisch journalistiek jubilaeum', Nederlands Tijdschrift voor Geneeskunde 73 (I929) 898-900

Rijnberk, Gerard van, 'Medische ethiek', Nederlands Tijdschrift voor Geneeskunde 80 (I936) 299I

Rijnberk, Gerard van, 'I940-Mei-I945, Aanvullingen en verbeteringen', Nederlands Tijdschrift voor Geneeskunde 89 (1945) 264-267

Sajet, Ben, Een leven lang. Verteld aan Hans Fels 
(Baarn 1977)

Samuel, Raphael, Theatres of Memory (Londen 1994)

Schaap, Louis, 'In memoriam Dr. S. Kroonenberg', Nederlands Tijdschrift voor Geneeskunde Io6 (I962) 49

Schellekens, Mark, Walter Süsskind, Hoe een zakenman honderden Joodse kinderen uit handen van de nazi's redde (Amsterdam 20II)

Schelvis, Jules, Vernietigingskamp Sobibor (Amsterdam 1993)

Schenck, Ca.M., 'De sterilisatie op eugenetische indicatie en het geldende recht', Nederlands Tijdschrift voor Geneeskunde 79 (1935) 2266-2268

Schenkel, Marjolein, De Twentse paradox. De lotgevallen van de joodse bevolking van Hengelo en Enschede tijdens de Tweede Wereldoorlog (Zutphen 2003)

Schöffer, Ivo, 'Nederland en de Joden in de jaren dertig in historisch perspectief', in K. Dittrich en H. Würzner (red.) Nederland en het Duitse Exil 1933-1940: Achttien essays (Amsterdam 1982)

Schrijvers, Piet, Rome, Athene, Jeruzalem. Leven en werk van Prof.dr. David Cohen (Groningen 2000)

Schwegman, Marjan, 'Uitzonderlijk of juist heel gewoon. Aantekeningen bij het ongemakkelijke begrip “heldendom”, in: Jaap Cohen en Hinke Piersma (red.), Moedige mensen. Helden in oorlogstijd (Amsterdam 20I4) 22-27

Seeligmann, Sigmund, 'Die Juden in Holland. Eine Characteristik' in: Festskript i Anledning af Professor David Simonsens 70-aarige Fødselsdag (Kopenhagen 1923) 253-257

Seidler, Eduard, Jüdische Kinderärzte 1933-1945. Entrechtet, geflohen, ermordet. (Basel 2007)

Shasha, Shaul M., 'Medicine in the Ghettos during the Holocaust', Harefuah Medical Journal I4I (2002) 4, 318-323

Silver, Daniel, Refuge in Hell. How Berlin's Jewish Hospital Outlasted the Nazis (Boston 2003)

Sitniakowsky, I., 'Overleven leidde vaak tot schuldgevoel. Sober relaas over hel van Sobibor', De Telegraaf, I2-5-1979

Sluiter, E., 'Suikerziekte bij Joden', Nederlands Tijdschrift voor Geneeskunde 73 (I929) II66
Smits, Boudewijn, Loe de Jong I9I4-2005. Historicus met een missie (Amsterdam 2014)

Snelders, Stephen, en Toine Pieters, 'Van degeneratie tot individuele gezondheidsopties', Gewina 26 (2003) 203-215

Somers, Erik, Voorzitter van de Joodse Raad. De herinneringen van David Cohen I94I-I943 (Zutphen 20Io)

Spanjaard, Jaap, Brieven 193I-I985 (Amsterdam 1993)

Speyer, Nico, 'Overzicht van den geschiedenis van den zelfmoord in Nederland', Nederlands Tijdschrift voor Geneeskunde 82 (1938) I599-I605

Stegge, Cecile aan de, Gekkenwerk. De ontwikkeling van het beroep psychiatrisch verpleegkundige in Nederland I830-1980 (Maastricht 20I2)

Steinberg, Maxime, La Persécution des Juifs en Belgique (1940-1945) (Brussel 2004)

Stern, Sam, Ziekenbroeder in kamp Westerbork (Westerbork 2004)

Stokvis, Benno, Advocaat in bezettingstijd (Amsterdam 1967)

Swaan, Abram de, Compartimenten van vernietiging. Over genocidale regimes en hun daders (Amsterdam 20I4)

Sijes, Ben, De arbeidsinzet. De gedwongen arbeid van nederlanders in Duitsland 1940-I945 (Den Haag I966)

Stuldreher, Coen, De legale rest. Gemengd gehuwde Joden onder de Duitse bezetting (Amsterdam 2007)

Szwajger, Adina, I Remember Nothing More: The Warsaw's Children's Hospital and the Jewish Resistance (Londen 1990)

Tammeling, B.P., Honderd vijfenzeventig jaar AZG (Groningen 1978)

Tausk, Marius, Organon. De geschiedenis van een bijzondere Nederlandse onderneming (Nijmegen I978)

Tec, Nechama, Resilience and Courage. Women, Men, and the Holocaust (Londen 2003)

Teeuwen, Rob, Het ziekenfondsbestel in historisch perspectief. Onderscheidene kenmerken van Nederlandse ziekenfondsen (Zeist 1998)

Temkin, Owsei, William K. Frankena, en Sanford H. Kadish, Respect for Life in Medicine, Philo- 
sophy, and the Law (Baltimore 1976)

Tetteroo, C.L.F., Mijn dagboek, oorlogskroniek van Kees Tetteroo (Zaltbommel 2007)

Thompson, Paul, Voice of the Past: Oral History (Oxford 2000 3)

Treub, Hector, Patiënt en geneesheer. Klinische les (Leiden 1892)

Treub, Hector, Medische fatsoensleer (Amsterdam 1903)

Tubergen, Frank van, Wout Ultee en Ruud Luijkx, 'The unwholesome theme of suicide', in: Chaja Brasz (red.), Dutch Jews as percieved by themselves and by others (Leiden 200I)

Tubergen, Frank van, en Wout Ultee, 'Political Integration, War and Suicide: the Dutch Paradox?' International Sociology 2I (2006) 223

Ughetti, G.B., Artsen en patiënten. Herinneringen van een geneesheer (Den Haag 1900)

Ultee, Wout, en Ruud Luijkx, 'De schaduw van een hand. Joods-gojse huwelijken en joodse zelfdodingen in Nederland 1936-1943' in: Henk Flap, en Wil Arts (red.), De organisatie van de bezetting (Amsterdam 1997)

Ultee, Wout en Ruud Luijkx, 'Jewish-Gentile Intermarriage in Six European Cities I9001940. Explaining Differences and Trends', The Netherlands Journal of Social Sciences 34 (1998) 2, I65-I93

Veld, N.K.C.A. in 't , De zuivering van artsen en advocaten (Den Haag 1983)

Venema, Derk, Rechters in oorlogstijd. De confrontatie van de Nederlandse rechterlijke macht met nationaal-socialisme en bezetting (Den Haag 2007)

Visser, Joost, Ben Crul e.a., Witte jassen en bruinhemden. Nederlandse artsen in de Tweede Wereldoorlog. Bijzondere getuigenissen van artsen en geneeskundestudenten 1940-I945 (Breda 20IO)

Vles, E.J., Een joodse arts in de bataafse tijd. Hartog de Lemon 1754-I823 (Rhoon 2000)

Voute, Peter, Only a Free Man. War Memories of Two Dutch Doctors 1940-1945 (Santa Fe 1982)

Vree, Frank van, De Nederlandse pers en Duitsland 1930-1939. Een studie over de vorming van de publieke opinie (Groningen 1989)

Vree, Frank van, In de schaduw van Auschwitz.
Herinneringen, beelden, geschiedenis (Groningen I995)

Vree, Frank van, Hetty Berg (red.), De Hollandsche Schouwburg. Theater, deportatieplaats, plek van herinnering (Amsterdam 2013)

Vries, Ben W. de, Remi. Portrait of a Young Dutch Jew in the Holocaust (Herzliya 2003)

Vries, Isidoor de, De vreemde waarheid. Herinneringen van een joodse jongen (I92I-I948) (Apeldoorn 1995)

Vries, Philip de, I94I M.C. I945. Geschiedenis van het verzet der artsen in Nederland (Haarlem 1949)

Waddington, I., 'The Development of Medical Ethics. A Sociological Analysis', Medical History I9 (I975) I, 36-5I

Wagt, Wim de, 'Thuis en niet-thuis in het Huis van Joles. Het Joles Ziekenhuis aan het Groot Heiligland (1930-I949)', in: K. v.d. Linden e.a., Kom ga sjoelen! Bijdragen over de geschiedenis van de joodse gemeenschap in Haarlem (Haarlem I999)

Wagt, Wim de, Joods Haarlem. Een topografie van hoop en herinnering (Wormer 2005)

Walsum, Sander van, Ook al voelt men zich gewond (Utrecht 1995)

Wasserstein, Bernard, On the Eve. The Jews of Europe Before the Second World War (Londen 20I2)

Weindling, Paul, Health, Race and German Politics between National Unification and Nazism I870I945 (Cambridge 1989)

Weindling, Paul, Nazi Medicine and the Nuremberg Trials. From Medical War Crimes to Informed Consent (Londen 2004)

Werkgroep Hilversums Verzet 1940-1945, Hilversum in onderdrukking en verzet 1940-1945 (Hilversum I985)

Wieberdink, J., 'Dr. S.M. Kropveld. Het begin van de Nederlandse hartchirurgie', Nederlands Tijdschrift voor Geneeskunde 133 (1989) 2238

Wielek, H. (ps. van Wilhelm Kweksilber), De oorlog die Hitler won (Amsterdam 1947)

Wiener, L.H., Wegens mensenkennis gesloten (Amsterdam I988)

Wiersma, E.D., 'Sterilisatie, een onderzoek naar de mogelijkheid eener wettelijke regeling der 
geslachtelijke onvruchtbaarmaking in Nederland', Nederlands Tijdschrift voor Geneeskunde 77 (1933) 5002

Wiersma, E.D. 'Sterilisatie en castratie', Nederlands Tijdschrift voor Geneeskunde 79 (1935) I074-I077 Wijsenbeek, Thera, Zieke lieverdjes. I2s jaar kinderzorg in het Emma Kinderziekenhuis (Amsterdam I990)

Wilde, P.A. de, 'Gouden artsjubileum Dr. H. Pinkhof', Nederlands Tijdschrift voor Geneeskunde 79 (I935) I029-IO3O

Wildervanck, L.S., 'Het overnemen van een practijk', Nederlands Tijdschrift voor Geneeskunde 8I (I937) 4870-4874

Wind, Eddy de, Eindstation Auschwitz (Amsterdam I98I)

Winick, Myron (red.), Hunger Disease. Studies by the Jewish Physicians in the Warsaw Ghetto (New York 1979)

Winkler, T.C., Dokter en patiënt ('s Hertogenbosch I880)
Withuis, Jolande, Weest manlijk, zijt sterk. Pim Boellaard (1903-200I) Het leven van een verzetsheld (Amsterdam 2008)

Wortman, J.L.C. De ethica aan het ziekbed (Haarlem i929)

Wyers, Suzette, Als ik wil kan ik duiken. Brieven van Claartje van Aals, verpleegster in de joods psychiatrische inrichting Het Apeldoornsche Bosch 1940-1943 (Amsterdam 1995)

Zee, Nanda van der, Om erger te voorkomen (Amsterdam 1997)

Zeeman, W.P.C., 'In memoriam dr. E. Marx, arts geworden 1906, doctorstitel 1925', Nederlands Tijdschrift voor Geneeskunde 84 (1940) 20752076

Ziekenoppasser, Hans, 'Stem uit het verleden', Nieuw Israëlitisch Weekblad, 3-4-2012

Zwarte-Walvisch, Klaartje de, Alles ging aan flarden (Amsterdam 2009)

\section{ZONDER AUTEUR}

'Het Nederlanderschap geëerd', Nieuw Israëlitisch Weekblad 23-6-1933

'Ik ben niet onderscheiden omdat ik de oorlog heb overleefd', De Tijd I3-I-I984

Het Joodsche Weekblad: uitgave van den Joodschen Raad voor Amsterdam I-3 (I94I-I943) (Amsterdam heruitgave 1979)

'Lijkopening in Joodsche ziekenhuizen', De Telegraaf $19-4-1939$
'Lijkopening nuttig voor de medische wetenschap. Ondanks verbod van het Israelietisch geloof toch toepassing noodig', Het Vaderland, staat-en letterkundig nieuwsblad, 26-4-1939

'Medische Kroniek', Algemeen Dagblad 2I-9-I933 Strekkend tot heil der lijdende menschheid. 75 jaar ziekenhuis Heerenveen (Drachten I988)

\section{ARCHIVALIA}

\section{Antoni van Leeuwenhoekziekenhuis}

Notulen vergadering dagelijks bestuur

\section{Museum Boerhaave}

N. Waterman, correspondentie betreffende Watermans particuliere laboratorium tijdens de oorlogsjaren I940-I945, correspondentie van zijn vrouw in Westerbork, Museum Boerhaave, Leiden,
MB, a 264, met dank aan Mieke de Mots en het Museum Boerhaave te Leiden

\author{
Dordrechts Archief DIEP \\ O. Cahen, archief 489
}

IISG Amsterdam

Ben Sajet-archief 
Benno Stokvis-archief

Joods Historisch Museum

Collectie: boeken, documenten, foto's, Joodse pers, museumstukken

\section{Lohamei Hagettaot / Ghetto Fighters Museum \\ Lohamei Hagettaot, Holland Section}

\section{Nationaal Archief}

Calmeyer archief, Centraal Bureau voor Genealogie Centraal Archief Bijzondere Rechtspleging

Geneeskundige Hoofdinspectie 1902-1952, 2.15.38 Inspecteurs van het staatstoezicht op krankzinnigen en krankzinnigengestichten, 2.15.40

Koninklijke Nederlandse Maatschappij ter bevordering der Geneeskunde 2.I9.053.0I

Medisch Contact 2.19.053.02

Militair Gezag 2.13.25

Ministerie van Justitie te Londen, Engelandvaarders

Ministerie van Onderwijs, personeel 2.I4.I7

Ministerie van Sociale Zaken, afdeling Volksgezondheid, 2.15.37

Rijksarbeidsbureau in Oorlogstijd 2.I5.20

Vereniging ten behoeve van het ziekenhuiswezen,

2.19.IIO.OI

Waterstaat/vervoerwezen, 2.I6.84

Zorg voor Vluchtelingen 2.04.58

\section{NIOD}

DOC I

DOC II

20: Generalkommissar für Verwaltung und Justiz

77: Hohere ss, waaronder Referat IV B4 en Zen-

tralstelle für jüdische Auswanderung

86: Beauftragten

09I: Deutsche Krankenkasse

Iorb: Kabinet Binnenlandse Zaken

I8Ig: J.H. Aa

I8Ij: David Cohen

I82: Joodsche Raad voor Amsterdam

I87: De Zwitserse Weg

2I2k: J.C.C. Borst

244: Dagboeken

Alfred Behrendt, inv.nr. 1547

Jeltje Eckert-Stroink, inv. nr. II92
Benedictus Koopman, inv.nr. I160

Salomon Koster, inv. nr. 996

Jacques Lobstein, inv.nr. 1625

J.C. Schultsz, inv.nr. I350

Antonius Hermanus Maria Johannes Gerardus

Sluijters, inv.nr. 458

Berthold Stokvis, inv.nr. II49

Herman Cornelis Voorhoeve, inv.nr. 1695

J. Zwaaf, inv.nr. 1624

25ob: Barneveld

250d: Kampen en gevangenissen buiten Nederland

25og: Vught, Konzentrationslager Herzogenbusch

25oi: Westerbork, Judendurchgangslager

284: Artsenzuivering

8I2: Stichting Comité Joods Verzet

\section{Knipselarchief}

KA II I24: Artsenverzet

KA II 979: Joden-Nederland, Artsen

KB I 9388: E.A. Cohen

KB II I68: Artsen, verzet

KB II 0773: Sterilisatie

KB II I273: Westerbork

KB II 2685: Westerbork

\section{Privéarchieven}

Familie Baruch, Amsterdam

Familie De Beer, Terband

Familie Van Coevorden, Amsterdam: Sally van

Coevorden, 'Zoals ik het beleefd heb' (Amsterdam;

z.j.) kopie in bezit auteur.

Familie Denekamp, Amsterdam

Familie Van Emde Boas, Amsterdam

Familie Fischer, Zeist

Familie Goudsmit, Amsterdam

Familie Van der Hal, Herzliyah

Familie De Jong, Peqi'in

H.F.B. Keijzer, Oudewater

Familie Kroonenberg, Amsterdam/Haarlem

D. van Loggem, Amsterdam

Familie Lopes Cardozo, Cambridge/Den Haag

Familie Muller, Driebergen

Familie Muller, Bussum

J. Niepoth, Amsterdam

Familie Reisel, Amsterdam

Familie Schaap, Amsterdam 
Familie Spanjaard, Amsterdam

Familie De Vries Robles, Amsterdam

W. Westerhof, Dordrecht

\section{Rode Kruis Den Haag}

Westerborkarchief: Joodsche Raad Cartotheek

\section{Stadsarchief Amsterdam}

022.2, inv.nr. 8: Statistisch Jaarboek Gemeente

Amsterdam 1940-I94I

334: Portugeesch Israëlietisch Ziekenhuis

687: NMG Afdeling Amsterdam

795: Centraal Israëlietische Ziekenverpleging

IOoI: Algemeen Ziekenfonds Amsterdam

I066: Centraal Israëlietisch Krankzinnigengesticht

I2I3: Joodse Invalide

I5OI: Frits Grewel

30I40: GG\&GD Amsterdam

30265, inv.nr. 647-654 en 950: Universiteit van

Amsterdam, faculteit geneeskunde, Arie de Froe

Stichting Historie Ziekenfondsen

3767888I3: ALZ (Heerenveen)

\author{
376789032: VHZ (Utrecht) \\ 256822182: AZH (Hilversum) \\ 376788907: Ziekenzorg (Utrecht)
}

\section{Yad Vashem}

M68, inv.nr. 175.9: Gemeentearchief Utrecht.

$\mathrm{O}_{2,2}$ 212: Max Benjamin, getuigenis

$\mathrm{O}_{2}, 638$ : Richard van Dam, getuigenis

O2, 357 Wiener: Herbert Kruskal

O2, 677 Wiener: Elisabeth Kalkstein-Neumann

O2, 688 Wiener: Hermann Schliesser

$\mathrm{O}_{3}$, inv.nr. 65I: Max Benjamin 'Eine prekäre

Situation'

$\mathrm{O}_{3}$, inv.nr. 942: Frederieke Henschel-Blueth

$\mathrm{O}_{3}$, inv.nr. 3968: Testimony Betty Levie

$\mathrm{O}_{3}$, inv.nr. 5142: Julius Elzas

$\mathrm{O}_{3}$, inv.nr. 5566: Testimony Jacov Bramson

$\mathrm{O}_{3}$, inv.nr. 5832: Testimony Juutje Duitscher

$\mathrm{O}_{3}$, inv.nr. II949: Testimony Anna Drukker-van

Dam

Pio, inv.nr. I52: Mark Dworzecki

\section{SPIELBERG-PROJECT 'T WEEDUIZEND GETUIGEN \\ VERTELLEN' \\ JOODS HISTORISCH MUSEUM}

Dina Angress-Dasberg

Carolina ter Beek-Frenkel

Josephine Benninga-Warendorf

Rosaliene Blocq-Vos

Rosa Bloemhof-Agsteribbe

Diny Boas-Vedder

Anne Bodenheimer

Juliette van Cleeff-Fernandes

Johnny van Coevorden

Max Cohen

Roosje Colthof

Maurits Coronel

Max van Dam

Martha Edersheim-de Vries

Dicky Ehrlich-Weile

Estella Emanuels-Mendels

Irene Fainman-Krausz
Hetty Fortuin-Blitz

Ernest Frank

Joachim Frank

Simon Frenkel

Mina Friedländer-Marcus

Jetty en Renée Pinto

Betsy Gezang-van Praag

Nelly Henriëtte Giethoorn-van Geens

Alice Gomperts

Martin Goslins

Joop Granaada

Govert de Haas

Lea de Haas-Leuiken

Jozef van der Hal

Dorothea Herschel

Herman Herschel

Ellis Hertzberger 
Emma Hoes-de Winter

Sara Jacobs

Abel de Jong

Tons Katzenstein-Hartogs

Gyula Kircz

Hans Klein

Marjon Koolhoven-Kalker

Max Koster

Henriëtte Kijzer

Ernst (Boes) Lankhout

Anita Leeser-Gassan

Johanna Leijs-Schakel

Lowina de Levie

Carla Lugt-Goudeket

Piet Meerburg

Henriëtte Malahi-Mendels

Hajo Meyer

Louis Micheels

David Moffie

Alida en Martinus Mussert

Jacques Nijburg

Sara Oesterman-Plas

Dina Oppenheimer

Carla Ossendrijver

Anna de la Parra-Pool

Henk Pelser

Sarah Pelser-Oudkerk

Jack Pinto
Alfred van der Poorten

Marianne van der Poorten-Stokvis

Benno Premsela

Maurits Prins

Elly Pruikenmaker-Monnickendam

Abraham Querido

Annie Reinfeld-Walg

Elsa Rodrigues Pereira-Jessurun d'Oliveira

Yvonne Samuels

Rudolf Jacob Sanders

Sijze Schortinghuis

Sera Schrijver

Abraham van der Sluijs

Jaap Soesan

Salomon van Son

Sophie Souget-Blindeman

Ima Shalom Spanjaard-van Esso.

Emanuel Speijer

Lily Spitzer-Hausdorff

Carla Tenzer-Hertzdahl

Sientje Thuis-Natkiel

Edward Vas Nunes

Isidoor de Vries

Virry de Vries Robles

Ida Wallach

Mary de Wit

Paula Zadoks

\section{WEBSITES}

Bevrijding intercultureel http://www.bevrijdingintercultureel.nl/bi/surijoods.html

Biografisch Woordenboek http://www.historici.

nl/Onderzoek/Projecten/BWN/lemmata/bwn4/ stokvis

Boston University http://www.bu.edu/bostonia/ winter-springI2/holocaust-doctors/

Diamant, Salomon http://www.thuisinbrabant.nl/ personen/d/diamant\%2c-salomon

http://www.boschboom.nl/Download/columns/

De\%2oBoschboom\%2015042007\%2014\%20

Theo\%2oHoogbergen.pdf

Engelandvaarders http://www.holywellhousepu-
blishing.co.uk/Zeemanshoop_voyage.html

Franse Joodse artsen http://clio-cr.clionautes.org/ la-medecine-francaise-et-les-juifs-I930-I945.html\#. VADhahZwvgI

Genootschap Joodse Wetenschap I. van Esso, 'Dr. Hermanus Pinkhof', http://www.genootschapjoodsewetenschap.nl/bijdragen-en-mededeelingen levensberichten 1956

Hausdorff, David A.M. van der Woel, 'Dr.

Hausdorff I9OI-I990' http://rjb.x-cago.com/ GARJB/I99I/I2/I99II23I/GARJB-I99II23I-OI47/ story.pdf 9-4-20I4

Historad Antoni van Leeuwenhoekziekenhuis 
http://www.historad.nl/nl/\#!/nl/Ioo-jaar-radiotherapie-antoni-van-leeuwenhoek-oorlogsjaren/joodse-medewerkers-ontslagen-op-last-van-bezetter/ Jacobs http://javapost.nl/20I2/03/27/aletta-jacobsen-de-indische-connectie/ 3-4-20I4.

Jacobson, Abraham http://www.crt-II.org/_ awards/_apdfs/Jacobson-Granaat_Rosa.pdf Evleth, Donna ,'The Ordre de Médécins and the Jews in Vichy France, 1940-1944' in: www. fh.oxfordjournals.org http://www.holocaust-history.org/klarsfeld/ French\%20Children/html\&graphics/Too95.shtml http://bdi.memorialdelashoah.org/internet/jsp/ core/MmsRedirector.jsp?id=58I79\&type=VICTIM Joods Biografisch Woordenboek http://www. joodsbw.nl

Joods Monument http://www.joodsmonument.nl Joods Monument Zaanstreek http://www.joodsmonumentzaanstreek.nl/pagina-I435-Wessel-Max. htm

http://www.joodsmonumentzaanstreek.nl/pagina2Io-Eisendrath-Bernard.htm

Joodse werkkampen http://www.joodsewerkkampen.nl

Koninklijke Bibliotheek, krantenarchief www. kb.nl De Vrije Stem I5-5-1943 www.kb.nl 15-7-1943: De Stem van Vrij Nederland; voor God, Koningin en Vaderland, brief van de kerken van Nederland aan de Rijkscommissaris www.kb.nl 3-6-43 Trouw, jaargang I, nr 6, 'Jodenleed in Nederland' Medisch Contact / Artsendatabank http://medischcontact-artsendatabankwoii.artsennet.nl
http://medischcontact.artsennet.nl/kennis-I/dossiers/geschiedenis/tweede-wereldoorlog/archievenen-documenten

Muller, Maurits Micha.reisel.net/memor/dagboek. htm

Nederlands Tijdschrift voor Geneeskunde http:// www.ntvg.nl

Oral History Oral History Association Pamphlet Number 3, http://www.baylor.edu/ -OHA/EvaluationGuidelines.html\#Principles and Standards http://www.isgeschiedenis.nl/archiefstukken/iederzijn-eigen-oorlog-egodocumenten-over-de-tweedewereldoorlog/

Project on Medicine and the Holocaust http:// www.projectmedholo.org

Testimonies https:/www.youtube.com/ watch?v=kbnUclxKkvw testimony Kitty Zilversmit-Fonteyn USC Shoah Foundation Sal van Son, documentaire. http://www.xs4all. $\mathrm{nl} /$-tfursten/apeldoornscheboschdoc/ Vermoedelijk op transport Raymund Schütz, Vermoedelijk op transport (masterscriptie archiefwetenschappen) (november 20Io, update juni 20II) http://www.joodsebibliotheek.nl/auteur/Noo/ Raymund-Schutz/boek/Igo/Vermoedelijk-optransport/I/txt/

Verzetsmuseum Amsterdam http://www.verzetsmuseum.org/museum/nl/tweedewereldoorlog/achtergrond/achtergrond,amsterdam/straatnamen Wellcome Library http://wellcomelibrary.org Wiener Library http://www.wienerlibrary.co.uk/

\section{TENTOONSTELLING}

Trail of the Magic Bullet. The Jewish encounter with Modern Medicine I860-I960. 26 feb- I2 aug 20I2. Yeshiva University Museum at The Center for Jewish History New York City. 


\section{GERAADPLEEGDE EN GEÏNTERVIEWDE PERSONEN}

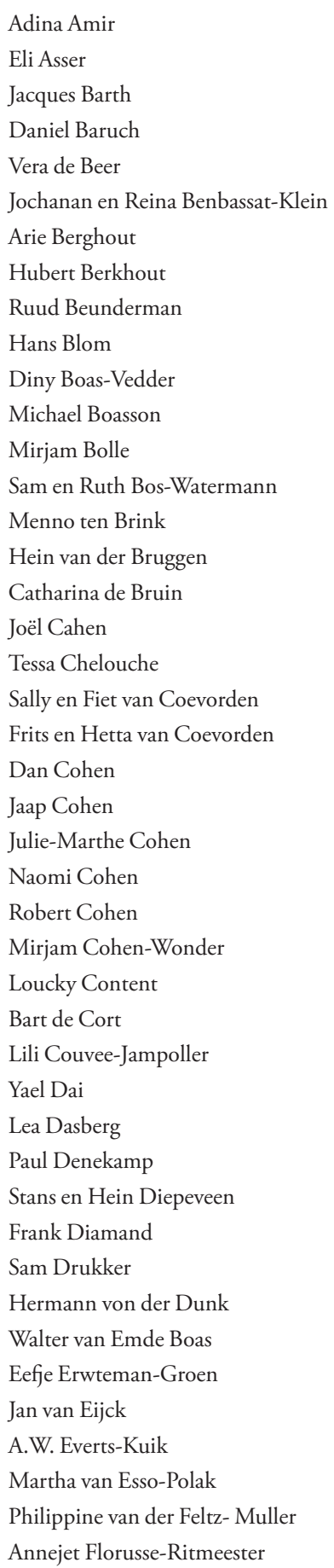

Maurits Frenkel

Iki Freud

Ralph van Furth

Evelien Gans

Wiet Gans

Leo en Jetty van Gelder-Pinto

Sieg en Leah Gitter

Frits en Annie Glaser

Esther Göbel

Judith Gobits

Caroline Godfried

Rob Goudsmit

Lydia Granaat-ten Doesschot

Pim Griffioen

Michael Grodin

Henk van der Gugten

Ilse de Haas-Vyth

Max en Linda Hamburger

Nico van Hasselt

Dov Hausdorff

Paul Hertzberger

Jenny Hertzberger-Gold

Joop Hes

Hugo Heijmans

Herman van der Hoeven

Frits Hoogewoud

Dick Houwaart

Annemie Houwink ten Cate

Willy Hijmans

Dik Jacobs

Abel en Ruth de Jong

Sophie Josephus Jitta

Betty Kazin

Hans en Marita Keilson

Robert Kiek

Sonja Kiek

Eldad Kisch

Clara Klein

Jaap Klein

Simon Kleijker

P.J. Knegtmans

Rosa Knorringa

Lily Korijn

Max en Hannah Koster-Souget 


\begin{tabular}{|c|c|}
\hline Anton Kras & Benjamin Ricardo \\
\hline Kees Kroonenberg & Arnold en Meta Rodrigues Pereira-van Rhijn \\
\hline Salomon Kroonenberg & Jaap Rodrigues Pereira \\
\hline Rob Kropveld & Suzanne Rodrigues Pereira \\
\hline Huib Lems & Avraham Roet \\
\hline David de Levita & Carel Roos \\
\hline Helene Levy & Julius Roos \\
\hline Pim Ligtvoet & Leesha Rose \\
\hline Diederik van Loggem & Suze Rottenberg-Glaser \\
\hline Ada Lopes Cardozo & Philip Rümke \\
\hline Lida Lopes Cardozo & Ingrid Ruis \\
\hline Koos Lubsen & Nora van de Rijt \\
\hline Fatima van der Maas & Jaap Sajet \\
\hline Helene Meerschwam & Ans Samama-Polak \\
\hline Joggli Meihuizen & Erik Schaap \\
\hline Frieda Menco & Otto Schaap \\
\hline Stelly Menco Ricardo & Mirjam Schipper \\
\hline Eljah Mendels & Frans Schreuder \\
\hline Fred Meijer & Jan Schrijver \\
\hline Ruth van der Meij & Max Schrijver \\
\hline Annemarie Meijler & Raymund Schütz \\
\hline Mirjam Mijatovitsch-Keesing & Herbert Serphos \\
\hline S.H. van Minden & Ted en Meijer van der Sluis \\
\hline Marcel Monnickendam & Ed Spanjaard \\
\hline Mieke de Mots & Sharon Strauss-Cohen \\
\hline Hein Muller & Kara Stones-Vujcich \\
\hline Boris de Munnick & Harry Stroeken \\
\hline Rosetta Musaph-Andriesse & Dick Swaab \\
\hline Moshe Nordheim & Els Swaab \\
\hline Jan Oonk & Louis Tas \\
\hline Henriëtte Ophir-van der Hal & Tsiwja Tauber-Hertzberger \\
\hline Hadassa Peled & Rob en Carla Teeuwen \\
\hline Toine Pieters & Ed van Thijn \\
\hline Sierk Plantinga & Selma Velleman \\
\hline Margot Plesser & Bob Vintura \\
\hline Bettine Polak & Wout Visser \\
\hline Freek Polak & Louis van Vollenhoven \\
\hline Rob Polak & Robert Vonk \\
\hline Herman van Praag & Ben en Annemarie de Vries \\
\hline Heleen Pronk & Hans de Vries \\
\hline Tsila Rädecker & Virry de Vries Robles \\
\hline Bob Reinalda & Ron Vunsh \\
\hline Leo van der Reis & Jan Wagenaar \\
\hline Jacqueline Reisel & Margreet Wagenaar-Fischer \\
\hline Wanda Reisel & A.H. Waterman \\
\hline Herman van Rens & Leo Waterman \\
\hline
\end{tabular}


Sam Waterman

Wim Westerhof

Bettie Weijl

Jaap Wittenburg
Carel Wolff

Hans Ziekenoppasser

Ik ben hen allen zeer erkentelijk voor hun welwillendheid hun verhalen met mij te delen. Hun bijdrage is van onschatbare waarde geweest en de hulp en vaak ook vriendschap die ik van hen heb mogen ontvangen zijn onvergetelijk.

Bijzondere dank ben ik verschuldigd aan Julie Blik, veelzijdig en kundig fotograaf en een geweldig mens, en aan mijn ouders, Bert en Nicoline van den Ende-van der Wilk voor hun niet-aflatende steun. 


\section{SUMMARY}

During the Second World War, did Dutch Jewish doctors manage to live up to the imperative 'remember you are a doctor'? I This book starts with that question. After having studied the experiences of 534 Dutch Jewish physicians who lived and worked under German occupation, the answer is: no, they could not under all circumstances. Under the extreme circumstances of the Shoah, situations in which a doctor's profession lost its meaning did occur. However, for most of these 534 doctors, their duty to their profession remained an important guiding principle in their lives. Duties ànd privileges remained linked to their profession, though the nature of the individual doctor's duties and privileges could differ widely. For the first time in the historiography this study gives insight into the people the doctors were, their group and individual characteristics and their experiences and actions under exceptional circumstances.

\section{SUMMARY}

Before the German occupation being a doctor was of utmost importance to all Dutch medical practitioners. The medical profession was more than just a job: it was considered a calling. Being a doctor was to follow a noble tradition of virtuous and altruistic behaviour. Doctors were expected to ease the sorrows and burdens of their patients. Inherent to this was an element of paternalism. Furthermore, collegiality was seen as a natural characteristic of the 
doctor's profession. As a group, physicians formed an elite, distinguished society. Whether a doctor was Jewish or non-Jewish, Catholic or Protestant, was considered of secondary importance. During the decades before the Second World War, Jewish physicians had gained a position of equality in the Dutch medical world. And outside that medical world, in general Dutch society, they could make a career and be quite successful. This was especially the case in Amsterdam, where approximately forty percent of doctors were Jewish. In the rest of the Netherlands Jewish physicians made up about 8 percent of all Dutch doctors and were well integrated into society.

The integration of Jewish physicians into general Dutch medical culture was not problematic because of the matching moral convictions of Jewish medical ethics on the one hand and non-Jewish 'neo-romantic' medical ethics on the other. Indeed, Jewish medical ethics, symbolised by Maimonides' Morning Prayer for the Physician, expressed the ideal of a doctor's typical paternalistic altruism, just as was stated by the professional Ethical Guidebook, published by the Dutch Medical Association (NMG). This consistency of Jewish and non-Jewish ethics made it possible for Jewish physicians to feel completely at ease in the world of Dutch medicine. The integration of Jewish colleagues in the Dutch medical world did not necessarily mean that they also lived fully assimilated. Various expressions of being bound to the Jewish background were possible. Religion, tradition, Zionism and anti-Semitism could each play a role in defining one's 'Jewishness'. Also 'racial awareness', then common terminology, could make them feel Jewish. However, in Dutch science there was doubt about the definition of 'race', especially in relation to the Jews. In the Netherlands, unlike in Germany, theories of racial hygiene and eugenics gained little popularity. But despite the fact that the great majority of the Dutch doctors rejected Nazi medicine and protested against discrimination of Jewish physicians in Germany, the rise of Nazi power in Germany still had its effects on Dutch medicine and Dutch Jewish physicians. Anti-Semitism and the fear of anti-Semitism grew in the thirties, after Hitler came to power in 1933 with the resulting influx of German Jewish refugees into Holland. This made the Dutch Jewish physicians inescapably aware of their own Jewish background. But still, before May Ioth I940, first and foremost they were (ordinary Dutch) doctors.

The German occupation of the Netherlands changed everything. Medical ethics were suddenly interpreted completely differently in various situations than ever before, sometimes in a manner which seemed bizarre from a prewar point of view. After the Dutch defeat in May I940, there were some panic-stricken Jewish doctors who fled or committed suicide, abandoning hearth 
and home, their practices and their responsibilities towards their patients. Their fear overruled their professional duties and privileges. A relatively large percentage of the Jews who committed suicide in those early war days appear to have been doctors. Explanations could be that these eleven doctors had easy access to lethal medication and had often been in contact with German Jewish refugees, who had informed them thoroughly about the appalling situation of the Jews under Nazi rule. That might have made their fear even greater than that of others. Even though their measure was drastic and was in no way according to normal professional ethics, there was a lot of sympathy for these eleven colleagues. It seems that there was a general consensus amongst doctors that the old rules didn't apply anymore. Nevertheless, most of the Jewish doctors did try to continue to live according to the professional standards they had internalised, even though they were soon robbed of their status as ordinary Dutch doctors by the subsequent discriminating measures which were taken against them. In the first year of the occupation they were excluded from Dutch medicine by a prohibition for Jews to work in the civil service and because they were forbidden to treat non-Jewish patients. The effects were obvious: practically, financially and morally. To cite Jewish psychiatrist Berthold Stokvis: the Jewish doctors were degraded to 'patient attendants'. At the same time, the Dutch medical profession as a whole -notwithstanding their average anti-Nazi sentiments and lack (but not complete absence) of anti-Semitismappeared incapable of keeping their Jewish colleagues on board. The medical establishment showed indecisiveness in the case of the exclusion of the Jewish colleagues, while at the same time the imposed nazification of Dutch medicine was fought tooth and nail and a medical resistance movement called 'Medisch Contact' was formed. Jewish doctors were, for safety reasons, advised not to participate in the resistance activities. This resulted in isolation of the Jewish doctors, who could only work for Jewish patients without the collegial support they had been used to. This meant that professional habits and traditional demeanours they had once taken for granted now were not as solid anymore. They were on their own. They lived in a sort of Jewish 'state within a state', albeit one without any real sovereignty.

In February I94I the Jewish Council was appointed by the German authorities to lead the excluded Jewish community. Via this institution the occupying powers could indirectly make the Jews obey the anti-Jewish measures. Moreover, the Nazi rulers made sure that great fear existed among the Dutch Jews, by arresting many of them at random at an early stage of the occupation. These Jews were sent to death camps such as Mauthausen and Buchenwald, where they quickly perished. Death notices reached their families and the rest of the 
terrified Jewish community. Jewish doctors were captured in these early raids, for example the one in Twente in September 194I. According to testimonies of these arrests they often responded in a traditional doctor's manner: with a feeling of responsibility towards patients and with a certain trust that they - since they were doctors- would be treated with respect. At the same time, others were more suspicious and saw enough reason now to leave everything behind, including their doctor's obligation and relative privilege. For many of them leaving their practices behind had become easier, because they had already lost their gentile patients, who had made up the majority of their work. However, most doctors stayed on their positions and continued their work. They tried to preserve normality by, for example, initiating a medical course for Jewish physicians. This attempt at preserving normality can in itself be viewed as a form of resistance. The Jewish Council facilitated this, and other, attempts to proceed with life as normally as possible. However, normality under the flag of the Jewish Council was not entirely straightforward. Everything performed in name of the Jewish Council was charged with political implications: was it acceptable to work for an institution created by the occupying authorities? Wouldn't that be collaboration, even if one tried to -as the Jewish Council called it- 'cooperate whilst opposing'? That question became extra poignant for the Jewish doctors in the beginning of 1942, when they were asked to perform medical examinations for Jewish labour camps in the North and East of the Netherlands. These examinations would benefit the occupier's purpose and were therefore politically fraught. Examples are known of doctors who refused to perform them. Some of them individually, after having had bad experiences during examinations in Amsterdam, others collectively, like a group of Jewish doctors in Groningen. Many others did perform the examinations, but found ways to legitimise their behaviour. They left their pre-war medical ethical obligation of objectivity and started to sabotage the examinations. They aimed to help as many patients as possible, if needed with all sorts of fake diagnoses and feigned diseases. Even though a couple of doctors were known to object to this and to stick to their pre-war medical ethical standards, the large majority of the doctors turned to this - under normal circumstances bizarre - practice. And they kept doing this when the Dutch Jewish population entered the next stage of the German occupation, mid 1942: large scale deportation. Doctors became even more creative in this phase, arranging fake sick beds and fine-tuning their false medical declarations to show their patients were too ill to be deported. Practicing medicine suddenly became a means of helping people escape from the feared deportations. This goal was of the utmost importance to the medical practitioners and led to them setting aside previously unquestioned medical 
ethical principles. One can address this as a more teleological (valuing the result, the goal of an act) than deontological (valuing the act itself) approach to medical ethics.

Medicine could provide Jewish patients with an escape from the deportations, but also started to become a form of protection for the doctors themselves. In the first six months of the deportations at least 54 Jewish doctors were arrested, which proves that being a doctor was no guarantee of being safe. But, being a doctor did serve as a method to be safer than average. Doctors working for the Jewish Council or as volunteers in transit camp Westerbork did enjoy a certain protection. For this protection they did have to make the political concession of working for the Jewish Council, but on the other hand it also gave them the opportunity to help others as true doctors. Physicians who were puzzled by this tangle of moral problems tried to escape abroad (in total 43 doctors fled the country) or in death: by committing suicide. There was a second wave of suicides in this period. At least five Jewish doctors were victims of suicide after the deportations started, but those who stayed behind were also confronted with the issue of suicides. The issue of suicide led to another medical ethical dilemma: should doctors try and save these people if they could, as their old professional conviction would have been, or should they leave these people alone because suicide was preferable to a worse fate in one of the concentration camps? Every Jewish doctor faced with this dilemma must have had an internal struggle. The Amsterdam Jewish Psychiatric Society looked deeper into the matter and concluded that circumstances had changed the way suicide should be dealt with. In this extreme situation, suicide was an understandable reaction often performed by mentally competent and healthy individuals and families. Not everybody who attempted to commit suicide really wanted to die though. Some of these attempts were directed at gaining admission to one of the hospitals. Where being ill had already become desirable because of is protective value, being admitted to hospital was considered to be even more attractive as a safer strategy yet.

The Germans had promised they would not deport hospital patients. As a result, hospitals became, instead of being places where you would rather not be, extremely popular. The numbers of people admitted to the Jewish hospitals rose enormously in the second half of 1942. Pseudo-patients and pseudo-personnel were taken in, not without risk to the hospital staff. The directors of the hospitals, in particular, put themselves at risk with this generosity. Medical specialists in the hospitals added another type of medical sabotage by performing fake operations on healthy 'patients'. Again, the original medical ethics - the principle 'first do no harm' - was set aside for a higher goal: mak- 
ing people unfit for deportation. Again: a shift from a deontological medical ethical approach to a teleological one. However, where the concrete norms of the old ethics were overruled by circumstantial pressures, the overarching value of working in the interest of the individual patient was held utmost. The directors of the hospitals acted according to what they saw as their duty as leading physicians of their institutions. They had incorporated their medical obligation to take care of their patients so profoundly, that they didn't leave them until the bitter end: the round-ups in the hospitals. Jacques Lobstein, director of the first Jewish hospital to be violently emptied by the Germans, mental institution 'Het Apeldoornsche Bosch', set the example. Like him, also the other directors stayed, rather heroically, 'as captains on their sinking ships'.

The raid in 'het Apeldoornsche Bosch', January 2Ist I943, formed a watershed: from that moment onwards people were convinced that even the sick and the hospital patients would not be safe anymore. Moreover, this gave a terrifying insight in the purpose of deportation. Whereas beforehand one could have believed Nazi propaganda that deportation meant being sent to a labour camp in Eastern Europe, now that frail and sick people were being deported this explanation was less credible. The belief that these obviously unfit 'labourers' would be murdered became widespread. Under these circumstances, the large majority of the doctors, Jewish and non-Jewish, decided that they could not take part in a new issue occurring mid 1943: the sterilisations of Jews in a 'mixed marriage'. Even though some physicians did see a beneficial role for medical sabotage, most doctors decided to stay far away from any involvement whatsoever. Meanwhile, the extent of the disaster that was taking place became more and more evident. Not only had the patients and pseudo-patients lost their last refuge in medicine, the doctors themselves also felt increasingly vulnerable. It became apparent that all so called 'Sperres', categories of exception, would be dismantled in the end, also the 'Sperre' of being a doctor. Doctors had lost most of their Jewish patients now, and with them their practical, financial and mental resources to remain proper doctors. They too were arrested on an ever increasing scale. Since they were fairly well informed through their contacts with colleagues and patients they might have felt the threat even more than others. Anyhow, it is clear that they were also in a better position than others to find ways to escape and they pursued legal means of escape at first and later resorted to illegal means. At least 125 Jewish doctors applied for the 'Barneveld-list', the list of protégés created by two government functionaries. Head inspector of health, C. Banning, who had previously cooperated in excluding the Jewish doctors from their collegial embedding, now showed a different attitude and did his utmost to save as many Jewish doctors as possi- 
ble. It worked out for forty-four of them. These physicians were placed in an abandoned castle in rural Barneveld and lived a relatively peaceful and quiet life until this last bastion was raided on September 29, 1943 and its inhabitants were sent to transit camp Westerbork.

On this day the Netherlands was officially declared 'Judenrein', free of Jews. It meant that no Jew could live in freedom in the Netherlands. Nevertheless, there were some exceptions and among those exceptions were some doctors. At least 2I Jewish doctors were officially declared non-Jewish by the Calmeyer-procedure, named after the responsible German official. This is a relatively large number. There were also 19 doctors in the group of originally Portuguese Jews who enjoyed protection until February 1944. Nearly Ioo Jewish doctors, a relatively large number too, were protected by their mixed marriage, but their position was a vulnerable one. Very rarely a Jewish doctor was considered to be so important to medical science that he was spared from deportation by the German authorities. These individuals lived in a desolate Amsterdam, longing for the Allied liberation. All others who were not already deported were living in hiding, sometimes with gentile patients or colleagues. Going into hiding was not an attractive proposition though; it meant an insecure future, an existence characterised by fear of discovery, dependence on others, intellectual isolation and boredom. Yet, a relatively large estimated percentage of $28 \%$ of Jewish doctors eventually went into hiding. Even then, some of them were able to continue to find meaning in their medical profession by treating patients incognito, reading medical literature or teaching others. Some doctors were involved in resistance movements.

Doctors seem to have been relatively good at finding some form of protection, since 'only' 253 of the 534 Jewish physicians were eventually deported; some after resistance or periods in hiding, some while obeying the German orders and some because they were convinced they should use their medical skills in the interest of the other detainees in the camps. Indeed, in terms of taking care of others, doctors could still do something with their profession in the concentration camps. In the Dutch camps of Amersfoort and Vught this was possible, but was much more difficult than in Westerbork, where there was excellent medical care. Doctors there tried to maintain a sort of normality in their extensive hospital barracks and outpatient clinics. Even so, the so called 'Medicina Westerborkiana' could not be entirely normal. There was the constant threat of further deportation to the East that again led to situations that were bizarre from a medical ethical viewpoint. Medical sabotage in all its varieties was performed here to save individuals from the deportation train. The direct result, however, was that someone else had to go in their place since the 
overall number of deportees had to remain the same. Doctors were therefore placed in a position of choosing between people. It was not easy for the doctors to deal with that kind of 'power'. Some decided to stay far removed from making choices like that. Others understandably yielded to the temptation to rescue their friends, family members and loved ones. One way to remain upright mentally and ethically was by maintaining normality, for example doing medical scientific research. The camp of Westerbork, bizarrely, was one of the few places in Holland where medical scientists experimented with the newly found drug penicillin. With the hospital transport of February 81944 however, most of the infrastructure and staff of the 'Medicina Westerborkiana' disappeared. The doctors faced their fate in the East with great fear, although doctors who were deported had somewhat better chances of survival than the average Dutch Jew. One in three deported doctors survived the concentration camps, as opposed to one in twenty-two in general. So, also for that reason, being a doctor could still be very meaningful, even in the camps.

In conclusion, one could say that this period of history illustrates the fact that medical ethics are malleable by circumstances, sometimes leading to (on the face of it) bizarre practices, but in the interests of altruistic and moral behaviour. This attempt to behave according to medical ethical principles under extreme and very difficult circumstances is inspiring to current generations of medical practitioners. 


\section{VALORISATIE-ADDENDUM}

\section{RELEVANTIE}

De discussie over medische ethiek is te allen tijde relevant, interessant en inspirerend. In de tijd die verstreken is sinds de hier beschreven periode is er in de geneeskunde veel veranderd, maar desalniettemin kunnen we ons nog altijd inleven in de actoren van deze geschiedenis.

In tijden van steeds verder doorgevoerde marktwerking in de zorg, verregaande specialisatie en technologisering van medische beroepen en het veelvuldig overhevelen van basale medische taken naar paramedisch personeel is het adagium 'Vergeet niet dat je arts bent' nog altijd actueel. Immers, het herinnert ook artsen van nu eraan wat de kern van hun beroep is: de medische zorgplicht. Ook het verhaal dat onder deze titel verteld wordt, is relevant voor de hedendaagse medische stand. Artsen van nu kunnen zich spiegelen aan de artsen alhier beschreven. Want hoeveel er ook in de tussentijd veranderd mag zijn, aspecten van het medische beroep blijven altijd hetzelfde. De relatie arts-patiënt is immers nog altijd een bijzondere. Deze kan niet gelijk getrokken worden met die van aanbieder-consument, ook al neigt men daar in het huidige zorgstelsel soms wel naar. Het cruciale verschil tussen een consument en een patiënt is de zwakke en afhankelijke positie van de patiënt. Ziek zijn betekent namelijk meestal kwetsbaar en onzeker zijn. Volledig autonoom zijn en autonome beslissingen nemen over een van de 'zorgaanbieder' af te nemen behandeling is in een dergelijke toestand veelal gewoonweg niet mogelijk, in weerwil van wat sommige zorgverzekeraars en beleidsmakers willen doen ge- 
loven. Men heeft als patiënt vaak behoefte aan advies, begeleiding en zorgzaamheid van de expert: de dokter. Uiteindelijk dient natuurlijk tot 'informed consent' gekomen te worden, maar dat hoeft een zekere bevoogding, of zo men wil paternalisme niet uit te sluiten. De taakopvatting van de artsen in dit boek beschreven, gekarakteriseerd door het ideaal van 'altruïstisch paternalisme', het van de schouders nemen van de zorgen van de patiënt, kan daarom ter inspiratie dienen van hedendaagse doktoren. Waar paternalisme in de huidige geneeskunde eigenlijk alleen een negatieve klank heeft, kan de positieve kant ervan wellicht weer meer in beeld komen. Dit verhaal benadrukt ook de menselijkheid van het medische vak. Veel meer dan in aanbieder-consument verhoudingen, geldt dat de arts-patiëntrelatie over heel wezenlijke, want met leven en dood te maken hebbende, onderwerpen gaat. Dat is de charme van het vak en maakt dat het genezen van een mens iets totaal anders is dan het repareren van een defect. Ook artsen van nu moeten niet vergeten dat ze een zeer bijzonder beroep uitoefenen.

Breder gezien roept dit boek ook op tot het niet vergeten van de Shoah, een nog altijd niet voor te stellen ramp in de geschiedenis van de mensheid. Wij mensen hebben zelfs, volgens filosoof Avishai Margalit, de plicht om te herinneren. Historisch besef in het algemeen kan immers inzicht in het heden verschaffen en relativeringsvermogen bevorderen. Historische kennis van de Shoah draagt daar niet alleen toe bij, maar stelt ook de menselijke natuur en de menselijke ethiek aan de kaak. Hoe slecht of hoe goed kan de mens zijn? Wat is goed en wat is slecht? Wat zouden wij zelf doen? Dit zijn vragen die al spoedig opkomen als men de geschiedenis van de Holocaust gaat bestuderen. Mogelijk en hopelijk stimuleert het zichzelf stellen van deze vragen gewetensvol handelen, medemenselijkheid, empathie en verdraagzaamheid. Niet alleen bij artsen, maar bij iedereen.

Het imperatief om niet te vergeten gaat ook, en niet in de laatste plaats, om het proberen levend te houden van de herinnering aan de individuen hier beschreven die de Shoah niet overleefden. Het noemen van hun namen houdt hun nagedachtenis in ere.

\section{DOELGROEPEN}

Uitgaand van voorgaande legitimering van dit onderzoek, wordt duidelijk dat de doelgroep van dit boek niet breed genoeg kan worden gezien. Eenieder die het adagium van 'niet vergeten' onderschrijft kan deze geschiedenis tot zich nemen. 
Heel specifiek richt dit boek zich natuurlijk op medici en daarbij ook op eenieder die zich met hen verwant voelt, of professioneel veel met hen te maken heeft. Paramedici zullen zich, gezien het op veel punten overeenkomstige karakter van hun beroep, ook zeker kunnen herkennen in delen van het verhaal. Naast de medici zullen, door het interdisciplinaire karakter van deze studie, ook historici geïnteresseerd zijn. Dit boek vult een lacune in de historiografie over de Tweede Wereldoorlog. Ook amateurhistorici en specifiek geïnteresseerden in de Tweede Wereldoorlog of Joodse geschiedenis zullen zich deze geschiedenis eigen willen maken.

Niet in de laatste plaats is dit boek geschreven voor de geïnterviewden, hun familieleden of nabestaanden zelf. Hen heb ik vanaf het begin middels drie- à viermaandelijkse nieuwsbrieven op de hoogte gehouden van de vorderingen van het onderzoek en ik heb van hen veel belangstelling en steun mogen ontvangen. Velen van hen hebben reikhalzend uitgekeken naar de uiteindelijke publicatie van het boek. Hun groep is behoorlijk omvangrijk geworden, gemeten aan het feit dat de laatste digitale nieuwsbrief gericht was aan 294 emailadressen, waarnaast nog eens 30 mensen een papieren nieuwsbrief kregen. Via deze weg zijn steeds meer mensen op de hoogte geraakt van dit onderzoek en hebben zich geïnteresseerd getoond. Onder hen ook journalisten, van onder andere De Volkskrant, de Groene Amsterdammer, het Parool en VPRO-wetenschapsradio. Zij hebben reeds aangegeven in deze diverse media aandacht te willen besteden aan het proefschrift, waardoor nog weer meer mensen bereikt zouden kunnen worden. Ook uitgeverij Boom zal de nodige marketing strategieën uitzetten om de reikwijdte van het boek zo groot mogelijk te maken.

\section{ACTIVITEITEN/PRODUCTEN}

Allereerst is natuurlijk het hoofdproduct van deze studie het boek 'Vergeet niet dat je arts bent' zoals dat is uitgegeven door Uitgeverij Boom te Amsterdam. Naar aanleiding van het promotieonderzoek heb ik echter ook reeds vele activiteiten ontplooid en diverse zijpaden bewandeld. Het blijkt dat er in dit onderwerp en aanverwante onderwerpen nog veel terrein braak ligt en dus veel te doen is. Er blijkt ook bij anderen veel belangstelling voor te bestaan.

Zo heb ik een paar kleine artikelen geschreven, voor het Joodse genealogietijdschrift Misjpoge en voor het Yearbook of Women's History. Voor het Genootschap voor de Joodse Wetenschap en voor het Genootschap voor Joodse Studies heb ik voordrachten gehouden. Gastcolleges en lezingen heb ik voorts verzorgd voor de Vrije Universiteit Amsterdam, de Council on International 
Educational Exchange, Limmoed, de Rotary en de GGD Amsterdam.

Over het Nederlandsch Israëlietisch Ziekenhuis heb ik, met een drietal anderen, onder wie conservator van het Joods Historisch Museum Julie-Marthe Cohen, een documentaire gemaakt, getiteld Hier kan me niets gebeuren. Hiervoor zijn de interviews met ooggetuigen, evenals in het promotie-onderzoek, als belangrijke - hier zelfs de belangrijkste - bron gebruikt. In de periode 20 I tot 2013 hebben we hieraan gewerkt. De première vond plaats in Kriterion, op I3 augustus 20I3, exact 70 jaar na de definitieve ontruiming van het ziekenhuis in I943. Deze bijeenkomst was bijzonder, zeker ook omdat diverse mensen die er 70 jaar eerder bij waren geweest, hier herenigd werden. De pers was vertegenwoordigd en een groot artikel verscheen in Het Parool, waarmee het ziekenhuis na al deze jaren de aandacht kreeg die het verdiende. De dvd van de documentaire en de online versie op Vimeo hebben inmiddels diverse huishoudens en, zo mogelijk nog belangrijker, educatieve- en archiefinstellingen, bereikt. Het ruwe filmmateriaal, vele uren aan interviews, is in het archief van het Joods Historisch Museum opgeslagen, waar het kan dienen als bron voor verder historisch onderzoek. De film is ook vertoond in het hoofdgebouw van de GGD Amsterdam, waar men dankzij deze en andere van mijn activiteiten doordrongen is geraakt van de eigen historie. In dit gebouw was namelijk oorspronkelijk het Joods verpleeghuis De Joodsche Invalide gevestigd.

Op 4 mei 2013 hield ik in de GGD een dag lang lezingen over de Joodsche Invalide in het kader van Open Joodse Huizen. Naar aanleiding daarvan gaf de directeur te kennen een permanente herinnering aan de Ji te willen plaatsen. Op I september jl. was het zover: een tweetal vitrinekasten en een diashow op scherm werden geopend, alsmede een plakkaat aan de gevel, waarmee de geschiedenis van de Joodsche Invalide de nodige aandacht heeft gekregen. Met kleinzoon L.B. Gans van de directeur van destijds, Isaac Gans, heb ik deze tentoonstelling opgezet en daarmee ook de aanzet gegeven tot verder onderzoek naar de Joodsche Invalide, hopelijk op termijn leidend tot een publicatie over dit onderwerp. Er is dus nu al sprake van een vervolgonderzoek naar aanleiding van mijn promotieonderzoek. Een ander nog braakliggend terrein dat om nader onderzoek vraagt, is de terugkeer van de Joodse artsen na de bevrijding en de moeilijkheden die velen daarbij ondervonden, met name als het ging om het terugkrijgen van hun praktijken.

Last but not least moet mijn samenwerking met fotografe Julie Blik genoemd worden. $\mathrm{Zij}$ heeft zich als een ware metgezel ontpopt door zich geheel belangeloos voor mijn project in te zetten en schitterende portretten te maken van velen van de geïnterviewden. We zijn zelfs samen verschillende keren naar Israël afgereisd om daar interviews af te nemen en portretten te maken. Een 
bijzondere samenwerking en vriendschap zijn het gevolg. De portretten zijn deels opgenomen in het uiteindelijke proefschrift, als illustraties, maar tevens zijn we van plan van onze gezamenlijke tochten een verslag te maken in de vorm van een tentoonstelling. Diverse informele toezeggingen voor plaatsing van deze tentoonstelling zijn reeds gedaan.

Verder te exploreren is nog eventuele samenwerking met het buitenland, bijvoorbeeld met de groep van Michael Grodin in Boston en met Chelouche et al. in Haifa.

\section{INNOVATIE}

Innovatie door dit onderzoek is met name te verwachten in de zin van reflectie, contemplatie en discussie over ethiek in de medische wereld. Het zou prachtig zijn als waarden als paternalistisch altruïsme, empathie, generalisme en collegialiteit - in een nieuw jasje - op de agenda van medici zouden komen nadat zij dit boek gelezen hebben.

\section{PLANNING/REALISATIE}

Wat betreft planning lijkt een en ander vrij logisch. Omstreeks de de datum van publicatie van het proefschrift zal ik, samen met uitgeverij Boom, een promotiestrategie uitvoeren. Ik stel me voor dat die zal bestaan uit het geven van lezingen en gastcolleges, op diverse lokcaties en voor diverse luisteraars in den lande en daarbuiten. Daarbij zal het boek te koop worden aangeboden. Ik hoop hiervoor de nodige tijd te kunnen vrijmaken.

Daarna zal ik me graag met het vervolgonderzoek bezighouden. Ook moet ik echter zelf niet vergeten dat ik arts ben. De geschiedenis heeft me gegrepen en ligt me zeer na aan het hart, maar ook ik - of zelfs juist ik - ben doordrongen van het feit dat ik een bijzonder beroep heb. De laatste maanden heb ik even niet als arts gepraktiseerd, maar ik wil dat zeker weer gaan doen. Ik hoop in de loop van 20I5, met de kennis en verdieping die het promotie-onderzoek me heeft gegeven, het artsenberoep weer heel praktisch op te pakken en me daar zo goed mogelijk voor in te zetten.

I Interviews with Hans Keilson, d.d. 20-II-2008 and I5-I-2009. 



\section{PERSONENREGISTER}

Aa, Bernard 76, 369

Ader, Bastiaan 233, 382, 399

Adler, Jacques 206, 207

Ailjon, Jacob I04, 362

Ali Cohen, Levy 37, 371, 372

Ariëns Kappers, Cornelis U. 260, 261, 386, 399

Arkel Zegwaard, J. Van 35, 349, 399

Arons, Jacob II5, I23

Aronsohn, Jo(hanna) 40, 293, 294

Asaph 43

Asscher, Abraham (Bram) II4, II5, I26, I45, I74, 195, 204, 224, 363, 368, 376, 377, 384, 393, 406

Asscher-Pinkhof, Clara 157, I58, 370, 379, 399

Audier, A.G. I87-I89, I9I, I93, 375

Aus der Fünten, Ferdinand Hugo I4I, I44, I5O, I52, I88, I9I-I95, 208, 210, 2I5, 220, 223, 232, $267,372,375-377,393$

Bak, Isidore 298

Baker, Robert 24, 344, 346, 399

Bank, Jan 22, 346, 399

Banning, Cornelis (Cees) 82, 83, 93, IOO, IO4, IO5, I2I, I44, 226, 239, 247-253, 255-257, 266, $333,358-364,368,381,383-386$

Barge, J.A.J. $\quad 85,261,359,404$

Baruch, Jacques 43, 35I, 390, 400

Batavier, Israël 93, 95, 360

Bauer, Yehuda 20, 23, 337, 345, 346, 397, 400

Becker-Jakli, Barbara I8, 345, 400

Behr, Eddy 7I

Behrendt, Alfred $\quad 278,389,414$

Bendien, Salomo $\quad \mathrm{I} 58,370$

Benjamin, Max 304, 394, 4I5

Benjamins, Charles Emile 38,39

Benzhöfer, Udo I8, 345, 400

Bergh, A. van den $\quad$ I82

Bergh, Sieg van den $313,394,400$

Berkel, Klaas van I4, 344, 356, 358, 359, 400
Berlin, Isaiah $342,397,405$

Bial, Arthur 294, 295, 299, 392, 393

Biegel, Salomon 40, 350, 400

Birnbaum, Otto 3II, 395

Blankenstein, Philip van 276

Bles, Jeanne 244,248

Blitz, Simon $\quad$ II6

Bloch, Max B. I04, 362, 371

Bloch, Israël 249, 250, 253, 385

Bloemist, Flip 220

Blok, Andries 162,370

Blom, Hans $\quad 22,53,346,352,354-356,400,415$

Boellaard, Pim 23, 346, 413

Boezeman, J.H. 295, 370, 392, 402

Böhmcker, Hans II4, II5, I24, I26, I35, 365, 388

Bokkel Huinink, A. Ten $47,48,351,352,361,365$, 370,400

Bolkestein, Gerrit 33

Bolle, Janny $\quad$ I79, 217, 373, 378, 403t

Bolle, Max 148, 369

Bolle-Levie, Mirjam 212, 365, 38I, 389, 400, 4I5

Bollegraaf, Ruben $\quad 23$, IOI, I32, I33, I64, 362, 366, $371,372,400$

Boom, Bart van der $33,348,353,367-369,376$, $378,396,410$

Borg, Jacques van den $\quad 74,357,40 I$

Borg, R. ter 279

Bork, Paul van 197, 376

Bornsztajn, Chawa 204

Borst, J.G.G. $\quad 282,287,390,414$

Bos-Watermann, Ruth $\quad$ I77, 220, 232, 357, 373, $380,382,389,415$

Bos, Sam I80, 221, 232, 273, 389

Boudier-Bakker, Ina $68,40 I$

Bouwdijk Bastiaanse, M.A. van 89, 230

Braak, J.W.G. ter 199

Brahn, Max 257

Bramson-Klein, Carolina 257,325 
Bramson, Jacob 83, 290-292, 294, 325, 391, 392

Broekman, E. 210, 373, 374, 378, 380

Bromberg, Richard I45, I46, 287, 368, $40 \mathrm{I}$

Bruin, Jacob de 38

Bruin, Maurits de $66,75,357,406$

Bruining, Hajo 283

Burema, L. 274, 389

Burgerhout, H. 75, 357, 401

Buys, Juda I52, 299, 369

Buzaglo-Coronel, Emmy 205

Buzaglo, Jacques I44, I82-I84, 204, 205, 235, 374, 377

Bijlsma, U.G. 59, 353, 400

Cahen, Bob 298

Cahen, Joël 53, 352, 354-356, 400, 4I5

Cahen, Oscar 56, 98, 318, 352, 36I, 4I3

Calmeyer, Hans Io, 90, 93, 95, I43, 230, 242, $259-264,266,267,269,272,278,282,333,384$, 386-388, 403, 408, 414

Carp, Eugène $78,357,358,40 I$

Carsten, N.T. 93,360

Chelouche, Tessa 23, 24, 27, 340, 342, 345-347, 397, 40I, 4I5

Chmielewsky, Karl 29I, 39I

Citroen, Salomon $80,8 \mathrm{I}$

Cleveringa, R.P. $\quad 85,86$

Coevorden, Johnny van $\mathrm{I} 78, \mathrm{I} 79,217,222,23 \mathrm{I}$, $232,277,373,380,382,414,418$

Coevorden, Sally van $373,380,389,414,415$

Cohen, David 62, II4-II6, I26-I28, I33-I35, I37, I44, I45, I5I, I83, I84, I95, 203, 2II, 224, 234, 293, 30I, 355, 357, 359, 36I-363, 365, 366-369, 374, 376-38I, 384, 39I, 393-395, 40I, 406, 4II, 4I4

Cohen, David Ezechiël 62, 349, 401, 402

Cohen, Elie Aron I5, 79, IOO-IO2, IO6, III, I34, I36, 196, 287, 288, 304, 307, 309, 312-315, 318, $325,334,336,344,358,366,367,376,394,395$, 397, 402, 414

Cohen, Ies I80, 217, 222

Cohen, Isaak $277,283,389,390,408$

Cohen, Jacob I2I, I22

Cohen, Menno Sallo II6

Cohensius-van der Hoeden, Esther 298

Cohensius, Isaac 297, 298, 392

Comte, A. Le 8I

Coronel, Samuel Senior 37
Cornwell, John I7, 345, 347, 402

Cramer, August W. 95

Creveld, Simon van $38,243,248,283,291,303-$ 306, 321, 364, 379, 384, 391, 394, 402

Dam, Samuel van 93

Dam, J. Van 246

Danby, Margaret $\quad$ I32, I33, 282

Dasberg, Isaac $\quad 56,97,272$

Dasberg, Simon I35

Deelman, H.T. $\quad$ I22

Deen, Isaac van 37, 60, 349, 409

Dekker-Benjamins, Margareta I36, 265

Denekamp, Albert E. I47, I52, I63, 252, 299, 310, $369,370,385,395,402$

Denekamp, Eliazer 252, 254

Deppner, Erich 296

Diamant, Salomon I33, 25I, 299, 419

Diehl, J.C. 8I

Dischner, Josef Hugo 296

Dobschiner, Ruth I84, 374, 402

Donders, F.C. 60

Dresden, Sem 34I

Dunk, Hermann von der 32, 348, 40I, 4IS

Dunner, Sally $232,234,266,267,387$

Durkheim, Emile 76, 77,357, 402

Edersheim, Henri $\quad$ I 52,369

Eerdman 272

Efron, John I5, I7, 344, 345, 402

Eggink, Chr. 8I

Eichmann, Adolf I4, 346

Eisendrath, Bernard I58, 370, 419

Eisendrath, Iris 158

Elzas, Maurits 55, I8I, 203, 205, 235, 249, 256, $352,354,373,374,377,410$

Emde Boas, Coen van 4I, 6I, 96, 219, 221, 282, $350,353,361,363,371,376,380,390,403,404$, 414

Emmering, Sieg 58,394

Engelhard, Chr. F. $\quad$ I99

Erwteman, Juda 262

Esso, Ben van I54, 368, 369

Esso, Ima van 154

Esso, Izaak van 4I, 62, 63, 7I, 97, I45, I54, I55, 299, 350, 354, 403, 419

Esso-van Son, Louise van I45

Fehmers, C. $47,48,351,400$ 
Fernandes, René 83, 266

Fiedeldij Dop, Ph.H. 274, 389, 403

Fischer, Franz 268

Fischer, Fritz 70, 71, 88, I04, 264, 356

Fortuin-Blitz, Hetty I49, 361, 369, 4I8

Frank, Ernest $192,375,418$

Frank, Otto II6, II8

Frank, Remi I89, 190

Franzie, Mozes 98, 392

Frederiks, K.J. I88, 246-248, 250, 25I, 253, 255, $257,262,333,385-387$

Frenkel-Wiener, Carolina 246,384

Frenkel, Lion 246, 384

Frenkel, Maurits II, I53, I58, 253, 343, 365, 366, $369,370,373,380,390,416$

Freud, Janos $66,88,267,355,360,388,403$

Friedberg, Benno 289

Friedenwald, Harry I5

Friedlander, Peter $30,347,403$

Friedländer, Saul I8, 22, 345, 403

Friedman, Philip I3

Froe, Arie de 260, 261, 263, 265, 387, 403, 4I5

Furth, Jacques 293, 39I

Furth, Willem van $67,272,370$

Gans, Abraham 282, 359

Gans, Evelien 22, 34I, 346, 354, 397, 403, 416

Gans, Isaac I8I

Gemmeker, Albert Konrad I45, I89, 230, 294, 296, 303, 306, 319, 32I-323, 396

Gitter, Sieg $32, \mathrm{I} 25, \mathrm{I5}, 348,365,416$

Glaser, Frits I2I, I22, I25, 364, 365, 416

Godfried, Emanuel I59, 215, 222, 231, 364

Goedhart, Frans 288, 390, 405

Gomperts, Cosman 88

Gomperts, Moritz I45, 297

Gompertz, Jacques I45, 297

Goudsmit, Jacob 66, 7I, I47, 207, 208, 215, 222, $232,234,25 \mathrm{I}, 252,266,267,3 \mathrm{II}, 355,362,385$

Goudsmit, Jos 252

Graaf, Nico de III, 359

Granaat, David 277, 282

Grewel, Frits 58, 6I, 282, 353, 37I, 383, 404, 4I5

Grodin, Michael 21, 23, 340, 346, 347, 354, 399, 404,416

Groen, Israël 243

Groen, Juda 54, 70, 86, I5I, 265, 266, 337, 352,
$364,387,390,402,404,406$

Grünwald, Abraham 95

Haan, Ido de I4, 23, 344, 346, 404

Haas, Albert $325,397,404$

Haas, Govert de I29, 276, 277, 365, 418

Haas, Rudolf de II7

Haas, Willem H.D. de 88

Hal, Cis van der 27I

Hal, Henriëtte van der $\quad 138,271$

Hal, Ies van der $\quad$ I36-I38, 27I, 29I, 322, 323, 36I, $366,367,388,391,396,404$

Hal, Jozef (Jo) van der $184,216,217,379,418$

Hal-Prins, Rosa van der 307, 394

Halioua, Bruno I8, I9, 345, 404

Hamburger, Hartog Jacob 38

Hamburger, Jacob 94, 97, 388

Hamburger, Max 55, 176, I77, 220, 233, 282, 322, $344,352,373,380,382,390,416$

Hammes, Th. $44,47-49,73,351,356,394,400$, 404

Haque, Omar 27, 347, 404

Harster, Wilhelm 262

Hartog, Henri A.Ph. 98

Hartogh, Alain I84, 204, 205, 219, 232, 266, 374, $377,380-382,387,404$

Hartogh sr., Jacob de $39,92,93,360$

Hartogh jr., J. de $252,253,354,373,385$

Hartogs, Jacques 66, 71, 355

Hausdorff, David $55,56, \mathrm{I} 48,352,355,369,419$

Heimans, Jacobus 320

Heimans, Theodoor 93, 360

Hemmes, G.D. $\quad 84,255,358,386$

Herschel, Herman 176,177, I79, 214, 215, 23I, $373,379,382,418$

Herschel, Thea 23I, 418

Hertz, Paul 3II, 395

Hertzberger, Ellis $15,299,304,305,311,316,318$, $324,325,336,356,358,393,395,396,418$

Hertzberger, Herman 99, I66

Hertzberger, Maurits $66,74,78,355,357,362$, 404

Hertzberger, Meijer IO3

Hertzberger, Salco I27, I55

Herwerden, Marianne van 60

Herz, Marcus 43

Herzberg, Abel I3, I4, I43, 294, 34I, 344, 363, 
$368,387,388,392,404,406$

Heijden, Chris van der 22, 23, 346, 404

Heijden, Max Louis van der 66, 355

Heijermans, Louis $37,38,85$

Heijligers, Mattie 234

Heymans van Amstel, Herman 303, 310

Hillesum, Etty 313, 394, 395, 404

Hillesum, Jaap 232, 234, 266, 267

Hippocrates $\mathrm{I} 3,24,25,32,35,43,45,48,49,73$ $79,297,348,407$

Hitler, Adolf I3, I7, I8, 24, 25, 28, 64, 73, 206, $294,328,345,347,357,371,377,381,382,387$, 391, 394, 402, 404, 405, 4I2

Hoeven, Henri van der 226

Horst, L.M. ter $\mathrm{I} 36,358,366,393$

Hugenholtz, P.Th. $\quad$ I22

Hijmans, H.M. 95, 360

Hijmans, Marinus Mortier 71, 249, 385

Hijmans, Willy $282,356,359,370,390,404,410$, 416

Hijmans van den Bergh, Abraham Albert 38, 39, $46,47,262,272,370,387,409$

Huddleston Slater, W.B. $45,351,405$

Huizinga, Johan 63

Ingen, José van 277

Israëls, Abraham Hartog 37,63

Italie, Gabriël $249,372,377,382-385,397,406$

Jacobs, Aletta 37, 40, 349, 350, 401, 409, 4I9

Jacobs, Izaäk 270

Jacobs, Jonas 66, I24, I48, $27 \mathrm{I}$

Jacobs-Melkman, Lena I48, 270, 27I, 369, 388

Jacobson, Abraham S. 210, 235, 248, 249, 378, 385,419

Jessurun d'Oliveira, Elsa 89, 264, 317, 323, 360, $387,395,396,418$

Joles, Selma I20, I75, 202, 354, 364, 373, 374, $377,4 I 2$

Jong, Loe de $\quad 15,16,22,25,33,58,78,79,243$, $275,344-347,352,354,358-360,362,363,365$, $366,368,371,375-381,384,388-395,406,4 I I$

Jong, Martin de 297, 392

Jong, Sally de 7I, 78, I28, I3I, I32, I46, I52, I68, I9I, I95, 20I, 243, 299, 300, 305, 313-315, 358, 369,384

Josephus Jitta, Nicolaas Marinus 39
Jotkowitz, Alan 24, 346, 405

Kaas, Andries 322, 35I, 396, 405

Kaas, Bep 220

Kahn, René 298

Kalker, Jos 67, 282

Kan, Pieter Thomas Leonard 357

Kannewasser, Max 233

Kantorowicz, Icchok I24

Kastein, Gerrit 282,405

Kat, Jan 6I, I86, 354

Kater, Joseph 55, I47, I6I, I62, I78, 217, 272, 278-28I, 352, 369-37I, 373, 379, 388, 389

Kater, Michael $\quad$ I7, 27, 77, 345, 347, 405

Katz, Michael 2I, 22, 346

Keilson, Hans I2, I25, 275, 276, 283, 343, 365, 389, 390, 397, 405, 416

Keizer, Madelon de I4, 344, 390

Kerssemakers, Lex 274, 389, 405, 406

Keijer, Koenraad 80

Klein, Alexander $\quad 38,254$

Klein, Frits 86, 88, 99, 274, 278, 389, 406

Klein, Samuel 67

Kleijn, A. De 249,385

Klomp, J.H. $\quad 287$

Kloosterman, S. 247, 251, 252, 385

Knapper, N. $\quad 75,357,406$

Koker, David 292, 39I, 406

Koningsberger, V.J. 86

Koningsbrugge, van 220

Koopman, Benedictus 2I4, 379, 4I4

Koot, Hendrik II4

Koster-Souget, Hannah $154,366,369,416$

Koster, Max I32, I54, 366, 416, 418

Koster, Salomon II, 73, 74, 76, 99, I04, I3I, I47, I60, I67, I7I, I80, I95, I97, 202, 207, 208, 2I2, 216, 218, 219, 238, 240, 24I, 244, 269, 272, 275, $276,282,293,339,342,343,356,357,361,362$, $366,369,370-372,374,376-380,383,384,388-$ 390, 414

Kotting, Nino 264

Kous, Joël van der 4I, 46, 350, 35I, 406

Krauss, Samuel I5, 344, 406

Kreuzwendedich von dem Borne, G.A. 86, 278

Kroonenberg, Kees 209, 373, 378-380, 382, 416

Kroonenberg, Salomon 4O, 42, I44, I59, I77-I79, 
I8I, I82, 205, 207-209, 2I3, 2I4, 23I, 232, 234, $235,247-249,3 \mathrm{II}, 350,364,368,373,378,380$, 382-384, 4II, 4I6

Kroonenberg-Leman, Sebilla 234

Kropveld, Alfred 298

Kropveld, Aron 266

Kropveld, Samuel $207,266,373,4 I 2$

Kruimel, dr. I7I

Kruskel, Herbert 3II, 395, 4I5

Kruyt, H.R. 86

Kruyt, J.P. $\quad 64,65,349,354,406$

Kudlien, Fridolf 26,347, 406

Kuttner, dr. 230

Kijzer, Jacob 94

Ladee, George 22I

Lages, Willy I45, 368,370, 393

Landauer, Karl 309, 371

Lange, Cornelia de 75,357,406

Langen, C.D. de 262, 272

Lankhout, Ernst (Boes) 65, I7I, 360, 418

Lankhout, Julius $67,92,254,355,372$

Laptos, Leo 323

Laqueur, Ernst $38,39,88,228,267,268,364$, 388,406

Leegstra $\quad 278$

Leeuw-Bernard, F.C. de 319, 396

Leeuwen, Max van II8

Leisen, Emanuel (Mani) I25, 243, 282, 365, 373, 384

Lémon, Hartog de 36,349, 400, 412

Lensky, Mordechai I9, 345, 406

Levie, Betty $89,98,103,212,283,360-362,378$, 390,415

Levie, H. 292

Levie, Herman de I48, I68, 272, $37 I$

Levie, Leon H. 95

Levie, Maurits de 299, 301, 393

Levy, David Meijer 93, 3I8

Levy, Gerard K. 66, 277

Levy, Willy 72, 75, 76, 79, 357, 403

Lewis, Dana 2I, 22, 346, 406

Leijdesdorff, Selma 33, 348-350, 352, 406

Leydesdorff, Julius 40, 388

Leydesdorff, L. 85

Leijer, D. de 94, 360
Lezer, Leo $\quad 83,214,244,256,362$

Lichtenstein, Salomon 226, 381

Lier, Eduard van $75,357,408$

Lier, John van I87, I90, I94, 302, 317, 393, 395

Lifton, Robert $26,347,407$

Lindeboom, G.A. 35, 348, 351, 407

Lobstein, Jacques I86-I93, I95-I97, I99, 203, $205,231,235,252,302,303,309,332,374-376$, 385,414

Lohr, Henriette I66, 371

Lopes Cardozo, Paul 57, 58, 261, 262

Luijkx, Ruud 77,352,356,357,4I2

Maimon, Moses ben (Maimonides) 43, 45, 46, 240, 24I, 328, 34I, 344, 35I, 400, 407, 408

Manheim, Izak 322

Marsman, M.W. I22

Massolt, Jan 220

Marx, Eugen 71, 72, 74, 357, 4I3

Mazirel, Lau 282

Mechanicus, Philip I77, 23I, 300, 307, 3II, 3I3, $317,318,323,373,382,392-396,407$

Meer, Joop van der 277

Meerloo, (Joost) Abraham 78, 79, 358, 37I, 407

Meeuwenoord, Marieke 33, 348, 39I, 407

Meihuizen, Joggli I4, 344, 350, 360, 362, 387, 397, 407,416

Menco, Antonie 270

Mendels, Eljah I9I, 375, 416

Mendels, Jonas I90, I9I, I93

Mendes da Costa, Samuel 38, 248, 249

Mendes de Leon, Charles 40, 82, 95, II7, I7I, 363

Meulen, Gejus van der 248

Meyer, Eduard W.P. $\quad$ I87, 208, 2II, 2I5, 2I6, 222, 226, 228-23I, 267, 3I9

Meijer, Sal 256

Meijers, Bernard (Benjamin) I22

Meijers, Max I22

Meyers, E.M. IO7, 230

Meyers, F.S. I56, I58, I62, I69, I70, 272, 370, 37I, 372,382

Meijler, Leopold 79, I35, 276

Michalczyk, John I7, I9, 345, 405, 408, 410

Micheels, Louis (Loet) I54, I55, 340, 356, 368 , $369,397,408,418$

Micheels, Pauline I4, 344, 408 
Miranda, David de 66, 2II, 282, 390

Moerel, Salomon $\quad$ I33

Moffie, David 39, 318, 344, 349, 382, 396, 418

Moleschott, J.A.W. 60

Monnickendam, Elly I80, 373, 380

Monnickendam, Guus I80, 277

Moraal, Eva 33, 308, 348, 392-394, 408

Mulder, Hans I4, 344, 408

Muller, Herbert 277

Muller, Maurits 35, 56, 75, I60, I71, 245, 254-257, $333,348,349,352,357,370,386,408,419$

Muntendam, P. $\quad 86,350,358,359,408$

Musaph, Herman $\quad$ II $5,276,389$

Muskens, L.J.J. 59, 353, 408

Mussert, Anton 278

Nadav, Daniel I9, 345, 408

Nahum, Henri I8, I9, 345, 408

Nassauer, Max 44, 35I, 408

Nathans, Samuel 42

Neuberger, Bertha I55

Neuberger, Jacob $\quad$ I55

Neuburger, Friedrich 3II, 392

Neufeld, Norbert $\quad 283,371$

Nieuwenhuysen, N. Van 287

Niks, Paul 277

Nink, Benjamin 324

Noordhoek Hegt, W.F. $\quad 274,275,355,389,402$

Nord, A.H.J. $\quad 83,84,358,361,365,383$

Nordheim, David I27, I28, 239, 361, 365, 383

Nuland, Sherwin B. I5, 344, 408

Nuys, verpleegster I9I

Oberman, G.W. $\quad 256,297,349,386$

Ossendrijver, Aron 100

Ottenstein, Hans 314, 382, 396

Oven, Ellen van 220

Pais, Benjamin I36, I39, 298

Parra, Herman de la II7, 288, 334

Parser, G. 302, 375

Peeters, H. 219, 355

Petersen I7I

Philips, Theodore 266

Picard, J.A. 272

Piebenga, P.J. $\quad$ I99

Pimentel, Mau Henriques I8O, 210, 224, 235, $354,372,373,378$

Pincus, Ludwig 76,357
Pinkhof-Asscher, Branca $\quad 157,379$

Pinkhof, Herman 4I, 42, 47, 52, 53, 55, 60, 62, 73, 107, 156-158, 306, 350, 351, 353, 354, 356, 362, $370,376,399,404,409,410,413,419$

Pinkhof, Jakob $157,158,370$

Pirenne, Henri 32

Plomp, Marije I4, 344, 405

Polak, Ans I83, 219, 354, 374, 380, 400, 417

Polak, Ben 216, 282, 37I, 372

Polak, Eliazer 67

Polak, Martha $154,356,368,369,416$

Polak-van Gelder, Regina I8I, 303

Polak, Willem $238,287,383$

Polak, Willy 303

Polak Daniëls, Anselm 67,370, 410

Polak Daniëls, Leonard $38,39,67,74,79,80$, I59, 353, 357, 370, 409

Polano, Machiel K. $67,95,360$

Poliakoff, Samuel 40, 60, 2II, 224, 234, 235, 353, 409

Poons, Mau 220, 372, 378, 409

Poorten, David van der $7 \mathrm{I}$

Poppers-Prins, Betty 290, 293, 39I

Praag, Salomon Wolfeus 66, 230, 254, 355, 356, $372,384,385,392$

Premsela, Bernard 4I, 71, 96, 99, 252, 282, 350, $356,361,390,409,410,418$

Presser, Jacques I4, 32, 78, II4, II5, I39, I42, I43, I72, I74, I8I, I87, I89, 202, 2I4, 232, 270, 294, $304,306-308,317,34 \mathrm{I}, 344,356,358-360,363$, $365-368,370-372,374,375,377,379-382,384,388$, 389, 39I-395, 406, 409

Prins, Machiel 306

Prins, Salomon II9, I2O, 364

Proosdij, Jaap van 264

Querido, Andries 254, 264, 321

Querido, Arie $\quad 47,58,88$, I86-I88, I90, I9I, I93, 194, 302, 349, 351, 359, 372, 374-376, 388, 396, 410

Querido-Nagtegaal, Tine I90

Raalte, Frans van $\quad$ I59

Reis, Maurits van der I35, I36, I38, I39, 298, 307

Reisel-Muller, Emmy 246, 257

Reisel, Jacques II, II8, II9, I25, I44, I52, 205-208, 222, 226, 238, 24I, 242, 244-246, 254, 256, 257 , $272,286,309,316,343,364,365,369,377,378$, 
$380,381,383-386,394,395$

Reuter, F. $\quad 82,106,187,358$

Ricardo, Benjamin 370, 391, 417

Ricardo, Eljakim 293, 294

Richter, Nico $\quad 282,390$

Ringelblum, Emanuel 33

Ritmeester, Sam I2I, 364

Rodegro, H. I26, I34-I36

Rodrigues Pereira, Arnold I5I, 214, 356, 369, 379, 380, 392, 417

Rodrigues Pereira, Elazar Aäron 72, 88, I24, I5I, 248, 279, 359

Roegholt, M.N. 212, 228-230, 382

Roeper, Max 58, 86, IOI, 27I, 282, 292, 323, 324, 391,396

Roland, Charles I9-22, 345, 410

Romijn, Peter 33, 348, 358, 360, 404, 410

Roos, Calmer I62, 216, 217

Roos, Jacob I45, 297, 370, 389

Roozendaal, Alexander I23, 3II

Roselaar, Emanuel I45, 297

Rothman, David 34, 347, 348, 406, 410

Rudelsheim, Letty 62, 310, 395, 400

Rümke, H. 272, 355

Rümke, H.C. 272

Rijn, Syl van de 208

Rijnberk, G. Van 4I, 350, 35I, 357, 410

Sajet, Ben 36, I20, 349, 364, 373, 4I0, 413

Sajet, Herman I20

Sajet, Jaap I2O, $4 I 7$

Sajet, Thea I2O

Salomon, Albert 230, 382

Salvendi, Hugo I45, 297

Samson, Marcus IO2, 392

Samuels, Jules 94

Sanders, Elkan 75, 357, 405

Sanders, Jacob 60, 79, 353, 401

Sarphati, Samuel 9, 36, 37, 343, 349, 404, 406

Schaap, Louis I29, I3I, I32, I44, I45, I47, I65, I83, 234, 238, 243, 292, 303, 364, 365, 366, 368, $369,371,373,374,378,383,384,39 I, 4 I I$

Schalij, F.A. I06, I08, I09, 248, 362, 384

Schalij, G.A. $\quad$ I08

Schipper, Johan I80, 373

Schippers, J.C. 248,384

Schlesinger, Kurt 3I4, 3I5
Schmidt, Fritz 246

Schol, Jacques 295, 296, 392

Schrijver, Hans 320

Schrijver, Joachim 292

Schrijver, Nardus $\quad 254,257$

Schwegman, Marjan 23, 346, 397, 406, 4II

Seeligmann, Sigmund 53,352, 4II

Sekir, Eliazer 7I

Shasha, Shaul I9, 345, 4II

Seidler, Eduard I8, 345, $4 I I$

Seyß-Inquart, Arthur I2, 84, 93, I09, 199, 225, 238, 28I, 359

Silver, Daniel I8, 345, $4 I I$

Simons, C.H. $\quad$ I87

Simons, Rita I45, 368

Simons, Salomon 67

Slager, David II7

Sluijs, Abraham van der $\quad$ I80, I8I, 374, 418

Sluzker, Edwin 2II, 376-378, 393

Snapper, Isidore 38

Soetendorp, Jacob II5

Soubice, Tobias 324

Souget, Aron 215

Souget, Max 215, 369, 416

Spangenthal, Isidor $\quad$ I27

Spanier, Fritz I52, 189, 230, 252, 295, 3I4, 318, $319,323,375,382,392,395,396$

Spanjaard, Jaap 56,57, I87, 190, 194, 196, 242, 26I, 352, 376, 384, 411

Speyer, Nico I88, I90, I9I, I93, 194, I96, 205, $323,356,358,372,375,379,4 I I$

Spijer, Salomon $\quad 84,87$, I23, I24, I29, I33, I35, I5O, I5I, I74, I82, 239, 249, 252, 300, 309, 362, $365,374,383$

Starkenstein, Emil 67, II7

Steinschneider, Moritz I5

Stempel, Maurits L. van der 83

Stern, Meyer I36

Stertzenbach, Werner 298, 393, 395

Stibbe, David 254, 257

Stibbe, Paul I52, 299, 302, 303, 369, 392, 393, 395

Stokvis, Barend Joseph 37,38

Stokvis, Benno 227, 228, 38I, 382, 386, 387, 4II, $4 I 4$

Stokvis, Berthold 9-I2, 36, 37, 69, 72, 77, 79, 86, 87, 98, IOI-IO3, II3, I30, I3I, I46, I48, I49, I62, 
I64-I68, 2I9, 22I, 227, 229, 230, 233, 240-242, 260, 26I, 329, 339, 340, 342, 343, 349, 356-359,

$36 I-371,377,379,380,382-384,386,414$

Stokvis- Ettlinger, Margolia 242

Stoppelman, Marietje 3II

Straaten, Joseph van II6

Streicher, Julius 59

Stroink, Jeltje 58

Stuldreher, Coen $\quad 227,229,380-382,386,387,4 I I$

Sturkop, Stephan 35, 349, 399

Süsskind, Walter 2I6, $4 I I$

Swaab, Ben I60, 26I

Swaab, Juda 26I, 386

Swaab, Leo 230, 26I

Swaan, Abram de 22, 346, 4 II

Szwajger, Adina I9, 345, $4 I I$

Tas, Jacques 304, 308, 3II, 3I8, 394-396

Taverne, B.M. 58

Taytelbaum, Maurits 83

Tec, Nechama 77,357

Teixeira de Mattos, Isaac 37

Thorbecke, J.R. $\quad 37,48$

Thijn, Ed van 232, 382, 417

Timmer, G. 358

Torres, Willem de IOI, 362

Treub, Hector $45,52,35 I, 352,412$

Tubergen, Frank van $77,356,357,370,372,4 I 2$

Tuntler, J.H. $\quad 87,208,224,249,363,380,385$

Ughetti, G.B. $44,35 I, 4 I 2$

Ultee, Wout 77, 352, 356, 357, 4I2

Valk, Van der 272

Vas Nunes, Emanuel 2II, 233, 263, 266, 267, 354,356

Vedder, Aron 71, I62, I65, 252, 254, 320

Vedder, Diny $255,356,370,371,385,396,415,418$

Veeger, L.A. $\quad 82,83,358,385$

Velleman-Pinto, Fie 304

Venema, Derk I4, 344, 350, 352, 405, 412

Verwey, R.A. $\quad 85$, 91-97, 98, I02, I05, I35, 238,

$247,360-363,383$

Verzendaal, Johan 8I, 358

Virchow, Rudolph 63

Visser, L.E. $\quad 40, \mathrm{II} 6, \mathrm{I} 23$, I25

Vollenhoven, Louis van $318,396,417$

Vomberg, Paulina 193, 194, 375, 376

Vorrink, Koos 282
Vos, Herman 99

Vos, Isidoor Henry Joseph 39, 71

Vries, David de I90, 194

Vries, Meyer de I29, I33, I35, 365, 366

Vries, Philip de I3, 343, 344, 349, 351, 358, 362, $376,377,389,4 I 2$

Vries, Simon de I45, 297, 302, 3II, 392, 393, 404

Vries Robles, Bernard de I5O, 216, 218, 221, 243, $267,369,378,388$

Vries Robles, S.B. de 89

Vromen-Snapper, Betsy 3II, 395

Waal, Frans de 340, 397

Wal, Elisabeth van der $190,302,375$

Wassink, W.F. 89

Waterman, Hein Israël 320,396

Waterman, Nathaniël (Nico) 89, I83, 268, 309, $388,396,413$

Weindling, Paul 2I, 347, 4I2

Weyel, Jacob 99, I00

Weijl, Bettie I84, 207, 208, 232, 373, 374, 378$380,382,4 I 7$

Weijl, Louis 40, 7I, IOI, II8, 254

Weijl-Snuijf, Rachel 7I, 247, 384

Weijl, Simon 7I

Wertheim, A.C. 65

Wesel, Nol van 233

Wessel, I. Io8

Wessels, Ben I80, 373

Westerhoff, Wim I48, 369, 388

Weve, H.J.M. 88

Wibaut, F. II8, 364

Wielek, H. I63, I64, 226, 227, 287, 304, 307, 37I, $377,381,382,387,391,394,412$

Wiener, Eduard $75,79,357,406$

Wilde, P.A. de 4I, 350

Wimmer, Friedrich 91, 262, 387

Wind, Eddy de II6, I5I, 244, 299, 3I8, 344

Winkel, Sylvain 290

Wit, Alfred de 97

Withuis, Jolande 23, 346, 4I3

Woerden, J. Van III, 363

Wolff, Carel I5I, I59, I60, I75, 269, 361, 369, 370, $373,381,388,417$

Wolff, J.B. I62, 225

Wolff, Joop 257

Wolff, Ludwig Karel 39 
Woortman, Joop 282

Wörlein, K. 220

Wortman, J.L.C. $45,35 I, 413$

Woudenberg, H.J. $\quad 8 \mathrm{I}$

Wijnberg, Rosalie 39, 40, 230, 231, 254, 255

IJben, Jan Meilof $220,221,267,380,387,410$

Zeehandelaar, Isidore II7, I2I, 287

Zeeman, W.P.C. $\quad 74,357,413$

Zeldenrust, Eduard 299

Zettel, Hans 229

Zöpf, Wilhelm 321, 396

Zuiden, Nathan (Nico) van 136, 139, 252, 297, 302, 393

Zwaaf, J. 131, 366, 414

Zwaap, Salomon 95, 117, 360, 361, 363

Zwanenberg, Saal van 268

Zwarte-Walvisch, Klara de 218, 290, 292, 379, 39I, 413 



\section{CURRICULUM VITAE}

Hannah Laetitia van den Ende

Naaldwijk, 28 oktober 1983

I995-200I: Johan de Witt gymnasium te Dordrecht

200I-2008: Geneeskunde, Rijksuniversiteit Groningen

2005-2007: Propedeuse Geschiedenis, Rijksuniversiteit Groningen

2008: Mastertraject Medische Geschiedenis, Vrije Universiteit Amsterdam 


